NUREG/CR-1755

\title{
Technology, Safety and Costs of Decommissioning Nuclear Reactors At Multiple-Reactor Stations
}

Prepared by N. G. Wittenbrock

Pacific Northwest Laboratory

Operated by

Battelle Memorial Institute

Prepared for

U.S. Nuclear Regulatory

Commission 


\title{
NOTICE
}

This report was prepared as an account of work sponsored by an agency of the United States Government. Neither the United States Government nor any agency thereof, or any of their employees, makes any warranty, expressed or implied, or assumes any legal liability or responsibility for any third party's use, or the results of such use, of any information, apparatus product or process disclosed in this report, or represents that its use by such third party would not infringe privately owned rights.

\author{
Available from \\ GPO Sales Program \\ Division of Technical Information and Document Control \\ U. S. Nuclear Regulatory Commission \\ Washington, D. C. 20555 \\ Printed copy price: $\$ 11.00$
}

and

National Technical Information Service

Springfield, Virginia 22161 


\section{Technology, Safety and Costs of Decommissioning Nuclear Reactors At Multiple-Reactor Stations}

Manuscript Completed: December 1981

Date Published: January 1982

Prepared by

N. G. Wittenbrock

Pacific Northwest Laboratory

Richland, WA 99352

\section{Prepared for}

Division of Engineering Technology

Office of Nuclear Regulatory Research

U.S. Nuclear Regulatory Commission

Washington, D.C. 20555

NRC FIN No. B2117 


\section{Availability of Reference Materials Cited in NRC Publications}

Most documents cited in NRC publications will be available from one of the following sources:

1. The NRC Pubiic Document Room, 1717 H Street., N.W.

Washington, DC 20555

2. The NRC/GFO Sales Program, U.S. Nuclear Regulatory Commission, Washington. DC 20555

3. The National Technical Information Service, Springfield, VA 22161

Although the listing that follows represents the majority of documents cited in NRC publications. it is not intended to be exhaustive.

Referenced documents available for inspection and copying for a fee from the NRC Public Document Room include NRC correspondence and internal NRC memoranda; NRC Office of Inspection and Enforcement bulletins, circulars, information notices, inspection and investigation notices; Licensee Event Reports; vendor reports and correspondence: Commission papers; and applicant and licensee documents and correspondence.

The following documents in the NUREG series are available for purchase from the NRC/GPO Sales Program: formal NRC staff and contractor reports. NRC-sponsored conference proceedings, and NRC booklets and brochures. Also available are Regulatory Guides, NRC regulations in the Code of Federat Regulations, and Nuclear Regulatory Commission issuances.

Documents available from the National Technical Information Service include NUREG series reports and technical reports prepared by other federal agencies and reports prepared by the Atomic Energy Commission, forerunner agency to the Nuclear Regulatory Commission.

Documents available from public and special technical libraries include all open literature items. such as books, journal and periodical articles, transactions, and codes and standards. Federal Register notices, federal and state legislation, and congressional reports can usually be obtained from these libraries

Documents such as theses, dissertations, foreign reports and translations, and non-NRC conference proceedings are available for purchase from the organization sponsoring the publication cited.

Single copies of NRC draft reports are available free upon written request to the Division of Technical Information and Document Control, U.S. Nuclear Regutatory Commission. Washington. DC 20555. 
STUDY LEADER

N. G. Wittenbrock

CONTRIBUTORS

P. L. Hendrickson

G. M. Holter

W. E. Kennedy, Jr.

J. D. Ludwick

E. B. Moore, Jr.

E. S. Murphy

R. I. Smith

EDITOR

D. R. Payson 

FOREWORO

BY

NUCLEAR REGULATORY COMMISSION STAFF

The NRC staff is reappraising its regulatory position relative to the decommissioning of nuclear facilities. (1) As a part of this activity, the NRC has initiated two series of studies through technical assistance contracts. These contracts are being undertaken to develop information to support the preparation of new standards covering decommissioning.

The basic series of studies covers the technology, safety, and costs of decommissioning reference nuclear facilities. Light water reactors and fuelcycle and non-fuel-cycle facilities are included. Facilities of current design on typical sites are selected for the studies. Separate reports are prepared as the studies of the various facilities are completed.

The first report in this series covers a fuel reprocessing plant; ${ }^{(2)}$ the second addresses a pressurized water reactor; ${ }^{(3)}$ and the third deals with a small mixed oxide fuel fabrication plant. (4) The fourth report, an addendum to the pressurized water reactor report, ${ }^{(5)}$ examines the relationship between reactor size and decommissioning cost, the cost of entombment, and the sensitivity of cost to radiation levels, contractual arrangements, and disposal site charges. The fifth report in this series deals with a low-level waste burial ground; ${ }^{(6)}$ the sixth covers a large boiling water reactor power station; ${ }^{(7)}$ and the seventh examines a uranium fuel fabrication plant. ${ }^{(8)}$ The eighth report covers non-fuel-cycle nuclear facilities. (9) The $n$ inth report, an addendum to the low-level waste burial ground report, ${ }^{(10)}$ supplements the description of environmental radiological surveillance programs used in the parent document. The tenth report deals with a uranium hexafluoride conversion plant. (11) This report, eleventh in the series, addresses the decommissioning of nuclear reactors at multiple-reactor power stations.

Additional decommissioning topics will be reported on the tentative schedule as follows:

FY 1982 - Research/Test Reactors

FY $1982 \bullet$ LWR Post-Accidents 
FY 1982 - Independent Spent Fuel Storage Installations

Fy 1983 - Fuel Cycle Post-Accidents

The second series of studies covers supporting information on the decommissioning of nuclear facilities. Four reports have been issued in the second series. The first consists of an annotated bibliography on the decommissioning of nuclear facilities. (12) The second is a review and analysis of current decommissioning regulations. (13) The third covers the facilitation of the decommissioning of light water reactors, (14) identifying modifications or design changes to facilities, equipment, and procedures that will improve safety and/or reduce costs. The fourth covers the establishment of an information base concerning monitoring for compliance with decomissioning survey criteria. (15) A fifth report on this same theme, entitled Technology and Cost of Termination Surveys Associated with Decommissioning of Nuclear Facilities, is intended for FY 1982.

The information provided in this report on multiple-reactor stations, including any comments, will be included in the record for consideration by the Commission in establishing criteria and new standards for decommissioning. Comments on this report should be mailed to:

Chief

Chemical Engineering Branch

Division of Engineering Technology

Office of Nuclear Regulatory Research

U.S. Nuclear Regulatory Commission

Washington, DC 20555

\section{REFERENCES}

1. Plan for Reevaluation of NRC Policy on Decomrnissioning of Nuclear Facilities. NUREG-0436, Rev. 1, Office of Standards Deveropment, U.S. Nuclear Regulatory Cornmission, December 1978.

2. Technology, Safety and Costs of Decommissioning a Reference Nuclear Fue? Reprocessing Plant. NUREG-0278, Pacific Northwest Laboratory for U.S. Nuclear Regulatory Commission, October 1977.

3. Technology, Safety and Costs of Decommissioning a Reference Pressurized Water Reactor Power Station. NUREG/CR-0130, Pacific Northwest Laboratory for U.S. Nuclear Regulatory Commission, June 1978. 
4. Technology, Safety and Costs of Decommissioning a Reference Small Mixed Oxide Fuel Fabrication Plant. NUREG/CR-0129, Pacific Northwest Laboratory for U.S. Nuclear Regulatory Commission, February 1979.

5. Technology, Safety and Costs of Decommissioning a Reference Pressurized Water Reactor Power Station. NUREG/CR-0130 Addendum, Pacific Northwest Laboratory for U.S. NucTear Regulatory Commission, August 1979.

6. Technology, Safety and Costs of Decommissioning a Reference Low-LeveI Waste Burial Ground. NUREG/CR-0570, Pacific Northwest Laboratory for U.S. Nuclear ReguTatory Commission, June 1980.

7. Technology, Safety and Costs of Decommissioning a Reference Boiling Water Reactor Power Station. NUREG/CR-0672, Pacific Northwest Laboratory for U.S. Nuclear Regulatory Commission, June 1980.

8. Technology, Saiety and Costs of Decommissioning a Reference Uranium Fuel Fabrication Plant. NUREG/CR-1266, Pacific Northwest Laboratory for U.S. Nuclear Regulatory Commission, October 1980.

9. Technology, Safety and Costs of Decommissioning Reference Non-Fuel Cycle Nuclear Facilities. NUREG/CR-1754, Pacific Northwest Laboratory for U.S. NucTear Regulatory Cominission, February 1981.

10. Technology, Safety and Costs of Decommissioning a Reference Low-Level Waste Burial Ground. NUREG/CR-0570 Addendum, Pacific Northwest Laboratory for U.S. Nuclear Regulatory Commission, May 1981.

11. Technology, Safety and Costs of Decommissioning a Reference Uranium Hexafluoride Conversion Plant. NUREG/CR-1757, Pacific Northwest Laboratory for U.S. Nuc Tear ReguTatory Commission, October 1981.

12. Decomissioning of Nuclear Facilities - An Annotated Bibliography. NUREG/CR-0131, Pacific Northwest Laboratory for U.S. Nuclear Regulatory Commission, August 1979.

13. Decommissioning of Nuclear Facilities - A Review and Analys is of Current Regulations. NUREG/CR-0671, Pacific Northwest Laboratory and Battelle Human Affairs Research Centers for U.S. Nuclear Regulatory Commission, August 1979.

14. Facilitation of Decommissioning of Light Water Reactors. NUREG/CR-0569, Pacific Northwest Laboratory for U.S. Nuclear Regulatory Commission, December 7979.

15. Monitoring for Compliance with Decommissioning Termination Survey Criteria. NUREG/CR-2082, 0ak Ridge National Laboratory for U.S. Nuclear Regulatory Comnission, June 1981 . 

Safety and cost information is developed for the conceptual deconmissioning of 1 arge (1175-MWe) pressurized water reactors (PWRs) and large (1155-MWe) boiling water reactors (BWRs) at multiple-reactor stations. Three decommissioning alternatives are studied: DECON (immediate decontamination), SAFSTOR (safe storage followed by deferred decontamination), and ENTOMB (entombment). Safety and costs of decommissioning are estimated by determining the impact of probable features of multiple-reactor-station operation that are considered to be unavailable at a single-reactor station, and applying these estimated impacts to the decommissioning costs and radiation doses estimated in previous PWR and BWR decommissioning studies. The multiple-reactor-station features analyzed are: the use of interim onsite nuclear waste storage with later removal to an offsite nuclear waste disposal facility, the use of permanent onsite nuclear waste disposal, the dedication of the site to nuclear power generation, and the provision of centra1ized services.

Five scenarios for decommissioning reactors at a multiple-reactor station are investigated. The number of reactors on a site is assumed to be either four or ten; nuclear waste disposal is varied between immediate offsite disposal, interim onsite storage, and inmediate onsite disposal. It is assumed that the decommissioned reactors are not replaced in one scenario but are replaced in the other scenarios. Centralized service facilities are provided in two scenarios but are not provided in the other three.

Decommissioning of a PWR or a BWR at a multiple-reactor station probably will be less costly and result in lower radiation doses than decommissioning an identical reactor at a single-reactor station. Regardless of whether the light water reactor being decommissioned is at a single- or multiple-reactor station:

- the estimated accupational radiation dose for decommissioning an LWR is lowest for SAFSTOR and highest for DECON

- the estimated cost of decommissioning a PWR is lowest for ENTOMB and highest for SAFSTOR

- the estimated cost of decommissioning a BWR is lowest for DECON and highest for SAFSTOR.

In all cases, SAFSTOR has the lowest occupational radiation dose and the highest cost. 



\section{REPORT CONTENTS OUTLINE}

\section{SECTIONS}

1 - INTRODUCTION

2 - SUMMARY

3 - DECOMMISSIONING: ALTERNATIVES. CONSIDERATIONS, AND STUDY APPROACH

4 - REGULATORY CONSIDERATIONS FOR DECOMMISSIONING

5 - FINANCING OF DECOMMISSIONING

6 - MULTIPLE-REACTOR STATION CONCEPTS

7 - CHARACTERISTICS OF THE REFERENCE LIGHT WATER REACTORS

8 - IMPACT OF MULTIPLE REACTORS ON DECOMMISSIONING COST

9 - IMPACT OF MULTIPLE REACTORS ON RADIATION DOSE FROM DECOMMISSIONING

10 - MULTIPLE-REACTOR STATION DECOMMISSIONING SCENARIOS

11 - FACILITATION OF DECOMMISSIONING

APPENDICES

A - WASTE DISPDSAL COST ESTIMATES

B - DETAILS OF THE IMPACTS OF CENTRALIZED SERVICES ON DECOMMISSIONING AT A MULTIPLE-REACTOR STATION

C - OCCUPATIONAL DOSES FROM INTERIM ONSITE NUCLEAR WASTE STORAGE 



\section{CONTENTS}

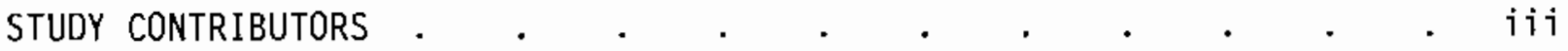

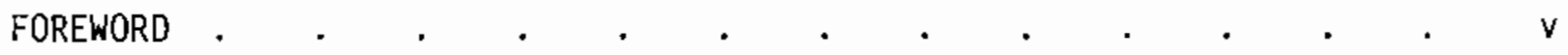

ABSTRACT . $\quad . \quad$. $\quad . \quad$. . . . . . . . . . . . . . $1 x$

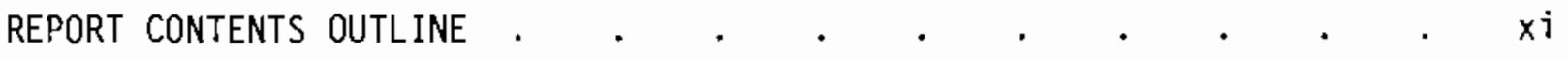

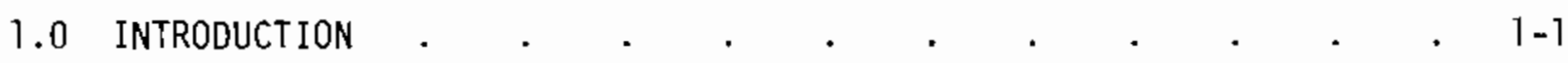

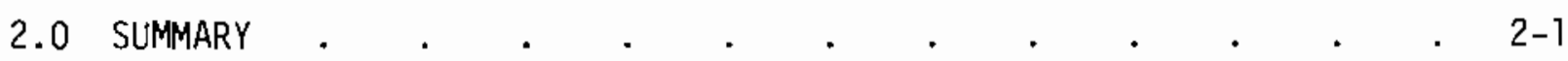

2.1 DECOMMISSIONING ALTERNATIVES AND STUDY APPROACH . . . $2-1$

2.2 REGULATORY CONSIDERATIONS FOR DECOMMISSIONING * . . 2-2

2.3 FINANCING OF DECOMMISSIONING . . . . . . . . . . 2-2

2.4 MULTIPLE-REACTOR STATION CONCEPTS . . . . . . . 2-3

2.5 REFERENCE LIGHT WATER REACTORS . . . . . . . 2-4

2.6 IMPACT OF MULTIPLE REACTORS ON DECOMMISSIONING COSTS .

2.7 IMPACT OF MULTIPLE REACTORS ON RADIATION DOSE . . . 2-1I

2.8 MULTIPLE-REACTOR STATION DECOMMISSIONING SCENARIOS - 2-12

2.9 FACILITATION OF DECOMMISSIONING . . . . . . . . 2-13

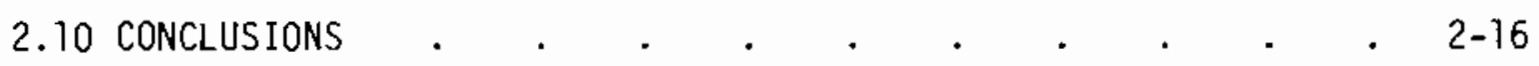

REFERENCES . . . . . . . . . . . . . . . . . . . . . . . . .

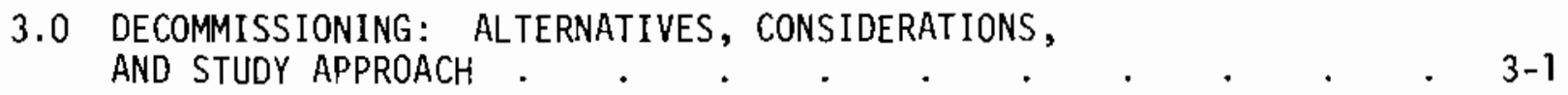

3.1 DECOMMISSIONING ALTERNATIVES . . . . . . . . . . 3-1

$3.1 .1 \mathrm{DECON} \cdot . \quad . \quad . \quad . \quad . \quad . \quad . \quad . \quad . \quad$. $3-1$

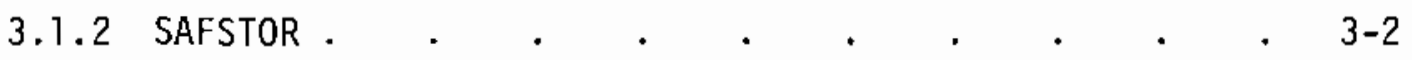

3.1 .3 ENTOMB . . . . . . . . . . . . . $3-3$

3.2 CONSIDERATIONS FOR DECOMMISSIONING . . . . . . . . $3-5$ 
3.2 .1 Economic . . . . . . . . . . $3-5$

3.2.1.1 Property Utilization Potential . . . . 3-5

3.2.1.2 Staffing . . . . . . . . . . 3-6

3.2.1.3 Radioactive Material Disposition . . . 3-6

3.2.1.4 Nuclear Waste Disposal Capabilities . . . 3-7

3.2.1.5 Planning and Preparation Requirements . . 3-8

3.2.1.6 Taxation . . . . . . . . . . 3-8

3.2.1.7 License and Insurance Fees . . . . . 3-9

3.2.1.8 Funding Availability . . . . . . 3-9

3.2 .2 Licensing $\quad . \quad$. $\quad . \quad$. $\quad . \quad$. $\quad . \quad$. $\quad . \quad 3-9$

3.2 .3 Societal . . . . . . . . . . . . 3-10

3.2 .4 Safety . . . . . . . . . . . $3-11$

3.2.4.1 Radiological Safety . . . . . . 3-11

3.2.4.2 Industrial Safety . . . . . . . 3-12

3.2.4.3 Environmental Safety. . . . . . 3-12

3.2.5 Schedule . . . . . . . . . . . 3-13

3.3 STUDY APPROACH. . . . . . . . . . . . . . . . $3-13$

3.3.1 Variables . . . . . . . . . . 3-13

3.3.1.1 Nuclear Waste Disposa\} . . . . . 3-14

3.3.1.2 Site Dedication . . . . . . . 3-14

3.3.1.3 Centralized Services. . . . . . 3-14

3.3.1.4 Number of Reactors Onsite. . . . . 3-14

3.3.1.5 Type of Reactor Being Decommissioned . . 3-15

3.3.2 Multiple-Reactor Station Scenarios . . . . 3-15

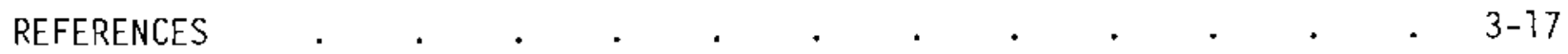


4.0 REGULATORY CONSIDERATIONS FOR DECOMMISSIONING . . . . . $4-1$

4.1 CURRENT FEDERAL REgULATIONS AND GUIDES . . . . . . . . . 4

4.2 MAJOR REgULATORY CONSIDERATIONS . . . . . . . . . . 4-4

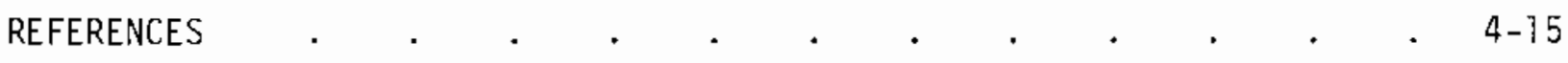

5.0 FINANCING OF DECOMMISSIONING . . . . . . . . . . . . $5-1$

5.7 ALTERNATIVES FOR PROVIDING DECOMMISSIONING FUNDS . . . 5-2

5.1.1 Prepaid Decommissioning Reserve . . . . . 5-3

5.1.2 Internal Unfunded Decommissioning Reserve . . . 5-3

5.1.3 Sinking Fund Payment to an Outside Escrow Account . 5-4

5.1.4 Payment from Revenue when Needed. . . . . 5-5

5.2 FINANCIAL PROVISIONS FOR PREMATURE PLANT SHUTDOWN . . . 5-5

5.2.1 Large Initial Payment . . . . . . . . 5-5

5.2.2 Higher Initial Sinking Fund Payments . . . . . 5-6

5.2 .3 Surety Bond . . . . . . . . . . . . 5-6

5.2.4 Decommissioning Insurance Pool . . . . . . . 5-6

5.3 DECOMMISSIONING FUNDING AT A MULTIPLE-REACTOR STATION -

REFERENCES . . . . . . . . . . . . . . . . . . . . $5-9$

6.0 MULTIPLE-REACTOR STATION CONCEPTS . . . . . . . . . 6-1

6.7 MULTIPLE-REACTOR STATIONS AND RELATED STUDIES . . . . $6-1$

6.2 management alternatives for a multiple-reactor station . 6-3

6.2.1 Reactor Types and Standardization . . . . 6-3

6.2.2 Site Dedication . . . . . . . . . . 6-5

6.2 .3 Timing of Construction . . . . . . . . 6-5

6.2.4 Reuse of Structures and Systems . . . . . 6-8

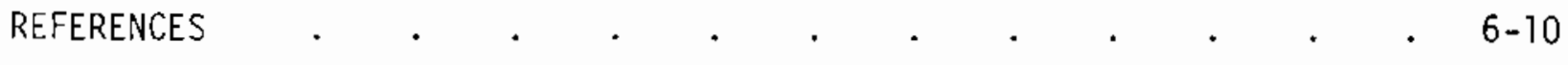


7.0 CHARACTERISTICS OF THE REFERENCE LIGHT WATER REACTORS . . . . 7

7.1 THE REFERENCE PRESSURIZED WATER REACTOR . . . . . . .

7.1.1 Nuclear Power Generation System . . . . . . 7-1

7.1.1.1 Reactor Vessel and Internals . . . . 7-1

7.1.1.2 Reactor Coolant System . . . . . 7-2

7.1.2 General Plant Arrangement . . . . . . . 7-6

7.1.2.1 Containment Building . . . . . . 7-6

7.7.2.2 Fuel Building . . . . . . . . . . 7-6

7.1.2.3 Auxiliary Building . . . . . . . . 7-6

7.1 .2 .4 Control Building . . . . . . 7-10

7.1.2.5 Turbine Building . . . . . . 7-10

7.1 .2 .6 Cooling Tower . . . . . . . . . . . . . . . . .

7.1 .2 .7 Other Structures . . . . . . 7-10

7.1.3 Radionuclide Inventories . . . . . . . 7-10

7.1.3.1 Accumulated Radionuclides Within
the Reference PWR . . . . . . . . .

7.1.3.2 Surface Contamination . . . . . . 7-13

7.1.4 Radiation Dose Rate Data . . . . . . 7-16

7.2 THE REFERENCE BOILING WATER REACTOR . . . . . . . 7-20

7.2.1 Nuclear Power Generation System . . . . . . 7-20

7.2.1.1 Reactor Vessel and Internals . . . . . 7-21

7.2.1.2 Reactor Water Recirculation System . . . 7-21

7.2.1.3 Power Conversion System . . . . . 7-27

7.2.2 General Plant Arrangement . . . . . . . 7-21

7.2.2.1 Reactor Building . . . . . . 7-23 
7.2.2.2 Turbine Generator Building . . . . 7-24

7.2.2.3 Radwaste and Control Building. . . . 7-24

7.2.2.4 other Structures . . . . . . 7-25

7.2.3 Radionuclide Inventories . . . . . . 7-26

7.2.3.1 Neutron-Activated Components . . . . 7-27

7.2.3.2 Surface Contamination . . . . . . 7-29

7.2.4 Radiation Dose Rate Data . . . . . . 7-32

7.2.4.1 Estimated Radiation Dose Rates at . . . 7-33
Shutdown . . . .

7.2.4.2 Estimated Concrete Surface Contamination . . 7-33
Levels at Shutdown . . .

7.2.4.3 Contaminated Concrete Rubble Volumes
Removed During DECON. . . . 7-33

REFERENCES . $. \quad . \quad . \quad . \quad . \quad . \quad . \quad . \quad . \quad . \quad$. $7-37$

8.0 IMPACT OF MULTIPLE REACTORS ON DECOMMISSIDNING COST .

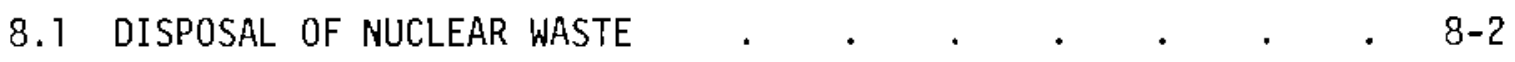

8.1.1 Offsite Nuclear Waste Disposal . . . . . . 8-2

8.1.2 Onsite Interim Nuclear Waste Storage . . . . 8-2

8.1.2.1 Cost of Interim Onsite Storage of

Nuclear waste from DECON . . . . . 8-6

8.1.2.2 Cost of Interim Onsite Storage of . . . 8-8
Nuclear Waste from SAFSTOR . .

8.1.2.3 Cost of Interim Onsite Storage of
Nuclear Waste from ENTOMB . . . . . 8-13

8.1.3 Onsite Nuclear Waste Disposal . . . . . 8-14

8.1.3.1 Cost of Onsite Disposal of Nuclear
Waste from DECON . . . . .

8.1.3.2 Cost of Onsite Disposal of Nuclear Waste from SAFSTOR . . . . . . 8-17 


\subsubsection{Cost of Onsite Disposal of Nuclear Waste from ENTOMB

\subsection{SITE DEDICATION}

8.3 AVAilability OF CENTRAlized SERVices . . . . . . $\quad$. $8-20$

8.3.1 Health Physics Services . . . . . 8-21

8.3 .2 Security forces .

8.3.3 Solid Waste Processing . . . . . . . . 8-26

8.3.4 Equipment Decontamination Services . . . . 8-28

8.3.4.1 Decontamination of Special Tools and Equipment . . . . . . . 8-30

8.3.4.2 Mobile Chemical Decontamination Equipment . . . . . . . . . $8-31$

\subsubsection{Central Electropolishing and} Chemical Decontamination Facility . . . 8-33

8.3.4.4 Equipment Decontamination Services . . . $8-34$
Summary . . . .

8.3.5 Maintenance Shops and Services . . . . . 8-36

8.3.6 Laundry Services . . . . . . . . . $8-36$

8.3.7 Transportation Services . . . . . . 8-37

8.3.8 Central Stores . . . . . . . . 8-37

8.3.9 Surmary of Centralized Services . . . . . 8-37

8.4 TYPE OF REACTOR . . . . . . . . . . . 8-37

8.5 NUMBER OF REACTORS AT STATION . . . . . . . . . 8-38

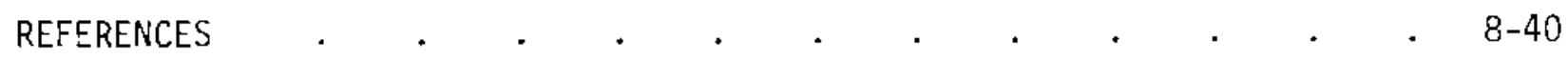

9.0 IMPACT OF MULTIPLE REACTORS ON RADIATION DOSE FROM
DECOMMISSIONING..
.

9.1 DISPOSAL OF NUCLEAR WASTE $\quad . \quad$. . . . . . . . . . . $9-2$

9.1.1 Offsite Nuclear Waste Disposal . . . . . . 9-2 
9.1.2 Onsite Interim Nuclear Waste Storage . . . . . 9-2

9.1.2.1 Radiation Doses from Onsite Interim
Storage of Nuclear Waste from DECON . . . . 9-3

$\begin{array}{ll}9.1 .2 .2 & \text { Radiation Doses from Onsite Interim } \\ \text { Storage of Nuclear Waste from SAFSTOR . . . 9-6 }\end{array}$

9.1.2.3 Radiation Doses from Onsite Interim
Storage of Nuclear Waste from ENTOMB . . 9-7

9.1.3 Onsite Nuclear Waste Disposal . . . . . . 9-16

9.2 SITE DEDICATION . . . . . . . . . . . 9-20

9.2.1 Impact on Radiation Doses from DECON . . . . . 9-22

9.2.2 Impact on Radiation Doses from SAFSTOR . . . 9-23

9.2.3 Impact on Radiation Doses from ENTOMB . . . . 9-23

9.3 CENTRALIZED SERVICES . . . . . . . . . . . . . 9-27

9.4 TYPE OF REACTOR . . . . . . . . . . . . . 9-29

9.5 NUMBER OF REACTORS AT STATION . . . . . . . . . 9-29

REFERENCES . . . . . . . . . . . . . . . . . . . 9-31

10.0 MULTIPLE-REACTOR STATION DECOMMISSIONING SCENARIOS . . . $\quad$ 10-1

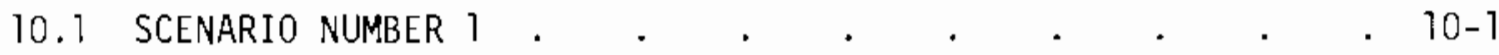

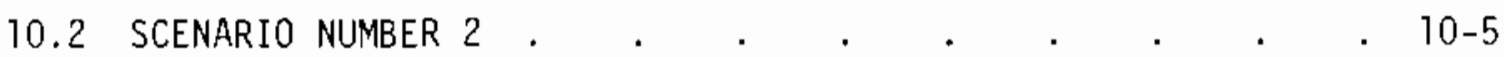

10.3 SCENARIO NUMBER $3 . \quad . \quad . \quad . \quad . \quad . \quad . \quad . \quad . \quad . \quad . \quad 10-5$

10.4 SCENARIO NUMBER 4. . . . . . . . . . . . . 10-8

10.5 SCENARIO NUMBER 5 . $5 . \quad . \quad . \quad . \quad . \quad . \quad . \quad$. . $10-16$

REFERENCES . . . . . . . . . . . . . . . . . . . . $10-19$

11.0 FACILITATION OF DECOMMISSIONING

11.1 Facilitation PLANNing . . . . . . . . . . . . . . . . .

11.T.1 Radiation Dose Reduction . . . . . . 11-2

11.3 .2 Cost Reduction . . . . . . . . . 11-2 
11.2 Facilitation Alternatives . . . . . . . . . 11-3

11.2.1 Improved Documentation. . . . . . . 11-3

11.2.2 Improved Access . . . . . . . . 11-4

11.2.3 Substitution and Purification Jf Materials . . 11-4

11.2.4 Design of the Biological Shield for Easy Removal , 11-4

11.2.5 Techniques for Improved Protection of Concrete
and Improved Removal of Contaminated Concrete 11-5

11.2.6 Special Shielded Maintenance Snop . . . . 11-6

11.2.7 Improved Shielding for Maintenance and Decommissioning . . . . . . . 11-6

11.2.8 Reduction of Radwaste Volume by Incineration . . 11-6

11.2 .9 Electropolishing . . . . . . . 11-6

11.2.10 Remote Maintenance and Decormissioning . . . 11-7

11.2.11 Special Decommissioning Tools and Techniques. . 11-7

11.3 FACILITATION OF DECOMMISSIONING AT MULTIPLE-REACTOR
STATIONS

11.3.1 Site Dedication. . . . . . . . . $11-8$

11.3.2 Onsite Nuclear Waste Storage on Disposal . . . 11-9

11.3 .3 Central Services. . . . . . . . . . 11-9

11.4 REUSE OF THE FACILITY . . . . . . . . . . . 11-9

11.4.1 Removal of the Intact PWR Reactor Pressure Vessel . 11-11

11.4.2 Removal of the Intact BWR Reactor Pressure Vessel . 11-14

11.4.3 Other Intact Vessel Removal Analyses. . . . 11-18

11.4.4 Modutar Biological Shield. . . . . . 11-18

REFERENCES . . . . . . . . . . . . . . . 11-21

APPENDIX A - NUCLEAR WASTE DISPOSAL COST ESTIMATES . . . . . A-1

A.1 ONSITE INTERIM STORAGE $. \quad \cdot \quad \cdot \quad \cdot \quad \cdot \quad \cdot \quad \cdot \quad \cdot A-1$

A.I.1 Reference PWR Decommissioning Wastes. . . . A-3 
A.1.1.1 Waste from DECON . . . . . . A-3

A.1.1.2 Waste from SAFSTOR . . . . . . A-11

A.1.1.3 Waste from ENTOMB . . . . . . A-19

A.1.2 Reference BWR Decommissioning Wastes . . . . A-22

A.1.2.1 Waste from DECON . . . . . . A-22

A.1.2.2 Waste from SAFSTOR . . . . . . A-28

A.1.2.3 Waste from ENTOMB . . . . . . A-34

A.2 ONSITE DISPOSAL OF NUCLEAR WASTE . . . . . . . . A-37

REFERENCES $\quad$. $\quad . \quad$. . . . . . . . . . . . A-39

APPENDIX B - DETAILS OF THE IMPACTS OF CENTRALIZED SERVICES ON
DECOMMISSIONING AT A MULTIPLE-REACTOR STATION * . . . B-1

B. 1 HEALTH PHYSICS SERVICES . . . . . . . . . . B-1

B.1.1 PWR DECON . . . . . . . . . . . B-2

B.1.2 PWR SAFSTOR . . . . . . . . . . . . B-2

B. 1.3 PWR ENTOMB . . . . . . . . . . . B

B. .4 BWR DECON . . . . . . . . . . . . . B

B. 1.5 BWR SAFSTOR . . . . . . . . . . . . B

B.1.6 BWR ENTOMB . . . . . . . . . . . B-8

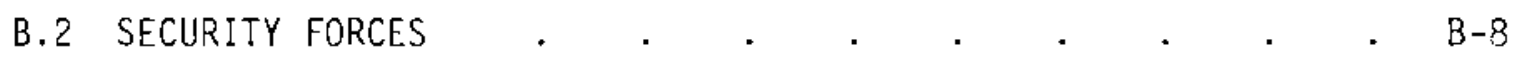

B.2.I PWR DECON . . . . . . . . . . . B-8

B.2.2 PWR SAFSTOR . . . . . . . . . . . B-11

B.2.3 PWR ENTOMB . . . . . . . . . . . . B 14

B.2.4 BWR DECON . . . . . . . . . . . . B-14

B.2.5 BWR SAFSTOR . . . . . . . . . . . . B-14

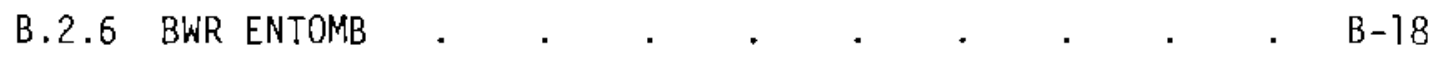

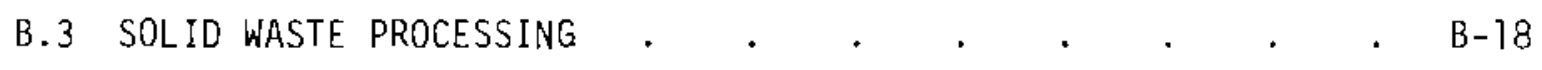


B.3.1 Cost Effects. . . . . . . . . . B-20

B.3.1.1 Cost Savings During Reactor Operations . . B-22

B.3.1.2 Cost Savings During Reactor Decommissioning . B-22

B.3.2 Radiation Dose Effects . . . . . . . . B-27

B.3.2.1 Waste Packaging Workers . . . . . B-27

B.3.2.2 Waste Transportation Workers . . . . B-27

B.3.2.3 Members of the Public . . . . . B-28

B.3.3 Sumnary . . . . . . . . . . . B-30

B.4 EquiPMENT DECONTAMINATION SERVICES . . . . . . . B-30

B.4.1 Decontamination of Special Tools and Equipment . . B-32

B.4.1.1 PWR DECON . . . . . . . . . . B-32

B.4.1.2 PWR SAFSTDR . . . . . . . . . . B

B.4.1.3 PWR ENTOMB. . . . . . . . . B-34

B.4.1.4 BWR DECON . . . . . . . . . . B-36

B.4.1.5 BWR SAFSTOR . . . . . . . B-36

B.4.1.6 BWR ENTOMB . . . . . . . . . . . B-39

B.4.2 Mobile Chemical Decontamination Equipment . • . B-39

B.4.3 Central Electropolishing and Chemical
Decontamination Facility . . . . . . B-39

B.4.3.1 Facility Costs . . . . . . . B-41

B.4.3.2 Potential Cost Savings . . . . . B-41

REFERENCES . . . . . . . . . . . . . . . . . . . . B

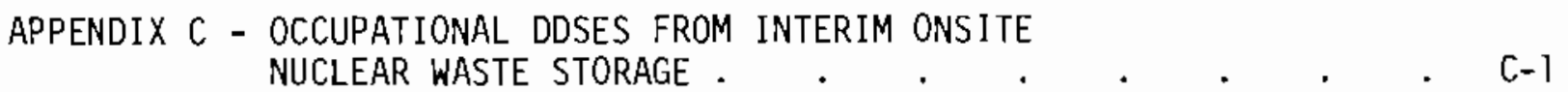

C. 1 NEUTRON-ACTIVATED REACTOR COMPONENTS . . . . . . . . C- 1

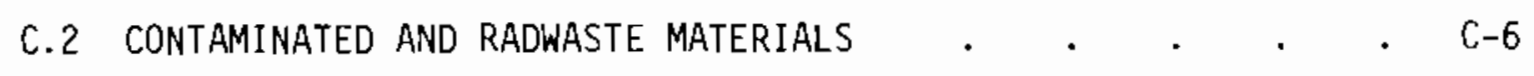

REFERENCES $. \quad . \quad . \quad . \quad . \quad . \quad . \quad . \quad . \quad . \quad . \quad . \quad c-13$ 


\section{FIGURES}

2.8-1 Multiple-Reactor Station Scenarios . . . . . . . 2-13

6.2-1 Lifetime Schedule for Construction, Operation, and DECON
of a 4-Reactor Station - Scenario I . . . . . . $6-6$

6-2-2 Lifetime Schedule for Construction, Operation, and DECON

6.2-3 Lifetime Schedule for Construction, Operation, and DECON of a 10-Reactor Station - Scenarios 3 and $4.0 .6-7$

6.2-4 Lifetime Schedule for Construction, Operation, and DECON
of a l0-Reactor Station - Scenario 5 . . . . . $6-7$

6.2-5 Lifetime Schedule for Construction, 0peration, and SAFSTOR
of a 10-Reactor Station - Scenarios 3 and 4. . . . 6-8

7.1-1 Pressurized Water Reactor . . . . . . . . . 7-2

7.1-2 PWR Reactor Vessel Internals . . . . . . . . . . . 7-3

7.7-3 Reactor Coolant System . . . . . . . . . . . . $7-4$

7.1-4 Steam Generator . . . . . . . . . . . . $7-5$

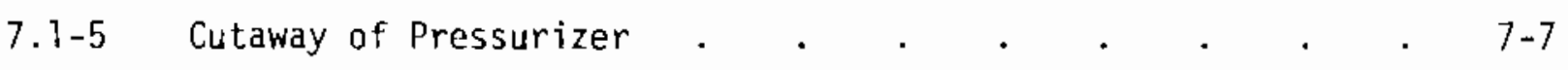

7.1-6 Typical Plant Layout . . . . . . . . . . . . . . . 7-8

7.1-7 Containment Building . . . . . . . . . . . . . . $\quad$. $7-9$

7.1-8 Radioactive Decay of Activated Corrosion Products . . . 7-18

7.1-9 Time Dependence of Radioactivity Levels and Radiation
Dose Rates in the Activated Reactor Components . . 7-19

7.2-1 Boiling Water Reactor . . . . . . . . . 7-20

7.2-2 Reactor Vessel and Internals . . . . . . . . 7-22

7.2-3 Reactor Water Recirculation System . . . . . . . 7-23

7.2-4 Power Conversion System . . . . . . . . . . . . 7-24

7.2-5 Site Layout of the Reference BWR Power Plant . . . . . 7-25

7.2-6 BWR Reactor Building . . . . . . . . . . . . . 7-26 
8.1-1 Onsite Interim Nuclear Waste-Storage Facility . . . 8-5

8.1-2 Schedule for Interim Onsite Storage of the Nuclear Waste from SAFSTOR . . . . . . . . . 8-9

8.3-] Health Physics Staff Organization for Decommissioning . . 8-23

8.3-2 Security Force Organization for Decommissioning . . . 8-26

10.0-1 Multiple-Reactor Station Scenarios . . . . . . . 10-1

11.4-1 Conceptual Design - Modular Biological Shield . . . 11-19

C.1-1 Time Dependence of Occupational Dose for Burial of Neutron-Activated PWR Components . . . . . . C C-4

C.1-2 Time Dependence of Occupational Dose for Burial of Neutron-Activated BWR Components . . . . . . C-4

C.1-3 Time Dependence of 0ccupational Dose for Retrieval of Neutron-Activated PWR Components . . . . . . C C-7

C.1-4 Time Dependence of Occupational Dose for Retrieval of Neutron-Activated BWR Components . . . . . . . C-7

C.2-1 Time Dependence of Occupational Dose for Burial of BWR Contaminated Material and Radwaste . . . . . C-10

C.2-2 Time Dependence of Occupational Dose for Burial of PWR Contaminated Material and Radwaste . . . . . C-10

C-2-3 Time Dependence of Occupational Dose for Retrieval of BWR Contaminated Material and Radwaste . . . . . C-12

C.2-4 Time Dependence of Occupational Dose for Retrieval of PWR Contaminated Material and Radwaste . . . . . C-12 


\section{TABLES}

2.6-1 Summary of Estimated Costs for Interim Onsite Nuclear Waste Storage with Later Removal to Permanent Offsite Disposal . 2-5

2.6-2 Summary of Estimated Costs for Permanent Onsite Nuclear Waste Disposal . . . . . . . . . . 2-6

2.6-3 Summary of Estimated Decommissioning Cost Reductions at a Multiple-Reactor Station . . . . . . . . 2-7

2.6-4 Summary of Cost Reductions Resulting from Centralized Services at a Multiple-Reactor Station . . . . . 2-10

2.7-1 Summary of Estimated 0ccupational Radiation Dose Reductions from Decommissioning One Reactor at a Mutiple-vs. Single-Reactor Station . . . . . . . . 2-11

2.7-2 Summary of Estimated Public Radiation Dose Reductions from Decomissioning One Reactor at a Multiple- vs. a Single-Reactor Station

2.8-1 Summary of the Estimated Costs for Multiple-Reactor Station Decommissioning Scenarios . . . . . . 2-14

2.8-2 Summary of the Estimated 0ccupational Radiation Doses for Multiple-Reactor Station Decommissioning Scenarios . . 2-15

6.2-1 Cost Estimate Summary - Light Water Reactors . . . . . 6-9

7.1-1 Radioactivity Levels in Major Activated Reactor Components at Time of Reactor Shutdown . . . . . . 7-12

7.1-2 Radioactivity Levels at the Inner Surface of the Activated Biological Shield at Reactor Shutdown . . . . 7-14

7.1-3 Radionuclide Inventory of PWR Surface Contamination . . 7-15

7.1-4 Estimated Radiation Dose Rates in the Reference PWR at Shutdown.$\quad \cdot \quad \cdot \quad \cdot \quad \cdot \quad \cdot$. $7-17$

7.2-1 Radionuclide Inventory in Neutron-Activated BWR Components . 7-28

7.2-2 Estimated Total Radioactivity in Neutron-Activated
Components . . . . . . . . . . . $7-29$

7.2-3 Radionuclide Inventory of BWR Surface Contamination . 7-31 
7.2-4 Summary of Surface Contamination in the Reference BWR . . 7-32

7.2-5 Estimated Radiation Dose Rates in the Reference BWR at Shutdown . . . . . . . . 7-34

7.2-6 Typical Measured Concrete Surface Contamination Levels in the Reference BWR at Shutdown . . . . . 7-35

7.2-7 Contaminated Concrete Rubble Volumes Renoved During DECON of the Reference BWR . . . . . . . 7-36

8.0-1 Summary of Decommissioning Cost Differerices . . . . . 8-1

8.1-1 Estimated Cost of Disposa1 of Nuclear Waste from DECON of a PWR Using Interim Onsite Waste Storage . . . 8-7

8.1-2 Estimated Cost of Disposal of Nuclear Waste from DECON of a BWR Using Interim Onsite Waste Storage. .

8.1-3 Estimated Total Cost Differences - Interim Onsite Nuclear Waste Storage vs. Immediate Offsite Nuclear Waste Disposal for DECON.

8.1-4 Estimated Cost of Disposal of Nuclear Waste from SAFSTOR of a PWR Using Interim Onsite Nuclear Waste Storage . . 8-10

8.1-5 Estimated Cost of Disposal of Nuclear Waste from SAFSTOR of a BWR Using Interim Onsite Nuclear Waste Storage . . 8-11

8.1-6 Estimated Total Cost Differences - Interim Onsite Nuclear Waste Storage vs. Immediate Offsite Nuclear Waste Disposal for SAFSTOR

8.1-7 Estimated Cost of Disposal of Nuclear Waste from ENTOMB of a PWR Using Interim Onsite Nuclear Waste Storage . . 8-13

8.1-8 Estimated Cost of Disposal of Nuclear Waste from ENTOMB of a BWR Using Interim Onsite Nuclear Waste Storage . . 8-14

8.1-9 Estimated Total Cost Differences - Interim Onsite Nuclear Waste Storage vs. Immediate Offsite Nuclear Waste Disposal for ENTOMB

8.1-10 Estimated Cost of Onsite Disposal of Nuclear Waste from DECON

8.1-11 Estimated Cost of Onsite Disposal of Nuclear Waste from SAFSTOR 
8.1-12 Estimated Cost of Onsite Disposal of Nuclear Waste

8.2-1 Cost and Dose Reduction Factors . . . . . . 8-20

8.2-2 Decommissioning Staff Labor Costs . . . . . . 8-21

8.3-1 Summary of Health Physics Staff Labor Costs for Decommissioning of an LWR at a Multiple-Reactor

Station

8.3-2 Surmary of Security Force Labor Costs for LWR Decommissioning at a Multiple-Reactor Station

8.3-3 Summary of Net Savings from Incineration of Combustible Radioactive Waste from Reactor Decommissioning . . . 8-29

8.3-4 Summary of Special Tools and Equipment Costs for LWR Decommissioning at a Multiple-Reactor Station

8.3-5 Estimated Cost for Mobile Chemical Decontamination

Equipment for PWR Decomarissioning . . . . . . 8-33

8.3-6 Estimated Costs and Potential Cost Savings Associated with Use of a Central Electropolishing Facility During Decommissioning

8.3-7 Summary of Net Cost Savings Associated with Centra? Decontamination Services During LWR Decommissioning . . 8-35

8.3-8 Summary of Net Savings by Providing Centralized Services - 8-38

8.4-1 Estimated Decommissioning Cost for Light Water Reactors $8-39$

9.0-1 Occupational Radiation Dose for Decommissioning One Reactor - Summary of Differences . . . . . . . 9-1

9.1-1 Estimated Occupational Radiation Doses from Disposal of the Nuclear waste from DECON of the Reference PWR . . . 9-4

9.1-2 Estimated Occupational Radiation Doses from Disposal of the Nuclear Waste from DECON of the Reference BWR . . . 9-5

9.1-3 Estimated Radiation Doses to the Public from Transportation of the Nuclear Waste from Decommissioning a Reactor by $D E C O N$ 
9.1-4 Estimated Occupational Radiation Doses from Disposal of the Nuclear Waste from SAFSTOR of the Reference PWR . . 9-8

9.7-5 Estimated 0ccupational Radiation Doses from Disposal of the Nuclear Waste from SAFSTOR of the Reference BWR . . 9-12

9.1-6 Summary of Occupational Doses from Disposal of Nuclear Waste from SAFSTOR of the Reference PWR . . . . . 9-76

9.7-7 Summary of Occupational Doses from Disposal of Nuclear Waste from SAFSTOR of the Reference BWR . . . . . 9-16

9.1-8 Estimated Radiation Doses to the Public from Transportation of the Nuclear Waste from Decommissioning a Reactor by SAFSTOR

9.1-9 Estimated Occupational Doses from Disposal of the Nuclear Waste from ENTOMB of the Reference PWR . . . 9-18

9.1-10 Estimated 0ccupational Doses from Disposal of the Nuclear Waste from ENTOMB of the Reference BWR . . . 9-19

9.1-11 Estimated Radiation Doses to the Public from Transportation of the Nuclear Waste from Decommissioning a Reactor by ENTOMB . . . . . . . . . . . 9-20

9.1-12 Estimated Transportation 0oses from Disposal of Nuclear Decomissioning Waste . . . . . . . . 9-21

9.2-1 Impact of Site Dedication on Estimated Occupational Radiation Doses from DECON of a PWR . . . . . 9-22

9.2-2 Impact of Site Dedication on Estimated Occupational Radiation Doses from DECON of a BWR . . . . . . 9-22

9.2-3 Impact of Site Dedication on Estimated Occupational Radiation Doses from Preparations for Safe Storage of a PWR . . . . . . . . . . . . 9-23

9.2-4 Impact of Site Dedication on Estimated Occupational Radiation Doses from Preparations for Safe Storage of a BWR. . . . . . . . . . . . . 9-24

9.2-5 Impact of Site Dedication on Estimated Cccupational Radiation Doses from Deferred Decontamination of a PWR . . 9-24

9.2-6 Impact of Site Dedication on Estimated Occupational Radiation Doses from Deferred Decontamination of a BWR . , 9-25 
9.2-7 Estimated Dose Reductions from Decommissioning Several

Reactors of One Type by SAFSTOR . . . . . . 9-25

9.2-8 Impact of Site Dedication on Estimated 0ccupational

Radiation Doses from ENTOMB of a PWR . . . . . 9-26

9.2-9 Impact of Site Dedication on Estimated Occupational

Radiation Doses from ENTOMB of a BWR . . . . . 9-26

9.4-1 Estimated 0ccupational Doses for Decommissioning LWRs . . 9-29

10.1-1 Multiple-Reactor Station Scenario 1 - Decommissioning

Cost Impact

10.1-2 Multiple-Reactor Station Scenario 1 - Impact on

Occupational Radiation Dose from Decommissioning . . 10-4

10.2-1 Multiple-Reactor Station Scenario 2 - Decommissioning

Cost Impact . . . . . . . . . . . 10-6

10.2-2 Multiple-Reactor Station Scenario 2 - Impact on

Occupational Radiation Dose from Decomissioning . . . 10-7

10.3-1 Multiple-Reactor Station Scenario 3 - Decommissioning

Cost Impact

10.3-2 Multiple-Reactor Station Scenario 3 - Impact on

0ccupational Radiation Dose from Decommissioning . . . 10-10

10.4-1 Multiple-Reactor Station Scenario 4a - PWRs -

Decommissioning Cost Impact . . . . . . . 10-12

10.4-2 Multiple-Reactor Station Scenario 4b - BWRs -

Decommissioning Cost Impact . . . . . . . 10-13

10.4-3 Multiple-Reactor Station Scenario 4a - PlWRs -

Impact on 0ccupational Radiation Dose from

Decommissioning

10.4-4 Multiple-Reactor Station Scenario 4b - BWRs Impact on Occupational Radiation Dose from

Decommissioning

$10-15$

10.5-1 Multiple-Reactor Station Scenario 5 - Decommissioning

Cost Impact

10.5-2 Multiple-Reactor Station Scenario 5 - Impact on

Occupational Radiation Dose from Decommissioning . . . 10-18 
11.4-1. Summary of Estimated Costs for Removal of the Intact Reactor Pressure Vessel from the Reference PWR . . ' . 11-14

11.4-2 Summary of Estimated Costs for Removal of the Intact Reactor Pressure Vessel from the Reference BWR. . 17-17

A.1-1 Decay Factors for Radioactivity Levels and Dose fiates of Neutron-Activated Materials in the Reference PliR. . . A-3

A.1-2 PWR Costs for Disposal of Neutron-Activated Materials at Various Times after Shutdown ... . A . A 5

A.1-3 Estimated Costs of Onsite Interim Storage of NeutronActivated Material from DECON of a PWR . . . . . A-9

A.1-4 Estimated Cost of Removal to Offsite Disposal of the Neutron-Activated Material from DECON of a PWR . . . A-10

A.1-5 Estimated Costs of Onsite Interim Storage of Contaminated Material from DECON of a PWR . . . . . . . A-10

A.1-6 Estimated Costs of Removal to Offsite Disposal of the Contaminated Material from DECON of a PWR . . . . A-11

A.1-7 Estimated Costs of Onsite Interim Storage of Radioactive Waste from DECON of a PWR . . . . . . . . . A-12

A.1-8 Estimated Costs of Removal to Offsite Disposal of Radioactive Waste from DECON of a PWR . . . . A-12

A.1-9 Estimated Costs of Onsite Interim Storage of Neutron-Activated Material from Deferred Decontamination of a PWR. . . . . . . . . A-13

A.1-10 Estimated Costs of Removal to Offsite Disposal of Neutron-Activated Material from Deferred Decontamination of a PWR. . . . . . . . A A A A

A.1-1] Estimated Costs of Onsite Interim Storage of Contaminated Material from Deferred Decontamination of a PWR . . . A-15

A.1-12 Estimated Costs of Removal to Offsite Disposal of Contaminated Material from Deferred Decontamination of a PWR. . . . . . . A-15

A.1-13 Estimated Costs of Onsite Interim Storage of Radioactive Waste from Preparations for Safe Storage of a PWR . . . A-16 
A.1-14 Estimated Costs of Removal to Offsite Disposal of Radioactive Waste from Preparations for Safe Storage

A.1-15 Estimated Costs of Onsite Interim Storage of Radioactive Waste from Deferred Decontamination of a PWR.

A.1-16 Estimated Costs of Removal to Offsite Disposal of Radioactive Waste from Deferred Decontamination of a PWR

A.1-17 Estimated Costs of Onsite Interim Storage of the

Reactor Internals from ENTOMB of a PWR . . . . . A-20

A. 1-18 Estimated Costs of Removal to Offsite Disposal of the

Reactor Internals from ENTOMB of a PWR . . . . . A-20

A.1-19 Estimated Costs of Onsite Interim Storage of

Contaminated Material from ENTOMB of a PWR

A. 1-20 Estimated Costs of Removal to Offsite Disposal of

Contaminated Material from ENTOMB of a PWR . . . . A-21

A. 1-21 Decay Factors For Radioactivity Levels and Dose Rates

of Activated Material in the Reference BWR . . . . A-22

A. 1-22 BWR Costs for Disposal of Neutron-Activated Materials at Various Times after Shutdown. . . . . . A-23

A.1-23 Estimated Costs of Onsite Interim Storage of

Neutron-Activated Material from DECON of a BWR . . . A-25

A.1-24 Estimated Costs of Removal to Offsite Disposal of

Neutron-Activated Material from DECON of a BWR . . . . A-26

A. 1-25 Estimated Costs of Onsite Interim Storage of

Contaminated Material from DECON of a BWR . . . . A-26

A.1-26 Estimated Costs of Removal to Offsite Disposal of

Contaminated Material from DECON of a BWR . . . . A-27

A. 1-27 Estimated Cost of Onsite Interim Storage of

Radioactive Waste from DECON of a BWR . . . . . A-27

A.1-28 Estimated Costs of Removal to Offsite Disposal of
Radioactive Waste from DECON of a BWR . . . . . A-28

A.1-29 Estimated Costs of Onsite Interim Storage of

Neutron-Activated Material from Deferred

Decontamination of a $B W R$. 
A. 1-30 Estimated Costs of Removal to Offsite Disposal of Neutron-Activated Material from Deferred

Decontamination of a BWR.

A. 1-31 Estimated Costs of Onsite Interim Storage of

Contaminated Material from Deferred Decontamination

of a BWR

A.1-32 Estimated Costs of Removal to Offsite Disposal of the

Contaminated Material from Deferred Decontamination

of a BWR. . . . . . . . A-32

A.1-33 Estimated Costs of Onsite Interim Storage of Radioactive Waste from Preparations for Safe Storage of a BWR . . . A-32

A. 1-34 Estimated Costs of Removal to Offsite Disposal of

Radioactive Waste from Preparations for Safe Storage

of a BWR

A.1-35 Estimated Costs of Onsite Interim Storage of Radioactive Waste from Deferred Decontamination of a BWR.

A.]-36 Estimated Costs of Removal to Offsite Disposal of Radioactive Waste from Deferred Decontamination of a BWR

A. 1-37 Estimated Costs of Onsite Interim Storage of BWR Reactor Interna]

A.1-38 Estimated Costs of Removal to 0ffsite Disposal of Reactor Internals from ENTOMB of a PWR . . . . . A-36

A.1-39 Estimated Costs of Onsite Interim Storage of Contaminated Material from ENTOMB of a BWR

A.1-40 Estimated Costs of Removal to Offsite Disposal of Contaminated Material from ENTOMB of a BWR . . . . A-37

B.1-1 Health Physics Staff Labor Requirements and Costs for PWR DECON and ENTOMB

B.1-2 Health Physics Staff Labor Requirements and Costs for PWR Preparations for Safe Storage

B.1-3 Health Physics Staff Labor Requirements and Costs for BWR DECON .

B.1-4 Health Physics Staff Labor Requirements and Costs for BWR Preparations for Safe Storage 
B. 1-5 Health Physics Staff Labor Requirements and Costs for BWR ENTOMB (scenario 1) . . . . . . . B-9

B.2-1 Security Force Labor Requirements and Costs for PWR DECON and ENTOMB

B.2-2 Security Force Labor Requirements and Costs for PWR Preparations for Safe Storage.

B.2-3 Security Force Labor Requirements and Costs for PWR Deferred Decontamination. . . . . . . B-13

B.2-4 Security Force Labor Requirements and Costs for BWR DECON

B.2-5 Security Force Labor Requirements and Costs for BWR Preparations for Safe Storage . . . . . . . B-16

B.2-6 Security Force Labor Requirements and Costs for BWR Deferred Decontamination.

B.2-7 Security Force Labor Requirements and Costs for BWR ENTOMB

B.3-1 Annual Costs for Disposal of Dry Combustible Wastes for an Operating LWR

B.3-2 Costs for Disposal of Incinerated Combustible Wastes from Decommissioning

B.3-3 Radiation Dose Reductions Resulting from Incineration of Dry Combustible Wastes from Decommissioning

B.3-4 Surmary of Net Savings and Radiation Dose Reductions for Incineration of Dry Combustible Wastes from LWR Decommissioning

B.4-1 Costs for Special Tools and Equipment for PWR DECON and ENTOMB

B.4-2 Costs for Special Tools and Equipment for PWR Preparations for Safe Storage.

B.4-3 Costs for Special Tools and Equipment for BWR DECON and ENTOM

B.4-4 Costs for Special Tools and Equipment for BWR Preparations for Safe Storage. 
B.4-5 Costs for Mobile Chemical Decontamination Equipment for PWR Decomissioning . . . . . . . . B-40

B.4-6 Mass of Contaminated Stainless Steel Equipment Outside Primary Containment Vessel of the Reference BWR . . . B-43

B.4-7 Estimated Costs and Potential Cost Savings Associated with Use of Central Electropolishing Facility During

Decommissioning . . . . . . . . . B-45

C.1-1 Waste Containers Required for Neutron-Activated

Reactor Components . . . . . . . . C-2

C.1-2 Occupational Doses and Data per Container for slit

Trench Waste Disposal - 1-Year-0ld Waste . . . . C-3

C. 1-3 Occupational Doses and Data per Container for Slit

Trench Waste Relocation after 30 Years . . . . . C-5

C.2-1 Waste Container Requirements for Contaminated and

Radwaste Material . . . . . . . . . C-8

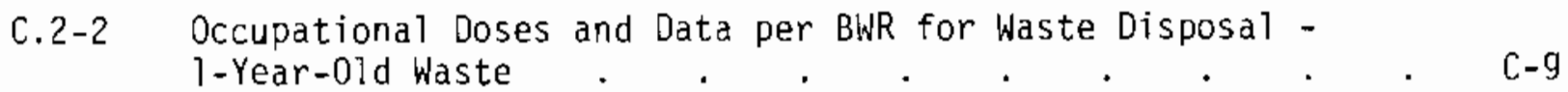

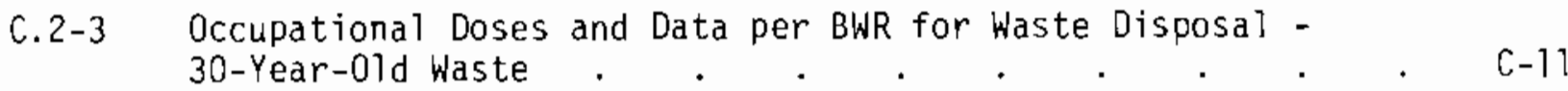




\subsection{INTRODUCTION}

Much attention is being given in the United States today to concerns about nuclear electric power generation. Chief among these concerns are the safe design, construction, and operation of nuclear power reactors and other nuclear fuel-cycle facilities and the safe disposal of nuclear waste.

In its regulatory role, the Nuclear Regulatory Commission (NRC) is developing criteria and standards for decontamination of retired facilities in connection with plant design objer,tives, plant decommissioning, and license terminations. To provide background information for this effort, the NRC is sponsoring a series of studies on the decommissioning of nuclear fuel-cycle facilities.

This report, one in the series, presents the results of a study on decommissioning of reactors at a multiple-reactor nuclear power station. Its objective is to determine the impacts on both safety and cost of decommissioning a nuclear power reactor at a site where other reactors are operating, being built, or being decommissioned, compared with the safety and cost of decomrnissioning a nuclear power reactor at a single-reactor power station. The sensitivities of both safety and cost to onsite versus offsite nuclear waste disposal, number of reactors onsite, availability of onsite central services, and reactor type (PWR or BWR) are examined. Two earlier decommissioning studies in this series provide the principal technical bases for these analyses. $(1,2)$

Several likely scenarios for multiple-reactor nuclear power stations are examined. Decommissioning alternatives studied within these scenarios are DECON (immediate decontamination), SAFSTOR (safe storage followed by deferred decontamination), and ENTOMB (entombment).

(1) R. I. Smith, G. J. Konzek, and W. E. Kennedy, Jr., Technology, Safety and Costs of Decommissioning a Reference Pressurized Water Reactor Power Station, NUREG/CR-0130, U.S. Nuclear Regulatory Commission Report by Pacific NorthWest Laboratory, June 1978.

(2) H. D. Oak, G. M. Holter, W. E. Kennedy, Jr., and G. J. Konzek, Technology, Safety and Costs of Decomissioning a Reference Boiling Water Reactor Power Station, NUREG/CR-0672, U.S. Nuclear Regutatory Comrission Report by Pacific Northwest Laboratory, June 1980. 


\subsection{SUMMARY}

The purpose of this study is to determine the differences in the costs and the associated radiation doses for decommissioning a reactor at a multiplereactor station compared with decommissioning an identical reactor at a singlereactor station. The study results are summarized in this section. This information is intended as background data for use in developing regulations and regulatory guides for decommissioning nuclear reactor power plants.

\subsection{DECOMMISSIONING ALTERNATIVES AND STUDY APPROACH}

Three alternatives for decommissioning the reactors at a multiple-reactor station are studied: DECON, SAFSTOR, and ENTOMB.

- DECON, called immediate dismantlement in previous studies on decommissioning of a PWR and a BWR at a single-reactor station, ${ }^{(1,2)}$ is the prompt removal from the site of all materials containing or contaminated with radionuclides at levels greater than permitted for unrestricted use of the property.

- SAFSTOR, called safe storage followed by deferred dismantlement in the previous LWR decommissioning studies, is the establishment and maintenance of the LWR power plant in a condition that poses an acceptable risk to the public and safely stores the property for as long as desired to allow decay of some of the radioactivity, followed by decontamination of the facility to the unrestricted release level.

- ENTOMB, called entombment in the previous LWR decommissioning studies, is the encasement and maintenance of the nonreleasable radioactive materials in a monolithic structure to ensure retention of the radionuclides until they have decayed to levels that permit unrestricted release of the site.

The sensitivity of the safety and cost to several variables is investigated for each of these decommissioning alternatives. The variables examined are nuclear waste disposal, site dedication to nuclear power generation, 
centralized services, number of reactors at the site, and types of reactors being decommissioned. Cost and radiation doses are estimated for five possible multiple-reactor station scenarios.

\subsection{REGULATORY CONSIDERATIONS FOR DECOMMISSIONING}

Regulations are in place under which decomissioning of nuclear reactor power plants can be covered. In some cases (i.e., security, safeguards, quality assurance) the existing regulations do not speak specifically to the question of decommissioning, but they can readily be interpreted as being applicable.

Areas where more specific guidance could be helpful are:

- Clarification of the criteria defining allowabie levels of contamination and dose rates for unrestricted release of decommissioned nuclear facilities.

- Definition of classes of radioactive waste, to more clearly indicate the acceptable disposition method for the highly radioactive neutronactivated components (i.e., disposal in shallow land burial sites or in deep geologic storage).

- Clarification of the financial qualifications and responsibility for decommissioning, to define the commitments of the facility owner for achieving the final status of unrestricted use of the property.

\subsection{FINANCING OF DECOMMISSIONING}

The NRC is considering the following criter a for evaluation of the effectiveness of alternative decommissioning financing methods:

1. the degree of decomtrissioning assurance provided

2. the cost of providing the assurance

3. the extent to which the consumers of the plant's power equitably share the cost of decommissioning

4. the flexibility to respond to changes in inflation and interest rates, reactor $1 \mathrm{ife}$, and estimated decommissioning costs 
5. the ability to accomodate different ownership and jurisdictional arrangements.

There are three principal financing alternatives for decommissioning a nuclear power station that meet these criteria to varying degrees:

- a prepaid decommissioning reserve controlled by an outside entity

- an internal decommissioning reserve, either funded or unfunded

- a funded reserve or sinking fund controlled by an outside entity.

The problem of providing assurance that adequate funds will be available for decommissioning a nuclear power reactor at a multiple-reactor station after final reactor shutciown is not significantly different from providing that assurance at a single-reactor station. The alternatives for accumulating funds for decommissioning a reactor appear equaliy applicable for a reactor at a single- or multiple-reactor station.

\subsection{MULTIPLE-REACTOR STATION CONCEPTS}

It is more likely that the reactors at a multiple-reactor station with a small number of reactors (i.e., four reactors) will be of the same type and design than it is for a station with a larger number of reactors. However, even at a multiple-reactor station with 10 or 20 reactors, it is probable that there will be several reactors of each type of LWR. Standardization of design gives the following advantages during the decommissioning of several identical reactors at a nuclear power station:

- It minimizes the planning effort for decommissioning the second and later reactors of an identical design.

- It improves the productivity of the decommissioning workers due to the experience gained on the first reactor.

- It improves the planning of decomissioning techniques and permits correction of mistakes.

If a site is dedicated to nuclear power generation, replacement reactors will be constructed on a schedule to result in startup of a replacement reactor just as an old reactor is retired. Such site dedication fosters a stable labor force for construction and decommissioning of the plants. 
Significant savings can be achieved over the construction of a new plant, if structures and systems (other than the nuclear reactor equipment of an old nuclear power plant) are refurbished and reused with a new nuclear steam supply system. Since much of the old nuclear reactor plant would be decontaminated in $\mathrm{place}$ and refurbished for use with a new nuclear reactor, decomrissioning of the old reactor plant would be simpier and less costly.

\subsection{REFERENCE LIGHT WATER REACTORS}

The reference light water reactors are the same as those described in References $I$ and 2. The reference PWR plant is an 1175-MWe (3500-MWt) Westinghouse pressurized water reactor, specifically the Trojan Nuclear Plant at Rainier, Oregon, operated by the Portland General Electric Company. The reference BWR plant is an 1155-MWe (3320-MW't) General Electric boiling water reactor being built by the Washington Public Power Supply Systern; it is designated as the WPPSS Nuclear Project No. 2 and is located near Richland, Washington.

\subsection{IMPACT OF MULTIPLE REACTORS ON DECOMMISSIONING COSTS}

The impact of having more than one reactor at a nuclear reactor power station on the cost of decomissioning one of the reactors is estimated by comparison with costs previously estimated for decommissioning a reactor at a single-reactor power station. Factors experienced in this analysis include several different approaches to disposal of low-level nuclear waste, the dedication of the site to nuclear power generation, the availability of centralized services, and the type and number of reactors present at the station.

Waste Disposal

The three options considered for disposal of the low-level nuclear waste generated while decommissioning a reactor at a multiple-reactor station are:

1. disposal at an offsite licensed low-level waste disposal facility

2. interim onsite storage with transfer to an offsite licensed low-level waste disposal facility at a later date

3. disposal at a permanent onsite low-level nuciear waste disposal facility. 
Decommissioning a single reactor at a multiple-reactor station results in the same quantity of nuclear waste for disposal and the same packaging, transportation and disposal-site handling and burial costs as decommissioning an identical reactor at a single-reactor station. Therefore, there is no impact on the cost of offsite nuclear waste disposal.

Storing nuclear waste from decommissioning onsite for a period of 30 to 100 years before transferring it to a permanent offsite waste disposal facility can result in cost savings. Interim onsite storage of nuclear waste with later permanent disposal offsite involves the following tasks:

- packaging

- transporting to interim onsite storage

- placing in interim storage

- retrieving from interim storage

- transporting to a permanent disposal facility

- placing in a permanent disposal facility.

Three categories of radioactive material, neutron-activated, contaminated, and radwaste, are considered in the nuclear waste disposal cost analyses. Costs of nuclear waste disposal with interim onsite storage are estimated for interim storage periods of 30,50 , and 100 years. Estimates of nuclear waste disposal costs for the three decominissioning alternatives are given in Table 2.6-1. These

TABLE 2.6-1. Summary of Estimated Costs for Interim Onsite Nuclear Waste Storage with Later Removal to Permanent Offsite Disposal

\begin{tabular}{|c|c|c|c|c|c|c|c|c|c|}
\hline \multirow[b]{3}{*}{$\begin{array}{l}\text { Decommissioning } \\
\text { Alternative }\end{array}$} & \multirow{3}{*}{$\begin{array}{l}\text { Safe } \\
\text { Storage } \\
\text { Period } \\
\text { (years) }\end{array}$} & \multicolumn{8}{|c|}{ Nuciear Waste Disposal Cost (s thousands) (d) } \\
\hline & & \multirow{2}{*}{\multicolumn{2}{|c|}{$\begin{array}{c}\text { Immediate } \\
\text { Offsite Disposal }\end{array}$}} & \multicolumn{3}{|r|}{ Interim Onsit } & \multicolumn{2}{|c|}{ Naste Storage } & \multirow[b]{2}{*}{$\underline{100 \mathrm{yr}^{(\mathrm{b}, \mathrm{c})}}$} \\
\hline & & & & $30 \mathrm{yr}(\mathrm{b}, \mathrm{c})$ & $\begin{array}{c}\text { PWR } \\
50 y r^{\{b, c\}}\end{array}$ & $100 y^{(b, c)}$ & $30 y r^{7 b}, c T$ & $\begin{array}{l}-B W R \\
50 y r(b, c)\end{array}$ & \\
\hline \multirow[t]{2}{*}{ DECON } & 0 & 10762 & 10850 & 12810 & 8550 & S530 & 11360 & 6970 & 6900 \\
\hline & 30 & 10790 & 10850 & 8280 & 8190 & 8160 & 7120 & 5335 & 6280 \\
\hline \multirow[t]{2}{*}{ SAFSTOR } & 50 & 4270 & 4700 & 3450 & 3370 & 3340 & 1900 & 1690 & 650 \\
\hline & 100 & 4230 & 4620 & 3400 & 3314 & 3300 & 1650 & 1490 & 1460 \\
\hline ENTOMB & 0 & 4580 & 7140 & 3390 & 2840 & 2820 & 6000 & 6010 & 3930 \\
\hline
\end{tabular}

(a) Costs are given in 1978 dollars and include a 25 contingency.

(b) Duration of the interim onsite waste storage period.

(c) Includes cost of placement of waste in interim onsite storage plus cost of removal at a later date to permanent offsite disposai. 
costs include a $25 \%$ contingency and are given in 1978 dollars for easy comparability with cost estimates in the previous PNL reactor decommissioning studies. $(1,2)$ With the exception of 30-year interim onsite storage of the nuclear waste from DECON, all of the nuclear waste disposal costs were reduced by using interim onsite storage of the nuclear waste, compared with immediate offsite disposal.

Factors that contribute to lower costs for onsite waste disposal than for offsite waste disposal are:

- lower transportation costs because of the short haul to the disposal site

- no overweight charges, since all travel is over private roads

- no relief driver charges, since only one driver is needed

- shielded cask liners may not be needed for some of the activated material, since the DOT maximum surface dose rate may be exceeded during travel over private roads.

Estimated nuclear waste disposal costs for permanent onsite disposal of the nuclear waste from decommissioning a PWR and a BWR are given in Table 2.6-2 for DECON, SAFSTOR, and ENTOMB. The costs of disposal at an offsite nuclear waste disposal facility are also given for comparison. All of the costs are in 1978 dollars and include a $25 \%$ contingency. Significant cost reductions are estimated in every instance. The estimated savings from using the different nuclear waste disposal options are summarized in Table 2.6-3.

TABLE 2.6-2. Surmary of Estimated Costs for Permanent Onsite Nuclear Waste Disposal

\begin{tabular}{|c|c|c|c|c|c|c|c|c|c|c|}
\hline \multirow{3}{*}{$\begin{array}{l}\text { Disposal } \\
\text { Location }\end{array}$} & \multicolumn{10}{|c|}{ Cost of Waste Disposal ( $\$$ thousands) $(a)$} \\
\hline & \multicolumn{2}{|c|}{ DECON } & \multicolumn{3}{|c|}{ PWR } & \multicolumn{3}{|c|}{ BWR } & \multicolumn{2}{|c|}{ ENTOMB } \\
\hline & PWR & $B$ BWR & $30 \mathrm{yr}^{(\mathrm{b})}$ & $50 \mathrm{yr}^{(b)}$ & $100 \mathrm{yr}^{(b)}$ & $30 \mathrm{yr}^{(b)}$ & $50 y^{(b)}$ & $100 \mathrm{yr}^{(\mathrm{b})}$ & PWR & $\overline{\mathrm{B}} \mathrm{WR}$ \\
\hline Offsite & 10760 & 10850 & 10990 & 4460 & 4400 & 10850 & 4700 & 4620 & 4580 & 7140 \\
\hline Onsite & 7050 & 5240 & $7 \quad 120$ & 2660 & 2660 & 5420 & 1070 & 940 & 1980 & 2700 \\
\hline Cost Reduction & 3710 & 5610 & 3870 & 1790 & 1740 & 5430 & 3630 & 3680 & 2600 & 4440 \\
\hline
\end{tabular}

(a) Costs are given in 1978 dollars and inciude a $25 \%$ contingency.

(b) Duration of safe storage period. 
TABLE 2.6-3. Summary of Estimated Nuclear Waste Disposal Cost Reductions at a Multiple-Reactor Station

\begin{tabular}{|c|c|c|c|c|c|c|}
\hline \multirow[b]{3}{*}{ Waste Disposal Option } & \multicolumn{6}{|c|}{ Cost Reductions ( $\$$ thousands) $(a)$} \\
\hline & \multicolumn{2}{|c|}{ DECON } & \multicolumn{2}{|c|}{ SAFSTOR $^{(b)}$} & \multicolumn{2}{|c|}{ ENTOMB } \\
\hline & PWR & BWR & $\overline{\mathrm{PWR}}$ & & $\overline{P W R}$ & $B W R$ \\
\hline \multicolumn{7}{|c|}{ Interim Onsite Storage for: ${ }^{(c)}$} \\
\hline 30 years & $(2050)^{(d)}$ & $(510)^{(d)}$ & 2510 & 3730 & 1190 & 1140 \\
\hline 50 years & 2210 & 3880 & 2600 & 4520 & 1740 & 3130 \\
\hline 700 years & 2230 & 3950 & 2630 & 4570 & 1760 & 3270 \\
\hline Permanent Onsite Disposal & 3710 & 5610 & 3870 & 5430 & 2600 & 4440 \\
\hline
\end{tabular}

(a) A $25 \%$ contingency is included in a 11 cost differences. Costs are in 7978 dollars.

(b) For deferred decontamination after 30 years of safe storage.

(c) Interim storage costs include costs of placement in interim onsite storage and removal to offsite disposa?.

(d) Parentheses indicate a cost increase.

\section{Site Dedication}

Dedication of a site to nuclear power generation results in replacement reactors being constructed on a schedule to achieve startup of a replacement reactor as an old reactor is shut down. At such dedicated sites, either relatively long periods of construction activity will occur periodically or there will be continuous construction activity at the site if the startup of the reactors is spaced to occur over a 30-year period.

Dedication of a multiple-reactor site to nuclear power generation:

- fosters stable operating and construction labor forces

- favors the establishment of interim onsite low-level waste storage or permanent onsite low-level waste disposal

- results in improved efficiency of construction and decommissioning as management and the labor force accumulate onsite experience

- encourages the provision of centralized services. 
It is expected that the efficiency of decommissioning the reactors at a multiplereactor station will improve after the first reactor is decommissioned due to the learning process. Cost and dose reduction factors are estimated using the following assumptions:

1. The reduction factor for planning and preparation for the second and each succeeding reactor of a particular type (PWR or BWR) is 0.50 .

2. The reduction factor for decommissioning operations for the second reactor of a particular type is 0.95 .

3. The reduction factor for decommissioning operations for the third and each succeeding reactor of a particular type is 0.90 .

Centralized Services

A number of centralized services that may be available at a multiplereactor station are:

- health physics services

- security forces

- solid waste processing

- equipment decontamination services

- maintenance shops and services

- laundry services

- transportation services

- central stores.

Centralized health physics services and a stiation-wide central security force could significantly reduce the cost of providing these services. The cost reductions derive largely from:

- the reduced staff overhead for each of these services

- the reduced peak-load staffing requirements per reactor, by providing a pool of personnel for each service.

In the decommissioning studies of the reference $P W R(1)$ and the reference $B R^{(2)}$ at single-reactor stations, it was assumed that the dry solid radioactive waste was mechanically compacted to achieve a five-fold volume reduction. 
A central waste incinerator at a multiple-reactor station can further reduce the volume of combustible radioactive waste by at least a factor of 5 , giving an overall volume reduction factor of 25 . Such an incinerator can yield significant reductions in waste disposal costs for both the operating and decommisioning phases of reactor life. The savings from using the incinerator, with capita? and operating costs considered, compared to merely compacting the combustible radioactive waste, are 65 to $70 \%$ of the compacted waste disposal cost for the PWR and 55 to $70 \%$ for the BWR.

Equipment decontamination services can be more fully utilized at a multiplereactor station than at a single-reactor station. The severa? types of equipment decontamination services considered are:

- decontamination of special tools and equipment used for decomissioning, allowing maintenance and reuse of these items

- mobile decontamination systems for in-situ chemical decontamination of piping and components

- central electropolishing and chemical decontamination facilities for improved decontamination of piping sections and components.

Development work on decontamination of metals by electropolishing indicates that much of the contaminated metal in piping and vessels at a nuclear power plant can be salvaged and sold for scrap. Electropolishing is an effective process for decontaminating piping, valves, and other equipment for refurbishment and reuse. Salvage of releasable decontaminated stainless steel, assuming $80 \%$ recovery, represents the largest component of the savings from the use of central decontamination services when decommissioning a PWR. For decomissioning a BWR, the decontamination and refurbishment of special tools and equipment for reuse generates most of the savings from the use of central decontamination services.

Central laundry services, central transportation services, and central stores provide a convenience for the operating and decomissioning phases of reactor $l i f e$ at a multiple-reactor station, but they do not generate significant savings during reactor decomissioning.

The savings from use of central services are sumarized in Table 2.6-4. 
TABLE 2.6-4. Sumnary of Cost Reductions Resulting from Centralized Services at a Muttiple-Reactor Station

\begin{tabular}{|c|c|c|c|c|c|c|}
\hline \multirow[b]{3}{*}{ Central Service } & \multicolumn{6}{|c|}{ Cost Reductions ( $\$$ thousands) $(\mathrm{a})$} \\
\hline & \multicolumn{2}{|c|}{ DECON } & \multicolumn{2}{|c|}{ 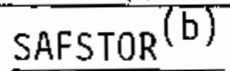 } & \multicolumn{2}{|c|}{ ENTOMB } \\
\hline & PWR & $B W R$ & $\mathrm{PWR}$ & $B W R$ & $\overline{P W R}$ & $B W R$ \\
\hline Radiation Monitoring & 580 & 770 & 900 & 1320 & 580 & 820 \\
\hline Security & 570 & 650 & 1010 & 1330 & 570 & 760 \\
\hline Solid Waste Proc & 170 & 280 & 180 & 320 & 170 & 280 \\
\hline Equipment Decontamination & 1420 & 1750 & 1430 & 1800 & 1420 & 1750 \\
\hline
\end{tabular}

(a) A $25 \%$ contingency is included in all cost differences. Costs are in 1978 dollars.

(b) For deferred decontamination after 30 years of safe storage.

Type of Reactor

The differences in the estimated decommissioning costs for PWRs and BWRs given in studies for single-reactor stations $(1,2)$ are also experienced in decommissioning reactors at a multiple-reactor station. Decommissioning costs for PWRs are impacted to about the same extent as for BWRs when costs at a multiplereactor station are compared to costs at a single-reactor station.

Number of Reactors

The number of reactors at a multiple-reactor station influences how the nuclear waste is disposed of, whether there is a continuing stable construction labor force, and whether, or which, centralized services are provided. With a smail number of reactors at the station, it is not likely that nuclear waste couid be disposed of onsite. It is also improbable that centralized services would be provided; however, special decommissioning tools and equipment probably would be shared. Improvement and economies in planning the decommissioning of successive reactors would be realized for a few as well as many reactors at a multiple-reactor station. If only a few reactors are located at the station, the continuing stability of the labor force would not be assured. Therefore, there would not be a continuing availability of experienced decommissioning workers. 


\subsection{IMPACT OF MULTIPLE REACTORS ON RADIATION DOSE}

The same factors examined in the cost analysis are considered in estimating the impact on the occupational and public radiation doses from decommissioning a reactor at a multiple-reactor station. Occupational radiation dose impacts consider the doses received by the decommissioning workers at the reactor plant, the transportation workers, and the burial ground workers. The impacts on the occupational doses of waste disposal options, site dedication, and centralized services are given in Table 2.7-1. The impacts on the public radiation doses of these same factors are given in Table 2.7-2.

TABLE 2.7-1. Summary of Estimated Occupational Radiation Dose Reductions from Decommissioning One Reactor at a Multiple-vs. a Single-Reactor Station $\frac{\text { Factor }}{\frac{\text { Waste Disposal }}{\text { Interim Onsite Storage for: }}}$

Occupational Radiation Dose Reductions (man-rem)

30 years
50 years
100 years
Permanent Onsite Disposal
Dedication $(\mathrm{c})$

$\begin{array}{cccccc}(72)^{(b)} & (47)^{(b)} & 74 & 68 & (6)^{(b)} & (33) \\ 72 & 55 & 77 & 87 & 12 & 26 \\ 75 & 60 & 78 & 88 & 13 & 29 \\ 90 & 101 & 90 & 101 & 23 & 67\end{array}$

\section{Site Dedication (c)}

Centralized Services

$75 \quad 129$

$21 \quad 29 \quad 65$

ENTOMB

\footnotetext{
(a) For preparations for safe storage and deferred decontamination after 30 years of safe s corage.

(b) Parentheses indicate a dose increase.

(c) For a multiple-reactor station with five reactors of one type.
} 
IABLE 2.7-2. Summary of the Estimated Public Radiation Dose Reductions from Decommissioning One Reactor at a Multiple-vs, a Single-Reactor Station

Public Radiation Dose Reductions

Factor

$\frac{\text { (man-rem) }}{\frac{\text { DECON }}{\text { PWR }}} \frac{\text { SAFSTOR }}{\text { BWR }} \frac{\text { ENTOMB }}{\text { PWR BWR }}$

\section{Waste Disposal}

Interim Onsite Storage for:

30 years

50 years

$\begin{array}{rrrrrr}3 & 5 & 18 & 17 & 1 & <? \\ 18 & 19 & 18 & 20 & 3 & 7 \\ 18 & 19 & 1 B & 20 & 3 & 7\end{array}$

Centralized Services

(a) For preparations for safe storage and deferred decontamination after 30 years of safe storage.

\subsection{MULTIPLE-REACTOR STATION DECOMMISSIONING SCENARIOS}

Five scenarios for multiple-reactor stations are investigated to determine the impact of the variables discussed in Subsection 2.6 on decommissioning costs and safety. These variables, the number of reactors at the station, the type of reactors, the nuclear waste disposal option, the dedication of the site to nuclear power generation, and the provision of central services are varied for the different scenarios. Details of the five scenarios are indicaied in Figure 2.8-1.

Scenarios 1 and 2 are for 4 -reactor stations and scenarios 3, 4, and 5 are for 10-reactor stations. Scenario 2 does not have a site dedicated to nuclear power generation, while the other four scenarios are at dedicated sites. Scenarios 4 and 5 are at dedicated sites with certral facilities and have either interim onsite nuclear waste storage or permanent onsite nuclear waste disposal.

Summaries of the decommissioning costs for the five scenarios and the decommissioning cost reductions compared to single-reactor station decommissioning 


\begin{tabular}{|c|c|c|c|c|c|c|c|c|c|c|c|c|}
\hline \multirow{3}{*}{$\begin{array}{c}\text { SCENARIO } \\
\text { NUMBER }\end{array}$} & \multirow{3}{*}{$\begin{array}{c}\text { NUMBER } \\
\text { Of } \\
\text { REACTORS }\end{array}$} & \multirow{2}{*}{\multicolumn{2}{|c|}{$\begin{array}{l}\text { TYPE OF } \\
\text { REACTOR }\end{array}$}} & \multicolumn{2}{|c|}{ RETIRED AFTER 40 YR } & \multirow{2}{*}{\multicolumn{2}{|c|}{$\begin{array}{l}\text { OLD REACTOR } \\
\text { REPLACED }\end{array}$}} & \multicolumn{3}{|c|}{ WASIE DISPOSAL. } & \multirow{2}{*}{\multicolumn{2}{|c|}{$\begin{array}{l}\text { CENTRAL } \\
\text { FACILITIES }\end{array}$}} \\
\hline & & & & \multirow{2}{*}{$\begin{array}{l}\text { I REACTOR } \\
\text { EVERY } 2 \text { YR }\end{array}$} & \multirow{2}{*}{$\begin{array}{l}\text { 1 REACTOR } \\
\text { EVERY } 4 Y R\end{array}$} & & & \multirow{2}{*}{$\begin{array}{l}\text { IMUEDIATE } \\
\text { OFFSIIE }\end{array}$} & \multirow{2}{*}{$\begin{array}{l}\text { ONSIIE } \\
\text { INTERIM } \\
\text { STORAGE }\end{array}$} & \multirow{2}{*}{$\begin{array}{c}\text { ONSITE } \\
\text { PERMANENT } \\
\text { DISPOSAL }\end{array}$} & & \\
\hline & & PWR & BWR & & & VES & & & & & YES & NÖ \\
\hline 1 & 4 & $x$ & & $x$ & & $x$ & & & $x$ & & & $x$ \\
\hline 2 & 4 & & $x$ & & $x$ & & $x$ & $x$ & & & & $x$ \\
\hline 3 & 10 & $x$ & $x$ & & $x$ & $x$ & & $x$ & & & & $x$ \\
\hline 4 & 10 & $x$ & $x$ & & $x$ & $x$ & & & $x$ & & $x$ & \\
\hline 5 & 10 & $x$ & $x$ & $x$ & & $x$ & & & & $x$ & $x$ & \\
\hline
\end{tabular}

FIGURE 2.8-1. Mutiple-Reactor Station Scenarios

costs are given in Table 2.8-1. Except for Scenario T (interim onsite nuclear waste storage for 30 years), the estimated decommissioning costs at a multiplereactor station are reduced, compared to single-reactor stations.

Table 2.8-2 gives a summary of the estimated occupational radiation doses for decommissioning one reactor at the multiple-reactor stations of the five scenarios. The dose reductions compared to the occupational doses for decommissioning a reactor at a single-reactor station are also given.

\subsection{FACILITATION OF DECOMMISSIONING}

The several alternatives or techniques for facilitating the decomissioning of nuclear power plants that are discussed are: improved documentation, improved access, substitution and purification of materials, design of the biological shield for easy removal, improved protection of concrete, improved removal of concrete, special shielded maintenance shop, improved shielding for maintenance and decomissioning, remote maintenance and decommissioning, and special tools and techniques. All of these alternatives and techniques are equally applicabie to reactors at single- or multiple-reactor stations.

Features of multiple-reactor station operation such as site dedication, onsite waste storage or disposal, and provision of centralized services are decominsioning facilitation options in and of themselves. 
TABLE 2.8-1. Summary of the Estimated Costs for Multiple-Reactor Station Decommissioning Scenarios

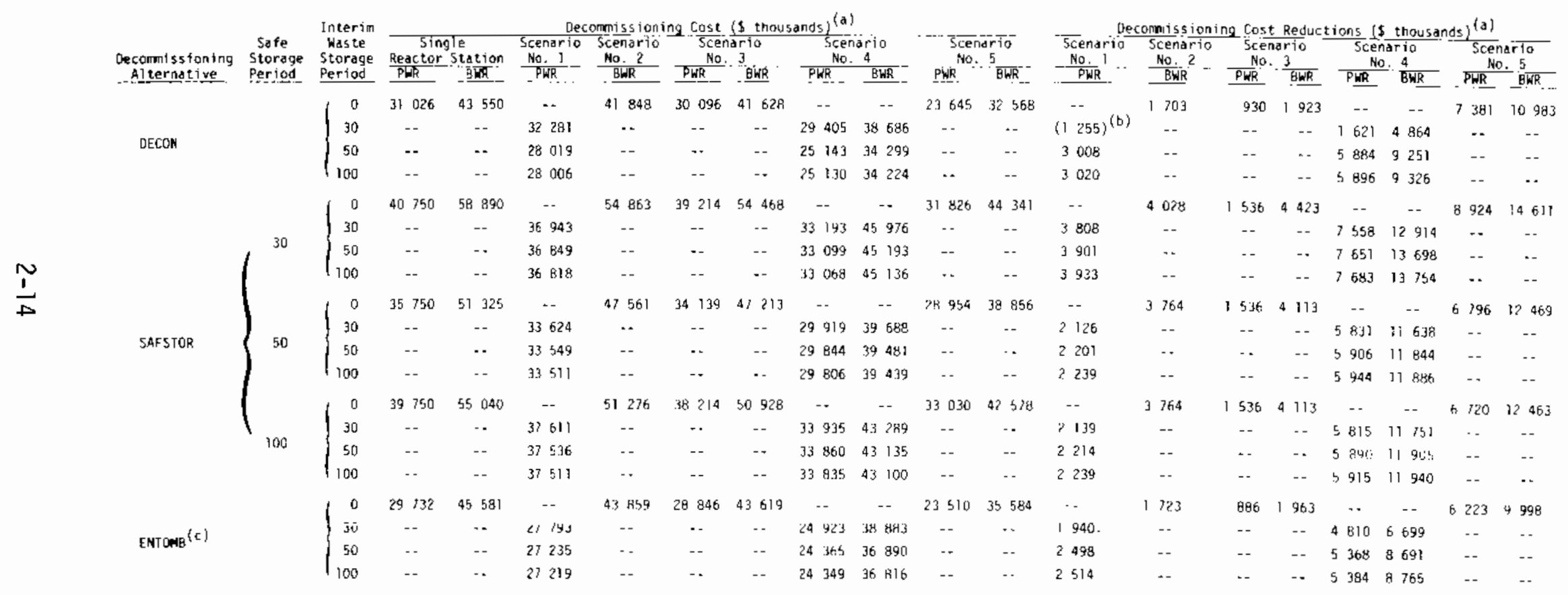

(a) Costs given in 1979 dallars and include a 25? contingency.

(c) These estimates include no costs that may be assaciated with final actions necessary for termination of the :icense. 
TABLE 2.8-2. Summary of the Estimated Occupational Radiation Doses for Multiple-Reactor Station Decommissioning Scenarios

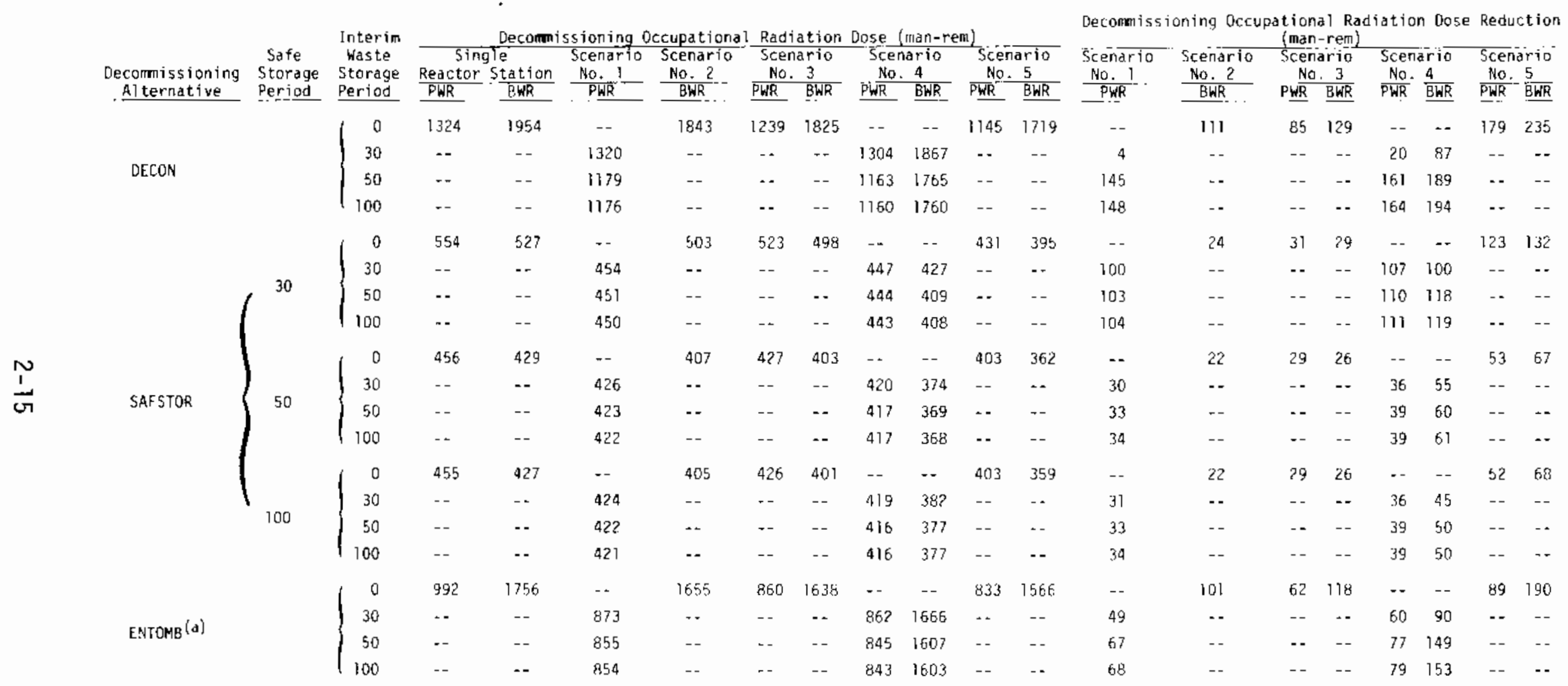

(a) These estimates do not include any doses that may be associated with actions necessary for the temination 
One of the alternatives for reactor retirement is conversion to a new nuclear- or fossil-fueled steam supply system. Reuse of those facilities at a nuclear power station that can be refurbished makes good economic sense. Based on capital cost studies for PWRs ${ }^{(3)}$ and BWRs, ${ }^{(4)}$ the structures and equipment other than the nuclear steam supply system account for about $70 \%$ of the initial direct construction cost. Analyses of removing the old reactor vessel and replacing it with a new vessel indicate that such action is feasible, but difficult, in the reference PWR and BWR nuclear power plants. Removal of a reactor vessel intact for disposal is also feasible but is generally more costly in terms of money and radiation dose than segmentation and disposal of the vesser.

Design features that should be incorporated to facilitate the removal or replacement of the reactor pressure vessel and other large equipment pieces are:

- an equipment hatch in the reactor containment building large enough to accommodate the intact reactor pressure vessel

- an equipment hatch located so that there is sufficient lay-down area in front of it, both in the containment building and in the adjacent building, so that the reactor vessel can be lined up with the hatch

- adequate supports in the containment building to handle the special cranes needed for very heavy loads such as the reactor pressure vessel and steam generators

- a readily removable roof section in the fuel building of a PWR and in the reactor building of a BWR that is large enough to accommodate the reactor pressure vessel

- an inner shield of modular design that can be removed and/or replaced.

\subsection{CONCLUSIONS}

Decommissioning of a PWR or BWR at a multiple-reactor station probably will be less costly and result in lower radiation doses than decommissioning of an 
identical reactor at a single-reactor station. Regardless of whether the light water reactor being decommissioned is at a single- or multiple-reactor station:

- the estimated occupational radiation dose for decommissioning an LWR is lowest for SAFSTOR and highest for DECON

- the estimated cost of decommissioning a PWR is lowest for ENTOMB (a) and highest for SAFSTOR

- the estimated cost of decommissioning a BWR is lowest for DECON and highest for SAFSTOR.

Decommissioning costs and occupational radiation doses for the two types of reactors are impacted in about the same way by the factors studied at multiplereactor stations. In determining if there is a cost advantage for decommissioning nuclear reactors at a multiple-reactor station versus a single-reactor station, the type of reactor, PWR or BWR, has little influence on the result.

The number of reactors at a multiple-reactor station may influence the availability of interim onsite nuclear waste storage, permanent onsite nuclear waste storage, or centralized services. Four or more reactors of a single type, along with dedication of the site to nuclear power generation, can lead to a relatively stable construction labor force and, with successive decommissioning of the reactors, lead to improvements in the efficiency of planning and execution of the decommissioning activities.

Interim onsite nuclear waste storage with later relocation to permanent offsite disposal or permanent onsite nuclear waste disposal can contribute to reduced decommissioning costs and occupational doses.

Providing centralized services, particularly health physics services, security force, central waste incineration, central equipment decontamination facilities, and special maintenance services can reduce decommissioning costs. of the central services studied, oniy waste volume reduction by incineration yields a significant reduction of the occupational radiation dose.

(a) ENTOMB cost estimates do not include the costs that may be associated with actions required for termination of the license. 


\section{REFERENCES}

1. R. I. Smith, G. J. Konzek and W. E. Kennedy, Ur., Technology, Safety and Costs of Decommissioning a Reference Pressurized Water Reactor Power Station, NUREG/CR-0130, U.S. Nuclear Regulatory Commission Report by Pacifjc Northwest Laboratory, June 1978.

2. H. D. Oak, G. M. Holter, W. E. Kennedy, Jr. and G. J. Konzek, Technology, Safety, and Costs of Decommissioning a Reference Boiling Water Reactor Power Station, NUREG/CR-0672, U.S. Nuclear Regulatory Commission Report by Pacific Northwest Laboratory, June 1980.

3. Capital Cost: Pressurized Water Reactor Plant, prepared for the U.S. Nuclear ReguTatory Commission and the Energy Resed "ch and Development Administration by United Engineers and Constructors, Inc., NUREG-0241, June 1977.

4. Capital Cost: Boiling Water Reactor Plant, prepared for the U.S. Nuclear ReguTatory Commission and the Energy Research and Oevelopment Administration by United Engineers and Constructors, Inc., NUREG-0242, June 1977. 


\subsection{DECOMMISSIONING: ALTERNATIVES, CONSIDERATIONS, AND STUDY APPROACH}

Once a nuclear reactor reaches the end of its useful life, it must be placed in a condition that assures that the impact of the facility upon public health and safety will be within acceptable bounds; achieving this condition is termed "decommissioning." Conditions that satisfy the requirements of decommissioning range from 1) minimal cleanup and subsequent physical security under licensing restrictions to 2) complete cleanup and removal of all radioactivity and release of the piant from all licensing restrictions. Aiternatives for decommissioning are discussed in Section 3.1; considerations for decommissioning are discussed in Section 3.2; and the approach taken for this study is discussed in Section 3.3.

\section{1 DECOHMISSIONING ALTERNATIVES}

Three alternatives available for decommissioning a nuclear power station are: DECON, immediate decontamination; SAFSTOR, safe storage followed by deferred decontamination; and ENTOMB, entombment. (a) Each of these alternatives is defined and discussed in the following subsections.

Before starting decommissioning by any of the three alternatives, the facility operating license may be amended to authorize possession but not operation of the facility. (3)

\section{$3.1 .1 \quad$ DECON}

DECON is the prompt removal from the site of all materials containing or contaminated with radionuclides at levels greater than permitted for unrestricted use of the property. Under present regulatory requirements, DECON is the only decommissioning alternative that allows termination of the facility license in a short time period. Demolition and removal of the decontaminated and uncontaminated structures, following DECON, is at the option of the owner and local government agencies.

(a) The terms "immediate decontanination" and "deferred decontamination" used in this study are the current terms for "immediate dismantlement" and "deferred dismantlement" used in the previous decommissioning studies of a PWR and a BWR at a single-reactor station. $(1,2)$ 
DECON meets the requirements for termination of the facility operating license and renders the LWR facility and site available for unrestricted use within a short pericd of time following final reactor shutdown. In this decommissioning alternative, large commitments of money (in a relatively short time frame), personnel radiation exposure, and disposal site space are made in exchange for prompt availability of the facility and site for other purposes. Additional considerations include the elimination of continuing security, maintenance, and surveiliance requirements (i.e., for SAFSTOR or ENTOMB), and the availability of the facility operations staff to form a decommissioning work force that is highly knowledgeable about the facility. Early termination of the license also satisfies the desirable objective of minimizing the number of sites dedicated to radioactive material storage.

\section{1 .2 SAFSTOR}

SAFSTOR is the establishment and maintenance of the reference LWR power station in a condition that poses an acceptable risk to the public and safely stores the property to allow decay of some of the radioactivity, followed by decontamination of the facility to an unrestricted level. Since materials having radioactivity levels above unrestricted release levels are still onsite, the amended nuclear license remains in force throughout the safe storage period.

Two categories ${ }^{(a)}$ of safe storage are possible:

- Custodial safe storage - minimum cleanup and decontamination is made and preventive maintenance of life-support and protection systems is performed to prepare the facility. The storage period requires fulltime, onsite surveillance crews to maintain the structure, the operating equipment, and the security of the property.

- Passive safe storage - comprehensive cleanup and decontamination sufficient to allow shutdown of all plant systems and installation of strong security barriers and remotely monitored electronic surveillance systems constitute the facility preparations. The storage period requirements include maintenance of structural integrity and prevention of intrusion into the facility.

(a) In this study, we consider only passive SAFSTOR, which is referred to only as "SAFSTOR." 
SAFSTOR satisfies the requirements for protection of the public while minimizing, to various degrees, the initial commitments of time, money, occupational radiation exposure, and waste disposal space. This advantage is offset by the need to maintain the amended nuclear license, by the associated restrictions placed on the use of the property, and by the increase in the number of sites dedicated to storage of radioactive materials. This approach requires continuing physical security, surveillance, and maintenance of structural integrity sufficient to ensure public protection. The level of security necessary will depend on the type and quantity of nuclear materials left and the safeguards needs of adjacent units with common "vital areas."

A storage period of 50 years makes possible a large reduction in personnel exposure and a decrease in the need for remote or shielded operations while removing the remaining radioactive material to make the property available for unrestricted use. However, the neutron activation products ${ }^{59} \mathrm{Ni}$ and ${ }^{94} \mathrm{Nb}$ in the reactor internals will not have decayed to acceptable levels even after a storage period of 100 years. Therefore, eventual dismantlement of at least the activated reactor components will be necessary to achieve a level of radioactivity that can meet the criteria for unrestricted use of the facility and termination of the possession-only license.

Deferred decontamination includes whatever actions are required at the end of a period of continuing care to teminate the licensee's amended nuclear 1 icense and to release the property for unrestricted use. Some disassembiy and disposal of activated components are still required, but the personnel radiation exposure and the disposal-site space requirements are potentially diminished. Deferred decontamination cannot, however, rely on the facility operations staff for personnel familiar with the facility.

\section{1 .3 ENTOHB}

ENTOMB is the encasement and maintenance of nonreleasable radioactive materials in a monolithic structure of concrete or other structural material. The structure should be sufficiently strong and long-lived to ensure retention of the radionuclides until they have decayed to levels that permit unrestricted release of the site. Depending on the approach taken, the entombment period can range from about 100 years to many thousands of years. 
ENTOMB is similar in nature to SAFSTOR in that it also consists of a period of facility and site preparation followed by a period of continuing care that includes security, surveillance, and maintenance activities. The level of security necessary will depend on the type and quantity of nuclear materials left and the safeguards needs of adjacent units with comon "vital areas." ENTOMB also requires the amended nuclear license to remain in force. The facility and site preparations include comprehensive cleanup and decontamination of equipment and structures outside of the entombment structure and confinement of nonreleasable materials within the monolithic structure. Continuing care activities are minimal.

Two approaches to ENTOMB are possible: 1) the reactor vessel internals, which have extremely long-lived radioactivity, are removed and shipped to a nuclear waste depository and 2) the reactor vessel internals are left in place. In each case, as much of the contaminated equipment from outside the entombment structure as can be stored in the entombment structure is moved there. In the first case, because of the relatively short half-lives of the entombed radioactivity, it may be possible, without dismantling the structure, to terminate the amended nuclear 1 icense and release the entombment structure for unrestricted use after a continuing care period of about 110 years. (However, present regulations and regulatory guidance do not allow such action without a comprehensive survey to establish that radioactive contamination is within acceptable release limits.) In the second case, existing regulations require the amended nuclear license to remain in force for an indefinite period of continuing care, unless the reactor vessel internais are removed at a later date.

When it becomes desirable to terminate the amended nuclear license for ENTOMB, dismantling of the entombment structure may be required in the first entombment approach and is required in the second approach. This represents a task that is much more difficult than dismantling the unentombed facility, since the entombment structure is built to endure for a long period of time. Therefore, the second approach to ENTOMB, and perhaps the first approach also, must be viewed as an almost irreversible commitment to long-term maintenance of the amended nuclear Ticense. However, dismantiement of the entombment structure is not impossible, only very difficult. 


\subsection{CONSIDERATIONS FOR DECOMMISSIONING}

Many considerations must be taken into account in choosing the appropriate decomissioning alternative for a specific situation. This section deals with many of the considerations in qualitative terms according to the following broad categories: economic, licensing, societal, safety, and schedule. It must be recognized that these cateogories are highly interrelated, but the interrelationships are only alluded to here.

\subsubsection{Economic}

While safety during decommissioning is the principal concern of the NRC, economic matters are probably the foremost consideration to stockholders (if a private utility), customers, utility managements, and utility rate conmissions. The following factors that control the economics of decommissioning are discussed:

- property utilization potential

- staffing

- radioactive material disposition

- waste disposal capabilities

- planning and preparation requirements

- taxation

- license and insurance fees

- funding availability.

\subsubsection{Property Utilization Potentia]}

The potential use of the deactivated plant is a principal economic concern. The site is certified for industrial purposes, and the structures and systems are licensed for nuclear power production. As such, they represent a significan investment in time and money. Although retrofitting of some auxiliary systems may be necessary to meet the extant licensing requirements, refurbishing of the primary systems to meet code requirements could facilitate the reactivation of the facility for power production.

However, if reactivation is not desirable or is not possible, use of the property for other purposes should be studied. The results could dictate the decommissioning alternative selected. 


\subsubsection{Staffing}

The availability of a sufficient number of properly trained and skilled personnel is a significant cost factor in decomissioning. For decomnissioning activities that commence immediately following final reactor shutdown, it is desirable to draw the personnel from the ranks of the plant operating staff. These personnel are very familiar with the structures, systems, radiation work procedures, and specific areas of radiation exposure potential. Specifically, supervisory personnel, health physics personnel, maintenance craft personnel, and personnel trained in conventional decontamination methods and in the operation of the systems required during decommissioning should be recruited prior to plant shutdown. The supervisory personnel are largely responsible for formulating the plans and making the preparations for decommissioning and, therefore, should be available to begin these duties approximately 2 years before plant shutdown. The other personnel should be available as necessary to augment the planning and preparation effort, to become trained in the operation of any special decommissioning equipment, and, then, to implement the plans.

Personnel transferred from el sewhere within the company or hired from outside labor poois will probably require training in radiation work procedures, as well as in special equipment operation, and this will constitute an added expense.

For decommissioning activities performed a significant length of time after final reactor shutdown, personnel must be selected from elsewhere with in the company or from the outside labor pool; however, at a multiple-reactor station there may be personnel available who are familiar with the reactor plant. Again, training becomes a cost factor. Alternatively, the job could be contracted with a firm that specializes in decommissioning work.

\subsubsection{Radioactive Material Disposition}

Two factors pertaining to radioactive material disposition help determine the cost of decommissioning. They are: 1) the amounts and kinds of radioactive materials on the property when decommissioning activities proceed and 2) the existing regulatory requirements concerning personnel radiation exposure, unrestricted release levels, and radioactive material handling and 
disposal. These factors directly affect the following aspects: decontamination and decommissioning procedures, packaging and transportation procedures, and time requirements for implementation. These aspects, in turn, help determine the kind, number, utilization, and efficiency of staff personnel.

\subsubsection{Nuclear Waste Disposal Capabilities}

A current major concern of nuclear facility owners is the availability of nuclear waste disposal sites. (4) It is still unclear whether components containing long-lived radioactivity in high concentrations, removed from, in, and around the reactor vessel, will require deep geologic disposal or only shallowland burial.

Another area of concern in this respect is the location and accessibility of operable nuclear waste disposal sites. The cost of shipping decommissioning wastes to disposal sites is determined in part by the distance traveled and in part by requirements imposed by states through which the radioactive materials must travel.

Although federal agencies dominate the regulatory process in the shipment of radioactive materials, state highway departments regulate gross vehicle weights and dimensions, as well as some other aspects of radioactive shipments. Currently, about half of the states have adopted the DOT Hazardous Materials Regulations to cover intrastate radioactive materials shipments. In addition, several states have adopted or proposed additional regulations for other aspects of radioactive materials shipments. $(5,6)$ These aspects include:

- special routing

- advance notification for shipments of large quantities

- state inspections of some types

- prohibition of certain types

- prior approval

- requirements of exclusive-use vehicles

- use of pilot vehicles

- speed restrictions

- specific hours of movement

- accompaniment of all shipments by radiation monitoring personnel. 
The variation of regulations between adjacent states often requires special considerations for interstate shipments.

There is a potential conflict between some of the proposed state laws and the provisions of the National Transportation Act of 1974 (Public Law 93-633, signed in 1975). This law prohibits states from adopting laws or regulations more stringent than federal regulations unless state regulations improve transportation safety. Even in this case, such rules can be adopted only if they do not unreasonably burden commerce.

\subsubsection{Planning and Preparation Requirements}

The cost of preparing the detailed decomissioning plans, the technical specifications, the safety analyses, and the documentation may be different for each of the decommissioning alternatives and should be considered. For example, a comprehensive decomissioning plan is required for DECON and ENTOMB, but for the first phase of SAFSTOR (preparations for safe storage), a somewhat less comprehensive initial plan maybe acceptable. A complete decommissioning plan is required prior to deferred decontamination (the final phase of SAFSTOR).

\subsubsection{Taxation}

A factor that could have considerable influence on the choice of alternative and time frame for decommissioning is the way that the facility is viewed by the local taxing authorities for property tax purposes. For example, it is possible that the plant in SAFSTOR or ENTOMB could be taxed at one of the following values: 1) an operating plant, 2) unimproved land, or 3) the land and structures minus the expected additional decomissioning costs (since the retired plant is a negative asset). The first alternative (which is unlikely) would force DECON of the plant, since the accumulated tax costs would, in a few years, exceed the cost of DECON. The third approach wou'd reduce the taxes to a very nominal amount, since the additional decommissioning costs could exceed the value of the land and structures. In practice, the tax rate will be negotiated between the local tax assessor and the plant owner. It will likely be based on a combination of the second and third situations given above, with land outside the exclusion area assessed at a value comparable with adjacent similar property and property within the exclusion area assessed at essentially zero value. Since 
the outer area of the site may be released for unrestricted use when the reactor has been placed in safe storage or entombment, it may be put to productive use to pay its property taxes.

\subsubsection{License and Insurance Fees}

Other economic factors that could have a role in determining the decommissioning alternative are the costs of licensing and the costs of nuclear liability insurance. Both, as presently applied, require a significant initial outlay and then diminish as the amount of residual radioactivity is reduced.

Licensing fees are required for amending the facility operating license to allow possession but not operation of the facility. Thereafter, inspection fees are levied based on the NRC inspection requirements. Presently, while any spent fuel remains on the site, safeguards inspections must continue as during operation. In addition, annua? health, safety, and environmental inspections must continue until the amended nuclear license is terminated.

The cost of nuclear liability insurance depends on the level of coverage required by the NRC as proof of financial protection during decommissioning. If the level must remain the same regardless of the plant condition, timely termination of the possession-only iicense is desirable.

\subsubsection{Funding Availability}

As with all projects, there are certain fixed costs during decommissioning (i.e., salaries, services, utilities, and maintenance) that continue once the project begins, regardless of the progress made towards project completion. If insufficient funding delays decommissioning activities, these fixed costs, plus the effect of inflation over the delay period, increase the overall decommissioning cost. Therefore, it is important that sufficient funds are available to complete the planned decommissioning activities as scheduled.

\subsubsection{Licensing}

Licensing in the nuclear industry is basically a question of responsibility for the protection of the workers and the public from undue exposure to regulated radioactive materials. In this respect, an organization is licensable only 
as it can demonstrate a continued ability and willingness to abide by the license requirements imposed by the NRC. Once the license is granted, the licensee agrees to accept the associated responsibilities until such time as the license is terminated (or transferred to another licensed organization, as allowed by regulation).

Termination of an amended nuclear license $i s$ conditional on the removai and proper disposal of nonreleasable radioactive materials. While the higher occupational exposure from DECON is undesirable, the requirements and responsibilities of maintaining the license may overshadow the exposure aspect and make this a)ternative desirable. The dynamic nature of government regulation may also make termination of the license desirable.

Another aspect of 1 icensing that must be considered is the license duration and the license renewal process and cost. Licenses are presently subject to a 40-year time 1 imit, at which time they must be renewed. The renewal review requirements comprise financial, safety, and environmental considerations similar to those for a license amendment situation. The costs of documenting these considerations and the NRC review costs for each required license renewal must be taken into account when choosing the decommissioning alternative.

\subsubsection{Societal}

Another consideration is that of public acceptance of the long-term presence of a retired facility. There is a reasonable probability that once the plant is no longer providing tax revenue and payroll to the community, the public may view the single-reactor station structures as an eyesore, a perceived hazard, or, at the least, an unproductive use of an otherwise useful site. Thus, pressures may mount for the removal of the retired structures. At a multiple-reactor station such public pressure could be less, or nonexistent, since the shutdown facility is located with other operating nuclear power reactors. While it is beyond the scope of this study to evaluate the likelihood of this concern, the plant owner should sample local public opinion on this question well in advance of setting his plans for decommissioning.

In the same vein, the NRC presently desires to minimize the number of sites permanently committed to the containment of radioactive materials. Removal and 
disposal of the reactor vessel internals is the only method whereby this desire can be fulfilled for the reference LWRs, even in the long run. Existing regulations allow the various decomissioning alternatives that are detailed in Section 3.1. But regulations are dynamic in nature and are subject to societal pressures; and, even though new regulations or changes to present regulations may never forbid the use of a particular decommissioning alternative, they could discourage or make impractical its use.

\section{2 .4 Safety}

Radiological, industrial, and environmental safety play an important role in decommissioning. Each is regulated by the federal government or the state government, or both, to provide the amount of protection from hazards that is deemed necessary. The selected decommissioning approach should provide the required safety for the workers and for the public, and should have minimal adverse impact on the environment.

\subsubsection{Radiological Safety}

In decommissioning an LWR, ${ }^{60} \mathrm{Co}$ is the prime contributor to the total accumulated occupational radiation dose. It appears as activated corrosion product contamination in and on equipment and structural surfaces and as an activation product in structural materials in and around the reactor vessel. Each decommissioning alternative results in a different accumulated occupational dose because of different exposure requirements.

Dose rates throughout the plant, largely determined by the amount and decay of ${ }^{60} \mathrm{Co}$, decay to approximately $10 \%$ of the original shutdown values after about 17.5 years and $1 \%$ after about 35 years, assuming no decontamination. Therefore, deferring the major decommissioning activity by even 17.5 years decreases the accumulated occupational dose. The reduction depends on the required decommissioning activities prior to that point in time and those necessary to complete the license-termination process. Relatively little reduction in total accumulated occupational dose is assumed to result from deferring decontamination beyond 30 years after placing a PWR in safe storage (Reference 1, P. 11-21). This is also assumed to be the case for a BWR (Reference 2, p. 11-15). 


\subsubsection{Industrial Safety}

Hazardous situations having the potential for occupational injuries and fatalities will arise during normal activities of each decommissioning alternative. The quantity and severity of occurrences associated with a given decommissioning alternative depend on the kinds of activities performed and the manpower and time requirements for that alternative. As with every industrial operation, proper industrial safety practices during decommissioning will minimize accidents.

\subsubsection{Environmental Safety}

Many of the environmental effects of plant operation will also be evident during decommissioning, but in most cases at greatly diminished levels. The environmental effects that pertain to decommissioning are radiation exposure, liquid and airborne radioactive release, and solid radwaste disposal. No thermal discharge is required during decommissioning except, perhaps, that associated with operation of an auxiliary boiler.

At final shutdown of a reference LWR, large volumes of water requiring disposal are present throughout the plant. Some of these volumes are in presumably noncontaminated systems and, after sampling, can be released directly to the environs via the blowdown line. Others, notably those contained in the spent fuel pool, the reactor vessel, etc., are contaminated in varying degrees and may require processing through the liquid radwaste system prior to discharge.

Airborne radioactive releases that result from normal decommissioning activities are smali in comparison to normal plant operation. (1) of the various decommissioning alternatives, SAFSTOR releases the least amount of airborne radioactivity, since much radioactivity has decayed by the start of deferred decontamination.

DECON generates the largest amount of solid radioactive wastes that must be placed in a licensed disposal facility. ENTOMB produces less, al though the entombed structure becomes a waste disposal site, and SAFSTOR (including deferred decontamination), the least. The major environmental impact of solid radioactive waste disposal is the land area that must be comitted to 
this activity. In addition, shipping these wastes to the disposal site produces the normal transportation noises, exhaust noises, exhaust fumes, and radiation doses .

\section{2 .5 Schedule}

A large percentage of the facility decommissioning cost is a fixed level of expenditure that is associated with the time span of the work rather than with the specific tasks. Therefore, the optimum schedule for any decommissioning alternative is one where the total time involved is the time required to efficiently complete the longest sequence of tasks. This dictates the necessary length of time (the critical path) to complete the entire job, and all other work should be completed within this time span. An optimum-sized, welltrained staff is essential: too many or too few people, as well as undertrained people, hamper the efficient completion of the work, thus increasing both the total cost and the total accumulated occupational radiation exposure. As previously discussed, insufficient funding to complete the work within the criticalpath time span also drives these totals upward.

\subsection{STUDY APPROACH}

The study identifies and quantifies the different technologies and the impacts on safety and costs of decomissioning a nuclear power reactor at a multiple-reactor site as compared to a single-reactor site. For each of the three decomissioning alternatives, DECON, SAFSTOR, and ENTOMB, the sensitivity of the safety and cost to several variables is expiored. Five scenarios for multiple-reactor stations are investigated. Detailed decommissioning analyses for a PWR and a BWR are presented in NUREG/CR-0130(1) and NUREG/CR-0672, (2) respectively, and provide the bases for the sensitivity analyses. These detailed analyses are not repeated in this study.

\subsubsection{Variables}

At a multiple-reactor site some facilities may be shared and some services may be centralized for more economical reactor operation. These and other variables are discussed in the following subsections. 


\subsubsection{Nuclear Waste Disposal}

Nuclear waste disposal is the major contributor to the public radiation dose from decommissioning a nuclear reactor and is a significant item in the decomrnissioning cost. In the studies of decommissioning LWRs at single-reactor stations, disposal of nuclear waste was considered only at an offsite, licensed nuclear waste disposal facility. Variations considered in this study include temporary onsite storage of nuclear waste, with eventual removal to a licensed disposal site, and permanent onsite disposal of low-level nuclear waste.

\subsubsection{Site Dedication}

Whether or not the site is dedicated to nuclear electric energy production can have an impact on the safety and cost of decommissioning of reactors. If the site is dedicated to nuclear generation of electricity, construction of the replacement reactor will be completed before final shutdown of the old reactor. The effect of the presence of the construction forces on the available skilled labor pool for the decommissioning crew is explored. Rotation of construction craftsmen between new reactor construction and decommissioning could help keep individual radiation exposures within regulatory limits, with minimal financial impact.

\subsubsection{Centralized Services}

Onsite, centralized services available during decomissioning of a reactor could facilitate the decommissioning program. Centralized services that may be available onsite are safety, security, fire protection, radiation monitoring, laundry, facjlities and personnel for decontamination, central shops, and transportation.

\subsubsection{Number of Reactors Onsite}

The number of reactors onsite will probably have a direct bearing on the extent of centralized services provided. In this study, sites with four and ten reactors are considered. Several nuclear reactor stations with three reactors are in operation at this time and other stations are planned for four reactors. Several studies of nuclear energy centers have concluded that centers containing 10 to 20 or more nuclear reactors are technically feasibie. (7-9) 


\subsubsection{Type of Reactor Being Decommissioned}

The impact of whether the reactor being decommissioned is a PWR or a BWR is investigated. The PNL decommissioning studies of a PWR ${ }^{(1)}$ and of a BWR ${ }^{(2)}$ show that there are differences in occupational exposure and cost for the two reactor types; in this study, however, the only effect of reactor type explored is that of the differences between decommissioning a reactor at a single-reactor site and at a multiple-reactor site.

\subsubsection{Multiple-Reactor Station Scenarios}

The five scenarios investigated for multiple-reactor stations are described below:

Scenario No. 1

- 4 reactors onsite

- only pressurized water reactors are located onsite

- after 40 years of operation of the oldest reactor, one reactor is shut down every 2 years

- a replacement reactor is started up as each old reactor is shut down

- nuclear waste is temporarily stored onsite and moved later to an offsite, licensed disposal facility

- central facibities are not provided onsite. Scenario No. 2

- 4 reactors onsite

- only boiling water reactors are located onsite

- after 40 years of operation of the oldest reactor, one reactor is shut down every 4 years

- the shutdown reactor is not replaced

- nuclear waste is sent to an offsite, licensed disposal facility

- central facilities are not provided onsite. 


\section{Scenario No. 3}

- 70 reactors onsite

- both PWR and BWR reactors are located onsite

- after 40 years of operation of the oldest reactor, one reactor is shut down every 4 years

- a replacement reactor is started up as each old reactor is shut down

- nuclear waste is sent to an offsite, licensed disposal facility

- central facilities are not provided onsite.

Scenario No. 4

- 10 reactors onsite

- both PWR and BWR reactors are located onsite

- after 40 years of operation of the oldest reactor, one reactor is shut down every 4 years

- a replacement reactor is started up as each old reactor is shut down

- nuclear waste is temporarily stored onsite and moved later to an offsite, licensed disposal facility

- central facilities are provided onsite. Scenario No. 5

- 10 reactors onsite

- both PWR and BWR reactors are located onsite

- after 40 years of operation of the oldest reactor, one reactor is shut down every 2 years

- a replacement reactor is started up as each old reactor is shut down

- low-level nuclear waste is disposed of onsite

- central facilities are provided onsite. 


\section{REFERENCES}

1. R. I. Smith, G. J. Konzek and W. E. Kennedy, Jr., Technology, Safety and Costs of Decommissioning a Reference Pressurized water Reactor Power Station, NUREG/CR-0130, U.S. Nuclear Regulatory Comission Report by Pacific Northwest Laboratory, June 1978.

2. H. D. Oak, G. M. Holter, W. E. Kennedy, Jr and G. J. Konzek, Technology, Safety, and Costs of Decommissioning a Reference Boiling Water Reactor Power Station, NUREG/CR-0672, U.S. Nuclear Regulatory Commission Report by Pacific Northwest Laboratory, June 1980.

3. Regulatory Guide 1.86, Termination of Operating Licenses for Nuclear Reactors, U.S. Atomic Energy Commission, June 1974.

4. L. C. Owen, "Current Solid Radwaste Concerns," Trans. Am. Nucl. Soc. 30:557, November 1978.

5. C. K. Beck, "Intergovernmental Relationships in the Transport of Radioactive Materials," Proceedings of the Second Annual Legislative Workshop, CONF-730588, Oak Ridge, Tennessee, May 1973.

6. W. A. Brobst, "The State of State Regulations," Proceedings of the 4th International Symposium on Packaging and Transportation of Radioactive Material, CONF-840901, Miami Beach, FTorida, September 1974.

7. Nuclear Energy Center Site Survey - 1975, U.S. Nuclear Regulatory Commission, NUREG-000T-ES, January 1974.

8. H. Harty, The Hanford Nuclear Energy Center, a Conceptual Study, PNL-2640, Pacific Northwest Laboratory, Richland, Washington, September 1978.

9. C. C. Burwell, M. J. Ohanian and A. M. Weinberg, "A Siting Poticy for an Acceptable Nuclear Future," Science, 204:1043-1051, 1979. 



\subsection{REGULATORY CONSIDERATIONS FOR DECOMMISSIONING}

Decommissioning of a nuclear reactor power plant must be accomplished in compliance with the applicable regulations, guides, and standards. In this section, current regulations, guides, and standards that apply to decomissioning a nuclear power reactor are cited. In addition, currently developing Nuclear Regulatory Commission (NRC) decommissioning policy is discussed.

Regulations and guidelines for nuclear facility decomissioning are dynamic. National policy relating to decomissioning of LWRs is changing, and new regulations are forthcoming. The NRC is developing a more explicit overall policy for decomissioning nuclear facilities. (1)

A comprehensive review and analysis of current regulations related to decommissioning of 1 icensed nuclear facilities was completed by Schilling, et ar., (2) and detailed discussions of the regulations and guides that apply to decomissioning PWRs and BWRs are given in References 3 and 4.

\subsection{CURRENT FEDERAL REGULATIDNS AND GUIDES}

Several references to decommissioning are contained in Titie 10 code of Federal Regulations (10 CFR). These references are:

- 10 CFR 50.33(f) ${ }^{(a)}$ - relates to the financial qualifications of the applicant for a license to construct, operate, and shut down and maintain the facility in a safe condition.

- 10 CFR 50.82 - outlines information and procedures necessary for the termination of any type of facility license.

- 10 CFR 51 - pertains to Jicensing and regulatory policy and procedures for environmental protection. Section 51.5(b)(7) provides guidance for determining whether an environmental impact statement is needed for decommissioning a nuclear facility.

Regulatory Guide 1.86, Termination of Operating Licenses for Nuclear Reactors, amplifies 10 CFR 50.82 and describes the acceptable decommissioning alternatives as well as the methods for satisfying 10 CFR 50.82 .

(a) Abbreviation for Section 50.33(f) of Title 30, Code of Federal Regulations, Part 50 (typical). 
A number of other federal regulations contain requirements that must be complied with during the decomissioning of a nuclear power plant. The following regulations contain requirements that are applicable to decommissioning a nuclear reactor:

10 CFR Part 19. Notices, Instructions, and Reports to Workers; Inspections

10 CFR Part 20. Standards for Protection Against Radiation

10 CFR Part 30. Rules of General Applicability to Domestic Licensing of Byproduct Material

10 CFR Part $40 . \quad$ Domestic Licensing of Source Material

10 CFR Part 51. Licensing and Regulatory Policy and Procedures for Environmental Protectior.

10 CFR Part $70 . \quad$ Domestic Licensing of Special Nuciear Material

10 CFR Part 71. Packaging of Radioactive Material for Transport and Transportation of Radioactive Material Under Certain Conditions

10 CFR Part 73. Physical Protection of Plants and Materials

10 CFR Part 140 . Financial Protection Requirements and Indemnity Agreements

10 CFR Part 150. Exemption and Continued Regulatory Authority in Agreement States Under Section 274

10 CFR Part 170. Fees for Facilities and Material Licenses and Other Reguiatory Services Under the Atomic Energy Act of 1954, As Amended

40 CFR Part 190. Environmental Protection Agency. Environmental Radiation Protection Standards for Nuclear Power Operation

49 CFR Parts 170- Department of Transportation. Hazardous Material 199 Regulations 
The following NRC Regulatory Guides are perceived to provide generic guidance for activities undertaken in decommissioning a nuclear reactor power plant:

1.8 Personnel Qualification and Training

1.16 Reporting of Operating Information

1.17 Protection of Nuclear Power Plants Against Industrial Sabotage

1.143 Design Guidance for Radioactive Waste Management Systems, Structtures, and Components Installed in Light-Water-Cooled Nuciear Power Plants

4.2 Preparation of Environmental Reports for Nuclear Power Stations

8.2 Guide for Administrative Practices in Radiation Monitoring

8.3 Film Badge Performance Criteria

8.4 Direct-Reading and Indirect-Reading Pocket Dosimeters

8.6 Standard Test Procedures for Geiger-Müller Counters

8.8 Information Relevent to Ensuring that Occupational Radiation Exposures at Nuclear Power Stations will be as Low As Reasonably Achievable

8.9 Acceptable Concepts, Mode1s, Equations, and Assumptions for a Bioassay Program

8.10 Operating Philosophy for Maintaining Occupational Radiation Exposure As Low As Reasonably Achievable

Several American National Standards Institute standards that are perceived applicable are:

ANSI N13.12 Control of Radioactive Surface Contamination of Material, Equipment, and Facilities to be Released for Uncontrolled Use 

ANSI N18.7-1972 Standards for Administrative Control of Nuclear Power Plants
ANSI 288.2-1969 Procedures for Respiratory Protection

\subsection{MAJOR REGULATORY CONSIDERATIONS}

At the end of the useful 1 ife of a nuclear power reactor, prompt termination of the NRC license is a desired objective. Removal of the radioactivity to levels permitting unrestricted use of the facility and site is mandatory for full license termination. Present policy and regulatory guidance that addresses nuclear facility decommissioning is not specific enough to adequately effect this objective in a manner consistent with protection of the public health and safety. (5) The NRC is currently reevaluating its policy on decommissioning of nuclear facilities, $(1,6,7)$ and its draft generic environmental impact statement on decormissioning, issued in January 1981, conciudes that the major adverse environmental impact of decommissioning is the commitment of small amounts of land for waste burial in exchange for reuse of the facility for other nuclear or nonnuclear purposes. (5) 


\section{REFERENCES}

1. Plan for Reevaluation of NRC Policy on Decommissioning of Nuclear Facilities, NUREG-0436, Revision 1, Office of Standards Development, U.S. Nuclear Regulatory Commission, December 1978.

2. A. H. Schilling, et al., Decomissioning Commercial Nuclear Facilities: A Review and Analysis of Current Regulations, NUREG/CR-0671, U.S. Nuclear Regulatory Comission Report by Pacific Northwest Laboratory and Battelle Human Affairs Research Centers, August 1979.

3. R. I. Smith, G. J. Konzek and W. E. Kennedy, Jr., Technology, Safety and Costs of Decommissioning a Reference Pressurized Water Reactor Power Station, NÜRE/CR-0130, U.S. Nuclear Regulatory Comission Report by Pacific Northwest Laboratory, June 1978.

4. H. D. Oak, et a1., Technology, Safety, and Costs of Decommissioning a Reference Boiling water Reactor Power Station, NUREG/CR-0672, U.S. Nuclear Regulatory Commission Report by Pacific Northwest Laboratory, June 1980.

5. Draft Generic Environmental Impact Statement on Decomissioning of Nuclear Facilities, NUREG-0586, U.S. Nuclear Regulatory Commission, January 1981.

6. G. D. Calkins, Plan for Reevaluation of NRC Policy on Decommissioning of Nuclear Facilities, NUREG-0436, Revision 1, Supplement 1, U.S. Nuclear Regulatory Commission, August 1980.

7. G. D. Calkins, Draft Thoughts on Regulation Changes for Decomissioning, NUREG-0590, U.S. Nuclear ReguTatory Commission, Rev. 2, August 1980. 



\subsection{FINANCING OF DECOMMISSIONING}

Alternatives for providing funds for decommissioning a nuclear power station are discussed in this section. This discussion is offered to hightight current regulatory approaches to funding decommissioning and NRC thinking on the subject.

Both federal and state governments have a responsibility to protect the health and safety of their citizens. In connection with this responsibility, a state in which a nuclear power plant is located is concerned that the operating utility has sufficient funds to decommission the plant after shutdown and that funds are available for unexpected contingencies during both plant operation and plant decommissioning. If the utility defaults or goes bankrupt, the state may have to assume financial responsibility for decommissioning.

Before the Three Mile Island accident two factors were presumed to provide a reasonably high degree of certainty that a utility will be financially capable of decommissioning a nuclear power plant. First, utilities generally have significant assets and, because of their regulated monopoly status, are allowed to recover their expenses and earn a reasonable return on their capital investment. Second, public-interest considerations relating to utilities' essential services to society suggest that a utility would not be allowed to become insolvent except in very rare instances. The very heavy financial strain on the Metropolitan Edison Company following the accident at TMI-2 is cause for further consideration of this presumption. For certain non-investor-owned utilities able to set their own rates (e.g., certain municipal utilities), the argument against insolvency is especially convincing. Nevertheiess, some form of financial assurance for decommissioning ma" be desirable. First, since most nuclear power plants are expected to operate 30 to 40 years and uitimate decommissioning may be delayed 50 to 100 years following final shutdown, predicting the financial stability of the utility involved is uncertain at best. Second, the utility may postpone decommissioning because it has no direct economic incentive to decommission a shutdown plant. Finally, a severe accident such as occurred 
at TMI-2 may financially cripple even a large, well-insured utility. For these reasons, steps need to be taken to ensure that funds are available for decommissioning.

\subsection{ALTERNATIVES FOR PROVIDING DECOMMISSIONING FUNDS}

The eventual cost of decommissioning should be considered as much a part of nuclear power generation costs as is the construction cost or cost of fuel, and decomissioning cost should be borne equitably by the consumers of the power produced during plant operation.

The NRC is considering five criteria to evaluate the relative effectiveness of alternative decommissioning financing methods. (1) These criteria are:

1. the degree of assurance provided that funds will be available

2. the cost of providing the assurance

3. the extent to which the consumers of the plant's power equitably share the costs of decommissioning

4. the flexibility to respond to changes in inflation and interest rates, reactor $1 \mathrm{ife}$, and estimated decomissioning costs

5. the ability to accommodate different ownership and jurisdictional arrangements.

Criterion 1 is considered most important; criteria 2 and 3 are next in importance; and criteria 4 and 5 must be met for a financing alternative to receive further consideration. (1)

There are three principal financing alternatives for decommissioning a nuclear power station that satisfy the above criteria to varying degrees:

- a prepaid decommissioning reserve controlled by an outside entity

- an internal deconanissioning reserve, either funded or unfunded

- a funded reserve or sinking fund controlled by an outside entity.

Combinations of these alternatives can also be used. These alternatives are discussed in the following subsections. A fourth alternative, payment of 
decommissioning costs from utility revenues when the funds are required, is considered in less detail because it fails to meet criteria 1 and 3 . 0ther alternatives, such as bonding or insurance pools, are considered briefly, principally in regard to decommissioning after a premature shutdown.

\subsubsection{Prepaid Decommissioning Reserve}

This alternative involves payment of the total expected decommissioning cost (in year-of-startup dollars) to an outside entity prior to the start of operations at the nuclear power plant. The funds remain completely outside the control of the utility during the operating lifetime of the plant. The outside entity invests and manages the funds until needed for decommissioning. No states are known to now use this financing approach.

Ideally, the outside entity would be an agency of the state. This arrangement not only provides stability in the care and management of the funds but could also provide a significant tax advantage. The Internal Revenue Service does not tax income accruing to the government of any political subdivision of the U.S. (2)

The prepayment financing alternative meets the five-selection criteria reasonably well. Of the three discussed financing alternatives, this alternative provides the greatest assurance that decommissioning funds will be available. If the fund is not subject to federal taxes, the return realized could exceed the utility's after-tax cost of capital, suggesting that the consumer may benefit more by having the funds in an outside escrow account than by having the funds reinvested in the utility's capital structure. This approach is equitable to electricity consumers because the revenues to recover the prepaid expense are collected over the entire operating life of the plant. The prepaid financing approach seems to satisfy criterion 5 and can satisfy criterion 4 as long as the responsible regulatory agency has the power to direct the utility to make future payments to the fund if estimated decomissioning costs escaiate faster than the fund's return on investment.

\subsubsection{Internal Unfunded Decommissioning Reserve}

An internal unfunded decommissioning reserve is the approach more prevalent in states with nuclear power plants. The most common procedure is to add the 
estimated cost of decommissioning as a negative salvage value to the original cost of the plant. Each year, the utility credits an unfunded reserve for decomissioning from operating revenues. At the end of the plant's operating life, the total accumulated negative salvage value depreciation is to equal the estimated cost of decommissioning (in year-of-startup dollars).

For investor-owned utilities, the recovery of future decommissioning expenses is complicated by federal tax regulations. Revenues collected for the decommissioning reserve are considered as taxable income. (3) However, the expense of decommissioning is presently not deductible until it is incurred (i.e., after plant shutdown). (4) Conceptually, the revenue requirements for this financing approach can be set so the sum of the after-tax revenues each year, compounded at the utility's after-tax cost of capital, provide the required after-tax decommissioning funds.

The chief disadvantage of the internal decomissioning reserve is the relative lack of decomissioning assurance as compared to the other two financing options, particularly with respect to premature decomissioning. From a cost and equity standpoint, it is difficult to generalize conclusions since the analysis is quite dependent both on taxing ard accounting practices and on financial assumptions. A principal advantage of this approach is that it fits easily into existing rate-making practices and does not require a new entity to oversee or manage the decominissioning funds.

\section{1 .3 Sinking Fund Payment to an Outside Escrow Account}

Under this financing option, the utility makes periodic payments to an outside escrow account, where the funds are invested in securities unti] they are needed for decommissioning. At least one state, Pennsylvania, has adopted this financing method.

If the escrow account is managed by a state agency, there is a good possibility that the income generated by the escrow account will not be subject to federal income taxes. It may also be possible to structure the account so an investor-owned utjlity's payments can be made from untaxed revenue. (1) If the escrow payment is not taxed, the utility's annual revenue requirement is simply equal to the annual payment. 
This approach seems to satisfy all five evaluation criteria reasonably wel1. It provides the flexibility needed to meet criteria 4 and 5 , It provides reasonable assurance of the availability of decommissioning funds, with the principal risk being that a plant may be shut down prematurely before adequate funds are collected. This approach is reasonably equitable, and payments to the fund can fluctuate with inflation so consumers are paying for decomissioning in dollars of constant purchasing power. The relative cost of this alternative is subject to assumptions on tax, accounting, and financial practices.

\subsubsection{Payment from Revenue when Needed}

Under this option, the utility takes no action until the funds are needed for decommissioning. At that time, the decommissioning costs are paid out of current revenues and decomissioning costs are treated as an allowable expense.

This option has the same disadvantage as the internal reserve option, a relative lack of assurance that the funds will be available. It has the additional disadvantage that the costs will be borne by people who do not benefit from the plant's operation.

\subsection{FINANCIAL PROVISIONS FOR PREMATURE PLANT SHUTDOWN}

Only the first alternative provides assurance that there will be adequate funds to pay for decommissioning if the nuclear power plant is shut down prematurely. Several options are available to reduce this risk of unavailability of funds in the event of premature shutdown. These include one or more of the options discussed below.

\subsubsection{Large Initial Payment}

The principal advantage of a large initial payment to a sinking fund prior to plant startup is the increased assurance it provides for meeting decommissioning costs. The principal disadvantage is the possibility of financial hardship on the utility, as under the prepayment funding alternative. A lesser disadvantage is the potential for inequitable distribution of decomissioning costs among the power consumers. 


\subsubsection{Higher Initial Sinking Fund Payments}

The advantages and disadvantages of higher per-unit payments (in constantvalue dollars) to a sinking fund during the early years of plant operation are comparable to those of the large-initial-payment option. This option's main advantage is the added assurance that adequate funds are available for decommissioning in the event of premature shutdown. A disadvantage is that power consumers during the early years will pay a disproportionate share of the decommissioning expenses.

\section{2 .3 Surety Bond}

A surety bond posted by the utility has two advantages. First, it is potentially manageable (less burdensome) for a small company that is unable to make a large initial cash payment. Second, it distributes decommissioning costs to the power consumers more equitably than a large initial cash payment.

\subsubsection{Decommissioning Insurance Pool}

This option for ensuring adequate premature decommissioning funding requires utilities (and operators of other nuclear fuel-cycie facilities) to make payments into a decommissioning insurance pool. The pool is obligated to pay for the decommissioning of a facility if the operator defauits. One problem with this option is the setting of appropriate premiums. To establish premiums, the pool administrator is required to estimate the likelihood of nonperformance or partial performance and the magnitude of the fund required to offset anticipated funding shortfalls. Another problem is the possibility that a decommissioning insurance pool might have to be established by the federal government, requiring congressional action.

\subsection{DECOMMISSIONING FUNDING AT A MULTIPLE-REACTOR STATION}

The problem of providing assurance that adequate funds will be available for decommissioning a nuclear power reactor after final shutdown is not significantiy different for a reactor at a multiple-reactor station than it is for a reactor at a single-reactor station. The alternatives for accumulating funds for decommissioning, discussed above in Subsection 5.1, are equally 
applicable for a reactor at a single- or multiple-reactor station. This is particularly true for reactors that operate for the full design lifetime of about 40 years.

Assuring that adequate funds are available for decommissioning a reactor that is prematurely shut down has received increased attention in the last few years. Several options available for reducing the risk that there will be insufficient funds are discussed above in Subsection 5.2. If several, or ali, of the reactors at a multiple-reactor station are owned by one utility, the funds accumulated for decomissioning the individual reactors can be pooled to provide a larger reserve to handle the premature decomissioning of one of the reactors. The pooling of decommissioning funds for a utility's reactors is not limited to reactors at a multiple-reactor station, though, since a utility operating several reactors at dispersed sites in one state could also elect to pool the funds accumulated for decommissioning the reactors.

The experience at Three Mile Island vividly illustrates the effect an accident at a reactor can have on an adjacent reactor. At a multiple-reactor station, where reactors probably would be located in groups of three or four reactors, a serious accident at one of the reactors could result in the extended shutdown of the other reactors in the group. However, even if the reactor at which the accident occurred were to be decommissioned prematurely, the probability is low that there would be technical justification for the premature decomissioning of the other reactors in the group. Startup of a reactor after an extended shutdown can be quite expensive. If the reactor that is forced to shut down during the recovery from an accident at an adjacent nuclear reactor is within a few years of planned shutdown, the utility may decide that it is more economical to decommission the reactor than to restart it.

If the likelihood of premature closure of a nuclear power station is increased by collocation, the degree of assurance of the availability of funds for decommissioning is somewhat decreased. This possibility suggests that more serious attention should be given to funding of decommissioning prior to plant startup and/or to the possibility of accruing funds for decommissioning at a faster rate than otherwise would be selected for an external sinking fund or 
internal decommissioning reserve. Alternatively, the reactor owner could be required to participate in an insurance pool to provide protection against premature plant closure. This concept is under review by the NRC and the nuclear liability insurance pools. (1) 


\section{REFERENCES}

1. Robert S. Wood, Assuring the Availability of Funds for Decommissioning Nuclear Facilities, NUREG-0584, Rev. 2, draft report issued 0ctober 1980 .

2. Internal Revenue Code, Section 115.

3. Ibid, Section 61(a).

4. Ibid, Section 162 . 



\subsection{MULTIPLE-REACTOR STATION CONCEPTS}

Multiple-reactor stations and studies of nuclear energy centers are described in this section. The management alternatives for a multiple-reactor station, including reactor types and standardization, site dedication, timing of construction, and reuse of structures and systems, are also discussed.

\subsection{MULTIPLE-REACTOR STATIONS ANO RELATED STUOIES}

Most of the operating or planned nuclear power reactors in the United States are located at stations with two or more reactors. Thirteen 2-reactor stations are in operation and an additional thirty-five 2-reactor stations are being constructed or planned. Three 3-reactor stations are in operation and seven more are planned. Two 4-reactor stations are planned.

No nuclear energy centers containing more than four reactors are currently planned; however, several studies on the feasibility of operating nuclear energy centers with more than four reactors have been reported. (1-3) An Atomic Energy Commission study ${ }^{(1)}$ published in 1974 examined nuclear energy centers with 10 to 40 reactors and related fuel-cycle and waste management facilities. A Nuclear Regulatory Commission study, ${ }^{(2)}$ Nuclear Energy Center Site Survey - 1975, considered three basic types of nuclear energy centers:

1. Power plant centers, consisting of 10 to 40 nuclear electric-generating units of 1200 MWe capacity each.

2. Fuel-cycle centers, consisting of fuel reprocessing plants, mixed oxide fuel fabrication facilities, and radioactive waste management facilities.

3. Combined centers, containing both power plants and fuel-cycle facilities. The Hanford Nuclear Energy Center study ${ }^{(3)}$ assumed that 20 to 40 nuclear power plants would be located at the center, together with an interim spent fuel storage facility and waste management facilities.

The conclusions drawn in these studies are in reasonably good agreement. In general, these conclusions state that: 
- Nuclear energy centers of up to 20 reactors are technically feasible.

- Nuclear energy centers would not unacceptably degrade the environment, decrease the reliability of the electrical power supply, or compromise safety.

- Nuclear energy centers of 10 to 20 reactors couid show some economic advantages - up to $12 \%$ savings in construction costs compared to singleor dual-reactor sites.

- Extra transmission costs could reduce or eliminate the construction net savings.

- Nuclear energy centers could result in stable construction labor pools.

- There is no apparent change in public safety from nuclear energy centers compared to dispersed siting of the same number of reactors.

- Energency response capabilities would be enhanced at nuclear energy centers.

- Nuclear energy centers should reduce concerns related to safeguarding fissionable material.

- Nuclear energy centers will probably evolve through normal utility growth by the year 2000 .

- Nuclear energy centers could be more vulnerable to acts of war. An article $e^{(4)}$ by Burwell, Ohanian, and weinberg argues for a nuclear facility siting policy that encourages locating new nuclear power reactors at sites of existing reactors. Such a policy, the article concludes, would lead to the development of nuclear energy centers as the demand for electricity increases. A recent GAO study ${ }^{(5)}$ found that locating future nuclear powerplants at existing sites offers important advantages which warrant consideration by the NRC. The GAO study cited advantages for decommissioning of nuclear reactors at a multiple-reactor station as follows:

"In view of the need to mothball or entomb a retired nuclear powerplant for 100 years or more, and the present regulatory uncertainty in the area of decommissioning and final powerplant disposition, placing future powerplants at existing nuclear sites would help the utilities to safely perform 
the necessary surveillance of retired facilities. The cobalt-60 induced radioactivity would have time to decay allowing utilities to reduce the occupational hazards associated with dismantiement. The contaminated retired facilities would be located within the perimeter of the controlled nuclear sites, and the site operating staffs could routinely perform the necessary maintenance, radioactive monitoring, environmental monitoring, and inspections during the long protective storage periods. A7so, continued use of sites for nuclear operations could reduce or elininate public and political pressures on utilities to dismantle retired nuclear powerplants at a time when the levels of induced radioactivity in the plants are still high."

\subsection{MANAGEMENT ALTERNATIVES FOR A MULTIPLE-REACTOR STATION}

In the nuclear energy center studies discussed in Section 6.1, it is assumed that the reactors will be located in groups of three (triads) or four (quads), with the groups separated from each other by sufficient distance to avoid interactions that could adversely affect the environment. This same arrangement of the reactors at a muitiple-reactor station is assumed in this decommissioning study.

In the following subsections, the various aiternatives available to the organization(s) operating the reactors at a multiple-reactor station are discussed. These alternatives may influence the safety and cost of decommissioning the reactors.

\subsubsection{Reactor Types and Standardization}

At a multiple-reactor station with a small number of reactors, say four reactors (a quad), it is more likely that the reactors will be of the same type and design, either PWR or BWR, than it is for a station having a larger number of reactors. However, even at a multiple-reactor station with 10 to 20 reactors, it is expected that there will be several reactors of each type. 
Standardization of the reactor type and design at a multiple-reactor station results in many advantages during construction, operation, and decommissioning. Standardization:

- Provides a major savings in engineering design, since it is carried out just once.

- Provides construction personnel with drawings for remaining units early, which gives flexibility to planning and manpower leveling, as well as improves productivity on the remaining units because of what was learned from the construction of the first unit; a similar improvement in productivity for decomissioning is anticipated after the first reactor is decommissioned.

- Simplifies operator training, since a group of identical reactors will have the same arrangement for controls, valves, and equipment.

- Minimizes the design input and safety review process for licensing the reactors.

- Provides fuel management flexibility during operation by fuel sharing between identical reactors.

- Reduces maintenance on identical units by correcting problems on subsequent units before the problems cause faiture.

Some of these advantages may also be realized by a utility having reactors of a standardized design located at several single-reactor stations. The principal advantages of standardization during decormissioning of several identical reactors at a nuclear power station are:

- the minimization of the planning effort for decommissioning the second and later reactors of an identical design

- the improvement in productivity of the decommissioning workers due to the experience they gained on the first reactor

- the improvement of decommissioning techniques and the correction of mistakes. 
A disadvantage of standardization is that both standardization of design and commonality of environment, management, equipment manufacturers, construction forces, and inspection tend to make common mode failure more likely at a nuclear energy center.

\subsubsection{Site Dedication}

When a nuclear power station is constructed, the site is committed for a period of up to 100 years or more, depending on whether the reactor is decommissioned by DECON, SAFSTOR, or ENTOMB. If the site is dedicated to nuclear power generation, replacement reactors will be constructed on a schedule that achieves startup of a replacement reactor just as an old reactor is retired. Site dedication of this type can foster a stable construction labor force for a much longer time than a multiple-reactor station at which the old reactors will not be replaced at retirement.

\subsubsection{Timing of Construction}

A nuclear energy center could be planned and scheduled so that construction and startup of its reactors occurs at regular intervals, say every 2 or 4 years, as indicated in the scenarios discussed in Section 3.4. It is more likely, however, that reactors will be added as the demand for electric energy increases the operating utility's service area. The five scenarios described in this study adequately illustrate the impact on safety and cost of decommissioning a reactor at a multiple-reactor station compared to decommissioning a reactor at a single-reactor station.

The lifetime schedules for construction, operation, and decommissioning of the reactors are shown in Figures 6.2-1 through 6.2-5 for the five scenarios described in Section 3.4. These figures illustrate how replacement reactors will be brought on-line as old reactors are retired at the end of their useful 1 ives, 40 years after startup. Figures $6.2-1$ through $6.2-4$ show decommissioning by the DECON alternative and Figure $6.2-5$ by the SAFSTOR alternative. A lifetime schedule for reactors decommissioned by ENTOMB would be essentially the same as the schedules shown for DECON in Figures 6.2-1 through 6.2-4. 


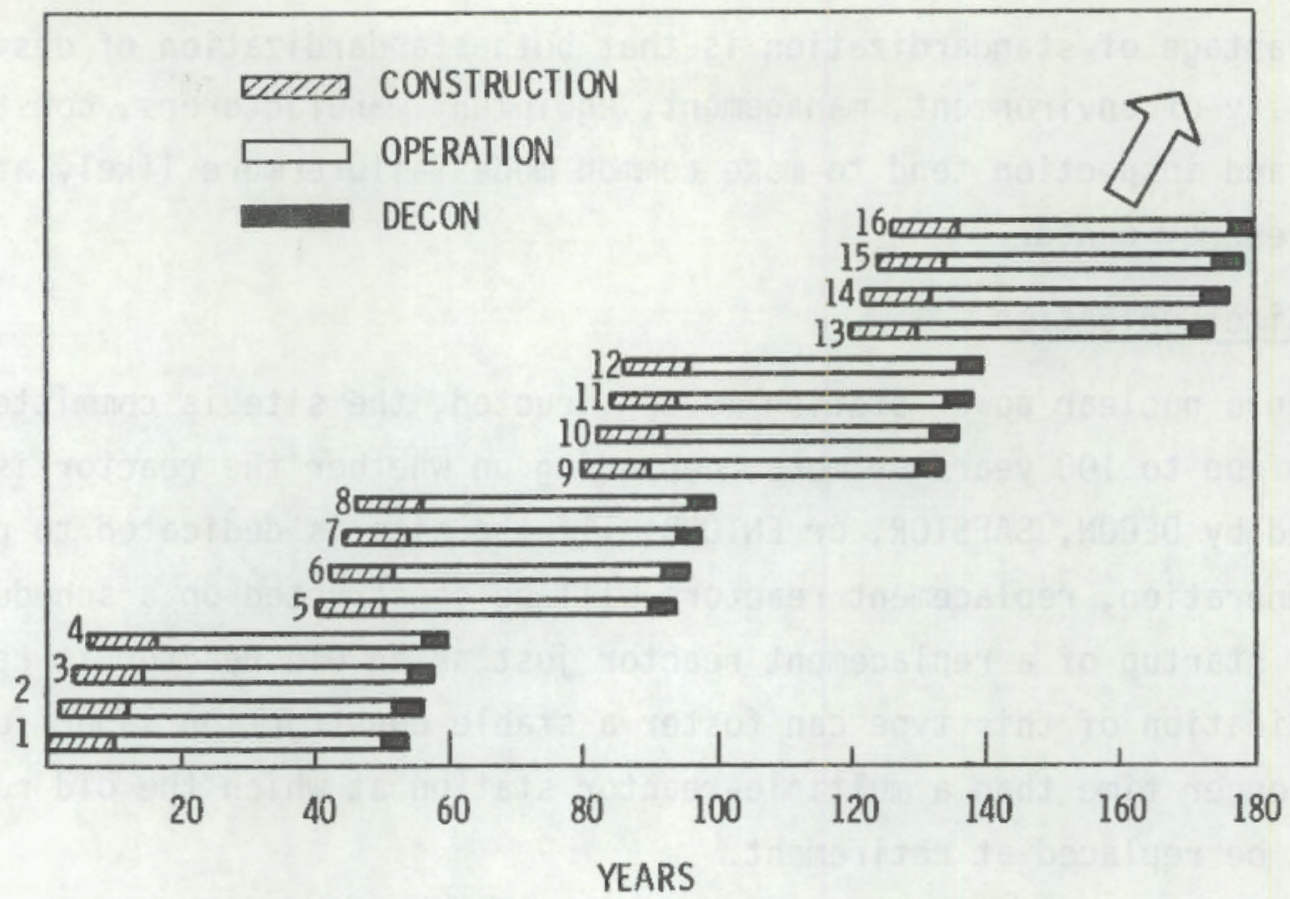

FIGURE 6.2-1. Lifetime Schedule for Construction, Operation, and DECON of a 4-Reactor Station - Scenario 1

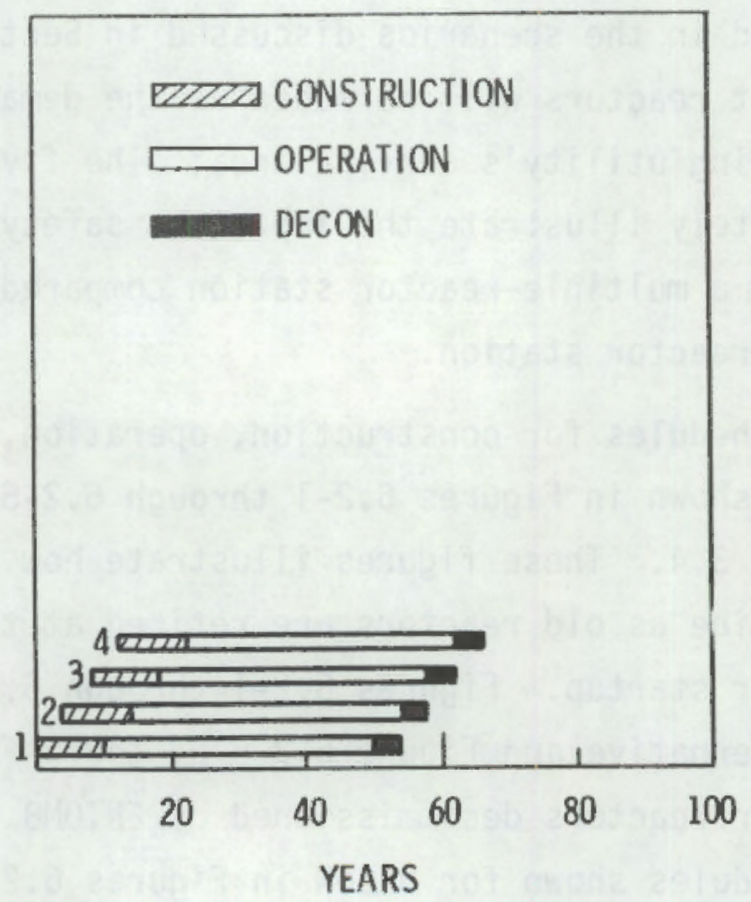

FIGURE 6.2-2. Lifetime Schedule for Construction, Operation, and DECON of a 4-Reactor Station - Scenario 2 


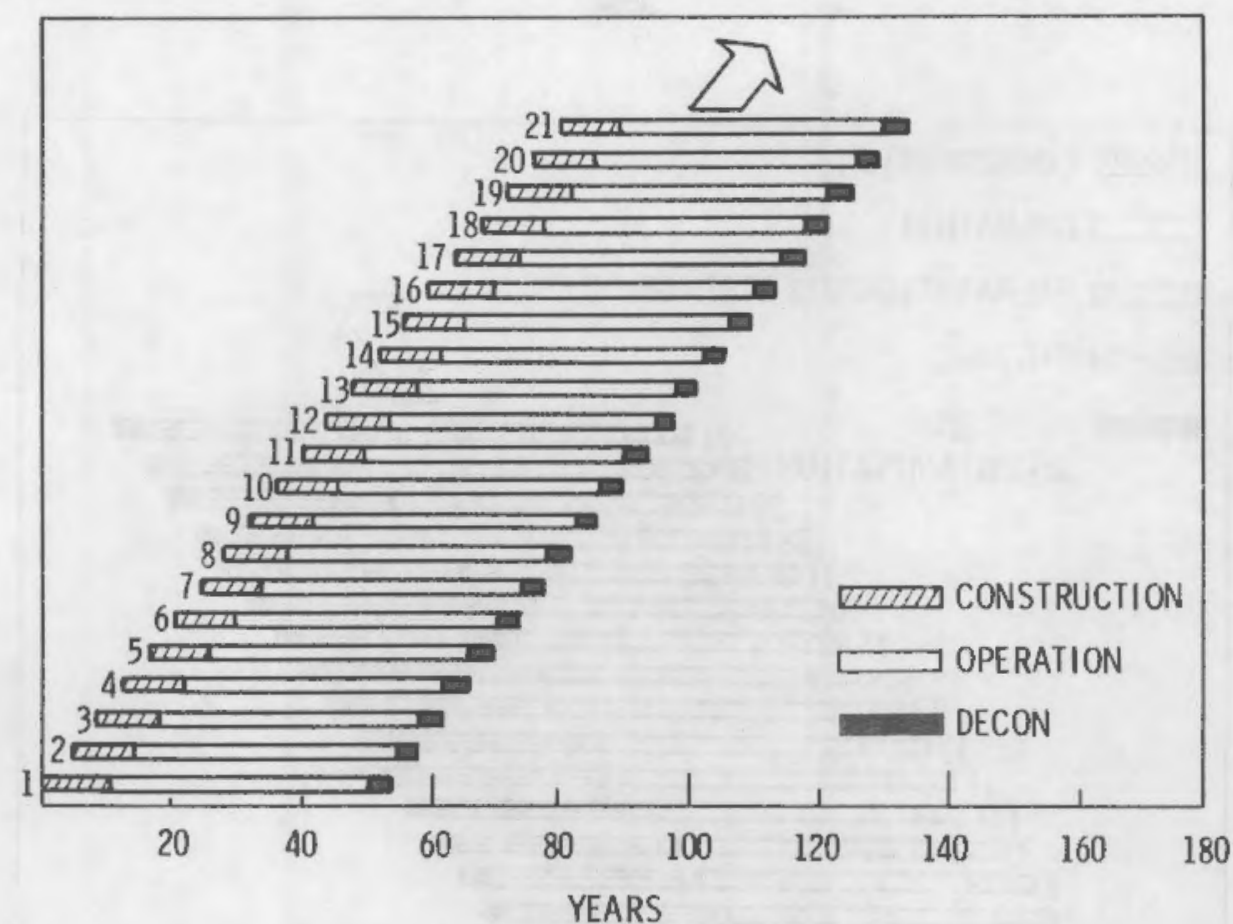

FIGURE 6.2-3. Lifetime Schedule for Construction, Operation, and DECON of a 10-Reactor Station - Scenarios 3 and 4

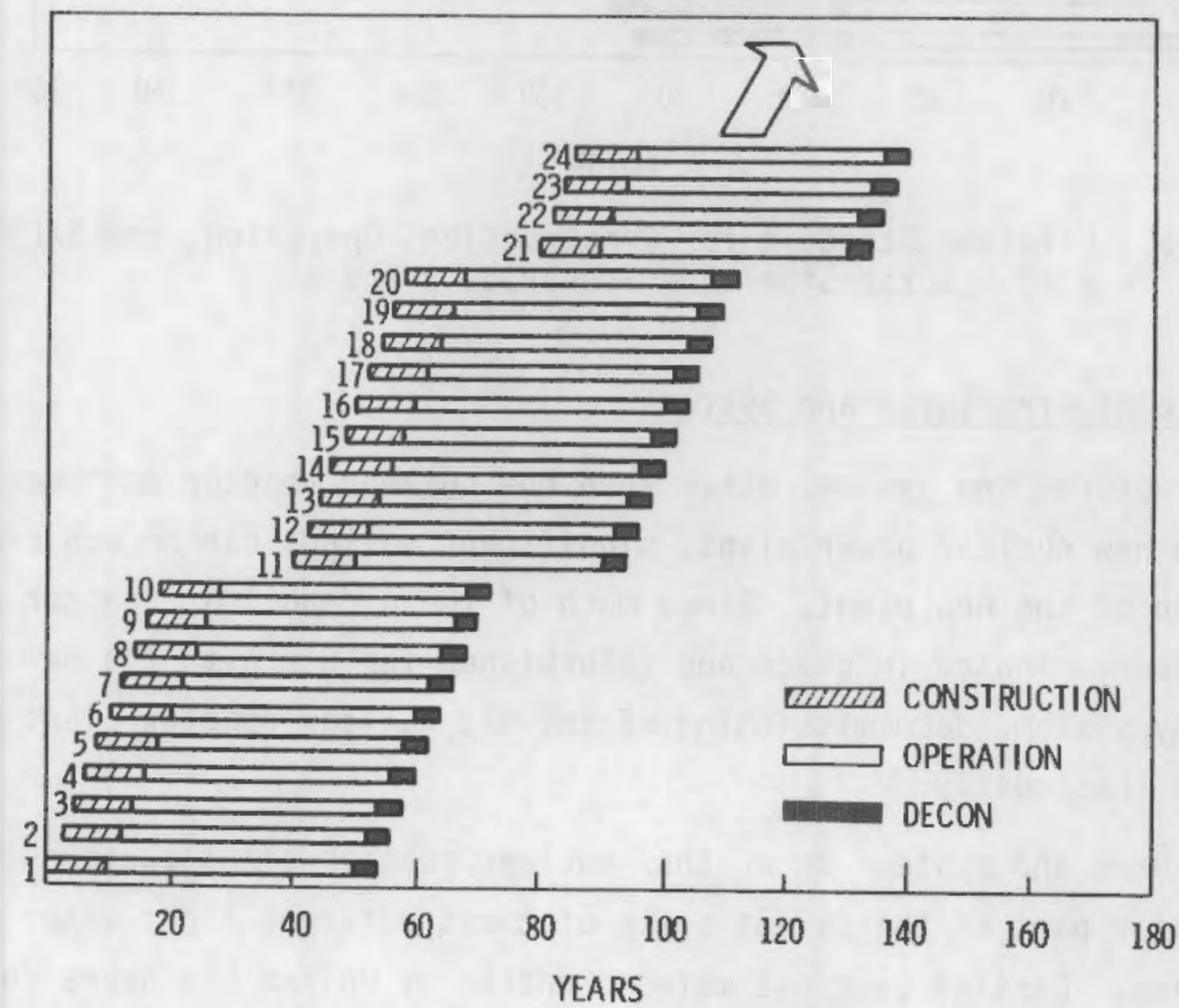

FIGURE 6.2-4. Lifetime Schedule for Construction, Operation, and DECON of a 10-Reactor Station - Scenario 5 


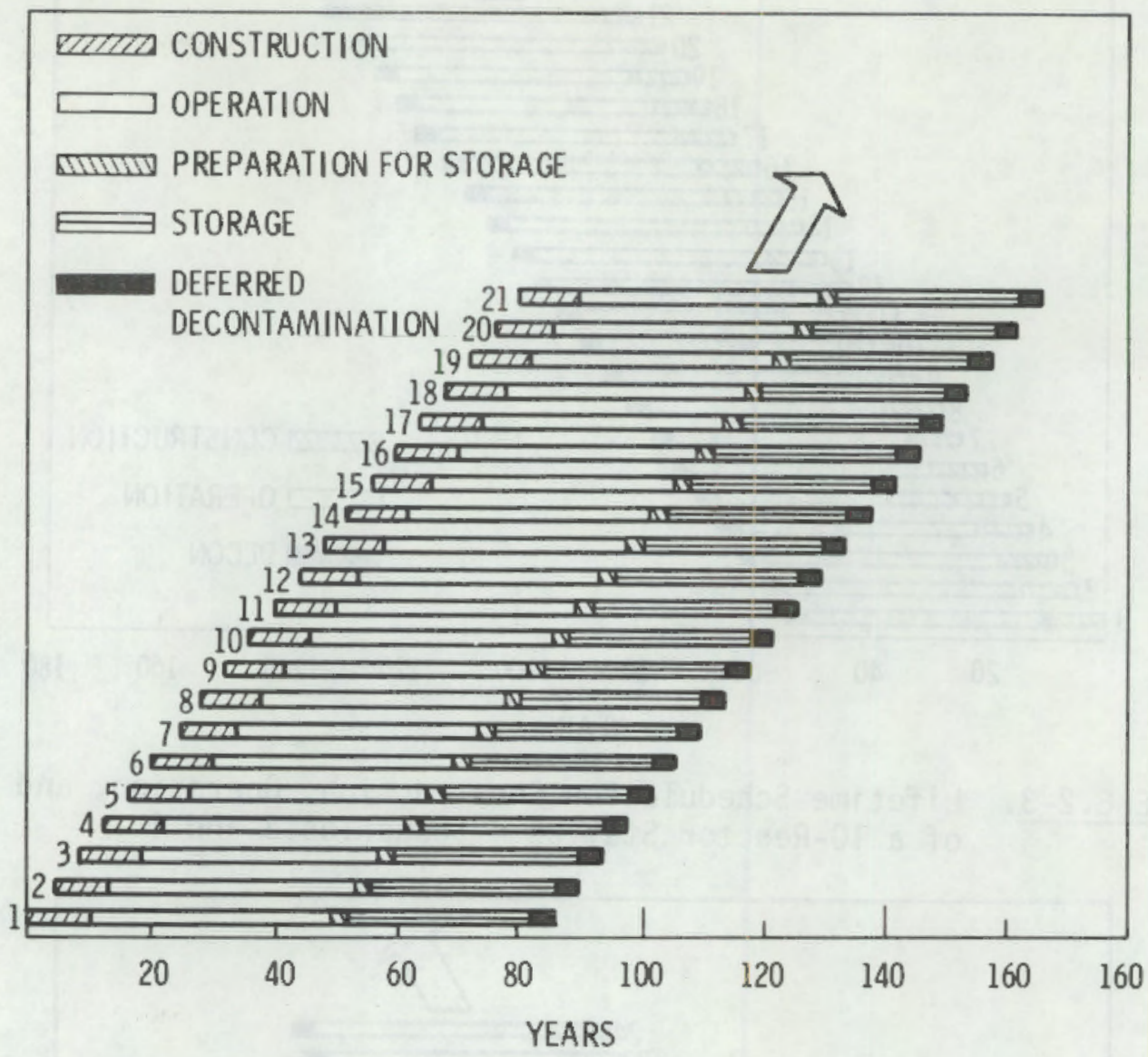

FIGURE 6.2-5. Lifetime Schedule for Construction, Operation, and SAFSTOR of a 10-Reactor Station - Scenarios 3 and 4

\subsubsection{Reuse of Structures and Systems}

If structures and systems other than the nuclear reactor equipment can be reused in a new nuclear power plant, significant savings can be achieved in the construction of the new plant. Since much of the old nuclear reactor plant would be decontaminated in place and refurbished for use with the new nuclear steam supply system, decommissioning of the old nuclear reactor plant would be simpler and less costly.

Structures and systems other than nuclear reactor plant equipment represent the major part of the direct costs of constructing a light-water reactor power station. Capital cost estimates prepared by United Engineers and Constructors $^{(6,7)}$ for a PWR and a BWR show the total direct construction costs, 
in 1978 dollars, to be $\$ 495$ million for a PWR and $\$ 507$ million for a BWR. The reactor plant equipment represents about $30 \%$ of the direct cost, $32 \%$ for the PWR and $29 \%$ for the BWR.

The estimated direct construction costs for a PWR and a BWR are given in Table 6.2-1. The direct construction costs for all of the plant other than the reactor plant equipment are estimated to be $\$ 335$ million for the PWR and $\$ 357$ million for the BWR. If refurbishment of these structures and systems costs as much as one-half of the original construction cost, there still would be a significant saving in the cost of the new plant. Possible means of facilitating removal and replacement of the nuclear reactor are discussed in Section 11.

TABLE 6.2-1. Cost Estimate Summary - Light Water Reactors

Construction Account

Structures and Improvements

Reactor Plant Equipment

Turbine Plant Equipment

Electric Plant Equipment

Miscellaneous Plant Equipment

Ma in Condenser Heat Reject System

Total Direct Costs

\section{Estimated Cost (\$ thousands)} PWR(a) BWR(D)

$119 \quad 126 \quad 133 \quad 167$

$156857 \quad 147 \quad 750$

$130766 \quad 137102$

$\begin{array}{llll}46 & 332 & 47 & 881\end{array}$

$\begin{array}{llll}13 & 870 & 13014\end{array}$

$\underline{25 \quad 368} \quad \underline{25 \quad 839}$

492319504753

(a) From Table 1-1, Reference 6. Estimated costs escalated to 1978 dollars using the Handy-Whitman Utilities Cost Index.

(b) From Table 1-1, Reference 7. Estimated costs escalated to 1978 dollars using the Handy-Whitman Utilities Cost Index. 


\section{REFERENCES}

1. Evaluation of Nuclear Energy Centers, U.S. Atomic Energy Commission, WASH-1288, January 1974.

2. Nuclear Energy Center Site Survey - 1975, U.S. Nuclear Regulatory Comission, NUREG-0001, January 1976.

3. H. Harty, The Hanford Nuclear Energy Center, A Conceptual Study, PNL-2640, Pacific Northwest Laboratory, Richland, Washington, September 1978.

4. C. C. Burwell, M. J. Ohanian and A. M. Weinberg, "A Siting Policy for an Acceptable Nuclear Future," Science 204: 1043 (June 8, 1979).

5. Existing Nuclear Sites Can Be Used For New Powerplants and Nuclear Waste Storage, Report to the Subcommittee on Energy and Power, House Committee on Interstate and Foreign Commerce, U.S. General Accounting Office, EMD-80-67, April 1, 1980.

6. Capital Cost: Pressurized Water Reactor Plant, NUREG-0241, United Engineers and Constructors, Inc., for the U.S. Nuclear Regulatory Commission, June 1977.

7. Capital Cost: Boiling Water Reactor Plant, NUREG-0242, United Engineers and Constructors, Inc., for the U.S. Nuclear Regulatory Commission, June 1977. 


\subsection{CHARACTERISTICS OF THE REFERENCE LIGHT WATER REACTORS}

This section describes the characteristics of the reference PWR and BWR power reactors. The reference reactors are the same as those described in the

PNL studies of decommissioning PWR and BWR reactors. ${ }^{(1,2)}$ Summaries of detailed information developed in these studies are presented. Included are descriptions of the reference reactors and estimates of the radiation dose rates throughout the stations at shutdown.

The information presented is typical of present-generation large LWRs. While some details will vary from station to station, these differences are not expected to have major impacts on the results of this study.

\subsection{THE REFERENCE PRESSURIZED WATER REACTOR}

The reference PWR power station in this study is a 3500-MWt (1175-MWe) pressurized water reactor (PWR) of the Westinghouse design, specifically the Trojan Nuclear Plant at Rainier, Oregon, operated by the Portland General Electric Company.

The principal plant systems and structures of the reference PWR are described briefly in this subsection. More detailed information can be found in the PWR decommissioning study by Smith et al. (1)

\subsubsection{Nuclear Power Generation System}

The nuclear power generation system is illustrated in the functional schematic diagram in Figure 7.1-1. The principal components and systems of interest are the reactor vessel (containing the fuel and coolant) and the reactor coolant system (RCS), which transfers the heat from the fuel to the secondary coolant system via the steam generator heat exchangers where steam is produced for use in the turbine generator.

\subsubsection{Reactor Vessel and Internals}

The reactor vessel is a right circular cylinder with a welded hemispherical bottom and removable hemispherical top, as illustrated in Figure 7.1-2. The vessel is constructed of carbon steel about $0.216 \mathrm{~m}$ thick, with the inside 


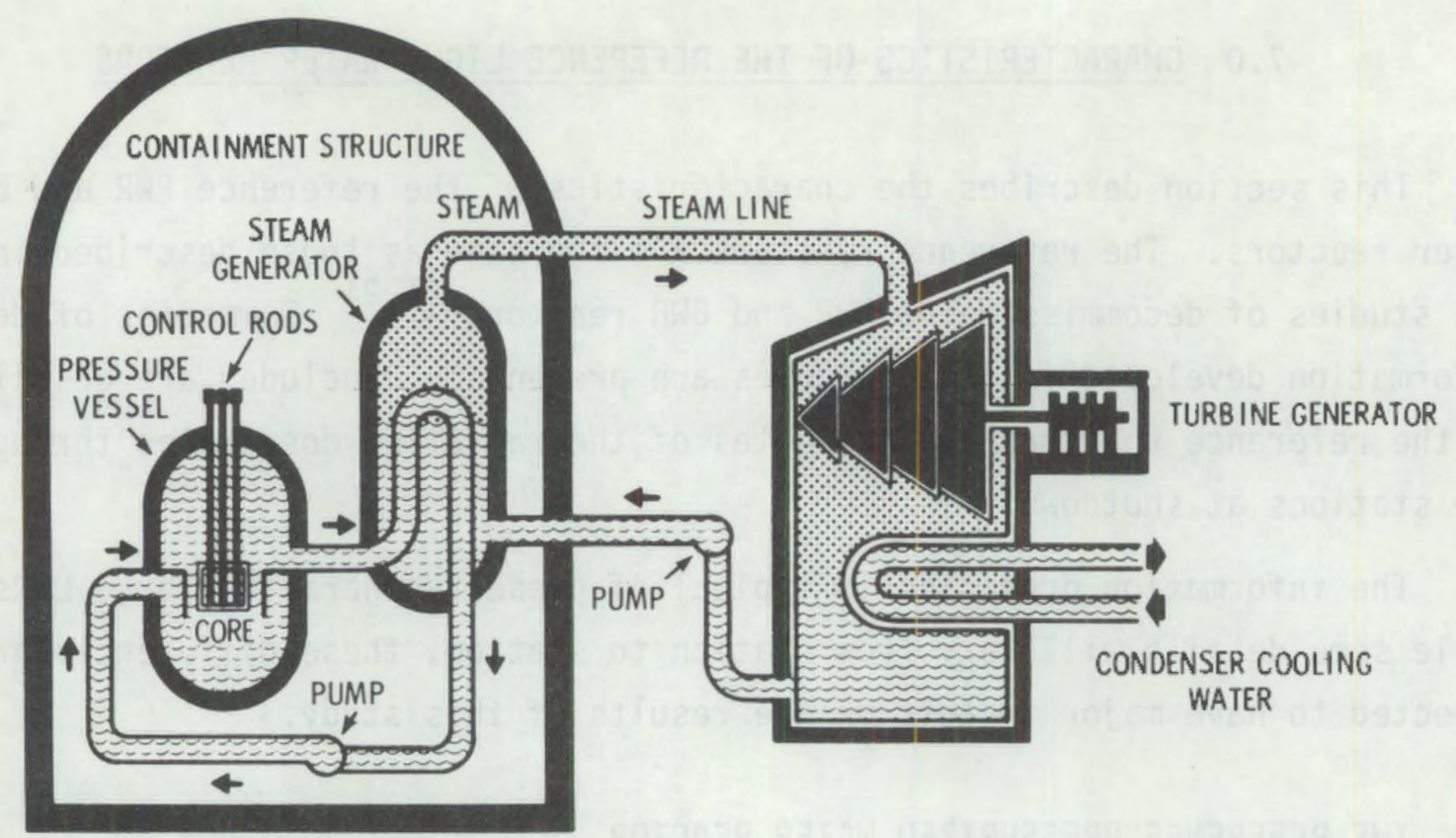

FIGURE 7.1-1. Pressurized Water Reactor

clad with stainless steel or Inconel about $4 \mathrm{~mm}$ thick. The approximate dimensions of the vessel are $12.6 \mathrm{~m}$ in height and $4.6 \mathrm{~m}$ in outer diameter, The vessel weighs nearly $400 \mathrm{Mg}$.

The vessel internal structures support and constrain the fuel assemblies, direct coolant flow, and guide in-core instrumentation, as well as provide some neutron shielding. The principal components are: the lower core support assembly (including the core barrel and shroud, with neutron shield pads and the lower core plate and supporting structure) and the upper core support and in-core instrumentation support assemblies. These structures are made of 304 stainless steel and have a total weight of about $190 \mathrm{Mg}$.

\subsubsection{Reactor Coolant System}

The reactor coolant system, schematically illustrated in Figure 7.1-3, consists of four loops for transferring heat from the reactor to the secondary coolant system. Each loop contains a U-tube steam generator, a reactor coolant pump, and connecting piping. Each steam generator, illustrated in Figure 7.1-4, is about $20.6 \mathrm{~m}$ in height, $3.4 \mathrm{~m}$ in diameter, weighs about $312 \mathrm{Mg}$, and contains nearly 3400 Inconel U-tubes. 


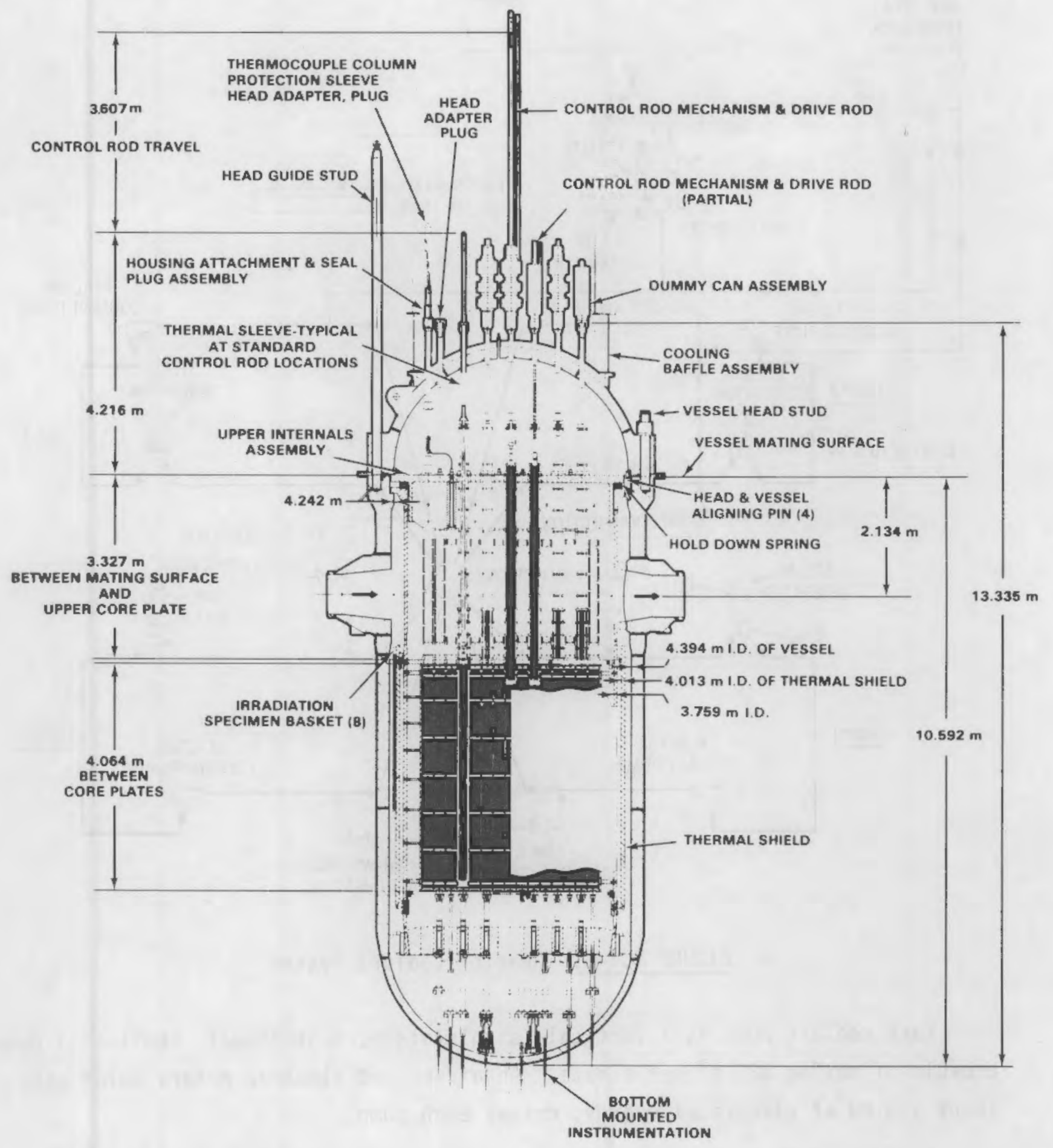

FIGURE 7.1-2. PWR Reactor Vessel Internals 


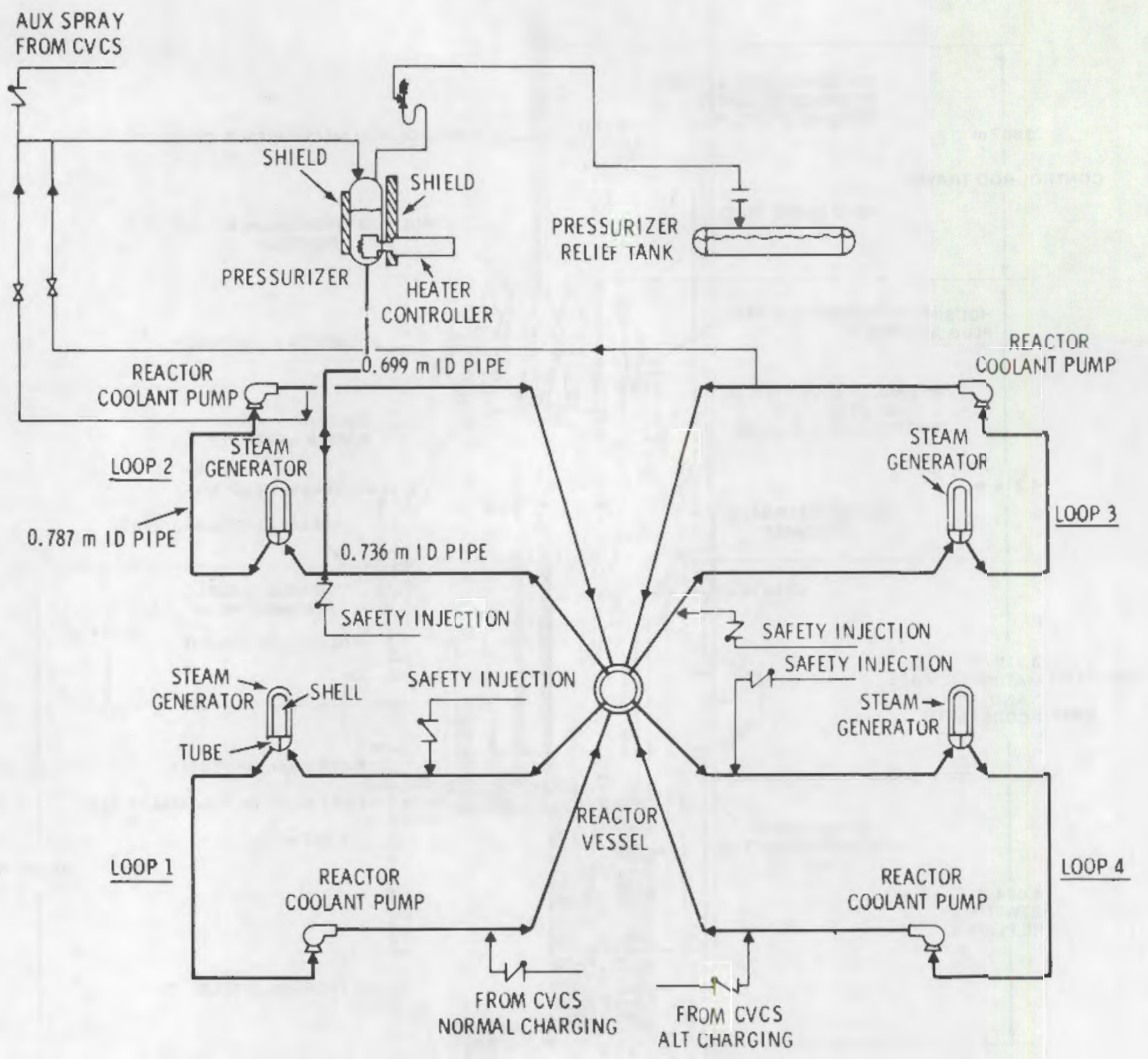

\section{FIGURE 7.1-3. Reactor Coolant System}

Each coolant pump is a vertical, single-stage, centrifugal, shaft-seal pump capable of moving $335 \mathrm{~m}^{3}$ per minute. An air-cooled electric motor, which uses about 4.5 MW of electrical energy, drives each pump.

A total of $81 \mathrm{~m}$ of large-diameter ( $0.7 \mathrm{~m} \mathrm{I.D.)} \mathrm{piping} \mathrm{connects} \mathrm{the}$ four loops of the reactor coolant system to the reactor vessel. This piping has wall thicknesses in the 59 to $66 \mathrm{~mm}$ range, and weighs slightly over $100 \mathrm{Mg}$. 


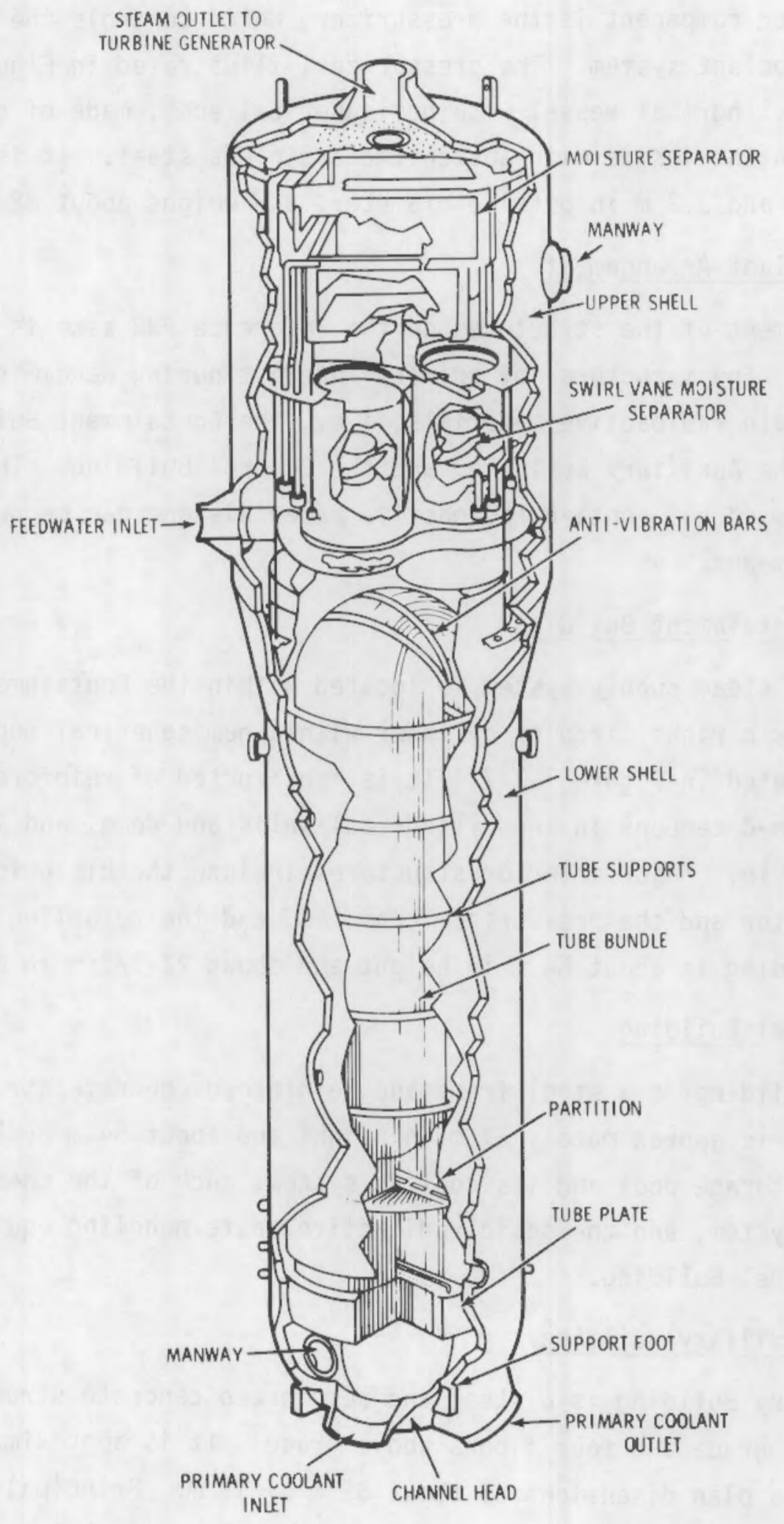

FIGURE 7.1-4. Steam Generator 
Another major component is the pressurizer, which controls the pressure in the reactor coolant system. The pressurizer, illustrated in Figure 7.1-5, is a vertical, cylindrical vessel with hemispherical ends, made of carbon steel and clad on the inside with austenitic stainless steel. It is about $16.1 \mathrm{~m}$ in height and $2.3 \mathrm{~m}$ in outside diameter, and weighs about $88.7 \mathrm{Mg}$.

\subsubsection{General Plant Arrangement}

The arrangement of the structures on the reference PWR site is illustrated in Figure 7.1-6. The structures of primary interest during decommissioning are those which contain radioactive materials, i.e., the Containment Building, the Fuel Building, the Auxiliary Building, and the Control Building. The other onsite structures do not contain radioactive materials and can be demolished by conventional means.

\subsubsection{Containment Building}

The nuclear steam supply system is located within the Containment Building. This structure is a right circular cylinder with a hemispherical top and a flat base, as illustrated in Figure 7.1-7. It is constructed of reinforced concrete, with post-tensioned tendons in the cylindrical walls and dome, and lined with a welded steel skin. Major interior structures include the biological shield, the steam generator and the pressurizer cubicles, and the refueling cavity. The Containment Building is about $64 \mathrm{~m}$ in height and about 22-1/2 $\mathrm{m}$ in diameter.

\subsubsection{Fuel Building}

The Fuel Building is a steel frame and reinforced concrete structure with four floors. It is approximately $27 \mathrm{~m}$ in height and about $54 \mathrm{~m}$ by $19 \mathrm{~m}$ in plan. The spent fuel storage pool and its cooling system, much of the chemical and volume control system, and the solid radioactive waste handling equipment are located in the Fuel Building.

\subsubsection{Auxiliary Building}

The Auxiliary Building is a steel and reinforced concrete structure with two floors below grade and four floors above grade. It is approximately $30 \mathrm{~m}$ in height and has plan dimensions of about $35 \mathrm{~m}$ by $19 \mathrm{~m}$. Principal systems contained in the Auxiliary Building include the liquid radioactive waste 


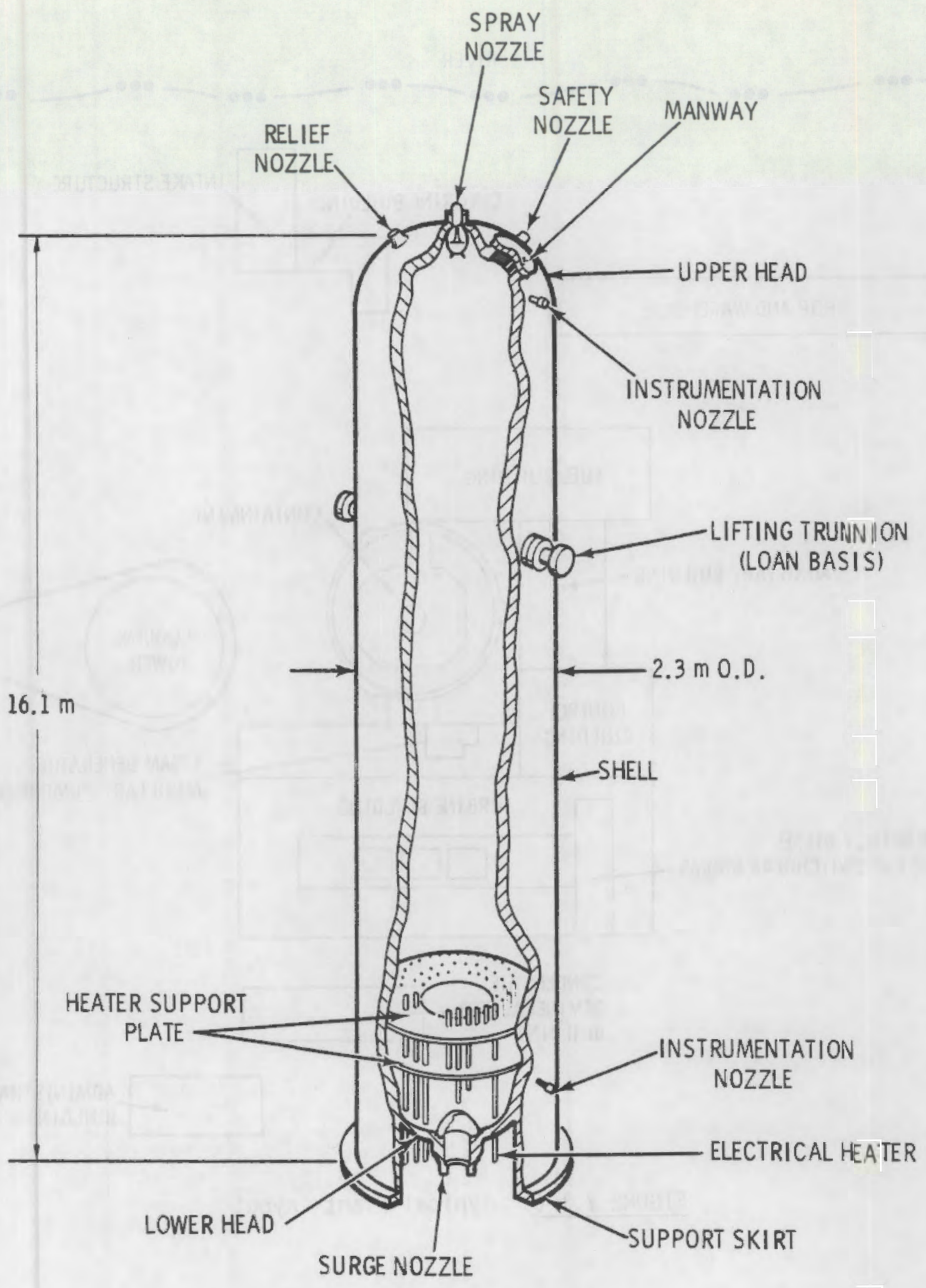

FIGURE 7.1-5. Cutaway of Pressurizer 

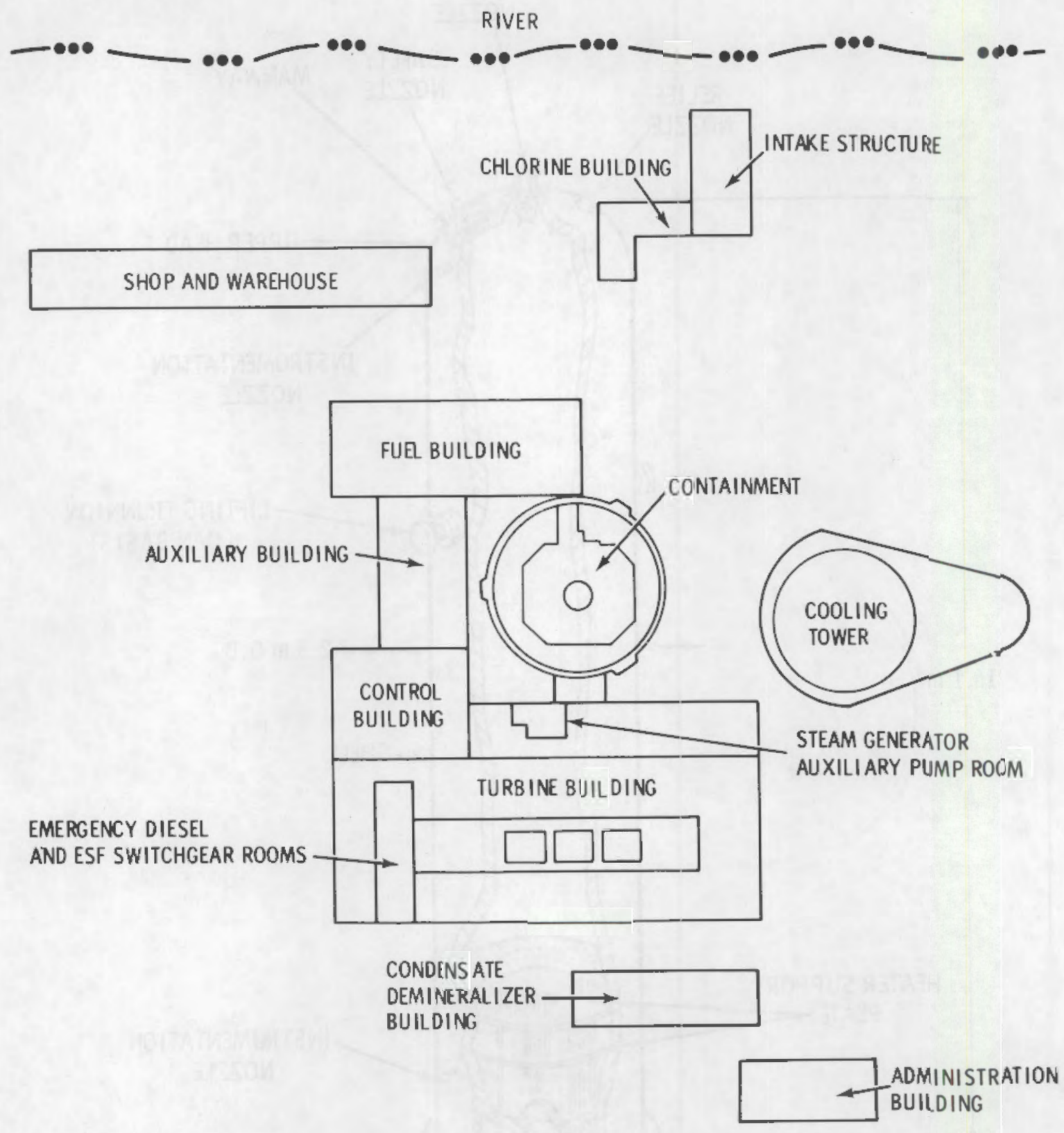

FIGURE 7.1-6. Typical Plant Layout 

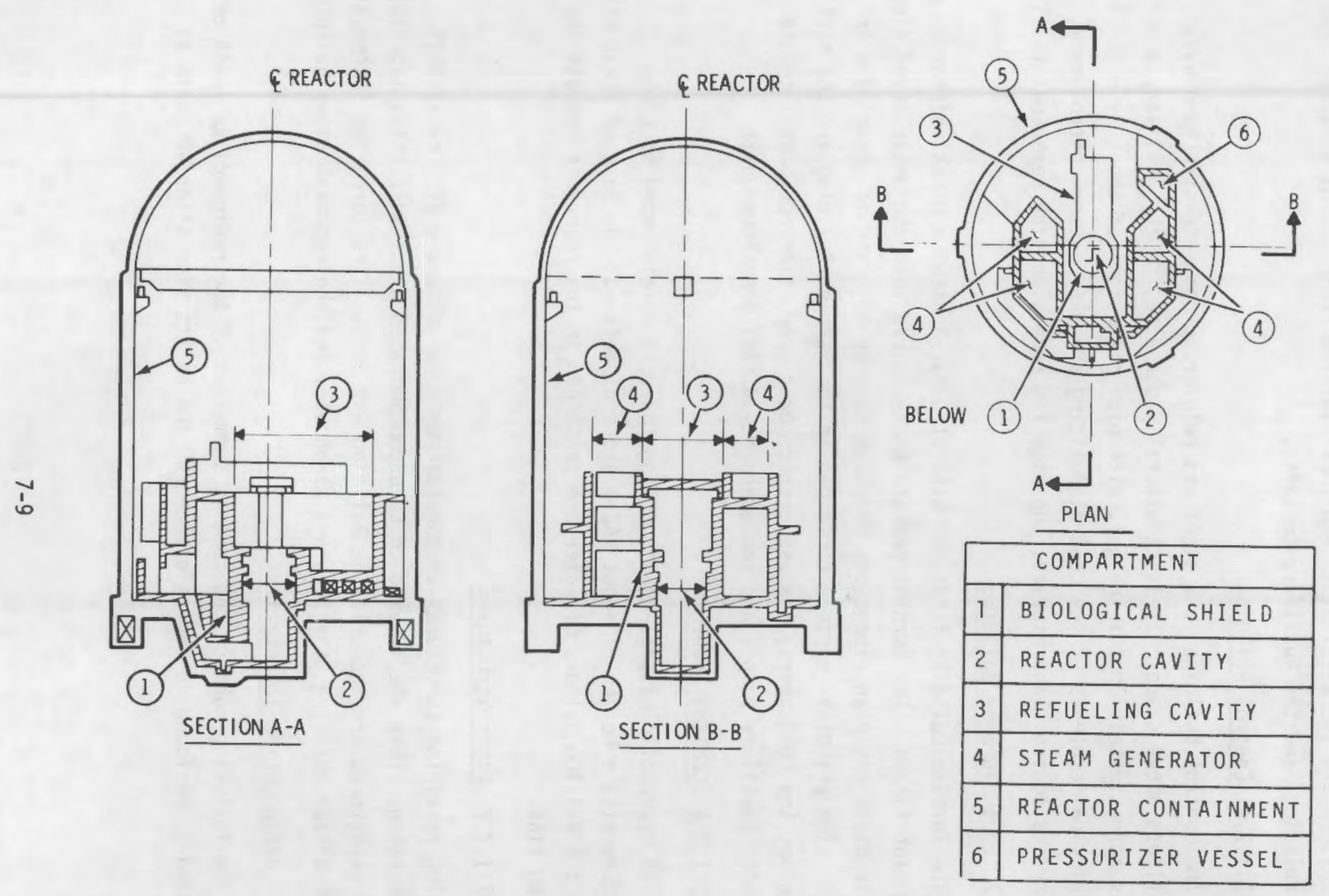

FIGURE 7.1-7. Containment Building 
treatment systems, the filter and ion exchanger vaults, the waste gas treatment system, and the ventilation equipment for the Containement Building, the Fuel Building, and the Auxiliary Building.

\subsubsection{Control Building}

The Control Building is a steel and reinforced concrete structure having four floors above grade. It is structurally connected to the Auxiliary Building and is approximately $18 \mathrm{~m}$ in height, with plan dimensions of about $31 \mathrm{~m}$ by $24 \mathrm{~m}$. The principal contents of the Control Building are the reactor control room, the process control laboratories, the counting rooms, and the personnel facilities.

\subsubsection{Turbine Building}

The Turbine Building is framed with structural steel and has reinforced concrete-slab floors. The turbine pedestals are poured into the grade-level floor. The structure has plan dimensions of about $95 \mathrm{~m}$ by $49 \mathrm{~m}$ and is about $33 \mathrm{~m}$ in height. The principal systems contained in the Turbine Building are the turbine generator, the condensers, the associated power production equipment, the steam generator auxiliary pumps, and the emergency diesel generator units.

\subsubsection{Cooling Tower}

The hyperbolic natural-draft cooling tower is a reinforced concrete structure with a height of about $142 \mathrm{~m}$ and a diameter at the base of about $119 \mathrm{~m}$. About 5.2 million gallons of water are contained in the reservoir beneath the cooling fins.

\subsubsection{Other Structures}

The remaining structures on the reference PWR site are of conventional construction. They are assumed to be uncontaminated with radioactive materials. These structures are the Chlorine Building and Intake Structure, the Condensate Demineralizer Building, the Shop and Warehouse, and the Administration Building.

\subsubsection{Radionuclide Inventories}

The following subsections contain summaries of the radionuclide inventories expected to be found in the reference PWR and on its site after 40 years of 
normal operation. Annual atmospheric releases of radionuclides from the operating PWR are derived from calculated and reported releases and are used to calculate estimates of the accumulation of radionuclides on the site from 40 years of normal PWR operation.

\subsubsection{Accumulated Radionuclides Within the Reference PWR}

Significant quantities of radionuclides remain in a nuclear power station at the time of final reactor shutdown even after the irradiated fuel has been removed. Neutron-activated structural materials in and around the reactor pressure vessel contain large, relatively immobile quantities of radioactivity. Radioactive corrosion products and fission products from failed fuel, which are transported throughout the station by the reactor coolant streams, are the principal contributors to the more mobile radioactive contamination on piping, floors, and pool surfaces.

Neutron-Activated Reactor Components and Structural Materials. Production of radioactive reactor components and structural materials by neutron activation is a normal result of reactor operation. The concentration of a particular radionuclide in a given location in the reactor depends on the neutron flux level at that location, the duration of the exposure to the neutron flux, the concentration of the parent isotope, and the cross section of that isotope for the production of the radioactive species. Radionuclide concentrations present at shutdown in the reactor vessel, in its internal structures, and in its surrounding shielding enclosure are calculated for the reference PWR, assuming 30 effective full-power years (EFPY), equivalent to 40 calendar years at $75 \%$ of full-power operation.

Specific activities at the time of reactor shutdown of the principal radionuclides of interest in decommissioning are listed in Table 7.1-1 for each of the major reactor components. Radionuclides having half-lives shorter than 35 days are not included. The upper and lower values for ${ }^{60} \mathrm{Co}$ activity listed in Table 7.1-1 are based on assumed initial concentrations for ${ }^{59} \mathrm{Co}$ impurity of 0.05 to $0.15 \mathrm{wt} \%$ in the 304 stainless steel components and of 0.006 to $0.012 \mathrm{wt} \%$ in the SA533 carbon steel pressure vessel. The ${ }^{93} \mathrm{Nb}$ trace impurity, parent of the ${ }^{94} \mathrm{Nb}$ radionuclide, is assumed to have a concentration in the 304 stainless 
TABLE 7.1-1. Radioactivity Levels in Major Activated Reactor Components at Time of Reactor Shutdown(a)

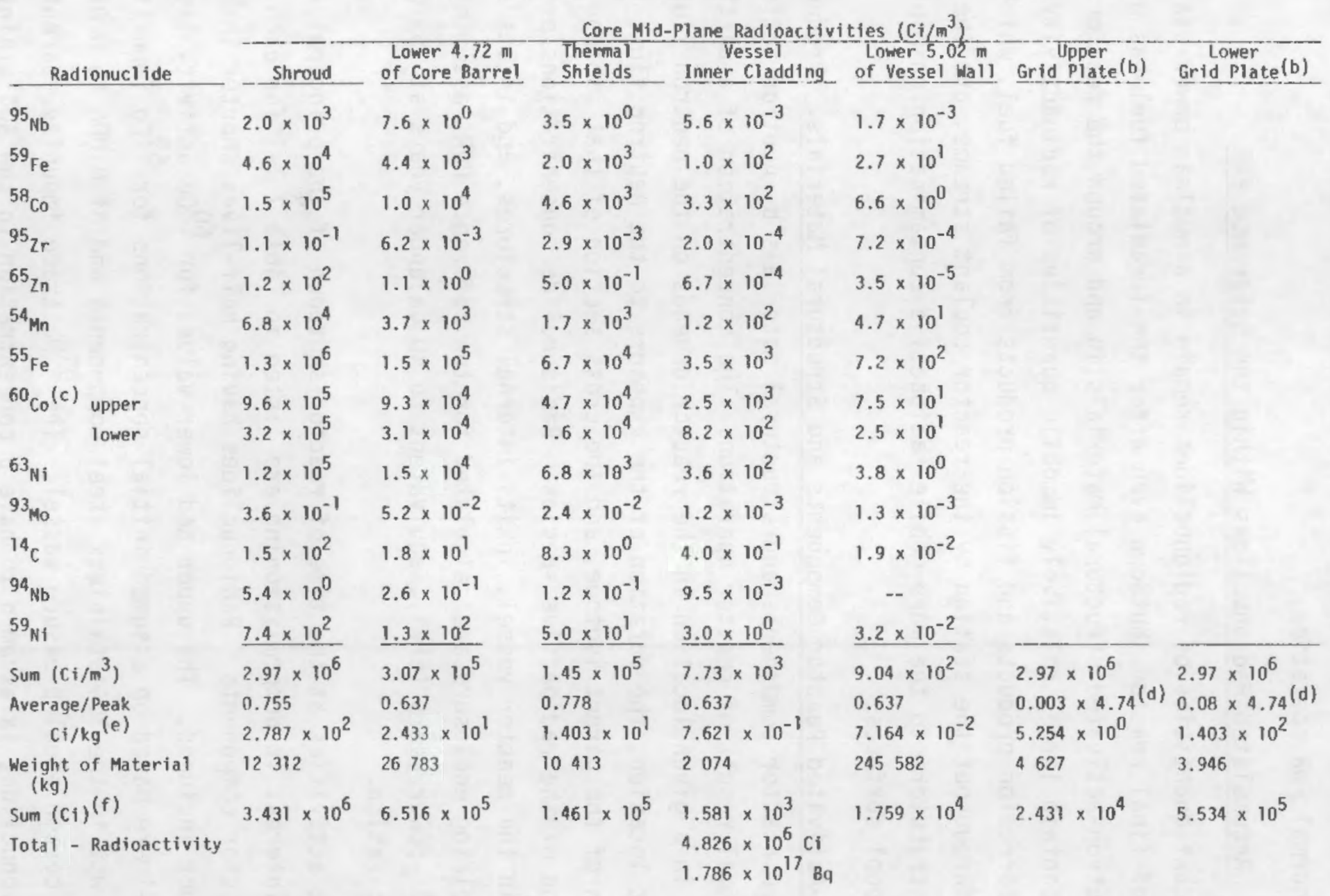

(a) From Table 7.3-2, Reference 1

(b) Normalized to shroud.

(c) Upper and lower bounds were computed using the maximum and minimum levels of ${ }^{59}$ Co contaminant in the materials. All totals

d) Activity coming the upper bound values.

Activity (Plate Average) $=4.74$, Activity (Shroud at Plate Location) 10.005 , upper plate

e) Conversion (Plate Edge) Activity (Shroud at Axial Midplane $=\left.\right|_{0,08}$, lower plate

(e) Thersion factor assumes stainless ste

f) The nuber of significant figures carried is for computational accuracy and does not imply precision to four places. 
steel of 0.016 percent by weight in the alloy. A total of over 4.8 million curies of radioactivity is calculated to be present in the activated reactor vessel and components at the time of final reactor shutdown.

The radioactivity inventory in the concrete biological shield is difficult to precisely define because the actual initial composition is not well known, particularly with regard to elements present in trace quantities. Calculations of activation products in the bioshield result in the listing given in Table 7.1-2. No rare earths are included in the calculation due to lack of quantitative data on their probable initial concentrations. The levels of radioactivity $\left(\mathrm{Ci} / \mathrm{m}^{3}\right)$ are those calculated to be present at final reactor shutdown.

\subsubsection{Surface Contamination}

Numerous radioactive materials, activated corrosion products from structural materials in contact with coolant, and fission products from leaking fuel are present in the reactor coolant streams during reactor operation. Some of these coolant-transported radioactive materials are deposited on internal surfaces of equipment and piping, on external surfaces, and on the surrounding site. Summaries of the radioactive inventories deposited as both internal surface contamination in piping and equipment and external surface contamination inside the reference PWR buildings and on the surrounding site are presented below.

Internal Surface Contamination. The composition of these activated corrosion product sources is derived from information available in the literature. Fractional activities of various corrosion products deposited on internal surfaces of equipment and piping are shown in Table 7.1-3. It can be seen that cobalt isotopes comprise $78 \%$ of the total activity at reactor shutdown.

External Surface Contamination. Contamination of surfaces external to the equipment and piping in the reference PWR occurs from leaks in the process systems. Contamination from leaks in areas normally accessible to operating personnel probably would be cleaned up according to operating procedures. Only in areas not accessible to operating personnel, such as ion exchanger vaults, would contamination build up throughout the lifetime of the plant. The fractional activities of the various corrosion and fission products that could be deposited on external surfaces in the PWR are shown in Table 7.1-3. It can be seen that cesium isotopes comprise $87 \%$ of the total activity at shutdown. 
TABLE 7.1-2. Radioactivity Levels at the Inner Surface of the Activated Biological Shield at Reactor Shutdown (a)

\begin{tabular}{|c|c|c|c|}
\hline Radionuclide & $\begin{array}{c}\text { Principal } \\
\text { Radiation } \\
\text { Emitted } \\
\end{array}$ & $\begin{array}{r}\text { Radioacti } \\
\text { Reference PWR } \\
\text { (calculated) } \\
\end{array}$ & $\begin{array}{l}\text { vity }\left(\mathrm{Ci} / \mathrm{m}^{3}\right) \\
\text { Elk River Reactor } \\
\text { (measured) }\end{array}$ \\
\hline${ }^{3} \mathrm{H}$ & $B$ & $2.9 \times 10^{-5}$ & \\
\hline${ }^{14} \mathrm{C}$ & B & $6.94 \times 10^{-4}$ & \\
\hline${ }^{22} \mathrm{Na}$ & $Y$ & Not calculated & $3.6 \times 10^{-2}$ \\
\hline${ }^{33} p$ & B & $3.24 \times 10^{-1}$ & \\
\hline${ }^{35} \mathrm{~s}$ & B & $3.17 \times 10^{-2}$ & \\
\hline${ }^{36} \mathrm{Cl}$ & $\gamma$ & $8.40 \times 10^{-6}$ & \\
\hline${ }^{37} \mathrm{Ar}$ & $\gamma$ & $2.15 \times 10^{-1}$ & \\
\hline${ }^{39} \mathrm{Ar}$ & B & $3.96 \times 10^{-2}$ & \\
\hline${ }^{40} \mathrm{~K}$ & $Y$ & $3.76 \times 10^{-5}$ & \\
\hline${ }^{41} \mathrm{Ca}$ & $\gamma$ & $7.00 \times 10^{-3}$ & \\
\hline${ }^{45} \mathrm{Ca}$ & B & $3.66 \times 10^{0}$ & \\
\hline${ }^{46} \mathrm{Sc}$ & $\gamma$ & $1.86 \times 10^{-4}$ & \\
\hline${ }^{51} \mathrm{Cr}$ & $\gamma$ & $1.04 \times 10^{-1}$ & \\
\hline${ }^{54} \mathrm{Mn}$ & $\gamma$ & $1.68 \times 10^{-1}$ & \\
\hline${ }^{55} \mathrm{Fe}$ & Y & $3.01 \times 10^{1}$ & \\
\hline${ }^{59} \mathrm{Fe}$ & $\gamma$ & $9.99 \times 10^{-1}$ & \\
\hline${ }^{58} \mathrm{Co}$ & Y & $2.15 \times 10^{-2}$ & \\
\hline${ }^{60} \mathrm{Co}$ & $\gamma$ & $6.69 \times 10^{-1}$ & $1.01 \times 10^{0}$ \\
\hline${ }^{59} \mathrm{Ni}$ & Y & $1.19 \times 10^{-3}$ & \\
\hline${ }^{63} \mathrm{Ni}$ & B & $1.40 \times 10^{-1}$ & \\
\hline${ }^{65} \mathrm{Zn}$ & $\gamma$ & $4.47 \times 10^{-7}$ & \\
\hline${ }^{93 m} \mathrm{Nb}$ & $\gamma$ & $2.77 \times 10^{-5}$ & \\
\hline${ }^{95} \mathrm{Nb}$ & $Y$ & $5.40 \times 10^{-6}$ & \\
\hline${ }^{93} \mathrm{Mo}_{\mathrm{O}}$ & Y & $6.69 \times 10^{-5}$ & \\
\hline${ }^{99} \mathrm{TC}$ & B & $4.93 \times 10^{-5}$ & \\
\hline${ }^{152} \mathrm{Eu}$ & y & Not calculated & $8.7 \times 10^{-1}$ \\
\hline
\end{tabular}

(a) From Table 7.3-5, Reference 1. 
TABLE 7.1-3. Radionuclide Inventory of PWR Surface Contamination at Reactor Shutdown

\begin{tabular}{|c|c|c|c|}
\hline Radionuclide & $\begin{array}{c}\text { Internal } \\
\text { Surface } \\
\text { Contamination (a) } \\
\end{array}$ & $\begin{array}{c}\text { External } \\
\text { Surface } \\
\text { Contamination (b) } \\
\end{array}$ & $\begin{array}{c}\text { Site } \\
\text { Surface } \\
\text { Contamination }(c) \\
\end{array}$ \\
\hline${ }^{51} \mathrm{Cr}$ & $2.4 \times 10^{-2}$ & $6.9 \times 10^{-4}$ & $4.7 \times 10^{-3}$ \\
\hline${ }^{54} \mathrm{Mn}$ & $3.6 \times 10^{-2}$ & $1.4 \times 10^{-3}$ & $1.1 \times 10^{-2}$ \\
\hline${ }^{55} \mathrm{Fe}$ & -- & $2.2 \times 10^{-2}$ & -- \\
\hline${ }^{59} \mathrm{Fe}$ & $8.2 \times 10^{-3}$ & $8.7 \times 10^{-4}$ & $2.2 \times 10^{-3}$ \\
\hline${ }^{57} \mathrm{Co}$ & 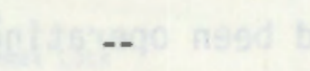 & -- & $5.2 \times 10^{-4}$ \\
\hline${ }^{58} \mathrm{Co}$ & $4.6 \times 10^{-1}$ & $7.5 \times 10^{-3}$ & $2.4 \times 10^{-2}$ \\
\hline${ }^{60} \mathrm{CO}_{\mathrm{O}}$ & $3.2 \times 10^{-1}$ & $7.5 \times 10^{-2}$ & $3.5 \times 10^{-1}$ \\
\hline${ }^{89} \mathrm{Sr}$ & -- & $1.2 \times 10^{-3}$ & $6.9 \times 10^{-4}$ \\
\hline${ }^{90} \mathrm{sr}$ & -- & $6.9 \times 10^{-4}$ & $6.9 \times 10^{-2}$ \\
\hline $90 y$ & -- & $6.9 \times 10^{-4}$ & $6.9 \times 10^{-2}$ \\
\hline${ }^{95} \mathrm{Zr}$ & $5.6 \times 10^{-2}$ & $2.5 \times 10^{-4}$ & $3.9 \times 10^{-3}$ \\
\hline${ }^{95} \mathrm{Nb}$ & $5.6 \times 10^{-2}$ & $2.5 \times 10^{-4}$ & $3.9 \times 10^{-3}$ \\
\hline${ }^{103} \mathrm{Ru}$ & $2.6 \times 10^{-2}$ & -- & $3.9 \times 10^{-4}$ \\
\hline $110 m_{A g}$ & -- & -- & $8.6 \times 10^{-4}$ \\
\hline${ }^{124} \mathrm{Sb}$ & - & $--\quad x^{2}$ & $4.8 \times 10^{-4}$ \\
\hline${ }^{125} \mathrm{Sb}$ & -- & -- & $6.9 \times 10^{-4}$ \\
\hline${ }^{129 m} \mathrm{Te}$ & -- & $3.1 \times 10^{-4}$ & -- \\
\hline $131_{1}$ & -- & $1.2 \times 10^{-2}$ & $7.3 \times 10^{-2}$ \\
\hline${ }^{134}$ Cs & -- & $1.2 \times 10^{-1}$ & $2.0 \times 10^{-2}$ \\
\hline${ }^{136} \mathrm{Cs}$ & -- & $1.1 \times 10^{-3}$ & $1.2 \times 10^{-4}$ \\
\hline${ }^{137} \mathrm{Cs}$ & $1.2 \times 10^{-3}$ & $7.5 \times 10^{-1}$ & $3.7 \times 10^{-1}$ \\
\hline${ }^{140} \mathrm{Ba}$ & $--(141290567$ & -- & $9.9 \times 10^{-4}$ \\
\hline $140_{L}$ & 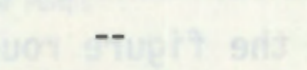 & -- & $9.9 \times 10^{-4}$ \\
\hline${ }^{141} \mathrm{Ce}$ & $6.6 \times 10^{-2}$ & 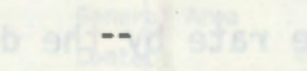 & $1.2 \times 10^{-5}$ \\
\hline${ }^{144} \mathrm{Ce}$ & 78 sint & 1) -- & $6.0 \times 10^{-4}$ \\
\hline Totals & T.0 & 1.0 & 1.0 \\
\hline
\end{tabular}

(a) From Table 7.3-7, Reference 1.

(b) From Table 7.3-10, Reference 1.

(c) Based on Table 7.3-14, Reference 1. 
Site Surface Contamination. Radioactive contamination is expected to be on the reference PWR site after 40 years of plant operation. An estimate of the radioactive contamination remaining onsite when the PWR is shut down after 40 years of operation is made, based on the 1975 reported releases from operating nuclear power stations. (5) The fractional activities of the various corrosion and fission products making up the site surface contamination are shown in Table 7.1-3.

\subsubsection{Radiation Dose Rate Data}

The measured radiation dose rate data used as the basis for this study came from six PWR reactor stations that had been operating from 3 to 6 years. The equilibrium levels of radiation dose rate from piping depositions have probably not yet been reached. However, the data presently available are not adequate to permit extrapolation to 30 years of full-power operation. (6) Therefore, composite radiation-level values created from data from six PWRs are used to estimate occupational radiation dose rates to decommissioning personnel without further upward adjustment. A representative sample of these estimated radiation dose rates is presented in Table 7.1-4. The wide range of dose rates shown in the table (from 0.001 to $30 \mathrm{R} / \mathrm{hr}$ ) is postulated to be typical for the reference PWR after final shutdown and before any chemical decontamination efforts.

The reactor coolant system radiation levels are caused primarily by the activated corrosion products ${ }^{58} \mathrm{Co}$ and ${ }^{60} \mathrm{Co}$. Measurements have shown that ${ }^{60} \mathrm{Co}_{0}$ increasingly dominates the radiation field after a few years of operation. Only ${ }^{58} \mathrm{Co}$ - and ${ }^{60} \mathrm{Co}$-deposited activities need to be considered for any immediate decommissioning approach, since these two radionuclides contribute more than $90 \%$ of the out-of-core radiation dose rates, with $70 \%$ of these attributed solely to ${ }^{60} \mathrm{Co} .(7)$ The relative decay rates of the principal activated corrosion products as a function of time are plotted in Figure 7.1-8, while the time dependence of radioactivity and the radiation dose rates in activated reactor components are shown in Figure 7.1-9. The curves in the figure roughly indicate the relative contribution to the dose rate by the different corrosion-product isotopes and the total activity as a function of time after reactor shutdown. The relative fraction of ${ }^{60}$ Co activity shown may be lower than that encountered in a plant that has operated 30 to 40 years, but these values represent presentiy available information. 
TABLE 7.1-4. Estimated Radiation Dose Rates in the Reference PWR at Shutdown (a)

Location

Type of
Measurement

Reactor Containment Building

Reactor Coolant Pump Bowl

RCS Piping, Cold Leg

Steam Generators

Emergency Personnel Lock

Floor Drains

Pressurizer Area

Regenerative Heat Exchanger ( $H x$ )

Between Steam Generator (SG)

Enclosure and Containment Vessel (CV)

Wall

Between RCS Pumps and SG's

$\begin{array}{lc}\text { Contact } & 12-30(\mathrm{c}) \\ \text { Contact } & 0.5-0.6 \\ \text { General Area } & 0.05 .-0.4 \\ \text { Inside Lock } & 0.001-0.012 \\ \text { Area } & \\ \text { Contact } & 0.1-0.6 \\ \text { General Area } & \leq 0.2 \\ \text { Contact } & 1-15 \\ \text { General Area } & \leq 0.025\end{array}$

Between Upper Internals Storage and $\mathrm{CV}$ Wall

Near CV Wall

General Area

$0.1-0.9$

General Area

$0.02-0.1$

Reactor Cavity, Inside Edge

General Area

0.005-0.02

Steam Generators

General Area

$0.1-1$

Auxiliary Building

Component Cooling Water Pumps

General Area

$\leq 0.2$

Waste Tank Room

Treated Waste Monitor Tanks

Pipeway

Resin Storage Tank

Volume Control Tank

Radwaste Evaporator Room

Waste Evaporator Panel

Demineralizers

HEPA Exhaust Filters

General Area

$\leq 0.15$

General Area

$0.2-0.4$

Contact

$0.01-0.3$

General Area

$0.05-0.15$

General Area

$>0.4$

General Area

$1-3$

General Area

$0.25-0.5$

General Area

$0.001-0.01$

General Area

$0.01-0.2$

Contact

$>0.005$

Fuel Building

Waste Holdup Tank Rooms

Water Heat Exchangers

Gas Stripper Feed Pumps

Druming Room

Drumming Room Entrance

CVCS Monitor Tanks

Boric Acid Evaporator Room

Spent Fuel Pool Pump

Spent Fuel Pool Skimmer filters

Controlled Access Machine Shop

Spent Fuel Pit

$\begin{array}{ll}\text { General Area } & 2-5 \\ \text { General Area } & 0.07-0.14 \\ \text { General Area } & \geq 0.025 \\ \text { General Area } & 0.2-1.5 \\ \text { General Area } & 0.2 \\ \text { Contact } & \leq 0.3 \\ \text { General Area } & 0.3-0.5 \\ \text { General Area } & \geq 0.05 \\ \text { General Area } & \geq 0.1 \\ \text { General Area } & 0.02-0.1 \\ \text { General Area } & \geq 0.025\end{array}$

(a) From Table 7.4-2, Reference 1.

(b) Contact means the closest approach to a surface (a surface dose rate) including the necessary geometry and source size corrections done in the field by the health physicist. General Area refers to the radiation field in a room or area; not specifically from one discrete source or direction, although a specific source or object may be the sole contributor to the General Area radiation level measurement.

(c) Example: 12-30 means in the range of from 12 to $30 \mathrm{R} / \mathrm{hr}$. 


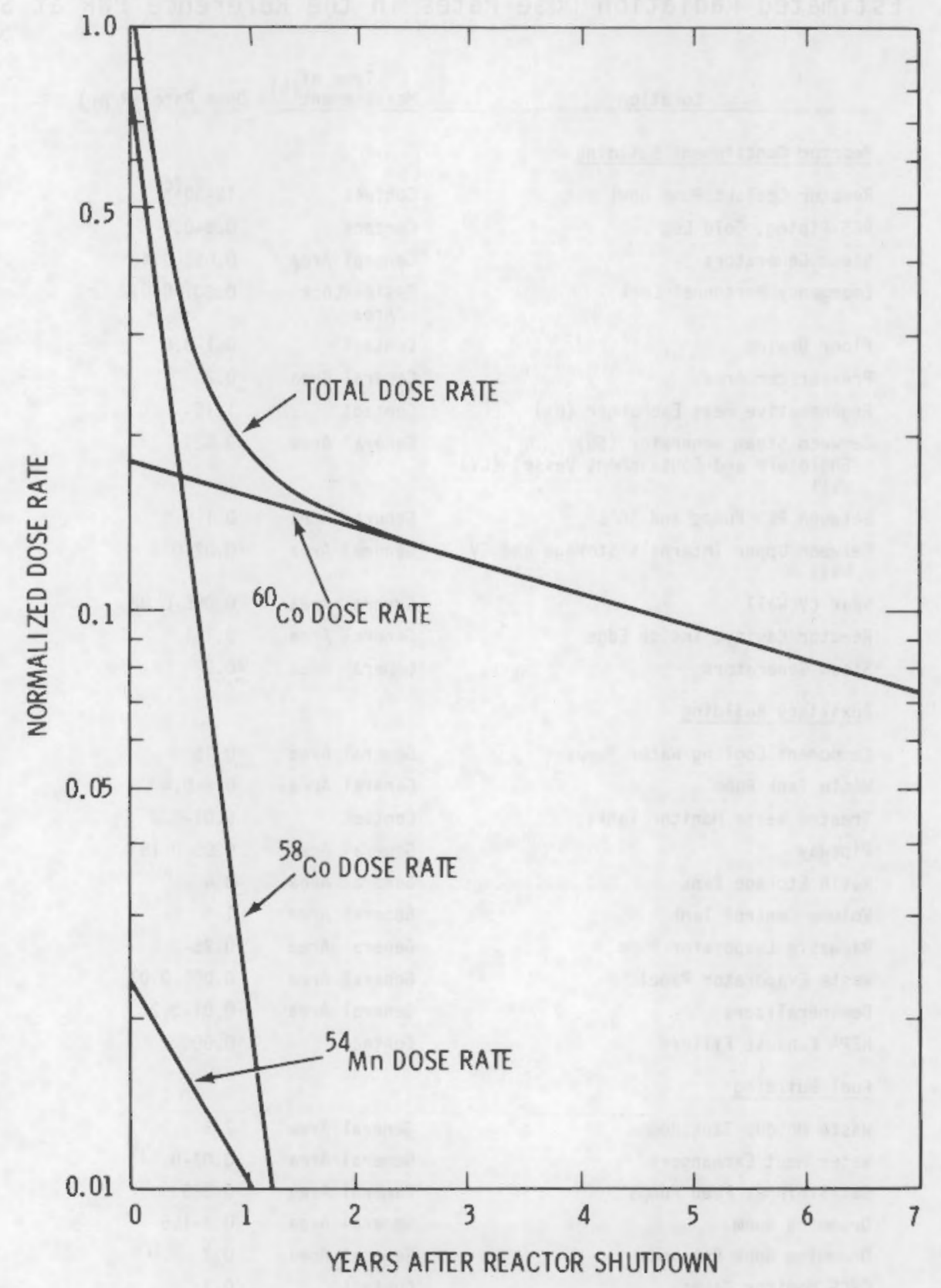

FIGURE 7.1-8. Radioactive Decay of Activated Corrosion Products 


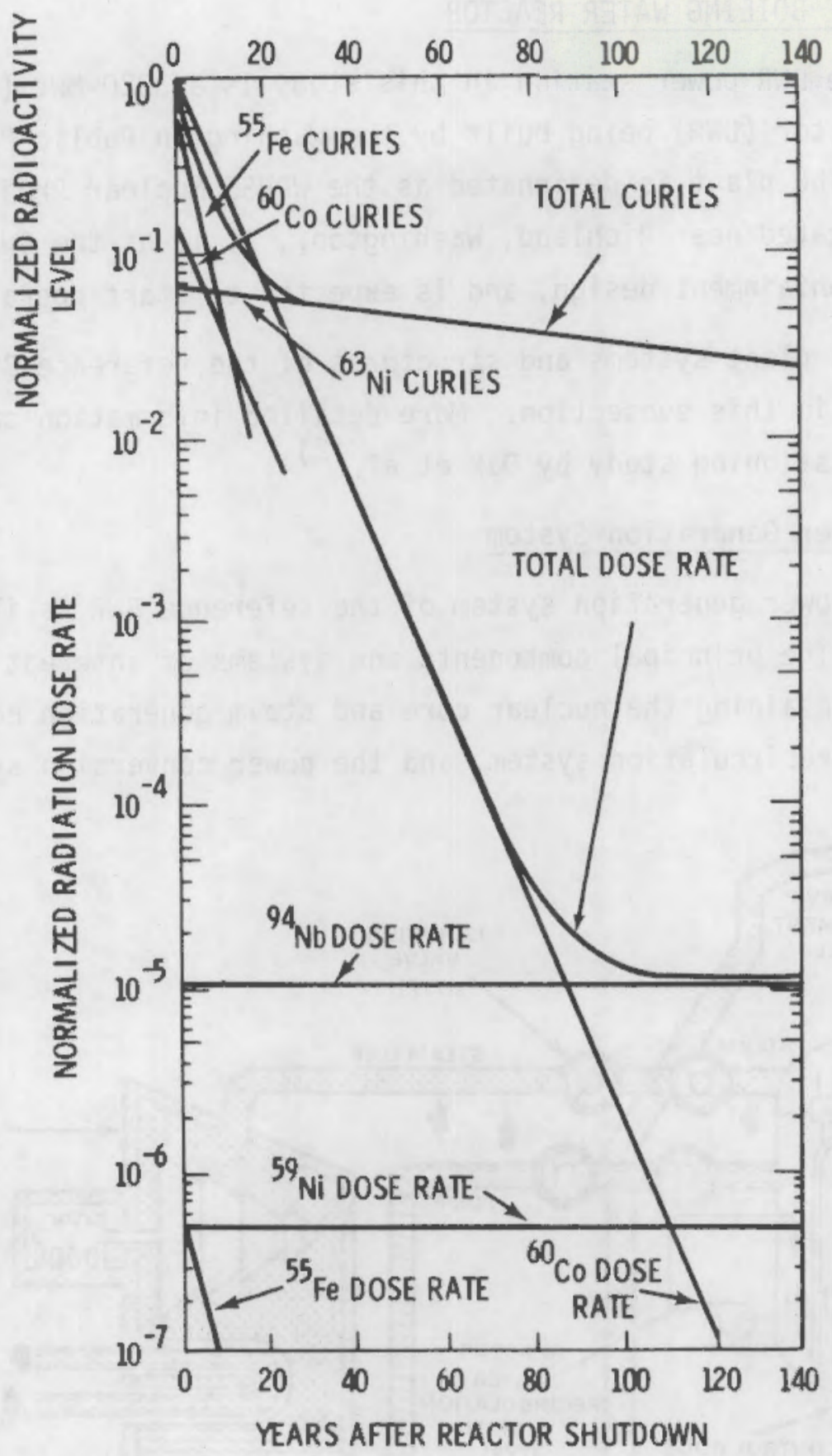

FIGURE 7.1-9. Time Dependence of Radioactivity Levels and Radiation Dose Rates in the Activated Reactor Components 


\subsection{THE REFERENCE BOILING WATER REACTOR}

The reference BWR power station in this study is a 3320-MWt (1155-MWe) boiling water reactor (BWR) being built by the Washington Public Power Supply System (WPPSS). The plant is designated as the WPPSS Nuclear Project No. 2 (WNP-2) and is located near Richland, Washington. It is of the BWR/5 class and the Mark-II containment design, and is expected to start operation in 1983.

The principal plant systems and structures of the reference BWR are described briefly in this subsection. More detailed information can be found in the BWR decommissioning study by oak et a1. (2)

\subsubsection{Nuclear Power Generation System}

The nuclear power generation system of the reference BWR is illustrated in Figure 7.2-1. The principal components and systems of interest are the reactor vessel (containing the nuclear core and steam generation equipment), the reactor water recirculation system, and the power conversion system.

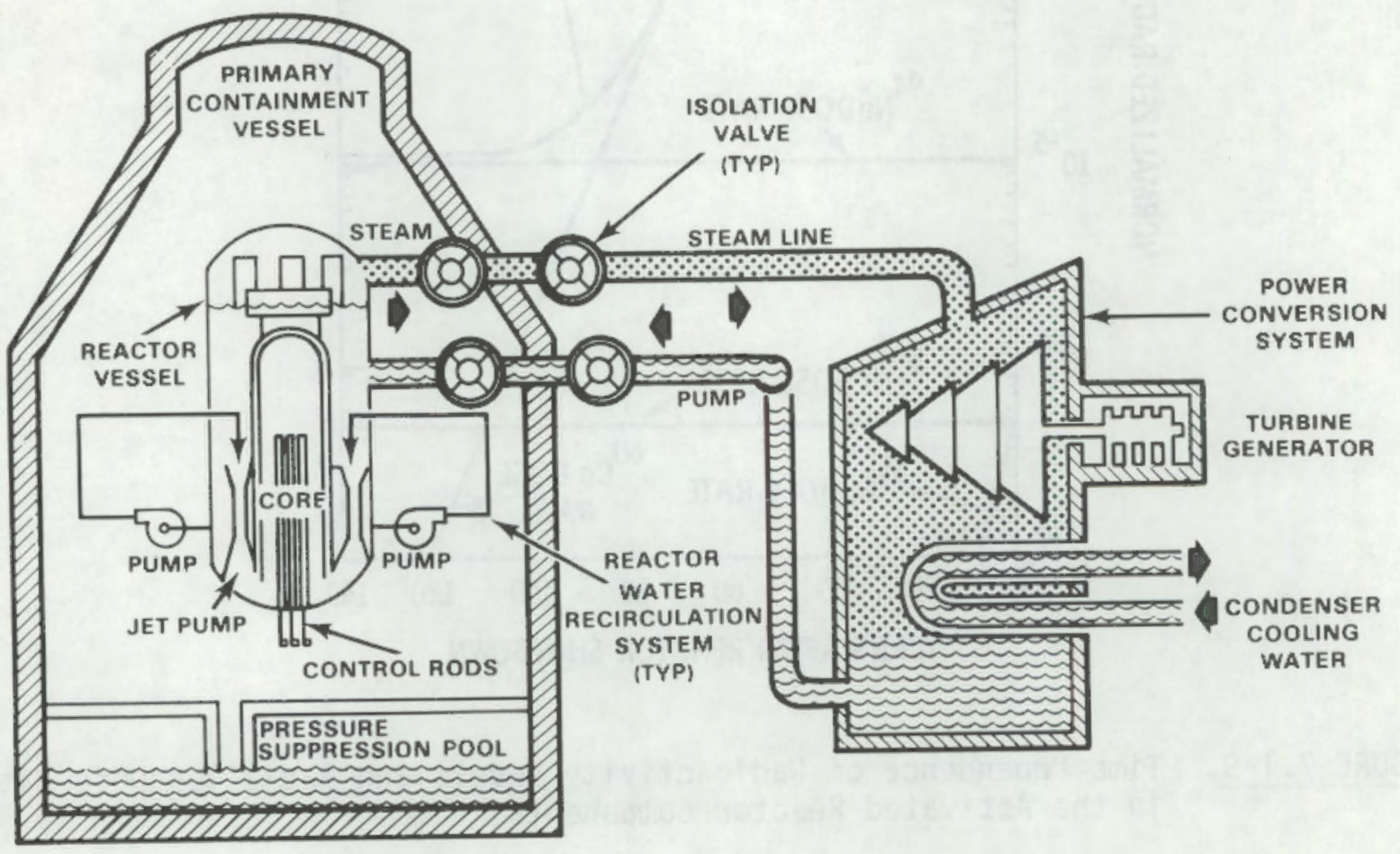

FIGURE 7.2-1. Boiling Water Reactor 


\subsubsection{Reactor Vessel and Internals}

The reactor vessel is a right circular cylinder with a permanently attached hemispherical bottom and a removable hemispherical top, as illustrated in Figure 7.2-2. The vessel is made of carbon steel about $0.171 \mathrm{~m}$ thick, with the inside clad with stainless steel about $3 \mathrm{~mm}$ thick. The approximate dimensions of the vessel are $22.2 \mathrm{~m}$ in height and $6.7 \mathrm{~m}$ in outer diameter. The mass of the vessel is nearly $750 \mathrm{Mg}$ empty.

The major reactor internal components are the core (fuel, flow channels, control rods, and instrumentation), the core support structure (including the core shroud, top fuel guide, and core support plate), the shroud head and steam separator assembly, the steam dryer assembly, the jet pumps, the feedwater spargers, and the core spray lines.

\subsubsection{Reactor Water Recirculation System}

The reactor water recirculation system, shown in Figure 7.2-3, has two loops external to the reactor vessel but inside the primary containment vessel. Each loop contains a pump, two motor-operated isolation valves, and one hydraulically operated flow-control valve. Each loop supplies reactor water to 10 jet pumps located inside the reactor vessel in the annular region between the core shroud and the vessel wall (refer to Figure 7.2-2).

\subsubsection{Power Conversion System}

The power conversion system converts the usable energy from the steam produced in the reactor vessel to electricity, condenses the steam, and heats the condensate and pumps it back to the reactor as feedwater. The system, shown in Figure 7.2-4, consists of a large steam turbine and generator, moisture separator-reheaters, a single-pass condenser, motor-driven condensate and condensate booster pumps, a full-flow condensate demineralizer system, turbinedriven feedwater pumps, and six stages of feedwater heating.

\subsubsection{General Plant Arrangement}

The arrangement of the structures on the reference BWR plant site is illustrated in Figure 7.2-5. The structures of primary interest during decommissioning are the Reactor Building, the Turbine Generator Building, and the 


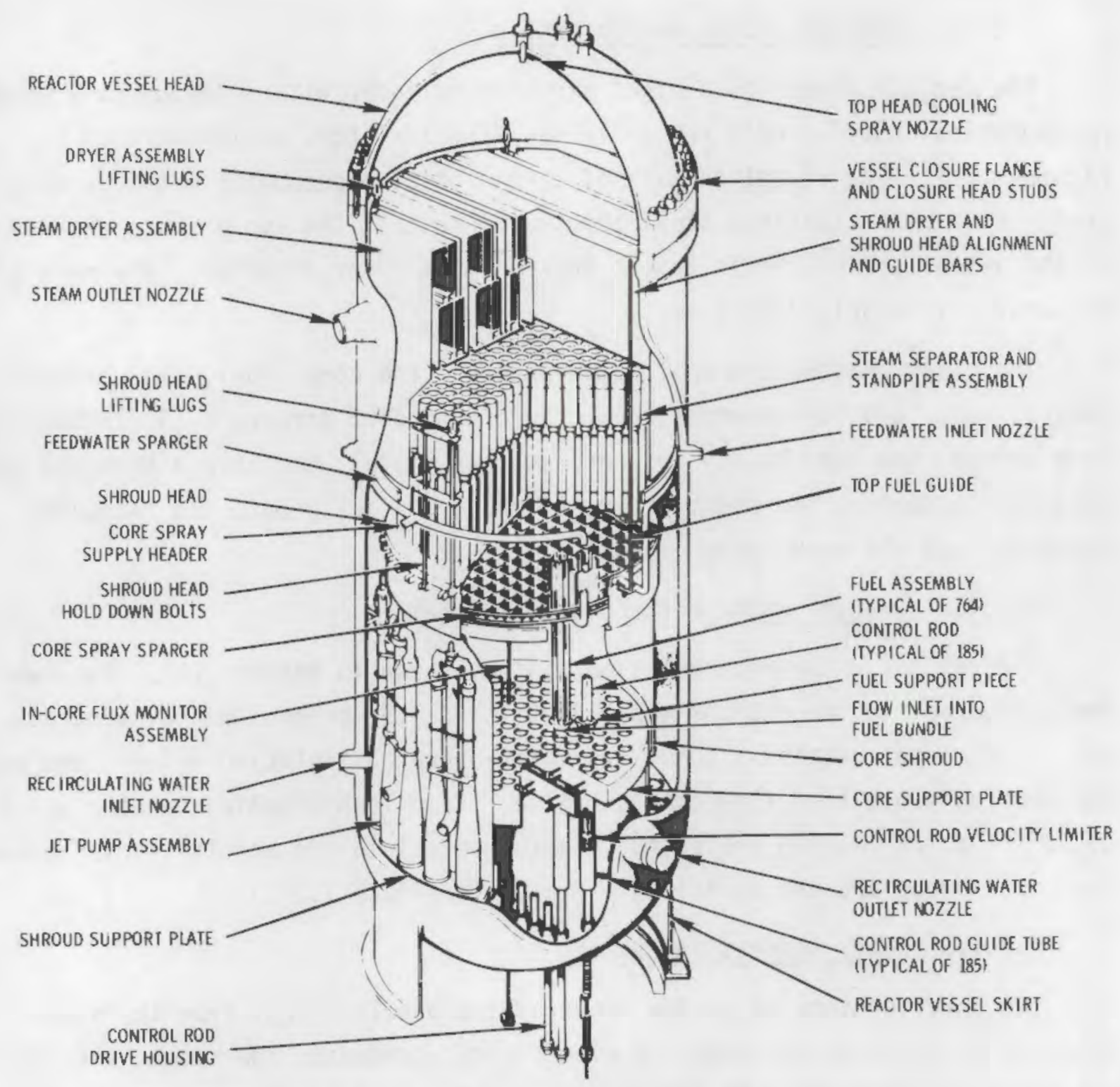

FIGURE 7.2-2. Reactor Vessel and Internals

Radwaste and Control Building. These buildings contain radioactive materials that require special handling during decommissioning. The other structures, if removed, are conventionally demolished.

The buildings in the main complex are in close proximity to each other but are physically separate from one another both above and below grade. 


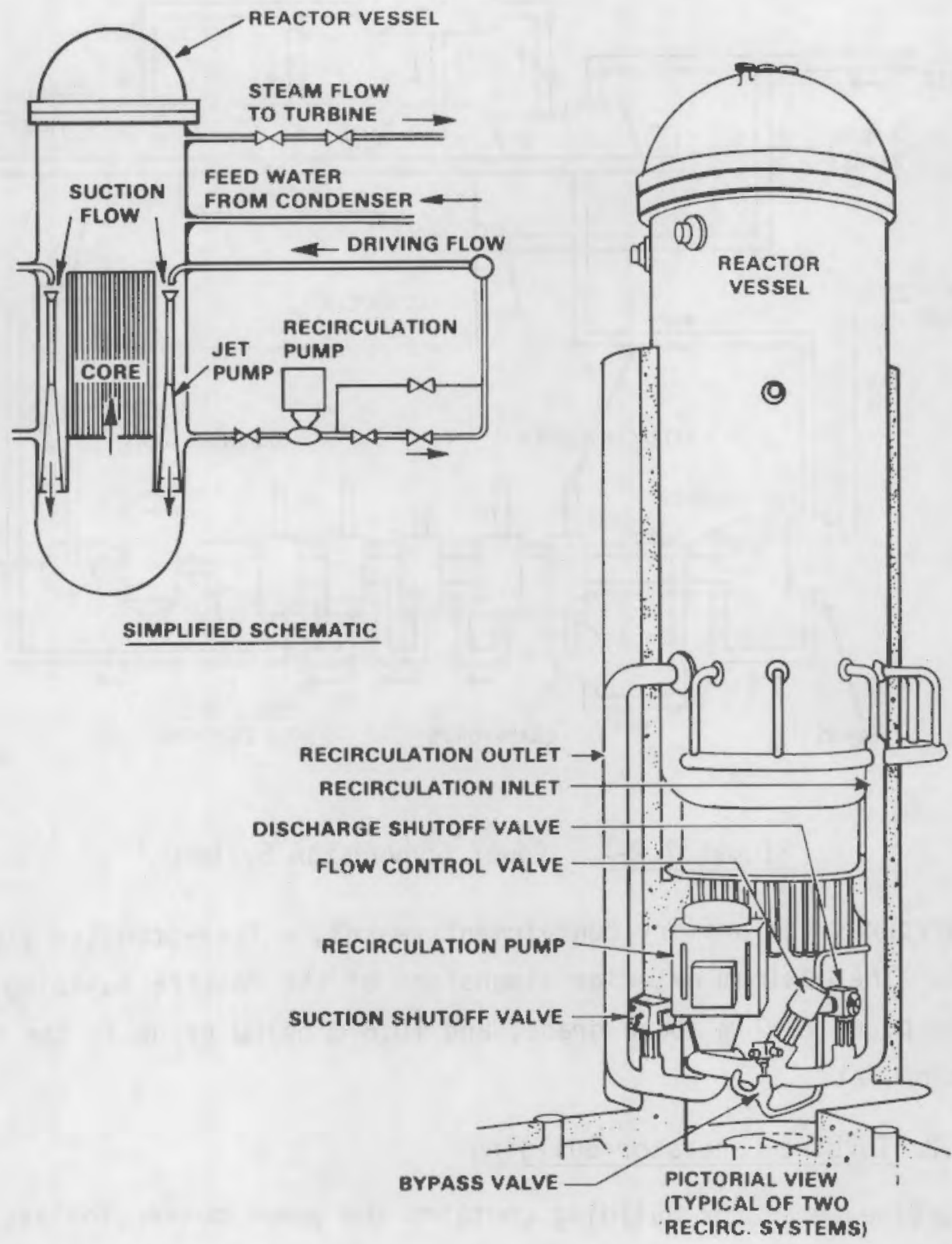

FIGURE 7.2-3. Reactor Water Recirculation System

\subsubsection{Reactor Building}

The Reactor Building, containing the nuclear steam supply system and its auxiliaries, is constructed of reinforced concrete capped by metal siding and roofing supported by structural steel. As shown in Figure 7.2-6, the 


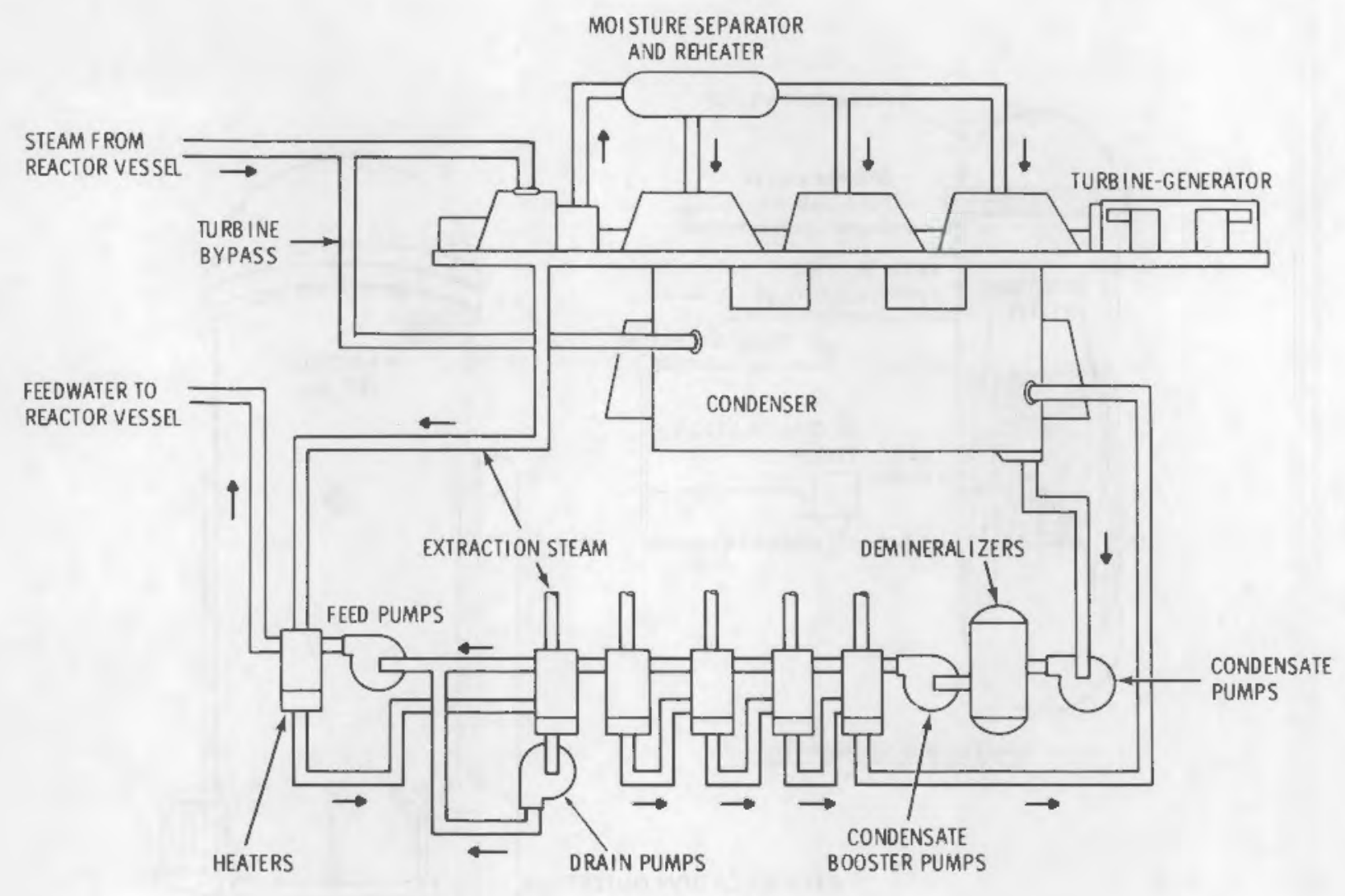

FIGURE 7.2-4. Power Conversion System

building surrounds the primary containment vessel, a free-standing steel pressure vessel. The maximum exterior dimensions of the Reactor Building are $41.9 \mathrm{~m}$ by $52.9 \mathrm{~m}$ in plan, $70.1 \mathrm{~m}$ above grade, and $10.6 \mathrm{~m}$ below grade to the bottom of the foundation mat.

\subsubsection{Turbine Generator Building}

The Turbine Generator Building contains the power conversion system equipment and auxiliaries. It is constructed of reinforced concrete capped by steel-supported metal siding and roofing, and is approximately $58.8 \mathrm{~m}$ by $91.4 \mathrm{~m}$ in plan and $42.5 \mathrm{~m}$ high. There are two floors above the ground floor. Two steel tanks for condensate storage are located within a reinforced concrete dike just outside the building.

\subsubsection{Radwaste and Control Building}

The Radwaste and Control Building houses, among other systems, the condenser off gas treatment system, the radioactive liquid and solid waste systems, 


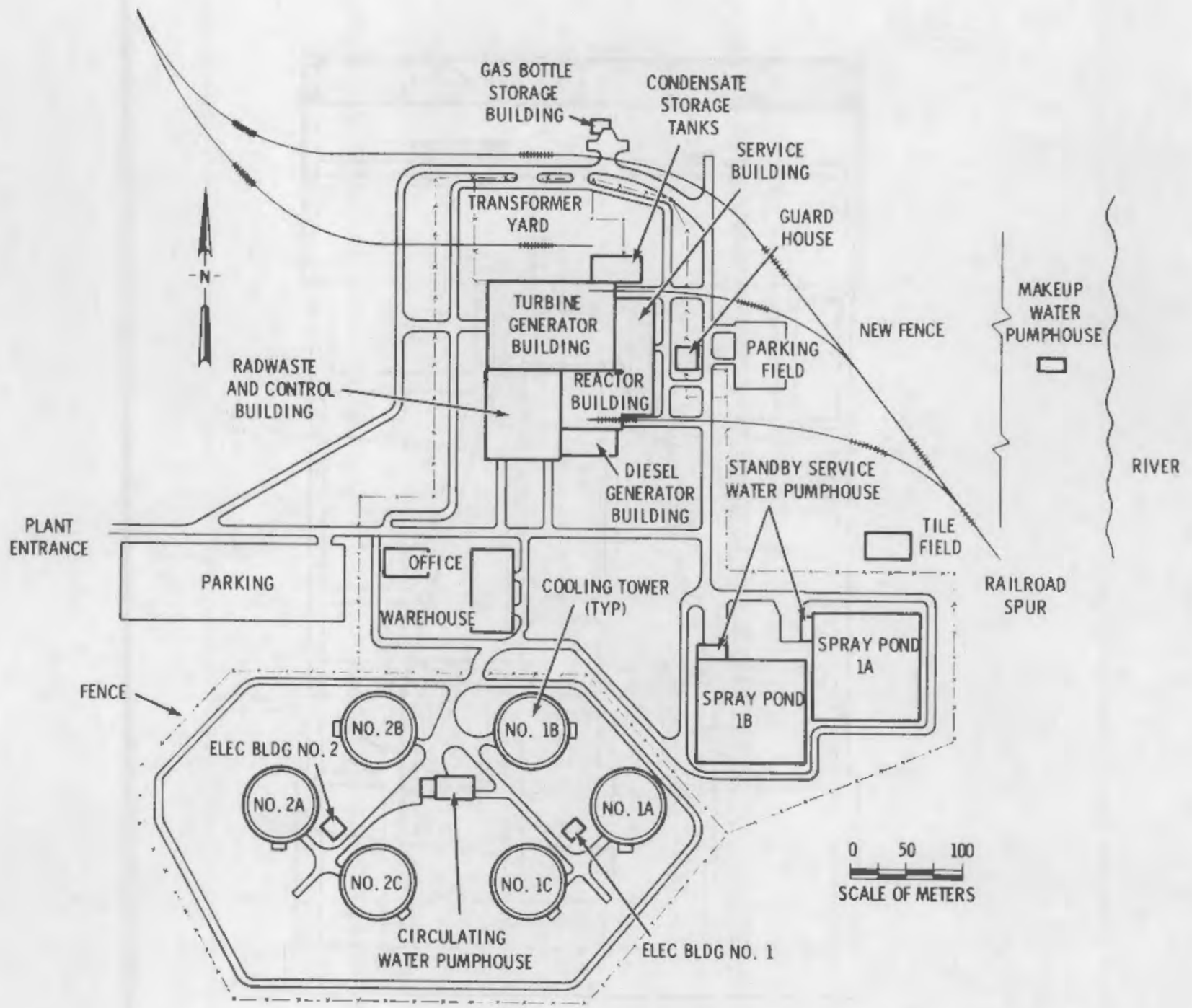

FIGURE 7.2-5. Site Layout of the Reference BWR Power Plant

the condensate demineralizer system, the reactor water cleanup demineralizer system, and the fuel pool cooling and cleanup demineralizer system. The building is constructed of reinforced concrete and metal-sided and -roofed structural steel, with two full floors and one partial floor above the ground floor. It is approximately $63.7 \mathrm{~m}$ by $48.8 \mathrm{~m}$ in plan and $32 \mathrm{~m}$ in overall height.

\subsubsection{Other Structures}

The remaining buildings of the reference BWR site complex, which, in this study, are assumed to be uncontaminated with radioactive material, are the Diesel Generator Building, the Service Building, the Cooling Tower Complex, the Spray 


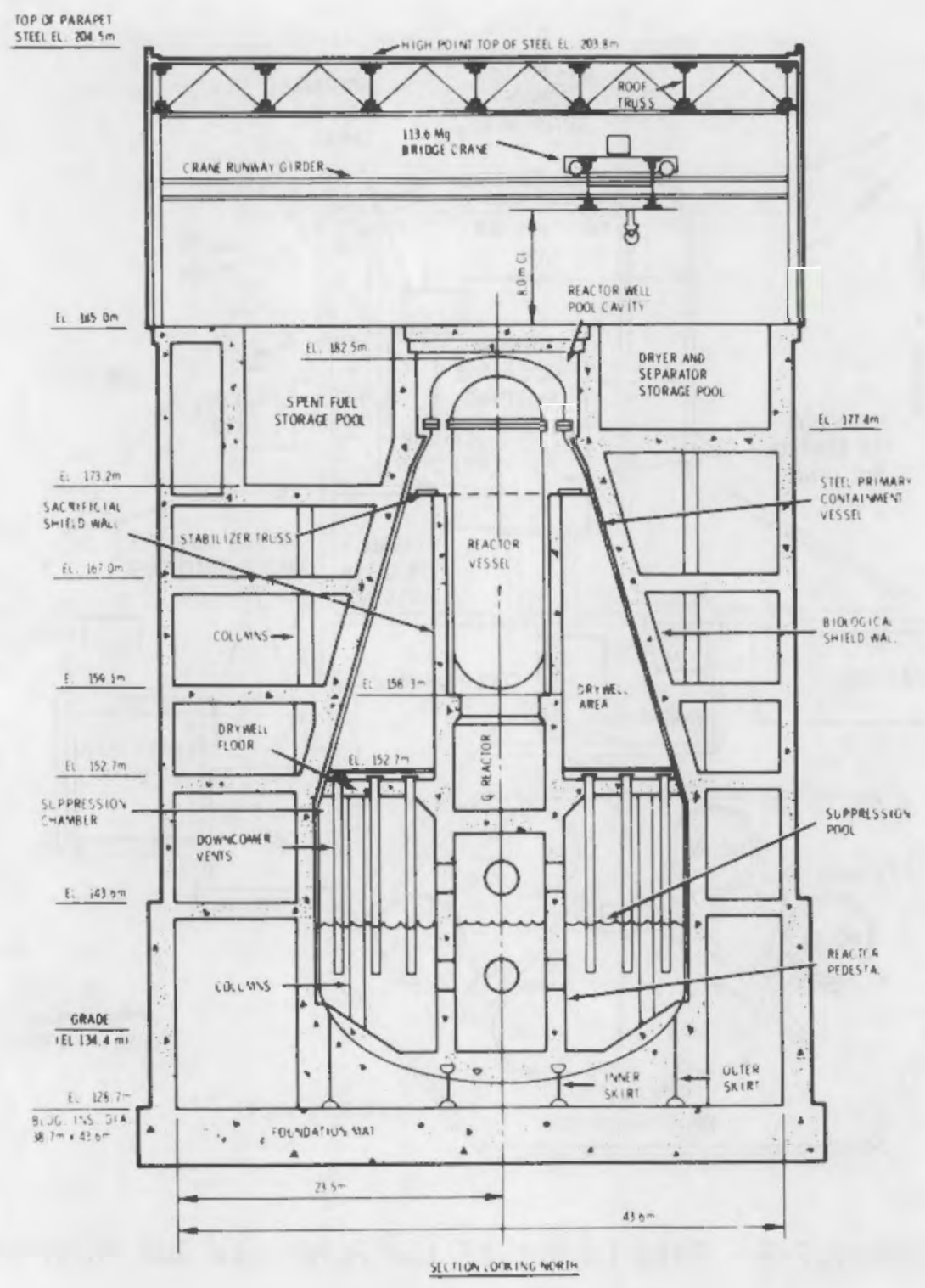

FIGURE 7.2-6. BWR Reactor Building

Pond Complex, the Makeup Water Pumphouse, the Office Building, the Warehouse, the Guardhouse, and the Gas Bottle Storage Building.

\subsubsection{Radionuclide Inventories}

The radionuclide inventories at the time of final reactor shutdown (excluding the irradiated spent fuel) are of two types: 1) neutron-activated components in and surrounding the reactor core and 2) surface contamination from fission 
products and activated corrosion products deposited inside certain piping and equipment systems, on some structural surfaces, and on the site. Details of the calculational methods used for estimating the radionuclide inventories at the reference BWR are presented in the BWR decommissioning study.

\subsubsection{Neutron-Activated Components}

Radioactive material is produced in the structural components in and around the reactor vessel because of interactions with neutrons produced in the reactor fuel during operation. Three basic types of materials are used in and around the reactor vessel: stainless steel (Type 304), carbon steel (Type SA533), and reinforced concrete. This subsection contains summaries of the radionuclide inventories for, the total radioactivity in, and selected dose rates for the neutron-activated components.

Radionuclide Inventories in Neutron-Activated Materials. The radionuclide inventories calculated for the neutron-activated materials at final reactor shutdown are presented in Table 7.2-1. These inventories are calculated using the thermal neutron flux distribution at the axial midplane of the fuel zone for 30 EFPY of operation. They are designed to represent maximum values of the neutron-induced radioactivity present in the reference BWR at final shutdown. Thus, the radioactivity concentrations listed in Table 7.2-1 are the maximum concentrations used in this study.

Total Radioactivity in Neutron-Activated Components. The total radioactivity in neutron-activated components is summarized in Table 7.2-2. Radioactivity totals in the reactor vessel and its internal components range from about $0.5 \mathrm{Ci}$ in a single control rod guide tube to about $6.3 \mathrm{million} \mathrm{Ci}$ in the core shroud. The sacrificial shield is calculated to contain about $166 \mathrm{Ci}$, and the total radionuclide inventory in all neutron-activated components of the reference BWR is about $6.6 \mathrm{million} \mathrm{Ci}$. The activated portion of the core shroud contains about $96 \%$ of the total radioactivity in the neutron-activated components. 


\section{TABLE 7.2-T. Radionuclide Inventory in Neutron-Activated BWR Components}

\begin{tabular}{|c|c|c|c|c|c|c|}
\hline \multirow[b]{2}{*}{ Radionuclide } & \multicolumn{2}{|c|}{ Stainless steel ${ }^{(a)}$} & \multicolumn{2}{|c|}{ Carbon Steel ${ }^{(b)}$} & \multicolumn{2}{|c|}{ Concrete $\{c\}$} \\
\hline & $\begin{array}{l}\text { Radioactivity } \\
\text { Concentration } \\
\text { at Shutdown } \\
\left.\text { (ci/m } \mathbf{m}^{3}\right) \\
\end{array}$ & 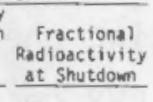 & $\begin{array}{l}\text { Radioactivity } \\
\text { concentration } \\
\text { at Shutdolom } \\
\text { (ci/m } \\
\text { (ci) }\end{array}$ & $\begin{array}{l}\text { Eractional } \\
\text { Radioactivity } \\
\text { at Shutdown }\end{array}$ & 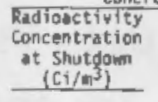 & $\begin{array}{l}\text { Fractional } \\
\text { Radioactivity } \\
\text { at Shutdom }\end{array}$ \\
\hline $3_{\mathrm{H}}$ & $4.65 \times 10^{-4}$ & $1.63 \times 10^{-10}$ & (d) & (d) & $2.58 \times 10^{-6}$ & $6.72 \times 10^{-7}$ \\
\hline $10_{8 e}$ & $2.63 \times 10^{-6}$ & $\ldots(e)$ & & & (d) & (d) \\
\hline${ }^{14} \mathrm{c}$ & $1.05 \times 10^{2}$ & $3.68 \times 10^{-5}$ & $6.77 \times 10^{-3}$ & $1.84 \times 10^{-5}$ & $1.36 \times 10^{-4}$ & $3.54 \times 10^{-5}$ \\
\hline $32 p$ & $1.11 \times 10^{2}$ & $3.89 \times 10^{-5}$ & $9.20 \times 10^{-1}$ & $2.51 \times 10^{-3}$ & $4.35 \times 10^{-2}$ & $1.13 \times 10^{-2}$ \\
\hline 33p & $6.65 \times 10^{2}$ & $2.33 \times 10^{-4}$ & & & & \\
\hline $35 s$ & $5.52 \times 10^{1}$ & $1.94 \times 10^{-5}$ & $1.76 \times 10^{-2}$ & $4.80 \times 10^{-5}$ & $3.25 \times 10^{-3}$ & $8.46 \times 10^{-4}$ \\
\hline${ }^{36} \mathrm{Cl}$ & $2.69 \times 10^{-4}$ & $\ldots(e)$ & & & $1.21 \times 10^{-6}$ & $3.15 \times 10^{-7}$ \\
\hline${ }^{37} \mathrm{Ar}$ & (d) & (d) & & & $3.08 \times 10^{-2}$ & $8.02 \times 10^{-3}$ \\
\hline${ }^{39} \mathrm{Ar}$ & & & & & $5.69 \times 10^{-3}$ & $1.48 \times 10^{-3}$ \\
\hline $40 \mathrm{~K}$ & & & & & $3.67 \times 10^{-5}$ & $9.55 \times 10^{-6}$ \\
\hline${ }^{4} \mathrm{Ca}$ & & & & & $7.90 \times 10^{-4}$ & $2.06 \times 10^{-4}$ \\
\hline${ }^{45} \mathrm{Ca}$ & & & & & $3.91 \times 10^{-1}$ & $1.02 \times 10^{-1}$ \\
\hline $46 \mathrm{sc}$ & & & & & $2.10 \times 10^{-6}$ & $5.47 \times 10^{-7}$ \\
\hline${ }^{s} \mathrm{Cr}_{\mathrm{r}}$ & $1.45 \times 10^{6}$ & $5.09 \times 10^{-1}$ & $1,75 \times 10^{0}$ & $4.77 \times 10^{-3}$ & $1.11 \times 10^{-2(f)}$ & $2.89 \times 10^{-3}$ \\
\hline${ }^{54} / \mathrm{m}$ & $8.50 \times 10^{3}$ & $2.98 \times 10^{-3}$ & $1.06 \times 10^{1}$ & $2.89 \times 10^{-2}$ & $9.60 \times 10^{-3(f)}$ & $2.50 \times 10^{-3}$ \\
\hline${ }^{55} \mathrm{Fe}$ & $9.22 \times 10^{5}$ & $3.24 \times 10^{-1}$ & $3.35 \times 10^{2}$ & $9.13 \times 10^{-1}$ & $3.15 \times 10^{0(f)}$ & $8.20 \times 10^{-1}$ \\
\hline $59 \mathrm{Fe}$ & $2.74 \times 10^{4}$ & $9.61 \times 10^{-3}$ & $9.44 \times 10^{0}$ & $2.57 \times 10^{-2}$ & $1.01 \times 10^{-1(f)}$ & $2.63 \times 10^{-2}$ \\
\hline${ }^{58} 8_{C 0}$ & $2.10 \times 10^{4}$ & $7.37 \times 10^{-3}$ & $1.49 \times 10^{0}$ & $4.06 \times 10^{-3}$ & $3.00 \times 10^{-3(f)}$ & $7.81 \times 10^{-4}$ \\
\hline${ }^{60}$ to & $3.36 \times 10^{5}$ & $1.18 \times 10^{-1}$ & $6.49 \times 10^{0}$ & $1 . n \times 10^{-2}$ & $6.45 \times 10^{-2(f)}$ & $1.68 \times 10^{-2}$ \\
\hline${ }^{59} \mathrm{Ni}$ & $6.36 \times 10^{2}$ & $2.23 \times 10^{-4}$ & $1.46 \times 10^{-2}$ & $3.98 \times 10^{-5}$ & $1.24 \times 10^{-4}$ & $3.23 \times 10^{-5}$ \\
\hline${ }^{63} \mathrm{Ni}$ & $8.75 \times 10^{4}$ & $3.07 \times 10^{-2}$ & $1.73 \times 10^{0}$ & $4.71 \times 10^{-3}$ & $1.47 \times 10^{-2(f)}$ & $3.83 \times 10^{-3}$ \\
\hline${ }^{65} \mathrm{Zn}$ & $3.23 \times 10^{1}$ & $1.13 \times 10^{-5}$ & $1.88 \times 10^{-6}$ & $5.12 \times 10^{-9}$ & & \\
\hline${ }^{93} \mathrm{zr}$ & $8.15 \times 10^{-6}$ &..$(e)$ & & & & \\
\hline${ }^{95} \mathrm{zr}$ & $1.41 \times 10^{-2}$ & $4.21 \times 10^{-5}$ & $1.62 \times 10^{-4}$ & $4.41 \times 10^{-7}$ & & \\
\hline $93 \mathrm{~m}_{\mathrm{NB}}$ & $1.35 \times 10^{-1}$ & $4.71 \times 10^{-8}$ & $3.90 \times 10^{-4}$ & $1.06 \times 10^{-6}$ & $3.05 \times 10^{-6}$ & $7.94 \times 10^{-6}$ \\
\hline${ }^{94}{ }_{\mathrm{Nb}}$ & $1.50 \times 10^{0}$ & $5.26 \times 10^{-7}$ & $8.30 \times 10^{-7}$ & $2.26 \times 10^{-9}$ & & \\
\hline${ }^{95} \mathrm{Nb}$ & $1.20 \times 10^{2}$ & $4.21 \times 10^{-5}$ & $3.76 \times 10^{-4}$ & $1.02 \times 10^{-6}$ & & \\
\hline${ }^{93}{ }_{\mathrm{mo}}$ & $3.26 \times 10^{-1}$ & $1.14 \times 10^{-7}$ & $9.39 \times 10^{-4}$ & $2.56 \times 10^{-6}$ & $7.36 \times 10^{-6}$ & $1.92 \times 10^{-6}$ \\
\hline${ }^{99} \mathrm{TC}$ & $3.18 \times 10^{-2}$ & $1.12 \times 10^{-8}$ & $2.64 \times 10^{-4}$ & $7.19 \times 10^{-7}$ & $4.08 \times 10^{-6}$ & $1.06 \times 10^{-6}$ \\
\hline $10 m_{\mathrm{Ag}}$ & $1.36 \times 10^{-2}$ & $2.58 \times 10^{-8}$ & & & $9.73 \times 10^{-8}$ & $2.53 \times 10^{-8}$ \\
\hline${ }^{106} \mathrm{Ag}$ & $8.67 \times 10^{1}$ & $3.04 \times 10^{-5}$ & & & $1.24 \times 10^{-4}$ & $3.23 \times 10^{-5}$ \\
\hline $109 m_{\mathrm{Ag}_{\mathrm{g}}}$ & $3.51 \times 10^{0}$ & $1.27 \times 10^{-6}$ & & & $2.56 \times 10^{-10}$ & $\ldots(e)$ \\
\hline${ }^{109} \mathrm{Cd}$ & $3.42 \times 10^{0}$ & $1.20 \times 10^{-6}$ & & & $2.17 \times 10^{-10}$ & $\ldots(\mathbf{e})$ \\
\hline $110^{2 m}$ & $8.04 \times 10^{0}$ & $2.82 \times 10^{-6}$ & & & $6.83 \times 10^{-5}$ & $1.78 \times 10^{-5}$ \\
\hline${ }^{110} \mathrm{Rg}_{\mathrm{Og}}$ & $2.02 \times 10^{2}$ & $7.09 \times 10^{-5}$ & & & $1.74 \times 10^{-3}$ & $4.53 \times 10^{-4}$ \\
\hline${ }^{151} \mathrm{sm}$ & $2.12 \times 10^{-2}$ & $7.44 \times 10^{-9}$ & & & $1.30 \times 10^{-3}$ & $3.39 \times 10^{-4}$ \\
\hline${ }^{152} \mathrm{Eu}$ & $1.12 \times 10^{-3}$ & $3.93 \times 10^{-10}$ & & & $1.00 \times 10^{-2}$ & $2.60 \times 10^{-3}$ \\
\hline${ }^{154} \mathrm{Eu}$ & $3.12 \times 10^{0}$ & $1.09 \times 10^{-6}$ & & & $1.31 \times 10^{-5}$ & $3.41 \times 10^{-4}$ \\
\hline${ }^{160} 0_{T 6}$ & $9.48 \times 10^{-4}$ & $3.33 \times 10^{-10}$ & & & & \\
\hline $5 m_{100}$ & $7.84 \times 10^{-4}$ & $2.75 \times 10^{-10}$ & - & $\ldots$ & $3.91 \times 10^{-6}$ & $1.02 \times 10^{-6}$ \\
\hline Totals & $2.85 \times 10^{5}$ & 1.00 & $3.67 \times 10^{2}$ & 1.00 & $3.84 \times 10^{0}$ & 1.00 \\
\hline
\end{tabular}

(a) Calculated at the inner surface of the 304 stainless steel core shroud, at the oxial midplane of (b) fuel zone, for 30 EFPY of operation. From Table 7.4-1, Reference 2

(b) Calculated at the inner surface of the 5.533 carbon steel reactor vessel, at the axtal midplane of the fuel zone, for 30 EFPY of operation. From Table 7.4-2. Reference 2.

(c) Calculated at the inner surface of the concrete portion of the sacrificial shield, at the axial midplane of the fuel 2one. for 30 EFPY of operation. From Table 7.4-3, Reference 2.

(d) A blank of the fuel

(f) Due iargely to structural steel in the sacrificial shield. 
TABLE 7.2-2. Estimated Total Radioactivity in Neutron-Activated Components (a)

\begin{tabular}{|c|c|c|c|}
\hline Component (quantity) & $\begin{array}{r}\text { Estimated } \\
\text { Activated } \\
\text { Volume }\left(\mathrm{m}^{3}\right) \\
\end{array}$ & $\begin{array}{l}\text { Radioactivity per } \\
\text { Component ( } \mathrm{Ci}) \\
\end{array}$ & $\begin{array}{r}\text { Estimated Total } \\
\text { Radioactivity (Ci) }\end{array}$ \\
\hline $\begin{array}{l}\text { Core Shroud (1) } \\
\text { Jet Pump As sembly (10) }\end{array}$ & $\begin{array}{l}3.75 \\
0.076\end{array}$ & $\begin{array}{l}6.30 \times 10^{6} \\
2.00 \times 10^{3}\end{array}$ & $\begin{array}{l}6.30 \times 10^{6} \\
2.00 \times 10^{4}\end{array}$ \\
\hline $\begin{array}{l}\text { Reactor Vessel (1) } \\
\text { Cladding } \\
\text { Shell Wall }\end{array}$ & $\begin{array}{l}0.428 \\
15.26\end{array}$ & $\begin{array}{l}4.58 \times 10^{2} \\
1.70 \times 10^{3}\end{array}$ & $2.16 \times 10^{3}$ \\
\hline $\begin{array}{l}\text { Sacrificial Shield (1) } \\
\text { Inner Shell } \\
\text { Reinforced Concrete Region } \\
\text { Outer Shell }\end{array}$ & $\begin{array}{r}2.19 \\
73.30 \\
6.22\end{array}$ & $\begin{array}{l}1.03 \times 10^{2} \\
3.47 \times 10^{0} \\
5.39 \times 10^{1}\end{array}$ & $1.60 \times 10^{2}$ \\
\hline $\begin{array}{l}\text { Steam Separator Assembly (1) } \\
\text { Shroud Head Plate } \\
\text { Steam Separator Risers }\end{array}$ & $\begin{array}{l}0.841 \\
0.376\end{array}$ & $\begin{array}{l}8.65 \times 10^{3} \\
9.52 \times 10^{2}\end{array}$ & $9.60 \times 10^{3}$ \\
\hline $\begin{array}{l}\text { Top Fuel Guide (1) } \\
\text { Orificed Fuel Support (193) } \\
\text { Core Support Plate (1) }\end{array}$ & $\begin{array}{l}0.310 \\
0.0036 \\
2.54\end{array}$ & $\begin{array}{l}3.01 \times 10^{4} \\
3.63 \times 10^{0} \\
6.50 \times 10^{2}\end{array}$ & $\begin{array}{l}3.01 \times 10^{4} \\
7.01 \times 10^{2} \\
6.50 \times 10^{2}\end{array}$ \\
\hline $\begin{array}{l}\text { Incore Instrument Strings (55) } \\
\text { Control Rod (185) } \\
\text { Control Rod Guide Tube (185) } \\
\text { Total }\end{array}$ & $\begin{array}{l}0.00026 \\
0.0019 \\
0.0024\end{array}$ & $\begin{array}{l}1.99 \times 10^{2} \\
9.61 \times 10^{2} \\
5.12 \times 10^{-1}\end{array}$ & $\begin{array}{l}1.10 \times 10^{4} \\
1.78 \times 10^{5} \\
9.47 \times 10^{1} \\
6.55 \times 10^{6}\end{array}$ \\
\hline
\end{tabular}

(a) These data are summarized from Table E.1-6 in Appendix E of Reference 2.

\subsubsection{Surface Contamination}

Both activated corrosion products (from structural materials in contact with the reactor water) and fission products (from leaking fuel) contribute to the radionuclide mixtures and levels of surface contamination. This subsection contains summaries of the radionuclide inventories and depositions of both internal surface contamination in piping and equipment and external surface contamination inside the reference BWR and on the surrounding site.

Internal Surface Contamination. Specific alloys used in the structural components of the reactor coolant system play a major role in the composition of the internal surface contamination. The activated corrosion product ${ }^{60} \mathrm{Co}$ is dominant in a BWR because of the abundance of its parent in structural materials, its large-formation cross section, its energetic decay, and its relatively long decay half-1ife. Cobalt-58 is only a minor source of radiation 
in a BWR, while in a PWR it is a significant contributor to the shutdown radiation levels. ( 8 ) Depending on the type of condenser tubes and condensate polishing system used, ${ }^{65} \mathrm{Zn}$ could be an isotope of concern.

Mobile fission products from leaking reactor fuel also contribute to the internal surface contamination. Their concentrations are directly related to the number of leaking fuel elements in the reactor core and thus will change during plant operation. The composition of internal surface contamination assumed in this study is summarized in Table 7.2-3.

External Surface Contamination in the Reference BWR. The mixtures of radionuclides found on external structural surfaces in the reference BWR are calculated based on an accumulation of the radionuclides present in the reactor water on a surface over the 30 EFPY plant life. (6) The resulting mixture accounts for both continuous accumulation and radioactive decay. External surface radioactive contamination at shutdown is shown in Table 7.2-3.

External Surface Contamination on the Site. Radionuclides are assumed to be deposited on the reference site as a result of normal BWR operation over 30 EFPY of service. Accidental releases are not expected to significantly increase the radioactivity present on the reference site, and are not considered in this analysis. Annual airborne radionuclide releases from operating BWRs vary widely and are dependent on such plant factors as size, operating conditions, and gaseous radwaste systems. For this study, the airborne releases are based on releases reported from 23 operating BWRs for 1975. (5) Because fuel failures were higher during this period than at present, these values may produce an overestimate of normal releases expected over a plant's operating life. The radionuclide depositions on the reference BWR site at shutdown following normal BWR operation for 30 EFPY are 1 isted in Table 7.2-3.

Surface Contamination Deposition in the Reference BWR. The estimated radioactivity depositions, both on internal piping and equipment surfaces and on external structural surfaces in the reference BWR, are summarized in Table 7.2-4. A total of $8.5 \times 10^{3} \mathrm{Ci}$ is estimated to be present on internal piping and equipment surfaces and on external surfaces in the reference BWR. 
TABLE 7.2-3. Radionuclide Inventory of BWR Surface Contamination

\begin{tabular}{|c|c|c|c|}
\hline \multirow[b]{2}{*}{ Radionuclides } & \multicolumn{3}{|c|}{ Fractional Radioactivity at Shutdown } \\
\hline & $\begin{array}{c}\text { Internal } \\
\text { Surface } \\
\text { Contamination (a) } \\
\end{array}$ & $\begin{array}{c}\text { External } \\
\text { Surface } \\
\text { Contamination }(b) \\
\end{array}$ & $\begin{array}{c}\text { Site } \\
\text { Surface (c) } \\
\text { Contamination (c) } \\
\end{array}$ \\
\hline $32 \mathrm{p}$ & (d) & $1.1 \times 10^{-3}$ & \\
\hline${ }^{51} \mathrm{Cr}$ & $2.1 \times 10^{-2}$ & $5.3 \times 10^{-2}$ & $2.9 \times 10^{-5}$ \\
\hline${ }^{54} \mathrm{~m}$ & $3.9 \times 10^{-1}$ & $7.2 \times 10^{-4}$ & $3.7^{1} \times 10^{-3}$ \\
\hline $55_{\mathrm{Fe}}$ & & $3.7 \times 10^{-1}$ & \\
\hline $59_{\mathrm{Fe}}$ & $2.5 \times 10^{-2}$ & $5.3 \times 10^{-4}$ & $1.8 \times 10^{-5}$ \\
\hline${ }^{58} \mathrm{Co}$ & $9.3 \times 10^{-3}$ & $5.6 \times 10^{-3}$ & $3.2 \times 10^{-4}$ \\
\hline${ }^{60} \mathrm{COO}_{\mathrm{O}}$ & $4.7 \times 10^{-1}$ & $2.9 \times 10^{-1}$ & $5.0 \times 10^{-2}$ \\
\hline${ }^{63} \mathrm{Ni}$ & & $3.4 \times 10^{-3}$ & \\
\hline${ }^{65} \mathrm{zn}$ & $6.1 \times 10^{-3}$ & $1.8 \times 10^{-2}$ & $1.1 \times 10^{-5}$ \\
\hline${ }^{89} \mathrm{Sr}$ & & $2.0 \times 10^{-3}$ & $1.1 \times 10^{-2}$ \\
\hline${ }^{90} \mathrm{Sr}$ & & $1.5 \times 10^{-2}$ & $2.7 \times 10^{-1}$ \\
\hline $90_{Y}$ & & $1.5 \times 10^{-2}$ & $2.7 \times 10^{-1}$ \\
\hline $91^{Y}$ & & $8.1 \times 10^{-4}$ & \\
\hline${ }^{95} \mathrm{Zr}$ & $4.0 \times 10^{-3}$ & $1.6 \times 10^{-4}$ & $6.9 \times 10^{-5}$ \\
\hline${ }^{95} \mathrm{Nb}$ & $4.0 \times 10^{-3}$ & $1.6 \times 10^{-4}$ & $6.9 \times 10^{-5}$ \\
\hline${ }^{103_{R u}}$ & $2.3 \times 10^{-3}$ & $2.9 \times 10^{-4}$ & \\
\hline${ }^{106}{ }_{\mathrm{Ru}}$ & $2.8 \times 10^{-3}$ & $3.9 \times 10^{-4}$ & $7.2 \times 10^{-4}$ \\
\hline $110 m_{A g}$ & & $8.8 \times 10^{-6}$ & $4.0 \times 10^{-5}$ \\
\hline${ }^{124} \mathrm{sb}$ & & & $2.9 \times 10^{-7}$ \\
\hline${ }^{125} \mathrm{Sb}$ & & & $3.0 \times 10^{-6}$ \\
\hline${ }^{129 m \mathrm{Te}}$ & & $4.9 \times 10^{-4}$ & \\
\hline${ }^{131} 1_{I}$ & & $1.5 \times 10^{-2}$ & $4.8 \times 10^{-4}$ \\
\hline${ }^{134} \mathrm{Cs}$ & $1.9 \times 10^{-2}$ & $8.8 \times 10^{-3}$ & $2.3 \times 10^{-2}$ \\
\hline${ }^{136} \mathrm{cs}$ & & $1.0 \times 10^{-4}$ & $2.0 \times 10^{-6}$ \\
\hline${ }^{137} \mathrm{Cs}$ & $3.4 \times 10^{-2}$ & $1.8 \times 10^{-1}$ & $3.7 \times 10^{-1}$ \\
\hline${ }^{140} \mathrm{Ba}$ & & $2.0 \times 10^{-3}$ & $3.2 \times 10^{-3}$ \\
\hline${ }^{140} \mathrm{La}$ & & $2.0 \times 10^{-3}$ & $3.2 \times 10^{-3}$ \\
\hline${ }^{141} \mathrm{Ce}$ & $3.0 \times 10^{-3}$ & $2.9 \times 10^{-4}$ & $8.0 \times 10^{-5}$ \\
\hline${ }^{144} \mathrm{Ce}$ & $8.1 \times 10^{-3}$ & $2.9 \times 10^{-4}$ & $2.3 \times 10^{-4}$ \\
\hline${ }^{143} \mathrm{pr}$ & & $2.0 \times 10^{-4}$ & \\
\hline${ }^{147} \mathrm{Nd}$ & - & $1.2 \times 10^{-5}$ & $\ldots$ \\
\hline Totals & 1.0 & 1.0 & 1.0 \\
\hline
\end{tabular}

(a) Based on a BWR sludge sample analysis given in EPRI 404-2. (6) From Table 7.4-6, Reference 2.

(b) From Table 7.4-7, Reference 2.

(c) From Table 7.4-8, Reference 2

(d) A blank indicates that the radionuclide is not present. 
TABLE 7.2-4. Summary of Surface Contamination in the Reference BWR ${ }^{(a)}$

\begin{tabular}{|c|c|c|}
\hline $\begin{array}{c}\text { Category } \\
\text { Building } \\
\end{array}$ & $\begin{array}{c}\text { Estimated } \\
\text { Total } \\
\text { Surface } \\
\text { Area }\left(\mathrm{m}^{2}\right) \\
\end{array}$ & $\begin{array}{c}\text { Deposited } \\
\text { Radioactivity } \\
\text { (Ci) } \\
\end{array}$ \\
\hline \multicolumn{3}{|l|}{ Internal Surfaces } \\
\hline Piping & $3.4 \times 10^{4}$ & $2.2 \times 10^{3}$ \\
\hline \multicolumn{3}{|l|}{ Equipment } \\
\hline Reactor Building & $8.6 \times 10^{3}$ & $1.9 \times 10^{3}$ \\
\hline Turbine Generator Building & $2.0 \times 10^{5}$ & $1.2 \times 10^{3}$ \\
\hline Radwaste and Control Building & $1.4 \times 10^{3}$ & $3.2 \times 10^{3}$ \\
\hline Subtotal, Internal Surfaces & & $8.5 \times 10^{3}$ \\
\hline \multicolumn{3}{|l|}{ External Surfaces } \\
\hline Reactor Building & $5.2 \times 10^{3}$ & $7.4 \times 10^{7}$ \\
\hline Turbine Generator Building & $1.9 \times 10^{3}$ & $4.4 \times 10^{0}$ \\
\hline Radwaste and Control Building & $2.0 \times 10^{3}$ & $3.6 \times 10^{1}$ \\
\hline Subtotal, External Surfaces & & $1.1 \times 10^{2}$ \\
\hline Total & & $8.6 \times 10^{3}$ \\
\hline
\end{tabular}

(a) From Table 7.4-10, Reference 2.

\subsubsection{Radiation Dose Rate Data}

The radiation dose rate in any specific area affects the planning of decommissioning work with respect to temporary shielding, work sequences, decontamination, and radiation exposure. Once these factors have been studied to determine the most efficient work sequence, it is possible to estimate the radiation exposure time and the resultant occupational dose for each task.

The degree to which concrete surfaces are contaminated determines how much surface requires removal and how much contaminated concrete rubble requires disposal.

This subsection presents summaries of data concerning radiation dose rates and concrete surface contamination for the reference BWR at final shutdown. 


\subsubsection{Estimated Radiation Dose Rates at Shutdown}

Measured shutdown radiation dose rate data were obtained from seven operational BWRs, Dresden Units 2 and 3 and Quad Cities Units 1 and 2 operated by Commonwealth Edison Company, Peachbottom Units 2 and 3 operated by Philadelphia Electric Company, and Monticello operated by Northern States Power Company. At the time of measurements, the reactors had operated commercially for from 3 to 8 years. Composites created from these data are used as radiation dose rates in the reference BWR at final shutdown. Typical samples of the composite radiation dose rates are shown in Table 7.2-5. Detailed lists of these radiation dose rates are contained in Figures $0.1-1$ through D. 1-7 in Appendix D of Reference 2.

\subsubsection{Estimated Concrete Surface Contamination Levels at Shutdown}

Measured concrete surface contamination level data were obtained from the same four operational BWR sites as were the dose rate data. Typical samples of composites of these data are listed in Table 7.2-6. More detailed lists of measured concrete surface contamination data are provided in Figures D.2-1 through 0.2-7 in Appendix D of Reference 2.

\subsubsection{Contaminated Concrete Rubble Volumes Removed During DECON}

The volumes of contaminated concrete rubble estimated removed during DECON of the reference BWR are summarized in Table 7.2-7 for the Reactor Building (outside Primary Containment), the Primary Containment, the Turbine Generator Building, and the Radwaste and Control Building. The maximum measured contamination level in each location is also displayed. 
TABLE 7.2-5. Estimated Radiation Dose Rates in the Reference BWR at Shutdown (a)

\begin{tabular}{l} 
Location \\
Reactor Bldg.,Elev. $128.7 \mathrm{~m}$ through $152.7 \mathrm{~m}$ \\
\hline Low-Pressure Core Spray Pump \\
High-Pressure Core Spray Pump \\
Residual Heat Removal Pump \\
Reactor Water Recirculation Pump \\
Drywell Equipment Hatch \\
Main Steam Tunnel \\
Reactor Bldg., Elev. $159.1 \mathrm{~m}$ through $185.0 \mathrm{~m}$ \\
Reactor Vessel (near the feedwater nozzles) \\
Reactor Water Cleanup Pumps \\
Residual Heat Removal Heat Exchanger Piping \\
Regenerative Heat Exchanger \\
Regenerative Heat Exchanger \\
Reactor Well Pool Cavity \\
Turbine Generator Bldg., Elev. $134.4 \mathrm{~m}$ (grade)
\end{tabular}

Type of
Measurement (b)
Dose Rate $(R / h r)$

$\begin{array}{ll}\text { Contact } & .005-.015 \\ \text { Contact Area } & .002=.008 \\ \text { General Area } & .020-.050 \\ & .100-.370 \\ \text { Contact Area } & .100-.090-.210\end{array}$

Main Condenser

Steam Jet Air Ejector Condenser

Condensate Storage Tanks

Turbine Generator Bidg., Elev. $143.6 \mathrm{~m}$

Turbine

High-Pressure Feedwater Heaters and Piping

Moisture Separator Drain Tank

General Area

$.001-.002$

Contact

General Area

$.700-3.0$

Contact

$100-12.0$

Contact

.800

Contact

$300-10.0$

General Area $\quad .020-.750$

Contact

$.015-.060$

Turbine Generator B1dg., Elev. $152.7 \mathrm{~m}$

Main Steam and Feedwater Pipe Chase

Low-Pressure Feedwater Heaters

Moisture Seoarator Reheater

$\begin{array}{ll}\text { General Area } & .002 \\ \text { Contact } & .002-.015 \\ \text { General Area } & .002 \\ & \\ \text { Contact } & .150-5.000 \\ \text { General Area } & .050-1.600 \\ \text { General Area } & .005-.150 \\ \text { General Area } & .005-.450 \\ \text { General Area } & .500-.620 \\ \text { General Area } & .010-.060 \\ & \\ & \\ \text { Contact } & .016-.040 \\ \text { Contact } & .020-6.000 \\ \text { Contact } & .200-.300\end{array}$

Radwaste and Control B1dg., Elev. $133.2 \mathrm{~m}$ through $142.3 \mathrm{~m}$

Floor Drain Collector Tanik

Floor Drain Collector Tank

Spent Resin Tank

Waste Sludge Phase Separator Tank Decontamination Solution Concentrator Waste Tank

Radwaste Centrifuge Room

$\begin{array}{ll}\text { Contact } & .002 \\ \text { Contact } & .002-.030 \\ \text { Genera } 1 \text { Area } & .001\end{array}$

Radwaste and Control Bldg., Elev. $148.4 \mathrm{~m}$ through $160.0 \mathrm{~m}$

Waste Demineralizer Pumps

Waste Demineralizer Piping

Decontamination Solution Concentrator

Contact

$200-.300$

(a) From Table 7.3-1, Reference 2.

(b) General Area refers to the radiation field in a room or area, not specifically from one discrete source or direction, although a specific source may be the sole contributor to the radiation measurement.

Contact means the closest approach to a surface (a surface dose rate) including the necessary geometry and source size corrections done in the field by the health physicist. 
TABLE 7.2-6. Typical Measured Concrete Surface Contamination Levels in the Reference BWR at Shutdown(a)

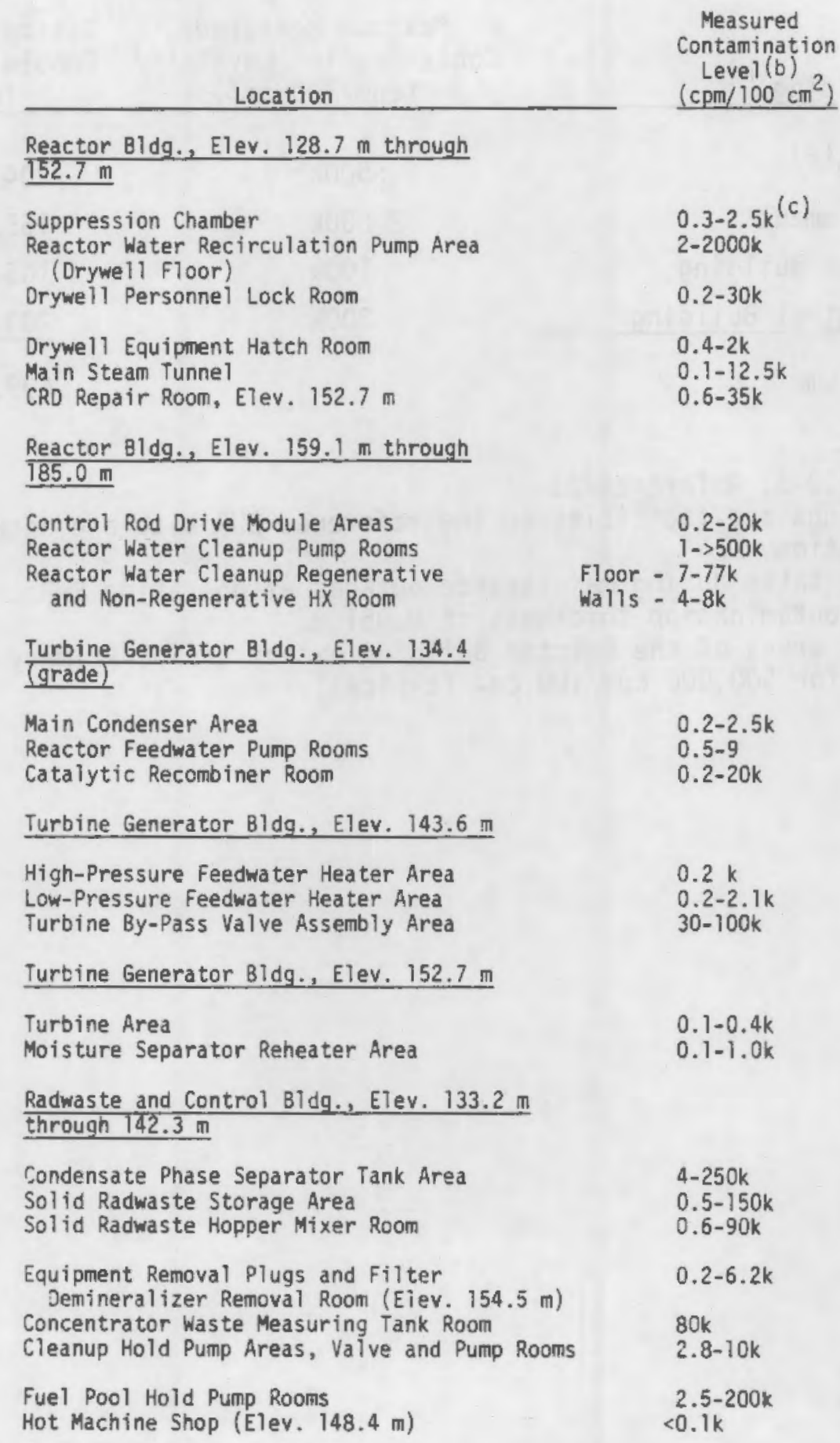

(a) From Table 7.3-2, Reference 2.

(b) Composite of measurements taken during maintenance outages at operating BWRs.

(c) $0.3-2.5 \mathrm{k}$ stands for 300 to $2,500 \mathrm{cpm} / 100 \mathrm{~cm}^{2}$ (typical). 
TABLE 7.2-7. Contaminated Concrete Rubble Volumes Removed During DECON of the Reference BWR(a)

\begin{tabular}{|c|c|c|}
\hline Building (b) & $\begin{array}{c}\text { Maximum Measured } \\
\text { Contamination Levels }(\mathrm{c}) \\
\left(\mathrm{cpm} / 100 \mathrm{~cm}^{2}\right) \\
\end{array}$ & $\begin{array}{l}\text { Estimated Tota } \\
\text { Rubble Volumes }(d) \\
\quad\left(m^{3}\right) \\
\end{array}$ \\
\hline Reactor Building $(e)$ & $>500 k^{(f)}$ & 204.5 \\
\hline Primary Containment & $2000 k$ & 155.8 \\
\hline Turbine Generator Building & $100 \mathrm{k}$ & 105.8 \\
\hline Radwaste and Control Building & $300 \mathrm{k}$ & 203.4 \\
\hline
\end{tabular}

(a) From Table 7.3-3, Reference 2.

(b) Other buildings and facilities on the reference BWR site are assumed to have no contamination.

(c) Measurements taken during maintenance outages at operating BWRs.

(d) Based on a contamination thickness of $0.051 \mathrm{~m}$.

(e) Includes all areas of the Reactor Building except inside Primary Containment.

(f) $500 \mathrm{k}$ stands for $500,000 \mathrm{cpm} / 100 \mathrm{~cm} 2$ (typical). 


\section{REFERENCES}

1. R. I. Smith, G. J. Konzek, and W. E. Kennedy, Jr., Technology, Safety and Costs of Decommissioning a Reference Pressurized Water Reactor Power Station, NUREG/CR-0130, U.S. Nuclear Regulatory Commission Report by Pacific Northwest Laboratory, June 1978.

2. H. D. Oak, G. M. Holter, W. E. Kennedy Jr., and G. J. Konzek, Technology, Safety and Costs of Decommissioning a Reference Boiling Water Reactor Power Station, NUREG/CR-0672, U.S. Nuclear Regulatory Commission Report by Pacific Northwest Laboratory, June 1980.

3. U.S. Nuclear Regulatory Commission, Steam Generator Repair Report Revision 1. Turkey Point Units 3 and 4, Docket Nos. 50-250 and 502-51, December 1977.

4. Design, Inspection, Operation and Maintenance Aspects of the WNSSS to Maintain Occupational Radiation Exposures as Low as Reasonably Achievable. WCRP-8872, Westinghouse Electric Corporation, Nuclear Energy Systems, Pittsburg, Pennsylvania, April 1977.

5. U.S. Nuclear Regulatory Commission, Radioactive Materials Released from Nuclear Power Plants (1975). NUREG-0218, March 1977.

6. S. G. Sawochka, N. P. Jacob, and W. L. Pearl, Primary System Shutdown Radiation Levels at Nuclear Power Generating Stations, EPRI 404-2, Final Report, Prepared by Nuclear Water and Waste Technology for the Electric Power Research Institute, Palo Alto, California, December 1975.

7. A. J. Kennedy, PWR Corrosion Products: Synthes is and Significance. Presented to the American Nuclear Society, November 27-December 2, 1977 in San Francisco, California, Babcock \& Wilcox Document Number RDTPL 77-24, November 1977.

8. M. G. Zimmerman, "Radiation Exposure from Neutron Activation Products at the End of LWR Lifetime," Trans. Am. Nucl. Soc., 27:784, 1977. 

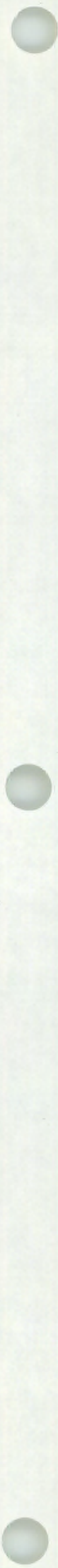


\subsection{IMPACT OF MULTIPLE REACTORS ON DECOMMISSIONING COST}

In this section the impact of having more than one reactor at a nuclear power station on the cost of decommissioning one of those reactors is developed by comparison with costs previously estimated for decommissioning reactors at power stations with only one reactor. Factors examined in this analysis include several different approaches to disposal of nuclear waste, the dedication of the site to nuclear power generation, the availability of centralized services, and the type and number of reactors present at the station.

The changes in the estimated decommissioning costs for DECON, SAFSTOR, and ENTOMB, relative to the base case single-reactor studies for the factors given above, are summarized in Table 8.0-1. (a) This information forms the basis for evaluating the decommissioning costs for the five different scenarios developed in Section 10.

TABLE 8.0-1. Summary of Decommissioning Cost Differences

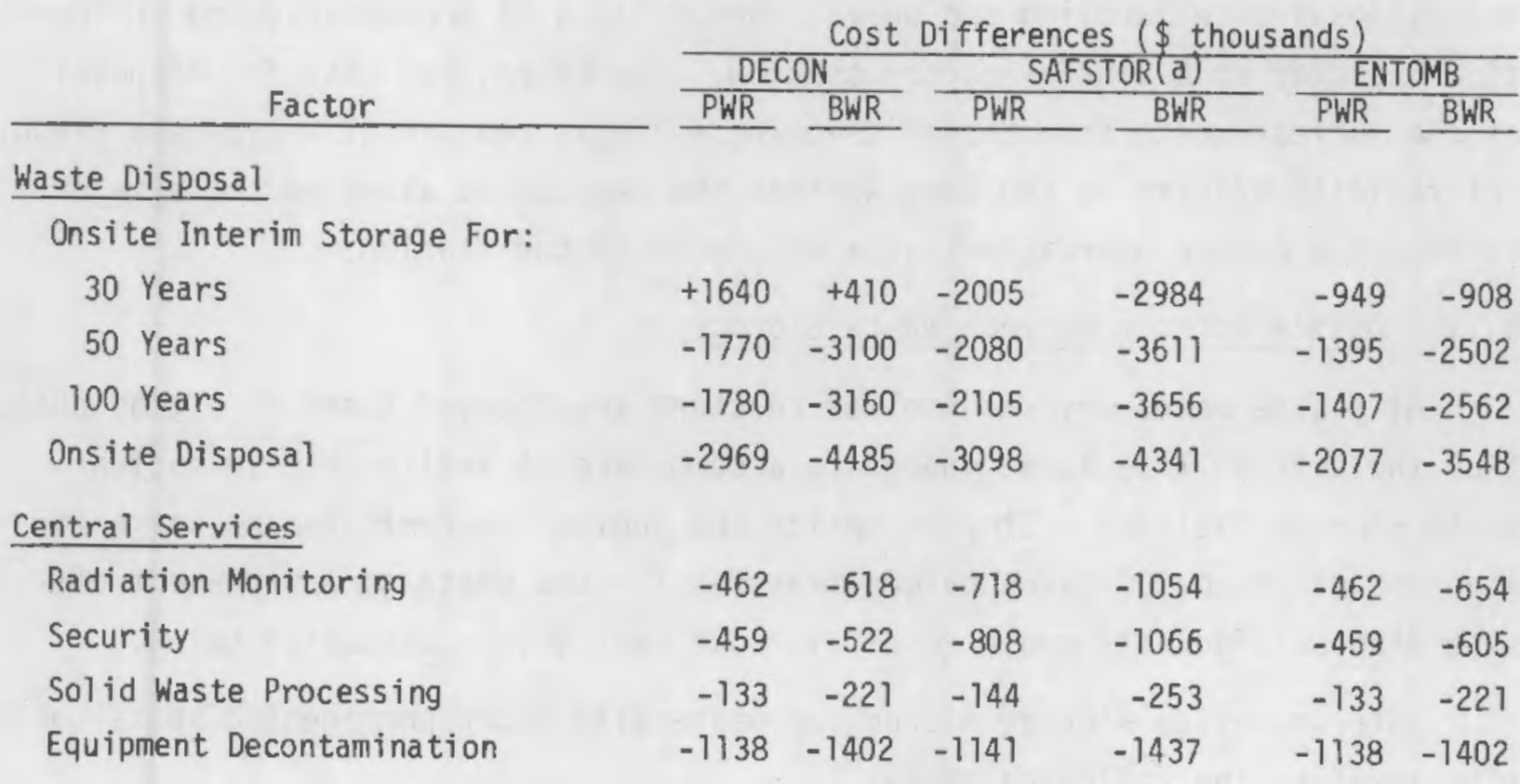

(a) For deferred decontamination after 30 years of safe storage.

(a) All costs in this study are estimated in 1978 dollars. 


\subsection{DISPOSAL OF NUCLEAR WASTE}

Several options for disposal of the nuclear waste generated by decommissioning a reactor at a multiple-reactor station are:

- burial offsite at a licensed disposal facility

- interim onsite storage with transfer to an offsite iicensed disposal facility at a later date

- burial onsite at a permanent nuclear waste disposal facility.

The impact of each of these options on the cost of disposal of nuclear waste from reactor decommissioning is discussed in the following subsections.

\subsubsection{Offsite Nuclear Waste Disposal}

In the studies of decommissioning a reference PWR ${ }^{(1)}$ and a reference BWR ${ }^{(2)}$ the nuclear waste was assumed to be sent offsite to a licensed nuclear waste facility. Decommissioning a single reactor at a multiple-reactor station will result in the same nuclear waste quantity, packaging cost, transportation cost, and disposal-site handling and burial charges as will decommissioning an identical reactor at a single-reactor station. Therefore, the cost for disposal of the nuclear waste from decommissioning a single reactor at a licensed disposal facility offsite is the same whether the reactor is alone on the site or is one of a number of reactors at a multipie-reactor station.

\subsubsection{Onsite Interim Nuclear Waste Storage}

At a site where several nuclear reactors are located there is a good chance that the site will be large enough to accommodate an onsite interim nuclear waste storage facility. Storing onsite the nuclear decommissioning waste for a period of 30 to 100 years before transferring the waste to a permanent offsite disposal facility could result in cost savings, as discussed below.

Interim onsite storage of nuclear waste with later permanent disposal offsite involves the following tasks:

- packaging

- transporting to interim onsite storage

- placing in interim storage 
- retrieving from interim storage

- transporting to a permanent disposal facility

- placing in a permanent disposal facility.

Several assumptions made in estimating the impact of interim onsite storage of nuclear waste are:

1. The quantity of nuclear waste placed in onsite interim waste storage is the same as would be sent immediately to an offsite waste disposal facility.

2. The packaging used for disposal of radioactive material is able to withstand interim storage, retrieval from storage, and relocation to an offsite permanent disposal facility without requiring repackaging.

3. Since transport to interim onsite waste storage is over private roads within a privately owned and controlled area, it is not necessary to meet the DOT surface radiation dose rate requirement. Shielding is provided for the truck cab to limit the dose rate to $2 \mathrm{mR} / \mathrm{hr}$. The radiation dose of workers is controlled to assure that it does not exceed the 10 CFR 20 7 imits. This assumption should result in fewer cask loads and the use of fewer shielded cask liners.

4. The cost of placing and maintaining nuclear waste in interim storage is equal to the disposal charge at a licensed waste disposal site $\left(\$ 93.57 / \mathrm{m}^{3}\right)$. (a)

5. There are no liner or curie surcharges at the onsite storage facility.

6. The cost of retrieving the waste from interim storage is the same as the disposal charge at a licensed waste disposal site $\left(\$ 93.57 / \mathrm{m}^{3}\right)$. (a)

7. After interim storage for 30 to 100 years some of the contaminated material will have decayed to levels permitting unrestricted release. Therefore, the quantity of nuclear waste that eventually must be sent to offsite disposal will decrease with increasing storage time.

(a) It is estimated that these placement and retrieval charges are greater than the cost of construction, operation, depreciation, and decommissioning of the interim waste storage facility. 
8. The liner and curie surcharges at the commercial waste disposal facility are lower after interim onsite storage because of the radioactive decay that has occurred.

9. For neutron-activated material the radioactive decay during interim storage of even 100 years is insufficient to permit unrestricted release of the material. Therefore, all of the neutron-activated material must be relocated to a licensed nuclear waste disposal facility after interim onsite storage.

10. A11 costs are expressed in 1978 dollars.

An onsite interim nuclear waste storage facility would be designed to remotely place the containers of waste in storage cells and remotely remove the containers at the end of the storage period. Design features and operating practices would minimize the radiation exposure of the workers. Since the nuclear waste could be in interim storage for as long as 100 years, the facilities would have to be designed for long life and require a minimum of maintenance.

The concept for the onsite interim nuclear waste storage facility is shown schematically in Figure 8.1-1. Basically, the facility consists of a row of concrete cells, $10 \mathrm{~m}$ square by $7 \mathrm{~m}$ deep, with concrete cover blocks that are thick enough to provide the necessary radiation shielding. A mobile gantry crane enclosed in a lightweight sheet-metal building is used to place the radioactive waste in and retrieve the waste from the cells. Both the bridge crane and the building are mounted on a chassis, $13 \mathrm{~m}$ wide by $16 \mathrm{~m}$ long, with a tracked carriage at each corner. The enclosure is provided primarily for weather protection, since the external surfaces of the waste containers will be free of smearable contamination when they are placed in the storage cells. A trap door in the roof of the crane building permits movement of containers and casks into and out of the structure.

The nuclear waste from decommissioning an LWR by DECON will fill about 30 of the cells. For a multiple-reactor station with 10 reactors, 300 cells will be needed for interim storage of the decommissioning waste. 


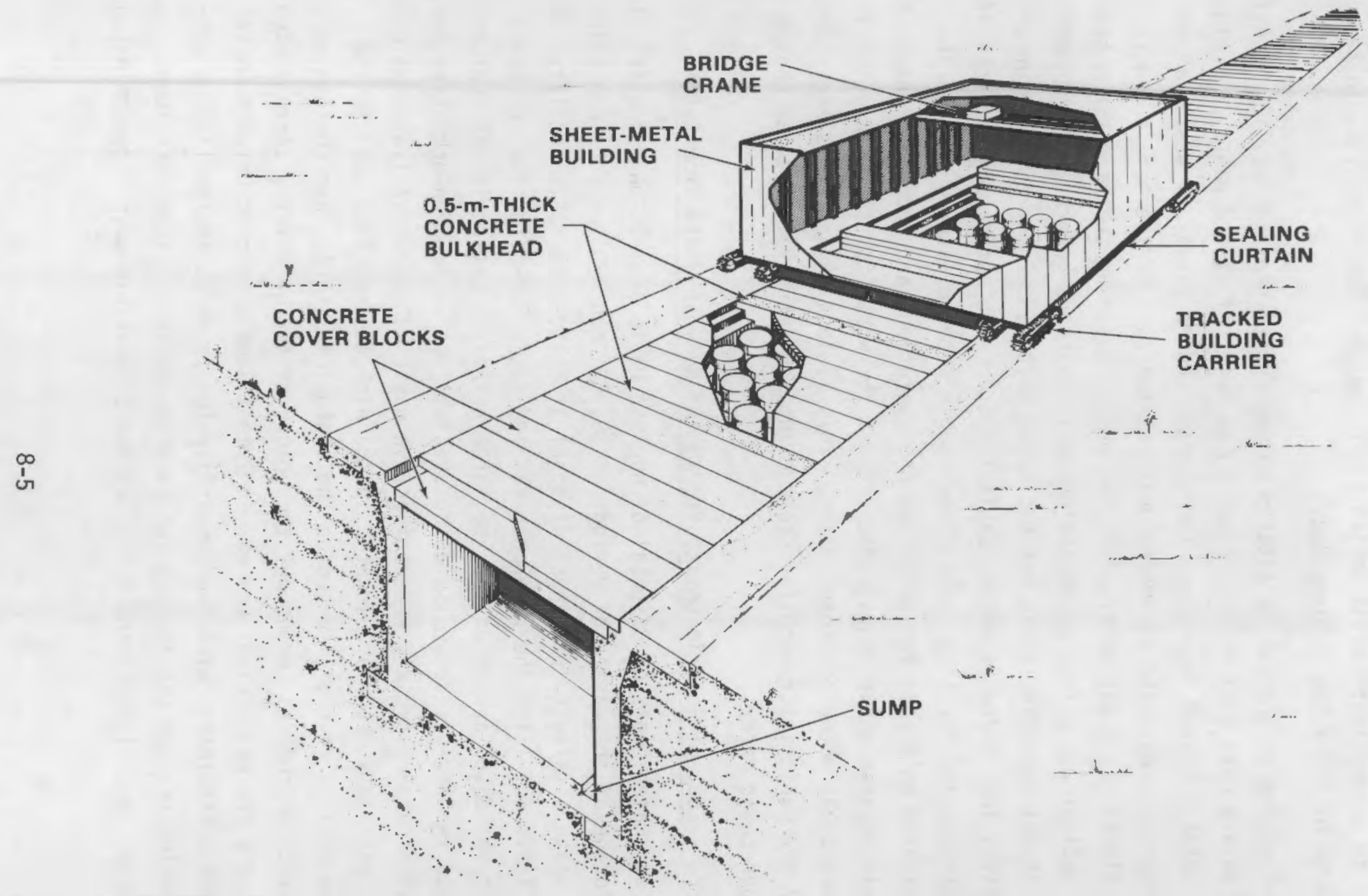

FIGURE 8.1-1. Onsite Interim Nuclear Waste-Storage Facility 
After a cell is filled with waste containers the cover blocks are installed and a waterproof seal is applied to the coverblocks. The floor of each cell is sloped to a sump that can be monitored for water. The capability to sample the contents of the sumps is provided.

Construction of the onsite interim nuclear waste storage facility is estimated to have a unit cost of $\$ 38.75$ per cubic meter of stored waste, assuming that the cells are used four times for storage and retrieval of waste before being decommissioned. The estimated unit capital cost of the mobile gantry crane is $\$ 16.67$ per cubic meter of stored waste, assuming that the crane handles the nuclear waste from decommissioning 10 reactors before it is decommissioned. Annual operating costs are estimated to be $\$ 3.22$ per cubic meter of stored waste, $10 \%$ of the estimated capital costs. The estimated unit cost of decommissioning the facility is $\$ 3.22$ per cubic meter of stored waste. The total estimated unit cost for construction, operation, and decommissioning of the interim nuclear waste storage facility if the waste is stored 30 years is $\$ 155.24$ per cubic meter of stored waste. This is less than the assumed charge of $\$ 93.57$ per cubic meter each for storage and for retrieval, a total charge of $\$ 187.14$ per cubic meter.

\subsubsection{Cost of Interim Onsite Storage of Nuclear Waste from DECON}

The estimated costs of disposal of nuclear waste from DECON using interim onsite storage of the waste for periods of 30,50 , and 100 years before shipping the waste offsite to permanent disposal at a licensed waste facility are given in Table 8.1-1 for the reference PWR and Table 8.1-2 for the reference BWR. Disposal costs are shown for the three principal categories of nuclear waste (used in previous decommissioning studies) ${ }^{(1,2)}$ : neutron-activated material, contaminated material, and radioactive waste. Neutron-activated materials are those materials which are located in the high neutron flux zone in and around the nuclear reactor, including the biological shield, and contain neutron activation products throughout the volume of the material. Contaminated materials are process piping, process equipment, tools, and structures whose surface are contaminated with neutron activation products and/or fission products. Radioactive wastes include ion exchange resins, filter cartridges, evaporator bottoms liquids, and miscellaneous combustible wastes contaminated 
TABLE 8.1-1. Estimated Cost of Disposal of Nuclear Waste from DECON of a PWR Using Interim Onsite Waste Storage

\begin{tabular}{|c|c|c|c|c|c|}
\hline \multirow[b]{3}{*}{ Storage Location } & \multirow[b]{3}{*}{$\begin{array}{l}\text { Years After } \\
\text { Shutdown } \\
\end{array}$} & \multicolumn{4}{|c|}{ Cost of Waste Disposal ( $\$$ thousands) } \\
\hline & & \multicolumn{3}{|c|}{ Type of Waste } & \multirow[b]{2}{*}{$\begin{array}{l}\text { Option } \\
\text { Total } \\
\end{array}$} \\
\hline & & $\begin{array}{l}\text { Neutron- } \\
\text { Activated }\end{array}$ & Contaminated & Radwaste & \\
\hline Offsite, Immediate ${ }^{(a)}$ & 0 & $2734^{(b)}$ & $5183^{(c)}$ & $693^{(d)}$ & 8610 \\
\hline Onsite, Interim & 0 & 1933 & 3467 & 240 & 5640 \\
\hline Offsite, Permanent & 30 & 708 & 3636 & 259 & $10245^{(e)}$ \\
\hline & 50 & 687 & 332 & 181 & $6840^{(e)}$ \\
\hline & 100 & 684 & 322 & 171 & $6827^{(e)}$ \\
\hline
\end{tabular}

(a) Base case. Cost of immediate offsite disposal of the nuclear waste.

(b) From Table G.4-3 of Reference 1.

(c) From Table G.4-4 and G.4-5 of Reference 1.

(d) From Table G.4-6 of Reference 1.

(e) Total includes cost of placing waste in interim storage.

TABLE 8.1-2. Estimated Cost of Disposal of Nuclear Waste from DECON of a BWR Using Interim Onsite Waste Storage

\begin{tabular}{|c|c|c|c|c|c|}
\hline \multirow[b]{2}{*}{ Storage Location } & \multirow[b]{2}{*}{$\begin{array}{l}\text { Years After } \\
\text { Shutdown }\end{array}$} & \multicolumn{4}{|c|}{ Cost of Waste Disposal ( $\$$ thousands) } \\
\hline & & $\begin{array}{l}\text { Neutron- } \\
\text { Activated }\end{array}$ & Contaminated & Radwaste & $\begin{array}{l}\text { Option } \\
\text { Total } \\
\end{array}$ \\
\hline Offsite, Immediate ${ }^{(a)}$ & 0 & $2300^{(b)}$ & $4909(c)$ & $1469^{(d)}$ & 8678 \\
\hline Onsite, Interim & 0 & 409 & 3337 & 447 & 4193 \\
\hline Offsite, Permanent & 30 & 870 & 3452 & 572 & $9086^{(e)}$ \\
\hline & 50 & 742 & 313 & 328 & $5576^{(e)}$ \\
\hline & 100 & 702 & 313 & 308 & $5516^{(e)}$ \\
\hline
\end{tabular}

(a) Base case. Cost of immediate offsite disposal of nuclear waste.

(b) From Table I.3-3 of Reference 2.

(c) From Table I.3-4 of Reference 2.

(d) From Tables H.5-10 and I.3-5 of Reference 2.

(e) Total includes cost of placing waste in interim storage. 
with radionuclides, such as plastic sheeting, rags, disposable protective clothing, etc. Also shown are the costs of initially placing the nuclear waste in interim storage onsite. Differences in the estimated cost of onsite interim storage of waste followed by offsite disposal are given in Table 8.1-3 for storage periods of 30,50 , and 100 years. Interim onsite storage of the nuclear waste for 30 years results in a higher total cost of waste disposal for both the reference reactors, $\$ 1.6$ million for the PWR and $\$ 0.4$ million for the BWR, because the 30 -year storage period is too short for the radioactivity on the contaminated material to decay to the level at which significant quantities of the contaminated material can be released. With temporary onsite storage for 50 or 100 years, waste disposal cost reductions of about $\$ 2$ million for the reference PWR and about $\$ 3$ million for the reference BWR are estimated.

TABLE 8.1-3. Estimated Total Cost Differences - Interim Onsite Nuclear Waste Storage vs. Immediate Offsite Nuclear Waste Disposal for DECON

\begin{tabular}{|c|c|c|}
\hline $\begin{array}{c}\text { Interim Onsite } \\
\text { Storage Period (yr) }\end{array}$ & $\frac{\text { Cost Differences }}{\text { PWR }}$ & $\frac{(\$ \text { thousands })^{(a, b)}}{B W R}$ \\
\hline 30 & +1640 & +410 \\
\hline 50 & -1770 & -3100 \\
\hline 100 & -1780 & -3160 \\
\hline
\end{tabular}

(a) The cost differences are based on the cost of placing the nuclear waste in interim onsite storage plus the cost of later removal and disposal offsite in a licensed waste disposal facility.

(b) A + sign indicates an increase in cost over the cost of immediate offsite waste disposal, and a - sign indicates a decrease in cost.

\subsubsection{Cost of Interim Onsite Storage of Nuclear Waste from SAFSTOR}

The schedule for disposal of the nuclear waste from SAFSTOR of the reference PWR with interim onsite storage of the waste is shown in Figure 8.1-2 for the case of a 30-year period of safe storage of the reactor and interim onsite storage of the nuclear waste for 50 years. The nuclear waste from 
PREPARATIONS FOR SAFE STORAGE

ONSITE INTERIM STORAGE FOR 50 YEARS

OF WASTE FROM PREPARATIONS FOR

SAFE STORAGE

REMOVE WASTE FROM INTERIM STORAGE

TO OFFSITE DISPOSAL

REACTOR SAFE STORAGE PERIOD

DEFERRED DECONTAMINATION

ONSITE INTERIM STORAGE FOR 50 YEARS

OF WASTE FROM DEFERRED DECONTAMINATION

REMOVE WASTE FROM INTERIM STORAGE TO

OFFSITE DISPOSAL

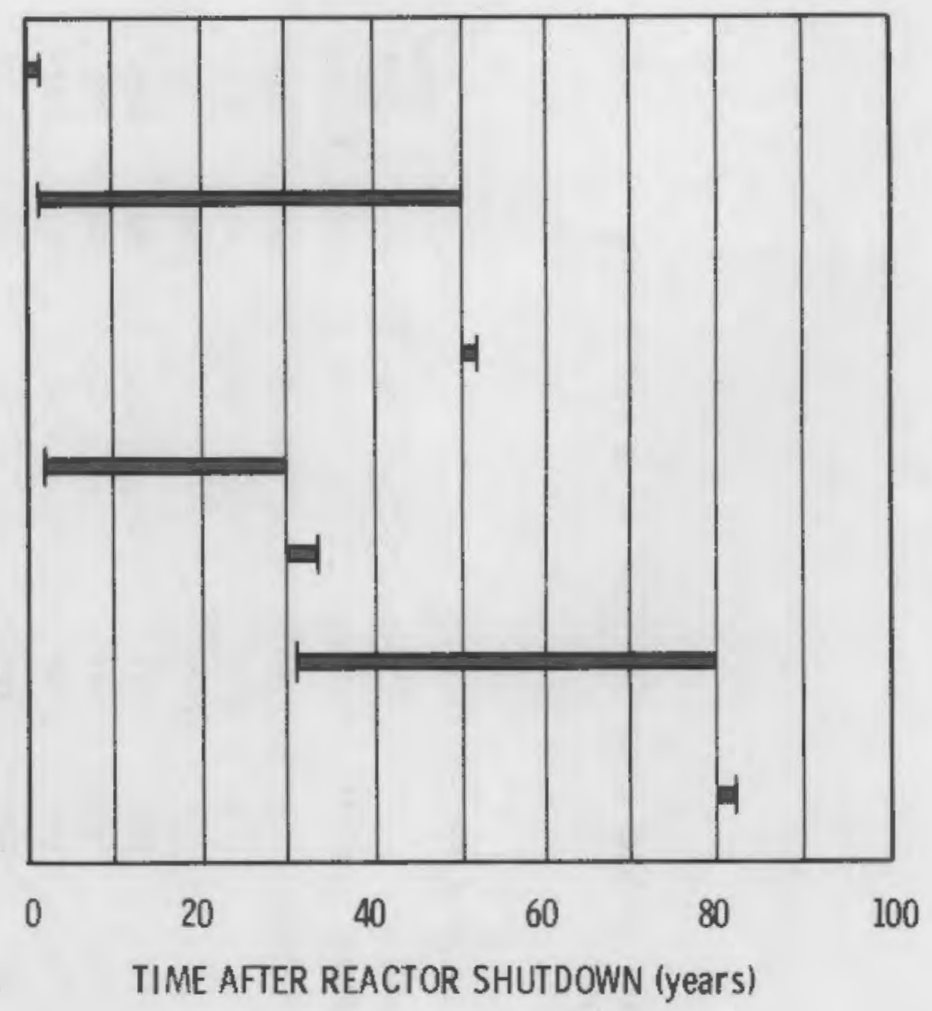

FIGURE 8.1-2. Schedule for Interim Onsite Storage of the Nuclear Waste from SAFSTOR (for a 30-year safe storage period of the reactor and interim onsite storage of the waste for 50 years)

preparations for safe storage is removed to an offsite waste disposal facility after 50 years of interim onsite storage; this would be 50 years after reactor shutdown. Nuclear waste from deferred decontamination is placed in interim onsite storage (30 years after reactor shutdown) and removed to an offsite waste disposal facility after 50 years of interim onsite storage ( 80 years after reactor shutdown).

The estimated costs of disposal of nuclear waste from SAFSTOR using interim onsite waste storage for 30,50 , and 100 years before removal to permanent disposal offsite at a licensed waste disposal facility are given in Tables 8.1-4 and 8.1-5 for the reference PWR and the reference BWR, respectively. Estimated costs for waste disposal are shown for preparations for safe storage and for deferred decontamination after 30,50 , and 100 years of safe storage. Disposal costs are presented for the three categories of nuclear waste, neutron-activated material, contaminated material, and radwaste. Tables 8.1-5 and 8.1-6 give the estimated cost of removing the nuclear waste generated during preparations 
TABLE 8.1-4. Estimated Cost of Disposal of Nuclear Waste from SAFSTOR of a PWR Using Interim Onsite Nuclear Waste Storage

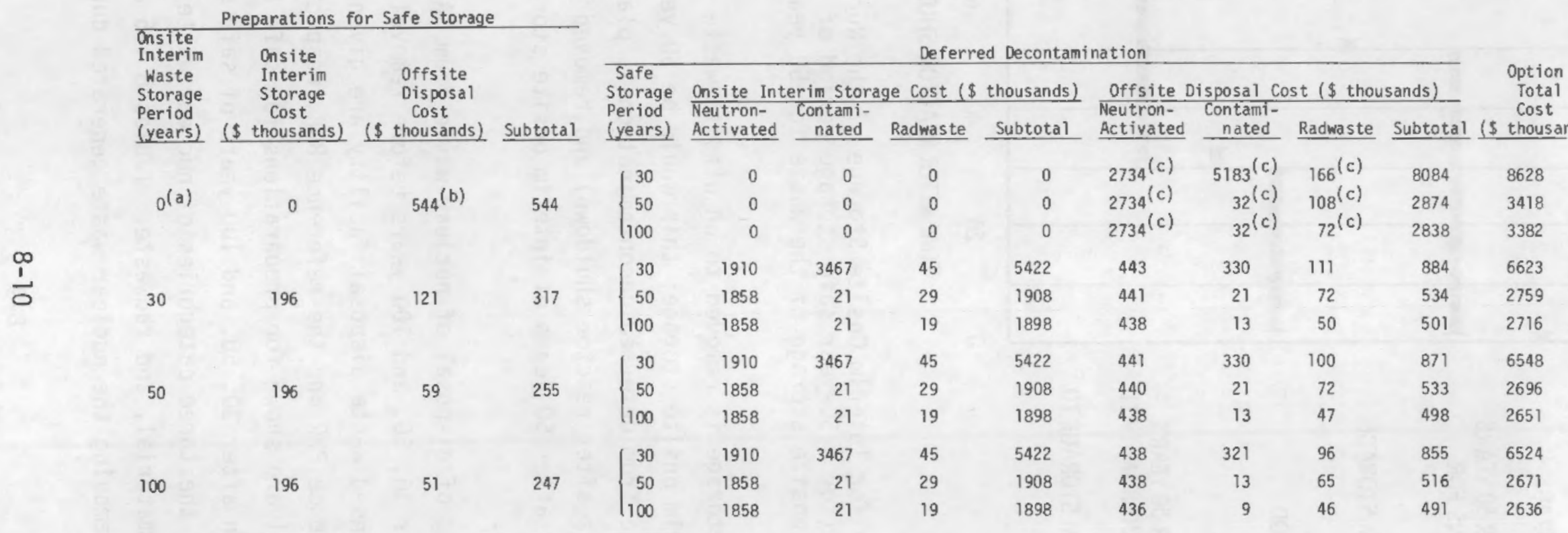

(a) Base case. Cost of immediate offsite disposal of nuclear waste.

(b) From Table H.3-2 of Reference 1. 1 . Numbers reduced to remove the $25 \%$ contingency. 
TABLE 8.1-5. Estimated Cost of Disposal of Nuclear Waste from SAFSTOR of a BWR Using Interim Onsite Nuclear Waste Storage

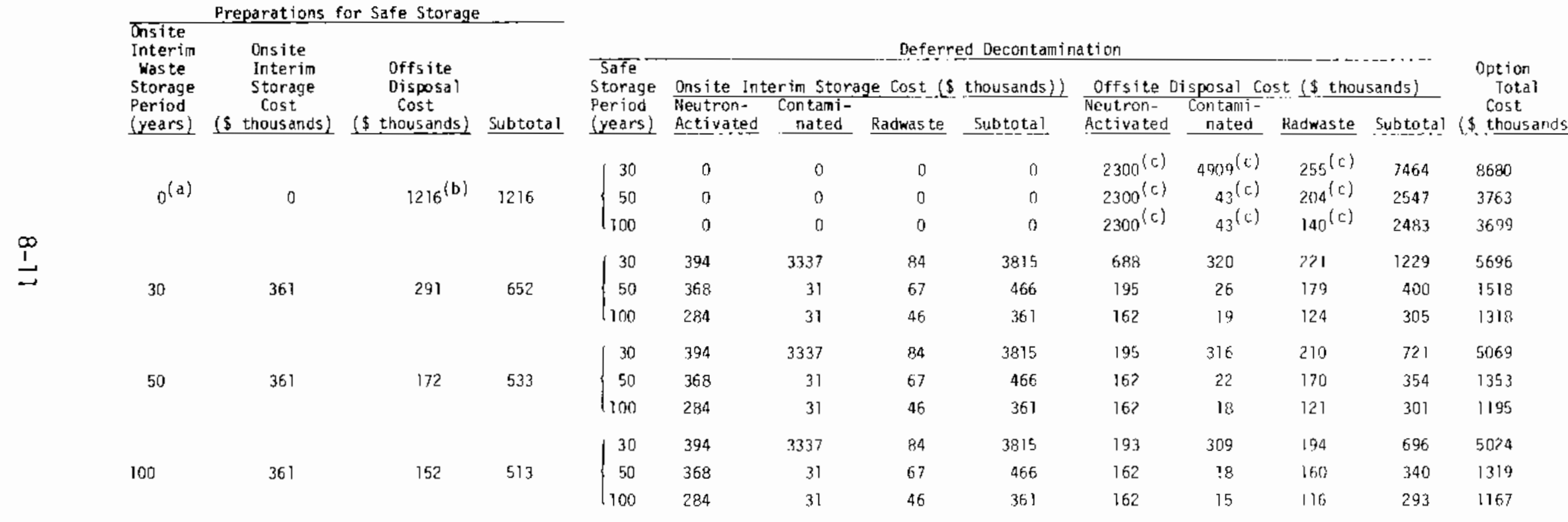

a) Base case. Cost of immediate offsite disposal of nuclear waste.

b) From Tables H.5-70 and J.5-3 of Reference 2.

(c) From Table J.7-2 of Reference 2. 
TABLE 8.1-6. Estimated Total Cost Differences - Interim Onsite Nuclear Waste Storage vs. Immediate offsite Nuclear Waste Disposal for SAFSTOR

\begin{tabular}{|c|c|c|c|c|c|c|}
\hline \multirow{3}{*}{$\begin{array}{l}\text { Interim 0nsite }(\mathrm{c}) \\
\text { Storage Period }(\mathrm{yr})\end{array}$} & \multicolumn{6}{|c|}{ Cost Differences $\left(\$\right.$ thousands) ${ }^{(a, b)}$} \\
\hline & \multicolumn{2}{|c|}{30 Year(d) } & \multicolumn{2}{|c|}{50 Year (d) } & \multicolumn{2}{|c|}{100 Year(d) } \\
\hline & PWR & BWR & PWR & BWR & PWR & BWR \\
\hline 30 & -2005 & -2984 & -660 & -2244 & -670 & -2381 \\
\hline 50 & -2080 & -3611 & -720 & -2408 & -730 & -2504 \\
\hline 100 & -2105 & -3656 & -750 & -2443 & -750 & -2532 \\
\hline
\end{tabular}

(a) The cost differences are based on the cost of placing the nuclear waste from both preparations for safe storage and deferred decontamination in interim onsite storage plus the cost of later removal and disposal in an offsite licensed waste disposal facility.

(b) A - sign indicates a decrease in cost under the cost of immediate offsite waste disposal.

(c) Time after waste is placed in onsite interim storage.

(d) Time after reactor shutdown.

for safe storage from interim storage to permanent disposal after interim storage periods of 30,50 , or 100 years. For the three deferred decontamination cases, the cost is given for removal of the nuclear wastes to offsite disposal at times of 30,50 , or 100 years after the waste was placed in onsite interim storage. This means that if deferred decontamination took place 30 years after reactor shutdown, removal to offsite disposal would be at 60 , 8D, or 130 years after reactor shutdown; with deferred decontamination 50 years after reactor shutdown, offsite disposal would be at 80,100 , or 150 years after shutdown; and with deferred decontamination 100 years after reactor shutdown, offsite disposal would be at 130, 150, or 200 years after shutdown.

Differences in the estimated cost of immediate offsite nuclear waste disposal and the estimated cost of onsite storage of nuclear waste followed by removal to an offsite disposal facility are given in Table 8.1-6 for interim storage periods of 30,50 , and 100 years. The lowest waste disposal costs for SAFSTOR with interim onsite waste storage are given by the case with 100 years of safe storage and 100 years of onsite interim waste storage, $\$ 2.6$ mi11ion for 
the reference PWR and \$1.T million for the reference BWR. However, the greatest reductions in the total waste disposal costs for both the PWR and the BWR are achieved by 100 years of interim onsite storage of the waste from deferred decontamination that takes place after 30 years of safe storage.

\subsubsection{Cost of Interim Onsite Storage of Nuclear Waste from ENTOMB}

The estimated costs of disposal of nuclear waste from ENTOMB with interim onsite storage of the waste before removal offsite to permanent disposal are given in Table 8.1-7 for the reference PWR and in Table 8.1-8 for the reference BWR. Disposal costs are shown for each of the three categories of nuclear waste: neutron-activated material, contaminated material, and radwaste. The differences between the cost of waste disposal with interim onsite storage for 30,50 , and 100 years and the cost of immediate offsite waste disposal are presented in Table 8.1-9. The greatest cost reductions are estimated to be achieved by interim onsite storage for 100 years, $\$ 1.4 \mathrm{million}$ for the PWR and $\$ 2.6$ million for the BWR. However, the incremental savings achieved by extending the storage period from 50 years to 100 years are estimated to be quite small.

TABLE 8.1-7. Estimated Cost of Disposal of Nuclear Waste from ENTOMB of a PWR Using Interim Onsite Nuclear Waste Storage

\begin{tabular}{|c|c|c|c|c|c|}
\hline \multirow[b]{3}{*}{ Location } & \multirow{3}{*}{$\begin{array}{l}\text { Years } \\
\text { After } \\
\text { Shutdown }\end{array}$} & \multicolumn{4}{|c|}{ Cost of Waste Disposal ( $\$$ thousands) } \\
\hline & & \multicolumn{3}{|c|}{ Type of Waste } & \multirow[b]{2}{*}{$\begin{array}{l}\text { Option } \\
\text { Total }\end{array}$} \\
\hline & & $\begin{array}{l}\text { Neutron- } \\
\text { Activated }\end{array}$ & Contaminated & Radwas te & \\
\hline Onsite, Interim & 0 & 945 & 401 & 240 & 1586 \\
\hline \multirow[t]{4}{*}{ Offsite, Permanent } & 0 & $2498^{(a)}$ & $472^{(a)}$ & $693^{(a)}$ & 3663 \\
\hline & 30 & 331 & 538 & 259 & $2714^{(b)}$ \\
\hline & 50 & 316 & 185 & 181 & $2268^{(b)}$ \\
\hline & 100 & 314 & 185 & 171 & $2256^{(b)}$ \\
\hline
\end{tabular}

(a) From Table 4.5-1 of Reference 3.

(b) Includes cost of placement of waste in interim onsite storage external to the entombment structure. 
TABLE 8.1-8. Estimated Cost of Disposa? of Nuclear Waste from ENTOMB of a BWR Using Interim Onsite Nuclear Waste Storage

\begin{tabular}{|c|c|c|c|c|c|}
\hline \multirow{3}{*}{$\begin{array}{l}\text { Storage } \\
\text { Locatjon }\end{array}$} & \multirow{3}{*}{$\begin{array}{l}\text { Years } \\
\text { After } \\
\text { Shutdown } \\
\end{array}$} & \multicolumn{4}{|c|}{ Cost of Waste Disposal ( $\$$ thousands) } \\
\hline & & \multicolumn{3}{|c|}{ Type of Waste } & \multirow[b]{2}{*}{$\begin{array}{l}\text { Option } \\
\text { Total } \\
\end{array}$} \\
\hline & & $\begin{array}{l}\text { Neutron- } \\
\text { Activated }\end{array}$ & Contaminated & Radwaste & \\
\hline Onsite, Interim & 0 & 484 & 1230 & 447 & 2161 \\
\hline \multirow[t]{4}{*}{ Offsite, Permanent } & 0 & $2394^{(a)}$ & $1846^{(b)}$ & $1469^{(c)}$ & 5709 \\
\hline & 30 & 741 & 1327 & 572 & $4801^{(d)}$ \\
\hline & 50 & 614 & 704 & 328 & $3207^{(d)}$ \\
\hline & 100 & 574 & 104 & 308 & $3147^{(d)}$ \\
\hline
\end{tabular}

(a) From Table K.3-3 of Reference 2 .

(b) From Table K.3-4 of Reference 2 .

(c) From Tables H.5-10 and I.3-5 of Reference 2. See Section K.3.1.3 of Appendix $K$ of Reference 2.

(d) Includes cost of placement of waste in interim onsite storage external to the entombment structure.

TABLE 8.1-9. Estimated Total Cost Differences - Interim Onsite Nuclear Waste Storage vs. Immediate Offsite Nuclear Waste Disposal for ENTOMB

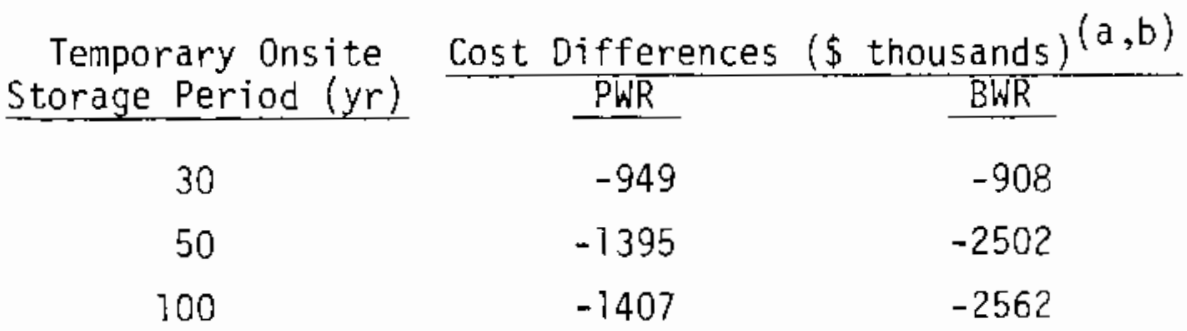

(a) The cost differences are based on the cost of placing the nuclear waste in interim onsite storage plus the cost of later removal and disposal in an offsite licensed waste disposa? facility.

(b) A - sign indicates a decrease in cost compared with cost of immediate offsite waste disposal.

\subsubsection{Onsite Nuciear Waste Disposal}

Sites where large numbers of nuclear power reactors are located conceivably will be large enough to include a permanent onsite low-level nuclear waste 
disposal facility. Permanent onsite low-level nuclear waste disposal facilities will be operated only at those multiple-reactor stations where the hydrology of the site will not cause flooding of the disposal facility. Any nuclear waste that must be disposed of in a deep geologic disposal facility will be sent offsite to a government-operated facility. Several factors that contribute to lower costs for onsite nuclear waste disposal are:

- lower transportation costs because of the short haul to the disposal site

- no overweight charges, since all travel is over private roads

- no relief driver charges, since only one driver is needed

- shielded cask liners may not be used for some of the activated materials, since travel is over private roads and the DOT maximum surface dose rate may be exceeded.

The following assumptions are made in estimating the effect of onsite nuclear waste disposal on decommissioning costs:

1. The quantity of nuclear waste sent to onsite waste disposal is the same as would be sent to an offsite waste disposal facility.

2. Since transport to the onsite waste disposal facility is over private roads in a privately owned and controlled area, it is not necessary to limit the container or cask surface dose rate to $0.2 \mathrm{R} / \mathrm{hr}$ as required by DOT for transport on public highways. Shielding is provided for the truck cab to 1 imit the dose rate to $2 \mathrm{mR} / \mathrm{hr}$. The radiation dose to workers is controlied proceduraliy to assure that jt does not exceed the 10 CFR 20 limits.

3. There are no curie or liner surcharges for onsite waste disposal.

4. When heavy loads such as casks are involved, the handling charge is equal to the handling charge for such a load at an offsite licensed waste disposal facility.

5. The disposal charge is the same as that at an offsite licensed waste disposal facility $\left(\$ 93.57 / \mathrm{m}^{3}\right)$ and covers the costs of construction, operation, and decomissioning of the facility. 
6. The onsite disposal facility is located $24 \mathrm{~km}$ from the reactor.

7. One-day cask rental is charged for each shipment.

\subsubsection{Cost of Onsite Disposal of Nuclear Waste from DECON}

The estimated costs of onsite disposal of the nuclear waste from DECON of the reference PWR and reference BWR are presented in Table 8.1-1D. The costs of offsite disposal of the waste are also given for comparison. The savings achieved by onsite waste disposal are about $\$ 3$ million for the PWR and about $\$ 4.5$ million for the BWR.

TABLE 8.7-10. Estimated Cost of Onsite 0isposal of Nuciear waste from DECON

\begin{tabular}{|c|c|c|c|c|}
\hline \multirow[b]{2}{*}{$\begin{array}{l}\text { Disposal } \\
\text { Location }\end{array}$} & \multicolumn{4}{|c|}{ Cost of Waste 0isposal ( $\$$ thousands) } \\
\hline & $\begin{array}{l}\text { Neutron- } \\
\text { Activated }\end{array}$ & Contaminated & Radwaste & \multirow[t]{2}{*}{ Total } \\
\hline & & Reference PWR & & \\
\hline Offsite & $2733^{(a)}$ & $5183^{(b)}$ & $693^{(c)}$ & 8609 \\
\hline \multirow[t]{3}{*}{ Onsite } & 7933 & 3467 & 240 & 5640 \\
\hline & & & Saving & 2969 \\
\hline & & Reference BWR & & \\
\hline Offsite & $2300^{(d)}$ & $4909^{(e)}$ & $1469^{(f)}$ & 8678 \\
\hline \multirow[t]{2}{*}{ Onsite } & 409 & 3337 & 447 & 4193 \\
\hline & & & Saving & 4485 \\
\hline
\end{tabular}

(a) From Table G.4-3 of Reference 1 .

(b) From Tables G-4-4 and G.4-5 of Reference 1.

(c) From Table G.4-6 of Reference 1.

(d) From Table I.3-3 of Reference 2.

(e) From Table I.3-4 of Reference 2.

(f) From Tables H.5-10 and I.3-5 of Reference 2. 


\subsubsection{Cost of Onsite Disposal of Nuclear Waste from SAFSTOR}

The estimated costs of onsite disposal of the nuciear waste from SAFSTOR of the reference PWR and reference BWR are given in Table 8.1-11. These costs are for disposal of the waste from preparations for safe storage plus the waste from deferred decontamination after 30,50, or 100 years of safe storage. The costs of offsite disposal of the nuclear waste from SAFSTOR, developed in the PWR and BWR decommissioning studies, (1,2) are given for comparison. Costs for onsite disposal of nuclear waste are shown to be lower than for offsite disposal. The estimated savings for both the PWR and the BWR are greatest if deferred decontamination is started 30 years after reactor shutdown, \$3.1 million for the PWR and $\$ 4.3$ milition for the BWR.

TABLE 8.1-11. Estimated Cost of Onsite Disposal of Nuclear Waste from SAFSTOR

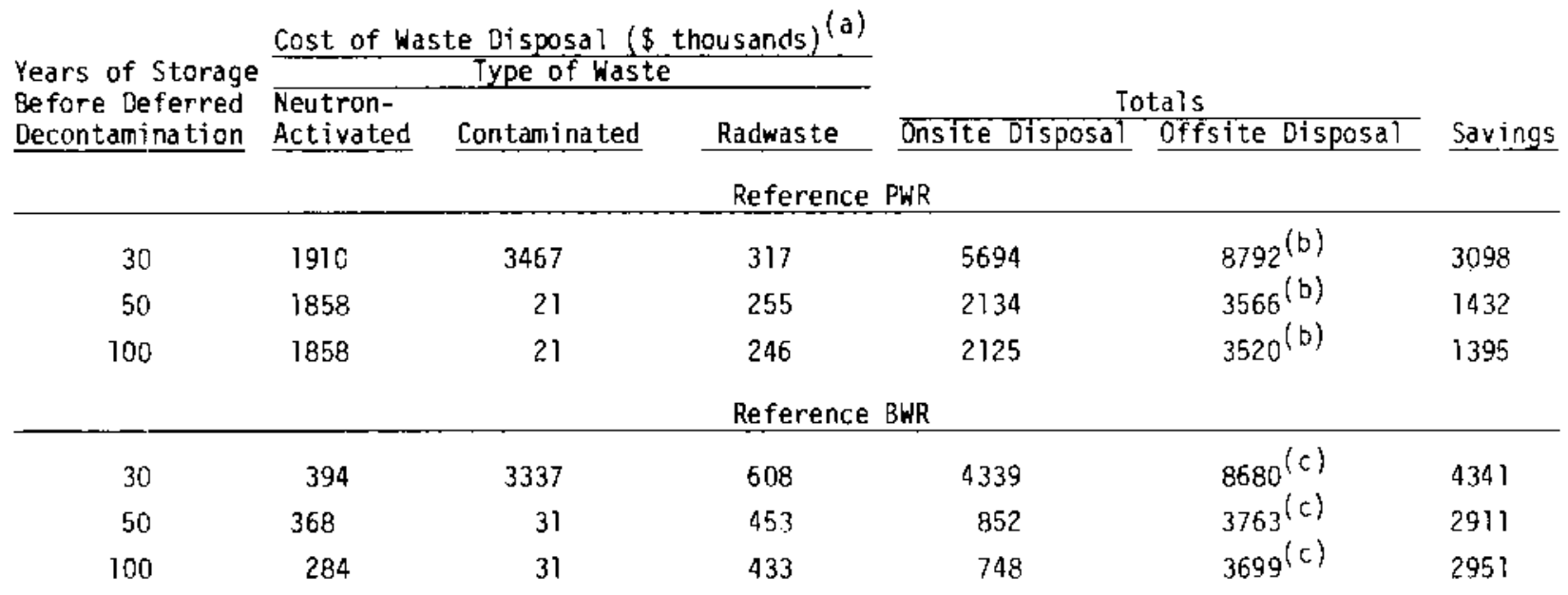

(a) Costs inciude cost of waste disposal from preparations for safe storage and from deferred decontamination.

(b) Based on Tables H.3-2 and H.5-2 of Reference I. Numbers reduced to remove $25 \%$ contingency.

(c) Based on Tables H.5-10, J.5-3, and J.7-2 of Reference 2 .

\subsubsection{Cost of Onsite Disposal of Nuclear Waste from ENTOMB}

In Table 8.1-12, the estimated costs of disposal of the nuclear waste from ENTOMB are given for onsite and offsite disposal. Onsite disposal of the nuclear waste from ENTOMB is estimated to save \$2.1 million for the PWR and $\$ 3.5$ million for the BWR. 
IABLE 8.1-12. Estimated Cost of Onsite Disposal of Nuclear Waste from ENTOMB

\begin{tabular}{|c|c|c|c|c|}
\hline \multirow[b]{2}{*}{$\begin{array}{l}\text { Disposal } \\
\text { Location }\end{array}$} & \multicolumn{4}{|c|}{ Cost of Waste Disposal ( $\$$ thousands) } \\
\hline & $\begin{array}{l}\text { Neutron- } \\
\text { Activated }\end{array}$ & Contaminated & Radwaste & \multirow[t]{2}{*}{ Total } \\
\hline \multicolumn{4}{|c|}{ Reference PWR } & \\
\hline Offsite & $2498^{(a)}$ & $472^{(a)}$ & $693^{(a)}$ & 3663 \\
\hline Onsite & 945 & 401 & 240 & $\underline{1586}$ \\
\hline & & & Saving & 2077 \\
\hline \multicolumn{5}{|c|}{ Reference BWR } \\
\hline Offsite & $2394^{(b)}$ & $1846^{(c)}$ & 1469 (d) & 5709 \\
\hline Onsite & 484 & 1230 & 447 & $216]$ \\
\hline & & & Saving & 3548 \\
\hline
\end{tabular}

(a) From Table 4.5-1 of Reference 3.

(b) From Table I.3-3 of Reference 2.

(c) From Table I.3-4 of Reference 2 .

(d) From Tables H.5-10 and I.3-5 of Reference 2.

\subsection{SITE DEDICATION}

Dedication of a site to nuclear power generation resuits in replacement reactors being constructed on a schedule to achieve startup of a replacement reactor as an old reactor is shut down. At such dedicated sites, either relatively long periods of construction activity will occur periodically or there will be continuous construction activity at the site if the startup of the reactors is spaced to occur over a 30-year period.

Dedication of a multiple-reactor site to nuclear power generation:

- fosters stable operating and construction labor forces

- favors the establishment of onsite interim nuclear waste storage or onsite nuclear waste disposal

- results in improved efficiency of construction and decommissioning as management and the labor force accumulate onsite experience

- encourages the provision of centralized services. 
It is expected that the efficiency of decomissioning the reactors at a multiple-reactor station will improve after the first reactor is decommissioned due to the learning process. Reductions in manpower requirements for decomissioning subsequent reactors of the same type at a multiple-reactor station result from the following factors:

- the minimization of the planning effort for decommissioning the second or later reactors of the same type

- the standardization and improvement of decommissioning techniques

- the stabilization of the work force, resulting in less time spent in learning or rehearsing decommissioning procedures

- the improvement of the productivity of decommissioning workers as a result of the learning experience on the first reactor.

The reduction in decommissioning manpower costs at multiple-reactor stations results principally from a reduction in the time required to perform a given operation, rather than from a reduction in the number of workers. Therefore, the total time to decommission a plant is reduced, and the cost reduction factors are applied to support staff labor as well as to decommissioning worker labor.

Assumptions used to estimate the cost reduction factors are:

1. The cost reduction factor for planning and preparation for the second and each succeeding reactor of a particular type (PWR or BWR) is 0.50 .

2. The cost reduction factor for decommissioning operations for the second reactor of a particular type is 0.95 .

3. The cost reduction factor for decommissioning operations for the third and each succeeding reactor of a particular type is 0.90 .

Cost reduction factors for decommissioning several reactors of the same type at a multiple-reactor station are shown in Table 8.2-1. These factors are also appiticable for estimation of occupational radiation dose reduction. 


\begin{tabular}{ccc} 
TABLE 8.2-1. & Cost and Dose Reduction Factors \\
$\begin{array}{c}\text { Number of } \\
\text { Reactors } \\
\text { of } \\
\text { One Type }\end{array}$ & $\begin{array}{c}\text { Average Cost Reduction Factor } \\
\text { Planning \& }\end{array}$ & $\begin{array}{c}\text { Preparation } \\
\text { Decommissioning } \\
\text { Operations }\end{array}$ \\
\cline { 1 - 2 } 1 & 1.0 & 1.0 \\
4 & $0.62(a)$ & $0.94(a)$ \\
5 & 0.60 & 0.93 \\
10 & 0.55 & 0.92 \\
20 & 0.53 & 0.91
\end{tabular}

(a) $\begin{aligned} \frac{1.0+.5+.5+.5}{4} & =0.62 \\ \frac{1.0+.95+.9+.9}{4} & =0.94\end{aligned}$

The factors given in Table 8.2-1 are used to estimate the decommissioning staff labor costs at multiple-reactor stations having four or five reactors of the same type. Table 8.2-2 gives the estimated staff labor costs for decomrnissioning several PWRs and BWRs by DECON, SAFSTOR, and ENTOMB; estimated staff labor costs for decommissioning a single reactor are given for comparison. These costs are used to estimate the savings in staff labor for the five scenarios studied in Section 10 .

\subsection{AVAILABILITY OF CENTRALIZED SERVICES}

A number of centralized site services may be available at a multiplereactor station. The centralized services considered in this study are:

- health physics services

- security forces

- solid waste processing

- equipment decontamination services

- maintenance shops and services

- laundry services

- transportation services

- central stores. 
TABLE 8.2-2. Decommissioning Staff Labor Costs

\begin{tabular}{|c|c|c|c|c|c|}
\hline \multirow[b]{2}{*}{$\begin{array}{l}\text { No. of Reactors } \\
\text { Decommissioned }\end{array}$} & \multicolumn{5}{|c|}{ Staff Labor Costs/Reactor ( $\$$ thousands) ${ }^{(a)}$} \\
\hline & DECON & $30 \mathrm{Yr}$ & $\frac{5 A F S T O R(B)}{50 Y r}$ & $100 \mathrm{Yr}$ & ENTOMB \\
\hline & \multicolumn{5}{|c|}{ PWRS } \\
\hline 1 & $7981^{(c)}$ & $11779^{(d)}$ & $11179^{(d)}$ & $11179^{(d)}$ & $7607^{(\mathrm{e})}$ \\
\hline 4 & 7345 & 10138 & 10138 & 10738 & 7001 \\
\hline \multirow[t]{2}{*}{5} & 7237 & 9950 & 9950 & 9950 & 6898 \\
\hline & \multicolumn{5}{|c|}{ BWRS } \\
\hline 1 & $15066^{(f)}$ & $24272^{(g)}$ & $21937(g)$ & $21937^{(g)}$ & $15424^{(h)}$ \\
\hline 4 & 13704 & 21050 & 18926 & 18926 & 14046 \\
\hline 5 & 13528 & 20734 & 18647 & 18647 & 13854 \\
\hline
\end{tabular}

(a) Security force labor costs deleted.

(b) Includes cost of preparations for safe storage and cost of deferred decontamination. No improvement in labor efficiency is anticipated for continuing care.

(c) Based on Table 10.7-2 of Reference 1.

(d) Based on Tables 10.1-2 and 10.2-2 of Reference 1.

(e) Based on Table 4.5-1 of Reference 3 .

(f) Based on Table I.3-6 of Reference 2.

(g) Based on Tables J.5-4 and J.7-2 of Reference 2.

(h) Based on Table K.3-5 of Reference 2.

The impact of providing each of these centralized services on the cost of reactor decommissioning is discussed in the following subsections. Centralized services are considered in this study for 10-reactor stations.

\subsubsection{Health Physics Services}

Centralized health physics services at a multiple-reactor station could significantly reduce the costs of health physics activities at each reactor, during both the reactor operating life and the decommissioning period following operation. The two major factors postulated to contribute to this cost reduction are: 
- the reduced health physics staff overhead at each reactor, resulting from the sharing of certain staff members between several reactors at the site

- the reduced peak-load staffing requirements per reactor, because the large poot of health physics technicians at the site can be shared between reactors as needed.

The health physics staff organizations considered for decomissioning in this analysis are shown in Figure 8.3-1. The staff organization without centralized services (Figure 8.3-1a) is essentially the same as that postulated for the PWR and BWR decommissioning studies (1,2) of single-reactor stations. In Figure 8.3-1b, the postulated organization with centralized hea? th physics services is shown as a three-tiered organization to reduce overhead manpower. At the multiple-reactor station level the health and safety supervisor is responsible for ail health physics activities at the station. He is aided by a clerk and the industrial safety specialist on the station level and by health physics supervisors at the group (or quad) level. (For administrative purposes the reactors are assumed to be located on the station in groups of four, or quads). At each reactor a health physicist, who reports to the group health physics supervisor, is in charge of the health physics activities.

In addition to the modified staff organization with centralized health physics services, a more efficient use of the health physics technicians is assumed. Manpower requirements and costs for these staff members are assumed to be reduced $10 \%$ from those required without centralized health physics services.

To calculate the decommissioning cost savings resulting from centralized health physics services, the costs for radiation monitoring with and without centralized health physics services in the PWR and the BWR decommissioning studies $(1,2)$ are used here as the base costs, because the costs would be the same whether a single reactor is alone on a site or operates independently (without centralized services) on a multiple-reactor site. The detailed calculations of the costs for the centralized health physics services are presented in Section B.l of Appendix B of this study and the results are sumparized here. To develop the costs for the centralized services, it is assumed that: 


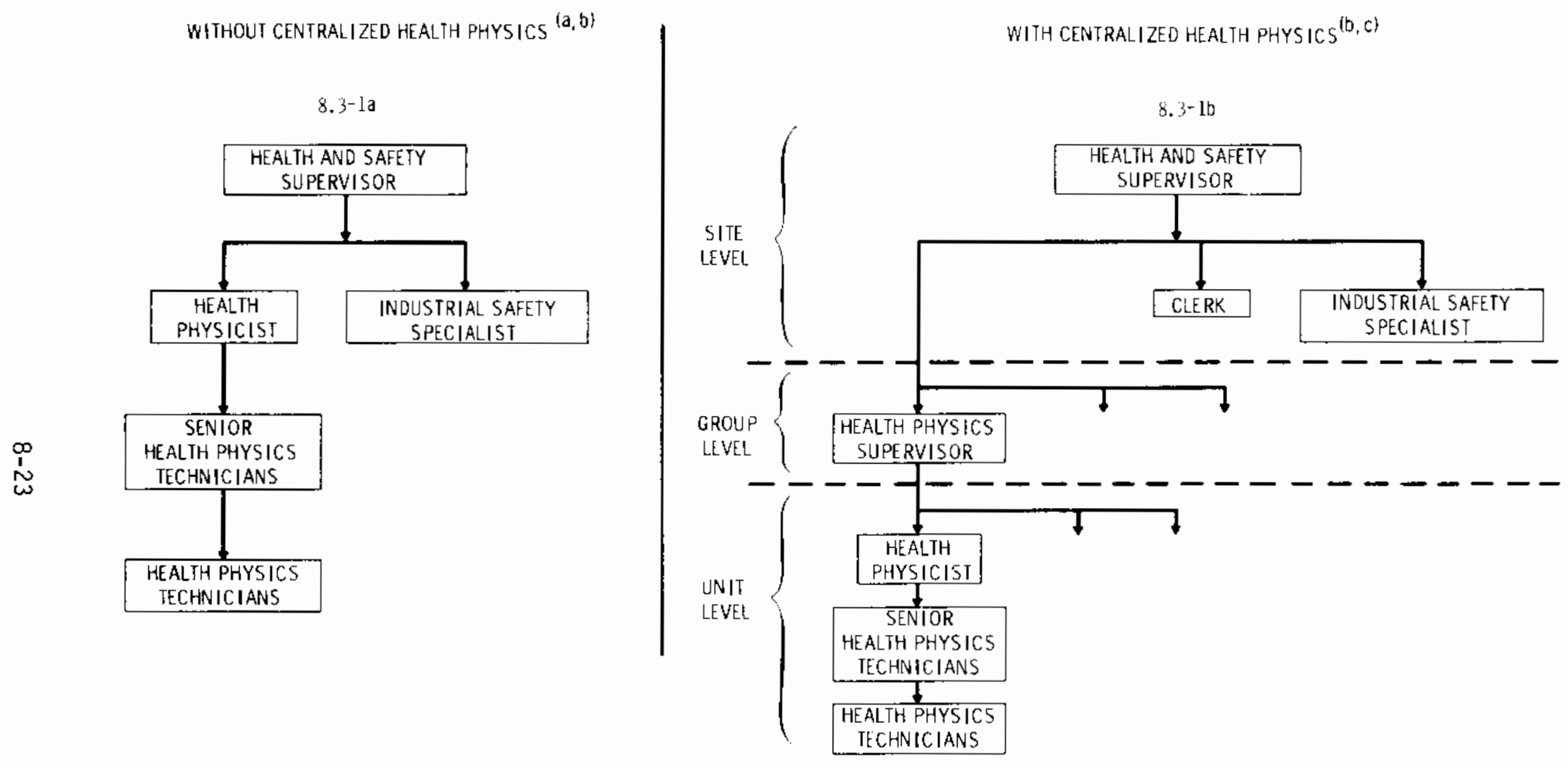

(a) BASED ON FIGURES 9.1-3 AND 9.2-6 OF REFERENCE 1 AND ON FIGURE H.1-l OF REFERENCE 2.

(b) PROTECTIVE EQUIPMENT ATTENDANTS UNAFFECTED BY ORGANIZATION CHANGE AND. THEREFORE, NOT INCLUDE D HL RE.

(c) ASSUMES SITE DIVIDED INTO THREE GROUPS OF REACTORS WITH THREE OR FOUR UNITS IN EACH GROUP.

FIGURE 8.3-1. Health Physics Staff Organization for Decommissioning 
- a site-wide overhead structure exists, reducing the overhead burden on each individual reactor

- labor requirements for senior health physics technicians and health physics technicians are reduced by $10 \%$ because sharing of technicians between reactors reduces the need to hire extra personnel for high dose-rate activities.

Health physics staff labor costs for decommissioning an LWR at a multiplereactor station, both with and without centralized health physics services, are summarized in Table 8.3-1 for the three decommissioning alternatives. Estimated net savings achieved by using centralized health physics services are also presented. These net savings are in the range of 30 to $40 \%$ of the base cost (without centralized services) for the PWR and in the range of 25 to $30 \%$ for the BWR. Overal1 savings are greater for the BWR than for the PWR because of the greater requirement for health physics personnel at the BWR, as estimated in References 1 through 3.

\subsubsection{Security Forces}

A station-wide central security force at a multiple-reactor station could provide security services more efficiently for each reactor than such services could be provided at a single-reactor station. Two factors that account for this cost reduction are:

- the overhead structure for each reactor can be reduced by sharing certain staff members between reactors

- the off-shift coverage at a reactor being decommissioned can be reduced or el iminated after the spent fuel has been shipped (no special nuclear material at reactor) if provision is made for routine spot-checks by roving security patrolmen, reducing the overall personnel requirement.

The organization structures for the security force considered in this study are shown in Figure 8.3-2. The security organization without centralized services, Figure 8.3-2a, is the same as that shown in Reference 2 for decommissioning the reference $B W R$. The organization of the security force with centralized services, shown in Figure 8.3-2b, assumes a three-level approach as 
TABLE B.3-1. Summary of Health Physics Staff Labor Costs for Decommissioning of an LWR at a Multiple-Reactor Station $(a)$

\begin{tabular}{|c|c|c|c|}
\hline Decommissioning Alternative & $\begin{array}{l}\text { Total Health } \\
\text { Labor Costs } \\
\text { w/o Centralized } \\
\text { Health Physics }\end{array}$ & $\begin{array}{l}\text { nysics Staff } \\
\text { thousands) } \\
\text { w/Centralized } \\
\text { Health Physics }\end{array}$ & $\begin{array}{l}\text { Net Savings } \\
\text { w/Centralized } \\
\text { Health Physics } \\
\text { (\$ thousands) }\end{array}$ \\
\hline \multicolumn{4}{|l|}{$\underline{P W R}$} \\
\hline DECON $(b)$ & 1424 & 962 & 462 \\
\hline \multicolumn{4}{|l|}{ SAFSTOR: ${ }^{(c)}$} \\
\hline $\begin{array}{l}\text { Preparations for Safe } \\
\text { Storage }\end{array}$ & 668 & 412 & 256 \\
\hline Deferred Decontamination (e) & 1424 & 962 & 462 \\
\hline Totals & 2092 & 1374 & 718 \\
\hline ENTOMB $^{(e)}$ & 1424 & 962 & 462 \\
\hline \multicolumn{4}{|l|}{$\underline{B W R}}$. \\
\hline $\operatorname{DECON}(f)$ & 2349 & 1731 & 618 \\
\hline \multicolumn{4}{|l|}{ SAFSTOR: ${ }^{(c)}$} \\
\hline $\begin{array}{l}\text { Preparations for Safe } \\
\text { Storage }(g)\end{array}$ & 7530 & 1094 & 436 \\
\hline Deferred Decontamination $(e)$ & 2349 & 173 & 618 \\
\hline Totals & 3879 & 2825 & 1054 \\
\hline $\operatorname{ENTOMB}^{(h)}$ & 2406 & 1752 & 654 \\
\hline
\end{tabular}

(a) Assumed to be a 10-reactor station.

(b) From Table B. l-1.

(c) Centralized health physics services are assumed to have no significant impact on costs for continuing care.

(d) From Table B.1-2.

(e) Assumed to be the same as for DECON.

(f) From Table B. 1-3.

(g) From Table B.1-4.

(h) Reactor vessel internals removed; from Tabie B.1-5.

described in Subsection 8.3.1 for centralized health physics services. At the station level the security supervisor and assistant security supervisor have overall responsibility for station security matters. Each of the reactor groups (quads) has a security shift supervisor assisted by security patrolmen at both the group and reactor levels. 
WITH CENTRALIZED SECURITY FORCES ${ }^{\text {(D) }}$

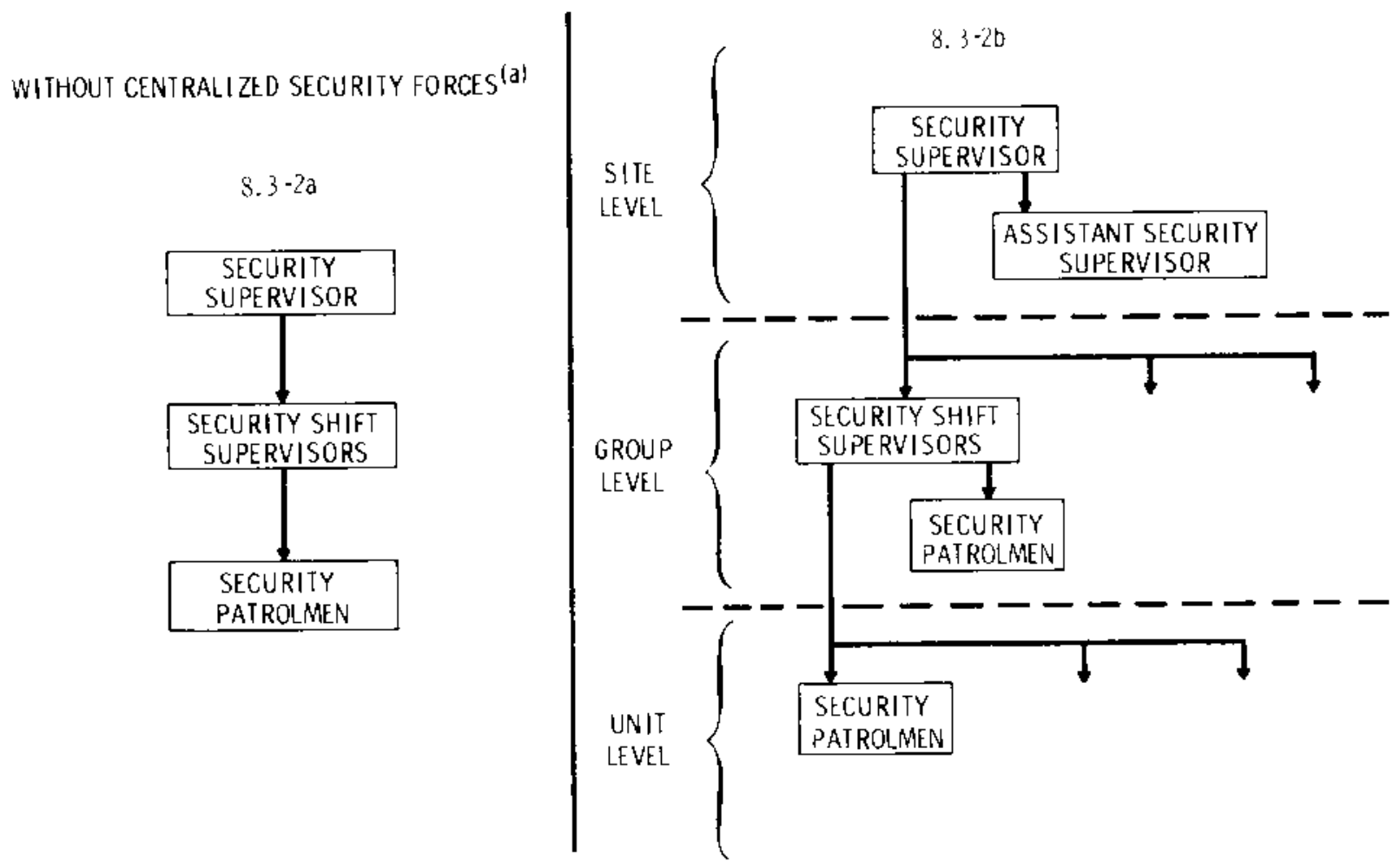

(a) BASED ON FIGURE H.1-1 OF REFE RENCE ?.

(b) ASSUMES SITE DIVIDED INTO THREE GROUPS OF REACTORS WITH THREE OR FOUR UNITS IN EACH GROUP.

FIGURE 8.3-2. Security Force Organization for Decommissioning

Estimated costs of providing security forces for decommissioning the reference PWR and the reference BWR at a multiple-reactor station, both with and without centralized security forces, are summarized in Tabie 8.3-2. The net savings possible by using a centralized security force are also presented. For the different alternatives, overall net savings with a central security force during the decommissioning of a reactor range from 21 to $32 \%$ of the cost of providing security with a separate security force at the reactor. The net savings percentages are not significantly influenced by the reactor type.

\subsubsection{Solid Waste Processing}

In the decommissioning studies of the reference $\mathrm{PWR}(1)$ and the reference $B W R^{(2)}$ at single-reactor stations, it was assumed that the dry solid radioactive 
TABLE 8.3-2. Summary of Security Force Labor Costs for LWR Decommissioning at a Multiple-Reactor Station(a)

Total Security Force Labor Costs W/0 Centralized w/Ce

Decommissioning Al ternative
Net Savings w/Centralized Security Forces (\$ thousands)

PWR

$\operatorname{DECON}(\mathrm{b})$

SAFSTOR: ${ }^{(c)}$

Preparations for Safe

Storage (d)

Deferred Decontamination $(\mathrm{e})$

Totals

ENTOMB $(f)$

$\underline{B W R}$

DECON $(g)$

SAFSTOR: (c)

Preparations for Safe Storage $(h)$

Deferred Decontamination $(i)$

Totals

ENTOMB $(j)$
2129

1670

459

1155

1005

150

1390

2545

$\underline{732}$

$\underline{658}$

1737

808

2129

1670

459

2495

1973

522

2032

1729

303

1622

859

763

3654

2588

1066

2671

2066

605

(a) Assumed to be a 10-reactor station.

(b) From Table B.2-1.

(c) Centralized security forces are assumed to have no significant impact on costs for continuing care.

(d) From Table B.2-2.

(e) From Table B.2-3.

(f) Assumed to be the same as for DECON.

(g) From Table B.2-4.

(h) From Table B.2-5.

(i) From Table B.2-6.

(j) From Table B.2-7. 
waste was compacted to achieve a five-fold reduction in volume. At a multiplereactor station, a central waste incinerator to serve the whole station can further reduce the volume of combustible radioactive waste by at least a factor of five, giving an overall volume reduction factor of 25 . A central waste incinerator can provide significant savings in waste disposal costs for both the operating and decommissioning phases of reactor life.

It is assumed in this study that a central waste incinerator is provided at the multiple-reactor station to process the combustible solid waste from the 10 operating reactors in five, two-shift days per week. In Section B.3 of Appendix B, the capital cost of the centra? waste incinerator is estimated to be $\$ 3.9$ million, or $\$ 390,000$ per reactor at the site. It is assumed that the annual operating and maintenance cost is $5 \%$ of the capital cost of the incinerator. Since this yields an annual savings when compared to disposal of compacted combustible waste of $\$ 36,000$ per operating reactor (see Table B.3-1 of Appendix B) and the decommissioning of a reactor generates only about $10 \%$ of the combustible radioactive waste over the reactor 40 -year lifetime, it is assumed that the capital cost of the incinerator is borne by reactor operation.

The cost of using the incinerator for reducing the volume of the combustible radioactive waste from decommissioning a reactor is only the additional incremental cost of operating and maintaining the facility during incineration of the waste. The net cost savings resulting from incineration of combustible radioactive waste during decommissioning a reactor at a multiple-reactor station are presented in Table 8.3-3. Savings for both types of reactors for each of the three decommissioning alternatives are given. The savings are small compared to the total cost of radioactive waste disposal for decommis sioning a reactor but represent a significant fraction of the disposal costs of compacted radioactive waste without incineration, 65 to $70 \%$ for the PWR and 55 to $70 \%$ for the BWR.

\subsubsection{Equipment Oecontamination Services}

Equipment decontamination services can be more fully utilized at a multiplereactor station than at a single-reactor station, thereby increasing the economy of these services and the economic incentive to provide improved services and 
TABLE 8.3-3. Summary of Net Savings from Incineration of Combustible Radioactive Waste from Reactor Decommissioning

Decommissioning Alternative

\section{PWR}

DECON/ENTOMB

SAFSTOR:

$$
\begin{aligned}
& \text { Preparations for Safe Storage } \\
& \text { Deferred Decontamination After } 30 \mathrm{yr} \\
& \text { Deferred Decontamination After } 50 \mathrm{yr} \\
& \text { Deferred Decontamination after } 100 \mathrm{yr} \\
& \text { Totals, w/30-yr Deferred Decontami- } \\
& \text { nation } \\
& \text { Totals, w/50-yr Deferred Decontami- } \\
& \text { nation } \\
& \text { Totals, w/100-yr Deferred Decontami- } \\
& \text { nation }
\end{aligned}
$$

$\underline{B W R}$

DECON/ENTOMB

SAFSTOR:

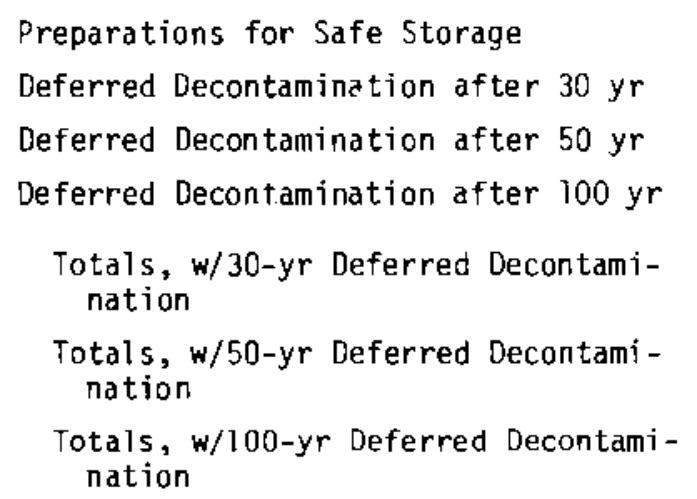

(a) From Table B.3-2 of Appendix 8.

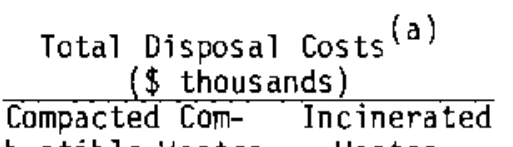
bustible Wastes Wastes

Net Savings with Incineration

(\$ thousands).
207

59

148

96

65

207

155

124

396

143

255

204

$\underline{140}$

398

347

283
74

133

40

104

68

45

144

108

$39 \quad 85$

$175 \quad 221$

$63 \quad 80$

$82 \quad 173$

$65 \quad 139$

$46 \quad 94$

145253

$128 \quad 219$

$109 \quad 174$ 
facilities at a multiple-reactor station. Several types of equipment decontamination services are considered here for inclusion in the centralized services:

- decontamination of special tools and equipment used for decommissioning, allowing maintenance and reuse of these items

- mobile decontamination systems for in-situ chemical decontamination of piping and components

- central electropolishing and chemical decontamination facilities for improved decontamination of pipe sections and components.

These services would provide significant benefits during both operation and decommissioning of a reactor. The resulting benefits during decommissioning are analyzed here.

\subsubsection{Decontamination of Special Tools and Equipment}

The special tools and equipment required to decommission an LWR represent a sizable cost investment. In the reference studies, (1-3) these items are not assumed to be salvaged after decommissioning and, thus, their full cost is assumed to be borne by a single decommissioning. However, most of these items could be reused if proper decontamination and maintenance were performed on them, reducing the net cost of decommissioning a reactor.

For the following analysis, it is assumed that the special decommissioning tools and equipment are decontaminated, maintained, or refurbished in the central maintenance shops, and reused where possible. An estimated useful lifetime (in terms of the number of decormissioning cycles) is assigned to each item, and the capital costs for the item are assumed to be shared equally by that number of cycles. The annual decontamination and maintenance costs are assumed to be $10 \%$ of the total capital cost of the item. However, each item is assumed to be used for only half of the total decommissioning period and, thus, the effective cost of decontamination and maintenance is assumed to be $5 \%$ per year over the total length of only one decommissioning schedule. Items with a useful lifetime of only one decomissioning cycle are not assumed to require any substantial decontamination or maintenance. The total costs 
with reuse (the costs for capital and for decontamination and maintenance) are compared to those costs without reuse to calculate the net savings resulting from decontamination, maintenance, and reuse of the special tools and equipment.

Details of the estimated costs of providing special tools and equipment for the decommissioning of PWRs with the tools and equipment being decontaminated and reconditioned for reuse where possible are given in Tables B.4-1 and B.4-2 of Appendix B. Similar estimated cost details for the decomissioning of BWRs are given in Tables B.4-3 and B,4-4.

Costs of special tools and equipment for decommissioning a reactor at a multiple-reactor station and the savings achievable with reuse of these tools and equipment are summarized in Table 8.3-4. The costs are shown both with and without decontamination and reuse of the items, and net savings for each reactor decommissioning with reuse of the items are also presented. Costs and savings with reuse of the tools and equipment are based on the assumption that no significant capital investment is required to provide space for decontamination and interim storage of these items, because there is judged to be adequate available space onsite.

Net savings per reactor decommissioned by decontamination and reconditioning of special tools and equipment for reuse are estimated to be between 40 and $60 \%$ of the total capital cost of the items, $\$ 300$ thousand for a PWR and u\$1.2 million for a BWR. The potential overall savings are higher for the BWR than for the PWR because of the estimated greater need for special tools and equipment in the BWR study (2) than in the PWR study. (I)

\subsubsection{Mobile Chemical Decontamination Equipment}

Mobile chemical decontamination equipment is assumed in the BWR study (2) to be used for in-situ decontamination of piping and components during decommissioning by any of the three alternatives. However, such equipment is not discussed in the PWR study. (1) The costs of using such equipment for PWR decommissioning are estimated here 1) to provide a common basis between PWR and BWR decontamination activities and 2) because such equipment is judged to provide additional benefits in terms of ease of decontamination, better control of the process, and more consistent conditions and, consequently, more consistent results. 
TABLE 8.3-4. Summary of Special Tools and Equipment Costs for LWR Decommissioning at a Multiple-Reactor Station(a)

Total costs/Decommissioning for Special Tools and Equipment (\$ thousands)

Decommissioning Alternative

PWR

DECON (b)

SAFSTOR:

Preparations for Safe Storage ${ }^{(C)}$

Deferred Decontamination

Totals

ENTOMB $(f)$

$\underline{B W R}$

DECON $(g)$

SAFSTOR:

Preparations for Safe Storage ${ }^{(h)}$

Deferred Decontamination

Totals

$\operatorname{ENTOMB}(j)$
Without Reuse

with Reuse

822

$\frac{762}{790}(\mathrm{~d})$

822

2016

$\frac{1728}{2079}(i)$
2016

Net Savings/

Decommissioning with Reuse

(\$ thousands)
495

327

$\begin{array}{ll}\frac{13}{457}(\mathrm{e}) & \frac{15}{470}(\mathrm{e}) \\ 495 & \frac{305}{320} \\ 495 & 327\end{array}$

(a) Assumed to be a 10 -reactor station.

(b) From Table B.4-1.

(c) From Table B.4-2.

(d) Calculated from Table H.5-2 of Reference 1.

(e) Calculated from value for DECON by multiplying by the ratio of the costs (without reuse) for deferred decontamination and DECON.

(f) Assumed to be the same as for DECON.

(g) From Table B.4-3.

(h) From Table B.4-4.

(i) From Table J.7-2 of Reference 2.

(j) Reactor vessel interna1s removed; assumed to be the same as for DECON.

In the BWR study, five mobile chemical decontamination units, estimated to cost $\$ 20,000$ each, and four mobile chemical mixing and heating units, costing $\$ 2,500$ each, are assumed to be used (see Tables I.3-9 and J.5-6 of Reference 2). Assuming proper maintenance and decontamination of the units, the cost of the units would not be charged to the decommissioning of a single reactor. In Tables B.4-3 and B.4-4 of Appendix B the estimated useful lifetime of such units is five reactor decommissionings. The savings for each reactor decomissioning achieved by using this portable chemical decontamination equipment for decormissioning five instead of one BWR is $\$ 68,700$ for OECON and ENTOMB and $\$ 74,200$ for SAFSTOR. 
It is assumed in this study that the same number of portable units are required in the decomissioning of the PWR as were assumed to be needed for the BWR. The estimated costs of these units for decomissioning a PWR are presented in Table 8.3-5, using the same rationale and assumptions as were used for the BWR. The savings per reactor shown for using the portable chemical decontamination equipment during the decommissioning of five PWRs are given as $\$ 72,000$ for DECON or ENTOMB and $\$ 81,000$ for SAFSTOR. The savings are greater for the PWR because equipment maintenance is costed as a function of the time schedule, 3 years for the PWR and 3-1/2 years for the BWR for DECON.

TABLE 8.3-5. Estimated Costs for Mobile Chemical Decontamination Equipment for PWR Decomissioning

\begin{tabular}{|c|c|c|c|c|c|c|}
\hline $\begin{array}{l}\text { Decommissioning } \\
\text { Alternative }\end{array}$ & $\begin{array}{c}\text { Estimated } \\
\text { Total Capital } \\
\text { Cost }(\$ \text { thousands })\end{array}$ & $\begin{array}{l}\text { Estimated Useful } \\
\text { Lifetime (No. of } \\
\text { Decommissionings)(b) }\end{array}$ & $\begin{array}{l}\text { Cost/De } \\
\text { Capital }\end{array}$ & $\begin{array}{l}\text { ommissioning wit } \\
\text { (\$ thousands) }(c) \\
\text { Maintenance }(d)\end{array}$ & $\begin{array}{l}\text { Reuse } \\
\text { Total }\end{array}$ & $\begin{array}{c}\text { Savings / } \\
\text { Decomissioning } \\
(\$ \text { thousands })\end{array}$ \\
\hline 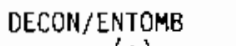 & 110 & 5 & 22 & 17 & 39 & 71 \\
\hline SAF $5 T O R^{(e)}$ & 110 & 5 & 22 & 7 & 29 & 81 \\
\hline
\end{tabular}

(a) From Table I.3-9 and Table J.5-6 of Reference 2.

(b) Assumes adequate maintenance.

(c) Rounded to the nearest $\$ 1000$.

(d) Based on assumed average rate of $5 \%$ of capital cost per year; assumes a 3-year decomissioning schedule for $D E C O N$ or entombment and a 16-month schedule for preparations for safe storage.

(e) Chemical decontamination equipment used only during preparations for safe storage.

\subsubsection{Central Electropolishing and Chemical Decontamination Facility}

A central electropolishing and chemical decontamination facility could be used to reclaim piping, valves, and other plant components for reuse or salvage, reducing both the net cost of decommissioning and the volume of waste requiring disposal. Electropolishing could also be used during construction to polish component surfaces before installation to reduce the subsequent rate of contamination buildup, thus reducing occupational radiation doses and costs for both operations and decommissioning. (4)

An electropolishing facility sized to provide adequate capacity to handle construction, operation, and decommissioning of a single-unit reactor station is described in Section 11 of Reference 5 . The information in the reference is used as a basis for the analysis presented in this study; major differences are: 
- The facility size is increased somewhat in this analysis to allow for occasional increased demands for the facility services from the 10 reactors onsite, and allow the processing of larger equipment items, with a lower overall cost per reactor than with individual units at each reactor.

- Chemical decontamination facilities are included here to provide more complete capability.

- Portable electropolishing equipment is aiso postulated to be included here for in-situ decontamination of plant components.

The estimated cost of a central electropolishing and chemical decontamination facility that can serve a multiple-reactor station with 10 operating reactors is $\$ 1.88$ million. In Appendix $B$ the total of the capital and operating costs charged to the decommissioning of a reactor is $\$ 235,000$.

Significant savings are achievable by cleaning contaminated stainless steel components to unrestricted release levels for either salvage as scrap or refurbishment and reuse of components. Savings resulting from electropolishing and salvage of stainless steel are two-fold. The material does not require disposal as radioactive waste and the metal can be sold as scrap.

The estimated costs and potential savings resulting from use of a central electropolishing facility during decommissioning a reactor are summarized in Table 8.3-6. The estimates do not include savings that would result from decontamination and refurbishment of components for eventual reuse. However, such reuse is desirable where possible and, with the appropriate capabilities onsite, is judged to occur in some cases. As an example, recovery of even a small fraction of the stainless steel valves in the reactor plant being decommissioned would yield considerable additional savings, even assuming that refurbishment of these valves would cost an average of $50 \%$ of their replacement costs. (Valve reconditioning typically costs iess than $50 \%$ of new-valve cost.) $)^{(6)}$

\subsubsection{Equipment Decontamination Services Sumary}

The net savings associated with the central decontamination services considered in this study are summarized in Table 8.3-7. The total net savings for 
TABLE 8.3-6. Estimated Costs and Potential Cost Savings Associated with Use of a Central Electropolishing Facility During Decomrissioning

\begin{tabular}{|c|c|c|c|c|c|}
\hline \multirow[b]{2}{*}{ Type of Reactor } & \multicolumn{3}{|c|}{$\begin{array}{c}\text { Facility Costs/Decommissioning } \\
(\$ \text { thousands })(a)\end{array}$} & \multirow{2}{*}{$\begin{array}{c}\text { Net Recovery } \\
\text { Value of } \\
\text { Stainless Steel } \\
\text { (\$ thousands) (a,d) }\end{array}$} & \multirow{2}{*}{$\begin{array}{c}\text { Wet Cost } \\
\text { Savings/ } \\
\text { Decommissioning } \\
(\$ \text { thousands })(a)\end{array}$} \\
\hline & Capital (b) & $\begin{array}{l}\text { Operation and } \\
\text { Maintenance (c) }\end{array}$ & Tota1 & & \\
\hline PWR & 47 & 388 & 235 & $975^{(e)}$ & 740 \\
\hline BWR & 47 & 188 & 235 & $472^{(f)}$ & 237 \\
\hline
\end{tabular}

(a) Rounded to the nearest $\$ 1000$.

(b) Based on a facility cost of $\$ 1,380,000,25 \%$ of which is assumed to be charged to deconmissioning, with 10 reactors at the site.

(c) Assumed to be !o\% of total capital cost/year; electropolishing associated with decommissioning estimated to be completed in 1 year.

(d) Based on $\$ 0.60 / \mathrm{kg}$ saivage value and $\$ 0.74 / \mathrm{kg}$ disposal cost, for a net recovery value of $\$ 1.34 / \mathrm{kg}$ (see p. 10-3 of Reference !).

(e) Based on $80 \%$ recovery of $910,000 \mathrm{~kg}$ potentially recoverable.

(f) Based on $80 \%$ recovery of $179,000 \mathrm{~kg}$ potentially recoverable stainless steel and $435,000 \mathrm{~kg}$ of potentially recoverable carbon steel.

TABLE 8.3-7. Summary of Net Cost Savings Associated with Central Decontamination Services During LWR Decommissioning

\begin{tabular}{|c|c|c|c|c|}
\hline \multirow[b]{2}{*}{ Decommissioning Al ternative } & \multicolumn{4}{|c|}{ Net Cost Savings Associated with Decontamination Options ( $\$$ thousands) $(a)$} \\
\hline & $\begin{array}{l}\text { Reuse of Speciat } \\
\text { Tools and Equipnent }\end{array}$ & $\begin{array}{l}\text { Mobile Decontam }(\mathrm{c}) \\
\text { ination Equipment }\end{array}$ & $\begin{array}{l}\text { Centra ETectropolishing } \\
\text { Facility with SS Recovery }\end{array}$ & Total \\
\hline \multicolumn{5}{|l|}{ PWR } \\
\hline DECON & 327 & 71 & 740 & 1138 \\
\hline SAFSTOR ${ }^{(e)}$ & 320 & 81 & 740 & 1141 \\
\hline ENTAMB & 327 & 71 & 740 & 1138 \\
\hline \multicolumn{5}{|l|}{ BWR } \\
\hline DECON & 1165 & $-{ }_{-}^{(f)}$ & 237 & 1402 \\
\hline SAFSTOR (e) & 1200 & _. & 237 & 1437 \\
\hline $\operatorname{ENTOMB}^{(9)}$ & 1165 & -- & 237 & 1402 \\
\hline
\end{tabular}

(a) Rounded to the nearest $\$ 1000$.

(b) From Tab7e B. 4-5.

(c) From Table B.4-6.

(d) From Table B, 4-8.

(e) For deferred decontamination after 30 years of safe storage.

(f) Implicitly included in Reference 3; net savings associated with decontamination and reuse included in reuse of special tools and equipment.

(g) Reactor vessel internals removed.

decommissioning a BWR are about $40 \%$ greater than the savings for decommissioning a PWR. This is attributable to the significantly greater estimated cost of special tools and equipment given in the BWR decommissioning study.

(2) 


\subsubsection{Maintenance Shops and Services}

Central maintenance shops at a multiple-reactor station could have substantially greater capability than the maintenance shop at a single-reactor station. During the reactor operation phase, the more normal and routine maintenance tasks would be accomplished in the maintenance shop at the reactors. The more difficult, special, and overload tasks would be performed at the central shops. Central maintenance shops would be of much greater value to reactor operation than to decommissioning.

During reactor decommissioning the central maintenance shops could:

- provide maintenance and refurbishment of the special tools and equipment that can be used for decommissioning several reactors

- provide refurbishment of reactor process equipment, such as valves, for reuse in other reactors.

These two services would be provided in conjunction with the central equipment decontamination services. The impact of central maintenance shops and services on decommissioning costs is included in the analyses presented in Subsection 8.3 .4 .1 .

\subsubsection{Laundry Services}

An onsite laundry is judged to have a minimal impact on decommissioning costs. A representative of a vendor of protective clothing (a) expressed doubt that an onsite laundry would reduce costs because:

- payscales at a commercial laundry probably would be lower than at an onsite laundry.

- after making the capital investment in the equipment it is not easy for the reactor operator/s to install new improved equipment that would reduce costs.

(a) John Murray, Safety and Supply Company, Seattle, Washington. 
The principal advantage of an onsite laundry would be that the service would be under the direct control of the utility, and would be less susceptible to transportation delays, strikes, and other scheduling problems.

\subsubsection{Transportation Services}

Onsite transportation services at a multiple-reactor station could provide:

- a variety of vehicles that match the needs more precisely, such as special heavy-equipment cask trailers, etc.

- potentially better availability and greater ease of scheduling.

The onsite capability would probably have to be augmented with other transportation services on occasion. Unit transportation costs would likely be about the same with or without onsite transportation services. However, scheduling should be easier with onsite transportation services, and offsite disruptions would be less likely to detrimentally affect the decommissioning effort.

\subsubsection{Central Stores}

A central stores installation at a multiple-reactor might achieve the cost advantage of quantity purchases of miscellaneous supplies. Reduced prices probably would not be available for special decomissioning tools and equipment because of the relativeiy small volume of these items required. No significant impact on decommissioning costs is perceived. The principal advantage of central stores would be more readily available stocks of miscellaneous supplies.

\subsubsection{Summary of Centralized Services}

Significant savings in decommissioning costs are achievable by providing some centralized services. Health physics services, security forces, solid waste processing, and decontamination services give the significant savings summarized in Table 8.3-8. Savings achievable for the different decommissioning alternatives range from about $\$ 2$ million for the PWR to about $\$ 4$ million for the BWR.

\subsection{TYPE OF REACTOR}

At multiple-reactor stations the two types of light water reactors being constructed are PWRs and BWRS. The estimated decommissioning costs for both 
TABLE 8.3-8. Summary of Net Savings by Providing Centralized Services (a)

\begin{tabular}{|c|c|c|c|c|c|}
\hline \multirow{2}{*}{$\begin{array}{l}\text { Decommissioning } \\
\text { Alternative }\end{array}$} & \multicolumn{5}{|c|}{ Net Savings (\$ thousands) } \\
\hline & $\begin{array}{l}\text { Health Physics } \\
\text { Services (b) }\end{array}$ & $\begin{array}{l}\text { Security } \\
\text { Forces (c) }\end{array}$ & $\begin{array}{l}\text { Solid Waste } \\
\text { Processing (d) }\end{array}$ & $\begin{array}{l}\text { Decontamination } \\
\text { Services (e) }\end{array}$ & Total \\
\hline \multicolumn{6}{|l|}{$\underline{\mathrm{PWR}}$} \\
\hline DECON & 462 & 459 & 133 & 1138 & 2193 \\
\hline SAFSTOR & 718 & $80 \mathrm{~B}$ & $144^{(f)}$ & 1141 & 2812 \\
\hline ENTOMB & 462 & 459 & 133 & 1138 & 2193 \\
\hline \multicolumn{6}{|l|}{ BhR } \\
\hline DECON & 618 & 522 & 221 & 1402 & 2763 \\
\hline SAFSTOR & 1054 & 1066 & $253^{(f)}$ & 7437 & 3810 \\
\hline ENTOMB & 654 & 605 & 221 & 1402 & 2882 \\
\hline
\end{tabular}

(a) Assumed to be a 10-reactor station.

(b) From Table 8.3-1.

(c) From Tabie 8.3-2.

(d) From Table 8.3-3.

(e) From Table 8.3-7.

(f) For deferred decontamination after 30 years of safe storage.

types are shown in Table 8.4-1 for DECON, SAFSTOR, and ENTOMB. These differences in decommissioning costs for the two types of LWRs are also experienced in decomissioning reactors at a multiple-reactor station. However, decommissioning costs for PWRS and BWRs are impacted to about the same extent at a multiple-reactor station as compared to a single-reactor station. Estimated cost impacts for both PWRs and BWRs are developed in Subsections 8.1, 8.2, and 8.3.

\subsection{NUMBER OF REACTORS AT STATION}

The number of reactors at the multiple-reactor station influences how the radioactive waste is disposed of, whether there is a continuing stable construction labor force, and whether or which centralized services are provided. With a small number of reactors at the station, say a quad, it is not likely that radioactive waste could be disposed of onsite. It is improbable that centralized services would be provided; however, special decormissioning tools 


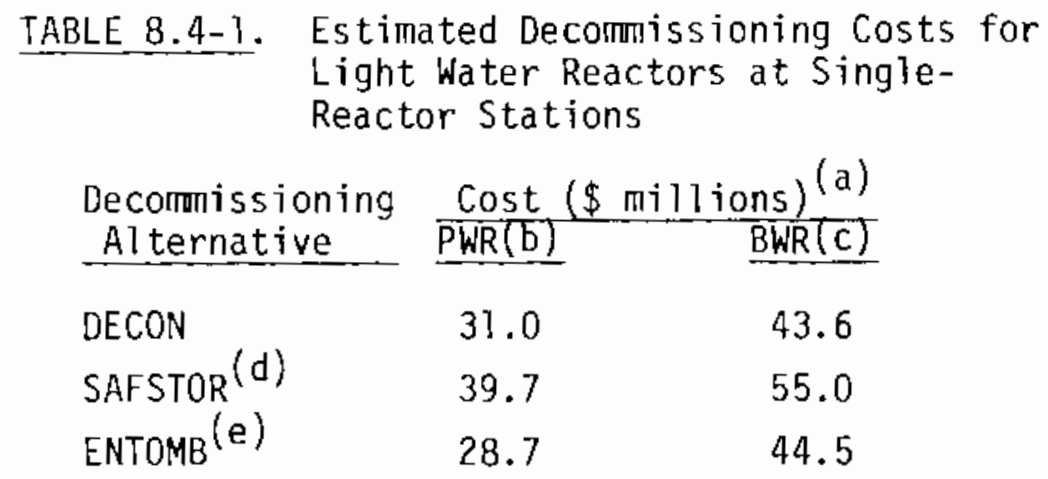

(a) Costs are estimated in 1978 dollars and include a $25 \%$ contingency.

(b) From Reference 3.

(c) From Reference 2 .

(d) Accumulated cost with deferred decontamination at 100 years.

(e) For entombment with reactor internals removed.

and equipment probably would be shared. Improvement and economies in planning the decommissioning of successive reactors would be realized for a few as well as many reactors at a multiple-reactor station. If only a few reactors are located at the station, the continuing stability of the labor force would not be assured. Therefore, there would not be a continuing availability of experienced decommissioning workers.

Detailed discussions of the multiple-reactor station scenarios in Section 10 illustrate the effect on deconmissioning costs of the number of reactors at the station. 


\section{REFERENCES}

1. R. I. Smith, G. J. Konzek and W. E. Kennedy, Jr., Technology, Safety and Costs of Decomissioning a Reference Pressurized water Reactor Power Station, NUREG/CR-0130, U.S. NucTear ReguTatory Commission Report by Pacific Northwest Laboratory, June 1978.

2. H. D. Oak, G. M. Holter, W. E. Kennedy, Jr., and G. J. Konzek, Technology, Safety and Costs of Decomissioning a Reference Boiling Water Reactor Power Station, NUREG/CR-0672, U.S. Nuclear ReguTatory Commission Report by Pacific Northwest Laboratory, June 1980.

3. R. I. Smith and L. M. Polenz, Technology, Safety and Costs of Decommissioning a Reference Pressurized Water Reactor Power Station, NUREG/CR-0130, Addendum, U.S. Nuclear Regulatory Comission Report by Pacific Northwest Laboratory, August 1979.

4. H.W. Arrowsmith, et a1. Electropolishing as a Decontamination Process: Progres 5 and Application, PNL-SA-6858, Pacific Northwest Laboratory, Richland, Washington, Apri? 1978.

5. E. B. Moore, Jr., Faciljtation of Decomissioning Light Water Reactors, NUREG/CR-0569, U.S. Nuclear ReguTatory Commission Report by Pacific Northwest Laboratory, December 1979.

6. M. P. Nicholas, "Reconditioning Makes 0ld Valves 'New, '" Chemical Engineering, May 22, 1978, pp. 117 and 118. 


\subsection{IMPACT OF MULTIPLE REACTORS ON RADIATION DOSE FROM DECOMMISSIONING}

The impact of decommissioning one of the reactors at a multiple-reactor power station on the radiation dose from decommissioning activities is estimated in this section by comparison with the radiation dose estimated for decommissioning a reactor at a single-reactor power station. The same factors examined in the cost analysis, section 8, are considered in this analysis, including: 1) several different approaches to disposal of radioactive waste, 2) the dedication of the site in perpetuity to nuclear power generation, 3) the availability of centralized services, and 4) the type and number of reactors at the station. The changes in the estimated occupational radiation doses from decommissioning the reference reactors by DECON, SAFSTOR, and ENTOMB, relative to the base-case single-reactor studies for the factors given above, are summarized in Table 9.0-i.

TABLE 9.0-1. Occupational Radiation Dose for Decommissioning One Reactor - Summary of Differences

\begin{tabular}{|c|c|c|c|c|c|c|}
\hline \multirow[b]{3}{*}{ Factor } & \multicolumn{6}{|c|}{ Radiation Dose Differences (man-rem) } \\
\hline & \multicolumn{2}{|c|}{ DECON } & \multicolumn{2}{|c|}{ SAFSTOR (d) } & \multicolumn{2}{|c|}{ ENTOMB } \\
\hline & PWR & BWR & PWR & BWR & PWR & BWR \\
\hline \multicolumn{7}{|l|}{ Waste Disposal } \\
\hline \multicolumn{7}{|c|}{ Onsite Interim Storage For: } \\
\hline 30 Years & +71.6 & +46.7 & -74.0 & -68.0 & +6.1 & +33.3 \\
\hline 50 Years & -72.0 & -55.1 & -77.4 & -86.7 & -11.6 & -25.9 \\
\hline 100 Years & -75.0 & -59.7 & -78.0 & -87.9 & -12.8 & -29.3 \\
\hline Onsite Disposal & -89.8 & -100.6 & -90.1 & -100.7 & -22.8 & -67.2 \\
\hline Site Dedication $(b)$ & -75.0 & -129.0 & -21.0 & -29.0 & -62.0 & -118.0 \\
\hline \multicolumn{7}{|l|}{ Central Services } \\
\hline Solid Waste Processing & -3.8 & -5.0 & -1.6 & -2.5 & -3.8 & -5.0 \\
\hline
\end{tabular}

(a) For deferred decontamination after 30 years of safe storage.

(b) For a multiple-reactor station with five reactors of one type. 


\subsection{DISPOSAL OF NUCLEAR WASTE}

Options for disposal of the nuclear waste generated by decommissioning a reactor at a multiple-reactor station are:

- burial offsite at a licensed disposal facility

- onsite interim storage with later transfer offsite to a licensed waste disposar facility

- burial onsite at a permanent nuclear waste disposal facility.

The impact of each of these options on the radiation dose from disposal of nuclear waste from reactor decommissioning is discussed in the following subsections.

\subsubsection{Offsite Nuclear Waste Disposal}

Decommissioning a reactor at a multiple-reactor station will generate the same quantity of nuclear waste as will decommissioning an identical reactor at a single-reactor station. The number of waste packages and shipments to the waste disposal site will be the same whether the reactor is at a single- or multiple-reactor station. Therefore, the occupational and public radiation doses are the same whether the reactor is alone on the site or is one of a number of reactors at a multiple-reactor station.

\subsubsection{Onsite Interim Nuclear Waste Storage}

The occupational radiation dose from disposal of the nuclear decommissioning waste is accumulated during shipment of the waste to the disposal site and during placement of the waste in the disposal facility. With onsite interim waste storage, each of the following tasks results in an occupational dose:

1. onsite transportation to the interim storage facility

2. placement of the waste in the interim storage facility

3. retrieval of the waste from the interim storage facility

4. transportation to the offsite disposal facility

5. placement of the waste in the offsite disposal facility.

Tasks 4 and 5 are the same as those for immediate disposal of the waste at an offsite nuclear waste disposal facility; however, the dose rates should be 
lower and there should be iess waste for disposal after a number of years of onsite interim storage. The radiation doses to the workers are estimated for each of the five tasks. Exposure of the public occurs only during transportation of the waste to the offsite waste disposal facility.

The offsite transportation doses are estimated using the same dose rate assumptions as were used in Reference 1, p. 11-26, which gives an occupationa 1 dose rate of 0.073 man-rem per shipment and a public dose rate of 0.015 man-rem per shipment. For onsite transportation to the interim storage facility, it is assumed:

- The truck driver spends $2 \mathrm{hr}$ in the cab while hauling the shipment and the dose rate is $2 \mathrm{mR} / \mathrm{hr}$.

- The driver spends 20 min outside of the cab at a distance of $2 m$ from the cargo and the dose rate is $10 \mathrm{mR} / \mathrm{hr}$.

- Since all movement is over private roads, there is no dose to the public. The occupational onsite transport dose is $[2 \mathrm{hr} \times 2 \mathrm{mR} / \mathrm{hr}+1 / 3 \mathrm{hr} \times 10 \mathrm{mR} / \mathrm{hr}]$ $\times 1$ driver $\times 0.001=0.0073$ man-rem per shipment.

Details of the estimation of the occupational doses for the other tasks involved in onsite interim storage of the nuclear waste are given in Appendix $C$. In the studies of decommissioning the reference $\mathrm{PWR}^{(1,2)}$ and the reference
$B W R$, (3) the radiation doses to the transport workers and the public were estimated, but the occupational doses to the workers at the waste disposal facility were not. In this study, however, estimates of the occupational doses to workers at the onsite nuclear waste disposal facility are included.

9.1.2.1 Radiation Doses from Onsite Interim Storage of Nuclear Waste from $\underline{D E C O N}$

The estimated occupational radiation doses for disposal of the nuclear waste from decominissioning the reference PWR by DECON are given in Table 9.1-1; for the reference BWR, these estimates are given in Table 9.1-2. Also given in the tables are the differences between the occupational radiation doses for immediate offsite disposal and onsite interim storage followed by offsite 
TABLE 9.1-1. Estimated Occupational Radiation Doses from Disposal of the Nuclear Waste from DECON of the Reference PWR

Es limated Occupational vose (man-remi)

\begin{tabular}{|c|c|c|c|c|c|c|c|}
\hline \multirow[b]{3}{*}{ Waste Disposal Task } & \multicolumn{7}{|c|}{ Eslimated Occupational Dose (man-reml) } \\
\hline & \multicolumn{3}{|c|}{ Inmediate orfs ite Disposal } & \multicolumn{4}{|c|}{ Onste Interim storage } \\
\hline & $\begin{array}{l}\text { Neutron- } \\
\text { Activated } \\
\text { Material }\end{array}$ & $\begin{array}{l}\text { Contaminated } \\
\text { Material \& } \\
\text { Radwaste }\end{array}$ & Iotal & $\begin{array}{l}\text { Neutron- } \\
\text { Activated } \\
\text { Material }\end{array}$ & $\begin{array}{l}\text { Contaminated } \\
\text { Material \& } \\
\text { Radwaste }\end{array}$ & Total & $\begin{array}{c}\text { Difference from } \\
\text { Inmediate } \\
\text { offsite Disposal }\end{array}$ \\
\hline Onsite Transport & - & -- & -- & 1.6 & 8.4 & 10.0 & 10.0 \\
\hline Placement in Interim Storage & $\sim$ & -- & -- & 95.0 & 27.0 & 122.0 & 122.0 \\
\hline Retrieval from Interim Storage & -- & $\sim$ & -- & & & & \\
\hline After 30 years & -- & -- & -- & 30.0 & 6.0 & 36.0 & 36.0 \\
\hline After 50 years & -- & - & -- & 1.0 & 0.5 & 1.5 & 1.5 \\
\hline After 100 years & $\cdots$ & -- & - & 0.02 & 0.03 & 0.05 & 0.05 \\
\hline Offsite Transport & 15.8 & 83.7 & 99.5 & & & & \\
\hline After 30 years & -- & - & - & 13.0 & 73.4 & 86.4 & $(13.1)^{(a)}$ \\
\hline After 50 years & -- & - & -- & 12.8 & 1.7 & 14.5 & $(85.0)$ \\
\hline After 100 years & -- & -- & -- & 12.8 & 1.5 & 14.3 & $(85.2)$ \\
\hline Placement in Offsite Disposal & 95.0 & 27.0 & 122.0 & & & & \\
\hline After 30 years & -- & -- & -- & 30.0 & 6.0 & 36.0 & $(86.0)$ \\
\hline After 50 years & -- & -- & -- & 1.0 & 0.5 & 1.5 & $(120.5)$ \\
\hline After 100 years & -- & -- & $\cdots$ & 0.02 & 0.03 & 0.05 & $(121.9)$ \\
\hline \multicolumn{8}{|l|}{ Total Difference } \\
\hline After 30 years & & & & & & & 71.6 \\
\hline After 50 years & & & & & & & $(72.0)$ \\
\hline After 100 years & & & & & & & $(75.0)$ \\
\hline
\end{tabular}

(a) ( ) indicates a reduction in dose. 
TABLE 9.1-2. Estimated Occupational Radiation Doses from Disposal of the Nuclear waste from $D E C O N$ of the Reference BWR

\begin{tabular}{|c|c|c|c|c|c|c|c|}
\hline \multirow[b]{2}{*}{ Waste Disposal Task } & \multicolumn{7}{|c|}{ Estimated Occupational Dose (man-reni) } \\
\hline & $\begin{array}{l}\text { Neutron- } \\
\text { Activated } \\
\text { Material }\end{array}$ & $\begin{array}{l}\text { Contaninated } \\
\text { Material \& } \\
\text { Radwaste }\end{array}$ & 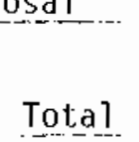 & $\begin{array}{l}\text { Neutrofi- } \\
\text { Activated } \\
\text { Material }\end{array}$ & $\begin{array}{l}\text { Coterial \& } \\
\text { Radwaste }\end{array}$ & TotaI & $\begin{array}{l}\text { Difference from } \\
\text { Inmediate } \\
\text { offsite Disposal }\end{array}$ \\
\hline Onsite Transport & - & -- & -- & 1.8 & 6.8 & 8.6 & 8.6 \\
\hline Placement in Interin Storage & -- & - & -- & 130.0 & 35.0 & 165.0 & 165.0 \\
\hline Retrieval from Interim Storage & -- & -- & -- & & & & \\
\hline After 30 years & -- & -- & -- & 13.0 & 7.2 & 20.2 & 20.2 \\
\hline After 50 years & - & - & +- & 1.5 & 0.72 & 2.22 & 2.2 \\
\hline After 100 years & - & - & -- & 0.02 & 0.05 & 0.07 & 0.07 \\
\hline Offsite Transport & 18.0 & 67.2 & 85.2 & & & & \\
\hline After 30 years & -- & -- & -- & 17.3 & 65.6 & 82.9 & $(2.3)^{(a)}$ \\
\hline After 50 years & -- & -- & -- & 15.6 & 1.5 & 17.1 & $(68.1)$ \\
\hline After 100 years & -- & -- & -- & 15.6 & 1.1 & 16.7 & $(68.5)$ \\
\hline Placement in Offsite Disposal & 130.0 & 35.0 & 165.0 & & & & \\
\hline After 30 years & -- & -- & -- & 13.0 & 7.2 & 20.2 & $(144.8)$ \\
\hline After 50 years & -- & -- & - & 1.5 & 0.7 & 2.2 & $(162.8)$ \\
\hline After 100 years & -- & - & - & 0.02 & 0.05 & 0.07 & $(164.9)$ \\
\hline Total Difference & & & & & & & \\
\hline After 30 years & & & & & & & 46.7 \\
\hline After 50 years & & & & & & & $(55.1)$ \\
\hline After 100 years & & & & & & & $(59.7)$ \\
\hline
\end{tabular}

(a) () indicates a reduction in dose. 
disposal after 30,50 , or 100 years of interim storage. With only 30 years of interim storage, the occupational radiation doses for disposal of radioactive waste from decommissioning for both the PWR and the BWR are greater than the occupational doses for immediate offsite waste disposal. With onsite interim storage for 50 or 100 years, there is a reduction of the occupational radiation dose for waste disposal when compared with immediate offsite disposal.

The estimated radiation doses received by the public from transportation of the radioactive waste from DECON to an offsite radioactive waste disposa] facility are given in Table 9.1-3 for immediate disposal and for disposal after 30,50 , or 100 years of onsite interim storage. The public radiation dose from shipment of the radioactive decomissioning waste to an offsite waste disposal facility is lower with onsite interim storage of the waste than it is for inmediate offsite disposal of the waste.

TABLE 9.1-3. Estimated Radiation Doses to the Public from Transportation of the Nuciear Waste from Decommissioning a Reactor by DECON

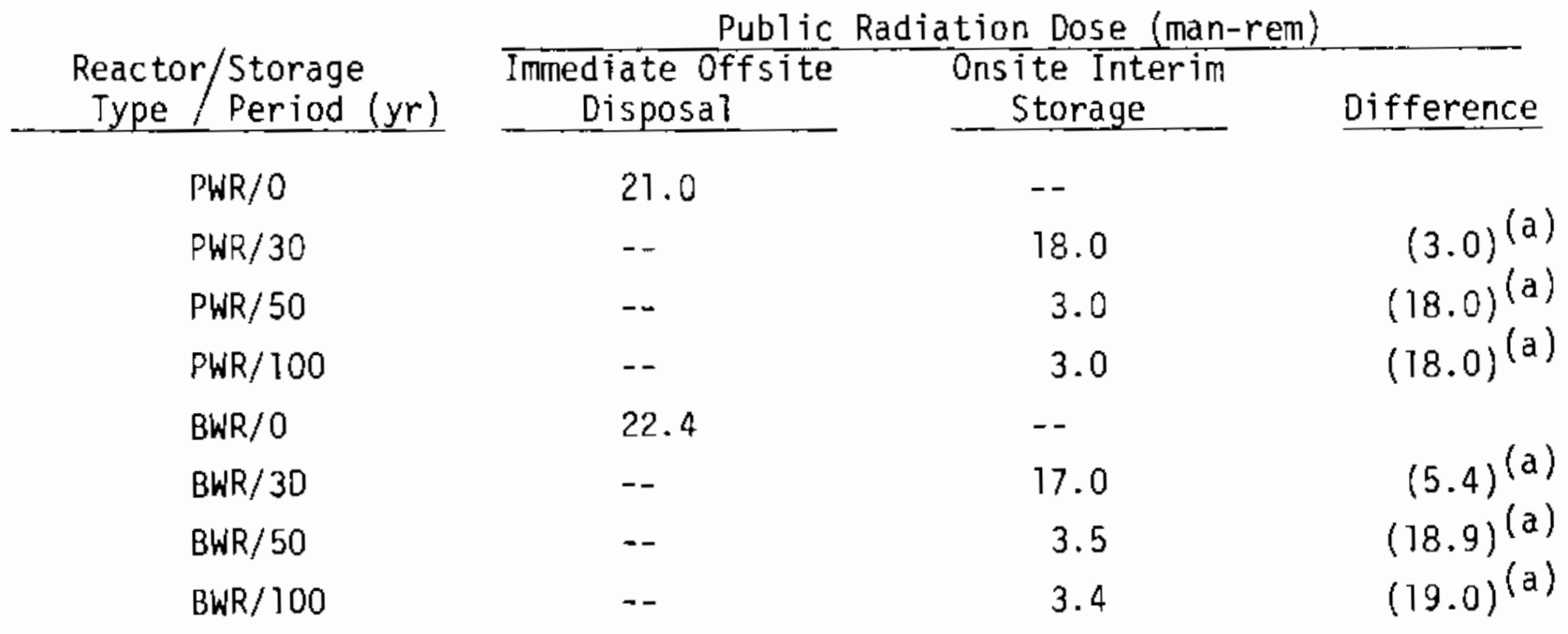

(a) ( ) indicates a reduction of the dose.

\subsubsection{Radiation Doses from Onsite Interim Storage of Nuclear Waste from SAFSTOR}

The estimated occupational radiation doses from the disposal of the nuclear waste generated by deconmissioning the reference PWR by SAFSTOR are given and 
compared with the doses from immediate offsite disposal in Table 9.1-4; for the reference BWR, these estimates are given and compared in Table 9.1-5. Differences between the occupational radiation doses from immediate offsite disposal of the waste from SAFSTOR and the doses from interim storage of the waste before offsite disposal are given in Table 9.1-6 for the PWR and in Table 9.1-7 for the BWR. For all combinations of safe storage periods and interim waste storage periods, the occupational radiation dose for waste disposal is reduced with onsite interim storage of the waste before it is finally sent to offsite storage.

The estimated radiation doses to the public from transportation of the nuclear waste from SAFSTOR to an offsite waste disposal facility are given in Table 9.1-8 for imodiate offsite disposal and for disposal after 30, 50, or 100 years of onsite interim storage. The pubiic doses shown include the doses from preparations for safe storage as well as those from deferred decontamination after 30, 50, or 100 years. For a 11 combinations of deferred decontamination and onsite interim storage periods, the radiation dose received by the public from transportation of the decommissioning waste from SAFSTOR is lower if the waste is placed in interim storage before it is shipped to an offsite waste disposal facility.

\subsubsection{Radiation Doses from Onsite Interim Storage of Nuclear Waste from} ENTOMB

Estimated occupational radiation doses for disposal of the nuclear waste from decommissioning the reference PWR by ENTOMB are given in Table 9.1-9; for the reference $B W R$, these estimates are given in Table 9.1-10. The tables also show the differences between the occupational radiation doses for immediate offsite disposal after 30, 50, or 100 years of interim storage. When the nuclear waste is removed from onsite interim storage after 30 years, the total occupational radiation dose for waste disposal is greater than the occupational dose for immediate offsite disposal. With onsite interim storage of 50 or 100 years, the occupational radiation dose for waste disposal is reduced, compared with the dose for immediate offsite disposal.

The estimated radiation doses received by the public from transportation of the nuclear waste from ENTOMB to an offsite waste disposal facility are given 
TABLE 9.1-4. Estimated Occupational Radiation Doses from Disposal of the Nuclear Waste from SAFSTOR of the Reference PWR

Estimated Occupational Dose (nan-rem)

\begin{tabular}{|c|c|c|c|c|c|c|c|}
\hline \multirow{3}{*}{ Waste Disposal Task } & \multicolumn{7}{|c|}{ Estimated Occupational Dose (man-rem) } \\
\hline & $\begin{array}{l}\text { Immedia } \\
\text { Neutron- } \\
\text { Activated } \\
\text { Material }\end{array}$ & $\begin{array}{l}\text { Offsite Disp } \\
\text { Contaminated } \\
\text { Material \& } \\
\text { Radwaste } \\
\end{array}$ & Total & $\begin{array}{l}\text { Onsite } \\
\text { Neutron- } \\
\text { Activated } \\
\text { Material }\end{array}$ & $\begin{array}{l}\text { Interim Stor } \\
\text { Contaminated } \\
\text { Material \& } \\
\text { Radwaste }\end{array}$ & Tota? & \multirow[t]{2}{*}{$\begin{array}{l}\text { Difference from } \\
\text { Immediate } \\
\text { offsite Disposal }\end{array}$} \\
\hline & & Preparations & For si & fe Storage & & & \\
\hline Onsite Transport & - & -- & -- & -- & 0.9 & 0.9 & 0.9 \\
\hline Placement in Interim Storage & -- & -- & -- & -- & 2.0 & 2.0 & 2.0 \\
\hline Retrieval from Interim Storage & -- & -- & -- & & & & \\
\hline After 30 years & -- & -- & -- & - & 0.44 & 0.44 & 0.44 \\
\hline After 50 years & -- & -- & -- & -- & 0.04 & 0.04 & 0.04 \\
\hline After 100 years & -- & -- & -- & -- & 0.002 & 0.002 & 0.002 \\
\hline Offsite Transport & - & 10.4 & 10.4 & & & & \\
\hline After 30 years & -- & -- & -- & -- & 2.1 & 2.1 & $(8.3)^{(a)}$ \\
\hline After 50 years & -- & -- & -- & -- & 0.5 & 0.5 & $(9.9)$ \\
\hline After 100 years & -- & -- & -- & & 0.4 & 0.4 & $(10.0)$ \\
\hline Placement in Offsite Disposal & -- & 2.0 & 2.0 & & & & \\
\hline After 30 years & -- & $\cdots$ & -- & - & 0.44 & 0.44 & $(1.6)$ \\
\hline After 50 years & -- & -- & $\cdots$ & -- & 0.04 & 0.04 & $(1.96)$ \\
\hline After 100 years & -- & -- & -- & -- & 0.002 & 0.002 & $(1.998)$ \\
\hline Total After 30 years & & & & & & & $(6.6)$ \\
\hline After 50 years & & & & & & & $(8.9)$ \\
\hline After 100 years & & & & & & & (9.1) \\
\hline
\end{tabular}


IABLE 9.1-4. (Contd)

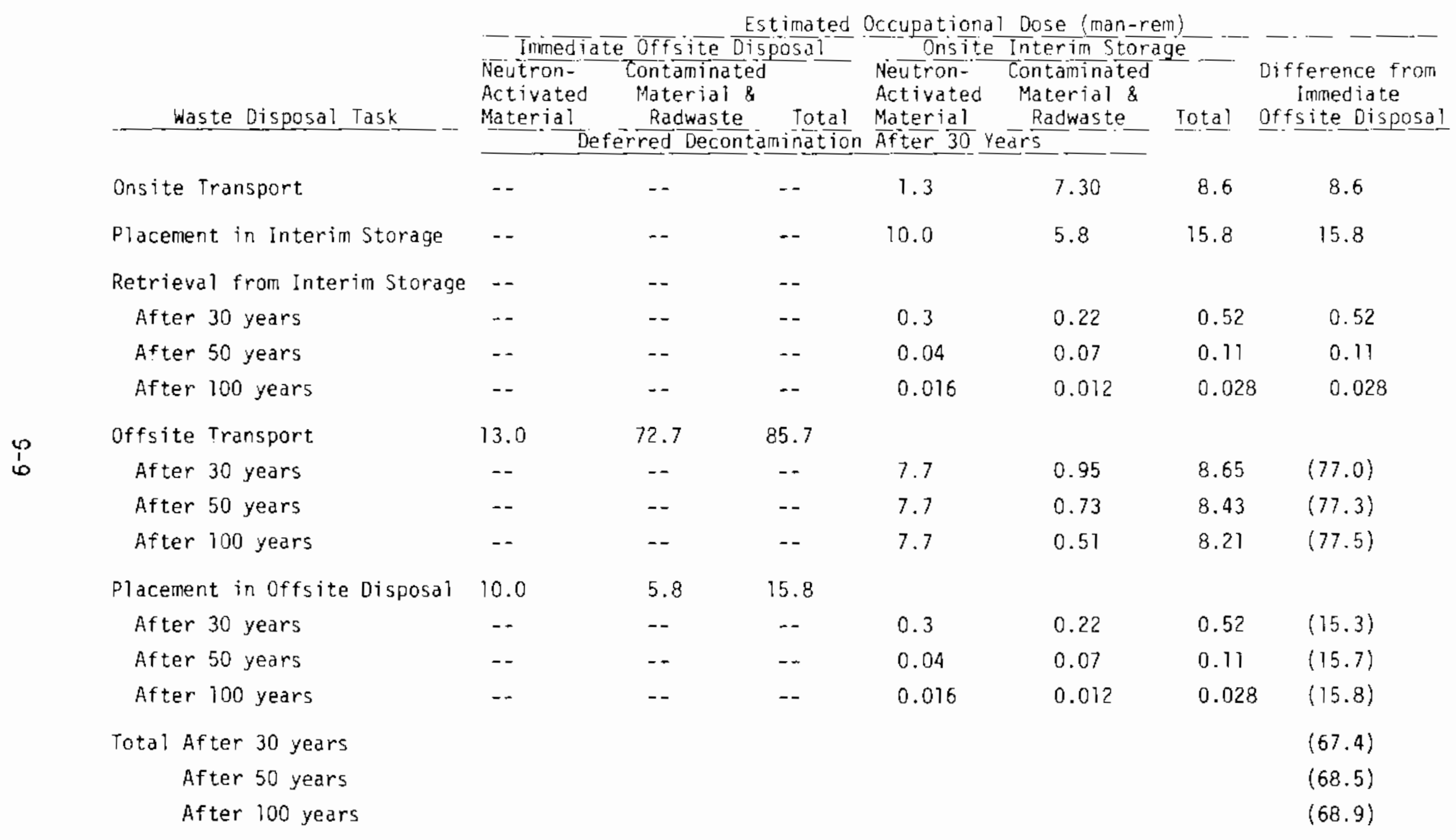


TABLE 9.1-4. (Contd)

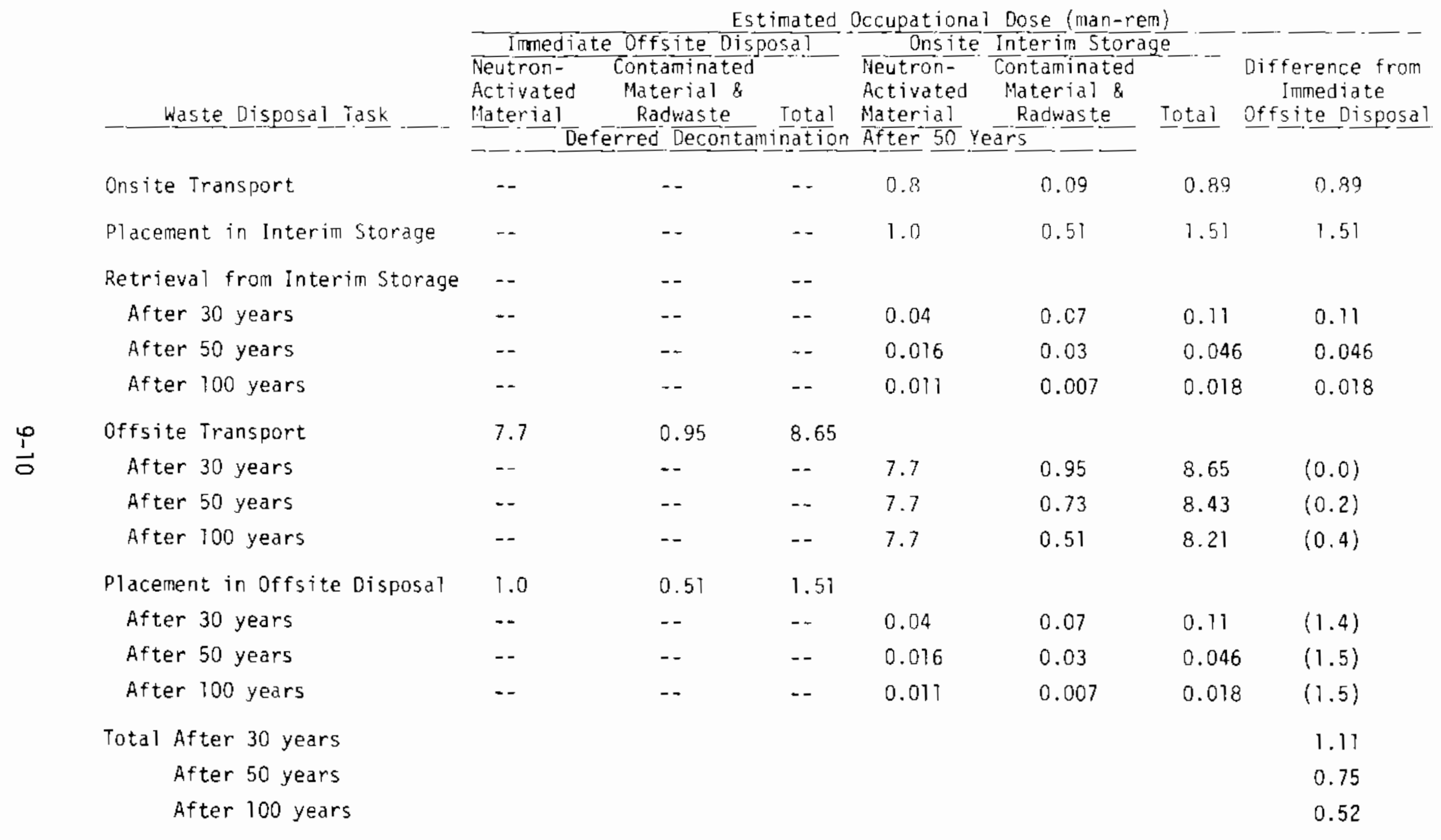


TABLE 9.1-4. (Contd)

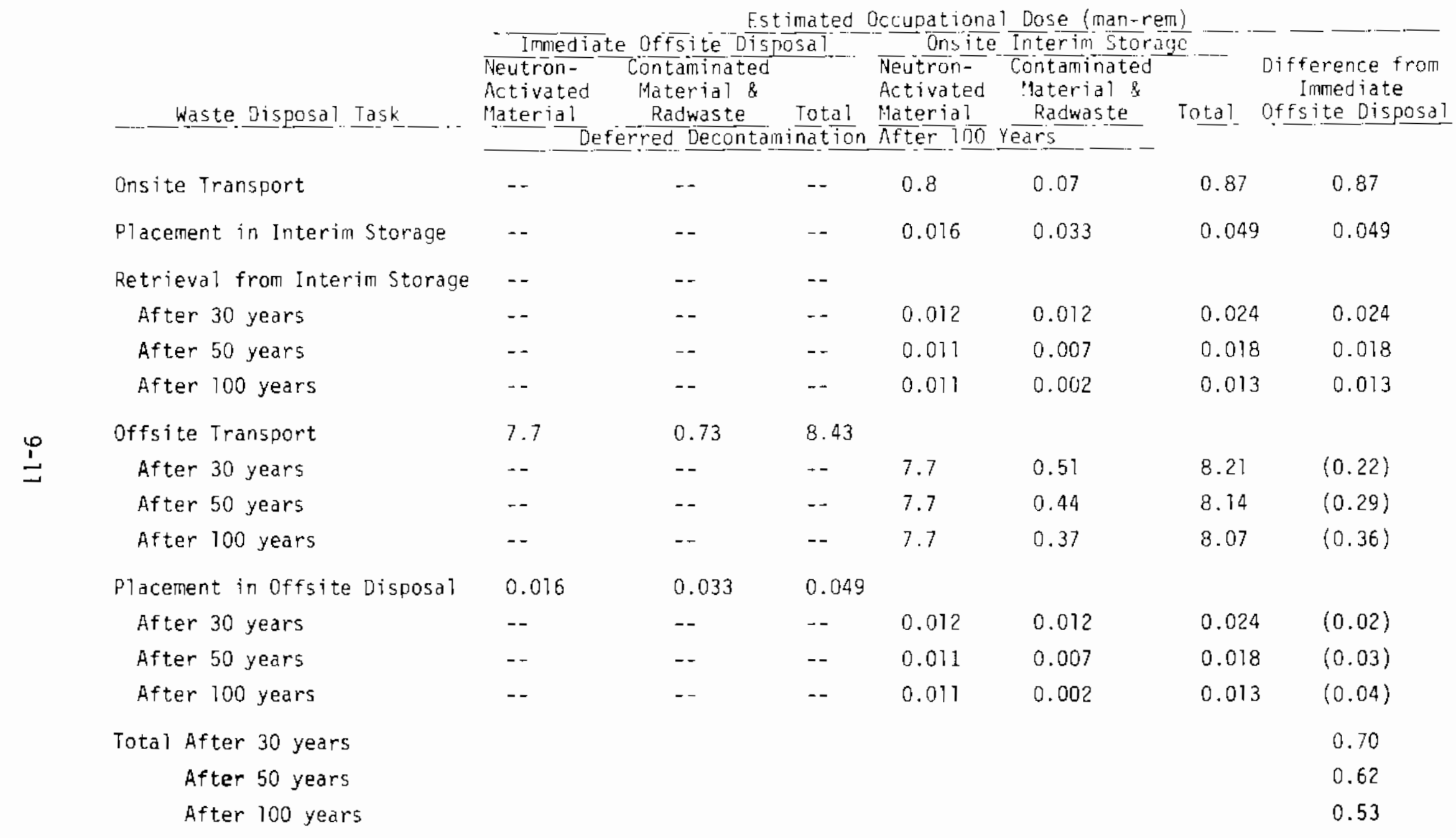

(a) () Indicates a reduction of the dose compared with immediate offsite disposal. 
TABLE 9.1-5. Estimated Occupational Radiation Doses from Disposal of the Nuclear Waste from SAFSTOR of the Reference BWR

\begin{tabular}{|c|c|c|c|c|c|c|c|}
\hline Waste Disposal Task & $\begin{array}{l}\text { Inmedi } \\
\text { Aeutron- } \\
\text { Activated } \\
\text { Material }\end{array}$ & $\begin{array}{l}\text { te Offsite } \frac{\text { Est }}{\text { Disp }} \\
\text { Contaminated } \\
\text { Material \& } \\
\text { Radwaste }\end{array}$ & $\begin{array}{l}\text { imated } \\
\text { Oosal } \\
\text { Total }\end{array}$ & $\begin{array}{l}\text { Occupationa } \\
\text { Onsite } \\
\text { Neutron- } \\
\text { Activated } \\
\text { Material }\end{array}$ & $\begin{array}{l}\text { Dose (man-re } \\
\text { Interim Stor } \\
\text { Contaminated } \\
\text { Material \& } \\
\text { Radwaste. }\end{array}$ & m) & $\begin{array}{c}\text { Sifference from } \\
\text { Inmediate } \\
\text { Offsite Disposal }\end{array}$ \\
\hline & & Preparations & For $S$ & Safe Storage & & & \\
\hline Onsite Transport & -- & -- & -- & -- & 0.7 & 0.7 & 07 \\
\hline Placement in Interim Storage & - & -- & - & - & 6.7 & 6.7 & 6.7 \\
\hline Retrieval from Interim Storage & -- & -- & -- & & & & \\
\hline After 30 years & -- & -- & -- & - & 1.5 & 1.5 & 1.5 \\
\hline After 50 years & $\cdots$ & -- & -- & -- & 0.14 & 0.14 & 0.14 \\
\hline After 100 years & -- & -- & - & - & 0.01 & 0.01 & 0.01 \\
\hline Offsite Transport & -- & 23.2 & 23.2 & & & & \\
\hline After 30 years & -- & -- & $\cdots$ & -- & 2.8 & 2.8 & $(20.4)^{(a)}$ \\
\hline After 50 years & - & -- & -- & -- & 1.2 & 1.2 & $(22.01)$ \\
\hline After 100 years & - & - & - & - & 0.9 & 0.9 & $(22.3)$ \\
\hline Placement in Offsite Disposal & -- & 6.7 & 6.7 & & & & \\
\hline After 30 years & -- & -- & -- & -- & 1.5 & 1.5 & $(5.2)$ \\
\hline After 50 years & - & - & - & -- & 0.14 & 0.14 & $(6.6)$ \\
\hline After 100 years & - & -- & -- & - & 0.01 & 0.01 & $(6.7)$ \\
\hline Total After 30 years & & & & & & & $(16.7)$ \\
\hline After 50 years & & & & & & & $(2 ? .1)$ \\
\hline After 100 years & & & & & & & $(21.6)$ \\
\hline
\end{tabular}


TABLE 9.1-5. (Contd)

Estimated Dccupational Dose (man-rem)

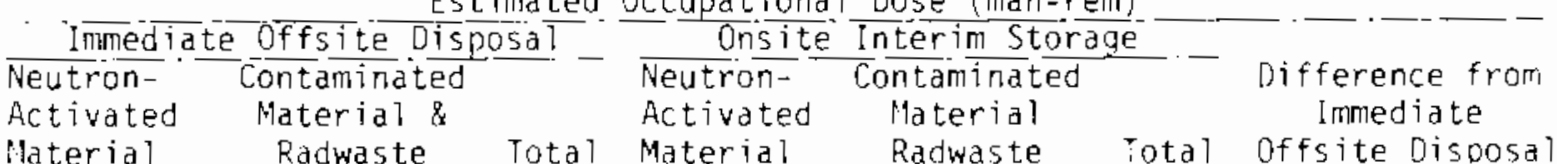

- Waste Disposal Task

Haterial Radwaste Deferred Decontamination After 30 Years

Onsite Transport

Placement in Interim Storage

Retrieval from Interim Storage

After 30 years

After 50 years

After 100 years

Offsite Transport

After 30 years

After 50 years

After 100 years

Placement in Offsite Disposal After 30 years

After 50 years

After 100 years

Total After 30 years

After 50 years

After 100 years

\begin{tabular}{|c|c|c|c|c|c|}
\hline-- & -- & 1.7 & 6.0 & 7.7 & 7.7 \\
\hline- & -- & 14.0 & 7.2 & 21.2 & 21.2 \\
\hline- & -. & & & & \\
\hline-- & -- & 0.5 & 0.3 & 0.8 & 0.8 \\
\hline-- & -- & 0.06 & 0.09 & 0.15 & 0.15 \\
\hline+ & -- & 0.008 & 0.018 & 0.026 & 0.026 \\
\hline 60.4 & 77.7 & & & & \\
\hline - & -- & 15.3 & 1.8 & 17.1 & $(60.6)$ \\
\hline-- & -- & 2.7 & 1.5 & 4.2 & $(73.5)$ \\
\hline-- & -- & 2.7 & 1.0 & 3.7 & $(74.0)$ \\
\hline 7.2 & 21.2 & & & & \\
\hline-- & - & 0.5 & 0.3 & 0.8 & $(20.4)$ \\
\hline$\cdots$ & $\cdots$ & 0.06 & 0.09 & 0.15 & $(21.1)$ \\
\hline-- & -- & 0.08 & 0.018 & 0.026 & $(21.2)$ \\
\hline & & & & & (51.3) \\
\hline & & & & & $(65.6)$ \\
\hline & & & & & $(66.3)$ \\
\hline
\end{tabular}


TABLE 9.1-5. (Contd)

\begin{tabular}{|c|c|c|c|c|c|c|c|}
\hline \multirow[t]{2}{*}{ Waste Disposal Task } & $\begin{array}{l}\text { Inimedia } \\
\text { Neutron- } \\
\text { Activated } \\
\text { Material }\end{array}$ & $\begin{array}{c}\text { Offsite Dis } \\
\text { Contaminated } \\
\text { Material \& } \\
\text { Radwaste }\end{array}$ & $\begin{array}{l}\text { imated } \\
\text { osa? }\end{array}$ & $\begin{array}{l}\text { Occupationa } \\
\frac{\text { Onsite }}{\text { Neutron- }} \\
\text { Activated } \\
\text { Material }\end{array}$ & $\begin{array}{l}\text { Dose (man-re } \\
\text { Interim Stora } \\
\text { Contaminated } \\
\text { Material \& } \\
\text { Radwaste }\end{array}$ & \multirow[t]{2}{*}{ Tota] } & $\begin{array}{c}\text { Difference from } \\
\text { Immediate } \\
\text { Offsite Disposal }\end{array}$ \\
\hline & & red Decontan & ination & After 50 & ars & & \\
\hline Onsite Transport & -- & -- & -- & 1.4 & 0.2 & 1.6 & 1.6 \\
\hline Placement in Interim Storage & -- & -- & -- & 1.6 & 0.8 & 2.9 & 2.4 \\
\hline Retrieval from Interim Storage & -- & -- & -- & & & & \\
\hline After 30 years & -- & -- & -- & 0.06 & 0.3 & 0.36 & 0.36 \\
\hline After 50 years & - & - & $\cdots$ & 0.02 & 0.05 & 0.07 & 0.07 \\
\hline After 100 years & -- & -- & -- & 0.008 & 0.01 & 0.018 & 0.018 \\
\hline offsite Transport & 14.4 & 1.8 & 16.2 & & & & \\
\hline After 30 years & -- & -- & -- & 2.7 & 1.5 & 4.2 & $(12.0)$ \\
\hline After 50 years & -- & -- & -- & 2.7 & 1.2 & 3.9 & $(12.3$ \\
\hline After 100 years & -- & - & -- & 2.7 & 0.9 & 3.6 & $(12.6)$ \\
\hline Placement in Offsite Disposal & 1.6 & 0.8 & 2.4 & & & & \\
\hline After 30 years & -- & -- & -- & 0.06 & 0.3 & 0.36 & $(2.0)$ \\
\hline After 50 years & -- & -- & - & 0.02 & 0.05 & 0.07 & $(2.3)$ \\
\hline After 100 years & -- & $-\cdots$ & $\cdots$ & 0.008 & 0.07 & 0.018 & $(2.4)$ \\
\hline Total After 30 years & & & & & & & $(9.6)$ \\
\hline After 50 years & & & & & & & $(10.5)$ \\
\hline After 100 years & & & & & & & $(11.0)$ \\
\hline
\end{tabular}


TABLE 9.1-5: (Contd)

Estimated Occupational Dose (man-rem)

\begin{tabular}{|c|c|c|c|c|c|c|c|}
\hline \multirow{4}{*}{ _. Waste Disposal Task } & \\
\hline & \multicolumn{7}{|c|}{ Onsite Interim stora } \\
\hline & $\begin{array}{l}\text { Neutron- } \\
\text { Activated } \\
\text { Material }\end{array}$ & $\begin{array}{l}\text { Contaminated } \\
\text { Material \& } \\
\text { Radwaste }\end{array}$ & & $\begin{array}{l}\text { Neutron- } \\
\text { Activated } \\
\text { Material }\end{array}$ & $\begin{array}{c}\text { Contaminated } \\
\text { Material \& } \\
\text { Radwaste }\end{array}$ & \multirow{2}{*}{ Total } & \multirow{2}{*}{$\begin{array}{l}\text { Difference from } \\
\text { Immediate } \\
\text { Offsite Disposal }\end{array}$} \\
\hline & \multicolumn{3}{|c|}{ Material $\frac{\text { Radwaste }}{\text { Deferred Decontamination }}$} & After 700 & Years & & \\
\hline Onsite Transport & -- & -- & -- & 0.2 & 0.1 & 0.3 & 0.3 \\
\hline Placement in Interim Storage & -- & -- & - & 0.02 & 0.05 & 0.07 & 0.07 \\
\hline Retrieval from Interim Storage & - & -- & -- & & & & \\
\hline After 30 years & -- & - & -- & 0.008 & 0.018 & 0.026 & 0.026 \\
\hline After 50 years & $\ldots$ & -- & -- & 0.008 & 0.010 & 0.018 & 0.018 \\
\hline After 100 years & - & - & -- & 0.007 & 0.002 & 0.009 & 0.009 \\
\hline Offsite Transport & 2.3 & 1.5 & 3.8 & & & & \\
\hline After 30 years & -- & - & -- & 2.3 & 1.0 & 3.3 & $(0.5)$ \\
\hline After 50 years & -- & - & -. & 2.3 & 0.9 & 3.2 & $(0.6)$ \\
\hline After 100 years & -- & -- & -- & 2.3 & 0.8 & 3.1 & $(0.7)$ \\
\hline Placement in Offsite Disposal & 0.02 & 0.05 & 0.07 & & & & \\
\hline After 30 years & - & -- & - & 0.008 & 0.018 & 0.026 & $(0.04)$ \\
\hline After 50 years & -- & -- & -- & 0.008 & 0.010 & 0.018 & $(0.05)$ \\
\hline After 100 years & -- & -- & -- & 0.007 & 0.002 & 0.009 & $(0.06)$ \\
\hline Total After 30 years & & & & & & & $(0.14)$ \\
\hline After 50 years & & & & & & & $(0.26)$ \\
\hline After 100 years & & & & & & & $(0.38)$ \\
\hline
\end{tabular}

(a) () indicates a reduction of the dose compared with immediate offsite disposal. 
TABLE 9.1-6. Summary of 0ccupational Doses from Disposal of Nuclear Waste from SAFSTOR of the Reference PWR

Deferred Decontamination After (years)

30

50

100

Dose Differences from Immediate offsite Disposal (man-rem) (a)

30 years Interim Storage Period 100 years

$(74.0)^{(b)}$

(5.5)

$(5.9)$
(77.4)

(a) Inciudes sum of occupational doses from preparations for safe storage and deferred decontamination.

(b) ( ) indicates a reduction of the occupational radiation dose compared with immediate offsite disposal.

TABLE 9.1-7. Summary of 0ccupationa] Doses from Disposal of Nuclear Waste from SAFSTOR of the Reference BWR

Deferred Decontamination After (years)

30
50
100

50

100 $\frac{\text { Dose Differences from Immediate Offsite Disposal }}{30 \text { years }} \frac{\text { (man-rem) }}{100 \text { years }}$ Interim Storage Interim Storage Interim Storage

$(68.0)^{(b)}$

(a) Includes sum of occupational doses from preparations for safe storage and deferred decontamination.

(b) ( ) indicates a reduction of the occupational radiation dose compared with immediate offsite disposal.

in Table 9.1-11 for immediate offsite disposal and for disposal after 30, 50, or 100 years of onsite interim storage. The table shows that the public radiation dose is reduced by onsite interim storage of the nuclear waste before sending it to an offsite disposal facility.

\subsubsection{Onsite Nuclear Waste Disposal}

Onsite disposal of nuclear waste differs from offsite disposal in the shorter transport distance from the reactor site to the waste disposal facitity. The occupational radiation dose for placement of the waste in the nuclear waste disposal facility is assumed to be the same for onsite disposal as it is for 
TABLE 9.1-8. Estimated Radiation Doses to the Public from Transportation of the Nuclear Waste from Decomissioning a Reactor by SAFSTOR

\begin{tabular}{|c|c|c|c|}
\hline \multirow[b]{2}{*}{$\begin{array}{l}\text { Reactor/Storage } \\
\text { Type / Period }(y r)\end{array}$} & \multicolumn{3}{|c|}{ Public Radiation Dose (man-rem) ${ }^{(a)}$} \\
\hline & $\begin{array}{l}\text { Immediate offsite } \\
\text { Disposal }\end{array}$ & $\begin{array}{l}\text { Onsite Interim } \\
\text { Storage }\end{array}$ & Difference \\
\hline $\mathrm{PWR} / 0$ & 19.7 & -- & \\
\hline $\mathrm{PWR} / 30$ & -- & 2.2 & $(17.5)^{(b)}$ \\
\hline $\mathrm{PWR} / 50$ & -- & 1.8 & (17.9) \\
\hline $\mathrm{PWR} / 100$ & - & 1.8 & $(17.9)$ \\
\hline $\mathrm{BWR} / 0$ & 20.8 & -- & \\
\hline $\mathrm{BWR} / 30$ & - & 4.1 & $(16.7)$ \\
\hline$B W R / 50$ & $\cdots$ & 1.2 & $(19.6)$ \\
\hline \multirow[t]{2}{*}{$B W R / 100$} & -- & 1.0 & $(19.8)$ \\
\hline & \multicolumn{3}{|c|}{ Deferred Decontamination After 50 Years } \\
\hline $\mathrm{PWR} / 0$ & 3.9 & -- & \\
\hline $\mathrm{PWR} / 30$ & -- & 2.1 & $(1.8)$ \\
\hline $\mathrm{PWR} / 50$ & -- & 1.8 & $(2.1)$ \\
\hline PWR/ 100 & - & 1.8 & $(2.1)$ \\
\hline $\mathrm{BWR} / 0$ & 8.1 & - & \\
\hline$B W R / 30$ & -- & 1.5 & $(6.6)$ \\
\hline$B W R / 50$ & -- & 1.1 & $(7.0)$ \\
\hline \multirow[t]{2}{*}{$B W R / 100$} & -- & 1.0 & $(7.1)$ \\
\hline & \multicolumn{3}{|c|}{ Deferred Decontamination After 100 Years } \\
\hline $\mathrm{PWR} / 0$ & 3.8 & - & \\
\hline $\mathrm{PWR} / 30$ & - & 2.1 & $(1.7)$ \\
\hline $\mathrm{PH} / \mathrm{R} / 50$ & -- & 1.8 & $(2.0)$ \\
\hline PWR/ 100 & -- & 1.8 & $(2.0)$ \\
\hline $\mathrm{BWR} / 0$ & 5.6 & -- & \\
\hline$B W R / 30$ & -- & 1.3 & $(4.3)$ \\
\hline$B W R / 50$ & -- & 1.0 & $(4.6)$ \\
\hline $\mathrm{BWR} / 100$ & - & 0.7 & $(4.9)$ \\
\hline
\end{tabular}

(a) Includes the dose from preparations for safe storage and from deferred decontamination.

(b) ( ) indicates reduction of the dose. 
TABLE 9.1-9. Estimated Occupational Doses from Disposal of the Nuclear Waste from ENTOMB of the Reference PWR

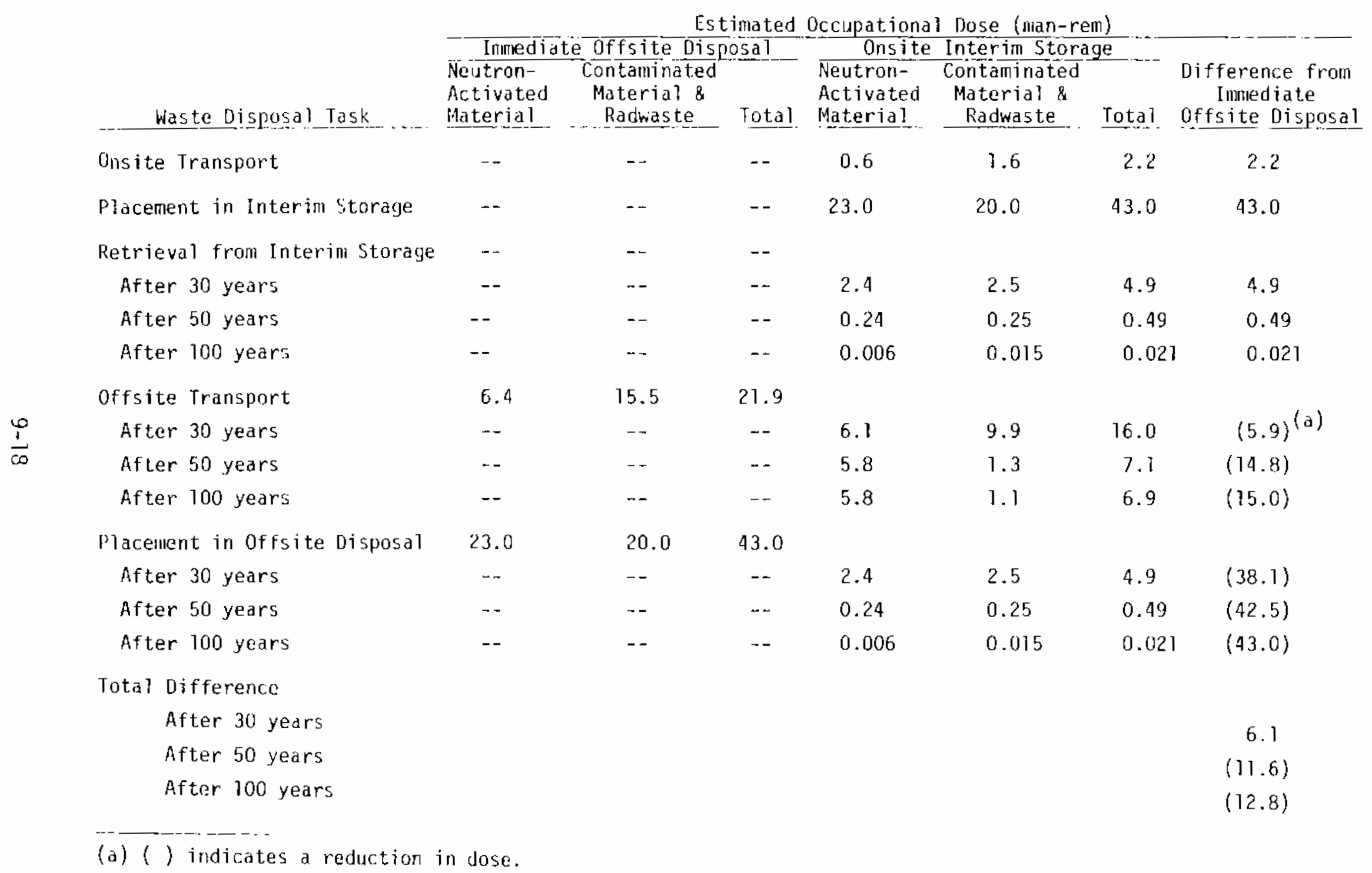


TABLE 9.1-10. Estimated Occupational Doses from Disposal of the Nuclear Waste from ENTOMB of the Reference BWR

Estimated Occupational Dose (man-rem)

\begin{tabular}{|c|c|c|c|c|c|c|}
\hline$d i a$ & $0 t$ & & Onsite & fin $3 t$ & & \\
\hline $\begin{array}{l}\text { utron- } \\
\text { tivated } \\
\text { terial }\end{array}$ & $\begin{array}{l}\text { Contaminated } \\
\text { Material \& } \\
\text { Radwaste }\end{array}$ & Tot & $\begin{array}{l}\text { Neutron- } \\
\text { Activated } \\
\text { Material }\end{array}$ & $\begin{array}{l}\text { Contaminated } \\
\text { Material \& } \\
\text { Radwaste }\end{array}$ & al & $\begin{array}{c}\text { Difference from } \\
\text { Immediate } \\
\text { Offsite Disposal }\end{array}$ \\
\hline
\end{tabular}

Onsite Transport

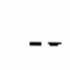

$--$

$--$

1.4

3.2

4.6

3.6

Placement in Interin Storage

$--$

$--115.0$

20.0

135.0

135.0

Retrieval from Interim Storage After 30 years

After 50 years

After 100 years

$$
-
$$$$
-
$$

Offsite Transport

After 30 years

After 50 years

After 100 years

$\begin{array}{ll}-- & 11.5 \\ - & 1.1 \\ - & 0.014\end{array}$

4.2

15.7

15.7

$--$

$-$

-

0.014

0.4

1.5

1.5

14.2

32.5

46.7

-- --

$--$

14.2

0.03

0.04

0.04

Placement in Offsite Disposal

$-$

$-$

- 12.7

30.8

45.0

$(1.7)^{(a)}$

$--$

--

12.7

1.5

14.2

$--$

1.1

13.8

After 30 years

After 50 years

After 100 years

\section{-.}

$--$

$--$

$$
20.0
$$

135.0

--

-.

\begin{abstract}
11.5
\end{abstract}
- 1.1

4.2

15.7

1.5

$-\infty \quad 0.014$

0.4

0.04

(179.3)

(133.5)

(135.0)

Total Difference

After 30 years

After 50 years

After 100 years

(a) () indicates a reduction in dose. 
TABLE 9.1-11. Estimated Radiation Doses to the Public from Transportation of the Nuclear Waste from Decomissioning a Reactor by ENTOMB

\begin{tabular}{|c|c|c|c|}
\hline $\begin{array}{l}\text { Reactor/Storage } \\
\text { Type / Period (yr) }\end{array}$ & $\begin{array}{l}\text { Public Radi } \\
\text { Immediate Offsite } \\
\text { Disposal }\end{array}$ & $\begin{array}{l}\text { ation Dose (man- } \\
\text { Onsite Interim } \\
\text { Storage }\end{array}$ & Dem) \\
\hline $\mathrm{PWR} / 0$ & 4.5 & - & \\
\hline $\mathrm{PWR} / 30$ & - & 3.3 & $(1.2)^{(a)}$ \\
\hline $\mathrm{PWR} / 50$ & -- & 1.5 & $(3.0)$ \\
\hline $\mathrm{PWR} / 100$ & - & 1.4 & $(3.1)$ \\
\hline$B W R / 0$ & 9.6 & - & \\
\hline $\mathrm{BWR} / 30$ & -- & 9.2 & $(0.4)$ \\
\hline $\mathrm{BWR} / 50$ & -- & 2.9 & $(6.7)$ \\
\hline$B W R / T D O$ & - & 2.8 & $(6.8)$ \\
\hline
\end{tabular}

(a) ( ) indicates a reduction of the dose.

offsite disposal. Differences in the occupational radiation doses for onsite and offsite disposal are due to the shorter transport distance for onsite disposal. There will be no exposure of the public to radiation during transportation of the nuclear waste to the onsite disposal facility, since movernent will be over private roads in a privately controlled area.

The estimated radiation doses to transportation workers are given in Tabie 9.1-12 for both offsite and onsite disposal of the nuclear waste from decommissioning the reference PWR and BWR. In ail cases, the radiation dose for onsite disposal of the waste is less than $10 \%$ of the dose for offsite disposal.

\subsection{SITE DEDICATION}

Dedication of a site to nuclear power generation results in replacement reactors being constructed on a schedule to achieve startup of a new reactor as an old reactor is shut down. At such dedicated sites, either relatively long 
TABLE 9.1-12. Estimated Transportation Doses from Disposal of Nuclear Decommissioning Waste

\begin{tabular}{|c|c|c|c|c|c|}
\hline \multirow{3}{*}{$\begin{array}{c}\text { Decommissioning/Reactor } \\
\text { Alternative / Type }\end{array}$} & \multicolumn{2}{|c|}{ Number of Shipments } & \multicolumn{3}{|c|}{ Transportation Dose (man-rem) } \\
\hline & offsite & Onsite & Offsite & Onsite & \\
\hline & Disposal & Disposal & Disposal & Disposal & Difference \\
\hline DECON/PWR & 1363 & 1326 & 99.5 & 9.7 & $(89.8)^{(a)}$ \\
\hline DECON/BWR & 1495 & 1168 & 109.1 & 8.5 & $(100.6)$ \\
\hline \multicolumn{6}{|l|}{ SAFSTOR/PWR } \\
\hline 30 years Safe Stge. & 1363 & 1288 & 99.5 & 9.4 & $(90.1)$ \\
\hline 50 years Safe Stge. & 330 & 207 & 24.1 & 1.5 & $(22.6)$ \\
\hline 100 years Safe Stge. & 324 & 204 & 23.7 & 1.5 & $(22.2)$ \\
\hline \multicolumn{6}{|l|}{ SAFSTOR/BWR } \\
\hline 30 years Safe Stge. & 1495 & 1148 & 109.7 & 8.4 & $(100.7)$ \\
\hline 50 years Safe Stge. & 560 & 326 & 40.9 & 2.4 & $(38.5)$ \\
\hline 100 years Safe Stge. & 555 & 157 & 40.5 & 1.1 & $(39.4)$ \\
\hline ENTOMB/PWR & 343 & 301 & 25.0 & 2.2 & $(22.8)$ \\
\hline ENTOMB/BWR & 985 & 639 & 71.9 & 4.7 & $(67.2)$ \\
\hline
\end{tabular}

(a) ( ) indicates a reduction of the dose.

periods of construction activity will occur periodically or there will be continuous construction activity at the site if the startup of the reactors is spaced to occur over a 30-year period.

It is expected that the efficiency of decommissioning the reactors at a multiple-reactor station will improve after the first reactor is decommissioned due to the learning process. In Subsection 8.2 of Section 8 , the impact of site dedication on the efficiency of decommissioning reactors of the same type is estimated. Since the improved efficiency of the decommissioning operations is attributed to shortening the schedule, the cost reduction factors given in Table 8.2-1 should also apply to occupational radiation dose reduction.

In this subsection, the dose reductions exprected are developed when four reactors of one type and five reactors of one type are decomisissioned at a dedicated site. 


\subsubsection{Impact on Radiation Doses from DECON}

The impact of site dedication on the occupational radiation doses from decomissioning the reference reactors by DECON is given in Table 9.2-1 for the PWR and in Table 9.2-2 for the BWR.

TABLE 9.2-1. Impact of Site Dedication on Estimated Occupational Radiation Doses from DECON of a PWR

\begin{tabular}{|c|c|c|c|c|c|}
\hline Builing & $\begin{array}{l}\text { Average Oco } \\
\text { Single- } \\
\text { Reactor } \\
\text { Station(a) }\end{array}$ & $\begin{array}{c}\text { upational D } \\
4 \text { Reaccors } \\
\text { of One } \\
\text { Type (5) }\end{array}$ & $\begin{array}{l}\text { se (man-rem) } \\
\text { Reactors } \\
\text { of One } \\
\text { Type }(5) \\
\end{array}$ & $\begin{array}{c}\text { Dose Reductio } \\
4 \text { Reactors } \\
\text { of One } \\
\text { Type } \\
\end{array}$ & $\begin{array}{l}\text { on (man-rem) } \\
5 \text { Reactors } \\
\text { of One } \\
\text { Type } \\
\end{array}$ \\
\hline Reactor Building & 490 & 461 & 456 & 29 & 34 \\
\hline Auxiliary Building & 227 & 213 & 211 & 74 & 16 \\
\hline Fuel Building & 134 & 126 & 125 & 8 & 9 \\
\hline Ancillaries & 233 & 219 & 217 & 14 & 16 \\
\hline Totals & 1084 & 1019 & 1009 & 65 & 75 \\
\hline
\end{tabular}

(a) From Table 11.3-T of Reference 1.

(b) Dose reduction factors - 0.94 for 4 reactors of one type and 0.93 for 5 reactors of one type.

TABLE 9.2-2. Impact of Site Dedication on Estimated 0ccupational Radiation Doses from DECON of a BWR

\begin{tabular}{|c|c|c|c|c|c|}
\hline Building & $\begin{array}{l}\text { Average 0co } \\
\text { Single- } \\
\text { Reactor } \\
\text { Station(a) }\end{array}$ & $\begin{array}{l}\text { upational Do } \\
4 \text { Reactors } \\
\text { of Ope } \\
\text { Type(b) } \\
\end{array}$ & $\begin{array}{c}\text { se } \\
5 \text { (man-rem) } \\
\text { Reactors } \\
\text { of One } \\
\text { Type (b) }\end{array}$ & $\begin{array}{l}\text { Dose Reducti } \\
4 \text { Reactors } \\
\text { of One } \\
\text { Type } \\
\end{array}$ & $\begin{array}{l}\text { (man-rem) } \\
5 \text { Reactors } \\
\text { of One } \\
\text { Type } \\
\end{array}$ \\
\hline Reactor Building & 891 & 838 & 829 & 53 & 62 \\
\hline $\begin{array}{l}\text { Turbine Generator } \\
\text { Building }\end{array}$ & 193 & 181 & 179 & 12 & 14 \\
\hline $\begin{array}{l}\text { Radwaste \& Control } \\
\text { Building }\end{array}$ & 530 & 498 & 493 & 32 & 37 \\
\hline Ancillaries & 231 & 217 & 215 & 14 & 16 \\
\hline Totals & 1845 & 1734 & 1716 & 111 & 129 \\
\hline
\end{tabular}

(a) From Table 11.2-1 of Reference 3 .

(b) Dose reduction factors - 0.94 for 4 reactors of one type and 0.93 for 5 reactors of one type. 
0ccupational dose reductions of $6 \%$ are estimated when four reactors of one type are decommissioned and of $7 \%$ when five reactors of one type are decommissioned.

\subsubsection{Impact on Radiation Doses from SAFSTOR}

The impact of site dedication on the occupational radiation doses from the preparations for safe storage is presented in Table 9.2-3 for the reference PlIR and in Table 9.2-4 for the reference BWR.

Impacts on the occupational doses from deferred decontamination of the reference reactors are given in Table 9.2-5 for the PIN and in Table 9.2-6 for the BWR.

Estimated reductions of the occupational dose attributable to the effificiencies that can be achieved by decommissioning several reactors of one type by SAFSTOR at a multiple-reactor station are given for both reference reactors in Table 9.2-7.

\subsubsection{Impact on Radiation Doses from ENTOMB}

The impacts of site dedication on the occupational radiation dose from decommissioning the reference reactors by ENTOMB are presented in Table 9.2-8 for the reference PWR and in Table 9.2-9 for the reference BWR.

TABLE 9.2-3. Impact of Site Dedication on Estimated 0ccupational Radiation Doses from Preparations for Safe Storage of a PWR

\begin{tabular}{|c|c|c|c|c|c|}
\hline Building & $\begin{array}{l}\text { Average Occ } \\
\text { Single- } \\
\text { Reactor } \\
\text { Station(a) }\end{array}$ & $\begin{array}{l}\text { pational Do } \\
4 \text { Reactors } \\
\text { of One } \\
\text { Type }(b) \\
\end{array}$ & $\begin{array}{l}5 \text { Reactors } \\
\text { of One } \\
\text { Type (b) }\end{array}$ & $\begin{array}{c}\text { Dose Reducti } \\
4 \text { Reactors } \\
\text { of one } \\
\text { Type }\end{array}$ & $\begin{array}{l}\text { on (man-rem) } \\
5 \text { Reactors } \\
\text { of One } \\
\text { Type }\end{array}$ \\
\hline Reactor Bujlding & 58 & 55 & 54 & 3 & 4 \\
\hline Auxitiary Building & 30 & 28 & 28 & 2 & 2 \\
\hline Fuel Building & 15 & 14 & 14 & 1 & 1 \\
\hline Ancillaries & 176 & 165 & 164 & 11 & 12 \\
\hline Totals & 279 & 262 & 260 & 17 & 19 \\
\hline
\end{tabular}

(a) From Table 11.3-2 of Reference 1.

(b) Dose reduction factors - 0.94 for 4 reactors of one type and 0.93 for 5 reactors of one type. 
TABLE 9.2-4. Impact of Site Dedication on Estimated 0ccupational Radiation Doses from Preparations for Safe Storage of a BiNR

\begin{tabular}{|c|c|c|c|c|c|}
\hline Building & $\begin{array}{l}\text { Average Oc } \\
\text { Single- } \\
\text { Reactor } \\
\text { Station (a) }\end{array}$ & $\begin{array}{l}\text { pationa } 1 \\
4 \text { Reactors } \\
\text { of One } \\
\text { Type (b) }\end{array}$ & $\begin{array}{l}\text { se } \frac{\text { (man-rem) }}{5} \text { Reactors } \\
\text { of One } \\
\text { Type (b) } \\
\end{array}$ & $\begin{array}{c}\text { Dose Reduct } \\
4 \text { Reactors } \\
\text { of One } \\
\text { Type }\end{array}$ & $\begin{array}{l}\text { (man-rem) } \\
5 \text { Reactors } \\
\text { of One } \\
\text { Type }\end{array}$ \\
\hline Reactor Building & 155 & 146 & 144 & 9 & 11 \\
\hline $\begin{array}{l}\text { Turbine Generator } \\
\text { Building }\end{array}$ & 18 & 17 & 17 & 1 & 1 \\
\hline $\begin{array}{l}\text { Radwaste \& Control } \\
\text { Building }\end{array}$ & 99 & 93 & 92 & 6 & 7 \\
\hline Ancillaries & 103 & 97 & 96 & 6 & 7 \\
\hline Totals & 375 & 353 & 349 & 22 & 26 \\
\hline
\end{tabular}

(a) From Table 11.2-3 of Reference 3.

(b) Dose reduction factors - 0.94 for 4 reactors of one type and 0.93 for 5 reactors of one type.

TABLE 9.2-5. Impact of Site Dedication on Estimated Occupational Radiation Doses from Deferred Decontamination of a PWR

\begin{tabular}{|c|c|c|c|c|c|}
\hline $\begin{array}{c}\text { Years After } \\
\text { Reactor } \\
\text { Shutdown }\end{array}$ & $\begin{array}{l}\text { Average 0co } \\
\text { Single- } \\
\text { Reactor } \\
\text { Station(a) }\end{array}$ & $\begin{array}{l}\text { Apational D } \\
4 \text { Reactors } \\
\text { of One } \\
\text { Type (b) }\end{array}$ & $\begin{array}{l}\text { e (man-rem) } \\
5 \text { Reactors } \\
\text { of One } \\
\text { Type }(\mathrm{b}) \\
\end{array}$ & $\begin{array}{l}\text { Dose Reducti } \\
4 \text { Reactors } \\
\text { of One } \\
\text { Type } \\
\end{array}$ & $\begin{array}{c}n \text { (man-rem) } \\
5 \text { Reactors } \\
\text { of One } \\
\text { Type }\end{array}$ \\
\hline 30 & 24 & 23 & 22 & 1 & 2 \\
\hline 50 & 2 & 2 & 2 & 0 & 0 \\
\hline 100 & 1 & 1 & 1 & 0 & 0 \\
\hline
\end{tabular}

(a) From Table H.6-l of Reference 1

(b) Dose reduction factors - 0.94 for 4 reactors of one type and 0.93 for 5 reactors of one type. 
TABLE 9.2-6. Impact of Site Dedication on Estimated Occupational Radiation Doses from Deferred Decontamination of a BWR

\begin{tabular}{|c|c|c|c|c|c|}
\hline & \multicolumn{3}{|c|}{ Average 0ccupationa1 Dose (man-rem) } & \multicolumn{2}{|c|}{ Dose Reduction (man-rem) } \\
\hline $\begin{array}{l}\text { Years After } \\
\text { Reactor } \\
\text { Shutdown }\end{array}$ & $\begin{array}{l}\text { Single- } \\
\text { Reactor } \\
\text { Station(a) }\end{array}$ & $\begin{array}{l}4 \text { Reactors } \\
\text { of One } \\
\text { Type(b) }\end{array}$ & $\begin{array}{l}5 \text { Reactors } \\
\text { of One } \\
\text { Type }(b)\end{array}$ & $\begin{array}{l}4 \text { Reactors } \\
\text { of One } \\
\text { Type }\end{array}$ & $\begin{array}{l}5 \text { Reactors } \\
\text { of One } \\
\text { Type }\end{array}$ \\
\hline 30 & 36 & 34 & 33 & 2 & 3 \\
\hline 50 & 3 & 3 & 3 & 0 & 0 \\
\hline 100 & $<1$ & $<1$ & $<1$ & 0 & 0 \\
\hline
\end{tabular}

(a) From Table 11.2-6 of Reference 3 .

(b) Dose reduction factors - 0.94 for 4 reactors of one type and 0.93 for 5 reactors of one type.

TABLE 9.2-7. Estimated Dose Reductions from Decommissioning Severa? Reactors of One Type by SAFSTOR

\begin{tabular}{|c|c|c|c|c|}
\hline \multirow{4}{*}{$\begin{array}{c}\text { Years of } \\
\text { Safe Storage }\end{array}$} & \multicolumn{4}{|c|}{ Dose Reduction (man-rem) (a) } \\
\hline & \multicolumn{2}{|c|}{ PWR } & \multicolumn{2}{|c|}{ BW'R } \\
\hline & 4 Reactors & 5 Reactors & 4 Reactors & 5 Reactors \\
\hline & of One Type & of One Type & of One Type & of One Type \\
\hline 30 & 18 & 21 & 24 & 29 \\
\hline 50 & 17 & 19 & 22 & 26 \\
\hline 100 & 17 & 19 & 22 & 26 \\
\hline
\end{tabular}

(a) Includes the dose reductions from preparations for safe storage and from deferred decontamination. 
TABLE 9.2-8. Impact of Site Dedication on Estimated 0ccupational Radiation Doses from ENTOMB of a PWR

\begin{tabular}{|c|c|c|c|c|}
\hline $\begin{array}{l}\text { Average aco } \\
\text { Single- } \\
\text { Reactor } \\
\text { Station(a) }\end{array}$ & $\begin{array}{l}4 \text { Retional } \\
\text { ốane } \\
\text { Type(b) } \\
\end{array}$ & $\begin{array}{l}\frac{\text { se (man-rem) }}{5} \text { Reactors } \\
\text { of One } \\
\text { Type(b) }\end{array}$ & $\begin{array}{c}\text { Dose Reduct } \\
4 \text { Reactors } \\
\text { of One } \\
\text { Type }\end{array}$ & $\begin{array}{l}\text { on (man-rem) } \\
5 \text { Reactors } \\
\text { of One } \\
\text { Type. }\end{array}$ \\
\hline 130 & 122 & 127 & 8 & 9 \\
\hline 292 & 274 & 272 & 18 & 20 \\
\hline 147 & 138 & 137 & 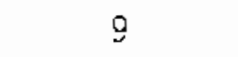 & 10 \\
\hline 378 & 355 & 352 & 23 & 26 \\
\hline 947 & 889 & 882 & 58 & 65 \\
\hline
\end{tabular}

(a) From Table 4.6-1 of Reference 2.

(b) Dose reduction factors -0.94 for 4 reactors of one type and 0.93 for 5 reactors of one type.

TABLE 9.2-9. Impact of Site Dedication on Estmated 0ccupational Radiation Doses from ENTOMB of a BWR

\begin{tabular}{|c|c|c|c|c|c|}
\hline Building & $\begin{array}{l}\text { Average Oc } \\
\text { Singie- } \\
\text { Reactor } \\
\text { Station }\{\text { a }\end{array}$ & $\begin{array}{l}\text { Apational Do } \\
4 \text { Reactors } \\
\text { of One } \\
\text { Type (b) }\end{array}$ & $\begin{array}{l}\text { se (man-rem) } \\
5 \text { Reactors } \\
\text { of One } \\
\text { Type(b) }\end{array}$ & $\begin{array}{c}\text { Dose Reduct } \\
4 \text { Reactors } \\
\text { of One } \\
\text { Type }\end{array}$ & $\begin{array}{c}\text { on (man-rem) } \\
5 \text { Reactors } \\
\text { of One } \\
\text { Type }\end{array}$ \\
\hline Reactor Building & 738 & 694 & 686 & 44 & 52 \\
\hline $\begin{array}{l}\text { Turbine Generator } \\
\text { Building }\end{array}$ & 195 & 183 & 18] & 12 & 14 \\
\hline $\begin{array}{l}\text { Radiwaste \& Control } \\
\text { Building }\end{array}$ & 521 & 490 & 485 & 31 & 36 \\
\hline Ancillaries & 230 & 216 & 214 & 14 & 16 \\
\hline Totals & 1684 & 1583 & 1566 & 101 & 118 \\
\hline
\end{tabular}

(a) From Table 11.2-3 of Reference 3.

(b) Dose reduction factors -0.94 for 4 reactors of one type and 0.93 for 5 reactors of one type. 


\subsection{CENTRAL IZED SERVICES}

Centralized services that may be available at a multiple-reactor station are:

- health physics services

- security forces

- solid waste processing

- equipment decontamination services

- maintenance shops and services

- laundry services

- transportation services

- central stores.

Consideration of the impact of these centralized services on the radiation doses from decommissioning the reactors shows the impact to be minor. Only one of these services, solid waste processing, is found to reduce the radiation doses.

Incineration of combustible solid wastes reduces the volume of these wastes by at least a factor of 5 , resulting in less waste to be packaged for shipment and in fewer shipments to the waste disposal facility. Reduction of the volume of waste handled could lead to potential radiation dose reduction for:

- plant workers who prepare and package the waste for shipment

- transportation workers involved in the shipment of the waste

- members of the public along the waste transport route.

After incineration, the volume of combustible waste packaged and shipped offsite is reduced by a factor of 5 , thus reducing both the time for packaging and the associated radiation dose. However, the extra steps of transporting the compacted waste to the incinerator and processing it involves some additional radiation dose to the workers involved. In this study, it is assumed that the extra dose offsets the dose reduction from reduced packing time.

Elimination of some of the shipments of combustibie radioactive waste to the radioactive waste disposal facility results in lower radiation doses to the transportation workers and the public. In Reference 1, it is estimated that 
the radiation doses from transportation of waste to the offsite radioactive waste disposal facility are 0.073 man-rem per shipment for the transportation workers and 0.075 man-rem per shipment for the public. Table B.3-3 of Appendix $B$ shows that incineration of combustible wastes give radiation-dose reductions for the transport workers of 3.8 man-rem for DECON or ENTOMB of a PWR and 5.0 man-rem for DECON or ENTOMB of a BWR. For SAFSTOR with 30-year deferred decontamination, the radiation dose reductions for transport workers are 1.6 man-rem for a PWR and 2.5 man-rem for a BWR. This tabie also shows radiationdose reductions for the public of 0.8 man-rem for DECON or ENTOMB of a PWR and 1.0 man-rem for DECON or ENTOMB of a BWR.

Centraijized health physics services reduce the number of management (overhead) personnel per reactor compared to such services for a single-reactor station. About the same number of health physics technicians are required at a reactor as would be required at a singie-reactor station. The amount of radiation monitoring that must be performed is not reduced with a centralized health physics operation; therefore, the radiation exposure of the health physics personnel is not changed significantly.

The centralized security force at a multiple-reactor station also has a smaller number of management personnel per reactor than a reactor at a singlereactor station. However, about the same number of securjty patrolmen are required at each reactor. Security personnel receive only minimal exposure to radiation in the course of their work. Therefore, a centralized security force does not significantly impact the occupational radiation dose from decommissioning a reactor.

Although central decontamination services can result in cost savings as discussed in Subsection 8.3, the use of these services does not reduce the dose rates for the decommissioning tasks compared with the dose rates estimated for decommissioning a reactor at a single-reactor station. Therefore, central decontamination services do not have an impact on the occupational radiation doses from decommissioning a reactor. 
Centralized maintenance shops, laundry services, transportation services, and central stores have no impact on the radiation dose rates where the decommissioning work is performed; therefore, these services have no impact on the occupational radiation dose.

\subsection{TYPE OF REACTOR}

At multiple-reactor stations, the two types of light water reactors being constructed are PWRS and B.SRS. The estimated radiation doses for decomissioning both types are shown in Table 9.4-1 for DECON, SAFSTOR, and ENTOMB. Similar differences in radiation doses for the two types of LWRs are also experienced in decomissioning reactors at a multiple-reactor station. However, decommissioning doses for PliRs and BWRs are impacted to about the same extent at a multiple-reactor station as at a single-reactor station. Estimated impacts on the radiation doses from decommissioning both PWRs and BWRs are developed in Subsections $9.1,9.2$, and 9.3 .

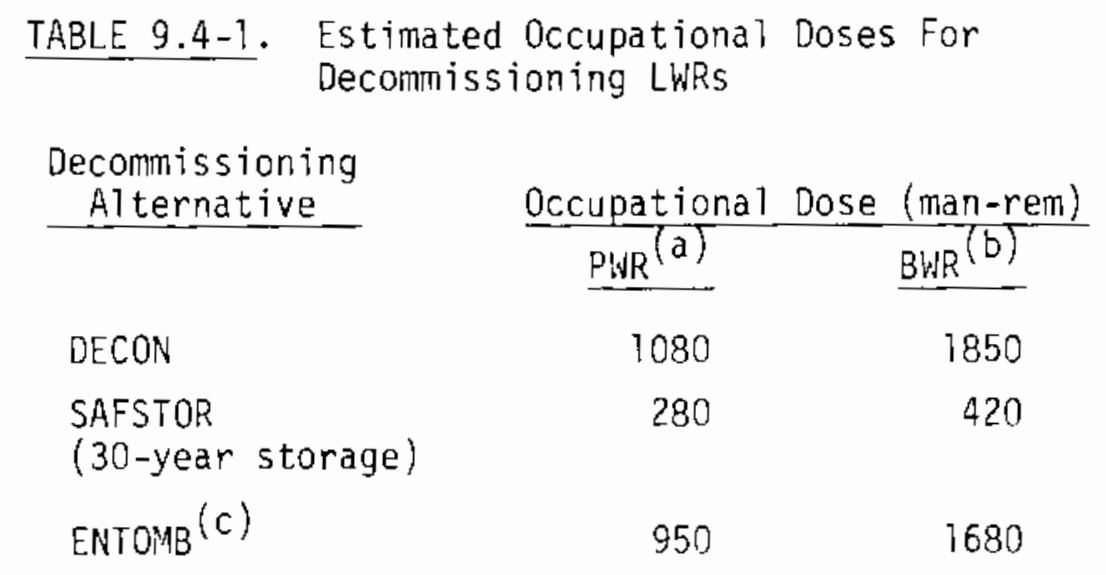

(a) From References 1 and 2 .

(b) From Reference 3 .

(c) For ENTOMB with reactor internals removed.

\subsection{NUMBER OF REACTORS AT STATION}

The number of reactors at the multiple-reactor station influences how the radioactive waste is disposed of, whether there is a continuing stable 
construction labor force, and whether or which centralized services are provided. With a small number of reactors at the station (say, a quad), it is not likely that radioactive waste could be disposed of onsite. It is improbable that centraized services would be provided; however, special decommissioning tools and equipment probably would be shared. Improvement and economies in planning the decommissioning of successive reactors would be realized for a few as well as many reactors at a multiple-reactor station. If only a few reactors are located at the station, the continuing stability of the labor force would not be assured. Therefore, there would not be a continuing availability of experienced decommissioning workers.

Detailed discussions of the multiple-reactor station scenarios in Section 10 illustrate the effect of the number of reactors at the station on the radiation doses from decomissioning a reactor. 


\section{REFERENCES}

1. R. I. Smith, G. J. Konzek, and W. E. Kennedy, Ur., Technology, Safety and Costs of Decommissioning a Reference Pressurized Water Reactor Power Station, NUREG/CR-0130, U.S. Nuclear Regulatory Commission Report by Pacific Northwest Laboratory, June 1978.

2. R. I. Smith and L. M. Polentz, Technology, Safety and Costs of Decommissioning a Reference Pressurized Water Reactor Power Station, NUREG/CR-0130 Addendum, U.S. Nuclear Regulatory Comimission Report by Pacific Northwest Laboratory, August 1979.

3. H. D. Oak, G. M. Holter, W. E. Kennedy, Jr., and G. J. Konzek, Technology, Safety and Costs of Decommissioning a Reference Boiling Water Reactor Power Station, NUREG/CR-0672, U.S. Nuclear ReguTatory Commission Report by Pacific Northwest Laboratory, June 1980. 



\subsection{MULTIPLE-REACTOR STATION DECOMMISSIONING SCENARIOS}

Five scenarios for multiple-reactor stations are investigated in this section to determine the impact of the variables discussed in Subsection 3.3 on decomissioning costs and safety. These variables, the number of reactors at the multiple-reactor station, the type of reactor, the nuciear waste disposa? option, the dedication of the site to nuclear power generation, and the provision of central services vary for the different scenarios. The three decommissioning alternatives, DECON, SAFSTOR, and ENTOMB, are studied for each scenario. The five scenarios described in Subsection 3.3 are shown in Figure 10.0-1.

The estimates of impacts on costs and radiation doses developed in Sections 8 and 9 are used to determine cost and radiation dose impacts for each of the scenarios.

\begin{tabular}{|c|c|c|c|c|c|c|c|c|c|c|c|c|}
\hline \multirow{3}{*}{$\begin{array}{l}\text { SCENARIO } \\
\text { NUMBER }\end{array}$} & \multirow{3}{*}{$\begin{array}{l}\text { NUMBER } \\
\text { OF } \\
\text { REACTORS }\end{array}$} & \multirow{2}{*}{\multicolumn{2}{|c|}{$\begin{array}{l}\text { TYPE OF } \\
\text { REACTOR }\end{array}$}} & \multicolumn{2}{|c|}{ RETIRED AFTER 40 YR } & \multirow{2}{*}{\multicolumn{2}{|c|}{$\begin{array}{l}\text { OLD REACTOR } \\
\text { REPLACF.D }\end{array}$}} & \multicolumn{3}{|c|}{ WASTE DISPOSAL } & \multirow{2}{*}{\multicolumn{2}{|c|}{$\begin{array}{l}\text { CENTRAL } \\
\text { FACILITIES }\end{array}$}} \\
\hline & & & & \multirow{2}{*}{$\begin{array}{l}\text { I REACTOR } \\
\text { EVERY } 2 \text { YR }\end{array}$} & \multirow{2}{*}{$\begin{array}{l}\text { I REACTOR } \\
\text { EVERY A YR }\end{array}$} & & & \multirow{2}{*}{$\begin{array}{l}\text { IMUEDIATE } \\
\text { OFFSITE }\end{array}$} & \multirow{2}{*}{$\begin{array}{l}\text { ONSITE } \\
\text { INTERIM } \\
\text { STORAGE }\end{array}$} & \multirow{2}{*}{$\begin{array}{l}\text { ONSITE } \\
\text { PERMANENT } \\
\text { DISPOSAL }\end{array}$} & & \\
\hline & & PWR & BWR & & & YES & NO & & & & YES & NO \\
\hline 1 & 4 & $x$ & & $x$ & & $x$ & & & $x$ & & & $x$ \\
\hline 2 & 4 & & $x$ & & $x$ & & $x$ & $x$ & & & & $x$ \\
\hline 3 & 10 & $x$ & $x$ & & $x$ & $x$ & & $x$ & & & & $x$ \\
\hline 4 & 10 & $x$ & $x$ & & $x$ & $x$ & & & $x$ & & $x$ & \\
\hline 5 & 10 & $x$ & $x$ & $x$ & & $x$ & & & & $x$ & $x$ & \\
\hline
\end{tabular}

FIGURE 10.0-1. Multiple-Reactor Station Scenarios

\subsection{SCENARIO NUMBER I}

In this scenario four PWRs are located at the multiple-reactor site. The reactors are started up at 2-year intervals; therefore, after 40 years of operation the reactors will be shut down and decommissioning started at 2-year intervals. At this station a new reactor is started up to take the place of each retired reactor. Nuclear waste from decommissioning the reactors is placed in 
onsite interim storage and at a later date removed to an offsite waste disposal faciitity. No central facilities are provided at this 4-reactor station. A 1ifetime schedule for this scenario is shown in Figure 6.2-1.

The cost of and radiation dose from decommissioning the reactors at this multiple-reactor station are impacted by the waste disposal option and by the experience gained in decomissioning several reactors of the same design. Onsite interim storage of the nuclear waste from decomtissioning one of the PWRs results in a lesser volume of nuclear waste that must eventually be sent to an offsite waste disposal facility. The length of the interim storage period determines the amount of radioactive decay that occurs before the waste is sent to offsite disposal and, thus, impacts the cost and radiation dose. The impacts of interim onsite waste storage on costs are developed in Subsection 8.1.2, and the impacts of the radiation dose are developed in Subsection 9.1.2. Cost and radiation dose impacts resulting from improvement in the efficiency of decommissioning with the successive decomissioning of four reactors of the same type are estimated in Subsections 8.2 and 9.2 , respectively.

Table 10.1-1 gives the estimated impacts on the cost of decommissioning one of four PWRs at a multiple-reactor station as compared to the cost of decommissioning a PWR at a single-reactor station. The net savings, as well as the estimated average decomissioning cost for the four PWRs, are given. Similarly, the estimated impacts on the occupational radiation doses are given in Table 10.1-2. These estimates of costs and radiation doses for the PWRs in the scenario are the averages for decomrnissioning four identical reactors.

Although the magnitudes of the decomissioning costs and occupational radiation doses are less, the relative standing of the costs and doses for the three decommissioning alternatives is not changed at the 4-reactor station compared to a single-reactor station. SAFSTOR results in the lowest occupational radiation dose but generally has a higher cost. ENTOMB, if the reactor can be released for unrestricted use after 100 years of surveillance, is estimated to have the lowest cost. DECON is estimated to have the highest radiation dose and an intermediate decommissioning cost. 


\section{TABLE 10.7-1. Multiple-Reactor Station Scenario T - Decommissioning Cost Impact (4 PWRs)}

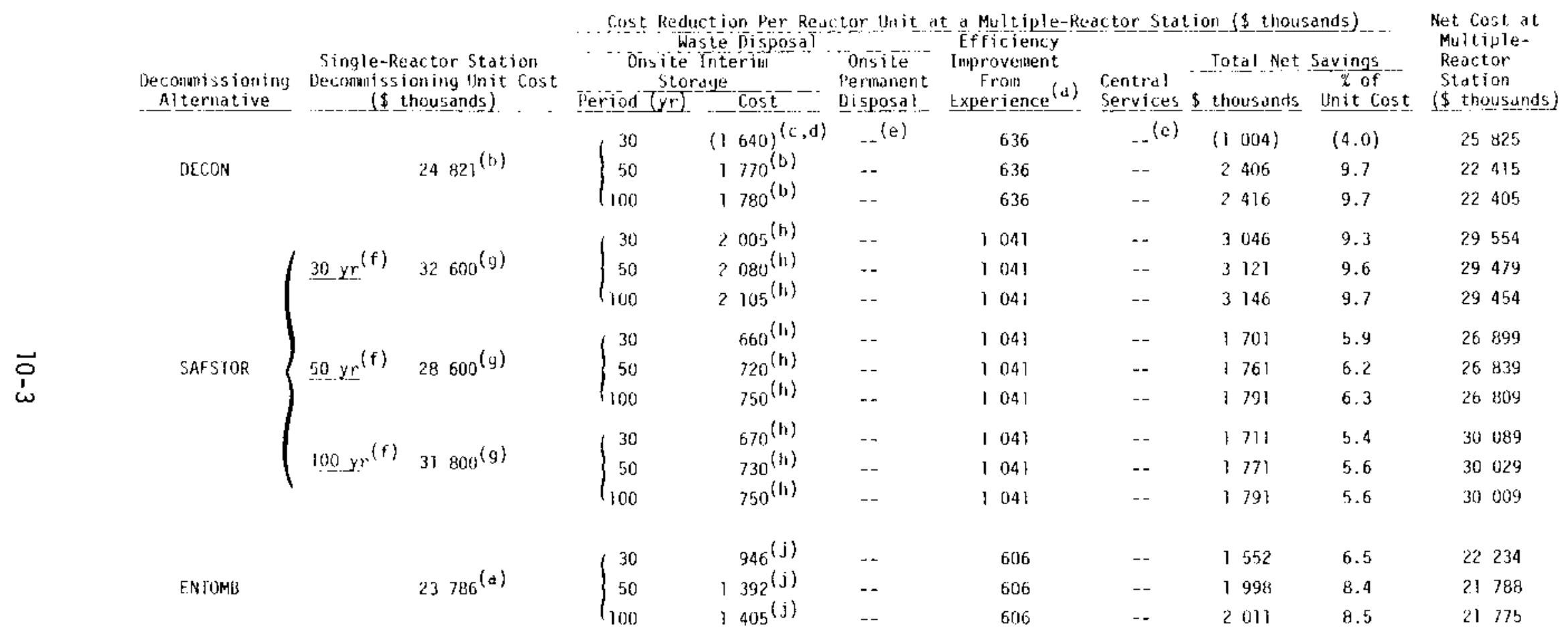

(o) Based on cost reduction factors in Table 8.2-1. 38\% saving of planning and preparation and $6 \%$ saving of decomiassioning operations costs.

(b) Fron able $4.5-1$, Reference 2 . ENTOMQ cost includes $\$ 4$ milition for loo years' surveillance.

(c) Froin loble $4.5-1$.

(d) () indicates a nejative nimber.

(e) Distes indicate not uset or not available.

(f) Sife storage perion for the reactor.

(a) Based on lable ti.b-4, Reference 1. with costs for spent fucl shipment and denolition services deleted.

(.j) Irom Table $8.1-9$ 

TABLE 10.1-2. Multiple-Reactor Station Scenario 1 - Impact on Occupational Radiation Dose from

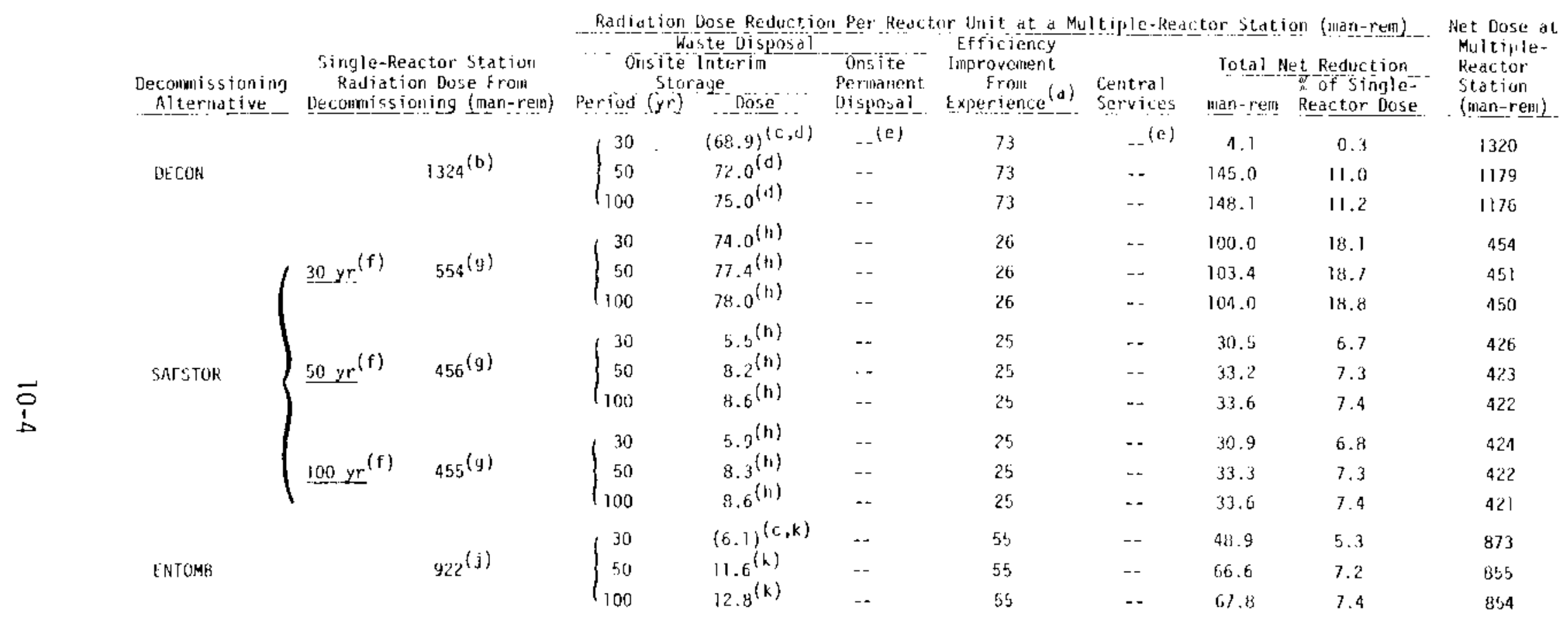

(a) Based on the dose reduction factors in Table $8.2-1$. 38\% saving on planning and preparation and 6\% saving on decumbsioning operations

(b) From Table 11.3-1 of Reference 1 and Tathle 9.1-12 of this reprort.

(c) () indicates an increase in the dose.

(d) Fromt Table $9.1 \cdot 1$.

(e) Dashes indicate not used ar not availabie.

(f) Safe storage period for reactor

(9) Based un Tables 11.3-2, $11.3-4$, and $11.3-5$ of Reference 1 and table $9.1-12$ of this report.

(h) From Table 9.1-5.

(j) Based on Table 4.6-1 of Reference 2 corrected for radioactive decay and Table $4.1-12$ of this report.

(k) From Table 9.1-9. 


\subsection{SCENARIO NUMBER 2}

Scenario Number 2 has four BWRs of similar design that started up at 4-year intervals. At the end of their operating life, the reactors are shut down and decommissioned but are not replaced with new nuclear power plants. Nuclear waste from decomissioning the reactors is sent immediately to an offsite waste disposal facility. No central facilities are provided at this multiple-reactor station. A lifetime schedule for Scenario 2 is given in Figure 6.2-2.

Immediate offsite disposal of nuclear waste from deconmissioning a reactor at a multiple-reactor station is accomplished for the same cost and results in the same occupational radiation dose as nuclear waste disposal from decommissioning a reactor at a single-reactor station. The only feature of this scenario that impacts the decomnissioning cost and radiation dose is the improvement in the efficiency of the planning and execution of the work at four identical plants. These impacts are discussed generically in Subsections 8.2 and 9.2

Table 10.2-1 gives the estimated average decommissioning cost and the average net savings for decommissioning a BWR at this multiple-reactor station. Estimated costs are given for each of the decommissioning alternatives, DECON, SAFSTOR, and ENTOMB. The estimated average occupational decommissioning doses for decommissioning a BWR at this station are given in Table 10.2-2.

The greatest cost savings in this scenario are achieved when the BWR is decommissioned by SAFSTOR; however, it is still the most expensive of the three alternatives. SAFSTOR does result in the lowest occupational radiation dose for decommissioning one of the reactors. DECON is estimated to be the least expensive for decommissioning one of the BWRs.

\subsection{SCENARID NUMBER 3}

The multiple-reactor station of Scenario Number 3 has 10 reactors, 5 PWRS and 5 BWRs. Reactors are started up at 4 -year intervals so that the station reaches the full generating capacity over a 36-year period (see Figure 6.2-3). With this construction schedule, the first reactor to start up is shut down 4 years after startup of the tenth reactor and is replaced by the eleventh 


\section{TABLE 10.2-1. Multiple-Reactor Station Scenario 2 - Decommissioning Cost Impact (4 BWRs)}

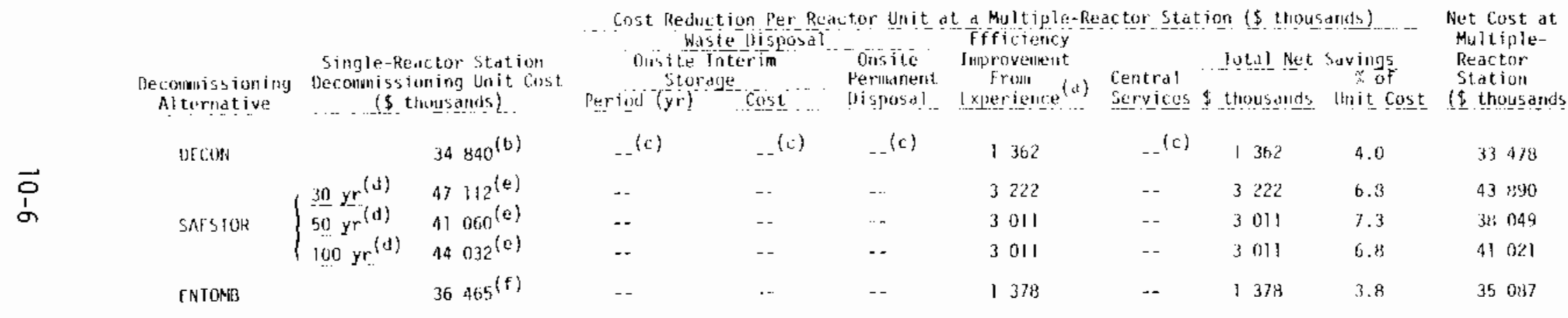

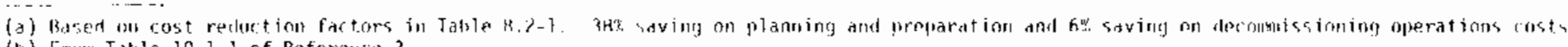
(1) Fromit Table 10.1-1 of Reference 3.

(c) Dashes indicate not used or not avaijable.

(d) Sute sturdge perind for the rcactor

(i) Hajed on Table lu.4-2 of Reterences 3 , without the $25 \%$ contingency.

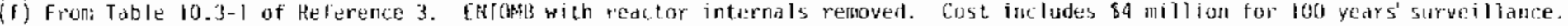


TABLE 10.2-2. Multiple-Reactor Station Scenario 2 - Impact on 0ccupational Radiation Dose from Decommissioning (4 BWRs)

\begin{tabular}{|c|c|c|c|c|c|c|c|c|c|c|}
\hline \multirow{3}{*}{$\begin{array}{l}\text { Decomissioning } \\
\text { Alternative. }\end{array}$} & \multirow{3}{*}{\multicolumn{2}{|c|}{$\begin{array}{l}\text { Single-Reactor Station } \\
\text { Radiation Dose From } \\
\text { Decomalissioning (filan-rem) }\end{array}$}} & \multicolumn{7}{|c|}{ Radiation pose Reduction Per Reactor Unit at a Multiple-Reactor Station (man-rem) } & \multirow{3}{*}{$\begin{array}{l}\text { Net Dose at } \\
\text { Muttiple- } \\
\text { Reactor } \\
\text { Station } \\
\text { (than-ren!) }\end{array}$} \\
\hline & & & \multicolumn{2}{|c|}{$\begin{array}{l}\text { Orisite Interim } \\
\text { Storage }\end{array}$} & \multirow{2}{*}{$\begin{array}{l}\text { Onsite } \\
\text { Pernilnent } \\
\text { oisposal. }\end{array}$} & \multirow{2}{*}{$\begin{array}{c}\text { Efficiency } \\
\text { Improventent } \\
\text { From } \\
\text { Experience }\end{array}$} & \multirow[b]{2}{*}{$\begin{array}{l}\text { Central } \\
\text { Services }\end{array}$} & \multicolumn{2}{|c|}{ Total Net Reduction } & \\
\hline & & & Perivid $7 y=$ & pose & & & & & $\begin{array}{l}\text { Q of Single- } \\
\text { Reactor Dose }\end{array}$ & \\
\hline DECON & & $1954^{(b)}$ & $-(c)$ & $--(c)$ & $-(c)$ & $111^{(d)}$ & $-(c)$ & 111 & 5.7 & 1843 \\
\hline & $30 y^{(e)}$ & $527^{(6)}$ & -- & -- & - & $24^{(f)}$ & -- & 24 & 4.6 & 503 \\
\hline SAFSTOR & $50 y y^{(e)}$ & $429^{(b)}$ & -- & -- & -- & $22^{(f)}$ & -- & 22 & 5.7 & 407 \\
\hline & $100 y^{(e)}$ & $427^{(b)}$ & -- & -- & $\cdots$ & $22^{(f)}$ & -- & 22 & 5.2 & 405 \\
\hline ENTOMB & & $1756^{(9)}$ & -- & -. & -- & $101^{(h)}$ & $=$ & 101 & 5.8 & 1655 \\
\hline
\end{tabular}

(a) Based on the dose reduction factors in Table 8.2-1. 3b\% saving on planning and preparation and 6\% saving on deconuissioning operations

(b) From Table $3.1-4$ of Reference 3 and Table $9.1-12$ of this report.

(c) Dashes indicate not used or not ayailable.

(d) From Table 9.2-2.

(e) Safe starage period for reactor.

(f) Troll Yable 9.2-7.

(g) From lable K.4-1 of Reference 3 and lable 9.1-12 of this report.

(h) From Table 9,2-9. 
reactor. The site of this multiple-reactor station is dedicated to nuclear power generation, with each retired reactor replaced with a new reactor as it is shut down. Nuclear waste from reactor operation and decommissioning is shipped immediately to an offsite waste facility. Central services are not provided at this station. Lifetime schedules for this scenario with decommissioning by DECON and SAFSTOR are given in Figures 6.2-3 and 6.2-5, respectively.

Improvement in the planning and execution of reactor decomissioning resulting from a stable local workforce and the learning experience of successively decommissioning several reactors of the same type is the only feature of this multiple-reactor station scenario that impacts the costs of and radiation dose from decommissioning the reactors.

The average decommissioning costs and net savings for decommissioning a PWR and a BWR are given in Table 10.3-1. Decommissioning costs are estimated for each of the alternatives, DECON, SAFSTOR, and ENTOMB. Occupational radiation dose estimates for decommissioning the reactors at this station are given in Table 10.3-2.

For both the PWRs and the BWRs, the estimated occupational radiation doses are lowest when the reactors are decommissioned by SAFSTOR and highest when deconmissioned by DECON. Estimated average decommissioning costs for the PWRS are lowest for ENTOMB and highest for SAFSTOR. Decommissioning the BWRs is estimated to be most costly by the SAFSTOR alternative and least costly by the OECON al ternative.

\subsection{SCENARIO NUMBER 4}

Ten reactors, 5 PWRs and 5 BWRs, are located at the multiple-reactor station in this scenario. A new reactor is started up every 4 years as shown in the lifetime schedules in Figures 6.2-3 and 6.2-5 for decommissioning by DECON and SAFSTOR with 30 years of safe storage, respectively. A new reactor is started up when an old reactor is retired, thus maintaining a full complement of 10 operating reactors after the tenth reactor has been started up. Nuclear waste from operation and decommissioning is placed in onsite interim storage 
TABLE 10.3-1. Multiple-Reactor Station Scenario 3 - Decommissioning Cost Impact (5 PWRs and 5 BWRs)

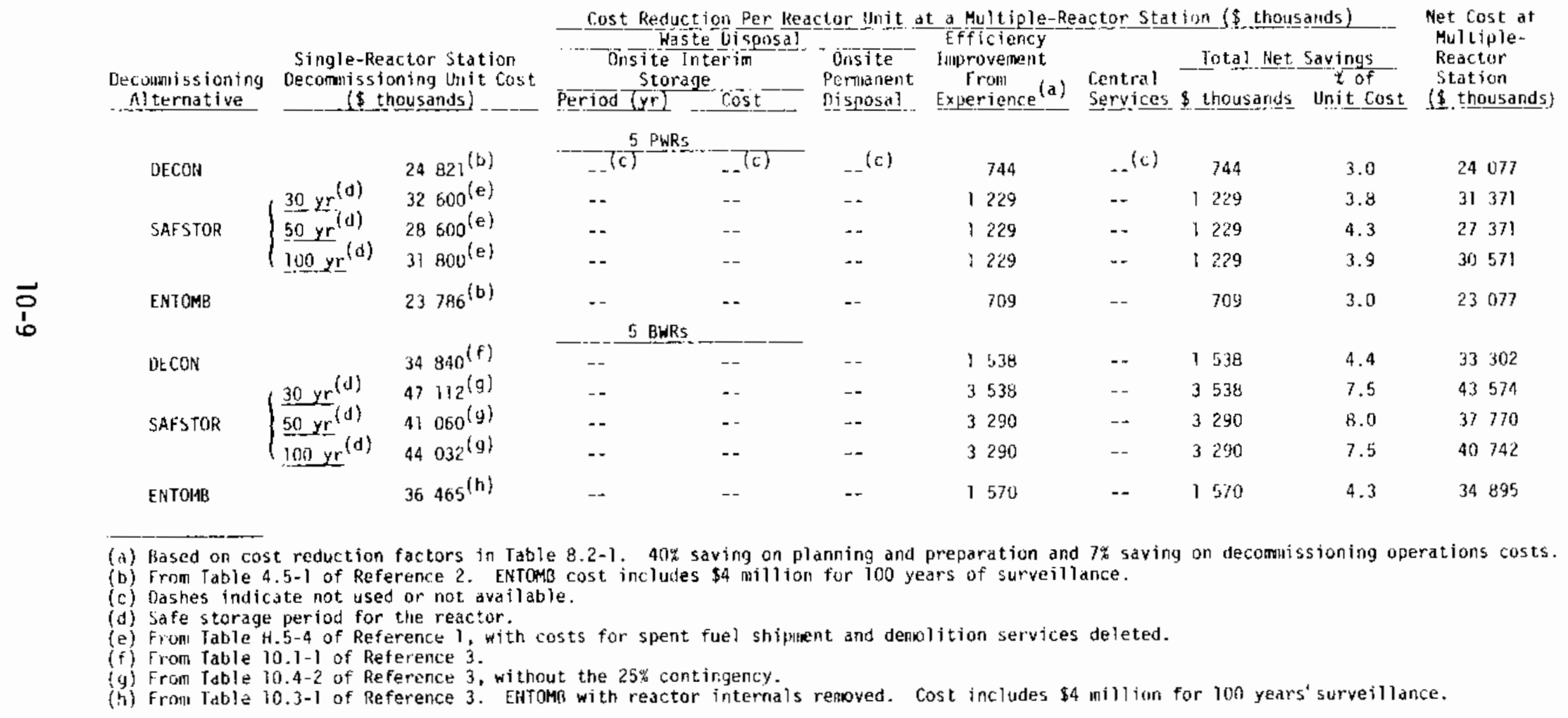


TABLE 10.3-2. Multiple-Reactor Station Scenario 3 - Impact on Occupational Radiation Dose from Decommissioning (5 PWRs and 5 BWRs)

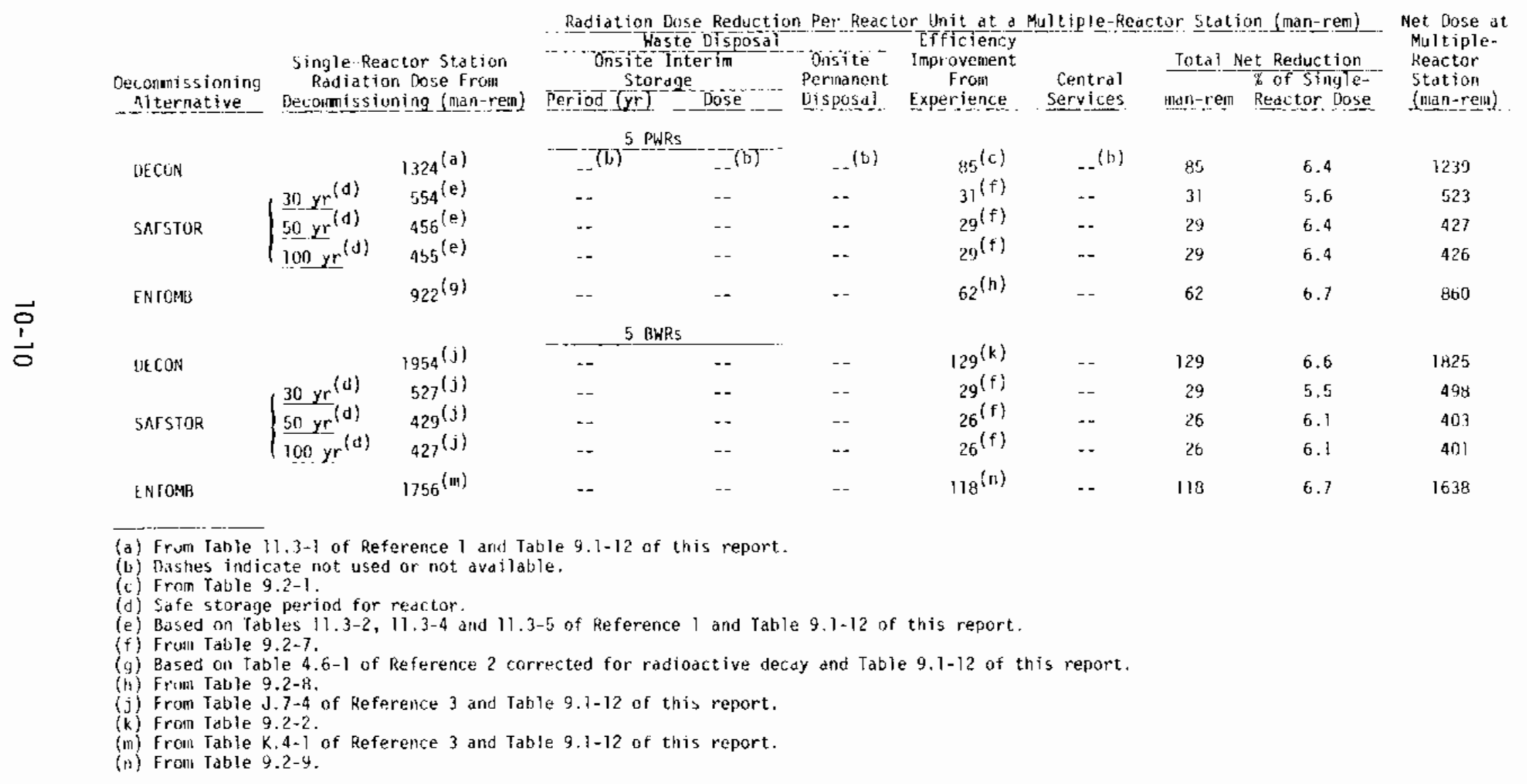


for a significant decay period before it is transferred offsite, either to a licensed waste disposal facility or, if releasable, to a nonradioactive waste disposal facility. Centralized facilities are provided at this multiple-reactor station.

Nuclear waste disposal, experience gained in successively decommissioning a number of identical reactors, and the availability of central services at this multiple-reactor station have an impact on the average occupational dose and cost of decommissioning the reactors. Radioactive decay during the period of onsite interim storage resuits in reducing the amount of waste that must be sent to an offsite waste disposal facility and in reducing the curie and liner surcharges on the waste sent to an offsite waste facility. Details of the estimates of the impacts on costs and occupational radiation doses of onsite interim storage of the nuclear waste are given in Subsections 8.1 .2 and 9.1 .2 , respectiveiy. Cost and radiation dose impacts resulting from improvement in the efficiency of the successive decommissioning of five identical reactors are developed in Subsections 8.2 and 9.2 , respectively.

Centralized services at this multiple-reactor station that impact cost are health physics services, security forces, solid waste processing, and decontamination services. Estimation of the cost impacts of these centralized services is discussed in detail in Subsection 8.3. The impact of the centralized services on radiation dose is minor. Onjy one of the services, solid waste processing, reduces the radiation dose. This is discussed in greater detail in Subsection 9.3 .

The decormissioning cost at this multiple-reactor station and the net savings compared to the decommissioning cost at a single-reactor station are given in Table 10.4-1 for the five PWRs and in Table 10.4-2 for the five BWRs. Average occupationa? doses and dose reductions compared to the doses for decommissioning a reactor at a single-reactor station are given in Table 10.4-3 for the PWRs and in Table 10.4-4 for the BWRs.

Savings in the costs of decommissioning the reactors are greater for this scenario than for the first three scenarios, ranging from 5 to $19 \%$ for the PWRs 


\section{TABLE 10.4-1. Multiple-Reactor Station Scenario 4a - PWRs - Decommissioning Cost Impact} (5 PWRs and 5 BWRs)

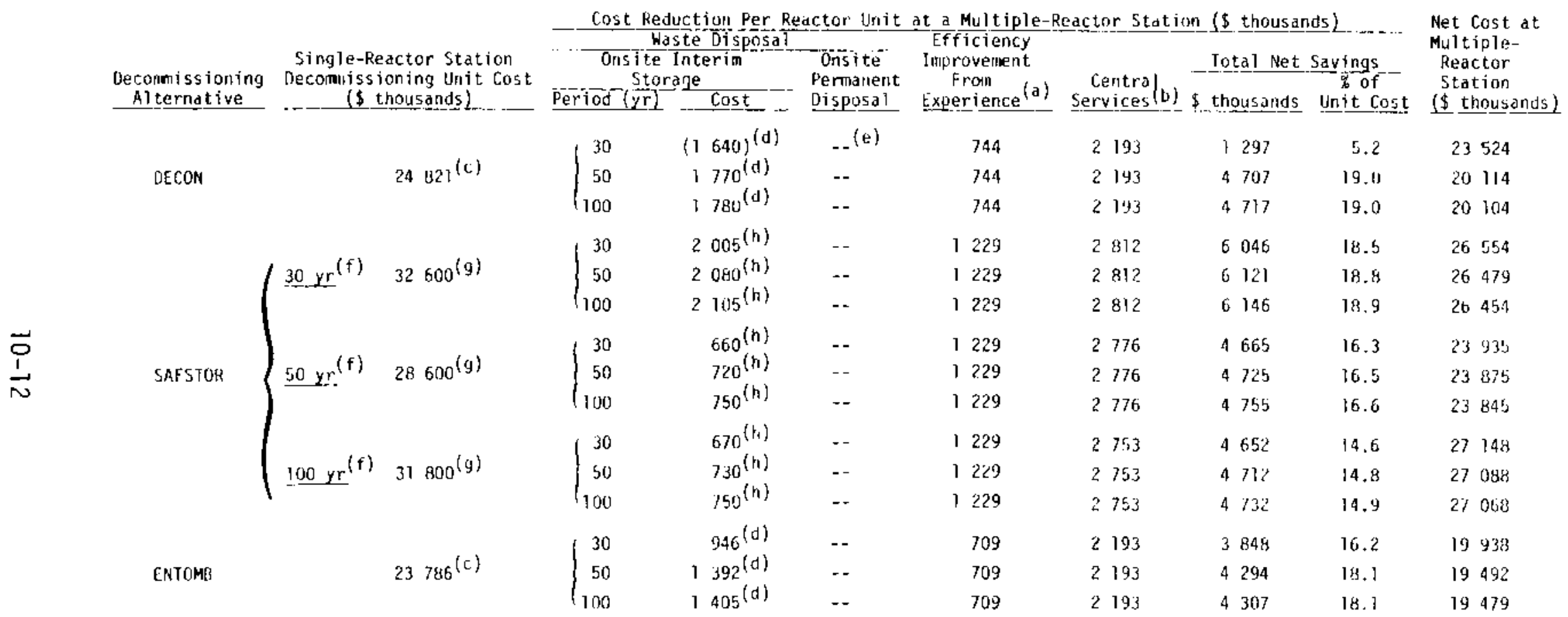

\footnotetext{
(a) Based on cost reduction factors in Table 8.2-1. 40\% saving on planning and preparation and 72 saving on deconilissioning operations costs.

Gron Tables $8,3-8$ and $8.3-3$.

c) Fron Table 4.5-1 of Reference 2. ENTOA1/3 cost includes \$4 inillion for loo years'surveillance.

d) Fron Table 8.0-1.

e) Jashes indicate not used.

Sace storage period for the reactor.

ference 1 , with costs for spent fuel shiment and demolition services deleted.

i) From Table $3.1-6$.
} 
TABLE 10.4-2. Multiple-Reactor Station Scenario 4b - BWRs - Decommissioning Cost Impact (5 PWRs and 5 BWRs)

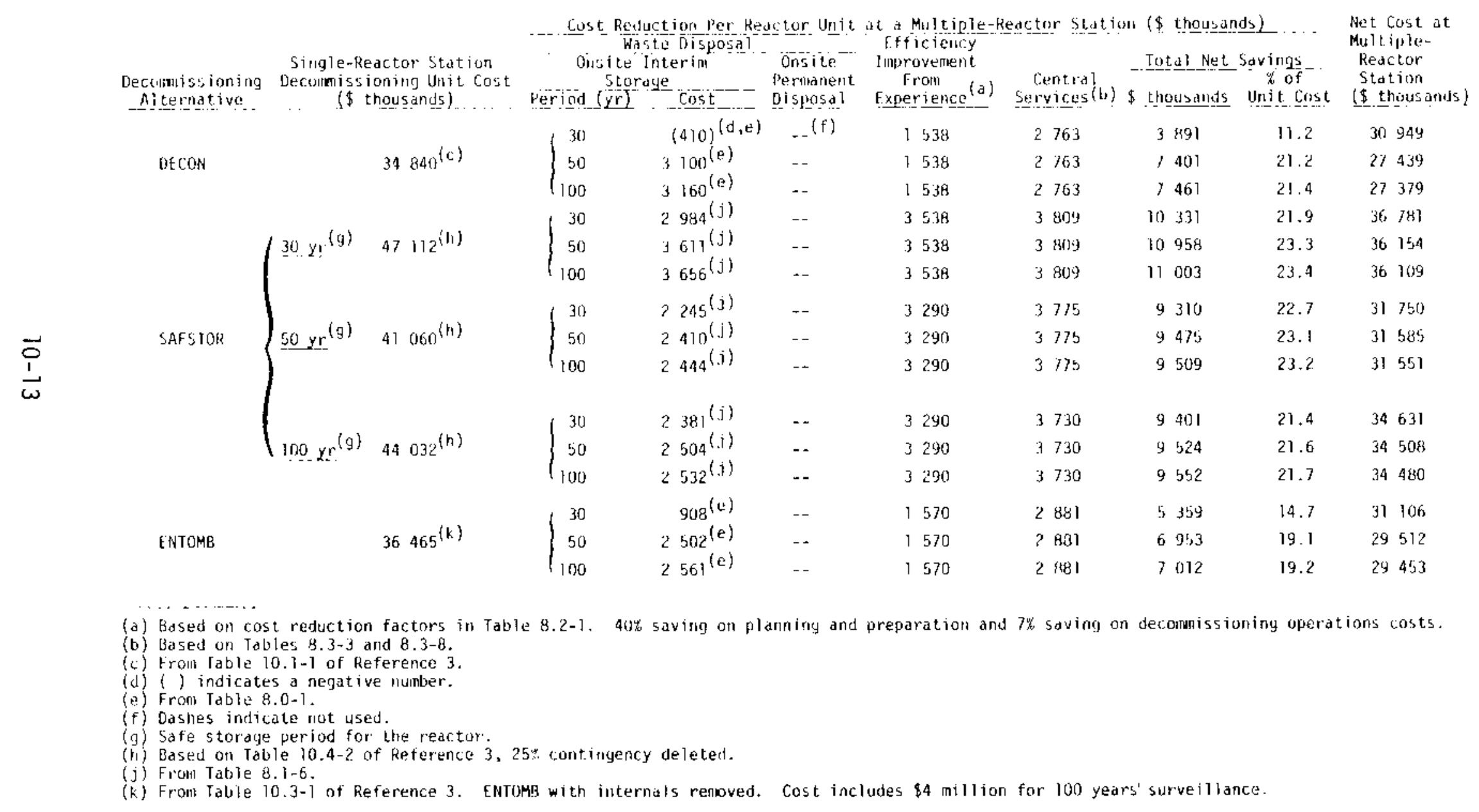


TABLE 10.4-3. Muttiple-Reactor Station Scenario 4a - PWRs - Impact on 0ccupational Radiation Dose from Decomissioning (5 PWRs and 5 BWRs)

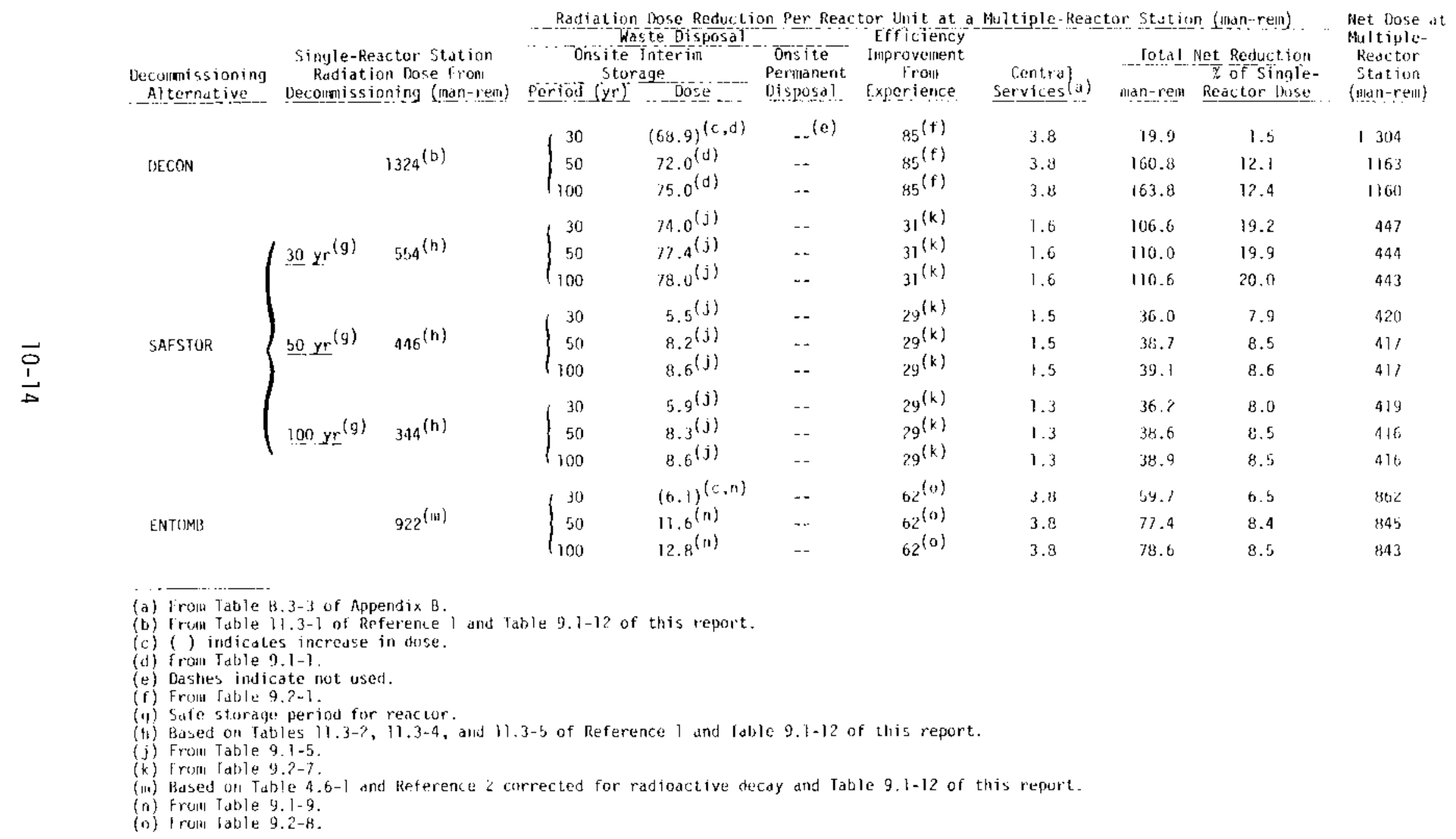


TABLE 10.4-4. Multiple-Reactor Station Scenario 4b - BWRs - Impact on 0ccupational Radiation Dose from Decormissioning ( 5 PWRs and 5 BWRs)

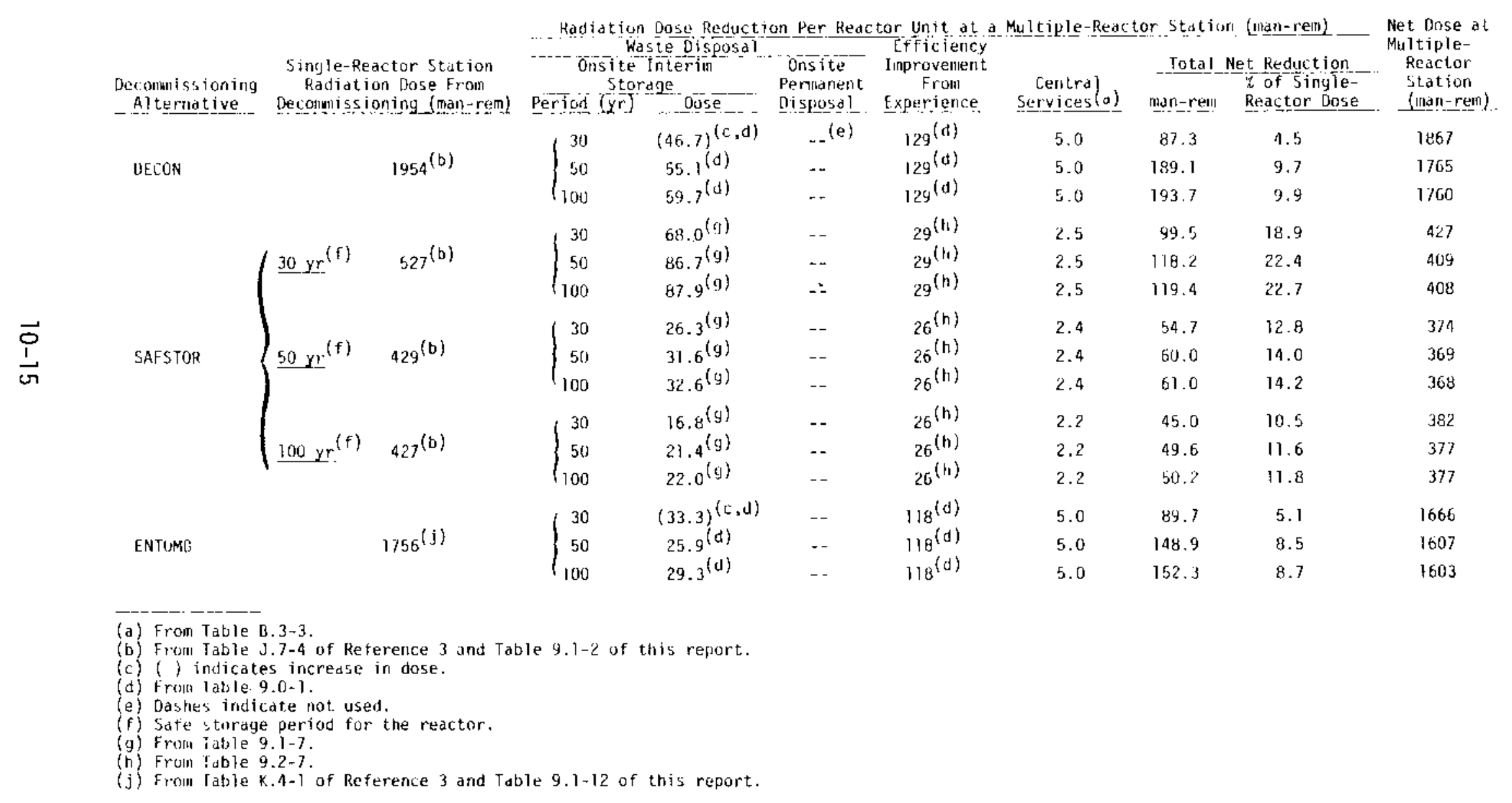


and 11 to $23 \%$ for the BWRs. ENTOMB gives the lowest decommissioning cost for the PWRS and SAFSTOR the highest. For the BWRs the costs of DECON are lowest and the costs of SAFSTOR highest.

Dose reductions are also generally greater for this scenario than for the first three, ranging up to $20 \%$ for the PWRs and up to $23 \%$ for the BWRs. Again, occupational doses are lowest for SAFSTOR and highest for DECON.

\subsection{SCENARIO NUMBER 5}

Five PWRs and five BWRs are located at the multiple-reactor station of Scenario Number 5. The reactors are started up and, after 40 years of operation, shut down at 2-year intervals. As each old reactor is shut down, it is replaced with a new reactor so that a full complement of 10 reactors is maintained on line. A permanent nuclear waste disposal facility is located onsite. Central facilities are provided at this multiplemreactor station.

Onsite permanent disposal of the waste, as well as the improvenent in efficiency with successive decommissioning of several reactors and the availability of centralized services, will reduce the average cost and occupational radiation dose from decomissioning the reactors at this multiple-reactor station compared to a single-reactor station. Details of the cost estimates for onsite disposal of nuclear wastes are discussed in Subsection 8.1.3.

Table 10.5-1 gives the estimated average decomissioning costs and net savings for decommissioning the reactors at this multiple-reactor station. The average occupational radiation doses and net dose reduction for decommissioning the reactors are given in Table 10.5-2.

The reductions in cost and occupational radiation dose for decommissioning a reactor at a multiple-reactor station compared to a single-reactor station are greater in this scenario than in any of the other scenarios. Cost reductions range from about 17 to $24 \%$ for the PWRs and from about 22 to $25 \%$ for the PWRs. Dose reductions range from about 10 to $22 \%$ for the PWRs and 11 to $25 \%$ for the BWRs. 
TABLE 10.5-1. Multiple-Reactor Station Scenario 5 - Decomimissioning Cost Impact (5 PWRs and 5 BWRs)

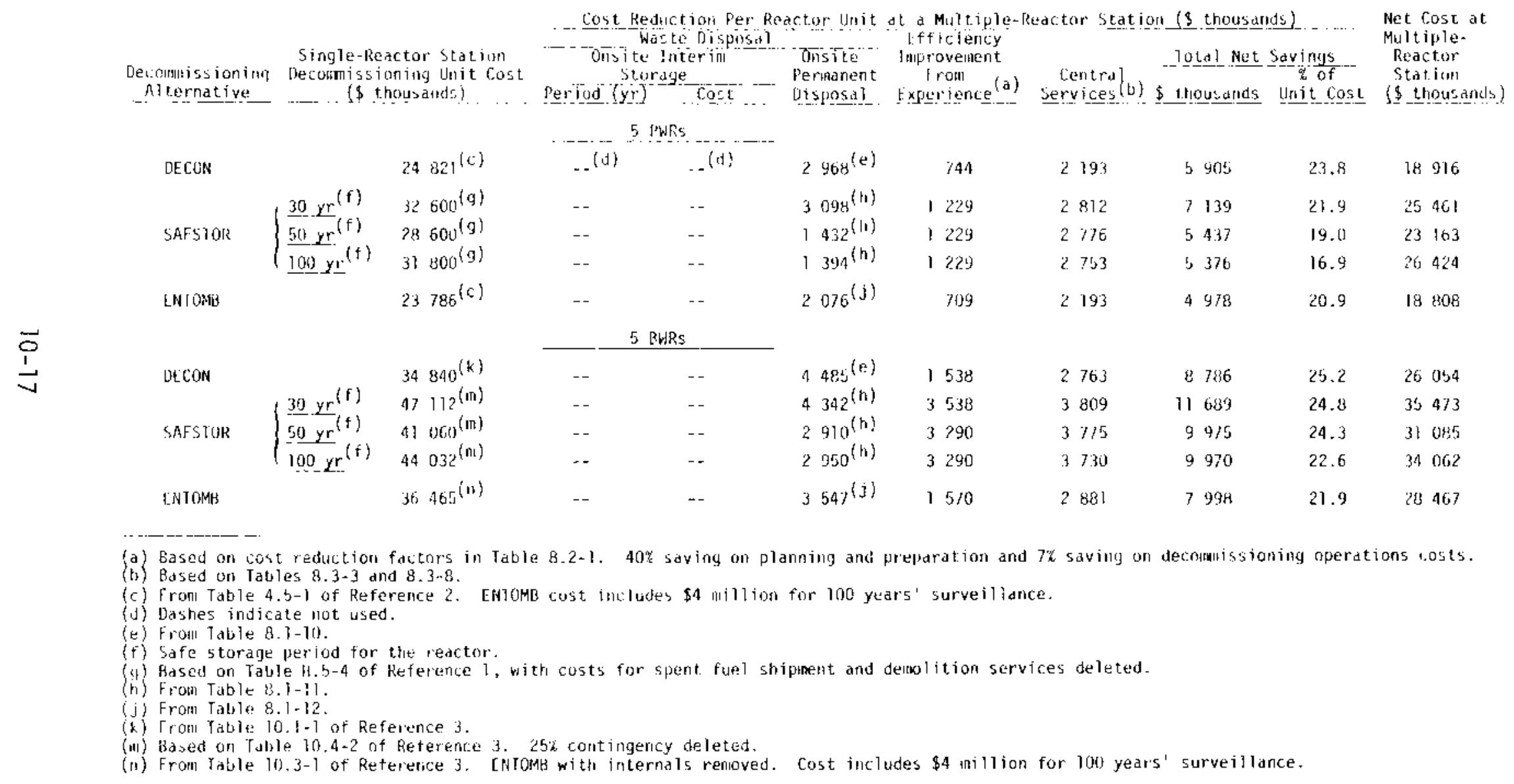


TABLE 10.5-2. Multiple-Reactor Station Scenario 5 - Impact on Occupational Radiation Dose from Decommissioning (5 PWRs and 5 BWRs)

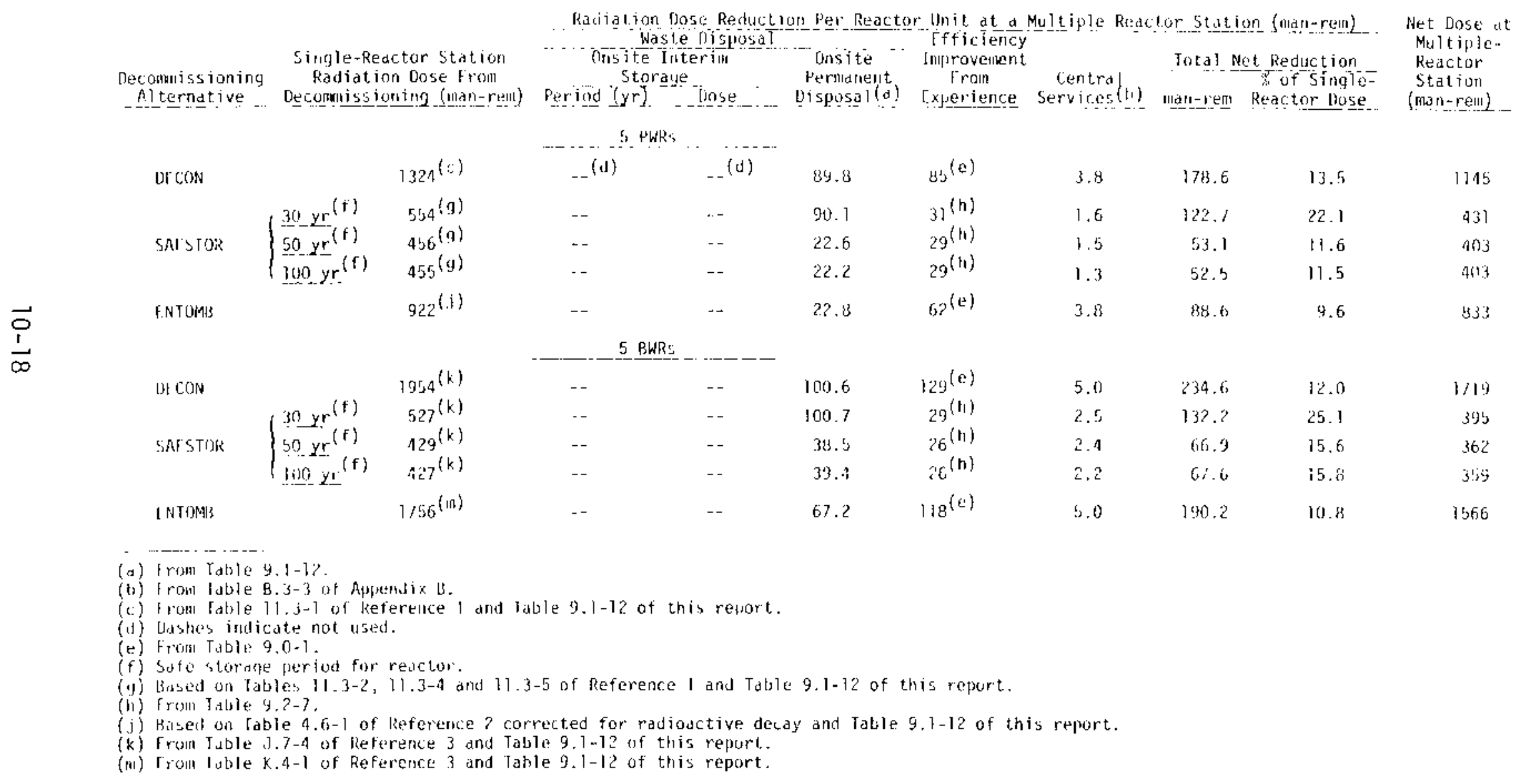




\section{REFERENCES}

1. R. I. Smith, G. J. Konzek and W. E. Kennedy, Jr., Technoiogy, Safety and Costs of Decommissioning a Reference Pressurized water Reactor Power Station, NUREG/CR-0130, U.S. Nuclear Regulatory Commission Report by Pacific Northwest Laboratory, June 1978.

2. R. I. Smith and L. M. Polentz, Technology, Safety and Costs of Decomissioning a Reference Pressurized Water Reactor Power Station, NUREG/CR-0130 Addendum, U.S. Nuclear Regulatory Commission Report by Pacific Northwest Laboratory, August 1979.

3. H. D. Oak, G. M. Holter, W. E. Kennedy, Jr., and G. J. Konzek, Technology, Safety and Costs of Decommissioning a Reference Boiling Water Reactor Power Station, NUREG/CR-0672, U.S. Nuclear Regulatory Commission Report by Pacific Northwest Laboratory, June 1980. 



\subsection{FACILITATION OF DECOMMISSIONING}

The principal purpose of decommissioning facilitation is to reduce occupational and public radiation doses resulting from decommissioning activities. other purposes include improving the safety of decommissioning, reducing the volume of radioactive waste, and reducing the cost of decommissioning. These purposes apply equally to single-reactor stations and to multiple-reactor stations; but they can often be more effectively achieved at multiple-reactor stations because of collocation of the reactors and sequential decommissioning. A recent discussion of the facilitation of decommissioning 1 ight water reactors, without particular regard to multiple-reactor stations, appears in NUREG/CR-0569. (1) The decommissioning facilitation alternatives presented in Reference 1 are reviewed briefly in Subsection 11.2. Facilitation of decommissioning a multiple-reactor station is discussed in Subsection 13.3, and the possibilities of conversion to a different steam supply system or refurbishment of the original nuclear steam supply system are discussed in Subsection 11.4.

\subsection{FACILITATION PLANNING}

The best way to facilitate the decommissioning of a reactor is to plan for decommissioning during the design phase. This is true because many decommissioning facilitation alternatives require design and construction modifications. It is also true because advantage can be taken of a facilitation alternative that also facilitates reactor maintenance and operation. In decommissioning, an opportunity exists only once to reduce radiation dose and cost, but in maintenance, an opportunity exists every year to reduce radiation dose and cost.

Planning at the design phase is especially appropriate for a multiplereactor station because advantage can be taken of collocation of the reactors, standardized design and construction, centralized services, and sequential decommissioning. At the very least, crew preparation and training time will be minimized and the decommissioning can be more efficiently carried out because the decommissioning procedures will be the same for similar reactors and because the same crews can be used for sequential decommissioning. 
In Subsections 11.1 .1 and 11.1.2, we comment briefly on the reduction of radiation doses and costs and on the advantages of selecting decommissioning facilitation alternatives that also facilitate maintenance. In Subsection 11.3 , we discuss decommissioning facilitation techniques that are unique to multiplereactor stations or that improve decommissioning at multiple reactor stations.

\subsubsection{Radiation Dose Reduction}

Any radiation dose reduction that can be effected by decommissioning facilitation will be some fraction of the tota? radiation dose expected from decommissioning. A suitable standard of comparison for a PWR is the 1080 manrem calculated for DECON of an 1175-MWe PWR single-reactor station (Reference 2, pp. 11-17). This value does not include the radiation dose from removal of the last core. A similar standard of comparison for a BWR is the 1760 man-rem calculated for DECON of an 1155-MWe BWR at a single-reactor station (Reference 3 , pp. $11-7$ and $11-8$ ).

of perhaps even greater importance than the reduction of radiation dose during decommissioning is the reduction of radiation dose during operation and maintenance of the reactor that might be made possible by any decormissioning facilitation alternative. The opportunities are much greater for dose reduction during maintenance than during decommissioning. The observed maintenance occupational radiation dose is presently about 450 man-rem per year for PWRs and about 500 man-rem per year for BWRs, or about 18,000 and 20,000 man-rem, respectively, over the 40-year operating lifetime of the reactor. (See Reference 1, Section 2.3.) Obvious1y, strategic decomissioning facilitation planning requires careful consideration to determine if a facilitation alternative will also facilitate maintenance.

\section{1 .2 Cost Reduction}

Costs associated with decommissioning facilitation alternatives include capital costs, costs of maintenance and operation (during both reactor operation and maintenance and decommissioning) and any cost savings during decommissioning. Some facilitation alternatives that will reduce the decommissioning radiation dose may involve an overall cost increase. Again, appropriate standards of 
comparison are the costs to DECON a reference, single-reactor station, 1175-MWe PWR and a reference, single-reactor station, 1155-MWe BWR, which are \$31 mi1lion and $\$ 43.6$ million, respectively. These costs do not include the costs for disposal of the final core or those for demolition of non-radioactive structures.

A cost reduction potentially much larger than any cost increase or cost reduction associated with decomissioning facilitation is the cost reduction associated with reduced downtime for maintenance. If a utility must buy replacement power from outside its system during maintenance periods, each day of maintenance will cost the utility approximately $\$ 500,000$ per day per reactor (assuming the utility must pay $2 t$ per kilowatt hour to replace the power from a 1200-Mke reactor). Thus, any decommissioning facilitation alternative that also reduces the time the reactor is out of service for maintenance (thereby eliminating the cost that must be paid for replacement power while the reactor is out of service) has the potential to pay for itself and perhaps for most of the decommissioning as well.

An obvious cost reduction strategy, then, is to look for decommissioning facilitation alternatives that will also increase operating time and decrease maintenance time. This must be done while the reactor is in the design phase.

\subsection{FACILITATION ALTERNATIVES}

Selected design features, special equipment, and construction techniques from Reference 1 that would facilitate decomissioning of single-reactor stations are reviewed briefly in this subsection. These alternatives obviously would also be useful in facilitating the decommissioning of reactors at a multiple-reactor station.

\subsubsection{Improved Documentation}

Documentation is the foundation of decommissioning facilitation. Correct as-built drawings; good construction photographs; scale models showing equipment arrangement, concrete pours, concrete penetrations, and the location of rebar; and accurate written and photographic maintenence records are vital to decomassioning. The value of these records is particularly evident when 
deferred decontamination is selected as the decomissioning alternative, because an operating crew knowledgeable about the facility will not be on hand to assist in the decommissioning.

\section{2 .2 Improved Access}

Access to contaminated equipment can be improved by the installation of removable roof and wall panels. These panels are already in place in some newer reactors. Improved access simplifies removal of equipment for maintenance, replacement, and for disposal during decomissioning.

\subsubsection{Substitution and Purification of Materials}

Removal of ${ }^{59}$ Co from stainless steels subject to activation will reduce the amount of ${ }^{60} \mathrm{Co}$ produced. ${ }^{60} \mathrm{Co}$ is responsible for a large fraction of the radiation dose received by workers during immediate decontamination. Substitution of alloys such as Zircalloy for stainless steels in areas subject to activation will also reduce the amount of ${ }^{60} \mathrm{Co}$ formed. However, care must be taken in situations where structural materiais are involved, where reactor neutron physics might be affected, and where other materials might be activated to form even less desirable activation products. Elimination of ${ }^{60} \mathrm{Co}$ in this manner would not be particularly helpful if safe storage of 30 to 50 years followed by deferred decontamination were selected as the decommissioning alternative, because much of the ${ }^{60}$ co would decay to innocuous levels during the storage period.

\subsubsection{Design of the Biological Shield for Easy Removal}

Two alternatives for improving the safety of removing the biological shield are: 1) elimination of the need to drill blasting holes under high dose rate conditions at the time of dismantlement by designing holes into the biological shield during construction, and 2) elimination of the blasting process altogether by installing a modular bjologica? shield that can be disassembled by means of a remote crane.

Preplacement of the vertical biasting holes during construction would eliminate the need for post-shutdown drilling by remote means. Biological shield thickness could be maintained by filling the holes with sand prior to pouring each succeeding vertical iff. 
Design of the biological shield as a series of modularized components may be reasonably accomplished in a BWR, where the shield serves only the function of personnel and equipment shielding. In a PWR, the biological shield also supports the reactor vessel and must be designed primarily for this purpose, with its secondary function being to provide sufficient shielding thickness. The support structure would consist of a frame of heavy carbon steel I-beams designed to support the reactor and to provide a receptacle for precast concrete panels, which are inserted and pressure-grouted in place after insertion. The biological shield would be made of layers of preformed concrete in onion-like layers held in place by the structural steel I-beams. Removal of the panels would be accomplished by remote-crane operation, which would exert enough lifting force to fracture the grout, allowing each panel to be put into proper containers for shipping. A modular design of the biological shield might also expedite removal of the reactor pressure vessel, should that become necessary during the life of the reactor. Careful attention would need to be paid to the design of the biological shield to assure structural strength and integrity under postulated accident scenarios.

\subsubsection{Techniques for Improved Protection of Concrete and Improved Removal of Contaminated Concrete}

At least three alternatives are possible to protect concrete surfaces from contamination or to facilitate the removal of contaminated concrete. The first is to protect all contaminable but non-submerged concrete surfaces with carbon steel liners. Care would need to be taken in the design of the facility to assure the structural integrity required to support the weight of the 1 iner. The second alternative is to protect these same surfaces with protective coatings. If the coating could be maintained intact throughout the operating lifetime of the plant, then any contamination could be readily washed off. The third alternative would el iminate drilling and simplify spalling through the installation of a carbon steel sandwich inside of potentially contaminable, but non-submerged, floors and walls at a depth of 4 inches. Air or liquid pressure applied between the plates would provide the spalling force. Again, careful attention would need to be paid to structural design. 


\subsubsection{Special Shielded Maintenance Shop}

Expanded maintenance shops with added special shielding would allow shielded laydown, maintenance, and dismantling of all but the largest pieces of reactor equipment. In this way, predismantling outside the shop, which usually involves unshielded operations and less efficient equipment, could be avoided.

\subsubsection{Improved Shielding for Maintenance and Decommissioning}

Two possible alternatives for the direct protection of personnel from radiation are: 1) pipe shielding to reduce background levels in work spaces, and 2) a self-contained, shielded vehicle with manipulator arms that can perform functions equivalent to remote cell manipulators. Lead shielding with an air gap or insulation could be added to piping to provide both thermal and radiation shielding. Background radiation would be reduced at mechanical equipment, valves, and pumps that require the major portion of maintenance in an operating plant. Some redesign of pipe supports would be required to support the additional weight. A self-contained, shielded vehicle equipped with manipulator arms could be developed that would permit maintenance and decommissioning activities to proceed in a manner similar to that employed in stationary manipulator-equipped shielded cells. This vehicle might require larger access areas with adequate room for maneuvering and enough distance between components requiring maintenance to permit reasonably close approach by the mobile unit, which would be mounted on a tracked vehicle and contain its own life-support system. Fail-safe power units would be required to ensure that the operator(s) could always leave the area.

\subsubsection{Reduction of Radwaste Volume by Incineration}

Reduction of the radwaste volume by incineration is discussed in detail in Subsections 8.3.3 and 9.3 and in Section B.3 of Appendix B.

\subsubsection{Electropolishing}

The impact of a central electropolishing facility at a multiple-reactor station is discussed in detail in Subsection 8.3.4 and in Section B.4 of Appendix B. 


\subsubsection{Remote Maintenance and Decommissioning}

Remote-controlled equipment offers the possibility of carrying out maintenance, monitoring, and decommissioning activities in high-radiation fields where contact maintenance results in excessive occupational radiation doses. A stateof-the-art robot could perform basic maintenance and decommissioning functions at a substantial reduction in radiation dose. Remote units capable of carrying out radiation surveillance, simple routine maintenance, and visual examination in medium- to high-radiation fields should require little maintenance, be reasonably compact, be reasonably inexpensive, be readily decontaminable, be mobile (both unit and console), and be remotely controlled. Ordinary industry requirements include limited space capability, operation in a range of temperatures and hazardous locations (i.e., little or no air, underwater), and ability to perform boring jobs without fatiguing. Nuclear requirements differ from these only in that they require operation in radiation fields. Reliability cannot be overemphasized, since a breakdown in service would not only delay a key operation, but could also compound the situation by adding robot removal and repair to the problem at hand.

\subsubsection{Special Decommissioning Tools and Techniques}

Unique problems caused by the presence of radiation fields call for the development of special decommissioning tools and techniques that speed cutting, drilling, and separation of radioactive components or that permit decomissioning workers to carry out their activities in lower radiation fields. Possible options include plasma-arc torch improvement, arc-saw improvement, explosive cutting, and a mobile, shielded, crane-mounted enclosure.

The plasma-arc torch is a metal-cutting device operated either in air or under water in which a high-temperature, high-velocity, small-diameter gaseous arc is struck between an electrode in the torch and the metal piece to be cut. The combined heat and force of the arc stream melt the metal and produce a highquality, saw-like cut. The required improvements include the developinent of improved manipulation techniques and the development of torches that would cut 70-mul-thick stainless steel under water and 240-mm-thick carbon steel in air. 
A prototype arc saw has been developed with a 36-inch-diameter saw blade capabte of being operated either in air or under water. Scaling up the saw blade to a diameter of 3 m appears to be feasible, which would allow cutting Targe-diameter pipes, heat exchangers, and tanks.

Explosive cutting appears particularly well-adapted for removing pipes up to $40 \mathrm{~mm}$ thick or for cutting small pieces of difficult geometry. Its particular advantages include unattended operation and ability to operate in areas inaccessible to other cutting techniques. Design work is needed to solve the problems of water pluming in underwater cuts, of insuring good explosive-tosurface contact, and of piacenent on difficult-to-reach surfaces.

A shielded, crane-mounted enclosure would permit direct observation and control of decommissioning operations being handled by the crane. It would also protect personnel conducting operations in the spent fuel storage pool or in the pressure vessel from intense radiation fields.

\subsection{FACILITATION OF DECOMMISSIONING AT MULTIPLE-REACTOR STATIONS}

All of the decomissioning facilitation options discussed in Subsection 11.2 apply, both individually and collectively, to reactors at a multiple-reactor station. Several of the factors discussed in Section 8 are facilitation options in and of themselves and are discussed briefly in the following subsections.

\subsubsection{Site Dedication}

Dedication of a site to nuclear power generation fosters standardization of design, sequential construction, collocation, and sequential decomissioning of the reactor plants. The improvement in decommissioning efficiency by sequentially decomissioning several reactors of the same type is discussed in Subsection 8.2. For decommissioning four reactors of a single type, it is estimated that the cost and dose reduction factor for the planning and preparation phase is 0.62 and for the decommissioning phase is 0.94 . The lower costs and radiation dose are a direct result of identical design and construction, more efficient planning, optimum use of crews familiar with the reactors, and more efficient use of dismantling tools and equipment. 


\subsubsection{Onsite Nuclear Waste Storage or Disposal}

Onsite interim storage of low-level nuclear waste with subsequent removal to an offsite waste disposal facility or onsite permanent nuclear waste disposal results in lower radiation doses and lower costs for most cases when compared with immediate offsite disposal of nuclear waste from decommissioning. Only for the DECON and ENTOMB decommissioning alternatives with 30 years of interim waste storage are the estimated occupational radiation doses greater than for immediate offsite disposal. The costs for disposal of the nuclear waste from DECON are also greater for onsite interim storage for 30 years when compared with immediate offsite disposal. For longer periods of onsite interim waste storage, both dose and cost reductions are realized.

Dnsite permanent nuclear waste disposal yields dose and cost reductions by virtue of the shorter hauling distance over which the waste is moved to the disposal facility.

\subsubsection{Central Services}

Providing radiation monitoring, security, solid waste processing, and decontamination services as central services at a multiple-reactor station yields decommissioning cost reductions for each of the services when compared with a single-reactor station. Details of the estimation of the cost reductions achieved with central services are discussed in Subsection 8.3 and in Appendix B.

Of the central services mentioned above, only centralized solid waste processing results in reduction of occupational radiation dose.

\subsection{REUSE OF THE FACILITY}

One of the alternatives for reactor retirement given in NRC Regulatory Guide 1.86 is:

"Conversion to a New Nuclear System or a Fossil Fuel System. This alternative, which applies only to nuclear power plants, utilizes the existing steam turbine system with a new steam supply system. The original nuclear steam supply system should 
be separated from the electric generating system and disposed of

in accordance with one of the previous three retirement alternatives."

Reuse of those facilities at a nuclear power station that can be refurbished makes good economic sense. Based on capital cost studies for PWRs (4) and BWRs, ${ }^{(5)}$ the structures and equipment other than the nuclear steam supply systems have capital costs (in 1978 dollars) of $\$ 335$ million for the PWR and $\$ 357$ million for the BWR.

In a study of the economic feasibility of extended-life operation of LWRs, C. A. Negin, et al.,$^{(6)}$ concluded that everything within a nuclear power plant that may degrade with age is refurbishable or replaceable. Removal and replacement of large components in the containment building of a nuclear power reactor has been demonstrated with the replacement of the steam generators at the Surry Nuclear Power Station. At the Duane Arnold Nuclear Station, the reactor pressure vessel nozzle safe ends were successfully replaced. Cost estimates for steam generator replacement at Surry and Turkey Point range from $\$ 50 \mathrm{million}$ to $\$ 100$ million and for replacement of the safe ends at Duane Arnold, about $\$ 20$ million. $(6)$

Replacement of the nuclear reactor pressure vessel could prove to be difficult in some of the existing reactor containment buildings. The reactor internals can be segmented and removed from the containment building as described in the PWR and BWR decommissioning studies. $(2,3)$ similarly, the reactor pressure vesse? can be cut up, packaged for shipment, and removed from the containment vessel as described in these decommissioning studies. However, the equipment hatches on some of the reactor containment buildings may be too smal? to accommodate a new reactor pressure vessel. The capacity of reactor containment building cranes is usualiy insufficient to lift heavy pieces of equipment such as reactor pressure vessels. The reactor pressure vessel in the reference PWR, for example, weighs about $300 \mathrm{Mg}$ and the reactor building crane has a capacity of only $113 \mathrm{Mg}$. So, to remove the reactor vessel from the reference PWR, special hoisting equipment would have to be set up in the reactor containment building. In order to handle the reactor vessel without adding an excessive amount of 
shielding, the reactor vessel internals, the most highly radioactive components in the nuclear plant, would be segmented, packaged, and shipped to a nuclear waste disposal site as described in References 2 and 3.

\subsubsection{Removal of the Intact PWR Reactor Pressure Vessel}

Layout of the reactor containment building and the fuel building of the reference PWR does not lend itself to convenient removal and replacement of the reactor pressure vessel. The laydown area on the operating floor level of the containment building is hardly adequate for handling the reactor pressure ves sel while closure plates are welded over each of the nozzle openings in preparation for moving the vessel to an interim storage facility. Furthermore, al though the containment building has an equipment hatch that is slightly larger in diameter than the reactor pressure vessel, the concrete shielding wall around the steam generator nearest the equipment hatch would prevent lining up the reactor vessel horizontally to pass through the equipment hatch. The laydown area in the fuel building adjacent to the equipment hatch is adequate for handling the old reactor pressure vessel and the new reactor vessel. However, the hoistway in the fuel building is not wide enough to accommodate the reactor pressure vessel, so the old vessel would have to be removed with an exterior, highcapacity crane through a hole cut in the roof of the fuel building.

An alternative to removing the reactor pressure vessel through the equipment hatch is to cut a hole in the dome of the reactor containment building for removing the vessel by vertical lift and laying the vessel down on a transporter. This alternative is not studied in detail because of the difficulty of restoring the integrity of the reactor containment structure after installation of the new reactor pressure vessel.

The reactor pressure vessel and the reactor internals are decontaminated before removal of the internals. The decontamination process is described in Section F.1.1 of Reference 2. Removal, packaging, and disposal of the reactor internals are accomplished as discussed in Appendix $G$ of Reference 2.

Before the intact reactor pressure vessel can be removed from the reactor cavity, the lines connected to the reactor pressure vessel must be cut. Since 
there is no access to the external surface of the reactor pressure vessel inside the biological shield, the pipes must be cut using internal cutting devices. Sections of the pipes outboard of the biological shield are removed so that internal cutting devices can be inserted in the pipes to cut the pipes adjacent to the reactor vessel wall.

A temporary, 400-Mg capacity crane is used for 1 ifting the reactor pressure vessel out of the reactor cavity. Contamination control is achieved by use of a temporary "greenhouse" over the refueling pool. The external surface of the reactor pressure vessel is cleaned by hoisting the vessel through a ring of high-pressure water jets. Before the reactor pressure vessel is moved from the reactor containment building, plates are welded over all of the nozzle openings.

A specialty rigging contractor is engaged for moving the reactor pressure vessel from the reactor containment building to the onsite interim storage facility.

The charges for placement of the reactor pressure vessel in the interim storage facility and retrieval therefrom are sufficient to cover the costs of construction, operation, and decommissioning of the storage cell.

The sequence for removal of the intact reactor pressure vessel from the reference PWR follows:

1. Remove, package, and ship the reactor internals to a nuclear waste disposal facility.

2. Remove a section of each line connected to the reactor vessel at the outer surface of the biological shield so that internal cutting tools can be inserted into the pipes.

3. Cut off the coolant loop nozzles just outboard of the reactor pressure vessel supports.

4. Cut off the remaining nozzles at the outer surface of the reactor pressure vessei.

5. Remove and package accessible insulation. 
6. Weld closures on bottom head nozzles.

7. Remove the control rod drives from the reactor vessel head, package, and ship them to a licensed nuclear waste disposal facility.

8. Seal the openings in the reactor vessel top head.

9. Install steel seal plate on top of the reactor pressure vessel.

10. Remove the steam generator shielding above the operating floor level that interferes with the laydown of the reactor vessel.

11. Install a temporary $400-\mathrm{Mg}$ crane above the operating floor.

12. Install a "greenhouse" over the refueling pool.

13. Install a high-pressure water-jet ring in the refueling pool for vessel decontamination.

14. Attach hoisting gear to the reactor vessel.

15. Lift the reactor vessel through the high-pressure water jet ring.

16. Weld closures on coolant inlet and outlet nozzles.

17. Remove "greenhouse."

18. Hoist the vessel from the reactor cavity and lay it down on a roller support in line with the equipment hatch.

19. Cut a hole in the roof of the fuel building through which the reactor pressure vessel can be removed.

20. Move the reactor vessel out of the containment building into the fuel building.

21. Lift the reactor vessel out of the fuel building and place it on an overthe-road transporter.

22. Move the pressure vessel to the onsite interim storage facility and place it in the storage cell.

23. Segment the vessel and package the segments for ultimate disposal at a licensed nuclear waste disposal facility, after the radiation dose rate has decayed to a level that permits contact work. 
A summary of the estimated cost of removing the intact reactor pressure vessel, storing it for 50 years, and segmenting, packaging, and disposing of the vessel is given in Table 11.4-1. The estimated total cost, $\$ 8,200,000$, is greater than the estimated cost of $\$ 5,157,000$ for removing the reactor pressure vessel in segments and disposing of the segments immediately, based on the cost estimates given in Reference 2 .

TABLE 11.4-1. Summary of Estimated Costs for Removal of the Intact Reactor Pressure Vessel from the Reference PWR

$\begin{array}{lr}\text { C_cost Category } & \begin{array}{r}\text { Estimated Cost } \\ \text { (\$ thousands) }\end{array} \\ \text { Removal and Disposal of Reactor Internals } & 3028 \\ \text { Decomissioning Worker Labor } & 261 \\ \text { Shielding for Vesse] Transport } & 23 \\ \text { Special Tools and Equipment } & 270 \\ \text { Disposal of Control Rods, Drives, \& Pipe Sections } & 44 \\ \text { Vessel Removal \& Transport } & 3460 \\ \text { Interim Storage Costs (50-Year Storage) } & 136 \\ \text { Segment Vessel } & 74 \\ \text { Disposal of Vessel Segments } & 915 \\ \text { Total } & 8211\end{array}$

The estimated occupational dose for removal of the intact reactor pressure vessel, storage for 50 years, and segmenting, packaging, and disposal of the segments is 172 man-rem. This estimate is about the same as the estimated occupational dose of 178 man-rem for removing the reactor pressure vessel in segments and disposing of the segments immediately, based on the occupational dose estimates given in Reference 2 .

\subsubsection{Removal of the intact BWR Reactor Pressure Vessel}

The Mark II containment of the reference BWR lends itself to relatively easy removal of the intact reactor pressure vessel. With the upper and lower shield plugs removed, the drywell head removed, and the section of the reactor 
building roof over the reactor removed, the reactor pressure vessei can be lifted vertically out of the building. A new reactor pressure vessel can be put in place by reversing the procedure.

Before the nuclear steam supply system is dismantled, the reactor pressure vessel and selected piping systems are chemically decontaminated. The procedures used and the costs incurred to perform this operation are discussed in Section H.5 of Reference 3. The procedures used and costs incurred to remove, package, and dispose of the reactor internais are described in Appendix I of Reference 3 .

The four steam lines and four instrument lines are connected to the reactor pressure vessel above the sacrificial shield and are accessible for cutting at the reactor pressure vessel wall. An additional 31 Tines penetrate the reactor vessel wall in the region of the sacrificial shield. In order to cut these ines at the outer surface of the reactor pressure vessel, a section of each line adjacent to the sacrificial shield is removed to provide access for the internal pipecutting tools or torches. Each of these 31 lines is cut at the outer surface of the reactor pressure vessel wail.

Two 1 ines are cut and 185 control rod drives are removed from the bottom head of the reactor pressure vessel, which is accessible through the control rod gallery.

A temporary crane with a lifting capacity of $700 \mathrm{Mg}$ is used to hoist the reactor pressure vessel out of the reactor cavity. As the vessel is hoisted from the reactor cavity, high-pressure water jets are directed at the outer surface of the vessel to remove any contamination. Sea? plates for contamination control are welded over the nozzle openings while the vessel is suspended from the temporary crane.

The reactor pressure vessel is lifted out of the reactor building through a hole in the roof and transported to the onsite interim storage facility by a contractor specializing in lifting and transporting very heavy vessels.

The charges for placement of the reactor pressure vessel in the interim storage facility and retrieval therefrom are sufficient to cover the costs of construction, operation, and decommissioning of the interim storage cell. 
The sequence for removal of the intact reactor pressure vessel from the reference BWR is:

1. Remove, package, and ship the reactor internals to a nuclear waste disposal facility.

2. Cut the four main steam 1 ines at the reactor vessel wall and remove a section of each line.

3. Cut the four instrument lines that enter the reactor vessel above the sacrificial shield.

4. Cut the remainder of the lines at the outer surface of the sacrificial shield and remove a section of each line so that internal cutting tools can be inserted into the pipes.

5. Cut each of the lines at the outer surface of the reactor vessel wall.

6. Remove the 185 control rod drive housings from the bottom head and sea? the openings.

7. Cut off the lines connected to the bottom head and seal the openings .

8. Remove and package accessible insulation.

9. Install steel seal plate on top vessel flange.

10. Install a temporary $700-M g$ crane over the reactor cavity.

11. Install a "greenhouse" over the reactor well.

12. Install a high-pressure water jet ring in the reactor well.

13. Attach hoisting gear to the reactor pressure vessel.

14. Lift the reactor pressure vessel through ring of high-pressure water jets.

15. Lift the vessel so that seal plates can be welded over the nozzle openings.

16. Lower the reactor vessel onto the pedestal.

17. Remove the "greenhouse."

18. Remove the section of the reactor building roof that is over the reactor cavity. 
19. Lift the reactor vessel out of the reactor building and place it on an over-the-road transporter, using a long-boomed crane.

20. Move the reactor pressure vessel to the onsite interim storage facility and place it in a storage cell.

21. Segment the reactor vessel and package the segments for disposal at a licensed nuclear waste disposal facility, after the radiation dose rate has decayed to a level that permits contact work.

The estimated costs of removing the intact reactor pressure vessel from the reference BWR, storing it for 50 years, and segmenting, packaging, and disposing of the segments are summarized in Table 11.4-2. The estimated total cost, $\$ 9,093,000$, is greater than the estimated cost of $\$ 8,483,000$ for removing the vessel in segments immediately, based on the cost estimates given in Reference 3 .

TABLE 11.4-2. Summary of Estimated Costs for Remova] of the Intact Reactor Pressure Vessei from the Reference BWR

\begin{tabular}{lc}
\multicolumn{1}{c}{ Cost Category } & $\begin{array}{c}\text { Estimated Cost } \\
\text { (\$thousands) }\end{array}$ \\
Removal and Disposal of Reactor Internals & 5333 \\
Decommissioning Worker Labor & 499 \\
Special Tools and Equipment & 326 \\
Disposal of Control Rods, Drives, \& Pipe Sections & 58 \\
Vessel Removal \& Transport & 2308 \\
Interim Storage Costs (50-Year Storage) & 118 \\
Segment Vessel & 183 \\
Disposal of Vessel Segments & 9093 \\
Total & \\
The estimated occupational dose for removal of the intact reactor pressure \\
storage for 50 years, and segmenting, packaging, and disposal of the
\end{tabular}


dose of 164 man-rem for removing the vessel in segments and disposing of the segments immediately, based on the occupational dose estimates given in Reference 3.

\section{1].4.3 Other Intact Vesse] Removal Analyses}

As part of the DOE-sponsored Shippingport Decommissioning Project, Burns and Roe, with support from Nuclear Energy Services, is performing analyses on a variety of scenarios for the removal and disposal of the reactor pressure vessel and its internals from the Shippingport Station during immediate dismantlement. These analyses are expected to be documented during CY-1982. While no quantitative estimates are presently available, initial results suggest that intact removal, transport, and disposal of the vessel and its internals may result in lower costs and occupational radiation dose than the other alternatives considered, for the particular situation at Shippingport Station. From calculations of the quantity and distribution of radioactivity in the vessel and its internals, it appears that the radioactivity will be sufficiently small to permit the assembly to be transported by barge as low specific activity (LSA) material shipment. The size and weight of the intact assembly precludes consideration of truck or rail shipment.

The much higher levels of radioactivity anticipated in the reactor vessels and their internals for the reference PWR and BWR appear to make intact removal and disposal of those vessels a less than optimum alternative, as indicated in the two preceding subsections.

\subsubsection{Modular Biological Shield}

A modular biological shield could conceivably reduce the occupational radiation dose from DECON of the facility or from installation of a new reactor pressure vessel if the facility is to be reused. However, a modular biological shield would have little impact on the cost and occupational radiation dose for removal of the intact reactor pressure vessel, since the modular biological shield would not be removed until after the reactor pressure vessel had been removed. 
Neutron activation of the concrete and steel in the biological shield is greatest at the inner surface of the shield and decreases rapidly through the wall of the shield. Virtually all of the activated material in the biological shield is present in the inner $1-m$ layer of the shield. In the modular shield concept shown in Figure 11.4-1, only that portion of the shield that will be activated during reactor operation is modularized. The modules form a rightcircular cylinder $6.1 \mathrm{~m}$ inside diameter, $7.9 \mathrm{~m}$ outside diameter, and $7.3 \mathrm{~m}$ high.

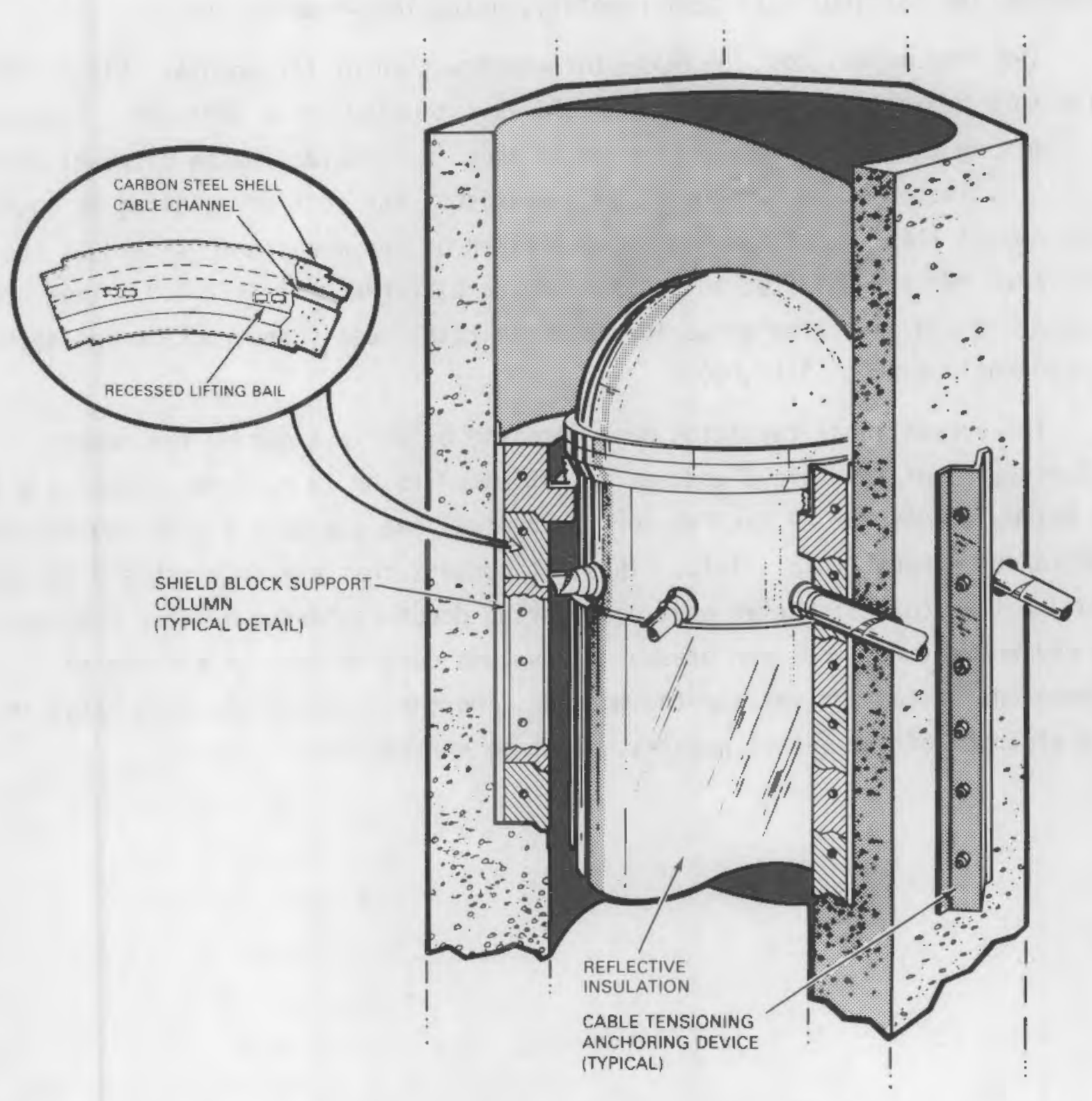

FIGURE 11.4-1. Conceptual Design - Modular Biological Shield 
There are six rings of modules. Each ring is $1.2 \mathrm{~m}$ high and contains eight modules. Each module weighs about $8 \mathrm{Mg}$. The modules are constructed by pouring concrete into carbon steel shells that are fabricated to close dimensional tolerances. As shown in Figure 11.4-1, the modules are stepped at the top and bottom to minimize radiation streaming and to provide lateral stability. Circumferential post-tensioned cables provide additional structural stability to that provided by the eight wide-flange I-beam columns. Each module has two recessed lifting bails in the top of the block. These bails are designed for engaging the lifting hooks semi-remotely, using long-handled tools.

The incremental cost increase for construction of the modular shield relative to a conventional monolithic shield is estimated to be $\$ 884,000$. The cost of removing the modules and disposing of them in a nuclear waste disposal facility is estimated to be $\$ 205,000$. By comparison, the cost of removing an equivalent amount $\left(145 \mathrm{~m}^{3}\right)$ of the activated portion of the monolithic shield at the reference PWR is estimated to be $\$ 337,000$, a difference of $\$ 172,000$. Thus, the modular shield is estimated to increase the total cost (construction and decommissioning) by about $\$ 712,000$.

The occupational radiation dose received by workers during the removal and disposal of the shield modules is estimated to be 13 man-rem, compared with an estimated dose of 29 man-rem for the removal and disposal of the equivalent portion of a monolithic shield. Thus, it appears that a modular shield design would not be cost-effective when considering decommissioning alone. However, if replacement of a reactor pressure vessel is considered, the ability to remove and restack or replace the modules, thereby reducing the dose rates in the vicinity of the vessel nozzles, might be worthwhile. 


\section{REFERENCES}

1. E. B. Moore, Jr., Facilitation of Decommissioning Light Water Reactors, NUREG/CR-0569, U.S. Nuclear Regulatory Commission Report by Pacific Northwest Laboratory, December 1979.

2. R. I. Smith, G. J. Konzek and W. E. Kennedy, Jr., Technology, Safety and Costs of Decommissioning a Reference Pressurized Water Reactor Power Station, NUREG/CR-0130, U.S. NuClear Regulatory Commission Report by Pacific Northwest Laboratory, June 1978.

3. H. D. Oak, et al., Technology, Safety and Costs of Decommissioning a Reference Boiling Water Reactor Power Station, NUREG/CR-0672, U.S. Nuclear Regulatory Commission Report by Pacific Northwest Laboratory, october 1979 .

4. Capital Cost: Pressurized Water Reactor Plant, NUREG-0241, prepared for the U.S. Nuclear Regulatory Commission and the Energy Research and Development Administration by United Engineers and Constructors, Inc., June 1977.

5. Capital Cost: Boiling Water Reactor Plant, NUREG-0242, prepared for the U.S. Nuciear Regulatory Commission and the Energy Research and Development Administration by United Engineers and Constructors, Inc., June 1977.

6. C. A. Negin, et a\}., "Planning Study and Economic Feasibility for Extended Life Operation of Light Water Reactor Plants," in Proceedings of ANS Topical Meeting on Decontamination and Decommissioning of Nuclear Facilities, ed., M. M. Osterhout, pp. 471-484, Plenum Press, New York and London, 1979. 

APPENDICES 
APPENDIX A

\section{NUCLEAR WASTE DISPOSAL COST ESTIMATES}

Three options for disposing of nuclear waste from reactor decommissioning are examined in this study: 1) immediate offsite disposa1, 2) onsite interim storage with later removal to offsite disposal, and 3) onsite disposal. Cost estimates for immediate offsite disposal of nuclear waste from multiple-reactor decomissioning are not discussed here because they are the same as for singlereactor decommissioning.

Waste disposal costs are estimated for decomissioning each type of reactor (PWR and BWR) by each of the three alternative methods, DECON, SAFSTOR, and ENTOMB. The nuclear waste disposal costs are estimated separately for neutronactivated material, contaminated material, and radioactive waste.

\section{A. 1 ONSITE INTERIM STORAGE}

Onsite interim storage of nuclear waste from the decomissioning of reactors may be used to reduce the cost of waste disposal. It is conceived that the nuclear waste at a multiple-reactor station could be placed in interim onsite storage for a period long enough for radioactive decay to reduce the quantity of waste that must be disposed of in a licensed burial facility. In this study, onsite interim storage periods of 30,50 , and 100 years are used in the cost estimates. At the end of the storage period, the nuclear waste is retrieved from the interim storage facility, checked for radiation dose rate, and shipped to an offsite licensed waste disposal facility.

Assumptions made in estimating the costs of onsite interim storage of nuclear waste are:

1. The quantity of nuclear waste placed in onsite interim waste storage is the same as would be sent to an offsite waste disposal facility.

2. The packaging used for disposal of radioactive material is able to withstand interim storage, retrieval from storage, and relocation to an offsite permanent disposal facility without requiring repackaging. 
3. Since transport to interim onsite waste storage is over private roads within a privately owned and controlled area, it is assumed that it is not necessary to meet the DOT surface radiation dose rate requirement. Shielding is provided for the truck cab to 1 imit the dose rate to $2 \mathrm{mR} / \mathrm{hr}$. The radiation dose of workers is controlled to assure that it does not exceed the 10 CFR 20 limits. This assumption should result in fewer cask loads and the use of fewer shielded cask liners.

4. The onsite interim waste storage facility is $24 \mathrm{~km}$ from the reactor and the onsite transport cost is $\$ 1.43 / \mathrm{km}$ for a truck.

5. The cost of placing and maintaining nuclear waste in interim storage is equal to the disposal charge at a licensed waste disposal site $\left(\$ 93.57 / \mathrm{m}^{3}\right)$. (a)

6. There are no 1 iner or curie surcharges at the onsite storage facility.

7. The cost of retrieving the waste from interim storage is the same as the disposal charge at a licensed waste disposal site $\left(\$ 93.57 / \mathrm{m}^{3}\right)$. (a)

8. After interim storage for 30 to 100 years, some of the contaminated material will have decayed to levels permitting unrestricted release. Therefore, the quantity of nuclear wastes that eventually must be sent to offsite disposal is less than would be sent immediately to offsite disposal.

9. The liner and curie surcharges at the commercial waste disposal facility are lower after temporary onsite storage because of radioactive decay that has occurred.

10. For neutron-activated material, the radioactive decay during temporary storage of even 100 years is insufficient to permit unrestricted release of the material. Therefore, all of the neutron-activated material must be relocated to a licensed waste disposal facility after interim onsite storage.

(a) It is estimated that these placement and retrieval charges are greater than the cost of construction, operation, depreciation, and decommissioning of the interim waste storage facility. 


\section{A.1.1 Reference PWR Decommissioning Wastes}

Data for determining the impact on costs of onsite interim storage of the nuclear wastes from decommissioning the reference PWR are taken from the study of decommissioning a reference PWR by Smith et al. (1) Radioactive decay factors for neutron-activated material used in the cost analyses are given in Table A.1-1 for the radioactivity levels and the dose rates.

\section{TABLE A.1-1. Decay Factors for Radioactivity Levels and Dose Rates of Neutron-Activated Materials in the Reference PWR}

\begin{tabular}{|c|c|c|}
\hline \multirow{2}{*}{$\begin{array}{l}\text { Time After } \\
\text { Shutdown } \\
\text { (Years) }\end{array}$} & \multicolumn{2}{|c|}{ Decay Factors (a) } \\
\hline & Radioactivity Level & Dose Rate \\
\hline 30 & $5.2 \times 10^{-2}$ & $1.9 \times 10^{-2}$ \\
\hline 50 & $4.6 \times 10^{-2}$ & $1.4 \times 10^{-3}$ \\
\hline 60 & $4.3 \times 10^{-2}$ & $3.7 \times 10^{-4}$ \\
\hline 80 & $3.7 \times 10^{-2}$ & $3.7 \times 10^{-5}$ \\
\hline 100 & $3.2 \times 10^{-2}$ & $1.3 \times 10^{-5}$ \\
\hline 130 & $2.6 \times 10^{-2}$ & $1.15 \times 10^{-5}$ \\
\hline 150 & $2.2 \times 10^{-2}$ & $3.1 \times 10^{-5}$ \\
\hline 200 & $1.5 \times 10^{-2}$ & $1.1 \times 10^{-5}$ \\
\hline
\end{tabular}

(a) Based on Figure C.3-1 of Reference 1.

The costs for disposal of the neutron-activated materials at 30,50, and 100 years after shutdown are given in Table A.1-2.

\section{A.1.1.1 Waste from DECON}

In the following subsections, estimated costs for disposal of each type of nuclear waste from DECON are developed for onsite interim storage and later offsite disposal of the waste. 

TABLE A.1-2. PWR Costs for Disposal of Neutron-Activated Materials at Various Times after Shutdown (Based on Table G.4-3, Reference 1)

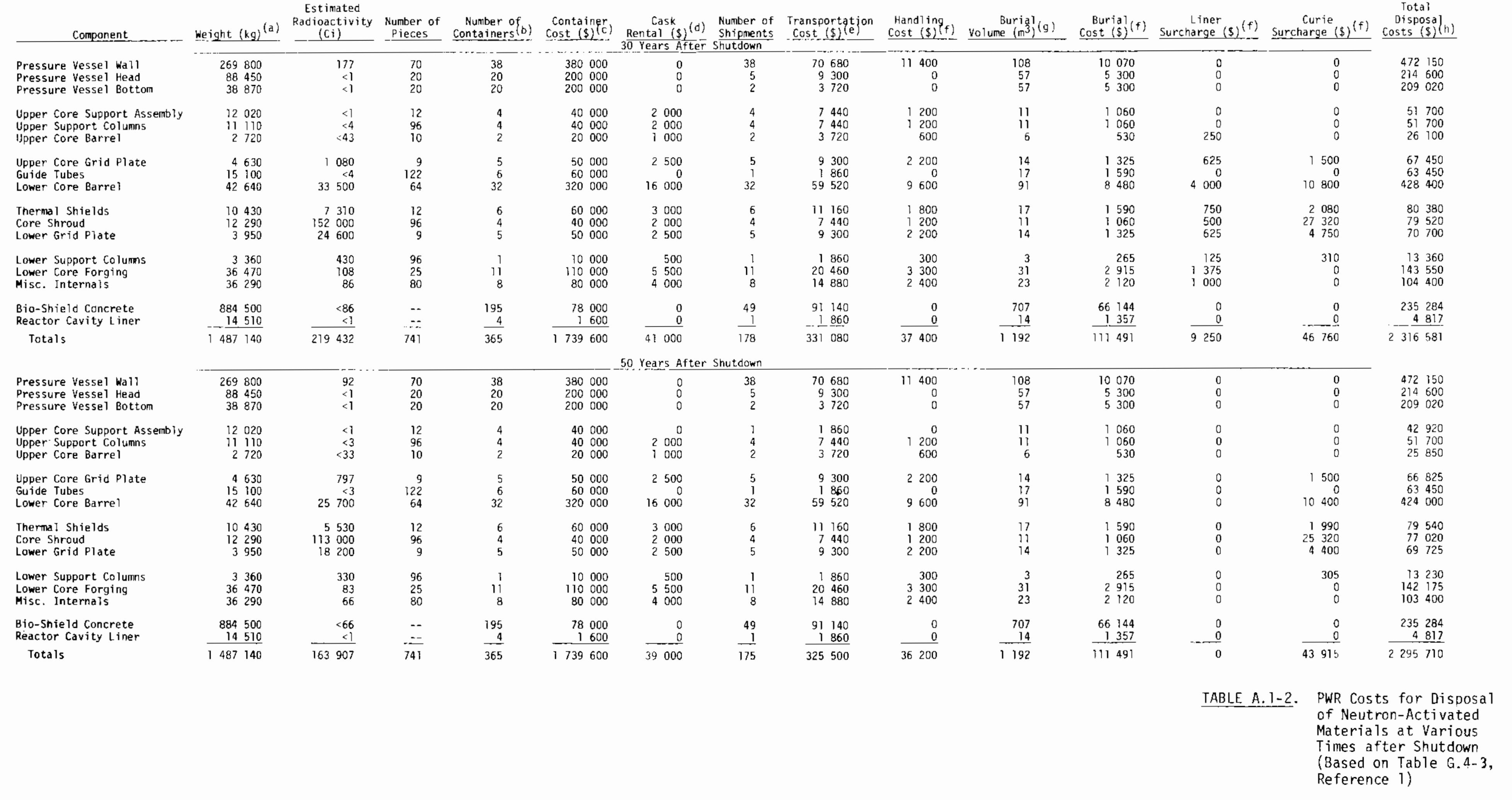




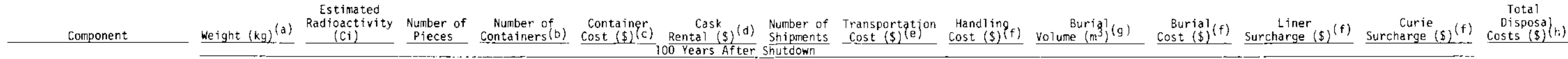

Pressure Vessel wall

$\begin{array}{rr}269800 & 64 \\ 88450 & <1 \\ 38870 & <1\end{array}$

Pressure vessel Head
Pressure vessel Bottom

Upper Core Support Assembly

Upper Support Columns
Upper Core Barrel

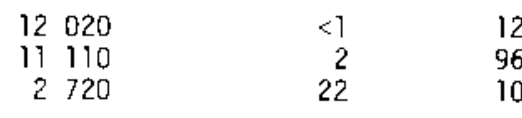

$\begin{array}{rrr}12020 & <1 & 12 \\ 11110 & 2 & 96 \\ 2720 & 22 & 10\end{array}$

I.jper Core Grid Plate

Guide Tubes
Lower Core Barrel

$\begin{array}{rrr}45630 & 557 & 9 \\ 15100 & 2\end{array}$

Thermal Shields

Lower Grid Plate

Lower Support Columns
Lower Core Forging

42640

$\begin{array}{rrr}42640 & 18000 & 64 \\ 10430 & 3870 & 12 \\ 12290 & 78500 & 96 \\ 3950 & 12700 & 9\end{array}$

$\begin{array}{rrr}3360 & 220 & 96 \\ 36470 & 55 & 25 \\ 36290 & 44 & 80\end{array}$

Bio-Shield Concrete
Reactor Cavity Liner

$36290-44-80$

Totals

884500
14510
1487140 $\frac{<44}{114040} \quad \frac{-}{741}$

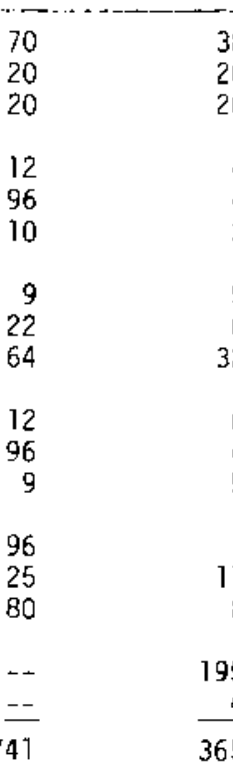

\begin{tabular}{rrrr}
38 & 380000 & 0 & 38 \\
20 & 200000 & 0 & 5 \\
20 & 200000 & 0 & 2 \\
4 & 40000 & 0 & 1 \\
4 & 40000 & 2000 & 4 \\
2 & 20000 & 1000 & 2 \\
5 & 50000 & 2500 & 5 \\
5 & 60000 & 1600 & 32 \\
32 & 320000 & 16000 & 6 \\
6 & 60000 & 3000 & 6 \\
4 & 40000 & 2000 & 4 \\
5 & 50000 & 2500 & 5 \\
1 & 10000 & 500 & 1 \\
11 & 110000 & 5500 & 11 \\
8 & 80000 & 4000 & 8 \\
195 & 78000 & 0 & 49 \\
4 & 7.1600 & 0 & 1 \\
\hline 365 & 1739600 & 39000 & 175
\end{tabular}

$\begin{array}{r}38 \\ 5 \\ 2 \\ 1 \\ 4 \\ 2 \\ 5 \\ 1 \\ 32 \\ 6 \\ 4 \\ 5 \\ 1 \\ 11 \\ 8 \\ 49 \\ 1 \\ 175 \\ \hline 7\end{array}$

70680
9300
3720

$\begin{array}{rr}1 & 860 \\ 7 & 440 \\ 3 & 1200\end{array}$

(a) Weights approximate, calculated from dimensions or obtained from Trojan FSAR.

the $50,000 \mathrm{ci} /$ container limit for burial.

(c) Based on Table I.2-1, Reference
(d) Based on Table I. $3-1$, Reference

(f) Based on Table I.4-4, Reference 1 .

g) Yolume includes the disposable container.
h) The number of figures shown is for computational accuracy and does not imply precision to that many significant figures. 

A.1.1.1.1 Neutron-Activated Material. The two major operations involved in disposal of the nuclear waste with onsite interim storage are: 1) placement of the waste in interim storage and 2) removal of the waste to permanent offsite disposal.

placement in Interim Storage. Several components of the cost of putting the neutron-activated material in interim storage are container cost, cask rental, transportation cost, handling cost, and placement cost. The estimated costs of putting the neutron-activated material from DECON of a reference PWR in onsite interim storage are presented in Table A.1-3.

\section{IABLE A.1-3. Estimated Costs of Onsite Interim Storage of Neutron-Activated Material from DECON of a PWR}

Cost Component
Containers
Cask Rental
Onsite Transportation
Handling
Placement
Total

$\operatorname{cost(\$ )}$
$1739600^{(a)}$
$16600^{(b)}$
$14840^{(c)}$
$50600^{(a)}$
$111491^{(a)}$
1933130

(a) From Table G.4-3, Reference 1 .

(b) 1-day cask rental (1/5 the cost given in Table G.4-3, Reference 1).

(c) 216 shipments with a round-trip distance of $48 \mathrm{~km}$. $216 \times 48 \times 1.431=\$ 14,840$

Removal to Offsite Disposal. Details of the cost estimates for removal of the neutron-activated material to an offsite licensed disposal facility are sumarized in Table A.1-4. 
TABLE A.1-4. Estimated Cost of Removal to Offsite 0isposal of the Neutron-Activated Material from DECON of a PWR

\begin{tabular}{|c|c|c|c|c|}
\hline $\begin{array}{c}\text { Cost } \\
\text { Component }\end{array}$ & $\begin{array}{c}\text { Costs }(\$) \\
30 \text { Year }\end{array}$ & $\begin{array}{r}\text { After Interim } \\
50 \text { Year }\end{array}$ & Storage & $\frac{\text { Period of }(a)}{100 \text { Year }}$ \\
\hline Retrieve From Interim Storage & 111490 & 114490 & & 111490 \\
\hline Cask Rental & 4] 000 & 39000 & & 39000 \\
\hline Transportation & 331080 & 325500 & & 325500 \\
\hline Handling & 37400 & 36200 & & 36200 \\
\hline Burial & 111490 & 111490 & & 111490 \\
\hline Liner Surcharge & 9250 & 0 & & 0 \\
\hline Curie Surcharge & 46760 & $43 \quad 918$ & & $41 \quad 430$ \\
\hline Totals & 688470 & 667600 & & 665110 \\
\hline
\end{tabular}

(a) From Table A.1-2.

A.1.1.1.2 Contaminated Material. The costs for the two major operations involved in disposal of contaminated material by onsite interim storage are estimated below.

Placement in Interim Storage. Estimated costs of putting the contaminated material from DECON of a reference PWR in onsite interim storage are given in Table A.1-5.

TABLE A.1-5. Estimated Costs of Onsite Interim Storage of Contaminated Material from DECON of a PWR

\begin{tabular}{lrr}
\multicolumn{1}{c}{ Cost Component } & & $\operatorname{Cost}(\$)$ \\
Containers & & $66330^{(b)}$ \\
Onsite Transportation & & $393200^{(\mathrm{c})}$ \\
Handiing & 1504598 \\
Placement & 3467450
\end{tabular}
(a) From Tables G.4-4 and G.4-5, Reference 1.
(b) 967 shipments with a round-trip distance of $48 \mathrm{~km}$.
(c) From Table G.4-4, Reference 1. 
Removal to Offsite Disposaz. Details of the cost estimates for removal of the contaminated material to an offsite licensed disposal facility are summarized in Table A.1-6.

TABLE A.1-6. Estimated Costs of Removal to Offsite 0isposal of the Contaminated Material from DECON of a PWR

\begin{tabular}{|c|c|c|c|}
\hline $\begin{array}{c}\text { Cost } \\
\text { Component }\end{array}$ & $\frac{\text { Costs }(\$) \text { After }}{30 \text { Year }}$ & $\begin{array}{l}\text { Interim Storag } \\
50 \text { Year }\end{array}$ & e Period of \\
\hline Retrieve from interim Storage & $310720^{(a)}$ & $310720^{(a)}$ & $310720^{(a)}$ \\
\hline Transportation & $1781680^{(b)}$ & $11520^{(d)}$ & $11520^{(d)}$ \\
\hline Handling & $39320\langle c\rangle$ & 0 & 0 \\
\hline Burial & $1504600^{(b)}$ & $9357^{(d)}$ & $9357^{(d)}$ \\
\hline Totals & 3636320 & 331597 & 331597 \\
\hline
\end{tabular}

(a) 4154 containers: Assume 4 man-hr per container; $\$ 18.70$ per man-hr. $4154 \times 4 \times 18.70=\$ 310,720$.

(b) From Tables G.4-4 and G.4-5, Reference 1.

(c) From Table G.4-4, Reference 1 .

(d) Based on $100 \mathrm{~m}^{3}$ of contaminated material sent to an offsite licensed burial facility.

A.1.1.1.3 Radioactive Waste. Estimated costs for placement of the radioactive waste in onsite interim storage and later removal to offsite permanent disposal are shown in Tables A.1-7 and A.1-8, respectively.

\section{A.1.1.2 Waste from SAFSTOR}

SAFSTOR involves two major activities that generate radioactive waste: 1) preparations for safe storage and 2) deferred decontamination at the end of the storage period. Waste disposal costs are estimated for deferred decontamination after storage periods of 30,50 , and 100 years. Since onsite interim storage of waste is being examined for storage periods of 30,50 , and 100 years, the cost of removal of the radioactive waste to an offsite licensed disposal facility is estimated for times after shutdown ranging from 60 to 200 years. 
TABLE A.1-7. Estimated Costs of Onsite Interim Storage of Radioactive waste from DECON of a PWR

\begin{tabular}{lr} 
Cost Component & Cost (\$j) \\
\hline Containers & $136650^{(a)}$ \\
Cask Rental & $12000^{(b)}$ \\
Onsite Transportation & $9820^{(c)}$ \\
Handling & $24000^{(d)}$ \\
Placement & $57876^{(a)}$ \\
$\quad$ Total &
\end{tabular}

(a) From Table G.4-6, Reference 1 .

(b) Assumed that shielded casks would be needed only for spent resins, spent filter cartridges, and evaporator bottom liquids. One day cask rental per snipment.

(c) i43 shipments with a round-trip distance of $48 \mathrm{~km}$. $143 \times 48 \times 1.431=\$ 9820$.

(d) Handiing costs from Table G.4-ó, Reference $I$, for spent resins spent filter cartridges, and evaporator bottom i iquids.

TABLE A.1-8. Estimated Costs of Removal to Offsite Disposal of Radioactive Waste from DECON of a PWR

Cost Component

Retrieval from
Cask Rental
Transportation
Liner Surcharge
Burial
Totals
Costs (\$) After Interim Storage Period of 30 Year 50 Year 100 Year

Interin storage

\begin{tabular}{rl}
112 & $650^{(a)}$ \\
10 & $000^{(b)}$ \\
94 & $480^{(c)}$ \\
2 & $500^{(f)}$ \\
49 & $780^{(f)}$ \\
\hline 259 & 410
\end{tabular}

$112650^{(a)}$

$112650^{(a)}$

0

$32640^{(d)}$

0 $26380^{(e)}$ 0

$\frac{35740(9)}{181300}$

(a) 1506 containers at 4 man-hr per container with a charge-out rate of $\$ 13.70$ per man-hr.

(b) Casks needed oniy for spent resins.

(c) 44 shipments at $\$ 1920$ per shipment.

(d) 17 shipments at $\$ 1920$ per shipment.

(e) 14 shipments at $\$ 1920$ per shipment.

(f) $532 \mathrm{~m}^{3}$ at $\$ 93.57$ per $\mathrm{m}^{3}$.

(g) $382 \mathrm{~m}^{3}$ at $\$ 93.57 \mathrm{per} \mathrm{m}^{3}$.

(h) $332 \mathrm{~m}^{3}$ at $\$ 93.57$ per $\mathrm{m}^{3}$. 
The estimated costs for the disposal of each type of nuclear waste from SAFSTOR of the reference PWR are developed in the following subsections for onsite interim storage and eventual offsite disposal.

A.1.1.2.1 Neutron-Activated Material. No neutron-activated material is removed from the reactor during the preparations for safe storage. During deferred decontamination, all of the neutron-activated material is removed from the reactor, packaged, and sent to onsite interim storage. The estimated costs for placement of the neutron-activated material in onsite interim storage are summarized in Table A.1-9.

TABLE A.1-9. Estimated Costs of Onsite Interim Storage of Neutron-Activated Material from Deferred Decontamination of a PWR

\begin{tabular}{|c|c|c|c|c|}
\hline $\begin{array}{c}\text { Cost } \\
\text { Component }\end{array}$ & $\frac{\text { Costs (\$) Af }}{30 \text { Year }}$ & ter Safe Stora & & $\begin{array}{l}\text { Period of } \\
100 \text { Year }\end{array}$ \\
\hline Containers & $1739600^{(a)}$ & $1739600^{(a)}$ & & $739600^{(a)}$ \\
\hline Cask Rental & $11200^{(b)}$ & 0 & & 0 \\
\hline Onsite Transportation & $12230^{(c)}$ & $7290^{(d)}$ & & $7290^{(d)}$ \\
\hline Handl ing & $35000^{(\mathrm{e})}$ & 0 & & 0 \\
\hline Placement & $111490^{(a)}$ & $111490^{(a)}$ & & $111490^{(a)}$ \\
\hline Totals & 1909520 & I 858380 & 1 & $858 \quad 380$ \\
\hline
\end{tabular}

(a) From Table G.4-3, Reference 1 .

(b) Casks used only for cask liners with a surface dose rate $>1.0 \mathrm{R} / \mathrm{hr}$.

(c) 178 shipments with a round-trip distance of $48 \mathrm{~km}$.

$178 \times 48 \times 1.431=\$ 12,230$

(d) 106 shipments $106 \times 48 \times 1.431=\$ 7,290$

(e) For cask shipments.

Estimated costs for removal of the neutron-activated material from onsite interim storage and disposal at an offsite licensed disposal facility are shown in Table A.1-10. Onsite interim storage periods of 30,50, and 100 years are used in the cost estimates. For deferred decontamination 30 years after reactor shutdown, removal to offsite disposal would occur 60,80 , and 100 years after reactor shutdown. 
TABLE A.1-10. Estimated Costs of Removal to Offsite Disposal of NeutronActivated Material from Deferred Decontamination of a PWR

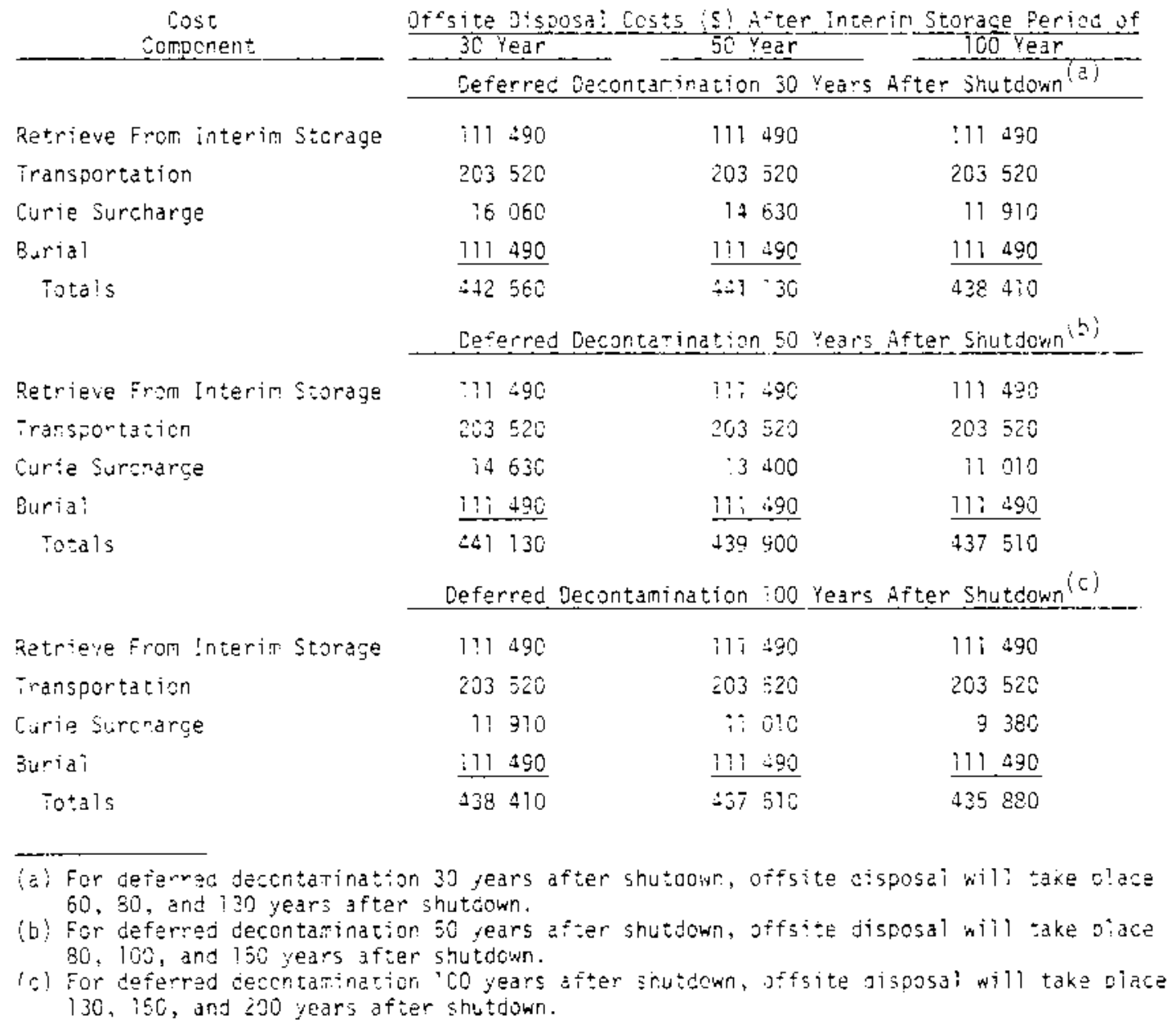

A.1.1.2.2 Contaminated Material. Contaminated material is removed from the reactor and placed in onsite interim storage during deferred decontamination, not during preparations for safe storage. Estimated costs for placement of the contaminated material in onsite interim storage are given in Table A.1-11.

Estimated costs for removal to offsite disposal of the contaminated material from onsite interim storage are shown in Table A.1-12. 
TABLE A.1-17. Estimated Costs of Onsite Interim Storage of Contaminated Material from Deferred Decontamination of a PWR

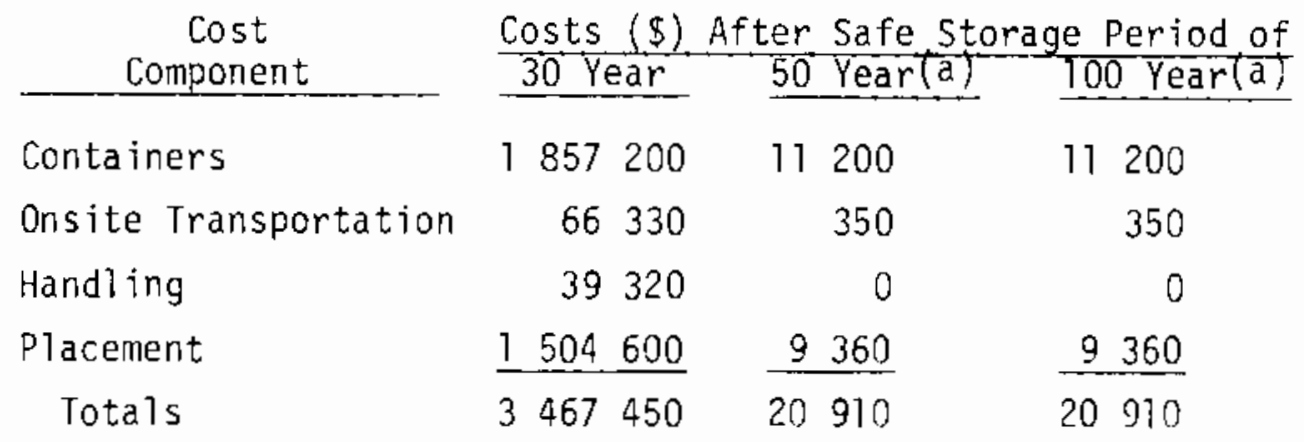

(a) Based on $100 \mathrm{~m}^{3}$ of contaminated material for disposal. See Table H.5-1, Reference 3.

TABLE A.1-12. Estimated Costs of Removal to Offsite Disposal of Contaminated Material from Deferred Decontamination of a PWR

\begin{tabular}{|c|c|c|c|}
\hline $\begin{array}{l}\text { Cost } \\
\text { Component }\end{array}$ & \multirow{2}{*}{\multicolumn{3}{|c|}{ 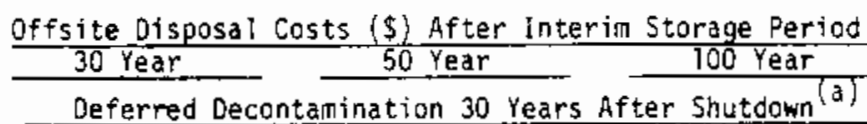 }} \\
\hline \multirow[b]{2}{*}{ Retrieve From Interin Storage } & & & \\
\hline & 310550 & 310550 & 310550 \\
\hline Transportation & 9600 & 9600 & 5760 \\
\hline Burial & 9360 & 9360 & 4680 \\
\hline \multirow[t]{2}{*}{ Totals } & 329510 & 329510 & 320990 \\
\hline & \multicolumn{3}{|c|}{ Deferred Decontamination 50 Years After Shutdown (b) } \\
\hline Retrieve From Interin Storage & 2100 & 2100 & 2100 \\
\hline Transportation & 9600 & 9600 & 5760 \\
\hline Burial & 9360 & 9360 & 4680 \\
\hline \multirow[t]{2}{*}{ Totals } & 21060 & 21060 & 12540 \\
\hline & \multicolumn{3}{|c|}{ Deferred Decontamination 100 Years After Shutdown $(c)$} \\
\hline Retrieve From Interia Storage & 2100 & 2100 & 2100 \\
\hline Transportation & 5760 & 5760 & 3840 \\
\hline Buriat & 4680 & 4680 & 2810 \\
\hline Totals & 12540 & 12540 & 8750 \\
\hline \multicolumn{4}{|c|}{$\begin{array}{l}\text { (a) For deferred decontamination } 30 \text { years after shutdown, offsite disposal will occur } \\
60,80 \text {, and } 130 \text { years after shutdown. } \\
\text { (b) For deferred decontamination } 50 \text { years after shutdown, offsite disposal will occur } \\
80,100 \text {, and } 150 \text { years after shutdown. } \\
\text { (c) For deferred decontamination } 100 \text { years after shutdown, offsite disposal will occur } \\
130,150 \text {, and } 200 \text { years after shutdown. }\end{array}$} \\
\hline
\end{tabular}


A.1.1.2.3 Radioactive Waste. All of the wet solid waste and some of the dry solid waste generated by SAFSTOR are disposed of during preparations for safe storage. Disposal costs are developed in two steps: 1) for those radioactive wastes generated during preparations for safe storage and 2) for those radioactive wastes generated during deferred decontamination.

Preparations for Safe Storage. Estimated costs for placement in onsite interim storage of the radioactive waste from preparations for safe storage are summarized in Table A.T-13.

TABLE A.1-13. Estimated Costs of Onsite Interim Storage of Radioactive Waste from Preparations for Safe Storage of a PWR

\begin{tabular}{|c|c|}
\hline Cost Component & $\operatorname{Cost}(\$)$ \\
\hline Containers & $114970^{(a)}$ \\
\hline Cask Renta 1 & $12000^{(\mathrm{b})}$ \\
\hline Onsite Transportation & $8450^{(c)}$ \\
\hline Handling & $24000^{(d)}$ \\
\hline Placement & $36330^{(\mathrm{e})}$ \\
\hline Total & 195750 \\
\hline
\end{tabular}

(a) From Table H.3-2, Reference 1.

(b) One day cask rental for each shipment. Casks used only for cask liners with a surface dose rate $>1 \mathrm{R} / \mathrm{hr}$.

(c) 139 shipments with round-trip distance of $48 \mathrm{~km}$.

(d) For spent resins, spent filter cartridges, and evaporator bottoms 1iquids.

(e) Assumed to be the same as the burial cost given in Table H.3-2, Reference $?$.

The estimated costs for removal to offsite disposal of the radioactive waste from preparations for safe storage are given in Table A.1-14. 
TABLE A.1-14. Estimated Costs of Removal to Offsite Disposal of Radioactive Waste from Preparations for Safe Storage of a PWR

\begin{tabular}{|c|c|c|c|c|}
\hline $\begin{array}{c}\text { Cost } \\
\text { Component }\end{array}$ & Offsite Disposal & Costs (\$) After Interin & Storage & $\begin{array}{l}\text { Period of } \\
\text { Year }\end{array}$ \\
\hline Retrieve From Interim Storage & $31550^{(\mathrm{d})}$ & $31550^{(a)}$ & & $550^{(a)}$ \\
\hline Cask Rental & $10000^{(\mathrm{b})}$ & 0 & & 0 \\
\hline Transportation & $55680^{(c)}$ & $13440^{(d)}$ & & $9600(\mathrm{e})$ \\
\hline Liner Surcharge & 2500 & 0 & & 0 \\
\hline Burial & $27520^{(\mathrm{f})}$ & $14040^{(9)}$ & & $9360^{(h)}$ \\
\hline Totals & 121250 & 59030 & 50 & 1) 510 \\
\hline
\end{tabular}

(a) 422 containers at 4 man-hr per container with a charge-out rate of $\$ 18.70$ per man-hr.

(b) Casks used only for those shipments with a cask-liner dose rate $>1$ p/hr. 5-day cask rental for each shipunent.

(c) 29 shipments at $\$ 1,920$ per shipment.

(d) 7 shipments at $\$ 1,920$ per shipment.

(e) 5 shipments at $\$ 1,920$ per shipment.

(f) $230 \mathrm{~m}^{3}$ at $\$ 93.57$ per $\mathrm{m}^{3}$.

(g) $150 \mathrm{~m}^{3}$ at $\$ 93.57$ per $\mathrm{m}^{3}$.

(h) $100 \mathrm{~m}^{3}$ at $\$ 93.57$ per $\mathrm{m}^{3}$.

Deferred Decontamination. Deferred decontamination after safe storage periods of 30,50 , and 100 years is studied. The estimated costs of placing the radioactive waste in onsite interim storage is shown in Table A.1-15, an the estimated costs of removal of the waste to offsite disposal is shown in Table A.7-16.

TABLE A.7-15. Estimated Costs of Onsite Interim Storage of Radioactive Waste from Deferred Decontamination of a PWR

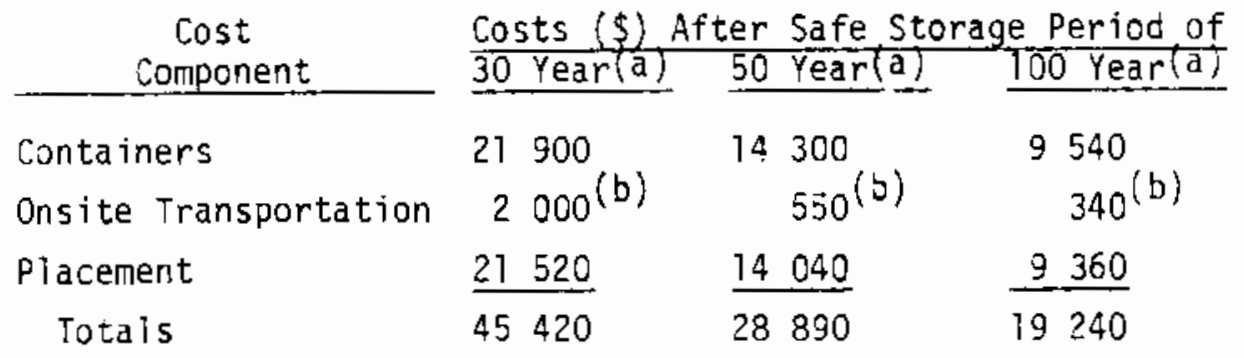

(a) Waste volumes assumed: 30 year $-230 \mathrm{im}^{3}$; 50 year $-150 \mathrm{~m}^{3}$; 100 year - $100 \mathrm{~m}^{3}$.

(b) Onsite round trip of $48 \mathrm{~km}$ at $\$ 1.431$ per $\mathrm{kn}$. Number of shipments: 30 year $-29 ; 50$ year $-8 ; 100$ year -5 . 
TABLE A. 3-16. Estimated Costs of Removal to Offsite Disposal of Radioactive Waste from Deferred Decontamination of a PWR

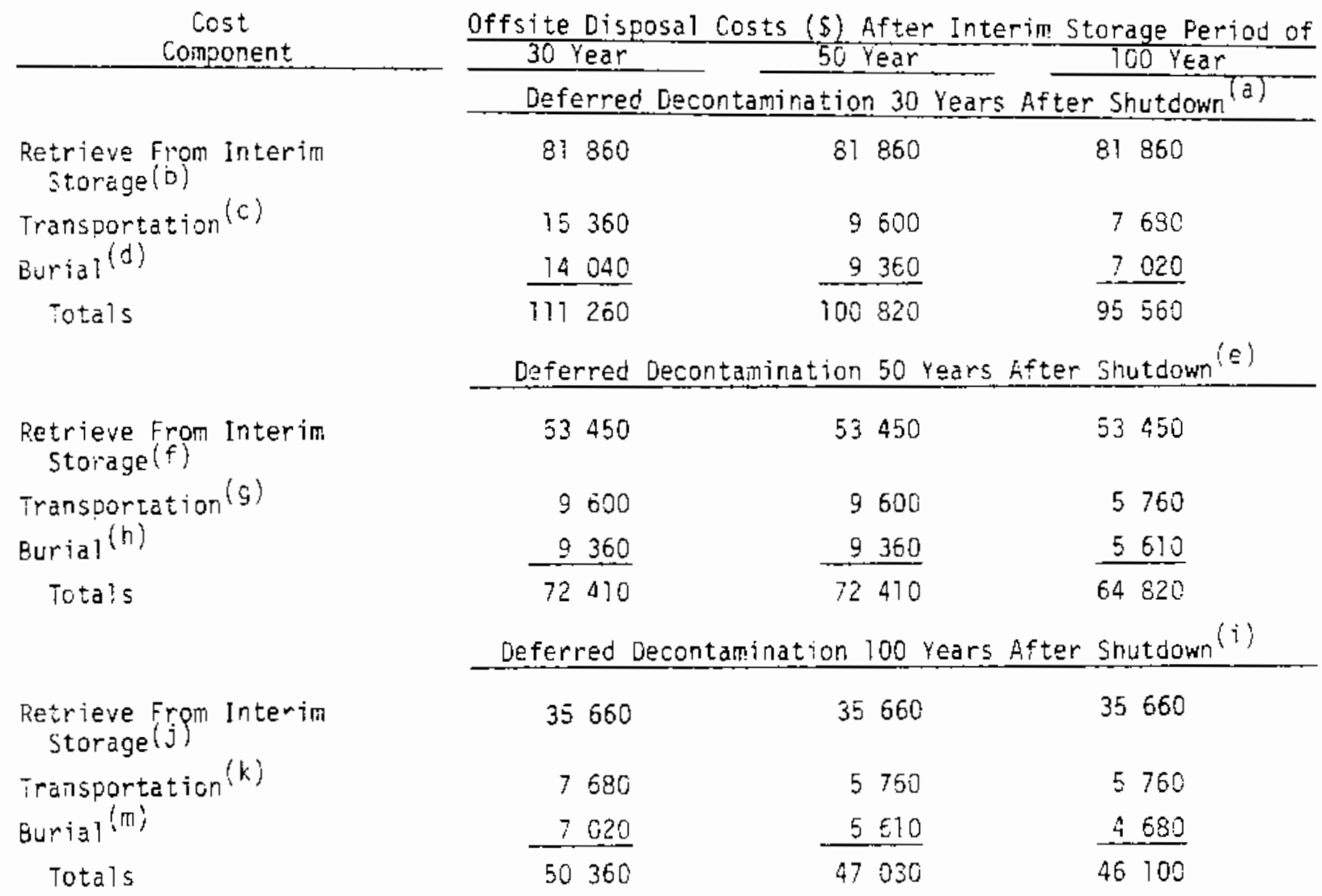

(a) For deferred decontamination 30 years after shlurdown, offsite disposal will occur 60 , 80 , and 130 years after shutdown.

(t) 1095 drums of waste. 4 man-hr per drum to check, segregate, and repackage. $\$ 19.70$ per mari-tir charge-out rate.

(c) 8 shipments for 30 years storage; 5 shipments for 50 years storage; 4 snipments for

(d) Burial volumes of waste assumed: $150 \mathrm{~m}^{3}$ at 30 years; $100 \mathrm{~m}^{3}$ at 50 years; $75 \mathrm{~m}^{3}$ at 100 years.

(e) For deferred decontaminaticn. 50 years after shutdown, offsite disposal will occur 80,100 , and 150 years after shutdown.

(f) 715 drums of waste retrieved, checked, segregated, and repackäged where necessary.

(g) 5 snipments for 30 or 50 years storage; 3 shipments for 100 years storage.

(h) Burial volumes of waste assumed: $100 \mathrm{~m}^{3}$ at 30 and 50 years stcrage; $60 \mathrm{~m}^{3}$ at 100 years storage.

(i) For deferred decontamination 100 years after shutdown, offsite disposai will occum 130,150 , and 200 years after shlitdown.

(j) 477 drums of waste retrieved, checked, and segregated.

(k) 4 shipments for 30 years storage; 3 shipments for 50 and 100 years storage.

(m) Burial volumes of waste assumed: $75 \mathrm{~m}^{3}$ at 30 years; $60 \mathrm{~m}^{3}$ at 50 years; $50 \mathrm{~m}^{3}$ at 100 years. 


\section{A.1.1.3 Waste from ENTOMB}

Decommissioning the PWR by ENTOMB utilizes the space below the operating floor of the containment building as a nuclear waste repository. Non-combustible contaminated materials from outside of the entombment space are placed in the voids in the entombment space; however, there is insufficient space to accommodate all of the contaminated material at the nuclear power plant. The remaining contaminated material and the radioactive waste are disposed of in the same manner as the contaminated material from DECON of a PWR. Two scenarios were proposed for ENTOMB in the PWR and BWR decomissioning studies. (1,2) In the first scenario, the neutron-activated reactor internals are removed and sent to waste disposal, and in the second scenario, the reactor internals are entombed. In this study, waste disposal for the first entombment scenario, with the reactor internals removed, is studied in detail. The impact on costs should be similar for the second scenario, but this impact is not examined in detail in this study.

Estimated costs for disposal of each type of radioactive material from ENTOMB by interim storage of the waste onsite followed by later removal to an offsite licensed disposal facility are developed in this subsection.

A.1.1.3.1 Neutron-Activated Material. Reactor internals are the only neutron-activated material removed during ENTOMB of the reference PWR. The estimated costs of placing the reactor internals in onsite interim storage are given in Table A.1-77. The estimated costs of removal of the reactor internals to offsite disposal after onsite interim storage periods of 30,50 , and 100 years are presented in Table A. -18 .

A.7.1.3.2 Contaminated Material. About $50 \%$ of the contaminated material in the PWR power plant is placed in the entombment structure. The estimated cost of onsite interim storage for the contaminated material not entombed is given in Table A.1-19. The cost estimates for removal of this material to an offsite licensed waste disposal facility are presented in Table A.1-20 for interim storage periods of 30,50 , and 100 years.

A.1.1.3.3 Radioactive Waste. In Reference 3 it is assumed that the quantity of radioactive waste generated by ENTOMB of the reactor is the same 
TABLE A.1-17. Estimated Costs of Onsite Interim Storage of the Reactor Internals from ENTOMB of a PWR

\begin{tabular}{|c|c|c|c|c|c|c|}
\hline & & & $\cos t$ & $s(\$)^{(x)}$ & & \\
\hline Component & Container & caskstb) & Handling & Transportation & Placement & Tota \\
\hline $\begin{array}{l}\text { Upper Core Support } \\
\text { Assembly }\end{array}$ & 40000 & 400 & 1200 & 275 & 1060 & 42935 \\
\hline Ipper Support Columns & 40000 & 400 & 1200 & 275 & 1060 & 42935 \\
\hline Upper Core Barre1 & 20000 & 200 & 600 & 137 & 530 & 21467 \\
\hline Upper Core Grid Plate & 50000 & 500 & 2200 & 345 & 1325 & 54370 \\
\hline Guide Tubes & 60000 & 600 & 1200 & 412 & 1590 & 63802 \\
\hline Lower Core Barrel & 320000 & 3200 & 9600 & 2198 & 8480 & 343478 \\
\hline Thermal ShieTd & 60000 & 600 & 1800 & 412 & 1590 & 64402 \\
\hline Core Sirroud & 40000 & 400 & 1200 & 275 & 1060 & 42935 \\
\hline Lower Grid Plate & 50000 & 500 & 2. 200 & 345 & 1325 & 54370 \\
\hline Lover Support Columns & 10000 & 100 & 300 & 70 & 265 & 10735 \\
\hline Lower Core Forging & 110000 & 1100 & 3300 & 756 & 2915 & $1 \longdiv { 8 } \quad 0 7 1$ \\
\hline Misc. Interrals & $80 \quad 000$ & 800 & 2400 & $5 \underline{50}$. & 2120 & $85 \quad 870$ \\
\hline Totals & 880000 & 8800 & 27200 & 6050 & 23320 & 945370 \\
\hline
\end{tabular}

(a) Based on Table 6.4-3, Reference 1.

(b) One-day cask rental.

TABLE A.1-18. Estimated Costs of Removal to Offsite Disnosal of the Reactor Internals from ENTOMB of a PWR

\begin{tabular}{|c|c|c|c|}
\hline $\begin{array}{c}\text { Cost } \\
\text { Component }\end{array}$ & Offsite Disposal & Costs (\$) After Interim & $\begin{array}{c}\text { Storage Period of } \\
100 \text { Year }\end{array}$ \\
\hline Retrieve From Interim Storage ${ }^{(a)}$ & 23320 & 23320 & 23320 \\
\hline Cask Rental & 41000 & 39000 & 39000 \\
\hline Transportation & 154380 & 148800 & 143800 \\
\hline Hand? ing & 26000 & 24800 & 24800 \\
\hline Liner Surcharge & 15750 & $13 \$ 50$ & 13150 \\
\hline Curie Surcharge & 46770 & 43920 & 41430 \\
\hline Burial & $23 \quad 320$ & 23320 & 23320 \\
\hline Totals & 330540 & 316310 & 313820 \\
\hline
\end{tabular}

(a) Assumed to be the sarle as the placement cost in Table A.1-17. 
TABLE A.1-19. Estimated Costs of Onsite Interim Storage of Contaminated Material from ENTOMB of a PWR

\begin{tabular}{|c|c|c|c|c|c|}
\hline \multirow[b]{2}{*}{ _....... Component } & \multirow[b]{2}{*}{ Volune $\left(\mathrm{m}^{3}\right)^{(\mathrm{a})}$} & \multicolumn{4}{|c|}{ Costs $(\$)$} \\
\hline & & Containers $^{(a)}$ & $\begin{array}{c}\text { Onsite } \\
\text { Iransportation }\end{array}$ & Placenent (a) & Total \\
\hline Tanks & 406 & 44800 & 960 & 37990 & 83750 \\
\hline Service Water System & 160 & 17600 & 410 & 14925 & 32935 \\
\hline Component Cooling System & 450 & 49600 & 1030 & 42061 & 92691 \\
\hline Condensate Storage System & 101 & 11200 & 210 & 9498 & 20908 \\
\hline Turbine Generator & 558 & 61600 & 1510 & 52237 & 115347 \\
\hline Compressed Air System & 51 & 5600 & 140 & 4749 & 10489 \\
\hline Glycol Heating System & 29 & 3200 & 70 & 2714 & 5984 \\
\hline [xtraction Steam System & 198 & $20 \quad 800$ & $48 \underline{0}$ & 17.638 & 38918 \\
\hline Totals & 1943 & 214400 & 4810 & 181812 & 407022 \\
\hline
\end{tabular}

(a) Based on Table G.4-5 of Reference 1.

TABLE A.1-20. Estimated Costs of Removal to Offsite Disposal of Contaminated Material from ENTOMB of a PWR

\begin{tabular}{|c|c|c|c|}
\hline $\begin{array}{c}\text { Cost } \\
\text { Component }\end{array}$ & $\frac{\text { Offsite Disposal }}{30 \text { Year }}$ & Costs (\$) After interim & Storage Period of \\
\hline Retrieve From Interin Storage ${ }^{(a)}$ & 181810 & 181810 & 181810 \\
\hline Transportation (b) & 174720 & 1920 & 1920 \\
\hline Burial $(c)$ & 181810 & 1120 & 1120 \\
\hline Totals & $538 \quad 340$ & 184850 & 184850 \\
\hline
\end{tabular}

(a) Assumed to be the same as the cost to place the material in interim storage.

(b) $21.4 \mathrm{~m}^{3} /$ shipment and $\$ 1,920 /$ shipment.

(c) $\$ 93.57 / \mathrm{m}^{3}$.

as the quantity generated by DECON. Therefore, the costs given below for the onsite interim storage and later offsite disposal of the radioactive waste from ENTOMB are the same as the costs developed for DECON of the reactor.

Place in interim storage - $\$ 240,350$
Remove to offsite disposa 1
After: 30 years storage - $\$ 259,410$
50 years storage - $\$ 181,030$
100 years storage $-\$ 170,600$. 


\section{A.1.2 Reference BWR Decormissioning Wastes}

The study of decommissioning a reference BUR by Oak et al. (2) is the source of the data for estimating the impact on costs of onsite interim storage of the nuclear wastes from decommissioning the reference BWR. Radioactive decay factors for neutron-activated material used in the cost analyses are given in Table A.1-21 for the radioactivity levels and the dose rates.

TABLE A.1-21. Decay Factors for Radioactivity Levels and Dose Rates of Activated Material in the Reference BWR

\begin{tabular}{|c|c|c|}
\hline \multirow{2}{*}{$\begin{array}{l}\text { Time After } \\
\text { Shutdown } \\
\text { (Years) } \\
\end{array}$} & \multicolumn{2}{|c|}{ Decay Factors (a) } \\
\hline & Radioactivity Level & Dose Rate \\
\hline 30 & $5.1 \times 10^{-2}$ & $1.9 \times 10^{-2}$ \\
\hline 50 & $4.0 \times 10^{-2}$ & $1.4 \times 10^{-3}$ \\
\hline 60 & $3.8 \times 10^{-2}$ & $3.7 \times 10^{-4}$ \\
\hline 80 & $3.4 \times 10^{-2}$ & $3.0 \times 10^{-5}$ \\
\hline 100 & $3.0 \times 10^{-2}$ & $9.6 \times 10^{-6}$ \\
\hline 130 & $2.4 \times 10^{-2}$ & $5.3 \times 10^{-6}$ \\
\hline 150 & $1.9 \times 10^{-2}$ & $5.2 \times 10^{-6}$ \\
\hline 200 & $1.0 \times 10^{-2}$ & $4.8 \times 10^{-6}$ \\
\hline
\end{tabular}

(a) Based on Figure E. 1-6 of Reference 2.

The costs of disposal of neutron-activated material from the reference BWR at 30,50 , and 100 years after shutdown are presented in Table A.1-22.

\section{A.1.2.1 Waste from DECON}

Estimates of the costs for disposal of each type of nuclear waste from DECON are developed in the following subsections for onsite interim storage and later offsite disposal of the waste.

A.1.2.1.1 Neutron-Activated Material. Estimated costs of onsite interim storage of the neutron-activated material from DECON of a BWR are sumarized in Table A.1-23. Since transport of the neutron-activated material to the 
TABLE A.T-22. BWR Costs for Disposal of Neutron-Activated Materials at Various Times after Shutdown (Based on Table 1.3-3, Reference 2)

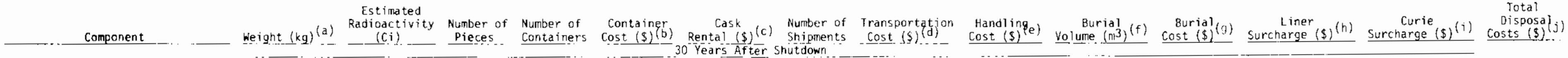
Steam Separator Assembly Fuel Support Pieces
Control Rods \& 1 -Core Instruments

$\begin{array}{rrrr}r 550 & 260 & 951 & 28 \\ 5420 & 19 & 740 & 14 \\ 19810 & 5122 & 610 & 8 \\ 3500 & 3 & 370 & 12 \\ 6000 & 542 & 110 & 40 \\ 2300 & 816 & 408 & 72 \\ 18500 & 18 & 258 & 31 \\ 32000 & 170730 & 558 & 70 \\ 157700 & 20 & 576 & 22 \\ 272000 & \ldots \leq 1 & .14 & -14 \\ 526730 & 172946 & 4595 & 311\end{array}$

$\begin{array}{rrr}12500 & 14000 & 14 \\ 6300 & 7000 & 7 \\ 48000 & 27600 & 8 \\ 5400 & 6000 & 6 \\ 18000 & 20000 & 20 \\ 32400 & 36000 & 72 \\ 13950 & 15500 & 16 \\ 31500 & 35000 & 70 \\ 9900 & 0 & 10 \\ 84000 & 0 & 14 \\ 262050 & 161100 & 237\end{array}$

26880
13440
15360
11520
38400
138240
330720
134400
19200
26880
455040

$\begin{array}{rr}5600 \\ 2800 \\ 12 & 310\end{array}$

$\begin{array}{rr}10 & 940 \\ 5 & 470 \\ 15 & 1400 \\ 4 & 380 \\ 14 & 1330\end{array}$

Jet Pump Assemblies
Top Fuel Guide

Core Support Plate Reactor vessel wall
Sacrifical Shield

Totals

9500
5420
19810
3500
6000
2300
18500
32000
157700
272.000
526730

. 213
50 Years After Shutdown

\begin{tabular}{rr}
957 & 28 \\
740 & 14 \\
610 & 8 \\
370 & 12 \\
110 & 40 \\
408 & 72 \\
258 & 31 \\
558 & 70 \\
576 & 22 \\
14 & 14 \\
\hline 4595 & 311
\end{tabular}

$\begin{array}{rr}12600 & 14000 \\ 6300 & 7000 \\ 48000 & 27600\end{array}$

Fuel Support Pieces
Control Rods \& In-Core Instruments

Control Rod Guide Tubes

Jet Pump Assemblies
Top Fuel Guide

Reactor Vessel wall

Totals

$\begin{array}{rrrr}9500 & 141 & 951 & 28 \\ 5420 & 10 & 740 & 14 \\ 19810 & 2778 & 610 & 8 \\ 3500 & 2 & 370 & 12 \\ 6000 & 294 & 110 & 40 \\ 2300 & 442 & 408 & 72 \\ 18500 & 10 & 258 & 31 \\ 32000 & 92600 & 558 & 70 \\ 157700 & 11 & 576 & 22 \\ \underline{272000} & <1 & 14 & 14 \\ 526730 & 96289 & 4595 & 311\end{array}$

$\begin{array}{rr}5400 & 6000 \\ 18000 & 20000 \\ 32400 & 36000\end{array}$

$\begin{array}{ll}13950 & 15500 \\ 31500 & 35000\end{array}$

9900
84000

262050

.- 100 Years After. Shutdown

Steam Separator Assembly

Fuel Support Pieces
Control Rods \& In-Core Instruments

$\begin{array}{rrr}12 & \\ 1200 & 14000 \\ 6300 & 7000\end{array}$

Control Rod Guide Tubes
Jet Pump Assemblies

Core Support Plate

Core Shroud
Reactor vessel wall
Sacrificiat Shield

Totals

526730

5400
18000
32400

$\begin{array}{r}13950 \\ 31500 \\ 9900 \\ 84000 \\ \hline 262050\end{array}$

200
20000
36000

$\begin{array}{r}15500 \\ 35000 \\ 0 \\ 0 \\ \hline\end{array}$

2400
8000
14400

6200
14000
$4 \quad 400$

$\begin{array}{r}4400 \\ -5600 \\ \hline 5\end{array}$

75710

\section{2360
15360}

$1 \quad 180$
38400
138240

5600
12310

800
19400

7080
134400
19200

14000

$\begin{array}{r}14000 \\ 4400 \\ 5600 \\ \hline\end{array}$

409980

64310

26880
2360
15

5600
12310

940
470
400
380
310
250
1030
2200
680
9530
20190

9700
1750
12410

0
0
2760 69120
31760
119840

(a) Estimated from volumes presented in Table E. 1-6, Reference 2 .
b) Based on information in Section $M .2$, Reference 2 .

Based on Table M.3-1. Reference

Based on cask handling fee in Table M.5-1, Reference 2

includes the disposable container; rounded to nearest whote $\mathrm{m}^{3}$

Desed on to nearest $\$ 10$.

j) The number of figures shown is for computational completeness only and does not imply accuracy to that many significant figures.

TABLE A.1-22. BWR Costs for Disposal of Neutron-Activated Materials at Various Times after Shutdown (Based on Table 1.3-3,
Reference 2) 

TABLEA.1-23. Estimated Costs of Onsite Interim Storage of Neutron-Activated Material from DECON of a $B W R$

\begin{tabular}{lr}
\multicolumn{1}{c}{ Cost Component } & Cost (\$) \\
\hline Containers & $262050^{(a)}$ \\
Cask Rental & $34420^{(b)}$ \\
Onsite Transportation & $16970^{(c)}$ \\
Handiing & $75710^{(d)}$ \\
Placement & $20190^{(d)}$ \\
$\quad$ Total & 409340
\end{tabular}

(a) From Table A.1-22.

(b) One-day cask rental for each shipment.

(c) 247 shipments with a round-trip distance of $48 \mathrm{~km}$.

(d) From Table 1.3-3 of Reference 2.

onsite interim storage facility is over private roads within a privately owned and controlled reservation, it is assumed that the surface dose rate on the shipping cask can be greater than DOT regulation permit on public highways. In order to pack more of the neutron-activated material in the cask liners, the thickness of the shielding instalied in the cask liners is reduced to the amount needed to meet DOT requirements after 30 years of radioactive decay. For the core shroud this permits doubling the amount of core shroud segments packed in each cask liner.

The estimated costs for removal of the neutron-activated material to an offsite licensed disposal facility after interim storage for 30,50 , and 100 years are given in Tab?e A.1-24.

A.1.2.1.2 Contaminated Material. The estimated costs of onsite interim storage of the contaminated material from DECON of a BWR are given in Tabie A.1-25.

Estimated costs of removal of the contaminated material to an offsite licensed disposal facility are presented in Table A.1-26. 
TABLE A.1-24. Estimated Costs of Removal to Offsite Disposal of NeutronActivated Material from DECON of a BWR

Cost Component

Retrieve From Temporary Storage ${ }^{(a)}$ Cask Rental(b)

Transportation (b)

Handling (b)

Liner Surcharge ${ }^{(b)}$

Curie Surcharge ${ }^{(b)}$

Buriaj (b)

Totals

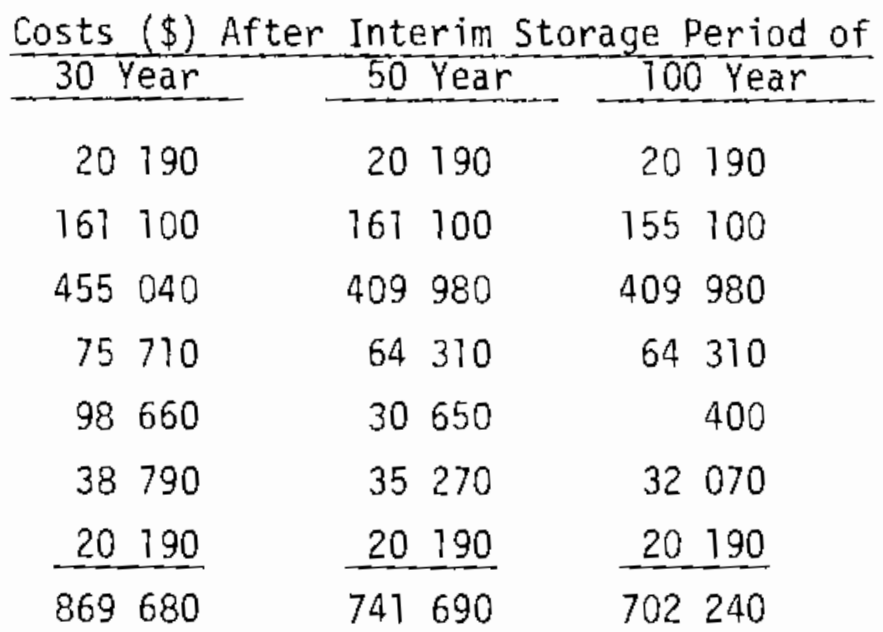

(a) Assumed to be the same as the burial cost.

(b) From Table A.1-22.

TABLE A.1-25. Estimated Costs of Onsite Interim Storage of Contaminated Material from DECON of a BWR

\begin{tabular}{|c|c|}
\hline Cost Component & $\operatorname{cost}(\$)$ \\
\hline Containers & $1669320^{(a)}$ \\
\hline Onsite Transportation & $55370^{(b)}$ \\
\hline PTacement & $1612410^{(a)}$ \\
\hline Total & $3337 \quad 100$ \\
\hline
\end{tabular}

(a) From Table I.3-4 of Reference 1.

(b) 806 shipments with round-trip distance of $48 \mathrm{~km}$.

A.1.2.1.3 Radioactive Waste. In Tabie A.1-27 the estimated costs of onsite interim storage of the radioactive waste from DECON of the reference BWR are presented. 
TABLE A.1-26. Estimated Costs of Removal to Offsite Disposal of Contaminated Material from DECON of a BWR

Cost Component

Retrieve From Interim Storage $(a)$

Transportation (b)

Burial

Totals
Costs $(\$)$ After Interim Storage Period of 50 Year 100 Year

\begin{tabular}{rrr}
30 Year & \multicolumn{1}{c}{50 Year } & \multicolumn{1}{r}{100 Year } \\
292980 & 292980 & 292980 \\
1547520 & 5760 & 5760 \\
1611180 & 14040 & 14040 \\
\hline 3451680 & 312780 & 312780
\end{tabular}

(a) 3919 containers. 4 man-hr per container for checking and segregating. $\$ 18.70$ per man-hr charge-out rate.

(b) After 30 years there are 806 shipments, and after 50 and 100 years there are 3 shipments.

(c) Burial cost $\$ 93.57$ per $\mathrm{m}^{3}$.

TABLE A.1-27 Estinated Costs of Onsite Interim Storage of Radioactive Waste from DECON of a BWR

\begin{tabular}{|c|c|}
\hline Cost Component & $\operatorname{cost}(\$)$ \\
\hline Containers $(\mathrm{a})$ & 281370 \\
\hline Cask Rental (b) & 5200 \\
\hline Hand 1 ing & 10400 \\
\hline Onsite Transportation (c) & 7900 \\
\hline Placement ${ }^{(d)}$ & $142 \quad 130$ \\
\hline Tota 1 & 447000 \\
\hline
\end{tabular}

(a) From Tabies H.5-10 and I.3-5 of Reference 2.

(b) Casks used only for containers with surface dose rates $>1 \mathrm{R} / \mathrm{hr}$. one day rental per shipment.

(c) 115 shipments with round-trip distance of $48 \mathrm{~km}$.

(d) Same as burial costs given in Tables H.5-10 and 1.3-5 of Reference 2. 
The estimated costs of removal of the nuclear waste from DECON of the reference BWR to an offsite licensed disposa? facility are given in Table A.1-28.

\section{A.1.2.2 Waste from SAFSTOR}

The two major decommissioning phases that generate nuclear waste are: 1) preparations for safe storage and 2) deferred decontamination at the end of the storage period. The rationale for estimating the waste disposal costs is the same for the reference BWR as that described for the reference PWR in subsection A.1.1.2.

Estimated costs for the disposai of each type of nuclear waste from SAFSTOR of the reference BWR are developed in the following subsections for onsite interim storage and eventual offsite disposal.

TABLE A.1-28. Estimated Costs of Removal to Offsite Disposal of Radioactive Waste from DECON of a BWR

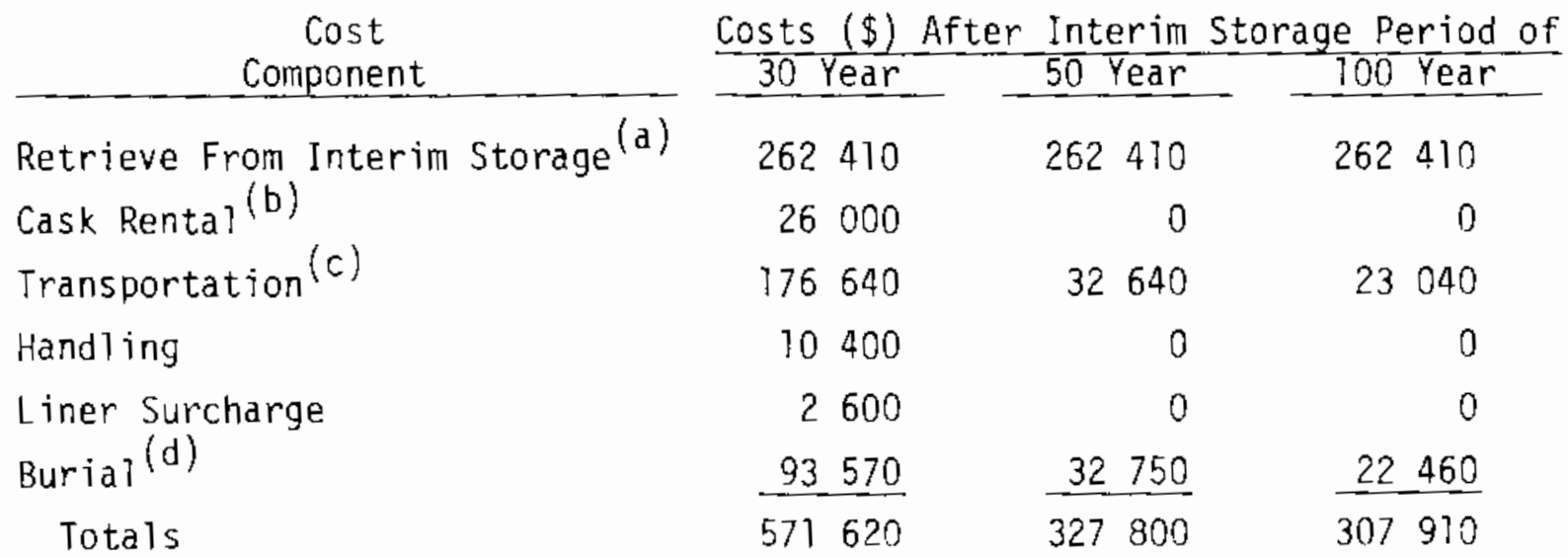

(a) 3510 containers at 4 man-hr per container and charge-out rate of $\$ 18.70$ per man-hr.

(b) Casks used only for containers with surface dose rate $>0.2 \mathrm{R} / \mathrm{hr}$.

(c) Transportation costs based on 92 shipments after 30 years, 17 shipments after 50 years, and 12 shipments after 100 years, at $\$ 1920$

(d) Burial volumes assumed $-1000 \mathrm{~m}^{3}$ after 30 years, $350 \mathrm{~m}^{3}$ after 50 years,
(dipment. and $240 \mathrm{~m}^{3}$ after 100 years. 
A.1.2.2.1 Neutron-Activated Material. No neutron-activated material is removed from the reactor during preparations for safe storage. During deferred decontamination, all of the neutron-activated material is removed from the reactor, packaged, and sent to onsite interim storage. The estimated costs for placement in onsite interim storage of the neutron-activated material removed during deferred decontamination are presented in Table A.T-29.

Estimated costs for removal to offsite disposal of the neutron-activated material from deferred decontamination after interim storage periods of 30,50 , and 100 years are given in Table A. $1-30$.

\section{A.1.2.2.2 Contaminated Material. Contaminated material is not removed} from the reactor during preparations for safe storage. The contaminated material is removed and placed in onsite interim storage during deferred decontamination. Estimated costs for placement of this material in onsite interim storage are presented in Table A. $1-31$.

IABLE A.1-29. Estimated Costs of Onsite Interim Storage of Neutron-Activated Material from Deferred Decontamination of a BWR

\begin{tabular}{|c|c|c|c|}
\hline $\begin{array}{c}\text { Cost } \\
\text { Component }\end{array}$ & Costs $(\$)$ & $\frac{\text { er Safe Stor }}{50 \text { Year }}$ & e Period of \\
\hline Containers & $262050^{(a)}$ & $262050^{(a)}$ & $262050^{(a)}$ \\
\hline Cask Rental(b) & 27920 & 23720 & 0 \\
\hline Onsite Transportation (c) & 16280 & 13530 & 2200 \\
\hline Hand I ing & 67110 & 48710 & 0 \\
\hline Placement & $20190^{(a)}$ & $20190^{(a)}$ & $20190^{(a)}$ \\
\hline Totals & 393550 & 368200 & $284 \quad 440$ \\
\hline
\end{tabular}

(a) From Table A.l-22.

(b) Casks used only if cask 1 iner surface dose rate $>1 \mathrm{R} / \mathrm{hr}$.

(c) Round-trip distance $48 \mathrm{~km} .237$ trips after 30 years; 197 trips after 50 years, and 32 trips after 100 years. 
TABLE A.1-30. Estimated Costs of Removal to Offsite Disposal of NeutronActivated Material from Deferred Decontamination of a BWR

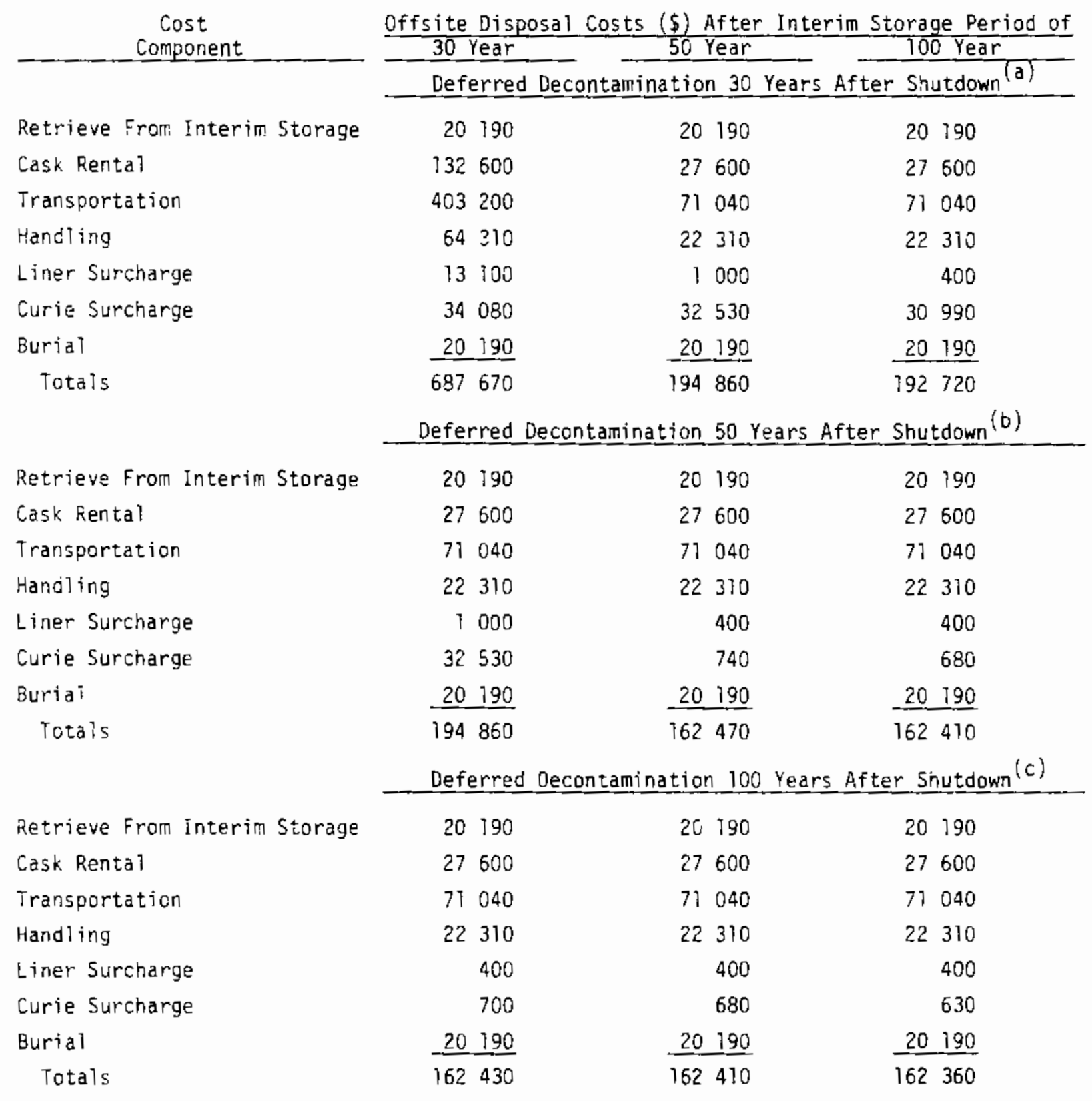

(a) For deferred decontamination 30 years after shutdown, offsite disposal occurs 60,80 , and 130 years after shutdown.

(b) For deferred decontamination 50 years after shutdown, offsite disposal occurs 80,100 , and 150 years after shutdown.

(c) For deferred decontamination 100 years after shutdown, offsite disposal occurs 130 , 150 , and 200 years after shutdown. 
TABLE A.1-31. Estimated Costs of Onsite Interim Storage of Contaminated Material from Deferred Decontamination of a BWR

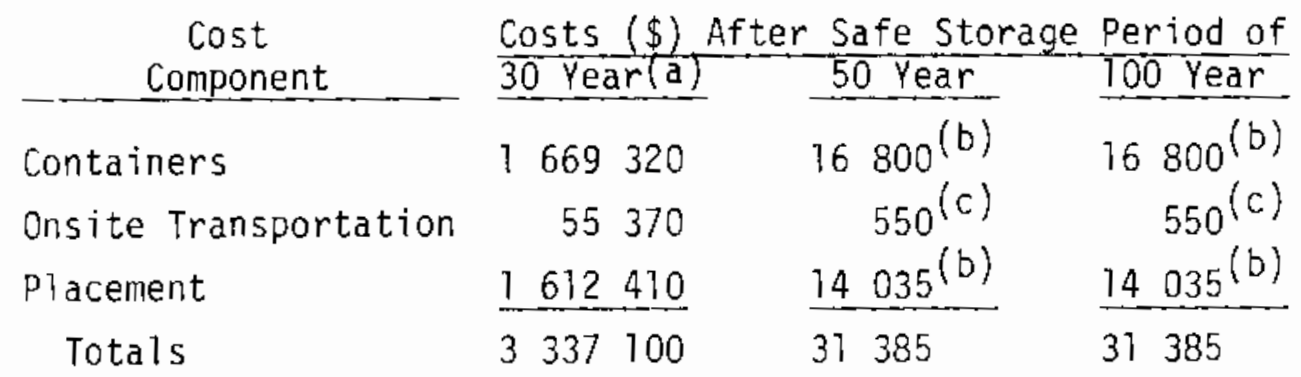

(a) Table 3.7-1 of Reference 2 shows the volume of contaminated waste to be the same after 30 years of safe storage as it is for DECON; therefore the costs should be the same. These costs are from Table A. $1-25$.

(b) Based on volume of $150 \mathrm{~m}^{3}$ after 30 years of safe storage, 42 containers.

(c) 8 shipments with a round-trip distance of $48 \mathrm{~km}$.

The estimated costs of removal to offsite disposal of the contaminated material from deferred decontamination of the reference $B W R$ are summarized in Table A. $1-32$.

A.1.2.2.3 Radioactive Waste. All of the wet solid radioactive waste and some of the dry solid radioactive waste generated by SAFSTOR are disposed of during preparations for safe storage. Disposal costs are developed in two steps: 1) for those radioactive wastes generated during preparations for safe storage and 2) for those radioactive wastes generated during deferred decontamination.

Preparations for Safe Storage. The estimated costs for placement in onsite interim storage of the radioactive waste from preparations for safe storage are summarized in Table A.1-33.

Estimated costs for removal to offsite disposal of the radioactive waste from preparations for safe storage are given in Table A.1-34.

Deferred Decontamination. The estimated costs of placing in onsite interim storage the radioactive waste from deferred decontamination after safe storage periods of 30,50 , and 100 years are presented in Table A.1-35. 
TABLE A.1-32. Estimated Costs of Removal to Offsite Disposal of the Contaminated Material from Deferred Decontamination of a BWR

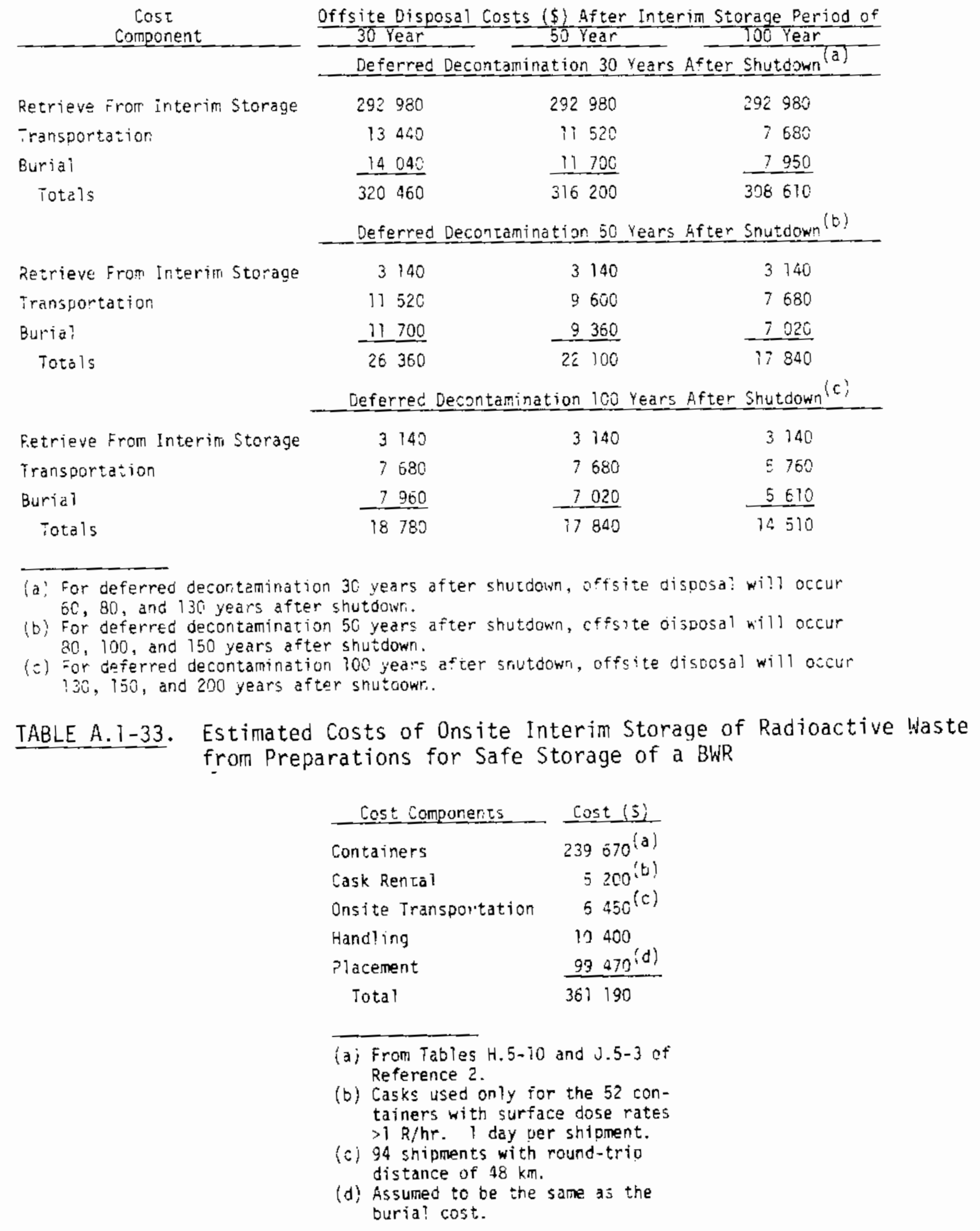


TABLE A.1-34. Estimated Costs of Removal to Offsite Disposal of Radioactive Waste from Preparations for Safe Storage of a BWR

\begin{tabular}{|c|c|c|c|}
\hline $\begin{array}{l}\text { Cost } \\
\text { Component }\end{array}$ & Offsite oisposal & Costs $(\$)$ After Interim & Storage Period of \\
\hline Retrieve From Interim Storage ${ }^{(a)}$ & 106590 & 106590 & 106590 \\
\hline Cask Rental ${ }^{(b)}$ & 26000 & 0 & 0 \\
\hline Transportation & $72960(c)$ & $32640^{(d)}$ & $23040^{(e)}$ \\
\hline Handling & 10400 & 0 & 0 \\
\hline Burial ${ }^{(f)}$ & 74860 & 32750 & 22460 \\
\hline Tot.als & 290810 & 171980 & $152 \quad 090$ \\
\hline
\end{tabular}

(a) 1425 containers at 4 man-hr per container with a charge-out rate of $\$ 18.70$ per man-hr.

(b) Casks used only for those shipments with a cask liner surface dose rate $>1 \mathrm{R} / \mathrm{hr}$. 5-day cask rental for a shipment.

(c) 38 shipments at $\$ 920$ per shipment.

(d) 17 shipments at $\$ 1920$ per shipment.

(e) 12 shipments at $\$ 1920$ per shipment.

(F) Burial volumes - $800 \mathrm{~m}^{3}$ after 30 years; $350 \mathrm{~m} 3$ after 50 years; $240 \mathrm{~m}^{3}$ after 100 years.

IABLE A.1-35. Estimated Costs of Onsite Interim Storage of Radioactive Waste from Deferred Decontamination of a BWR

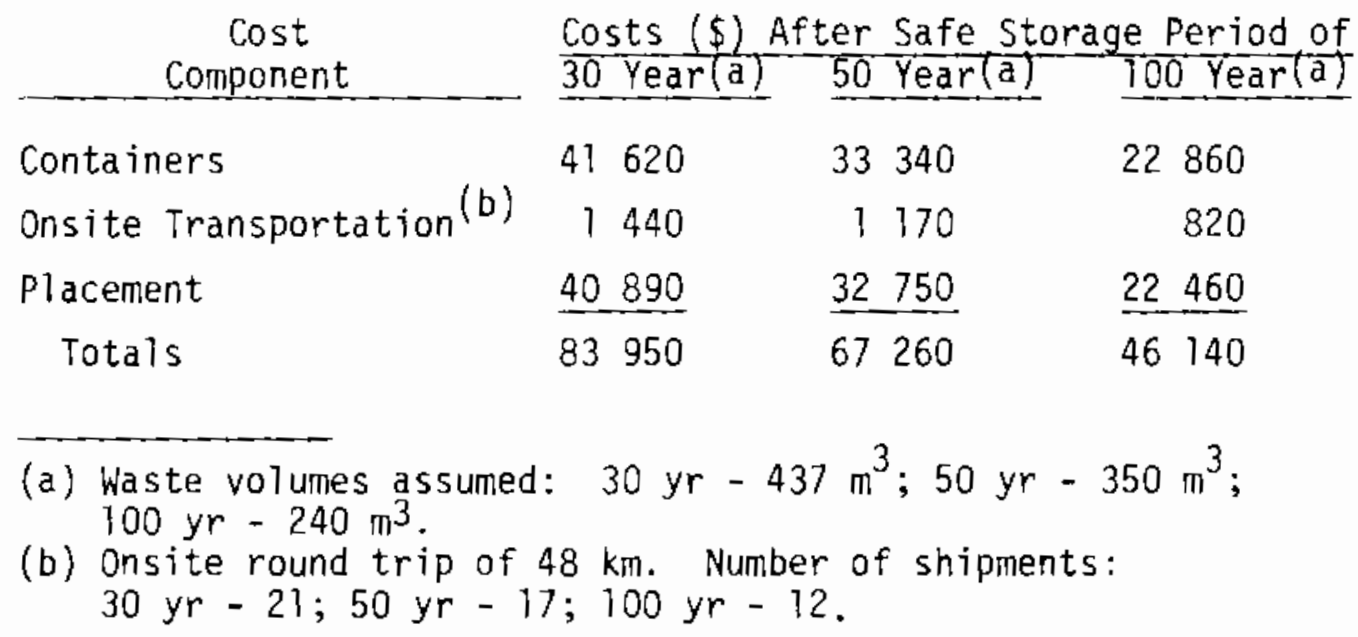


Costs of the removal of the radioactive waste from deferred decontamination to offsite disposal after a period of interim storage are estimated and summarized in Table A.1-36.

TABLE A.1-36. Estimated Costs of Removal to Offsite Disposal of Radioactive Waste from Deferred Decontamination of a BWR

\begin{tabular}{|c|c|c|c|}
\hline $\begin{array}{c}\text { Cost } \\
\text { Component }\end{array}$ & \multicolumn{3}{|c|}{$\begin{array}{l}\text { Offsite Disposal Costs (\$) After Interim Storage Period of } \\
\frac{30 \text { Year }}{50} \text { Year }\end{array}$} \\
\hline & \multicolumn{3}{|c|}{ Deferred Decontamination 30 Years After Shutdown (a) } \\
\hline Retrieve From Interim Storage & $155 \quad 500$ & 155500 & 155500 \\
\hline Transportation & 32540 & 26880 & 19200 \\
\hline Burial & 32750 & $27 \quad 140$ & 19650 \\
\hline \multirow[t]{2}{*}{ Totals } & 220890 & 209520 & 194350 \\
\hline & \multicolumn{3}{|c|}{ Deferred Decontamination 50 Years After Shutdown (b) } \\
\hline Retrieve From Interim Storage & 124620 & 124620 & 124620 \\
\hline Transportation & 25880 & 23040 & 17280 \\
\hline Burial & $27 \quad 135$ & 22460 & 17780 \\
\hline \multirow[t]{2}{*}{ Totais } & 178635 & 170120 & 159680 \\
\hline & \multicolumn{3}{|c|}{ Deferred Decontamination 100 Years After Shutdown (c) } \\
\hline Retrieve From Interim. Storage & 85450 & 85450 & $85 \quad 450$ \\
\hline Transportation & 19200 & 17280 & 15360 \\
\hline Burial & 19650 & 17780 & 14970 \\
\hline Totals & 124300 & $120 \quad 510$ & 115780 \\
\hline
\end{tabular}

(a) For deferred decontamination 30 years after shutdown, offsite disposai will occur 60,80 , and 130 years after shutdown.

(b) For deferred decontamination 50 years after shutdown, offsite oisposal will occur 80,100 , and 150 years after shutdown.

(c) For deferred decontamination 100 years after shutoowr, offsite disposal will occur $i 30,350$, and 200 years after shutdown.

\section{A.1.2.3 Waste from ENTOMB}

The primary containment vessel is used as the entombment structure for decomissioning the reference BWR by ENTOMB. The free space inside the contajnment vessel is filled with contaminated material from outside the containment vesse1. Contaminated material in excess of the containment vessel capacity and the radioactive waste are sent to a waste disposal facility. As 
is the case for the reference PWR, the ENTOMB scenario with the reactor internals removed is studied in detail in this study.

Estimated costs for disposal of each type of nuclear waste from ENTOMB by interim storage of the waste onsite followed by later removal to an offsite licensed disposal facility are covered in this subsection.

A.1.2.3.1 Neutron-Activated Material. The reactor internals are the only neutron-activated material removed during ENTOMB of the reference BWR. Estimated costs of placing the reactor internals in onsite interim storage are given in Table A.1-37, and estimated costs for the removal of the reactor internals to an offsite disposal facility after onsite interim storage of 30 , 50, and 100 years are presented in Table A. 1-38.

A.1.2.3.2 Contaminated Material. About two-thirds of the contaminated material located outside the containment vessel is placed in the vessel for entombment. The remainder of this material is considered here to be placed in onsite interim storage and later moved to an offsite licensed waste disposal facility. The estimated costs for onsite interim storage of this remaining contaminated material are given in Table A.1-39. In Table A.1-40 the estimated costs are presented for the removal of the contaminated material from ENTOMB to an offsite licensed disposal facility after interim storage periods of 30 , 50 , and 100 years.

A.1.2.3.3 Radioactive Waste. In Reference 2 it is assumed that the quantity of radioactive waste generated by ENTOMB of the reactor is the same as the quantity generated by DECON. Therefore, the costs shown below for the onsite interim storage and later offsite disposal of the radioactive waste from ENTOMB are the same as the costs developed for DECON of the reactor.

$$
\begin{aligned}
& \text { Place in interim storage - } \$ 447,000 \\
& \text { Removal to offsite storage } \\
& \text { After: } 30 \text { years storage - } \$ 571,620 \\
& 50 \text { years storage - } \$ 327,800 \\
& 100 \text { years storage - } \$ 307,910
\end{aligned}
$$


TABLE A.1-37. Estimated Costs of Onsite Interim Storage of BWR Reactor Internals

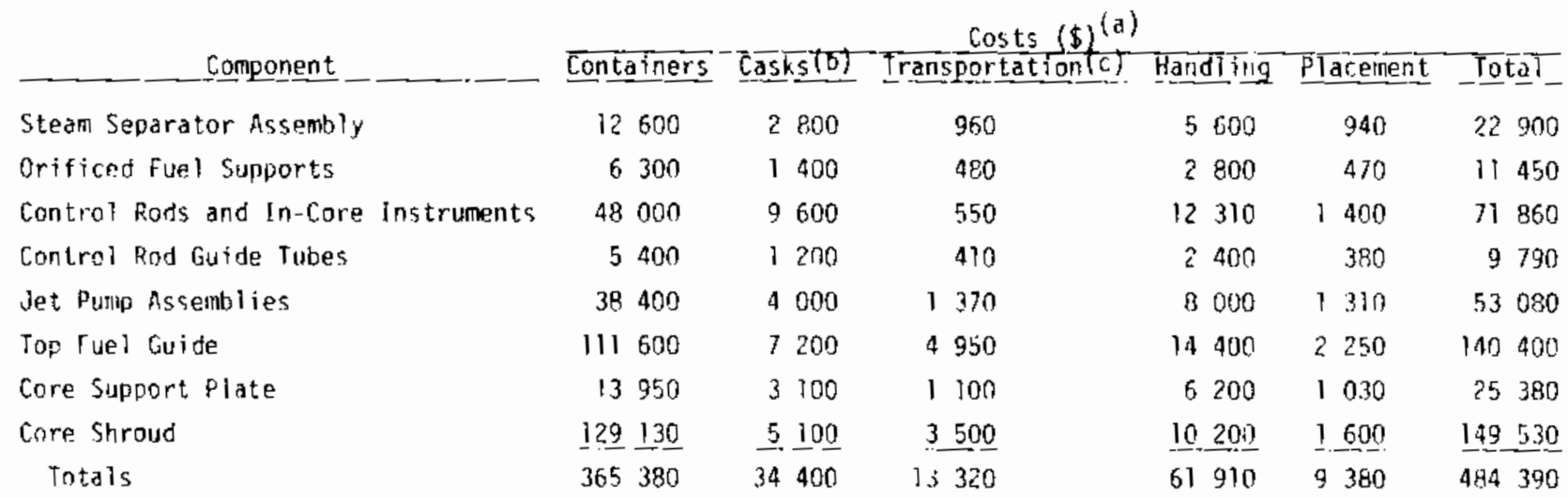

(a) Based on Table K.3-3 of Refarence 2 .

(b) One-day cask rental per shipment.

(c) Round-trip distance to onsite interim storage facility - $48 \mathrm{~km}$.

TABLE A.1-38. Estimated Costs of Removal to Offsite Disposal of the Reactor Internals from ENTOHB of a BWR

\begin{tabular}{|c|c|c|c|}
\hline Cost & Offsite Disposal & $\operatorname{costs}(\$)$ After Interin & Storage Period of \\
\hline Component & 30 Year & 50 Year & 100 Year \\
\hline Retrieve From Interim Storage (a) & 9380 & 9380 & 9380 \\
\hline Cask Rental & 151600 & 151600 & 145600 \\
\hline Transportation & 372480 & 327420 & 327420 \\
\hline Handling & 61910 & $50 \quad 150$ & $50 \quad 150$ \\
\hline Liner Surcharge & 97560 & 30650 & 400 \\
\hline Curie Surcharge & 38790 & 35270 & 32070 \\
\hline Burial & 9380 & 9380 & 9 380 \\
\hline Totals & 741100 & 613850 & 574400 \\
\hline
\end{tabular}

(a) Assumed in be the sane as the placement cost in Table A.T-37. 
TABLE A.1-39. Estimated Costs of Onsite Interim Storage of Contaminated Material fron ENTOMB of a BWR

\begin{tabular}{lr} 
Cost Component & Cost $(\$)$ \\
\cline { 1 - 2 } Containers & $561320^{(a)}$ \\
Onsite Transportation & $22670^{(b)}$ \\
Handling & $45360^{(a)}$ \\
Placement & $600720^{(c)}$ \\
$\quad$ Total & 1230070
\end{tabular}

(a) From Table K.3-4 of Reference 2.

(b) 330 shipments with round-trip distance of $48 \mathrm{~km}$.

(c) $6420 \mathrm{~m}^{3}$ at $\$ 93.57$ per $\mathrm{m}^{3}$.

TABLE A.1-40. Estimated Costs of Removal to Offsite Disposal of Contaminated Material from ENTOMB of a BWR

\begin{tabular}{|c|c|c|c|}
\hline $\begin{array}{c}\text { Cost } \\
\text { Component }\end{array}$ & $\begin{array}{c}\text { Offsite Disposal } \\
30 \text { Year }\end{array}$ & Costs (\$) After Interim & Storage Periud of \\
\hline Retrieve From Interifi Storage (a) & 92930 & 92930 & $9 ? 930$ \\
\hline Transportation $(b)$ & 633600 & 5760 & 5760 \\
\hline Burial & 600720 & $5 \quad 240$ & 5240 \\
\hline Totals & 1327250 & 103930 & 103930 \\
\hline
\end{tabular}

(a) 1243 containers. Assumed 4 man-hr per container at a charge-out rate of $\$ 18.70$ per man-hr.

(b) 330 shipments after 30 years and 3 shipments after 50 or 100 years.

\section{A.2 ONSITE DISPOSAL OF NUCLEAR WASTE}

Onsite disposal of nuclear waste involves essentiaily the same operations as placing radioactive material in onsite interim storage. In this study, it is assumed that the onsite disposal facility is operated by the operating utility and that liner surcharges and curie surcharges are not levied. It is further assumed that the onsite disposal facility is located $24 \mathrm{~km}$ from the 
reactor(s) being decommissioned, the same distance assumed for the onsite interim storage facility. With these assumptions, the estimated costs for onsite disposal of radioactive waste are the same as the costs for onsite interim storage of the waste.

For DECON of the PWR, the estimated costs for onsite disposal of the nuclear wastes are the same as the costs given in Tabies A.1-3, A.1-5, and A.1-7. For DECON of the BWR, the estimated costs for onsite disposal of the nuclear wastes are the same as those given in Tables A.1-23, A.1-25, and A.1-27.

Estimated costs for disposal of the nuclear wastes from SAFSTOR of the PIUR are the same as those given in Tables A.1-9, A.1-11, A.1-13, and A.1-15. For SAFSTOR of the BWR, the estjmated costs of onsite disposal of the nuclear wastes are the same as the costs given in Tables A.1-29, A.1-31, A.1-33, and A.7-35.

Estimated costs for disposal of the nuclear wastes from ENTOMB of the reference PWR are the same as the costs presented in Tables A.1-17 and A.1-19. For the BWR, the costs are the same as those given in TabJes A.1-37 and A.7-39. 


\section{REFERENCES}

1. R. I. Smith, G. J. Konzek, W. E. Kennedy, Jr., Technology, Safety and Costs of Decommissioning a Reference Pressurized Water Reactor Power Station, NUREG/CR-0130, U.S. Nuclear Regulatory Comission Report by Pacific Northwest Laboratory, June 1978.

2. H. D. Oak, G. M. Holter, W. E. Kennedy, Jr., and G. J. Konzek, Technology, Safety, and Costs of Decommissioning a Reference Boiling Water Reactor Power Station, NUREG/CR-0672, U.S. Nuclear ReguTatory Commission Report by Pacific Northwest Laboratory, June 1980.

3. R. I. Smith and L. M. Polenz, Technology, Safety, and Costs of Decomissioning a Pressurized Water Reactor Power Station, NUREG/CR-DT30 Addendum, U.S. Nuclear ReguTatory Commission Report by Pacific Northwest Laboratory, August 1979. 



\section{DETAILS OF THE IMPACTS OF CENTRALIZED SERVICES ON DECOMMISSIONING AT A MULTIPLE-REACTOR STATION}

The costs and radiation doses associated with decommissioning a single reactor located on a muitiple-reactor station may be affected by the availability of centralized site services. The impacts associated with the following centralized services are examined in this study:

- health physics services

- security forces

- solid waste processing

- equipment decontamination services

- maintenance shops and services

- 1aundry services

- transportation services

- central site stores.

In this appendix, details of the analyses of the impacts associated with centralized services are presented. Oniy the first four services listed above are analyzed in detail in this study and, therefore, only these four are considered in this appendix. The analyses are developed based on estimates for decommissioning reactors at single-reactor sites, as presented in References 1 through 3.

\section{B.T HEALTH PHYSICS SERVICES}

Centralized heaith physics services are anticipated to reduce the costs of health physics activities at a reactor sited on a multiple-reactor station during both operation and decomissioning. Two factors are postulated to contribute to this cost reduction:

- The overhead structure for each reactor can be reduced by sharing certain 5 taff members between reactors.

- The large pool of health physics technicians at the site can be shared between reactors, reducing the peak-load staffing requirements per reactor. Centraization of the health physics services is not anticipated to change the occupational radiation dose for decommissioning a reactor. 
The heaith physics staff labor requirements and costs during decommissioning, both with and without centralized heaith physics services, are presented here for the various combinations of reactor types and decommissioning alternatives considered in this study. Net savings with centralized health physics services are calculated from these results.

\section{B.1.1 PWR DECON}

Health physics staff labor requirements and costs for DECON of the reference PWR are shown in Table B.1-1. Manpower requirements from Table 10.1-2 of Reference 1 are used for decommissioning without centralized health physics; these vaiues are modified appropriately for decomissioning with centralized health physics to account for the reduced overhead structure and the more efficient use of technicians postulated. A total of about 44 man-years, costing about $\$ 1.42$ million, is required without centralized health physics as compared to about $32-1 / 2$ man-years at a cost of about $\$ 960,000$ with centralized health physics. Net savings with centralized health physics are 11-1/2 man-years and approximate7y $\$ 460,000$.

\section{B.1.2 PWR SAFSTOR}

Heal th physics staff labor requirements and costs for the preparations for safe storage phase of PWR SAFSTOR are shown in Table B.1-2, based on information from Table 10.2-2 of Reference 1. Without centralized health physics services, about 19 man-years and approximately $\$ 670,000$ are estimated to be required. With centralized health physics, these requirements are reduced to about 13 man-years and approximately $\$ 410,000$, for net savings of 6 man-years and neariy $\$ 260,000$.

Centralized health physics services are anticipated to have no significant cost effects during the continuing care phase of SAFSTOR at the reference PWR.

Deferred decontamination of the reference PWR is anticipated to require essentially the same work force as DECON (see P. H-30 of Reference 1). Therefore, the health physics staff labor requirements and costs are assumed to be the same and, thus, centralized health physics services during the deferred decontamination phase of PWR SAFSTOR are estimated to provide net savings of $11-1 / 2$ manyears and about $\$ 460,000$, as shown previousiy in Table B. $7-1$. 


\section{TABLE B.1-1. Health Physics Staff Labor Requirements and Costs for PWR DECON and ENTOMB}

\begin{tabular}{|c|c|c|c|c|c|c|c|c|}
\hline \multirow{2}{*}{ Without Centralized Hed th Physics $(c)$} & \multicolumn{5}{|c|}{$\begin{array}{l}\text { Tine Relative to Final Reactor shutdown (year) } \\
-2 \\
\text { Antual Stafflabor Requirenent (man years) }\end{array}$} & \multirow[t]{2}{*}{$\begin{array}{l}\text { Tutal Staff } \\
\text { Labor Required } \\
\text { (nari-years) }\end{array}$} & \multirow[t]{2}{*}{$\begin{array}{l}\text { Cust per } \\
\text { Man-Year(a) } \\
(\$ \text { thoursands) }\end{array}$} & \multirow[t]{2}{*}{$\begin{array}{l}\text { Total Stat } \\
\text { Lahor Cost } \\
\text { (\$ thousar }\end{array}$} \\
\hline & & & & & & & & \\
\hline $\begin{array}{l}\text { Health and Safety Supervisar } \\
\text { Industrial Safety Specialist } \\
\text { Radioactive Shipulent Specialist. }\end{array}$ & $\begin{array}{l}0.3 \\
0.3 \\
0\end{array}$ & $\begin{array}{l}1.0 \\
1.0 \\
1.0\end{array}$ & $\begin{array}{l}1.0 \\
1.0 \\
1.0\end{array}$ & $\begin{array}{l}1.0 \\
1.0 \\
1.0\end{array}$ & $\begin{array}{l}1.0 \\
1.0 \\
1.0\end{array}$ & $\begin{array}{l}4.3 \\
4.3 \\
4.0\end{array}$ & $\begin{array}{l}50.4 \\
43.8 \\
32.9\end{array}$ & $\begin{array}{l}216 \\
180 \\
131\end{array}$ \\
\hline $\begin{array}{l}\text { Health Physicist } \\
\text { Senior Health Physics Iechnician } \\
\text { Heal th Physics ieclinicion }\end{array}$ & $\begin{array}{l}0 \\
0 \\
0\end{array}$ & $\begin{array}{l}0.5 \\
1.0 \\
3.0\end{array}$ & $\begin{array}{l}1.0 \\
2.0 \\
7.0\end{array}$ & $\begin{array}{l}1.0 \\
2.0 \\
7.0 \\
\end{array}$ & $\begin{array}{l}1.0 \\
1.0 \\
5.0\end{array}$ & $\begin{array}{r}3.5 \\
6.0 \\
22.0 \\
\end{array}$ & $\begin{array}{l}39.4(d) \\
32.9(d) \\
25.1\end{array}$ & $\begin{array}{r}137 \\
197 \\
552 \\
\end{array}$ \\
\hline $\begin{array}{l}\text { Totals, without Centralized Heaith } \\
\text { Phiysics }\end{array}$ & 0.6 & 7.5 & 13.0 & 13.0 & 10.0 & 44.1 & & 1424 \\
\hline
\end{tabular}

Physics
th Centralized Health Physics (e)

\section{Site Level ${ }^{(f)}$}

Health and Safoty Supervisor Industrial Safety Specialist

clerk

0.1
0.1
0.1

Group kevel $(h)$

Heaith Physics Supervisor

Radioactive Shipment Specialist

Unit Lever

Health Physicist

Senior Health Physics Technician(j)

Health Physics Technician(j)

Totals, With Centralized Health Physics

Net Savings With Centralized Hea)th Physics

$\begin{array}{ll}0 & 0 \\ 0 & 0\end{array}$

(a) Based on Table 1.1-7 of Reference 1.

(b) Rounded to the nearest $\$ 100$

(c) Based on organization showi in figure 8.3-1a; manpower requirements taken from Table 10.1-2 of Reference 1 .

(d) Based on value given in Table M.1-l of Reference 3, to provide consistency between PWR and BWR results.

\begin{tabular}{|c|c|c|c|c|c|c|c|}
\hline $\begin{array}{l}0 \\
0 \\
0 \\
0\end{array}$ & $\begin{array}{l}0.5 \\
0.9 \\
2.7\end{array}$ & $\begin{array}{l}1.0 \\
1.8 \\
6.3 \\
\end{array}$ & $\begin{array}{r}1.0 \\
1.8 \\
6.3 \\
\end{array}$ & $\begin{array}{l}1.0 \\
0.9 \\
4.5\end{array}$ & $\begin{array}{r}3.5 \\
5.4 \\
19.8 \\
\end{array}$ & $\begin{array}{l}39.4(\mathrm{~d}) \\
32.9 \\
25.1\end{array}$ & $\begin{array}{r}137.9 \\
777.7 \\
497.9\end{array}$ \\
\hline$\underline{0.3}$ & 5.0 & 10.0 & 10.0 & 7. 3 & 32.6 & & 962.0 \\
\hline
\end{tabular}

(e) Based on organization shown in Figure $8.3-1$, with manpower requirements from Table $10.1-2$ of Reference 1 modified appropriateiy: rounded to next higher 0.1 man-year.

(f) Single unit assumed to bear lot of total site cost.

(h) Frum Table M. I- 1 of Reference 3 .

(i) Study estimate.

(j) Based on an assuned $10 \%$ reduction of the marimer requirements without centralized health physics. 
TABLE B.1-2. Health Physics Staff Labor Requirements and Costs for PWR Preparations for Safe Storage

Position

Tine Relative to final Reactor Shutdown (year) rotal Staff

Cost per Total Staff(a) Anulai stait Labor Requirenents (nan-years) (nan-years)

(\$ thousands) (\$ thousands)

Without Centralized Health Physics $(c)$

Health and Safety Supervisor

Industrial Safety Specialist

Radioactive Shipment Specialist

$\begin{array}{lll}0.3 & 1.0 & 1.0 \\ 0.3 & 1.0 & 1.0 \\ 0 & 1.0 & 1.0 \\ 0 & 0.5 & 1.0 \\ 0 & 1.0 & 2.0 \\ \underline{0} & \underline{1.5} & \underline{3.0} \\ \underline{0.6} & \underline{6.0} & \underline{9.0}\end{array}$

$\begin{array}{ll}0.4 & 2.7 \\ 0.4 & 2.7 \\ 0.4 & 2.4 \\ 0.4 & 1.9 \\ 0.7 & 3.7 \\ \underline{1.0} & 5.5 \\ \underline{3.3} & \underline{18.9}\end{array}$

$\begin{array}{lr}50.4 & 136.1 \\ 43.8 & 118.3 \\ 32.9 & 79.0 \\ & \\ 39.4 & 74.9 \\ 32.9(d) & 121.7 \\ 25.1 & 138.0 \\ & 668.0\end{array}$

With Centralized Itealth Physics (e)

\section{site Level (f)}

Health and Safety Supervisor

Industrial Safety Specialist

clerk

$\begin{array}{lll}0.1 & 0.1 & 0.1 \\ 0.1 & 0.1 & 0.1 \\ 0.1 & 0.1 & 0.1\end{array}$

Group Lever ${ }^{(h)}$

Health Physics Supervisor

Radfoactive Shiponent. Specialist

0
0

0.3
0.3

0.1

0.1

0.1

0.4
0.4

50.4

$20.3(\mathrm{~g})$

20.2

$\begin{array}{lll}0.1 & 0.1 & 0.4\end{array}$

8.1

Unit Level

Hearth Physicist
Senior Health Mlysics lechnician $(j)$

_. Health Physics Technician(j)

Totals, with Centralized Hedith Physics

$\begin{array}{lll}0 & 0.5 & 1.0 \\ 0 & 0.9 & 1 . \\ 0 & 1.4 & \underline{2} . \\ 0.3 & \underline{3} .7 & \underline{6} .\end{array}$

0.3

0.1

0.7

$43.8^{(i)}$

30.7

Net Savings With Centralized Health Physics

1.0
1.8
2.7
6.4

\begin{tabular}{l}
0.4 \\
0.7 \\
0.9 \\
\hline
\end{tabular}

1.9

5.0

$39.4(d)$

25.1

74.9

$\frac{0.9}{2.5}$

12.?

125.5

0.8

6.0

$\underline{411} . \underline{8}$

(a) Based on Table J.i-l of Reference 1.

(b) Rounded to the nearest \$100?.

(c) Based on organization shown in Figure $8.3-19$; manpower requirements taken from Jable 10.2-2 of Reference 1 , rounded to next higher 0.1 man-year.

(d) Based on value given in Tabie M.i-i of Reference 3, to provide consistency between PliR and BWR results.

(e) Based on orgasization shown in Figure $8.3-7 b$, with manpower requirenents from Tabie 10.2.2 of Reference 1 modified appropriately; rounded to next highter 0.1 mian-year.

(f) Single unit assumed to bear lo\% of total site cost.

(g) From Table $M, 1-1$ of Reference 3 .

(h) Single unit assumed to bear $30 \%$ of total group cost (10\% of total site cost assuning 3 groups).

(i) Study estimate.

(j) Based on an dssumed 10\% reduction of the manpower requirenents without centraized health phys ics. 
Total net savings with centralized health physics during SAFSTOR of the reference PWR are estimated to be 17-1/2 man-years and about $\$ 720,000$.

\section{B.1.3 PWR ENTOMB}

The schedule of events for ENTOMB of the reference PWR is very similar to that for DECON (see p. 4-6 of Reference 2). Therefore, the manpower requirements and costs for health physics services are assumed to be the same as those shown previously in Table B.7-7. Centralized health physics services during ENTOMB are thus estimated to result in net savings of $11-1 / 2$ man-years and about $\$ 460,000$.

\section{B. 1.4 BWR DECON}

Manpower requirements and costs for health physics staff during DECON of the reference $B W R$ are shown in Table B.1-3, based on information presented in Table 1.2-3 of Reference 3. A total of close to 78 man-years, costing almost $\$ 2.35$ million, is required without centralized health physics as compared to almost 62 man-years, costing about $\$ 1.73$ million, with centralized health physics. Net savings with centralized health physics are 16 man-years and about $\$ 620,000$.

\section{B. 1.5 BWR SAFSTOR}

Heaith physics staff labor requirements and costs for the first phase of BWR SAFSTOR, preparations for safe storage, are shown in Tabie B.1-4, based on information from Table 3.4-i of Reference 3. Without centralized heaith physics services, 49 man-years and about $\$ 1.53$ milition are estimated to be required. With centralized health physics, these requirements are reduced to 38 man-years and about $\$ 1.09$ miliion, for net savings of 11 man-years and aimost $\$ 440,000$.

During the continuing care period of BWR SAFSTOR, centralized heaith physics services are anticipated to have no significant effects.

The basic work force and time required for deferred decontamination of the reference BWR are the same as for DECON (see p. J-40 of Reference 3 ). Therefore, the health physics staff labor requirements and costs are assumed to be the same and, thus, centralized health physics services during the deferred decontamination phase of SAFSTOR are estimated to result in net savings of 16 man-years and almost $\$ 620,000$, as shown previously in Table B. -3 .

$$
\text { B-5 }
$$


TABLE B.1-3. Health Physics Staff Labor Requirements and Costs for BWR DECON

\begin{tabular}{|c|c|c|c|c|c|c|c|c|c|}
\hline Posițion & Ine & Staff & $\begin{array}{l}\text { Final } \\
\text { or Reg }\end{array}$ & actor. & int down & $y \in \frac{a r}{4}$ & $\begin{array}{l}\text { Jotal Staff } \\
\text { Lathor Required } \\
\text { (man-yedrs) }\end{array}$ & $\begin{array}{c}\text { Cost per } \\
\text { Man-Year(a) } \\
\text { (\$ thousands) }\end{array}$ & $\begin{array}{l}\text { Jotal Staf } \\
\text { Labor costs } \\
\text { (\$ thousang }\end{array}$ \\
\hline \multicolumn{10}{|l|}{ Without Centralized Hedith Physics $\{c\}$} \\
\hline $\begin{array}{l}\text { Health and Safety Supervisor } \\
\text { Industrial Safety Specialist } \\
\text { Radioactive Shipment Specialist }\end{array}$ & $\begin{array}{l}1.0 \\
0,3 \\
0\end{array}$ & $\begin{array}{l}1.0 \\
1.0 \\
1.0\end{array}$ & $\begin{array}{l}1.0 \\
1.0 \\
1.0\end{array}$ & $\begin{array}{l}1.0 \\
1.0 \\
1.0\end{array}$ & $\begin{array}{l}1.0 \\
1.0 \\
1.0\end{array}$ & $\begin{array}{l}0.8 \\
0.5 \\
0.4\end{array}$ & $\begin{array}{l}5.8 \\
4.8 \\
4.4\end{array}$ & $\begin{array}{l}50.4 \\
43.8 \\
32.9\end{array}$ & $\begin{array}{l}292.3 \\
210.2 \\
144.8\end{array}$ \\
\hline $\begin{array}{l}\text { Health Physicist } \\
\text { Senior Health Physics Technician } \\
\text { Heaith Physics Tecnnician }\end{array}$ & $\begin{array}{l}0 \\
0 \\
0\end{array}$ & $\begin{array}{l}0.5 \\
1.0 \\
3.0\end{array}$ & $\begin{array}{r}1.0 \\
2.5 \\
14.3 \\
\end{array}$ & $\begin{array}{r}1.0 \\
2.2 \\
14.9\end{array}$ & $\begin{array}{r}1.0 \\
2.7 \\
14.0\end{array}$ & $\begin{array}{l}0.5 \\
1.0 \\
3.8\end{array}$ & $\begin{array}{r}4.0 \\
8.8 \\
50.0\end{array}$ & $\begin{array}{l}39.4 \\
32.9 \\
25.1\end{array}$ & $\begin{array}{r}157.6 \\
289.5 \\
1255.0\end{array}$ \\
\hline Totals, Without Centralized Hea & 1.3 & 7.5 & 20.8 & 21.1 & 20.1 & 7.0 & 77.8 & & 2349.4 \\
\hline
\end{tabular}

With Centralized Hedith Physics (d)

Site ievei (e)

\section{Heal th and Safety Supervisor}

Industrial Safety specialist

on clerk

$\begin{array}{ll}0.1 & 0.1 \\ 0.1 & 0 \\ 0.1 & 0.1\end{array}$

Group Level (f)

liealth Physics Supervisor

Radioactive Shiprent Specialist

Unit Leve?

Heal th fhysicist

Health fhysicist
Senior llealth Physics Techujcian $(h)$
Health Physics Technician(h)

Totais, With Centralized Health Physics

0
0
0
0.3

0.1
0.1
0.1

\section{$0.1 \quad 0.1$}

$\begin{array}{lll}0.1 & 0.1 & 0.1\end{array}$

\section{$\left(\frac{10}{10}\right.$}

Net Savings With Centralized Health Physics

0.3
1.0

0.3

0.1

0.1

$\begin{array}{ll}0.1 & 0.1 \\ 0.1 & 0.1\end{array}$

0.6
0.6
0.6

50.4
43.8

20.3

26.3

$\begin{array}{lll}0.3 & 0.3 & 0.3\end{array}$

0.3

0.3

0.3

$\begin{array}{ll}0.3 & 0.2 \\ 0.3 & 0.2\end{array}$

\begin{tabular}{rrrrr}
0.5 & 1.0 & 1.0 & 1.0 & 0.5 \\
0.9 & 2.3 & 2.0 & 1.9 & 0.9 \\
2.7 & 12.9 & 13.5 & 12.6 & 3.5 \\
\hline 5.0 & 17.1 & 17.4 & 16.4 & $\underline{5.6}$
\end{tabular}

1.4
1.4

$43.8(0)$
32.9

61.3

(a) Based on Table M.1-1 of Reference 3.

(b) Rounded to the nearest $\$ 100$.

(c) Based on organization shown in Figure 8.3-la: manpower requirements taken from Jable $1.2-3$ of Reference 3 .

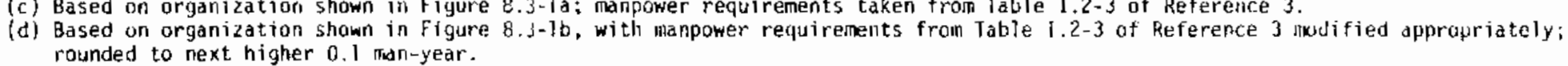

(e) Single unit assumed to bear $10 \%$ of total site cost.

(f) Single unit assumed to bear $30 \%$ of total group cost (10\% of total site cost assuming 3 groups).

(g) Study estimate.

(h) Based on an assumed $10 \%$ reduction of the manpower requirements witlout rentralized health physics. 
TABLE B.1-4. Health Physics Staff Labor Requirements and Costs for BWR Preparations for Safe Storage

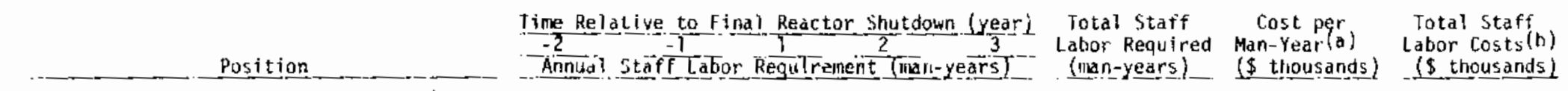

Without Centralized Hed th Physics (c)

\begin{tabular}{|c|c|c|c|c|c|c|c|c|}
\hline $\begin{array}{l}\text { Health and Safety Supervisor } \\
\text { Industrial Safety Sperialist } \\
\text { Radioactive Shipnent Specialist }\end{array}$ & $\begin{array}{l}0.5 \\
0.2 \\
0\end{array}$ & $\begin{array}{l}1.0 \\
1.0 \\
1.0\end{array}$ & $\begin{array}{l}1.0 \\
3.0 \\
1.0\end{array}$ & $\begin{array}{l}1.0 \\
1.0 \\
1.0\end{array}$ & $\begin{array}{l}0.8 \\
0.5 \\
0.4\end{array}$ & $\begin{array}{l}4.3 \\
3.7 \\
3.4\end{array}$ & $\begin{array}{l}50.4 \\
43.8 \\
32.9\end{array}$ & $\begin{array}{l}216.7 \\
162.7 \\
111.9\end{array}$ \\
\hline $\begin{array}{l}\text { Health Plysicist } \\
\text { Senior Health Physics Teennician } \\
\text { Health Physics IEchnician }\end{array}$ & $\begin{array}{l}0 \\
a \\
0\end{array}$ & $\begin{array}{l}0.5 \\
1.0 \\
3.0\end{array}$ & $\begin{array}{r}1.0 \\
2.2 \\
13.0 \\
\end{array}$ & $\begin{array}{l}1.0 \\
2.2 \\
9.1\end{array}$ & $\begin{array}{l}0.5 \\
1.4 \\
2.7 \\
\end{array}$ & $\begin{array}{r}3.0 \\
6.8 \\
27.8 \\
\end{array}$ & $\begin{array}{l}39.4 \\
32.9 \\
25.1\end{array}$ & $\begin{array}{l}118.2 \\
223.7 \\
697.8 \\
\end{array}$ \\
\hline Totals, Without Centralized Healt & 0.7 & 7.5 & 19.2 & 15.3 & 6.3 & 49.0 & & 1530.4 \\
\hline
\end{tabular}

With Centralized Health Physics ${ }^{(d)}$

Site Level (e)

Health and Safety Supervisor

industrial Safety Specialist

Group Level ${ }^{(f)}$

Health Physics Supervisor

Radioactive Shipment Specialist

$\begin{array}{lll}0.1 & 0 \\ 0.1 & 0 \\ 0.1 & 0.1\end{array}$

$\begin{array}{lll}0.1 & 0.1 & 0.1 \\ 0.1 & 0.1 & 0.1\end{array}$

$0 . ? \quad 0.1$

$\begin{array}{ll}0.1 & 0.1 \\ 0.1 & 0\end{array}$

$\begin{array}{llll}0.1 & 0.5 & 50.4 & 25.2 \\ 0.1 & 0.5 & 43.8 & 21.9 \\ 0.1 & 0.5 & 20.3 & 10.2\end{array}$

Health Physicist
Senior Health Physics Technician (h)

Mealth Physics Technician(h)

Totals, with Centralized Heal th Physics

$\stackrel{0}{0}$

0.3
0.3

$0.3+3$

0.3
0.3

0.2

1.1

$43.8^{(9)}$

48.2

\begin{tabular}{rrrr}
0 & 0.5 & 1.0 & 1.0 \\
0 & 0.9 & 2.0 & 2.0 \\
0 & $\underline{2.7}$ & $\underline{11.7}$ & $\mathbf{8 . 2}$ \\
\hline
\end{tabular}

$\underline{0.3}$

$\underline{5.0}$

$\frac{11.7}{15.6}$

$\begin{array}{r}1.0 \\ 2.0 \\ 8.2 \\ 12.1 \\ \hline 12.1\end{array}$

\begin{tabular}{l}
0.5 \\
1.3 \\
2.5 \\
\hline$\underline{5.0}$
\end{tabular}

3.0

39.4

32.9
25.7

118.2

25.1

38.0

630.0

Net Savings With Centralized Health Physics

$0.4 \quad 2.5$

3.6

3.2

1.3

11.0

093.9

\footnotetext{
(a) Based on Table H.1-1 of Reference 3.

(b) Rounded to the nearest $\$ 100$.

(c) Based on organization shown in Figure 8.3-1a; manpuwer requirements taken from Table J.4-1 of Reference 3.

(d) Based on organization shown in Figure $8.3-7 \mathrm{~b}$, with manpower requirements trom Table $3.4-1$ of Reference 3 modified appropriately; rounded to next higher 0.1 inan-year.

(e) Single unit assumed to bear iox of total site cost.

(f) Single unit assumed to bear $30 x$ of total group cost $(10 \%$ of total site cost assuming 3 groups).

(g) Study estimate.

(h) Based on an assumed $10 \%$ reduction of the manpower requirements without centralized health physics.
} 
Centralized health physics services are estimated to result in total net savings for BWR SAFSTOR of 27 man-years and about $\$ 1.05$ million.

\section{B. 1.6 BWR ENTOMB}

Based on information presented in Table K.2-2 of Reference 3, manpower requirements and costs for health physics staff for BWR ENTOMB (reactor vessel internals removed) are shown in TabTe B.1-5. Totals of almost 79 man-years and about $\$ 2.41$ million are required without centraiized health physics as compared to 62 man-years and about $\$ 1.75$ million with centralization. Centralized health physics services result in net savings of almost 17 man-years and about $\$ 650,000$ for scenarjo 1.

\section{B. 2 SECURITY FORCES}

Centralized security forces are anticipated to reduce the costs associated with security functions at a reactor sited on a muitiple-reactor station during both operation and decommissioning. Two factors are postulated to account for this cost reduction:

- The overhead structure for each reactor can be reduced by sharing certain staff members between reactors.

- Off-shift coverage at a reactor being decommissioned can be reduced or eiminated after the spent fuel has been shipped (no special nuclear material at reactor) if provision is made for routine spot-checks by roving security patroimen, reducing the overall personnel requirement.

Centralization of the security forces is not anticipated to change the occupational radiation dose for decommissioning a reactor.

The security force labor requirements and costs during decommissioning, both with and without centraijzed security forces, are presented here for the decomissioning of both the PWR and the BWR by all the decomissioning alternatives considered in this study. Net savings resulting from centralization of the security forces are calculated from these results.

\section{B.2.1 PWR DECON}

Security force labor requirements and costs for DECON of the reference PWR are presented in Table B.2-1, based on the schedule shown in Figure 9.1-2 of 
TABLE B.1-5. Health Physics Staff Labor Requirements and Costs for BWR ENTOMB

\begin{tabular}{|c|c|c|c|c|c|c|c|c|c|}
\hline Position & \multicolumn{6}{|c|}{ 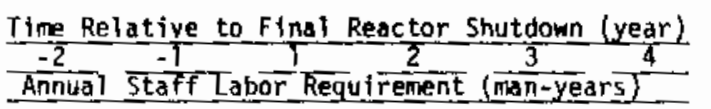 } & \multirow[t]{2}{*}{$\begin{array}{l}\text { Total Staff } \\
\text { Labor Required } \\
\text { (man-years) }\end{array}$} & \multirow[t]{2}{*}{$\begin{array}{l}\text { Cost per } \\
\text { Man-Year (a) } \\
\$ \text { thousands) }\end{array}$} & \multirow[t]{2}{*}{$\begin{array}{l}\text { Total Staff } \\
\text { Labor Costs } b) \\
\text { ( } \$ \text { thousands) }\end{array}$} \\
\hline \multicolumn{7}{|l|}{ Without Centralized Health Physics $(c)$} & & & \\
\hline $\begin{array}{l}\text { Health and Safety Supervisor } \\
\text { Industrial Safety Specialist } \\
\text { Radioactive Shipment Specialist }\end{array}$ & $\begin{array}{l}1.0 \\
0.3 \\
0\end{array}$ & $\begin{array}{l}1.0 \\
1.0 \\
1.0\end{array}$ & $\begin{array}{l}1.0 \\
1.0 \\
1.0\end{array}$ & $\begin{array}{l}1.0 \\
1.0 \\
1.0\end{array}$ & $\begin{array}{l}1.0 \\
1.0 \\
1.0\end{array}$ & $\begin{array}{l}1.2^{(d)} \\
0.9 \\
0.7\end{array}$ & $\begin{array}{l}6.2 \\
5.2 \\
4.7\end{array}$ & $\begin{array}{l}50.4 \\
43.8 \\
32.9\end{array}$ & $\begin{array}{l}312.5 \\
227.8 \\
154.6\end{array}$ \\
\hline $\begin{array}{l}\text { Health Physicist } \\
\text { Senior Health Physics Technician } \\
\text { Hea?th Phys ics Technician }\end{array}$ & $\begin{array}{l}0 \\
0 \\
0 \\
\underline{0}\end{array}$ & $\begin{array}{l}0.5 \\
1.0 \\
3.0 \\
\end{array}$ & $\begin{array}{r}1.0 \\
2.4 \\
13.9 \\
\end{array}$ & $\begin{array}{r}1.0 \\
2.3 \\
13.6 \\
\end{array}$ & $\begin{array}{r}1.0 \\
2.0 \\
12.0 \\
\end{array}$ & $\begin{array}{l}0.8 \\
2.0 \\
6.2 \\
\end{array}$ & $\begin{array}{r}4.3 \\
9.7 \\
48.7 \\
\end{array}$ & $\begin{array}{l}39.4 \\
32.9 \\
25.1\end{array}$ & $\begin{array}{r}169.4 \\
319.1 \\
1222.4 \\
\end{array}$ \\
\hline \multicolumn{10}{|l|}{ With Centralized Health Physics $(e)$} \\
\hline \multicolumn{10}{|l|}{ Site Level $(f)$} \\
\hline $\begin{array}{l}\text { Health and Safety Supervisor } \\
\text { lndustrial Safety Specialist } \\
\text { Clerk }\end{array}$ & $\begin{array}{l}0.1 \\
0.1 \\
0.1\end{array}$ & $\begin{array}{l}0.1 \\
0.1 \\
0.1\end{array}$ & $\begin{array}{l}0.1 \\
0.1 \\
0.1\end{array}$ & $\begin{array}{l}0.1 \\
0.1 \\
0.1\end{array}$ & $\begin{array}{l}0.1 \\
0.1 \\
0.1\end{array}$ & $\begin{array}{l}0.2 \\
0.1 \\
0.1\end{array}$ & $\begin{array}{l}0.7 \\
0.6 \\
0.6\end{array}$ & $\begin{array}{l}50.4 \\
43.8 \\
20.3\end{array}$ & $\begin{array}{l}35.3 \\
26.3 \\
12.2\end{array}$ \\
\hline \multicolumn{10}{|l|}{ Group Level ${ }^{(g)}$} \\
\hline $\begin{array}{l}\text { Health Physics Supervisor } \\
\text { Radioactive Shipment Specialist }\end{array}$ & $\begin{array}{l}0 \\
0\end{array}$ & $\begin{array}{l}0.3 \\
0.3\end{array}$ & $\begin{array}{l}0.3 \\
0.3\end{array}$ & $\begin{array}{l}0.3 \\
0.3\end{array}$ & $\begin{array}{l}0.3 \\
0.3\end{array}$ & $\begin{array}{l}0.3 \\
0.3\end{array}$ & $\begin{array}{l}1.5 \\
1.5\end{array}$ & $\begin{array}{l}43.8^{(h)} \\
32.9^{(h)}\end{array}$ & $\begin{array}{l}65.7 \\
49.4\end{array}$ \\
\hline \multicolumn{10}{|l|}{ Unit Level } \\
\hline $\begin{array}{l}\text { Health Physicist } \\
\text { Senior Health Physics Technictan(i) } \\
\text { Health Physics Technician(i) }\end{array}$ & $\begin{array}{l}0 \\
0 \\
0\end{array}$ & $\begin{array}{l}0.5 \\
0.9 \\
2.7 \\
\end{array}$ & $\begin{array}{r}1.0 \\
2.2 \\
12.5 \\
\end{array}$ & $\begin{array}{r}1.0 \\
2.1 \\
12.3 \\
\end{array}$ & $\begin{array}{r}1.0 \\
1.8 \\
10.8 \\
\end{array}$ & $\begin{array}{l}0.8 \\
1.8 \\
5.6 \\
\end{array}$ & $\begin{array}{r}4.3 \\
8.8 \\
44.0 \\
\end{array}$ & $\begin{array}{l}39.4 \\
32.9 \\
25.1\end{array}$ & $\begin{array}{r}169.4 \\
289.5 \\
1104.4 \\
\end{array}$ \\
\hline Totals, With Centralized Health Physics & $\underline{0.3}$ & $\underline{5.0}$ & 16.7 & 16.3 & 14.5 & $\underline{9.2}$ & $\underline{62.0}$ & & 1752.2 \\
\hline Net Savings With Centralized Health Physics & 1.0 & 2.5 & 3.6 & 3.6 & 3.5 & 2.6 & 16.8 & & 653.6 \\
\hline \multicolumn{10}{|c|}{$\begin{array}{l}\text { (a) Based on Table M.l-1 of Reference } 3 \text {. } \\
\text { (b) Rounded to the nearest } \$ 100 \text {. } \\
\text { (d) Based on organization shown in Figure } 8.3-1 \mathrm{a} \text {; manpower requirements taken from Table } K, 2-2 \text { of Reference } 3 \text {. } \\
\text { though it extends into year } 5 \text {; from Table } \mathrm{K} \text {.2-2 of Reference } 3 \text {. } \\
\text { (e) Based on organization shown in Figure } 8.3-1 \mathrm{~b} \text {, with manpower requirements from Table } k .2-2 \text { of Reference } 3 \text { modified appropriately; rounded } \\
\text { to next higher } 0.1 \text { man-year. } \\
\text { (f) Single unit assumed to bear } 10 \% \text { of total site cost. } \\
\text { (g) Single unit assumed to bear } 30 \% \text { of total group cost }(10 \% \text { of total site cost assuming } 3 \text { groups). } \\
\text { (h) Study estimate. } \\
\text { (i) Based on an assumed } 10 \% \text { reduction of the manpower requirements without centralized health physics. }\end{array}$} \\
\hline
\end{tabular}




\section{TABLE B.2-1. Security Force Labor Requirements and Costs for PWR DECON and ENTOMB}

\begin{tabular}{|c|c|c|c|c|c|c|c|}
\hline & Postion. & \multicolumn{3}{|c|}{$\begin{array}{l}\text { Tine Relative to Final Reactor Shutdown (year). } \\
\text { - Annual Staff Labor Reguirement (man-years) }\end{array}$} & \multirow[t]{2}{*}{$\begin{array}{l}\text { Totai Staff } \\
\text { habor Required } \\
\text { (man-years) }\end{array}$} & $\begin{array}{c}\text { Cost per } \\
\text { Man-Year(a) } \\
\text { \$ thousands) }\end{array}$ & $\begin{array}{l}\text { Total } S t a f f \\
\text { l.abor } \cos t 5(b) \\
\$ \$ \text { thousands) }\end{array}$ \\
\hline & \multicolumn{6}{|l|}{ Without Centralized Security Forces (c) } & \\
\hline & $\begin{array}{l}\text { Security Supervisor } \\
\text { Security Shift Supervisor } \\
\text { Security Patrolmen }\end{array}$ & $\begin{array}{r}1.0 \\
5.0 \\
39.0 \\
\end{array}$ & $\begin{array}{r}1.0 \\
5.0 \\
21.7\end{array}$ & $\begin{array}{r}1.0 \\
5.0 \\
13.0 \\
\end{array}$ & $\begin{array}{r}3.0 \\
15.0 \\
73.7\end{array}$ & $\begin{array}{l}32.9 \\
30.7 \\
21.3\end{array}$ & $\begin{array}{r}98.7 \\
460.5 \\
1569.8 \\
\end{array}$ \\
\hline & \multicolumn{7}{|l|}{ With Centralized Security Forces (e) } \\
\hline & \multicolumn{7}{|l|}{ Site Levei ${ }^{(f)}$} \\
\hline & $\begin{array}{l}\text { Securfty Supervisor } \\
\text { Assistant Security Supervisor }\end{array}$ & 0.1 & $\begin{array}{l}0.1 \\
0.1\end{array}$ & 0.1 & $\begin{array}{l}0.3 \\
0.3\end{array}$ & $32.9(9)$ & $\begin{array}{l}9.9 \\
9.2\end{array}$ \\
\hline 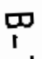 & \multicolumn{7}{|l|}{ Group Leve ${ }^{(h)}$} \\
\hline $\overrightarrow{0}$ & $\begin{array}{l}\text { Security Shift Supervisor } \\
\text { Security Patrolrien }\end{array}$ & $\begin{array}{l}1.5 \\
3.0\end{array}$ & $\begin{array}{l}1.5 \\
3.0\end{array}$ & $\begin{array}{l}1.5 \\
3.0\end{array}$ & $\begin{array}{l}4.5 \\
9.0\end{array}$ & $\begin{array}{l}30.7 \\
21.3\end{array}$ & $\begin{array}{l}138.2 \\
191.7\end{array}$ \\
\hline & \multicolumn{7}{|l|}{ Unit Level } \\
\hline & Security Patuoluen(i) & 39.0 & 17.0 & -6.0 & 62.0 & 21.3 & 1320.6 \\
\hline & Totals, With Centralized Security Forces & 43.7 & 21.7 & $\underline{10.7}$ & $76 . ?$ & & $\underline{1669}, \underline{6}$ \\
\hline & Net Savings With Centralized Security Forces & 1.3 & 6.0 & 8.3 & 15.6 & & 459.4 \\
\hline & \multicolumn{7}{|c|}{ 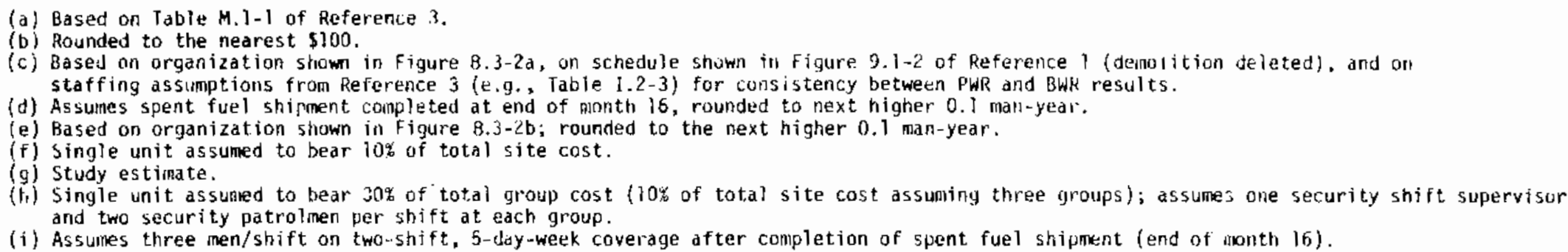 } \\
\hline
\end{tabular}


Reference 1, with demolition deleted. The requirements and costs with centralized security forces take into account both the reduced overhead structure per reactor and the elimination of continuous off-shift coverage after offsite shipment of spent fuel. A total of about $91-1 / 2$ man-years, costing almost $\$ 2.13$ million, is required without centralization as compared to about 76 manyears, costing almost $\$ 1.67$ million, with centralization. Thus, centralized security forces result in net savings of about $15-1 / 2$ man-years and almost $\$ 460,000$.

\section{B.2.2 PWR SAFSTOR}

Security force labor requirements and costs for the first phase of PWR SAFSTOR, preparations for safe storage, are presented in Table B.2-2, based on the decommissioning schedule shown in Figure 9.2-5 of Reference 1 . Without centralized security, 50-1/2 man-years and about $\$ 1.15$ million are estimated to be required. With centraiized security forces, these requirements are reduced to about 46 man-years and just over $\$ 1.00 \mathrm{million}$, for net savings of almost 4-1/2 man-years and $\$ 150,000$.

Centralized security forces are anticipated to result in no significant savings during the continuing care period of SAFSTOR and, therefore, no requirements and costs are calculated for this period.

Security force labor requirements and costs for deferred decontamination (the final phase of SAFSTOR) of the reference PWR are given in Table B.2-3, based on the decommissioning schedule for DECON shown in Figure 9.1-2 of Reference 1. The results differ from the results for DECON because of the reduced requirements for security patrolmen at the reactor (both with and without centralization). These reduced requirements reflect the offsite shipment of spent reactor fuel prior to the start of deferred decontamination. Without centralized security, 57 man-years costing almost $\$ 1.39$ million are estimated to be required. With centralized security forces, these totals are reduced to about 32 man-years and about $\$ 730,000$, resulting in net savings of almost 25 man-years and about $\$ 660,000$ with centralization.

Total net savings resulting from centralized security forces during SAFSTOR of the reference PWR are estimated to be 29 man-years and $\$ 810,000$. 
TABLE B.2-2. Security Force Labor Requirements and Costs for PWR Preparations for Safe Storage

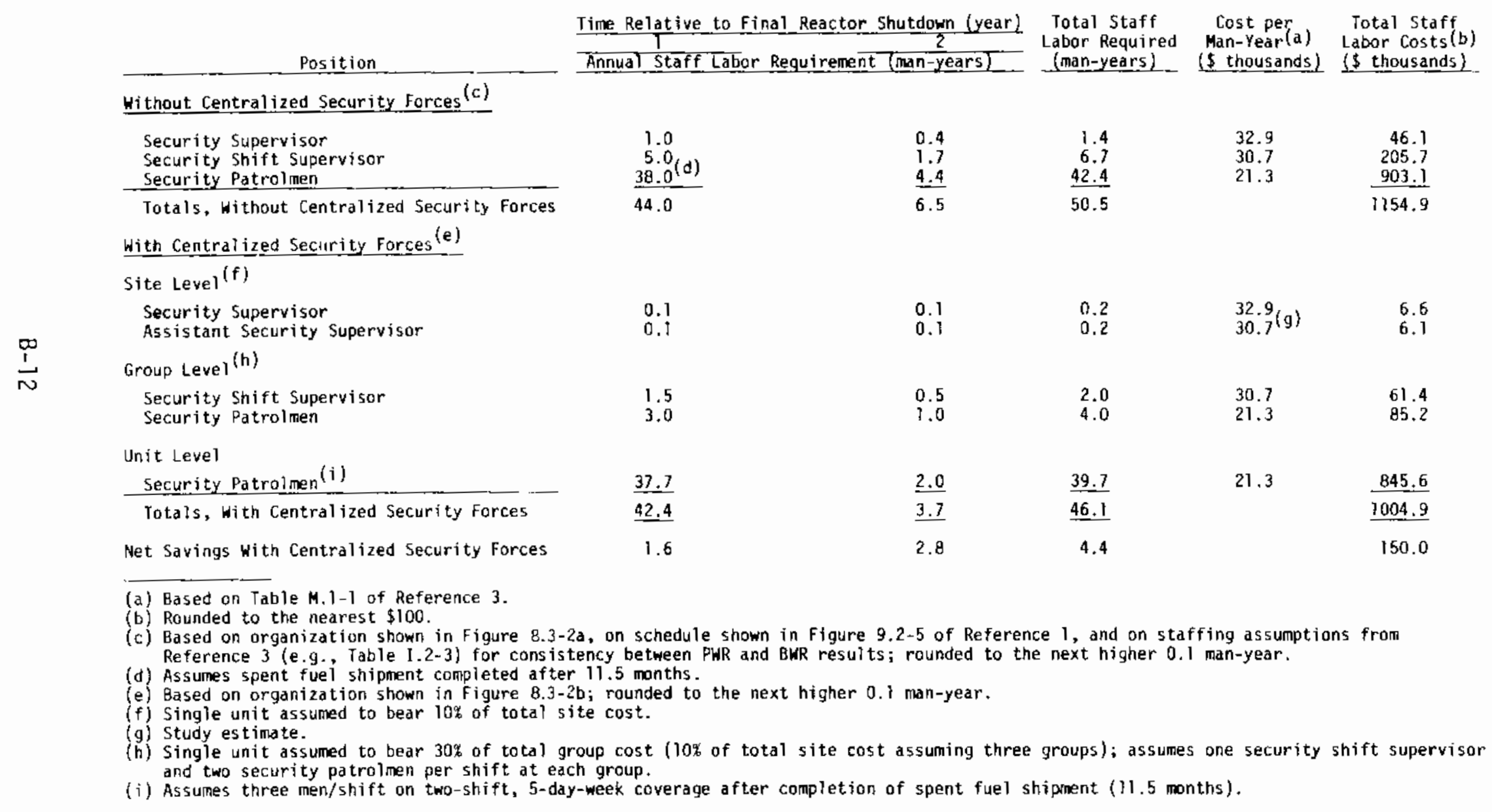




\section{TABLE B.2-3. Security Force Labor Requirements and Costs for PWR Deferred Decontamination}

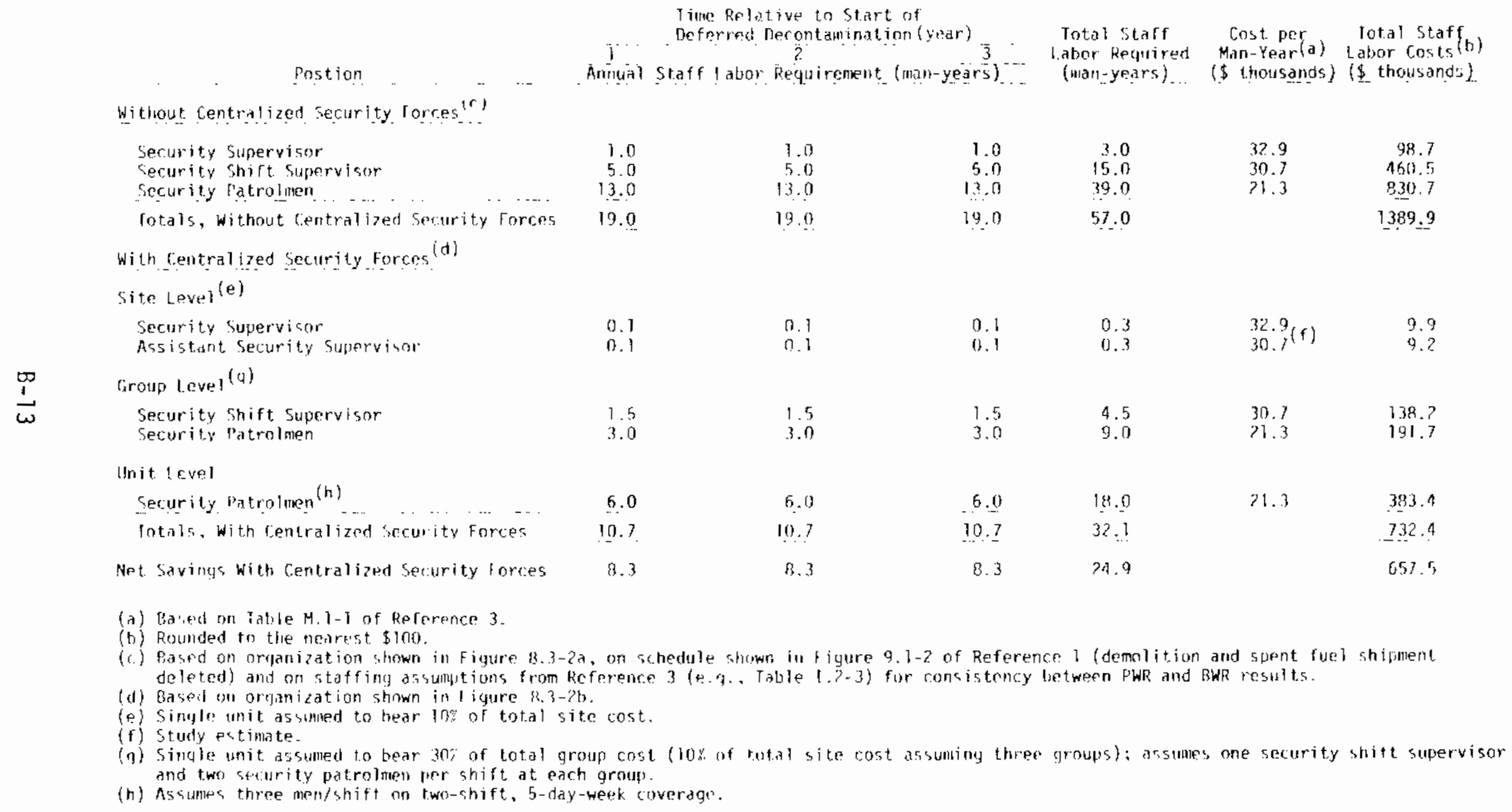




\section{B.2.3 PWR ENTOMB}

The schedule of events for entombment of the reference PWR is very simitar to that for DECON, as stated previously in Section B.1.3. Therefore, the security staff requirements and costs for entombment are assumed to be the same as those given previously in Table B.2-1. Centralized security during ENTOMB is thus estimated to result in net savings of about $15-1 / 2$ man-years and $\$ 460,000$.

\section{B.2.4 BWR DECON}

Manpower requirements and costs for security personnel during DECON of the reference BWR are shown in Table B.2-4. Manpower requirements from Table 1.2-3 of Reference 3 are used for decommissioning without centralized security; these vaiues are modified appropriately for decomissioning with centralized security to account for both the reduced overhead structure and the elimination of continuous off-shift coverage after offsite shipment of spent fuel. A total of 107-1/2 man-years, costing aimost $\$ 2.50$ million, is required without centrailized security as compared to almost 90 man-years, costing about $\$ 1.97$ million, with centralization of the security forces. Net savings with centralized security are thus about $17-1 / 2$ man-years and over $\$ 520,000$.

\section{B.2.5 BWR SAFSTOR}

Security force labor requirements and costs for preparations for safe storage, the first phase of SAFSTOR, are presented in Table B.2-5, based on information from Table 3.4-1 of Reference 3. Without centralized security forces, $88-1 / 2$ man-years and about $\$ 2.03$ million are estimated to be required. With centralized security, these totais are reduced to about 79 man-years and almost $\$ 1.73$ milition, for net savings of almost $9-1 / 2$ man-years and about $\$ 300,000$.

During the continuing care period of BWR SAFSTOR, centralized security forces are anticipated to result in no significant savings and, therefore, labor requirements and costs are not calculated for this period.

Security force labor requirements and costs for deferred decontamination of the reference BWR are presented in Table B.2-6. The requirements are based 
TABLE B.2-4. Security Force Labor Requirements and costs for BWR DECON

Position

Ine Relative to Final Reactor Sliutdown (year)

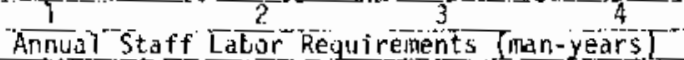

Total staff abor Required

Cost per (man-years) (\$ thousands)

Total Staff abor $\operatorname{Cos} t_{5}(\mathrm{~b})$

Without Centraijized Security forces (c)

\section{Security Supervisor}

Security Shift Supervisor

Security Patrolmen

Totals, Without Centralized Security Forces

with Centralized Security Forces (d)

Site Level ${ }^{(e)}$

Security Supervisor

Assistant Security Supervisor

Group Level $(\mathrm{g})$

Security Shift Supervisor

Security Patrolinen

Unit Leve!

Security Patrulien (h)

Totals, with Centralized Security Forces

Net Savings with Centraized Security Forces
1.0

5.0
39.0

45. 0

0.1

0.1

0.1

1.0
5.0

2B. 0

34.0
0.5
2.5

$\underline{6.5}$

$\underline{9.5}$
32.9

30.7
21.3

175.2
537.3

3.5
77.5

86.5

107.5

1842.5

2495.0

1.5
3.0

1.5
3.0

0.1

0.1
0.1

0.4

$32.9(f)$

13.2

3.0

1. 5

0.8

5.3
10.5

30.7
21.3

162.7

39.0
43.7 $\quad \underline{25.3}$

6.0

$-\frac{3.0}{5.5}$

73.3

21.3

1561.3

1.34 .0

8.3

4.0

17.6

1973.2

521.8

(a) Based on Table M.1-1 of Reference 3.

(b) Rounded to the nearest $\$ 100$

(c) Based on organization shown in Figure 8.3-2a; manpower requirements taken from Table $1.2-3$ of Reference 3 .

(d) Based on orjanization show in Figure 8.3 - $2 \mathrm{~b}$; rounded to the next higher 0.1 man-year.

(e) Single unit assulned to bear in of total site cost.

(f) 5 tudy estionate.

(g) Single unit assumed to bear 30\% of total group cost (10\% of total site cost assuming three groups); assumes one security shift supervisor and two security patrolnen per shift at each group.

(h) Assurues three men/shift on two-shift, 5-day-week coverage after completion of spent fiel shipuent. (end of month 19 ). 


\section{TABLE B.2-5. Security Force Labor Requirements and Costs for BWR Preparations for Safe Storage}

\section{Postion}

Without Centralized Security Forces $(c)$

Security Supervisor

Security Shift Supervisur

Security Patrolmen

Totals, Without Centralized Security farces

Witl Centralized Security Forces (d)

$\frac{1}{a}$

\section{Site Level ${ }^{(e)}$}

Security Supervisor

Assistatit Security Supervisor

Group Level ${ }^{(9)}$

Security Shift Supervisor

Security Patroluen

Unit Level

Security patrolnen $(h)$

Totals, With Centralized Security forces

Met Savings with Centralized Security Forces

\section{Time Relative to Final Reactor Shutdown (year)} Annual Staff Labor Requireinent (man-years). (nean-years).

Cost per Total staft
Man-Year(a) Labor Costs $($ i) Man-Year(a) Labor Cosis (n)
(\$ thousands) (\$ thousdids)

\begin{tabular}{|c|c|c|c|c|c|}
\hline $\begin{array}{r}1.0 \\
5.0 \\
39.0\end{array}$ & $\begin{array}{r}1.0 \\
5.0 \\
28.0 \\
\end{array}$ & $\begin{array}{l}0.5 \\
2.5 \\
6.5 \\
\end{array}$ & $\begin{array}{r}2.5 \\
12.5 \\
73.5 \\
\end{array}$ & $\begin{array}{l}32.9 \\
30.7 \\
21.3\end{array}$ & $\begin{array}{r}82.3 \\
383.8 \\
1565.6 \\
\end{array}$ \\
\hline 45.0 & 34.0 & 9.5 & 88.5 & & 2031.7 \\
\hline $\begin{array}{l}0.1 \\
0.1\end{array}$ & $\begin{array}{l}0.1 \\
0.1\end{array}$ & $\begin{array}{l}0.1 \\
0.1\end{array}$ & $\begin{array}{l}0.3 \\
0.3\end{array}$ & $\begin{array}{l}32.9 \\
30.7\end{array}$ & $\begin{array}{l}9.9 \\
9.2\end{array}$ \\
\hline $\begin{array}{l}1.5 \\
3.0\end{array}$ & $\begin{array}{l}1.5 \\
3.0\end{array}$ & $\begin{array}{l}0.8 \\
1.5\end{array}$ & $\begin{array}{l}3.8 \\
7.5\end{array}$ & $\begin{array}{l}30.7 \\
21.3\end{array}$ & $\begin{array}{l}116.7 \\
159.8\end{array}$ \\
\hline 39.0 & 25.3 & 3.0 & 67.3 & 21.3 & 1433.5 \\
\hline 43.7 & 30.0 & 5.5 & $\underline{79}: \underline{2}$ & & 1729.1 \\
\hline 1.3 & 4.0 & 4.0 & 9.3 & & 302.6 \\
\hline
\end{tabular}

(a) Based on Table M.1-l of Reference 3.

(b) Rounded to the nearest $\$ 100$.

(c) Based on organizatiun shiwn in Figure 8.5-\%a; manpower requirements taken from Table J.4-1 of keference 3.

(c) Based on organizatiun shizwn in Figure $8.5-\% \mathrm{a}$; manpower requirements taken from Table $J .4-$

(e) Single site assumed to bear $10 \%$ of total site cast.

(f) Study estimate.

(h) Assunies three men/shift on two-shift, 5-day-week coierage after completion of spent tucl shijilent (end of unonth 19). 


\section{TABLE B.2-6. Security Force Labor Requirements and Costs for BWR Deferred Decontamination}

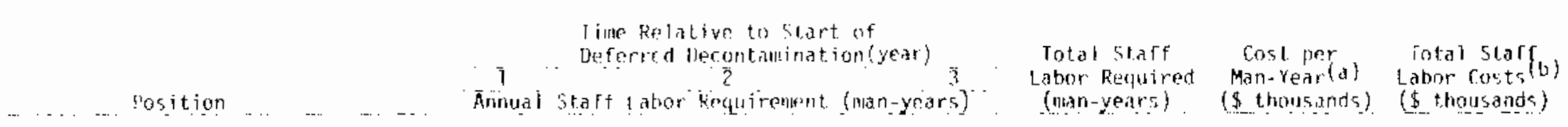

Without Centralized security Forces(u)

Security Supervisor

Security Shift Subervisor

Security Eatrolmen

1.0

5.0
13.0

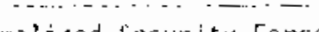

with central ized security forcess. (d)

site Leveile)

Security supervistr

$\frac{1}{1}$

Ciroup lever (o)

Securily shift supervisor

Spcurity bistroblien

lonit leneil

Security Patrolmen $(h)$
Totals, with Centralized serurity Forces

19.0

1.0
5.0
13.0
19.0

1.0
5.0
3.0
19.0
0.5
2.5
2.5
6.5
9.5

1. 3.5

11.5
45.5

32.9

30.7
21.3

115.2

45.5

969.2

19.0

66.5

1621.7

Net Savings with centralized security forces

\begin{tabular}{|c|c|c|c|c|c|c|}
\hline 0.1 & 0.1 & 0.1 & 0.1 & 0.4 & $32.9(\mathrm{f})$ & $1,3.2$ \\
\hline & 0.1 & 0.1 & 0.1 & 0.4 & $30.7^{(1)}$ & 12.3 \\
\hline 1.5 & 1.5 & 1.5 & 0.8 & 5.3 & 30.7 & 162.7 \\
\hline 3.10 & 3.0 & 3.0 & 1.5 & 10.5 & 27.3 & 223.7 \\
\hline 6.0 & 6.0 & 6.0 & 3.0 & 21.0 & 21.3 & 447.3 \\
\hline 10.7 & 10.7 & 10.7 & 5.5 & 37.6 & & $359 . i$ \\
\hline
\end{tabular}

$\begin{array}{llllll}8.3 & 8.3 & 8.3 & 4.0 & 28.9 & 762.5\end{array}$

(a) Based on Jable M.1-1 of Reference 3 .

(b) Rounded tor the nearest $\$ 100$.

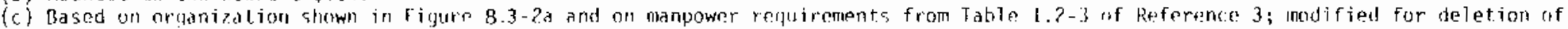
spent fuel shipment.

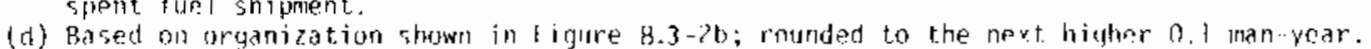

(e) single unit assimed to hear lio of total site cost.

(f) study art as

(a) single unit assumed to bedr 30\% of total groub cost (10\% nf total sito cost ascuming three qroums); assuanes one security shift supervisor arid two security patiolnen per shift at each group.

(h) Ascumes three men/shift on two-shift, 5 -day-week coverage. 
on information from Table 1.2-3 of Reference 3 for DECON of the plant, modified to reflect the offsite shipment of the spent reactor fuel prior to deferred decontamination. Without centralized security, 66-1/2 man-years and about $\$ 1.62$ million are estimated to be required. With centralized security, these totals are reduced to about $37-1 / 2$ man-years and almost $\$ 860,000$, resulting in net savings of aimost 29 man-years and approximately $\$ 760,000$.

Total net savings with centralized security forces for BWR SAFSTOR are estimated to be about 38 man-years and almost $\$ 1.07$ million.

\section{B.2.6 BWR ENTOMB}

Based on information presented in Table K.2-2 of Reference 3, manpower requirements and costs for security personnel for BWR ENTOMB are given in Table B.2-7. Totals of about 114-1/2 man-years and approximate1y $\$ 2.67$ mition are required without centraljzed security as compared to 94 man-years and almost $\$ 2.07$ million with centralization. Centralized security forces thus result in net savings of over 20-1/2 man-years and $\$ 600,000$.

\section{B. 3 SOLID WASTE PROCESSING}

Centralized solid waste processing facilities at a multiple-reactor site can provide significant savings in waste disposal costs, during both the operating and the decommissioning phases of reactor $1 \mathrm{ife}$, by reducing the volume of wastes requiring shipment and disposal. Reductions in radiation exposures, both to workers and to the public, can also result because of the reduced handling and shipping requirements.

This analysis assumes a central waste incineration facility capable of handiing 1) all dry combustible wastes generated by the 10 operating reactors onsite as well as 2) the dry combustible wastes resulting from the onsite decommissioning activities (when they commence). The results for this case (with incineration) are compared to those of the base case, given in References 1 through 3, in which these wastes are assumed to be compacted for shipment offsite.

Compaction of dry combustible wastes is assumed to reduce the waste volume by an average of $5: 1$. This is the same factor used in estimating disposal 
TABLE B.2-7. Security Force Labor Requirements and Costs for BWR ENTOMB

Iime Relative to Flnal Reactor Shutdown (year) $\frac{\text { Total Staff }}{2}$ Labor Required Man-Year(a) Labor Costs(b) Position

Anmua) Staff Labor Requirements (man-years) $\begin{gathered}\text { Labor Required } \\ \text { (man-years) }\end{gathered}$

\$ thousands) (\$ thousands)

Without Centralized Security Forces ${ }^{(c)}$

Security Shift Supervisor

Security Patrolmen

Totals, without Centralized Security Forces

\section{0}

$\begin{array}{r}5.0 \\ 39.0 \\ \hline\end{array}$

\subsection{0}

$\begin{array}{r}5.0 \\ 28.0 \\ \hline\end{array}$

$\begin{array}{r}1.0 \\ 5.0 \\ 13.0 \\ \hline\end{array}$

$\begin{array}{r}0.9 \\ 4.4 \\ 11.4 \\ \hline 16.7\end{array}$

$\begin{array}{r}3.9 \\ 19.4 \\ 91.4 \\ \hline 114.7 \\ \hline\end{array}$

32.9
30.7

21.3

128.3

$\underline{45.0}$

34.0

19.0

16.7

1946.8

2670.7

With Centralized Security Forces (d)

Site Level ${ }^{\text {(e) }}$

$\frac{1}{\infty}$

\section{Security Supervisor}

Assistant Security Supervisor

Group Level $(g)$

Security Shift Supervisor

Security Patrolmen

$\begin{array}{lllll}0.1 & 0.1 & 0.1 & 0.7 & 0.4 \\ 0.1 & 0.1 & 0.1 & 0.1 & 0.4 \\ 1.5 & 1.5 & 1.5 & 1.4 & 5.9 \\ 3.0 & 3.0 & 3.0 & 2.7 & 11.7 \\ \underline{39.0} & \underline{25.3} & \underline{6.0} & \underline{5.3} & \underline{9.6} \\ \underline{43.7} & \underline{30.0} & \underline{10.7} & \underline{9.6} & \underline{94.0} \\ 1.3 & 4.0 & 8.3 & 7.7 & 20.7\end{array}$

$32.9(\mathrm{f})$

13.2

Unit Level

Security Patrolmen $(h)$

Totals, With Centralized Security Forces

Net Savings with Centralized Security Forces

1.3

4.0

8.3

4.․․․

20.7

$30.7(f)$

12.3

(a) Based on Table M.1-1 of Reference 3

(b) Rounded to the nearest $\$ 100$.

(c) Based on organization shown in Figure 8.3-2d; manpower requirements from Table X.2-2 of Reference 3 .

(d) Based on organization shown in figure $8.3-2 b$; rounded to the next higher 0.1 man-year.

(e) Single unit assumed to bear $10 \%$ of total site cost.

f) Study estimate.

(g) Single unit assumed to bear $30 \%$ of total group cost (10\% of total site assuming three groups); assumes one security shift supervisor and two security patrolmen per shlft at each group.

(n) Assumes three men/shift on two-shift, 5-day-week coverage after completion of spent fuel shipment (end of month 19 ). 
requirements in the reference decommissioning studies (see, for example, page G-33 of Reference 1 and page I-4I of Reference 3) and agrees with that reported in another analysis of incineration versus compaction (see page 10-1 of Reference 4). Incineration is assumed to reduce the volume an additional factor of 5:1, for an overal] volume reduction of $25: 1$ for incineration. (4) The volume reduction factor for incineration depends on the type of waste involved and on the incinerator used. The factor used here falls in the center of the range reported in the literature, from an overall volume reduction (from uncompacted wastes) of about $10: 1^{(5,6)}$ to a reduction of about 35 or $40: 1 .(7,8)$

The effects of incineration of the dry combustible wastes on both costs and radiation doses are presented here for the various combinations of reactor types and decommissioning aiternatives considered in this study.

\section{B. 3.7 Cost Effects}

A 1 arge LWR averages about $142 \mathrm{~m}^{3}$ of compacted trash annuaily, with an 85 to $100 \%$ combustible content (see page 10-2 of Reference 4 ). Thus, for a site with 10 operating reactors, the average annual production of compacted combustible trash is about $1420 \mathrm{~m}^{3}$. To maximize the cost savings of onsite incineration, the central incinerator must be sized to process ail of this waste. Assuming two-shift/day, 5-day/week operation of the facility (48\% availability), the nominal rated (instantaneous) capacity of the facility is about $2980 \mathrm{~m}^{3}$ per year of compacted waste.

From page 10-3 of Reference 4, an incinerator servicing a twin-reactor site involves a capital cost of about $\$ 2$ million. Again, assuming an annual production of $142 \mathrm{~m}^{3}$ of compacted combustible waste per reactor, this incinerator is sized to process $284 \mathrm{~m}^{3}$ /year of waste, under normal operating conditions. Assuming the need for incineration at a twin-reactor site to be somewhat variable and discontinuous, it is postulated that the incinerator operates 5 to 6 shifts/ week (one shift/day for a 5-day week or two consecutive shifts 3 days a week). This results in the unit being operated 24 to $29 \%$ of the time, giving the unit a nominal rated (instantaneous) capacity of between 980 and $1180 \mathrm{~m}^{3}$ per year.

Based on the above information, the incinerator for the twin-reactor site must be scaled up by a factor of between 2.5 and 3.0 to be properly sized for the 10-reactor site. For the subsequent calculations, the latter number is used to ensure the conservatism of the cost estimate. 
Equipment size and capital cost correlate fairly well by the logarithmic relationship known as the "six-tenths factor," shown by:

$$
c_{n}=r^{0.6} c
$$

where:

$$
\begin{aligned}
& C_{h}=\text { the capital cost of the new plant } \\
& C=\text { the capital cost of the previous plant } \\
& r=\text { the ratio of new to previous capacity. }
\end{aligned}
$$

Thus, for the incinerator at the 10-reactor site:

$$
c_{h}=(3.0)^{0.6} \cdot \$ 2,000,000
$$

This yields a capital cost of about $\$ 3.9$ million for the postulated incinerator, or $\$ 390,000$ per reactor at the site.

Assuming annual operating and maintenance costs to be $5 \%$ of the original capital cost, maintenance and operation of the incinerator are estimated to cost $\$ 195,000 /$ year, or $\$ 19,500 /$ year per reactor. With $142 \mathrm{~m}^{3}$ of compacted waste processed for each reactor, this yields a unit cost for operation and maintenance of $\$ \$ 137 / \mathrm{m}^{3}$ of compacted waste for $\$ 685 / \mathrm{m}^{3}$ of incinerated product, assuming the $5: 1$ volume-reduction factor given previous $7 y$ ).

Assuming 40 years of operation for each reactor (see page 7-16 of Refererence 1), each reactor generates about $5680 \mathrm{~m}^{3}$ of compacted combustible waste during its operating lifetime. During decomissioning, up to $284 \mathrm{~m}^{3}$ of compacted combustible waste are generated at a PWR (page G-33 of Reference 1) and up to $678 \mathrm{ml}^{3}$ at a BWR (page I-41 of Reference 3). Thus, on average, decomissioning accounts for less than $10 \%$ of the combustible wastes generated at a reactor and, consequently, less than $10 \%$ of the waste processed through the incinerator. Therefore, because the incinerator mainly benefits the operations phase of each reactor, it is assumed here that all capital costs are borne by reactor operations. 


\section{B.3.1.1 Cost Savings During Reactor Operations}

As stated previously, w $142 \mathrm{~m}^{3}$ of compacted combustible wastes are generated annually at a large LWR. This volume of waste fills about 675 steel drums, $0.27-m^{3}$-capacity.

From the previous discussion, the capital cost of the incinerator for the 10 -reactor site is $\$ 3.9$ million, or $\$ 390,000$ per reactor. Operation and maintenance costs are $\$ 19,500 /$ year per reactor. Deconmissioning costs for the incinerator are $\$ 39,000$ per reactor. Assuming a 40-year operating life for a reactor, the combined annual costs for capita1, for operation and maintenance, and for decomissioning are $\$ 30,225$ for each reactor.

Table B.3-7 summarizes the annual costs for disposal of dry combustible wastes, either with compaction or with incineration, during the operating lifetime of an LWR at a 10-reactor site. Annual net savings with incineration are also shown. As evidenced by the table, the postulated incinerator results in annual savings of about $\$ 35,000$ for each reactor, or $\$ 351,000$ for the entire 10-reactor site. The total net savings associated with incineration during the 40 -year operating lifetimes of the 10 reactors is estimated to be $2 \$ 14$ million. Thus, it can be seen that the incinerator facility represents significant cost savings during operations.

\section{B.3.1.2 Cost Savings During Reactor Decommissioning}

As stated previously in Section B.3.1, the capital costs of the incinerator are assumed to be borne solely by the reactor operations. Therefore, the costs of using the facility to process decommissioning wastes are only the additional incremental costs of operating and maintaining the facitity during incineration of these wastes. This additional cost, also derived in Section B.3.1, is $\$ 137 / \mathrm{m}^{3}$ of compacted combustible waste fed into the facility. (It is assumed that, in order to handie the decommissioning waste, a third shift is added to the facility operating schedule as needed.)

Costs for disposal of incinerated combustible wastes from decommissioning, based on the previous assumptions, are presented in Table B.3-2 for the various combinations of reactor types and decommissioning alternatives considered in this study. Also presented are the net savings associated with incineration as 
TABLE B.3-1. Annual Costs for Disposal of Dry Combustible Wastes for an Operating LWR

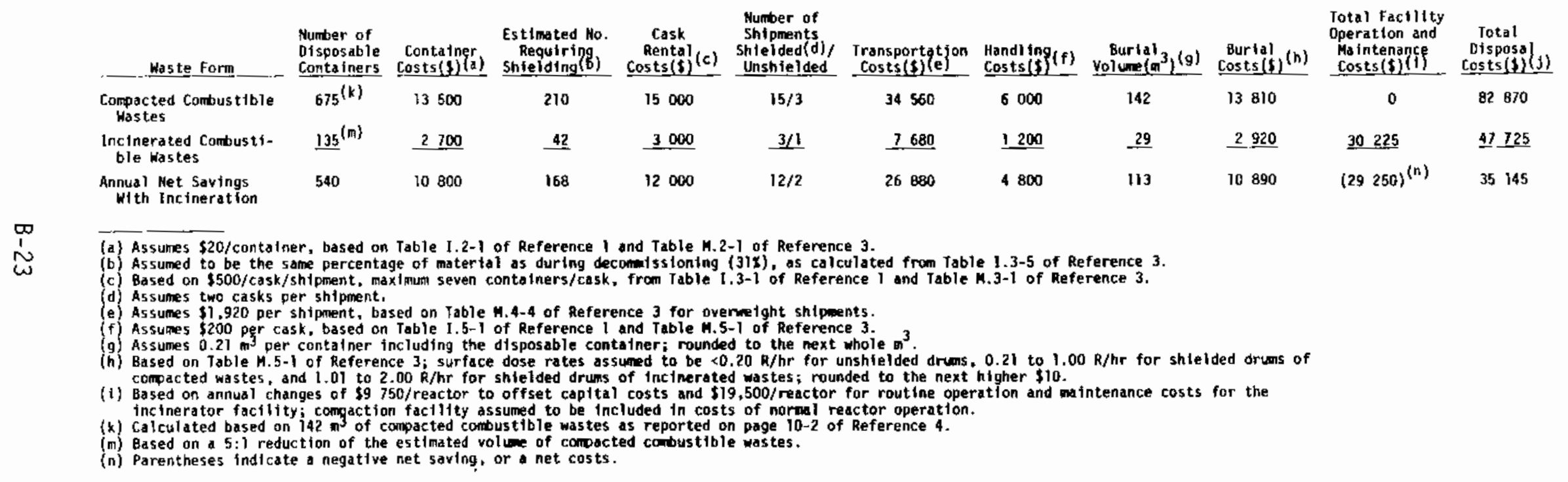





\begin{tabular}{|c|c|c|c|c|c|c|c|c|c|c|c|c|c|}
\hline Decomissioning Alternative & $\begin{array}{l}\text { Number of } \\
\text { Oisposable } \\
\text { Containers (a) }\end{array}$ & $\begin{array}{l}\text { Container } \\
\text { Costs }(\$) \text { (b) }\end{array}$ & $\begin{array}{l}\text { Estimated No. } \\
\text { Requiring } \\
\text { Shielding(c) }\end{array}$ & $\begin{array}{c}\text { Cask } \\
\text { Rental } \\
\text { Costs }(\$)(d)\end{array}$ & $\begin{array}{l}\text { Number of } \\
\text { Shipments } \\
\text { Shiel ded (e)/ } \\
\text { Unshijelded }\end{array}$ & $\begin{array}{l}\text { Transportation } \\
\text { Costs }(\$\})\{f\}\end{array}$ & 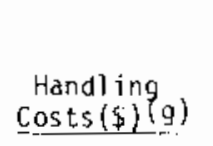 & $\begin{array}{c}\text { Burial } \\
\text { volume }\left(m^{3}\right)\end{array}(h)$ & $\begin{array}{r}\text { Burial } \\
\operatorname{Costs}(\$) \\
\underline{0}(i)\end{array}$ & $\begin{array}{c}\text { Facility } \\
\text { Operation and } \\
\text { Maintenance } \\
\text { Costs }(\$)(\$)\end{array}$ & $\begin{array}{l}\text { Total Disposa } \\
\text { With } \\
\text { Incineration }\end{array}$ & $\frac{\operatorname{costs}(\$)^{(k)}}{\text { Without }}$ & $\begin{aligned} \text { Net cost } \\
\text { Savings hit } \\
\text { Incinergation! }\end{aligned}$ \\
\hline \multicolumn{14}{|l|}{ PWR } \\
\hline $\begin{array}{l}\text { OECON/ENTOMB }(m) \\
\text { SAFSTOR: }\end{array}$ & 270 & 5400 & 84 & 6000 & $6 / 2$ & 15360 & 2400 & 57 & 5840 & 38840 & 73840 & 207430 & 133590 \\
\hline Preparations for Safe storage ${ }^{(n)}$ & 54 & 1080 & 27 & 2000 & $2 / 1$ & 5760 & 800 & 12 & 1240 & 7770 & 18650 & 59250 & 40600 \\
\hline $\begin{array}{l}\text { Deferred Decontamination After } 30 \text { Years }(0) \\
\text { Deferred Decontamination After } 50 \text { Years }(0) \\
\text { Deferred Decontamination After } 100 \text { Years }\end{array}$ & $\begin{array}{l}220 \\
143 \\
.96\end{array}$ & $\begin{array}{l}4400 \\
2860 \\
1920\end{array}$ & $\begin{array}{l}0 \\
0 \\
0\end{array}$ & $\begin{array}{l}0 \\
0 \\
0\end{array}$ & $\begin{array}{l}0 / 2 \\
0 / 1 \\
0 / 1\end{array}$ & $\begin{array}{l}3840 \\
1920 \\
1920 \\
\end{array}$ & $\begin{array}{r}0 \\
0 \\
-. \\
-\end{array}$ & $\begin{array}{r}47 \\
31 \\
21 \\
\end{array}$ & $\begin{array}{r}4330 \\
2810 \\
1890 \\
\end{array}$ & $\begin{array}{l}31650 \\
20570 \\
13810 \\
\end{array}$ & $\begin{array}{l}44220 \\
28860 \\
19.540 \\
\end{array}$ & $\begin{array}{l}148100(\mathrm{p}) \\
96300(\mathrm{p}) \\
64600(\mathrm{p})\end{array}$ & $\begin{array}{l}103880 \\
688140 \\
45060\end{array}$ \\
\hline $\begin{array}{l}\text { Total, w/30-Year Deferred Decontamination } \\
\text { Total, } / 50 \text { - Year Deferred Decontamination } \\
\text { Total, w/170-Year Deferred Decontanination }\end{array}$ & $\begin{array}{l}274 \\
197 \\
150\end{array}$ & $\begin{array}{l}5480 \\
3940 \\
3000\end{array}$ & $\begin{array}{l}27 \\
27 \\
27\end{array}$ & $\begin{array}{l}2000 \\
2000 \\
2000\end{array}$ & $\begin{array}{l}2 / 3 \\
2 / 2 \\
2 / 2\end{array}$ & $\begin{array}{l}9 \overline{9600} \\
7680 \\
7680\end{array}$ & $\begin{array}{l}800 \\
800 \\
800\end{array}$ & $\begin{array}{l}59 \\
43 \\
33\end{array}$ & $\begin{array}{l}5 \quad 570 \\
4050 \\
3130\end{array}$ & $\begin{array}{l}39420 \\
28340 \\
21580\end{array}$ & $\begin{array}{l}62870 \\
46810 \\
38190\end{array}$ & $\begin{array}{l}207350 \\
155550 \\
123850\end{array}$ & $\begin{array}{r}144480 \\
108840 \\
85660\end{array}$ \\
\hline \multicolumn{14}{|l|}{ EWR } \\
\hline $\begin{array}{l}\text { OECON/ENTOMB }(9) \\
\text { SAFSTOR: }\end{array}$ & 645 & 12900 & 200 & 14500 & $15 / 3$ & 34560 & 5800 & 136 & 13940 & 92780 & 174480 & 395650 & 221170 \\
\hline Preparations for safe storage $(r)$ & 228 & 4560 & 71 & 5500 & $6 / 1$ & 13440 & 2200 & 48 & 4930 & 32800 & 63430 & 142670 & 79240 \\
\hline $\begin{array}{l}\text { Deferred Decontamination After } 30 \text { Years }(s) \\
\text { Deferred Decontamination After } 50 \text { Years }(s) \\
\text { Deferred Decontamination After } 100 \text { Years }(s)\end{array}$ & $\begin{array}{l}417 \\
334 \\
229 \\
\end{array}$ & $\begin{array}{l}8340 \\
6680 \\
4.580 \\
\end{array}$ & $\begin{array}{l}0 \\
0 \\
0 \\
-0\end{array}$ & $\begin{array}{r}0 \\
0 \\
0 \\
0\end{array}$ & $\begin{array}{l}0 / 3 \\
0 / 2 \\
0 / 2 \\
.012 \\
\end{array}$ & $\begin{array}{r}5760 \\
3840 \\
3840\end{array}$ & $\begin{array}{l}0 \\
0 \\
0\end{array}$ & $\begin{array}{l}88 \\
71 \\
49 \\
-1\end{array}$ & $\begin{array}{l}8200 \\
6570 \\
4500 \\
\end{array}$ & $\begin{array}{l}59990 \\
48050 \\
32940 \\
\end{array}$ & $\begin{array}{l}82.290 \\
65 \\
45.860 \\
\end{array}$ & $\begin{array}{l}255000(\mathrm{t}) \\
204000(\mathrm{t}) \\
140.000(\mathrm{t})\end{array}$ & $\begin{array}{l}172710 \\
138860 \\
.94 \quad 140\end{array}$ \\
\hline $\begin{array}{l}\text { Total, w/30-Year Deferred Decontamination } \\
\text { Total, w/50-Year oeferred Decontamination } \\
\text { Total, w/100-Year Deferred Decontanination }\end{array}$ & $\begin{array}{l}645 \\
562 \\
457\end{array}$ & $\begin{array}{rl}12 & 900 \\
11240 \\
9\end{array}$ & $\begin{array}{l}71 \\
71 \\
71\end{array}$ & $\begin{array}{l}5500 \\
5500 \\
5500\end{array}$ & $\begin{array}{l}6 / 4 \\
6 / 3 \\
6 / 3\end{array}$ & $\begin{array}{l}19200 \\
17280 \\
17280\end{array}$ & $\begin{array}{l}2200 \\
2200 \\
2200\end{array}$ & $\begin{array}{r}136 \\
119 \\
97\end{array}$ & $\begin{array}{rl}13 & 130 \\
11500 \\
9 & 430\end{array}$ & $\begin{array}{l}92790 \\
80850 \\
65740\end{array}$ & $\begin{array}{l}745720 \\
128570 \\
109290\end{array}$ & $\begin{array}{l}397670 \\
346 \\
2870 \\
282 \\
670\end{array}$ & $\begin{array}{l}251950 \\
218100 \\
173380\end{array}$ \\
\hline
\end{tabular}

(a) Based on a 5:1 reduction of estimated volumes of compacted combustible dry wastes from References 1 and 3, rounded to the next higher whole

(b) Assumes $520 /$ container, based on Table $1.2-1$ of Reference 1 and Table M.2-I of Reference 3.
(c) For DECON, ENTOMB, and preparations for safe storage the samie percentage of incinerated

Definerated material is assumed to require shieiding as was assumed for

(d) Compacted combustible wastes in References 1 and 3 ; no shielding assuined to be required for deferred decontanination.

(e) Assumes two casks per shipment.

Assumes $\$ 200$ per cask, based on Table Table M. 4-4 of Reference 3 for overweight shipment.

Assumes $0.21 \mathrm{~m}^{3}$ per container including the disposable container; rounded to the next whole $\mathrm{m}^{3}$

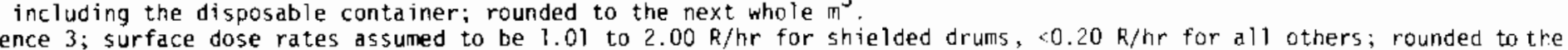

(j) Based on $\$ 137 / \pi^{3}$ of compacted waste fed into the facility, rounded to the nearest $\$ 10$.

(k) The number of $f$ igures shown is for computational completeness and does not imply accuracy to that many significant figures.

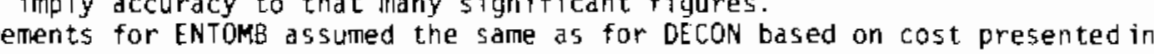

(n) Based on information from Table $H .3-2$ and pages $H-14$ through $H-16$ of Reference 1 .

D) Calculated by multiplying the disposal cost for DECON by the ratio of the waste volumes for deferred decontanination and DECON.

(a) Based on information from Table $1.3-5$ of Reference 3 ; requirements for ENTOMB assumed the same as for DECON based on discussion of radioactive wastes

(r) Based on information from Table $3.5-3$ of Reference 3.

(r) Based on information from Table J.5-3 of Reference 3.
(5) Calculated from burial volumes presented in Table $3.7-1$ of Reference 3.
(t) From Table $3.7-2$ of Reference 3 .

TABLE B. 3-2. Costs for Disposal of Incinerated Combustible Wastes from Decormissioning 

compared to disposal of the compacted combustible wastes. The savings are small compared to the total costs of waste management for decommissioning but represent a significant fraction of the disposal costs for compacted combustible wastes without incineration.

\section{B.3.2 Radiation Dose Effects}

Reduction of the volume of waste handied could lead to potential radiation dose reductions for:

1. plant workers who prepare and package the waste for shipment

2. transportation workers involved in the shipment of the waste

3. members of the public along the waste transport route.

Dose reductions are calculated here only for waste disposal activities during decomissioning, and not for activities during the operating lifetime of the plant, even though such dose reductions would occur during both operations and decommissioning.

\subsubsection{Waste Packaging Workers}

After the combustible wastes are compacted at the individual reactor site, they are transported to the incinerator and burned. The resuiting ash is then packaged in burial drums for transportation to and disposal at a low-level waste burial ground. The actual volume of waste packaged and shipped offsite is reduced by a factor of 5 from the compacted volume, thus reducing both the time required for packaging and the associated occupational radiation dose. However, the extra step of transporting the compacted waste to the incinerator and processing it there involves some radiation dose to the workers involved. For this analysis, this extra dose is assumed to offset the dose reduction resulting from reduced packaging time. Therefore, no significant net dose reduction is anticipated for the waste packaging workers.

\section{B.3.2.2 Waste Transportation Workers}

The radiation dose estimates presented for transpcrt workers in the PWR and the BWR decomissioning studies are based on the maximum allowable dose rates for each shipment in exclusive-use trucks. (See pages 11-27 and 11-28 of Reference 1 and pages $\mathrm{N}-74$ and $\mathrm{N}-75$ of Reference 3.$)$ The dose factors from the 
BWR study are used here for consistency. The estimated radiation doses to transport workers from routine waste transportation activities, as shown in Table 11.4-2 of Reference i, are:

\begin{tabular}{cc} 
Transport Workers & $\begin{array}{c}\text { Radiation Dose } \\
\text { Per Shipment } \\
\text { (man-rem) }\end{array}$ \\
\hline Truck Drivers & $7.0 \times 10^{-2}$ \\
Garagemen & $3.3 \times 10^{-3}$ \\
Tota 1 & $7.3 \times 10^{-2}$
\end{tabular}

Thus, the total transport worker dose is $7.3 \times 10^{-2}$ man-rem/shipment, based on one-way trips of $800-\mathrm{km}$ each. Based on this unit dose per shipment value and on the reduction in the total number of shipments required, the radiation dose reductions for transport workers resulting from incineration of the combustible wastes are presented in Tabie $8.3-3$.

\section{B.3.2.3 Members of the PubTic}

The radiation dose estimates for members of the public along the waste transport routes are again based on the maximum aillowable dose rates for each shipment, as they were for transport workers (see Section B.3.3.2). Again, the dose factors from the PWR study are used here for consistency. The estimated radiation doses to members of the public from routine waste transportation activities, as given in Table 11.4-2 of Reference 1, are:

$\begin{array}{lc}\begin{array}{c}\text { Members of } \\ \text { the Public }\end{array} & \begin{array}{c}\begin{array}{c}\text { Radiation Dose } \\ \text { Per Shipment } \\ \text { (man-rem) }\end{array} \\ \text { Onlookers }\end{array} \\ \begin{array}{c}5.0 \times 10^{-3} \\ \text { General Public } \\ \text { Total }\end{array} & \frac{1.0 \times 10^{-2}}{1.5 \times 10^{-2}}\end{array}$

Thus, the total public dose is $1.5 \times 10^{-2}$ man-rem per shipment, Based on this unit dose per shipment and on the number of shipments saved by incineration, the radiation dose reductions for members of the public are given in Table B.3-3. 
TABLE B.3-3. Radiation Dose Reductions Resulting from Incineration of Dry Combustible Wastes from Decommissioning

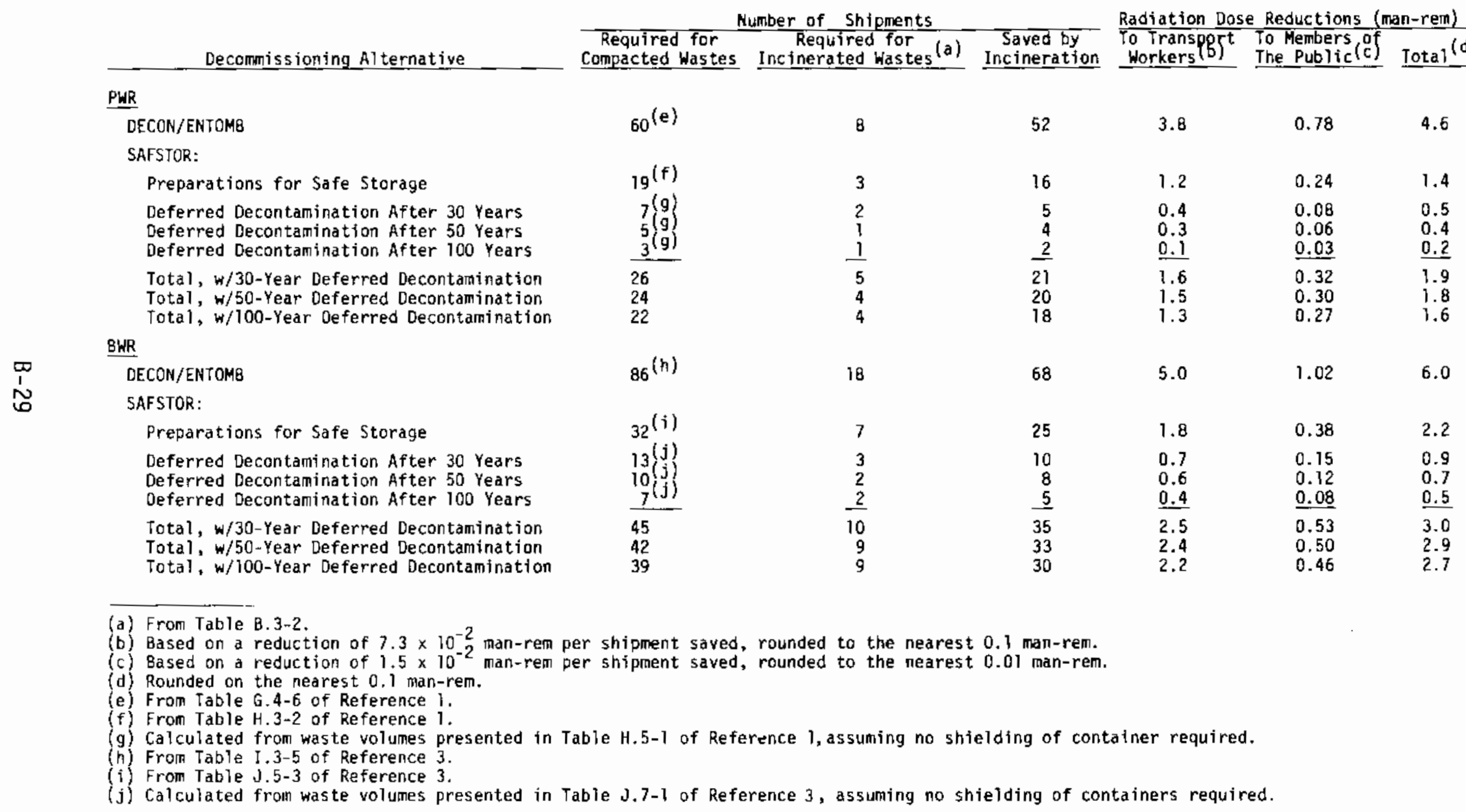




\section{B.3.3 Summary}

The net cost savings and radiation dose reductions during the decomissioning of an LWR at a multiple-reactor site, resulting from incineration of dry combustible wastes, are presented in Table B.3-4.

Cost savings resulting from the incineration facility are in the range of 65 to $70 \%$ of the disposal costs of the compacted combustible wastes for the PWR and 55 to $70 \%$ for the BWR. However, the dollar value savings are higher for the BWR than for the PWR because of the larger volume of waste requiring disposal at the BWR.

The radiation dose reductions are directly proportional to the number of waste shipments saved by incineration and, therefore, represent about $80 \%$ reductions in the doses to transport workers and to the pubitic from shipment of these wastes. However, these dose reductions are relatively small when compared to the overall radiation doses resulting from decommissioning. Dose reductions are larger for the BWR than for the PWR because more waste requires disposal from the BWR and, consequently, more waste shipments can be eliminated by incineration.

\section{B.4 EQUIPMENT DECONTAMINATION SERVICES}

Equipment decontamination services (and associated facilities) can be more fully utijized at a multi-reactor station than at a single- or twin-unit station, thereby increasing the economy of these services and the economic incentive to provide improved services and facilities at a multi-reactor station. Severai types of equipment decontamination services are considered here for inclusion in the centralized services available at a multi-reactor station:

- decontamination of special tools and equipment used for decommissioning, allowing maintenance and reuse of these items

- mobile decontamination systems for in-situ chemical decontamination of piping and components

- central electropolishing and chemical decontamination facilities for improved decontamination of pipe sections and components. 
TABLE B.3-4. Summary of Net Cost Savings and Radiation Dose Reductions for Incineration of Dry Combustible Wastes from LWR Decommissioning

\begin{tabular}{|c|c|c|c|c|c|c|}
\hline \multirow[b]{2}{*}{ Decommissioning Al ternative } & \multicolumn{2}{|c|}{$\begin{array}{l}\text { Total Disposal costs } \\
(\$ \text { thousands }) \text { (a) }\end{array}$} & \multirow{2}{*}{$\begin{array}{c}\text { Net Cost } \\
\text { Savings With } \\
\text { Incineration } \\
\text { (\$ thousands)(a) }\end{array}$} & \multicolumn{3}{|c|}{ Radiation pose Reductions (nan-rem) (b) } \\
\hline & $\begin{array}{l}\text { Corlyacted Com- } \\
\text { bustible wastes }\end{array}$ & $\begin{array}{l}\text { Incinerated } \\
\text { Wastes }\end{array}$ & & $\begin{array}{l}\text { To Transport } \\
\text { Workers }\end{array}$ & $\begin{array}{l}\text { To Members } \\
\text { of the Public }\end{array}$ & Total \\
\hline \multicolumn{7}{|l|}{ PWP. } \\
\hline DECON/ENTOMB & 207.4 & 73.8 & 133.6 & 3.8 & 0.78 & 4.6 \\
\hline \multicolumn{7}{|l|}{ SAFSTOR: } \\
\hline Preparations for Safe Storage & 59.3 & 18.7 & 40.6 & 1.2 & 0.24 & 1.4 \\
\hline $\begin{array}{l}\text { Deferred Decontamination After } 30 \text { Years } \\
\text { Deferred Decontamination After } 50 \text { Years } \\
\text { Deferred Decontamination After } 100 \text { Years }\end{array}$ & $\begin{array}{r}148.1 \\
96.3 \\
64.6\end{array}$ & $\begin{array}{l}44.2 \\
28.2 \\
19.5 \\
\end{array}$ & $\begin{array}{r}103.9 \\
68.1 \\
45.1\end{array}$ & $\begin{array}{l}0.4 \\
0.3 \\
0.3\end{array}$ & $\begin{array}{l}0.08 \\
0.06 \\
0.03\end{array}$ & $\begin{array}{l}0.5 \\
0.4 \\
0.2\end{array}$ \\
\hline $\begin{array}{l}\text { Totals, w/30-Year Deferred Decontamination } \\
\text { Totals, w/50-Year Deferred Decontamination } \\
\text { Totals, w/100-Year Deferred Decontamination }\end{array}$ & $\begin{array}{l}207.4 \\
155.6 \\
123.9\end{array}$ & $\begin{array}{l}62.9 \\
46.8 \\
38.2\end{array}$ & $\begin{array}{r}144.5 \\
108.7 \\
85.7\end{array}$ & $\begin{array}{l}1.6 \\
1.5 \\
1.3\end{array}$ & $\begin{array}{l}0.32 \\
0.30 \\
0.27\end{array}$ & $\begin{array}{l}1.9 \\
1.8 \\
1.6\end{array}$ \\
\hline \multicolumn{7}{|l|}{ BWR } \\
\hline [IFCON/ENTOMB & 395.7 & 174.5 & 221.2 & 5.0 & 1.02 & 6.0 \\
\hline \multicolumn{7}{|l|}{ SAISTOR: } \\
\hline Preparations for Safe Storage & 142.7 & 63.4 & 79.2 & 1.8 & 0.38 & 2.2 \\
\hline $\begin{array}{l}\text { Deferred Decontamination After } 30 \text { Years } \\
\text { Deferred Decontamination After } 50 \text { Years } \\
\text { Deferred Decontamination After } 100 \text { Years }\end{array}$ & $\begin{array}{l}255.0 \\
204.0 \\
140.0\end{array}$ & $\begin{array}{l}82.3 \\
65.7 \\
45.9\end{array}$ & $\begin{array}{r}172.7 \\
138.9 \\
94.1\end{array}$ & $\begin{array}{l}0.7 \\
0.6 \\
0.4\end{array}$ & $\begin{array}{l}0.15 \\
0.12 \\
0.08\end{array}$ & $\begin{array}{l}0.9 \\
0.7 \\
0.5\end{array}$ \\
\hline $\begin{array}{l}\text { Totals, w/30-Year Deferred Decontamination } \\
\text { Totals, w/50-Year Deferred Decontamination } \\
\text { Totals, w/l00-Year Deferred Decontamination }\end{array}$ & $\begin{array}{l}397.7 \\
346.7 \\
282.7\end{array}$ & $\begin{array}{l}145.7 \\
128.6 \\
109.3\end{array}$ & $\begin{array}{l}252.0 \\
218.1 \\
173.4\end{array}$ & $\begin{array}{l}2.5 \\
2.9 \\
2.2\end{array}$ & $\begin{array}{l}0.53 \\
0.50 \\
0.46\end{array}$ & $\begin{array}{l}3.0 \\
2.9 \\
2.7\end{array}$ \\
\hline
\end{tabular}

(a) From Table B.3-2: rounded to the nearest $\$ 100$.

(b) From Table B.3-3. 
These services would provide significant benefits during both operation and decommissioning of a reactor. The resulting benefits during decommissioning are analyzed here.

\section{B.4.1 Decontamination of Special Too]s and Equipment}

The special tools and equipment required to decommission an LWR represent a sizable cost investment. In the reference studies, (1-3) these items are not assumed to be salvaged after decommissioning and, thus, the full cost of these items is assumed to be borne by a single decommissioning. However, most of these items could be reused if proper decontamination and maintenance were performed on them, reducing the net cost of decommissioning a reactor.

For the following analysis, it is assumed that the special decommissioning tools and equipment are decontaminated, maintained, and reused where possible. An estimated useful lifetime (in terms of the number of decommissioning projects) is assigned to each item, and the capital costs for the item are assumed to be shared equaliy by that number of projects. Decontamination and majntenance costs are assumed to be $10 \%$ per year of the total capital cost of the item. However, each item is assumed to be used for only half of the total decomissioning period and, thus, the effective cost of decontamination and maintenance is assumed to be $5 \%$ per year over the total length of the decomissioning schedule. Items with a useful lifetime of only one decommissioning project are not assumed to require any substantial decontamination or maintenance. The total costs with reuse (the costs for capital and for decontamination and maintenance) are compared to those costs without reuse to calculate the net savings resulting from decontamination, maintenance, and reuse of the special tools and equipment.

\section{B.4.1.] PWR DECON}

The costs for special tools and equipment for PWR DECON at a 10-reactor station, both with and without decontamination and reuse, are presented in Table B.4-1, together with net cost savings per decommissioning project with reuse. A total of over $\$ 820,000$ is required without reuse while only about $\$ 495,000$ is required with reuse. Net savings from decontamination and reuse of the tools and equipment are about $\$ 326,000$, about $40 \%$ of the total capital cost of the items. 
TABLE B.4-T. Costs for Special Tools and Equipment for PWR DECON and ENTOMB

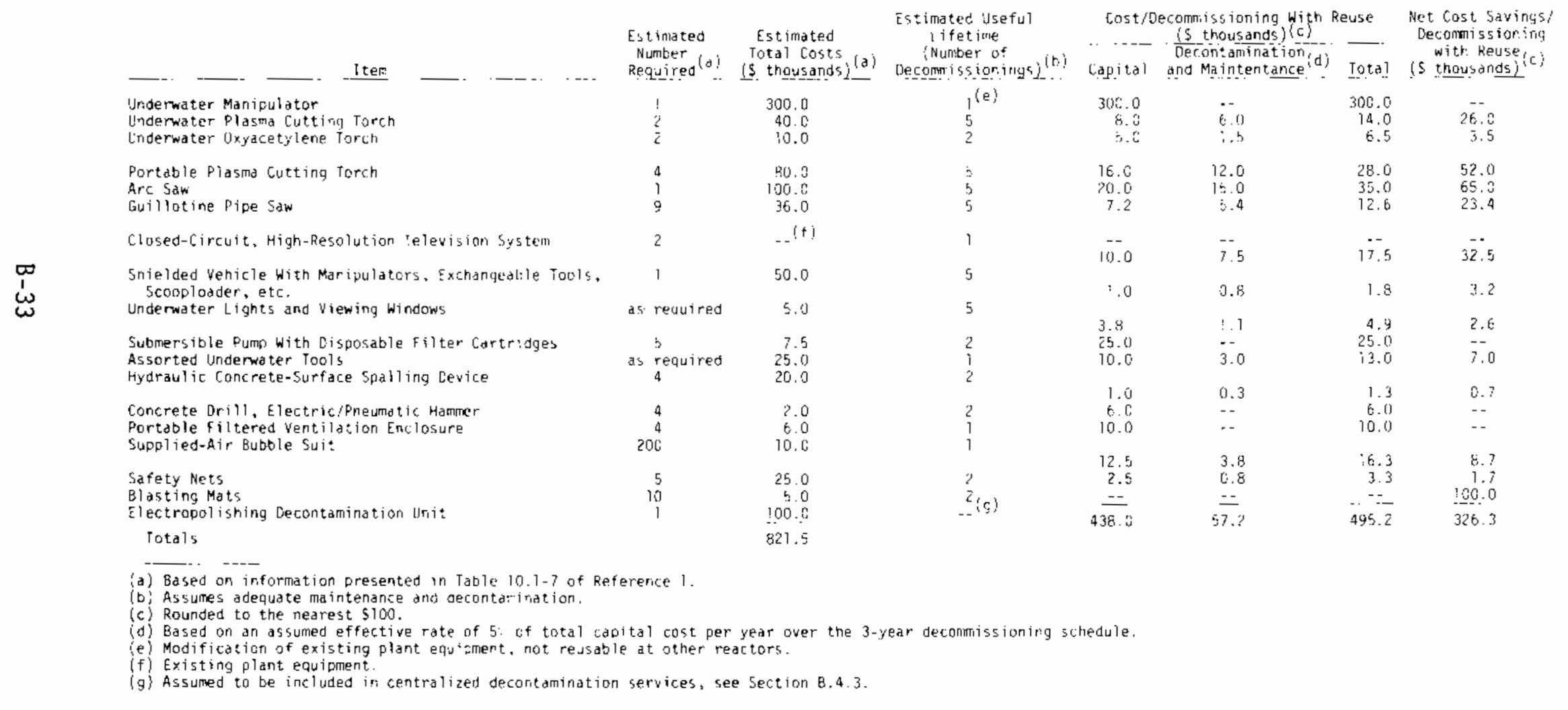




\section{B.4.1.2 PWR SAFSTOR}

The costs for special tools and equipment for the first phase of SAFSTOR (preparations for safe storage) at a PWR are presented in Table B.4-2. Shown are costs both with and without decontamination and reuse, and net savings with reuse are also included. About $\$ 27,000$ is required without reuse as compared to only about $\$ 13,000$ with reuse, resulting in net savings per decommissioning cycle (with reuse) of about $\$ 14,000$, or almost $52 \%$ of the total capital cost of the items.

No significant expenditures for tools and equipment are required during the continuing care period and, therefore, no significant cost savings are anticipated and no calculations are performed here.

The cost for special tools and equipment for deferred decontamination is $\$ 60,000$ less than that for DECON $(\$ 75,000$ less with $25 \%$ contingency included, see Table H.5-2 of Reference 1); thus, the total cost is $\$ 761,500$. However, no details are given concerning the specific items involved. Assuming the special tools and equipment required for deferred decontamination are essentially the same as those required for DECON, the same percentage savings should apply to both cases. Using the 40\% savings derived in Section B.4.1.7, the total cost per decommissioning project is estimated to be about $\$ 457,000$ and the resulting net savings are nearly $\$ 305,000$.

Overall costs for special tools and equipment during PWR SAFSTOR are thus nearly $\$ 790,000$ without reuse as compared to about $\$ 470,000$ with reuse, resulting in net savings of almost $\$ 320,000$ with decontamination, maintenance, and reuse of these items.

\section{B.4.1.3 PWR ENTOMB}

Table 4.5-1 of Reference 2 shows the costs for special tools and equipment during PWR entombment to be the same as those during DECON. Thus, the results for ENTOMB are assumed to be the same as those presented previousiy in Table B.4-1, based on the assumption that the actual items involved in the two cases are essentially the same. 
TABLE B.4-2. Costs for Special Tools and Equipment for PWR Preparations for Safe Storage

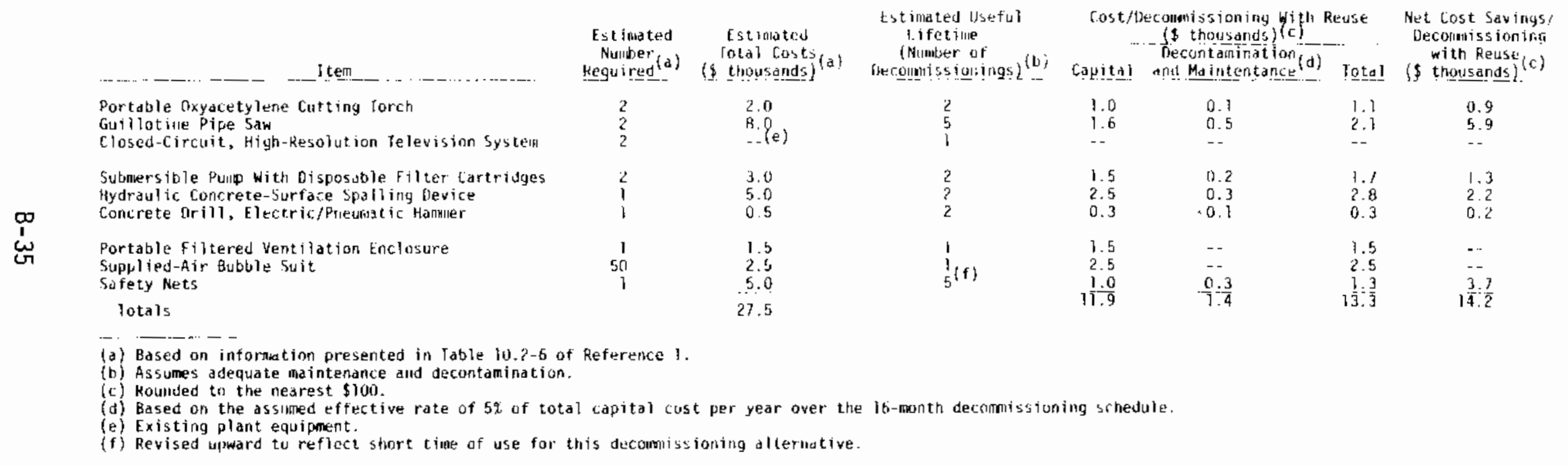




\section{B.4.1.4 BWR OECON}

For BWR DECON at a 10-reactor station, the costs for special tools and equipment, both with and without decontamination and reuse, are presented in Table B.4-3. Also inciuded in the table are the net cost savings resulting from decontamination and reuse of these items. The total cost of the items is $\$ 2.02$ million without reuse as compared to $2 \$ 850,000$ with reuse. Thus, reuse results in net savings of nearly $\$ 1.17$ million per decommissioning project, or about $58 \%$ of the total capital cost.

\section{B.4.1.5 BWR SAFSTOR}

At a BWR, the costs for special tools and equipment for preparations for safe storage, the initial phase of SAFSTOR, are presented in Table B.4-4. Costs both with and without decontamination and reuse are included, as are net savings resulting from reuse. About $\$ 350,000$ is required without reuse as compared to about $\$ 150,000$ with reuse. Net savings per decommissioning project with reuse are almost $\$ 200,000$, or about $56 \%$ of the total capital cost.

As discussed previousiy for PWR SAFSTOR, no significant expenditures for tools and equipment are required for continuing care and, thus, no estimates of savings are calculated here.

The costs for special tools and equipment for deferred decontamination, from Table J.7-2 of Reference 3, are $\$ 1.728$ million. Again, as for deferred decontamination of the PWR, no specifics are provided on the items involved. Assuming the items required are essentially the same as those for DECON, the same percentage savings ( $58 \%$, see Section B.4.1.4) should apply. Thus, the costs for special equipment and materials with reuse are about $\$ 730,000$ and the net savings are about $\$ 1.00 \mathrm{million}$.

Overall costs for special tools and equipment during BWR SAFSTOR are thus almost $\$ 2.08$ million without reuse as compared to less than $\$ 880,000$ with reuse, resulting in net savings of nearly $\$ 1.20 \mathrm{million}$ with decontamination, maintenance, and reuse of these items. 


\section{TABLE B.4-3. Costs for Special Tools and Equipment for BWR DECON and ENTOMB}

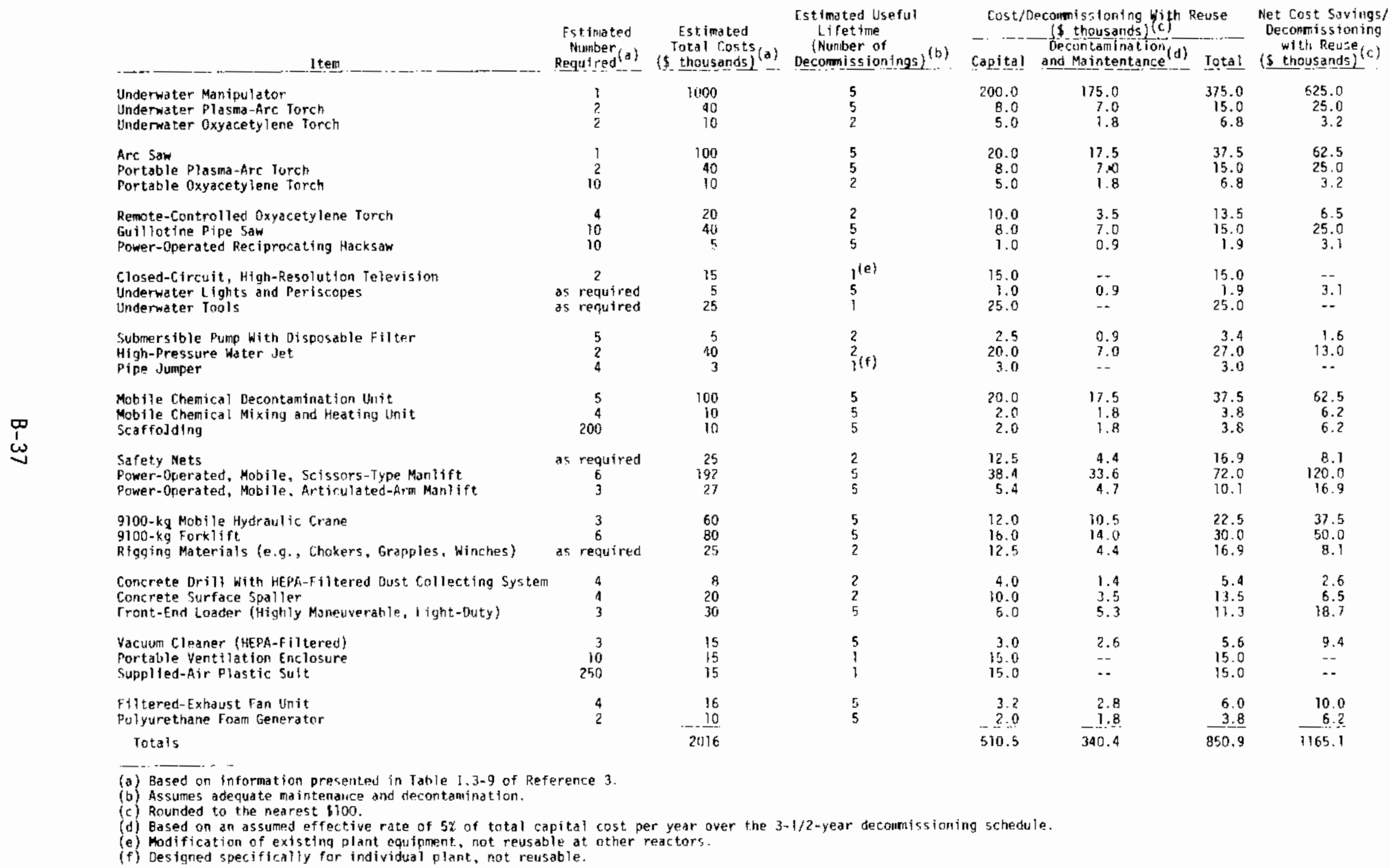




\section{TABLE B.4-4. Costs for Special Tools and Equipment for BWR Preparations for Safe Storage}

\begin{tabular}{|c|c|c|c|c|c|c|c|}
\hline$\ldots$ & $\begin{array}{l}\text { Estinated } \\
\text { Number } \\
\text { Requinged }\end{array}$ & $\begin{array}{l}\text { Estinuted } \\
\text { rotat cost5 } \\
\text { (\$ thousonds) }\end{array}$ & $\begin{array}{l}\text { Estimated Userul } \\
\text { Lifet imp } \\
\text { (Numiner of } \\
\text { Decomissionings) (b) }\end{array}$ & $\begin{array}{l}\text { Cost. } / \text { R } \\
\text { Capital }\end{array}$ & 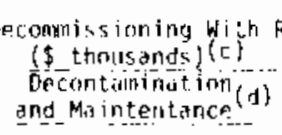 & Rewse & $\begin{array}{l}\text { Net Cost Savings/ } \\
\text { Decunruissioning } \\
\text { with Reuse (c) } \\
\text { (\$ thousands) }\end{array}$ \\
\hline $\begin{array}{l}\text { Portable Oxyacetylene Forch } \\
\text { Suilotine Pipe Saw } \\
\text { Power-Operated Reciprocating Hacksaw }\end{array}$ & $\begin{array}{l}2 \\
2 \\
2\end{array}$ & $\begin{array}{l}1.0 \\
8.0 \\
1.0\end{array}$ & $\begin{array}{l}? \\
5 \\
5\end{array}$ & $\begin{array}{l}0.5 \\
1.6 \\
0.2\end{array}$ & $\begin{array}{l}0.1 \\
1.0 \\
0.1\end{array}$ & $\begin{array}{l}0.5 \\
2.6 \\
0.3\end{array}$ & $\begin{array}{l}0.4 \\
5.4 \\
0.7\end{array}$ \\
\hline $\begin{array}{l}\text { Closed-Circuit, High-Resolution Television } \\
\text { Sutmersible Pump with 0isposable Filter } \\
\text { High-Pressure water Jet }\end{array}$ & $\begin{array}{l}1 \\
5 \\
2\end{array}$ & $\begin{array}{r}7.5 \\
5.0 \\
40.0\end{array}$ & $\begin{array}{l}1^{(e)} \\
? \\
2\end{array}$ & $\begin{array}{r}7.5 \\
2.5 \\
20.0\end{array}$ & $\begin{array}{l}\ddot{-} \\
0.6 \\
5.0\end{array}$ & $\begin{array}{r}7.5 \\
3.1 \\
25.0\end{array}$ & $\begin{array}{l}-- \\
1.9 \\
15.0\end{array}$ \\
\hline $\begin{array}{l}\text { Iow-Pressure Water Jet } \\
\text { Pipe Juigper } \\
\text { Hobile Chemical necontamination Unit }\end{array}$ & $\begin{array}{l}1 \\
1 \\
5\end{array}$ & $\begin{array}{r}15.0 \\
7.0 \\
100.0\end{array}$ & $\begin{array}{l}7 \\
7(f)\end{array}$ & $\begin{array}{r}7.5 \\
3.0 \\
20.0\end{array}$ & $\begin{array}{c}1.9 \\
-- \\
12.5\end{array}$ & $\begin{array}{r}9.4 \\
3.0 \\
37.5\end{array}$ & $\begin{array}{c}5.6 \\
67.5\end{array}$ \\
\hline $\begin{array}{l}\text { Mabile Chemical Mixing and leating Unit } \\
\text { Staffolding } \\
\text { Safety Nets }\end{array}$ & $\begin{array}{c}4 \\
50 \\
\text { as required }\end{array}$ & $\begin{array}{r}10.0 \\
2.5 \\
10.0\end{array}$ & $\begin{array}{l}5 \\
5 \\
2\end{array}$ & $\begin{array}{l}2.0 \\
0.5 \\
5.7\end{array}$ & $\begin{array}{l}1.3 \\
0.3 \\
1.3\end{array}$ & $\begin{array}{l}3.3 \\
0.8 \\
6.3\end{array}$ & $\begin{array}{l}6.7 \\
1.7 \\
3.7\end{array}$ \\
\hline $\begin{array}{l}\text { Fower-Operated, Mobile, Scissors-Type Manl ift } \\
\text { Power-Operated, Mobile, Articulated-Arm Manl ift } \\
\text { 9lino-kg-Capacity Forklift }\end{array}$ & $\begin{array}{l}2 \\
1 \\
1\end{array}$ & $\begin{array}{r}64.0 \\
9.0 \\
13.3\end{array}$ & $\begin{array}{l}5 \\
5 \\
5\end{array}$ & $\begin{array}{r}12.8 \\
1.8 \\
2.7\end{array}$ & $\begin{array}{l}8.0 \\
1.1 \\
1.7\end{array}$ & $\begin{array}{r}20.8 \\
2.9 \\
4.1\end{array}$ & $\begin{array}{r}43.2 \\
6.1 \\
8.9\end{array}$ \\
\hline $\begin{array}{l}\text { Rigging Haterials (e.g., Chockers, Grapples, Winches) } \\
\text { Concrete Drill with HEFA-filtered Dust Collectiriq } \\
\text { System } \\
\text { Concrete Surface Spaller }\end{array}$ & $\begin{array}{l}\text { as required } \\
1 \\
1\end{array}$ & $\begin{array}{l}5.0 \\
2.0 \\
5.0\end{array}$ & $\begin{array}{l}2 \\
2 \\
?\end{array}$ & $\begin{array}{l}2.5 \\
1.0 \\
2.5\end{array}$ & $\begin{array}{l}0.6 \\
0.3 \\
0.6\end{array}$ & $\begin{array}{l}3.1 \\
1.3 \\
3.1\end{array}$ & $\begin{array}{l}1.9 \\
0.7 \\
1.9\end{array}$ \\
\hline $\begin{array}{l}\text { Front-end Loader (Highly Maneuverable, l iqht-nuty) } \\
\text { Yacuuth Cleaner (HEPA-Filtered) } \\
\text { Portable Ventilation Enclosure }\end{array}$ & $\begin{array}{l}3 \\
3 \\
3\end{array}$ & $\begin{array}{r}10.0 \\
15.0 \\
4.5\end{array}$ & $\begin{array}{l}5 \\
5 \\
1\end{array}$ & $\begin{array}{l}2.0 \\
3.0 \\
4.5\end{array}$ & $\begin{array}{l}1.3 \\
1.9 \\
-.-\end{array}$ & $\begin{array}{l}3.3 \\
4.9 \\
4.5\end{array}$ & $\begin{array}{r}6.7 \\
10.1 \\
--\end{array}$ \\
\hline $\begin{array}{l}\text { Supplied-Air Plastic Suit } \\
\text { rolyurethane Foam Generator } \\
\text { Paint Sprayer } \\
\text { lotals }\end{array}$ & $\begin{array}{r}100 \\
2 \\
4\end{array}$ & $\begin{array}{r}5.1) \\
10.0 \\
4.0 \\
350.8\end{array}$ & $\begin{array}{l}1 \\
5 \\
5\end{array}$ & $\begin{array}{r}6.0 \\
2.0 \\
0.8 \\
111.9\end{array}$ & $\begin{array}{r}-- \\
1.3 \\
0.5 \\
4 i .4\end{array}$ & $\begin{array}{r}5.0 \\
3.3 \\
15 \frac{1}{3} \cdot \frac{3}{3}\end{array}$ & $\begin{array}{r}6.7 \\
2.7 \\
197 . \frac{7}{5}\end{array}$ \\
\hline $\begin{array}{l}\text { (a) Based on information presented in Table J.5-6 of } \\
\text { (b) Assumes adequate maintenace and decontamination. } \\
\text { (c) Rounded to the nearest } \$ 10 \text {. } \\
\text { (d) Based on an assumed effective rate of } 5 \% \text { of total } \\
\text { (o) Modificatian of existing olant equipment, not reus } \\
\text { (i) Designed specificalyy for individual plant, not re }\end{array}$ & $\begin{array}{l}\text { Reference } 3 . \\
\text { capiral cost } \\
\text { sable at other } \\
\text { eusabie. }\end{array}$ & $\begin{array}{l}\text { per year over } \\
\text { reactors. }\end{array}$ & $2-1 / 2-y e a r$ d & ז1ו & le. & & \\
\hline
\end{tabular}




\section{B.4.1.6 BWR ENTOMB}

For BWR entombment with the reactor vessel internais removed, the special toois and equipment required are assumed to be the same as for DECON, as stated on p. K-29 of Reference 3. Thus, the results for ENTOMB are the same as those presented previously in Table $8.4-3$.

\section{B.4.2 Mobile Chemical Decontamination Equipment}

Mobile chemical decontamination equipment is postulated in the BWR study ${ }^{(3)}$ to be used for in-situ decontamination of piping and components during decommissioning by any of the three alternatives. However, such equipment is not discussed in the PWR study. (1) The costs of using such equipment for PWR decommissioning are estimated here 1) to provide a common basis between PWR and BWR decontamination activities and 2) because such equipment is judged to provide additional benefits in terms of ease of decontamination, better control of the process, and more consistent conditions and, consequentiy, more consistent results.

For the BWR study, five mobile chemical decontamination units, estimated to cost $\$ 20,000$ each, are assumed to be used. In addition, four mobile chemical mixing and heating units, costing $\$ 2,500$, are postulated to be required. (See Tables I.3-9 and J.5-6 of Reference 3.) It is assumed here that the same number of units would be used for PWR decontamination work.

Assuming proper maintenance and decontamination of the units, the costs of the units would not have to be borne by a single reactor. In Tables B.4-3 and B.4-4 presented previousiy, it is assumed that such units will last for the decommissioning of five reactors. Applying the same assumptions to PWR decommissioning, the estimated costs of these units are presented in Table B.4-5. The total costs with reuse are $\$ 38,500$ for DECON or ENTOMB and $\$ 29,300$ for preparations for safe storage. It should be noted that, although these are additional costs not included in the PWR study, the incremental cost is relatively small and reuse of the units results in large (65 to $75 \%)$ savings over one-time use at a single reactor.

\section{B.4.3 Central Electropolishing and Chemical Decontamination Facility}

A central electropolishing and chemical decontamination facility could be used to reclaim piping, valves, and other plant components for reuse or salvage, 


\section{TABLE B.4-5. Costs for Mobile Chemical Decontamination Equipment}

for PWR Decomanissioning

\begin{tabular}{|c|c|c|c|c|c|c|}
\hline $\begin{array}{c}\text { Decommissioning } \\
\text { Alternative }\end{array}$ & $\begin{array}{c}\text { Estimated } \\
\text { Total Capital } \\
\text { Cost }(\$ \text { thousands })^{(a)}\end{array}$ & $\begin{array}{l}\text { Estimated Useful } \\
\text { Lifetime (Wo, of } \\
\text { Decommissionings) (b) }\end{array}$ & $\begin{array}{l}\text { Cost/Der } \\
\text { Capital }\end{array}$ & $\begin{array}{l}\text { onmissioning wit } \\
(\$ \text { thousands) }(c) \\
\text { Haintenance }(d)\end{array}$ & $\begin{array}{l}\text { I Reuse } \\
\text { TotaI }\end{array}$ & $\begin{array}{l}\text { Savings/ } \\
\text { Decommissioning } \\
\text { (s thousands) }\end{array}$ \\
\hline $\mathrm{BECl}$ & 110.0 & 5 & $? 2.0$ & 16.5 & 38.5 & 71.5 \\
\hline SAFSTOR & 110.0 & 5 & $\therefore 2.0$ & 7.3 & 29.3 & 80.7 \\
\hline
\end{tabular}

(a) Frnm Table I.3-9 and Tabie 1.5-6 of Reference 3.

(b) Assumes adequate maintenance.

(c) Rounded to the nearest $\$ 100$.

(d) Based on assumed average rate of $5 \%$ of capital cost per year; assumes a 3-year decomissioning schedule for DECON or ENTOMB and a 16 -month schedule $f_{i}$ or preparations for safe storage.

(e) Chemical decontamination equipment used only during preparations for safe starage.

reducing both the net cost of decommissioning and the volume of waste requiring disposal. Electropolishing could also be used during construction to polish component surfaces before installation to reduce the subsequent rate of contamination buildup, thus reducing occupational radiation doses and costs for both operations and decommissioning. (10)

An electropolishing facility sized to provide adequate capacity to handle construction, operation, and decommissioning of a single-unit reactor station is described in Section 11 of Reference 4. The information in the reference is used as a basis for the analysis presented in this study; major differences are:

- The facility size is increased somewhat in this analysis to allow for occasional increased demands for the facility services from the 10 reactors onsite.

- Chemical decontamination facilities are included here to provide more complete capability.

- Portable electropolishing equipment is also postulated to be included here for in-situ decontamination of plant components. 
The costs and potential savings associated with a central electropolishing and chemical decontamination facility are estimated here.

\section{B.4.3.1 Facility Costs}

For this study, it is assumed that the central electropolishing and chemical decontamination facility is housed in a building measuring about $27 \mathrm{~m}$ by $37 \mathrm{~m}$ in plan, with v1000 $\mathrm{m}^{2}$ of space. Using an assumed cost of $\$ 1080 / \mathrm{m}^{2}$ as given on page 11-3 of Reference 4, the structure's capital cost is $\$ 1.08$ million. A permanently installed electropolishing unit (polishing and rinsing tanks, electrical supply equipment, and controls) capable of handling components up to about $6 \mathrm{~m}$ long and $2 \mathrm{~m}$ in diameter is estimated to cost an additional $\$ 500,000$. Chemical decontamination facilities and a portable electropolishing unit for in-situ work are assumed to add $\$ 250,000$ and $\$ 50,000$, respectively, to bring the total capital cost of the facility to $\$ 1.88$ million.

It is anticipated that all of the electropolishing required during the decommissioning of a single reactor could be performed in 1 year of actual facility operation. Using an assumed rate of $10 \%$ of total capital cost per year, maintenance and operation of the facility are estimated to cost $\$ 188,000$ per decommissioning cycle.

The total facility cost per decomissioning cycle is the capital cost attributable to decomissioning plus the operation and maintenance cost. For this analysis, it is assumed that the facility is used both during reactor construction and operation as well as during decomissioning. Thus, it is assumed that decomissioning bears $25 \%$ of the capital cost. The capital cost per decommissioning cycle at a 10-reactor site is therefore $\$ 47,000$ and the total facility cost per decommissioning is $\$ 235,000$.

\section{B.4.3.2 Potential Cost Savings}

Significant cost savings would result from cleaning contaminated (but nonactivated) stainless steel components to unrestricted release levels, thus permitting either salvage as scrap or refurbishment and eventual reuse of components. 
The savings resulting from electropolishing and salvage of stainless steel are two-fold. The material does not require disposal as radioactive waste, eliminating the costs for packaging, shipping, and burial. In addition, the metal can be sold as scrap for further savings. On page 10-3 of Reference 1, the eliminated cost of disposal and the salvage value are estimated at $\sim 74 \$ / \mathrm{kg}$ and $v 60 \$ / \mathrm{kg} \mathrm{F.0.B}$. at the site, respectively, yielding total savings of $\$ 1.34 / \mathrm{kg}$ of stainless steei electropolished to unrestricted release levels.

For the PWR decommissioning, it is estimated that there is over $0.91 \mathrm{mil}$ lion $\mathrm{kg}$ of potentialiy saivageable stainless steel removed from the facility (see p.10-3 of Reference 1). Assuming that $20 \%$ of this material is of complex geometry and would be extremely difficult to survey for release, a total of $80 \%$ of the materiai (v0.73 million $\mathrm{kg}$ ) is anticipated to be saivaged. At $\$ 1.34 / \mathrm{kg}$, this yields a savings of $\$ \$ 975,000$. Subtracting the costs for retirement of capital and for facility operation and maintenance $(\$ 235,000$, from Section B.4.3.1), the net savings for PWR decomissioning are $\$ 740,000$.

A BWR contains much less stainiess steel than a PWR and, consequently, the potential for salvage is considerably lower. Table B.4-6 shows the contaminated stainless steel equipment outside the primary containment vessel of the reference BWR. The total mass of this equipment is about $115,000 \mathrm{~kg}$. In addition, the pool liners are potentialiy salvageable. Only the spent fuel storage pool and the dryer and separator pool are included in this analysis; not considered are the reactor well pool cavity liner, because of its relatively small area and higher contamination leveis, and the spent fuel storage racks, because their composite structure would make salvage very difficult. The spent fuel storage pool has two cavities, the main cavity and the siipping cask storage area. The dimensions of these two cavities (from Figure C.3-5 of Reference 3 and Figure 3.8-34 of Reference 11) are:

- main cavity - $12.2 \mathrm{~m}$ by $10.4 \mathrm{~m}$ by $11.8 \mathrm{~m}$ deep

- shipping cask storage area $-3.0 \mathrm{~m}$ by $3.0 \mathrm{~m}$ by $4.5 \mathrm{~m}$ deep.

Based on these dimensions, the liner floor area and the lined wall area of the spent fuel storage pool are $126.9 \mathrm{~m}^{2}$ and $587.4 \mathrm{~m}^{2}$, respectively, for a total iiner surface area in the pool of $714.3 \mathrm{~m}^{2}$. The dryer and separator pool has dimensions (from Figure 3.8-35 of Reference 11 ) of $12.6 \mathrm{~m}$ by $12.2 \mathrm{~m}$ by $7.6 \mathrm{~m}$ deep. Thus, the lined floor and wall areas of the dryer and separator pool are 
TABLE B.4-6. Mass of Contaminated Stainless Steel Equipment Outside Primary Containment Vessel of the Reference BWR

\begin{tabular}{|c|c|c|c|c|}
\hline$\underline{E K N(a)}$ & Equipment I tem/Quantity & Mass, Each & $\begin{array}{l}\text { Total Mass } \\
(\mathrm{kg}) \\
\end{array}$ & Reference \\
\hline $\begin{array}{l}-- \\
-- \\
--\end{array}$ & $\begin{array}{l}\text { Piping, Reactor Building } \\
\text { Piping, Turbine Generator Building } \\
\text { Piping, Radwaste and Control Building }\end{array}$ & $\begin{array}{ll}-- \\
\cdots\end{array}$ & $\begin{array}{rr}25 & 368 \\
7 & 895 \\
16 & 667\end{array}$ & $\begin{array}{l}\text { (b) } \\
(b)\end{array}$ \\
\hline $\begin{array}{l}308 \\
309 \\
331\end{array}$ & $\begin{array}{l}\text { Chemical Waste Tank/2 } \\
\text { Distillate Tank } / 2 \\
\text { Concentrator Feed Pump } / 2\end{array}$ & $\begin{array}{ll}5 & 030 \\
5 & 030 \\
& 254\end{array}$ & $\begin{array}{l}10060 \\
10060 \\
508\end{array}$ & $\begin{array}{l}(c) \\
\text { (c) } \\
(c)\end{array}$ \\
\hline $\begin{array}{l}332 \\
333 \\
334\end{array}$ & $\begin{array}{l}\text { Chemical Waste Pump/2 } \\
\text { Distillate Tank Pump/2 } \\
\text { Detergent Drain Pump } / 2\end{array}$ & $\begin{array}{l}479 \\
231 \\
175\end{array}$ & $\begin{array}{l}958 \\
462 \\
350\end{array}$ & $\begin{array}{l}\text { (c) } \\
\text { (c) }\end{array}$ \\
\hline $\begin{array}{l}386 \\
435\end{array}$ & $\begin{array}{l}\text { Decontamination Solution Concentrator } / 2 \\
\text { Decon. Solution Conc. Bottoms Recycie } \\
\text { Pumo/2 }\end{array}$ & $\begin{array}{r}3409 \\
844\end{array}$ & $\begin{array}{ll}6 & 818 \\
1 & 688\end{array}$ & $\begin{array}{l}\text { (c) } \\
\text { (c) }\end{array}$ \\
\hline 302 & Condensate Phase Separator Tank/2 & 3182 & 6364 & (d) \\
\hline $\begin{array}{l}304 \\
320 \\
321\end{array}$ & $\begin{array}{l}\text { Condensate Backwash Receiver Tank/1 } \\
\text { Condensate Siudge Discharge Mixing Pump/1 } \\
\text { Condensate Decant. Pump } / 1\end{array}$ & $\begin{array}{r}920 \\
420 \\
420\end{array}$ & $\begin{array}{r}920 \\
420 \\
420\end{array}$ & $\begin{array}{l}\text { (d) } \\
\text { (d) }\end{array}$ \\
\hline $\begin{array}{l}322 \\
305 \\
327\end{array}$ & $\begin{array}{l}\text { Condensate Backwash Transfer Pump } / 1 \\
\text { Spent Res in Tank/ } \\
\text { Spent Resin Pump/l }\end{array}$ & $\begin{array}{l}420 \\
658 \\
102\end{array}$ & $\begin{array}{l}420 \\
658 \\
102\end{array}$ & $\begin{array}{l}\text { (d) } \\
\text { (d) }\end{array}$ \\
\hline $\begin{array}{l}306 \\
328 \\
330\end{array}$ & $\begin{array}{l}\text { Waste Sludge Phase Separator Tank/1 } \\
\text { waste Decant Pump/1 } \\
\text { Waste Sludge Discharge Mixing Pump/1 }\end{array}$ & $\begin{array}{r}5497 \\
102 \\
288\end{array}$ & $\begin{array}{r}5497 \\
102 \\
288\end{array}$ & $\begin{array}{l}\text { (d) } \\
\text { (d) }\end{array}$ \\
\hline $\begin{array}{l}311 \\
335 \\
408\end{array}$ & $\begin{array}{l}\text { Decon. Solution Conc. Waste Tank } / 2 \\
\text { Gecon. Solution Conc. Waste Pump } / 1 \\
\text { Concentrator Waste Measuring Tank } / 1\end{array}$ & $\begin{array}{l}712 \\
254 \\
386\end{array}$ & $\begin{array}{l}1424 \\
254 \\
386\end{array}$ & $\begin{array}{l}\text { (d) } \\
\text { (d) }\end{array}$ \\
\hline $\begin{array}{l}379 \\
380 \\
409\end{array}$ & $\begin{array}{l}\text { Hopper Mixer } / 2 \\
\text { Waste Processing Pump } / 1 \\
\text { Centrifuge } / 2\end{array}$ & $\begin{array}{l}2727 \\
136 \\
454\end{array}$ & $\begin{array}{r}5454 \\
136 \\
908\end{array}$ & (d) \\
\hline \multirow[t]{2}{*}{$\begin{array}{l}307 \\
329 \\
337\end{array}$} & $\begin{array}{l}\text { Cleanup Phase Separator Tank/2 } \\
\text { Cleanup Decant Pump/1 } \\
\text { Cleanup Sludge Discharge Mixing Pump/l }\end{array}$ & $\begin{array}{l}2041 \\
102 \\
284\end{array}$ & $\begin{array}{r}4082 \\
102 \\
284 \\
\end{array}$ & $\begin{array}{l}\text { (d) } \\
\text { (d) }\end{array}$ \\
\hline & Totar & & 115055 & \\
\hline
\end{tabular}
(a) $E K N=$ Equipment Key Number.
(b) Table C.3-11 of Reference 3 .
(c) Table C.5-1 and Tabie C.3-6 of Reference 3 .
(d) Tabie C.5-3 and Table C.3-6 of Reference 3 . 
$153.7 \mathrm{~m}^{2}$ and $377.0 \mathrm{~m}^{2}$, respectively, for a total liner area in this pool of $530.7 \mathrm{~m}^{2}$. For the two pools, the lined area is $1245.0 \mathrm{~m}^{2}$ and, at a thickness of $0.0064 \mathrm{~m}$ (see p. C-62 of Reference 3 ), the total solid volume of the liners is $7.97 \mathrm{~m}^{3}$. At a density of $28030 \mathrm{~kg} / \mathrm{m}^{3}\left(0.29 \mathrm{lb} / \mathrm{in}^{3}\right.$, from $\mathrm{p}$. 23-39 of Reference 12), the total mass of stainless steel in the two pool iiners is about $64,000 \mathrm{~kg}$. Thus, the total salvageable stainless steel in the BWR is estimated to be about $779,000 \mathrm{~kg}$. Assuming as before, for the PWR, that $80 \%$ of the material is recovered at a savings of $\$ 1.34 / \mathrm{kg}$, savings are estimated at $\backsim \$ 192,000$.

The large quantities of carbon stee? in equipment, piping, and valves in the BWR have a low salvage value, $25.5 \mathrm{k} / \mathrm{kg}$; however, the elimination of disposa? costs of $274 \downarrow / \mathrm{kg}$ makes it cost effective to decontaminate this material, giving a savings of $79.5 \$ / \mathrm{kg}$. In Table C.3-11 of Reference 3 , the mass of contaminated carbon steel piping and valves is given as $435,000 \mathrm{~kg}$. Assuming that $80 \%$ of the carbon steel is salvaged at a savings of $79.5 \$ / \mathrm{kg}$, the savings are estimated to be $\imath \$ 280,000$.

Total savings from salvaging the stainless and carbon steel are $\$ 472,000$, which results in a net savings of $\$ 237,000$ per BWR decommissioning.

The estimated costs and potential cost savings resulting from use of the central electropolishing facility during decommissioning are summarized in Table B.4-7. It should be noted that the estimates presented do not inciude savings that would result from recovery and refurbishment of components for eventual reuse. However, such recovery and refurbishment is desirable where appropriate and is likely to result in incremental cost savings. The recovery of even a small percentage of the stainiess steel yalves in the plant being decommissioned would yield considerable additional savings, even assuming that refurbishment of these valves would cost an average of $50 \%$ of their replacement costs. (Valve reconditioning typically costs less than $50 \%$ of new-valve cost.) 
TABLE B.4-7. Estimated Costs and Potential Cost Savings Associated with Use of a Central Electropolishing Facility During Decommissioning

Facility Costs/Decommissioning
(\$ thousands) (a)

Type of Reactor Capital(b) Maintenance(c) Total

\section{Net Recovery} Value of Stainless Stee 1 $(\$$ thousands $)(a, d)$

235

235

$$
975^{(e)}
$$$$
472^{(f)}
$$

Net Cost

Savings/

Deconmissioning, (\$ thousands) (a)

710

237

(a) Rounded to the nearest $\$ 1000$.

(b) Based on a facility cost of $\$ 1,880,000,25 \%$ of which is assumed to be charged to decommissioning, with 10 reactors at the site.

(c) Assumed to be $10 \%$ of total capital cost/year; electropolishing associated with deconmissioning estimated to be completed in 1 ycar.

(d) Based on $\$ 0.60 / \mathrm{kg}$ salvage value for stainless steel and $\$ 0.79 / \mathrm{kg}$ disposal cost, for a net recovery value of $\$ 1.34 / \mathrm{kg}$ (see $0.10-3$ of Reference 1). Carbon steel has a salvage value of $\$ 0.055 / \mathrm{kg}$ to give a net recovery value of $\$ 0.795 / \mathrm{kg}$.

(e) Based on $80 \%$ recovery of $910,000 \mathrm{~kg}$ potentially recoverabie stainless steel.

(f) Based on $80 \%$ recovery of $179,000 \mathrm{~kg}$ potentially recoverahle stainless steel and $435,000 \mathrm{~kg}$ of potentially recoverable carbon steel. 


\section{REFERENCES}

1. R. I. Smith, G. J. Konzek and W. E. Kennedy, Jr., Technology, Safety and Costs of Decommissioning a Reference Pressurized water Reactor Power Station, NUREG/CR-0130, U.S. Niclear Regulatory Commission Report by Pacific Northwest Laboratory, June 1978.

2. R. I. Smith and L. M. Polentz, Technology, Safety and Costs of Decomissioning a Reference Pressurized Water Reactor Power Station, NUREG/CR-0130 Addendum, U.S. Nuclear Regulatory Comission Report by Pacific Northwest Laboratory, August 1979.

3. H. D. Oak, G. M. Holter, W. E. Kennedy, Jr., and G. J. Konzek, Technology, Safety and Costs of Decommissioning a Reference Boiling Water Reactor Power Station, NUREG/CR-0672, U.S. Nuclear Regulatory Commission Report by Pacific Northwest Laboratory, June 1980.

4. E. B. Moore, Jr., Facilitation of Decommissioning Light water Reactors, NUREG/CR-0569, U.S. Nuclear Regulatory Commission Report by Pacific Northwest Laboratory, December 1979.

5. J. R. May, T. K. Thompson, and J. W. McConnel1, Jr., "Fluidized Bed Radioactive Waste Volume Reduction System." In Management of Low-Level Radioactive Waste, pp. 287-294, Pergamon Press, Elmsford, New York, 1979.

6. J. R. May, "Radioactive Waste Volume Reduction," Newport News Industrial Corporation, Power Engineering, October 1978.

7. S. S. Freeman, et a1., "The Mound Laboratory Cyclone Incinerator for Radioactive Waste," In Management of Low-Level Radioactive Waste, pp. 323-332, Pergamon Press, Elmsford, New York, 1979.

8. J. Richardson, D. A. Lee, "Activity Measurements at a Waste Volume Reduction Facility" In EPA 520/3-79-002, Low-Level Radioactive Waste Management, pp. 196-202, May 1979.

9. J. B. Weaver and H. C. Bauman, "Cost and Reliability Estimation," pp. 25-16 and 25-17. In Chemical Engineers' Handbook, 5th Ed., McGraw-Hili Book Company, New York, New York, 1973.

10. H. W. Arrowsmith, et al., Electropolishing as a Decontamination Process: Progress and Application, PNL-SA-6858, Pacific Northwest Laboratory, Richland, Washington, April 1978.

11. WPPSS Nuciear Project No. 2 Final Safety Analys is Report, Washington Public Power Supply System, Richland, Washington, February 1977. 
12. R. B. Norden, "Materials of Construction," In Chemical Engineers' Handbook, 5th Ed., McGraw-Hi11 Book Company, New York, New York, 1973.

13. M. P. Nicholas, "Reconditioning Makes 01d Valves 'New'," Chemical Engineering, May 22, 1978, pp. 117 and 118. 

APPENDIX C

\section{OCCUPATIONAL DOSES FROM INTERIM ONSITE NUCLEAR WASTE STORAGE}

The purpose of this appendix is to estimate the occupational doses associated with the placement of decommissioning wastes in and the retrieval of decommissioning wastes from an onsite interim waste storage facility. It is assumed that such a facility wilt be designed to: minimize occupational doses, provide safe and secure storage for up to 100 years, and permit safe retrieval of radioactive materials for relocation offsite. Doses are estimated for the highly radioactive neutron-activated reactor components and the combined contaminated and radwaste materials removed from both a reference PWR and a reference BWR. This analysis is not intended to result in an "exact" solution; however, the resulting doses are intended to be an estimate (based on key assumptions) that will be useful in the comparative analysis. Much of the occupational dose analysis discussed here is based on the results of previous studies in this series. (1-3)

\section{C.T NEUTRON-ACTIVATED REACTOR COMPONENTS}

A list of the number of waste containers required for neutron-activated reactor components from the PWR and the BWR is given in Table C.1-1. This table shows the number of waste containers required for DECON, SAFSTOR, and ENTOMB, as well as the average radioactivity per container.

Occupational doses from waste burial are estimated using the work descriptions and dose rates discussed in Reference 3 . Table C.1-2 contains the estimated occupational doses and data per canister of waste for burial of l-yearold neutron-activated (slit trench) waste. The dose rates in this table are based on $5000 \mathrm{Ci}$ per waste container, and are reduced by an order of magnitude as an assumed facility design shielding factor. This is not an unreasonabie assumption since a simple calculation indicates that less than $0.4 \mathrm{~m}$ of concrete will reduce the dose rate of $1.0-\mathrm{MeV}$ gamma rays by an order of magnitude.

For the BWR, values from Table C.1-1 indicate that each canister contains about four times more radioactivity than the $5000 \mathrm{Ci}$ assumed in Table C.1-2. Using the dose versus contamination level relationship shown in Figure E.2-4 of 
TABLE C.1-]. Waste Containers Required for Neutron-Activated Reactor Components

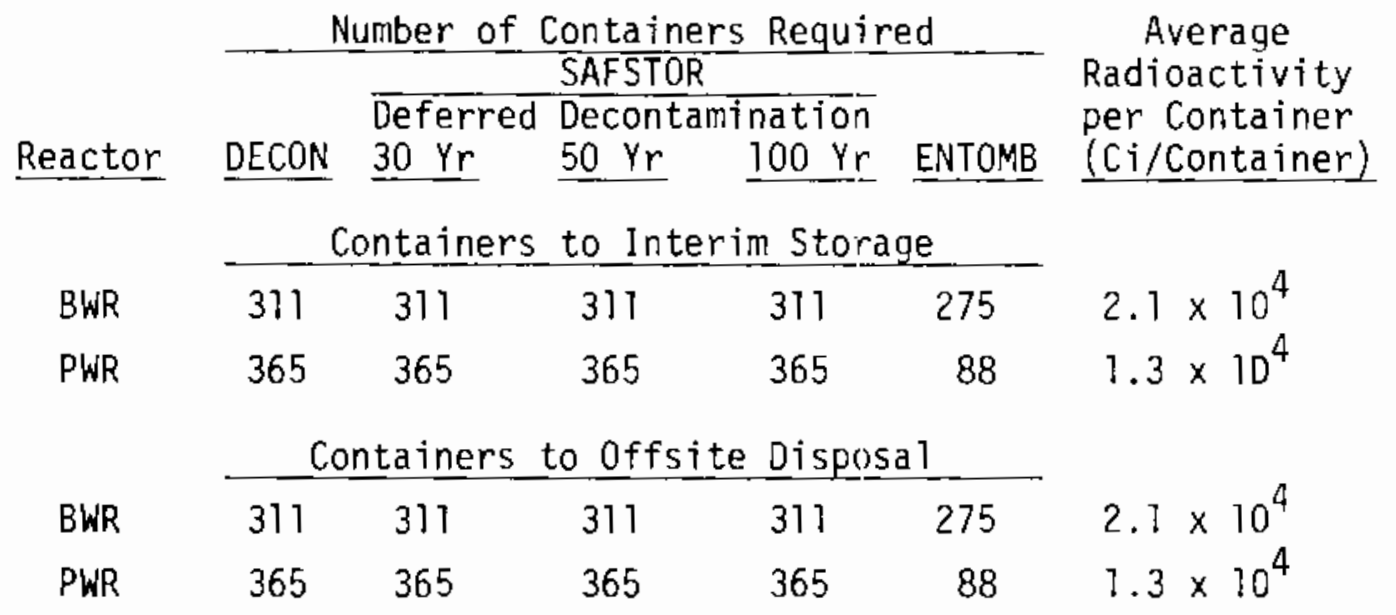

Reference 2, increasing radioactivity content by a factor of 4 increases the surface dose rate by a factor of about 2.6. This lower increase in the dose than the increase in radioactivity content is due to self-shielding of the material involved. For the PWR, a similar analysis indicates that the dose rate will increase by a factor of about 1.7. If these dose rate correction factors are applied to the dose per canister value from Table C.1-2 and if the resulting corrected dose rate is multiplied by the number of containers of waste handled for each decommissioning option, the total occupational doses are estimated. The time dependence of the burial doses for neutron-activated components is shown in Figure C.1-1 for the PWR and in Figure C.1-2 for the BWR. The shapes of these curves are based on the dose rate curves shown for the PWR in Figure 7.4-1 of Reference 1 (p. 7-39) and for the BWR in Figure E.1-6 of Reference 2 ( $p . E-23)$.

Occupational doses from neutron-activated component waste retrieva? operations are estimated in a manner similar to that used for waste burial. Table C.1-3 gives the estimated occupational doses per container of waste for the relocation of 30-year-01d neutron-activated (slit trench) waste. The dose rates and data shown are directly from Reference 3 (Tabie I.2-1, p. I-32) without the inclusion of a facility design shielding factor. If the same selfshielding dose correction factor developed for PhR and BWR waste burial is used along with the canister requirements, occupational waste retrieval doses can be calculated. The time dependence of the neutron-activated component 


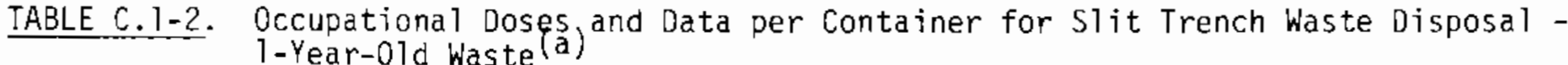

\begin{tabular}{|c|c|c|c|c|c|c|c|}
\hline Operation & Personnel/Number & Personnel Location & $\begin{array}{l}\text { Exposure Time } \\
\text { per Container } \\
\quad(\mathrm{hr}) \\
\end{array}$ & $\begin{array}{l}\text { Dose Rate } \\
\text { at Location } \\
\text { (rem/hr) }\end{array}$ & $\begin{array}{l}\text { Dose at } \\
\text { Location per } \\
\text { Worker (rem) }\end{array}$ & $\begin{array}{l}\text { Total Dose per } \\
\text { Worker }(\text { rem })\end{array}$ & $\begin{array}{l}\text { Total vose } \\
\text { per Category } \\
\text { (nian-rem) }\end{array}$ \\
\hline \multirow{5}{*}{$\begin{array}{l}\text { Waste Unloading and } \\
\text { Disposal }\end{array}$} & Foreman (1) & $4 \mathrm{~m}$ (Skyshine) & 1 & $4.0 \times 10^{-5}$ & $4.0 \times 10^{-5}$ & $4.0 \times 10^{-5}$ & $4.0 \times 10^{-5}$ \\
\hline & Laborers (2) & $\begin{array}{l}0.3 \mathrm{~m} \text { from Cask } \\
1 \mathrm{~m} \text { from Cask } \\
4 . \mathrm{m} \text { (Skyshine) }\end{array}$ & $\begin{array}{l}0.25 \\
0.25 \\
1\end{array}$ & $\begin{array}{l}2.0 \times 10^{-1} \\
1.0 \times 10^{-2} \\
4.0 \times 10^{-5}\end{array}$ & $\begin{array}{l}5.0 \times 10^{-2} \\
2.5 \times 10^{-3} \\
4.0 \times 10^{-5}\end{array}$ & $5.2 \times 10^{-2}$ & $1.0 \times 10^{-1}$ \\
\hline & Equipment Operator (2) & $\begin{array}{l}10 \mathrm{~m} \text { from Container } \\
\text { plus } 0.4 \mathrm{~m} \text { Concrete }\end{array}$ & 0.25 & $8.2 \times 10^{-2}$ & $2.0 \times 10^{-2}$ & & \\
\hline & & $4 \mathrm{~m}$ (5kyshine) & 1 & $4.0 \times 10^{-5}$ & $4.0 \times 10^{-5}$ & $2.0 \times 10^{-2}$ & $4.0 \times 10^{-2}$ \\
\hline & Health Physics Tech. (1) & $\begin{array}{l}4 \mathrm{~m} \text { (Skyshine) } \\
5 \mathrm{~m} \text { from Container } \\
\text { plus } 0.4 \mathrm{~m} \text { Concrete }\end{array}$ & 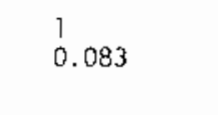 & $\begin{array}{l}4.0 \times 10^{-5} \\
3.3 \times 10^{-1}\end{array}$ & $\begin{array}{l}4.0 \times 10^{-5} \\
2.7 \times 10^{-2}\end{array}$ & $2.7 \times 10^{-2}$ & $2.7 \times 10^{-2}$ \\
\hline \multirow[t]{2}{*}{$\begin{array}{l}\text { Cover and Over- } \\
\text { burden Placement }\end{array}$} & Equipment Operator $(1)$ & $\begin{array}{l}2 \pi \text { above Trench } \\
\text { plus } 80 \text { mा Stee } 1\end{array}$ & $18^{(\mathrm{b})}$ & $2.0 \times 10^{-6(b)}$ & $-(c)$ & -- & $\cdots$ \\
\hline & Health Physics Tech (1) & I m over Trench & $4.5^{(b)}$ & $2.0 \times 10^{-5(b)}$ & -- & -- & $-\ldots$ \\
\hline $\begin{array}{l}\text { Total for all } \\
\text { Operations }\end{array}$ & 8 & & & & & & $1.7 \times 1$ \\
\hline
\end{tabular}

(a) Based on Table I.2-1 from Reference 3, with dose rates corrected to 1 year of radioactive decay, for burial of 1 container of waste. Note: $40 \mathrm{~cm}$ of concrete is assumed to reduce the dose rate by at least a factor of 10 .

(b) Cover and overburden placement is assumed to take 3 days. The hours and dose rates (in rem/hr) shown are for the entire operation, and

(c) These doses are for the total operation and are less than $1 \times 10^{-4}$; thus they are not considered further.

(d) The average dose to one of eight workers is about 21 millirem per container. 


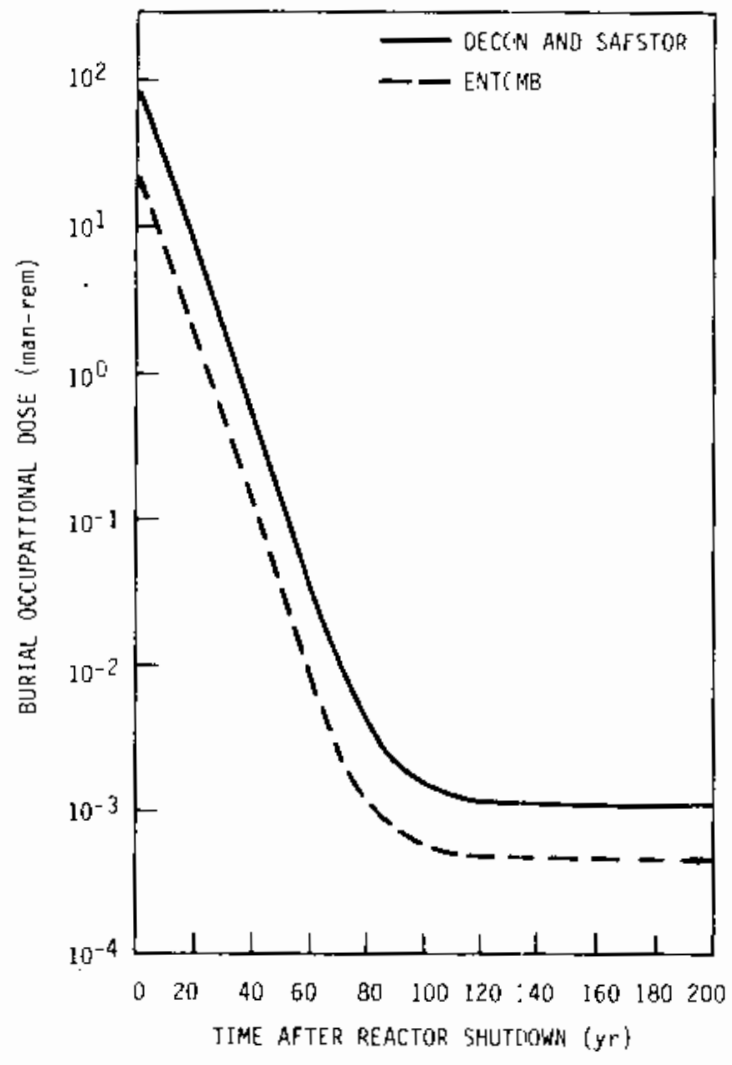

FLGURE C.1-1. Time Dependence of Occupational Dose for Burial of Neutron-Activated PWR Components

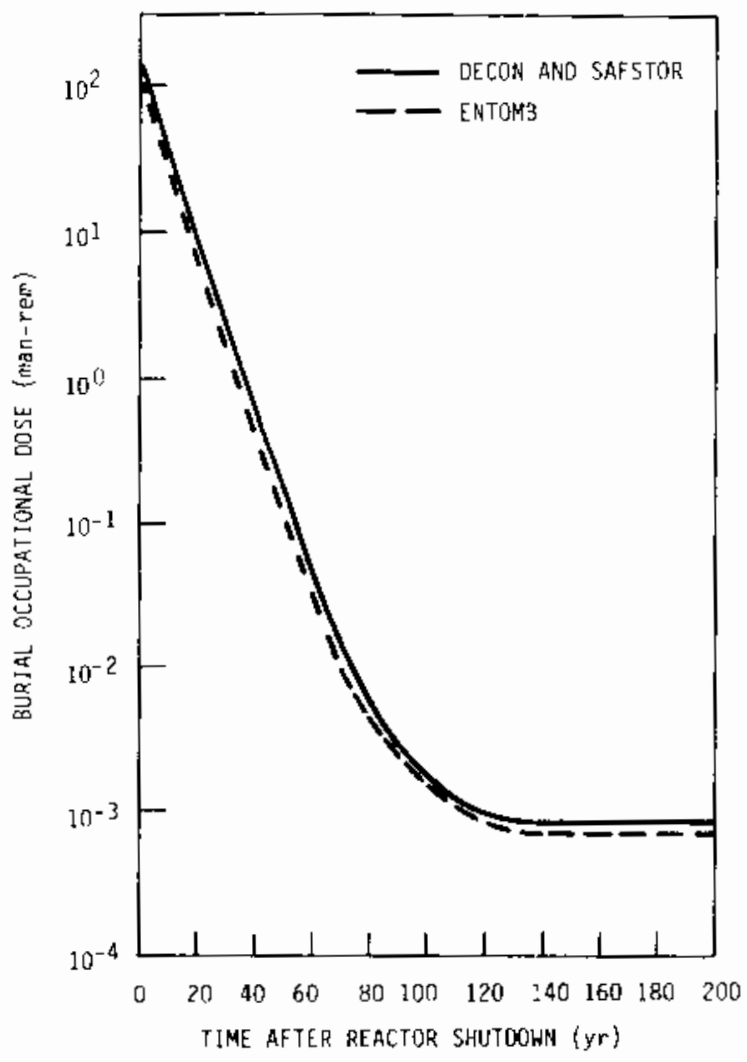

FIGURE C.1-2. Time Dependence of Occupational Dose for Burial of Neutron-Activated BWR Components

$$
\text { C-4 }
$$


TABLE C.1-3. Occupational Doses and Data per Container for STit Trench Waste Relocation after 30 Years (a)

\begin{tabular}{|c|c|c|c|c|c|c|c|}
\hline Operation & Personnel/Number & Personnel Location & $\begin{array}{l}\text { Exposure Time } \\
\text { per Container } \\
\text { (hr) }\end{array}$ & $\begin{array}{l}\text { Dose Rate } \\
\text { at Location } \\
(\text { rem/hr) } \\
\end{array}$ & $\begin{array}{l}\text { Dose at } \\
\text { Location per } \\
\text { Worker (rem }\end{array}$ & $\begin{array}{l}\text { Total Dose per } \\
\text { Worker. (rem) }\end{array}$ & $\begin{array}{l}\text { Total Dose } \\
\text { per Category } \\
\text { (man-rem) }\end{array}$ \\
\hline $\begin{array}{l}\text { Dverburden and } \\
\text { Cover Removal }\end{array}$ & $\begin{array}{l}\text { Equipment Operator (1) } \\
\text { Health Physics Tech. (1) }\end{array}$ & $\begin{array}{l}2 \mathrm{~m} \text { above Trench plus } \\
80 \text { mm Steel } \\
1 \text { m over Trench }\end{array}$ & $18^{(b)}$ & $\begin{array}{l}2.0 \times 10^{-6(b)} \\
2.0 \times 10^{-5(b)}\end{array}$ & $\begin{array}{l}(c) \\
--\end{array}$ & -- & -- \\
\hline \multirow{4}{*}{$\begin{array}{l}\text { Waste Exhumation } \\
\text { and Loading }\end{array}$} & Foremian (1) & 4 in (Skyshine) & 1 & $2.1 \times 10^{-5}$ & $2.1 \times 10^{-5}$ & $2.1 \times 10^{-5}$ & $2.1 \times 10^{-5}$ \\
\hline & Equipment Operator (2) & $\begin{array}{l}10 \mathrm{~m} \text { from Canister } \\
4 \mathrm{~m} \text { (Skyshine) }\end{array}$ & 0.25 & $\begin{array}{l}1.8 \times 10^{-2} \\
2.1 \times 10^{-5}\end{array}$ & $\begin{array}{l}4.5 \times 10^{-3} \\
2.1 \times 10^{-5}\end{array}$ & $4.5 \times 10^{-3}$ & $9.0 \times 10^{-3}$ \\
\hline & Laborers (2) & $\begin{array}{l}0.3 \mathrm{~m} \text { from Cask } \\
1 \mathrm{~m} \text { from Cask } \\
4 \mathrm{~m} \text { (Skyshine) }\end{array}$ & $\begin{array}{l}0.25 \\
0.25 \\
1\end{array}$ & $\begin{array}{l}4.0 \times 10^{-3} \\
2.0 \times 10^{-4} \\
2.1 \times 10^{-5}\end{array}$ & $\begin{array}{l}1.0 \times 10^{-3} \\
5.0 \times 10^{-5} \\
2.1 \times 10^{-5}\end{array}$ & $1.0 \times 10^{-3}$ & $2.0 \times 10^{-3}$ \\
\hline & Health Physics Tech. (1\} & $\begin{array}{l}4 \mathrm{~m} \text { (5kyshine) } \\
5 \mathrm{~m} \text { from Canister }\end{array}$ & 0.083 & $\begin{array}{l}2.1 \times 10^{-5} \\
7.1 \times 10^{-2}\end{array}$ & $\begin{array}{l}2.1 \times 10^{-5} \\
5.9 \times 10^{-3}\end{array}$ & $6.0 \times 10^{-3}$ & $6.0 \times 10^{-3}$ \\
\hline $\begin{array}{l}\text { Total for a } 11 \\
\text { Operation }\end{array}$ & $B$ & & & & & & $3.7 \times 10^{-2(d)}$ \\
\hline
\end{tabular}

(a) Based on Table 1.2-1, Reference 3, with dose rates corrected to 30 years of radioactive decay, for relocation of 1 container of waste.

(b) Overburden and cover removal is assumed to take 3 days. The hours and dose rates $\{$ in rem/hr\} shown here are for the entire operation, and

(c) These doses are for the total operation and are less than $1 \times 10^{-4}$; thus they are not considered further.

(d) The average dose to one of eight workers is about 2 millirem per container. 
waste retrieval doses is shown in Figure C.1-3 for the PWR and in Figure C.1-4 for the BWR. Again, the shapes of these curves are based on the dose rate curves shown for the PWR in Figure 7.4-1 of Reference 1 and for the BWR in Figure E. 1-6 of Reference 2.

\section{C.2 CONTAMINATED AND RADWASTE MATERIALS}

A list of the number of waste containers required for contaminated and radwaste materials from the PWR and BWR for each decommissioning alternative is given in Table C.2-7. Deferred decontamination is assumed to occur at either 30, 50, or 100 years after reactor shutdown, and the wastes are assumed to be held in onsite interim storage for 30,50, or 100 years. The data show the amount of waste that is estimated to be shipped offsite for each aiternative and interim storage period. A11 of the occlpational doses estimated in this section are based on the number of containers required for the DECON and ENTOMB alternatives. All dose rates are based on an average amount of radioactivity per container, corrected for radioactive decay and shielding considerations. No attempt is made to estimate the dose rates from the containers required for all of the SAFSTOR options. Rather, it is assumed that the same quantity of inaterial is involved at an average concentration and that the dose may be obtained from the DECON or ENTOMB time-dependent curves. This assumption simplifies the efforts, and should not result in answers that grossly misrepresent the occupational dose. The doses obtained in this manner are not "exact" solutions, but they are useful in this comparative anaiysis.

Occupational doses from waste burial are estimated using the work descriptions and dose rates discussed in Reference 3 . It is difficult to determine the occupational dose per container; thus the doses are calculated based on the time it takes to bury all the waste associated with the BWR. Doses for the PWR are found by direct ratio of the waste volumes invoived for the two types of reactors.

Table C.2-2 contains the estimated occupational doses and data for burial of 1-year-old BWR wastes. The BWR waste will fill about 1.5 reference trenches (defined in Reference 3); thus the exposure times shown have been increased by a factor of 7.5. The dose rates from Table I.2-3 of Reference 3 have been 


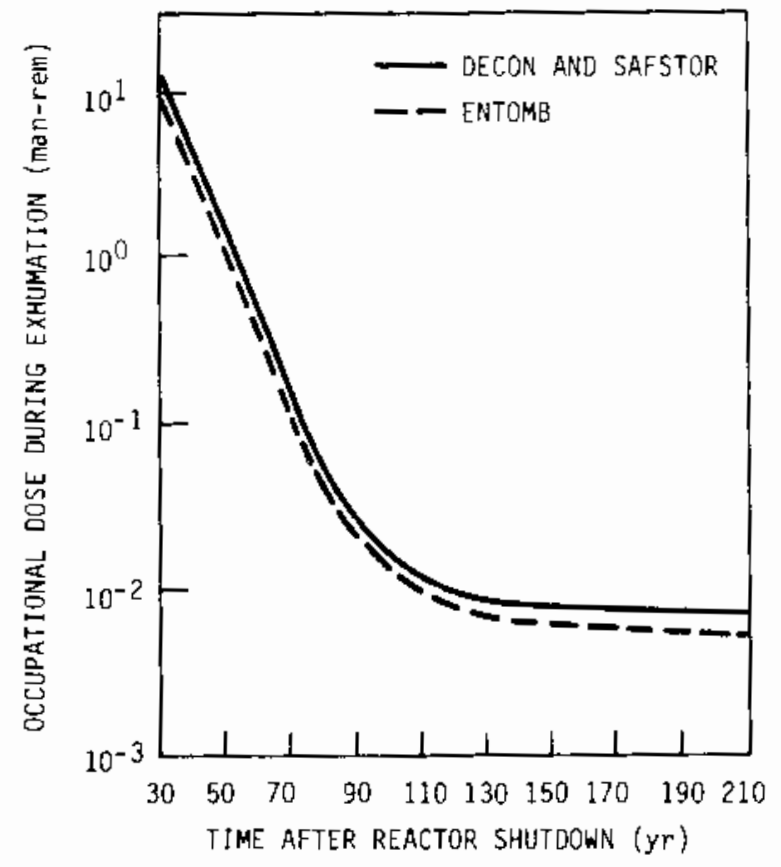

FIGURE C.1-3. Time Dependence of Occupational Dose for Retrieval of Neutron-Activated PWR Components

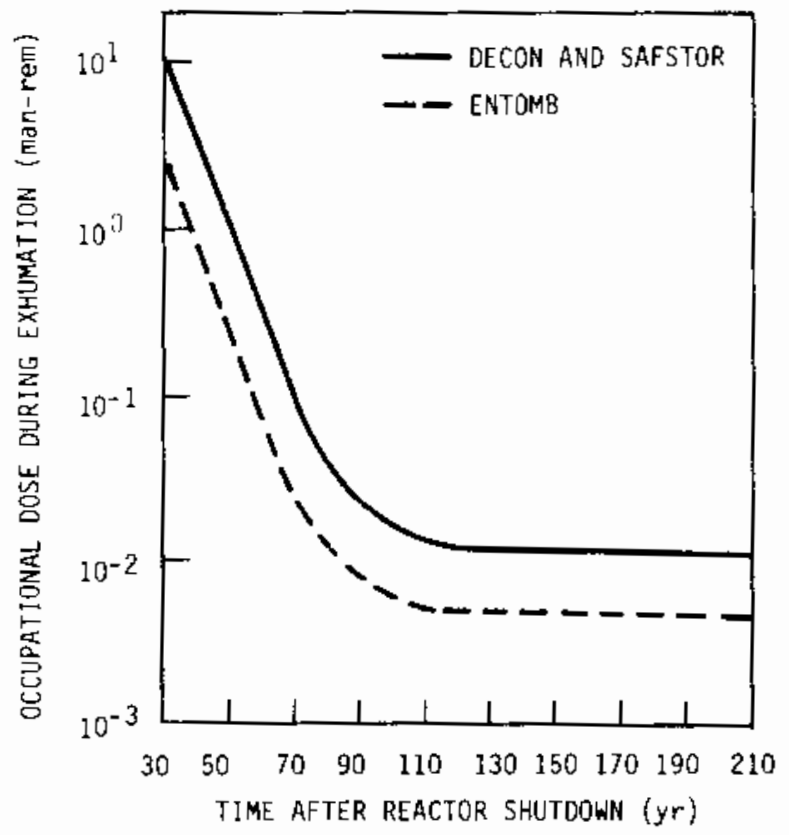

FIGURE C. 3-4. Time Dependence of Occupational Dose for Retrieval of Neutron-Activated BWR Components 
TABLE C.2-1. Waste Container Requirements for Contaminated and Radwaste Materials

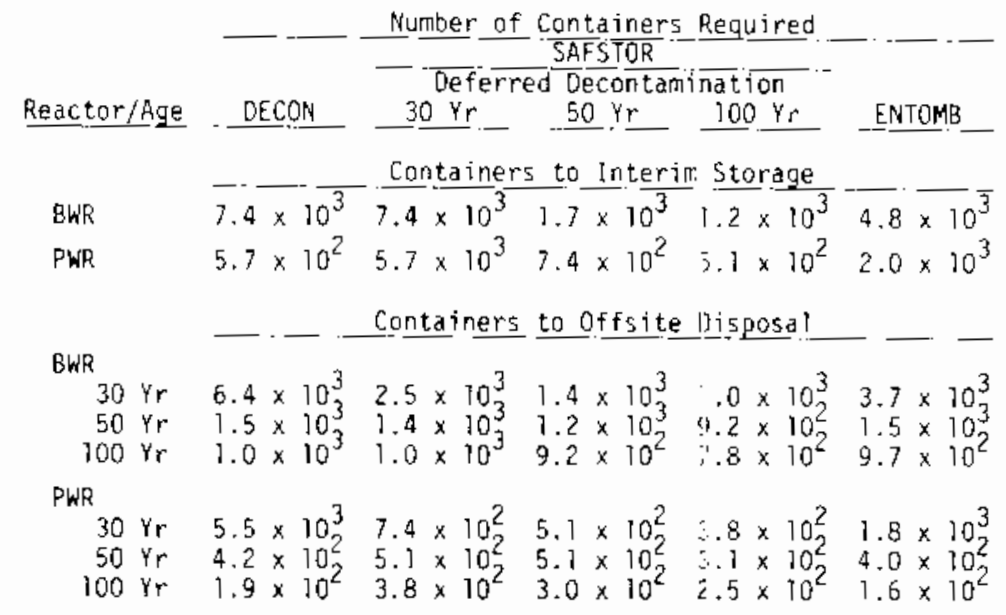

reduced by a factor of 10 as an assumed facility design shielding factor, the same factor used for the neutron-activated reactor component waste disposal analysis. The average waste container radioactivity concentrations for both the PWR and BWR are found to be between 2 and $3 \mathrm{ci} / \mathrm{m}^{3}$ for 7 -year-old waste. These concentrations are assumed to be equa? to the $2.9 \mathrm{ci} / \mathrm{m}^{3}$ concentration used for 30-year-old waste in Reference 3 . The resulting occupational doses for contaminated and radwaste material burial are shown in Table C.2-2, and the time dependence is shown in Figure C.2-7. The time dependence of the burial occupational doses for the PWR is found by ratio and is shown in Figure C.2-2. The shapes of these curves are based on the total dose curve in Figure E.2-1 of Reference 2.

0ccupational doses for waste retrieval are found in a manner similar to that used for waste burial. Table C.2-3 contains occupational doses and data for retrieval of 30-year-0ld BWR waste. The dose rates and data shown are from Table 1.2-3 of Reference 3, corrected for radioactive decay without a facility design shielding factor. Again, the exposure times are increased by a factor of 1.5 since BWR waste will fill 1.5 reference trenches. The time dependence of the occupational doses for retrieving BWR waste is shown by the curves in Figure C.2-3. Similar doses for retrieving PWR wastes are found by ratio of the waste volumes, and are shown in Figure C.2-4. The shapes of these curves are based on the total dose curve in Figure E.2-1 of Reference 2. 


\section{TABLE C.2-2. Occupationa? Doses and Data per BWR for Waste Disposal - 1-Year-01d Waste (a)}

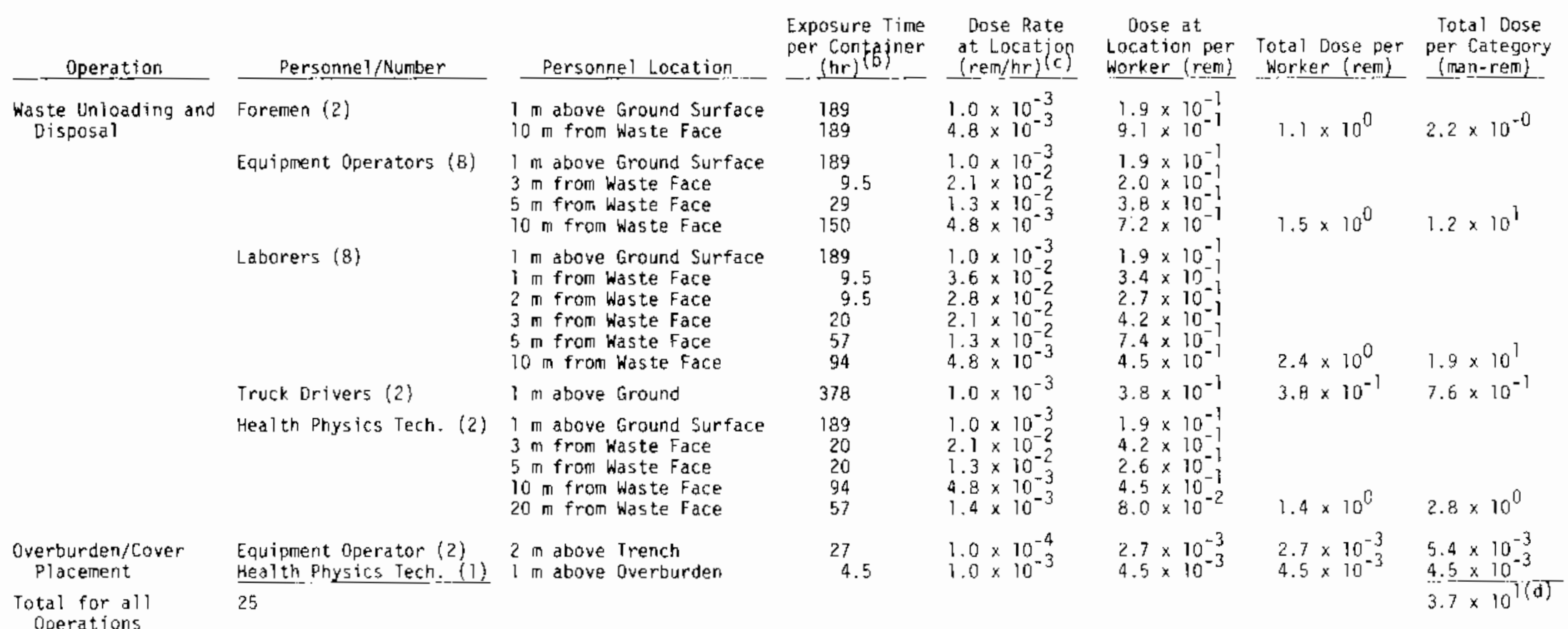

(a) Based on Table 1.2-3 of Reference 3 with corrected dose rates and exposure times.

(b) Waste from the BWR fills 1.5 trenches; thus all times from iable I.2-3 are multiplied by 1.5 .

(c) Dose rates are reduced by a factor of 10 from those reported in Table $1.2-3$, assuming dose reduction is achieved through facility design.

(d) The average dose to one of 25 workers is about 1.5 rem. 


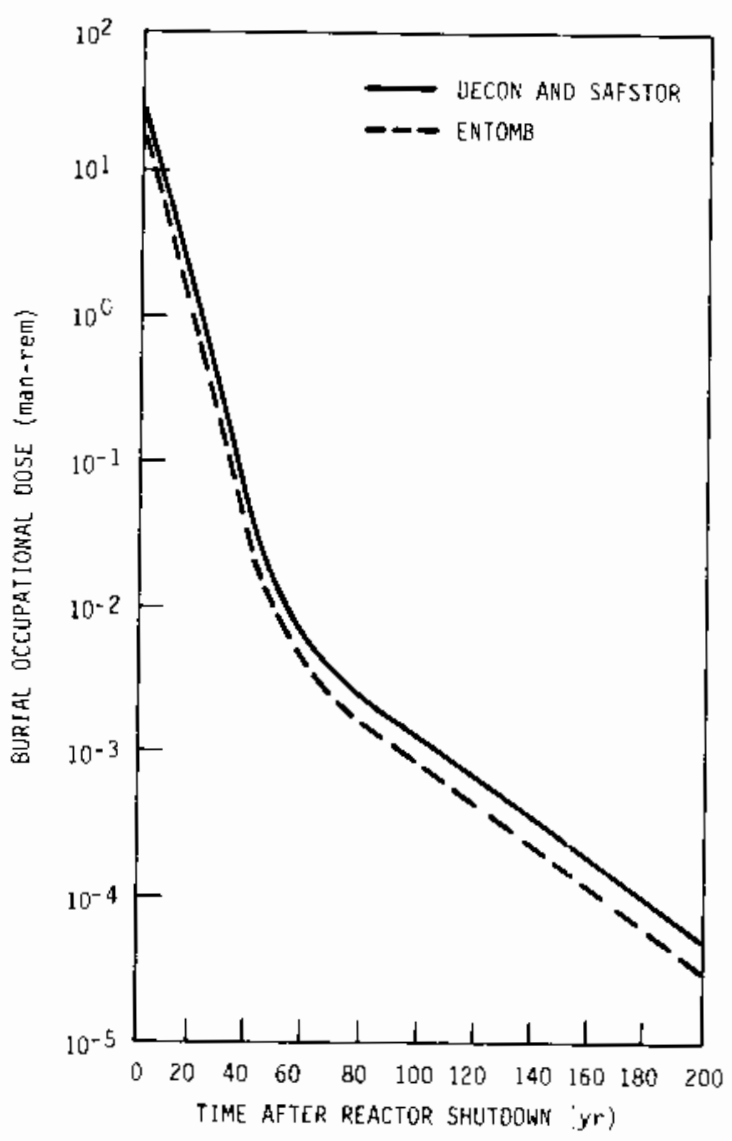

FIGURE C.2-1. Time Dependence of Occupational Dose for Burial of BWR Contaminated Material and Radwaste

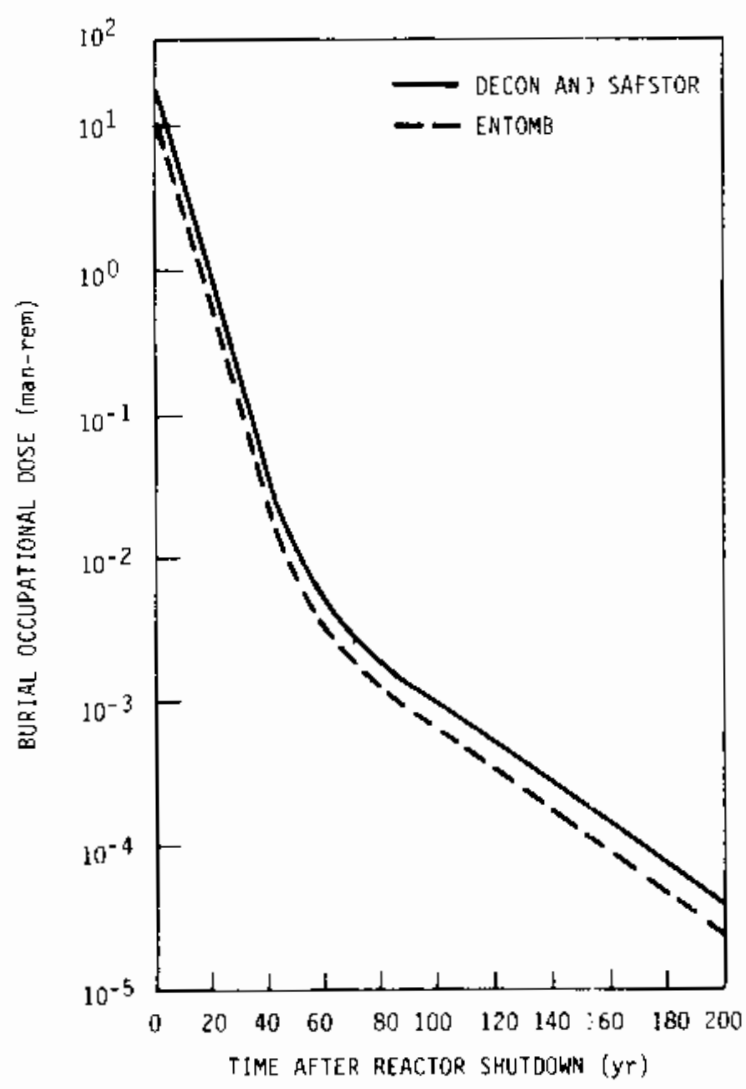

FIGURE C.2-2. Time Dependence of Occupational Dose for Burial of PWR Contaminated Material and Radwaste 


\section{TABLE C.2-3. Occupational Doses and Data per BWR for Waste Retrieval - 30-Year-01d Waste $(a)$}

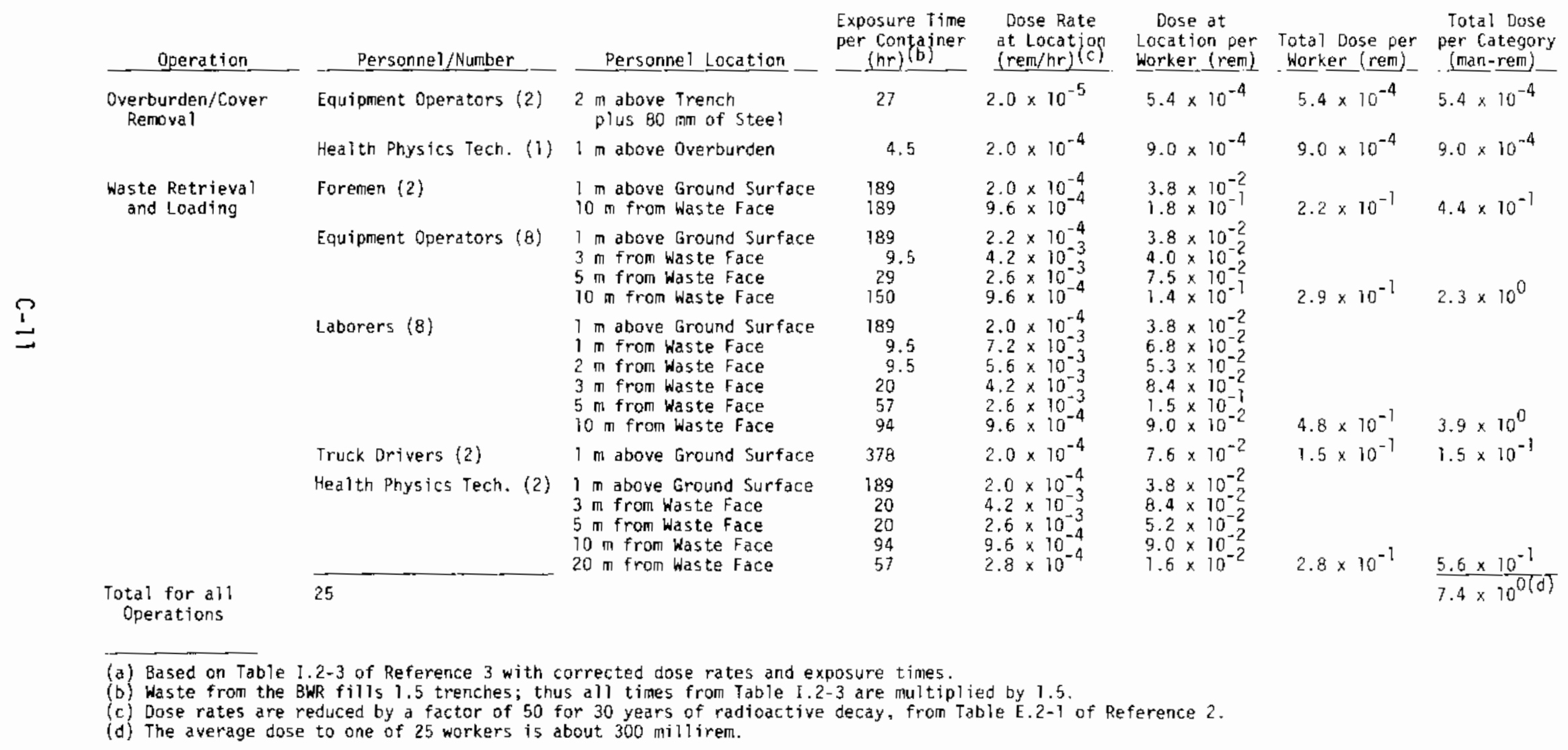




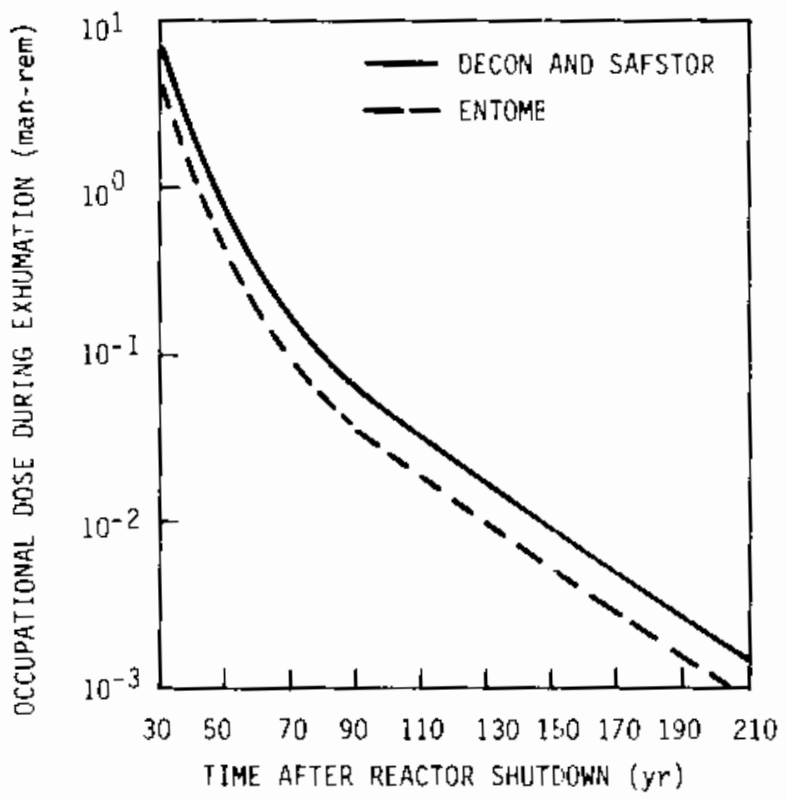

FIGURE C.2-3. Time Dependence of Occupational Dose for Retrieval of BWR Contaminated Material and Radwaste

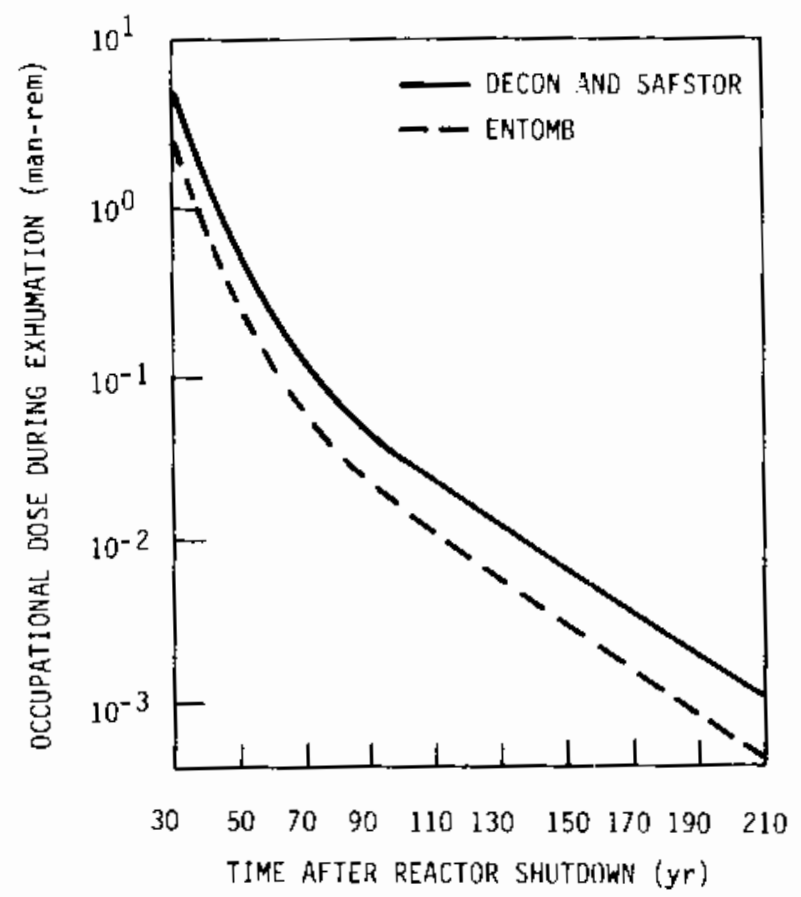

FIGURE C.2-4. Time Dependence of Occupationa1 Dose for Retrieval of PWR Contaminated Material and Radwaste 


\section{REFERENCES}

1. R. I. Smith, G. J. Konzek and W. E. Kennedy, Jr., Technology, Safety and Costs of Deconmissioning a Reference Pressurized Water Reactor Power Station, NUREG/CR-0130, U.S. Nuclear Regulatory Commission Report by Pacific Northwest Laboratory, June 1978.

2. H. D. Oak, G. M. Holter, W. E. Kennedy, Jr., and G. J. Konzek, Technology, Safety and Costs of Decomimissioning a Reference Boiling Water Reactor Power Station, NUREG/CR-0672, U.S. Nuclear Regulatory Commission Report by Pacific Northwest Laboratory, June 1980.

3. E. S. Murphy and G. M. Holter, Technology, Safety and Costs of Decommissioning a Reference Low-Level Waste Burial Ground, NUREG/CR-0570, U.S. Nuclear Regulatory Commission Report by Pacific Northwest Laboratory, June 1980. 

Technology, Safety and Costs of Decomissioning Huclear Reactors at Multiple-Reactor Stations

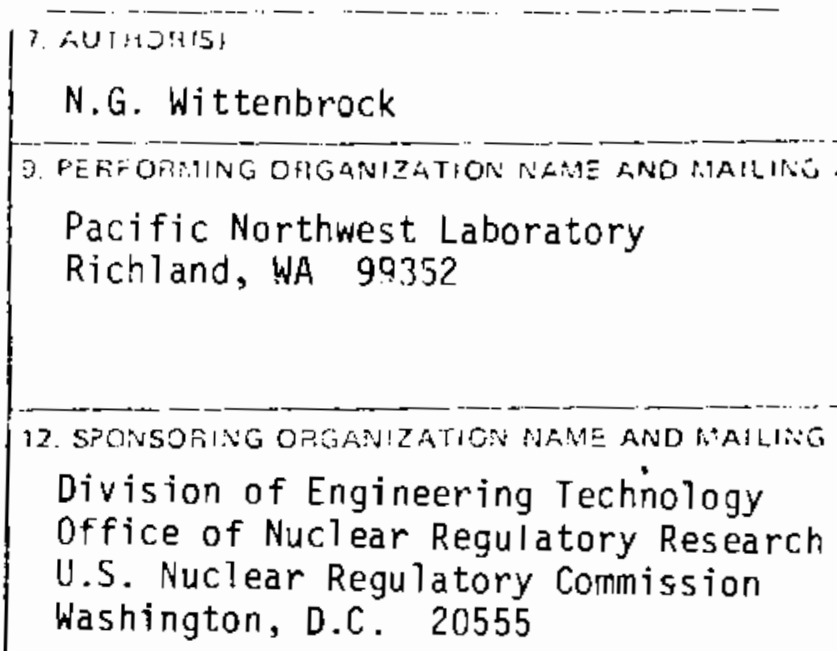

13. TYPE OF REPOAT

Technical data base

15. SIPPLENENTARY NOTES

14. (LEDVe $42, m k$ )

16. ABSTAACT (200 wORCS or less)

Safety and cost information is developed for the conceptual decommissioning of . large (1175-MWe) pressurized water reactors (PWR) and large (1155-MWe) boi]ing water reactors (BWR) at multiple-reactor stations. Three decommissioning alternatives are studied: DECON (immediate decontamination), SAFSTOR (safe storage followed by deferred decontamination), and ENTOMB (entombment). Safety and costs of decommissioning are estimated by determining the impact of probable features of multiple-reactor-station operation that are considered to be unavailable at a singlereactor station, and applying these estimated impacts to the decommissioning costs and radiation doses estimated in previous PWR and BWR decommissioning studies. The multiple-reactor-station features analyzed are: the use of interim onsite nuclear waste storage with later removal to an offsite waste disposal facility, the use of permanent onsite nuclear waste disposal, the dedication of the site to nuclear power generation, and the provision of centralized services. 
